\title{
Heerdgang in Zuidelijk Limburg : een vorm van extensieve beweiding in verleden, heden en toekomst
}

Citation for published version (APA):

Hillegers, H. P. M. (1993). Heerdgang in Zuidelijk Limburg : een vorm van extensieve beweiding in verleden, heden en toekomst. [Doctoral Thesis, Maastricht University]. Natuurhistorisch Genootschap in Limburg. https://doi.org/10.26481/dis.19930604hh

Document status and date:

Published: 01/01/1993

DOI:

10.26481/dis.19930604hh

Document Version:

Publisher's PDF, also known as Version of record

\section{Please check the document version of this publication:}

- A submitted manuscript is the version of the article upon submission and before peer-review. There can be important differences between the submitted version and the official published version of record.

People interested in the research are advised to contact the author for the final version of the publication, or visit the DOI to the publisher's website.

- The final author version and the galley proof are versions of the publication after peer review.

- The final published version features the final layout of the paper including the volume, issue and page numbers.

Link to publication

\footnotetext{
General rights rights.

- You may freely distribute the URL identifying the publication in the public portal. please follow below link for the End User Agreement:

www.umlib.nl/taverne-license

Take down policy

If you believe that this document breaches copyright please contact us at:

repository@maastrichtuniversity.nl

providing details and we will investigate your claim.
}

Copyright and moral rights for the publications made accessible in the public portal are retained by the authors and/or other copyright owners and it is a condition of accessing publications that users recognise and abide by the legal requirements associated with these

- Users may download and print one copy of any publication from the public portal for the purpose of private study or research.

- You may not further distribute the material or use it for any profit-making activity or commercial gain

If the publication is distributed under the terms of Article $25 \mathrm{fa}$ of the Dutch Copyright Act, indicated by the "Taverne" license above, 

Heerdgang in Zuidelijk Limburg

Een vorm van extensieve beweiding

in verleden, freden en toekomst

\section{PROEFSCHRIFT}

ter verkrijging van de graad van doctor

aan de Rijksuniversiteit Limburg te Maastricht,

op gezag van de Rector Magnificus, Prof. Mr. M.J. Cohen,

volgens het besluit van het College van Dekanen,

in het openbaar te verdedigen

op vrijdag 4 juni 1993 om 16.00 uur

door

\section{Henricus Paschalis Maria Hillegers}

Geboren te Meerssen 
PROMOTOR

Prof. Dr.J.C.G.M. Jansen

CO-PROMOTOR

Prof. Dr. V. Westhoff

BEOORDELINGSCOMMISSIE:

Prof. Dr. J.C.S. Kleinjans, voorzitter

Prof. Dr. G.J. Boekschoten, Vrije Universiteit Amsterdam

Prof. Dr. J. Goossens, Universiteit van Münster i/W, Duitsland

Dr. K.V. Sỳkora, Landbouwuniversiteit Wageningen

Prof. Dr. A.M. van der Woude, Landbouwuniversiteit Wageningen 
Voor Alsem, Bitterzoet en Hazelnoot 
UITGAVE: STICHTING NATUURPUBLICATIES LIMBURG

(9) NATUURIISTORISEII GENOOTSCHAP IN LIMBURG

\section{Maastricht 1993}

Niets uit deze uitgave mag worden verveelvoudigd en/of openbaar gemaakt door middel van druk: fotokopie, microfilm of op welke andere wijze dan ook, zonder voorafgaande schriftelijke toestemming van de uitgever. 


\section{INHOUDSOPGAVE}

DeEL... Toponymisch deel, het verleden

HOOFDSTUK I, Inleiding en overzicht, bronnenmateriaal.

werkwijze en doelstelling van het onderzoek

2. Heerdgang-indicatieve toponiemen 16

3. Bies(t)-toponiemen 22

4. Drenk-toponiemen 28.

5. Groen-toponiemen 32

6. Mes/mis-toponiemen, heerdgang of kerkgang? $\quad 40$ :

7. Dries-toponiemen en het drieslagstelsel 46.

8. Heerdgang en ontginningsgeschiedenis. een schets van de processen en patronen van de humane occupatie in Zuid-Limburg

DeEL. II. Botanisch-oecologisch deel, van verleden naar heden

HOOFDSTUK 9. Schraallanden, voormalige functies en huidige bedreigingen $\quad 66$

10. Het Thero-Airion in Limburg 76

II. Algemene oecologie van het driesland $\quad 84$

12. Flora en vegetatie van de driesgronden
op de Sint-Pietersberg, bij Maastricht

13. Veedriften en hun vegetaties, realiteit en reconstructie 104

14. Hartgespan, een karakteristieke plantesoort voor vegetaties langs veedriften?

DEEL III. Extensieve beweiding in het natuurbeheer, de toekomst HOOFDSTUK 15. De rol van het mergellandschaap in het natuurbeheer

Zusammenfassung _ 129

Summary $\quad 130$

Rèsumé _13!

$\begin{array}{lr}\text { Literatuur } & 132\end{array}$

\begin{tabular}{l|l} 
Lijst van kaarten & 137
\end{tabular}

$\begin{array}{ll}\text { Bijlagen } & 138\end{array}$

$\begin{array}{lr}\text { Cụrriculum vitae } & 160\end{array}$ 


\title{
I INLEIDING EN OVERZICHT, BRONNEN- MATERIAAL, WERKWIJZE EN DOELSTELLING VAN HET ONDERZOEK
}

\author{
"Een toponymist is een schaap met vijf poten."
}

Uit de ondertitel van dit boek "Een vorm van extensieve beweiding in verleden, heden en toekomst" blijkt reeds een driedeling, De hoofdstukken van deel I behandelen historische en geografische aspecten van de heerdgang naar aanleiding van een onderzoek naar een bepaalde groep toponiemen. De hoofdstukken van deel II betreffen actuele oecologische thema's van de heerdgang. Deel III bestaat uit één hoofdstuk en schetst de mogelijkheden in de toekomst van een methode van landgebruik, die wordt aangeduid met heerdgang. Dit is een vorm van extensieve beweiding.

Omdat de tegenovergestelde vorm daarvan, de intensieve beweiding die op dit moment in Nederland de gangbare is, een duideliiker beeld van beweiding voor de huidige lezer geeft dan de extensieve, wordt in deze inleiding eerst een korte karakteristiek gegeven van intensieve en vervolgens van extensieve beweiding. Tenslotte wordt het begip heerdgang omschreven.

Onder intensieve beweiding wordt verstaan een wijze van voedselomzetting, warbil een plantaardige grondstof, het gewas in de wei- de, op een zo efficiènt mogelijke manier door gedomesticeerde herbivoren wordt omgezet in produkten, die verder door de mens worden benut. Intensieve beweiding is een vorm van bio-industriêle veehouderij en gaat: gepaard met grootschaligheid, mechanisatie, het gebruik van kunstmest, herbiciden en andere materialen of methoden van de biotechnologie.

Een extensieve beweiding wordt gekenmerkt door een veel minder efficiënte voedselomzetting, hetgeen resulteert in een gemiddeld lagere opbrengst. Daar staat tegenover dat er minder hoeft te worden geînvesteerd in de weidegronden en het daarop weidende vee. Bovendien worden schadelijke effecten op het milieu vermeden, hetgeen op langere termiin het grote voordeel van deze methode zal vormen.

Er zijn diverse gradaties van extensieve beweiding bekend (zie figuur I, i), In het kader van deze studie speelt één bepaalde vorm van extensieve beweiding de hoofdrol: de historische "heerdgang", waarbij het vee onder leiding van een herder (= heerd) dagelijks de weidegronden bezocht en 's nachts werdop- gestald. De weidegronden die eigendom waren van de gemeente werden niet bemest of op andere wijzen verzorgd. Het systeem van heerdgang heeft eeuwenlang in het gebied van onderzoek bestaan en zowel figuurlijk als letterlijk duidelijke sporen in het landschap achtergelaten. Dit is het thema van deel I uit deze studie: een historisch overzicht van deze ene vorm van extensieve beweiding in het gebied van onderzoek.

Gezien de continuïteit van deze vorm van landschapsgebruik gedurende vele eeuwen door de mens en zijn vee en het daarmee in verband staande aanpassingsvermogen van vele soorten planten en dieren die zich in deze "wilde" weidegronden wisten te handhaven, is het niet verwonderlijk dat de extensieve beweiding is "herontdekt" door de naturterrein beherende instanties. In diverse Noordwesteuropese natuurreservaten. voor zover deze in het verleden extensief werden beweid, zijn delen van het landschap opnieuw via deze methode in beheer genomen. En met succes: de voormalige soortenrijkdom en stabiliteit, handzame maten voor de natuurwaarde van deze oecosystemen.

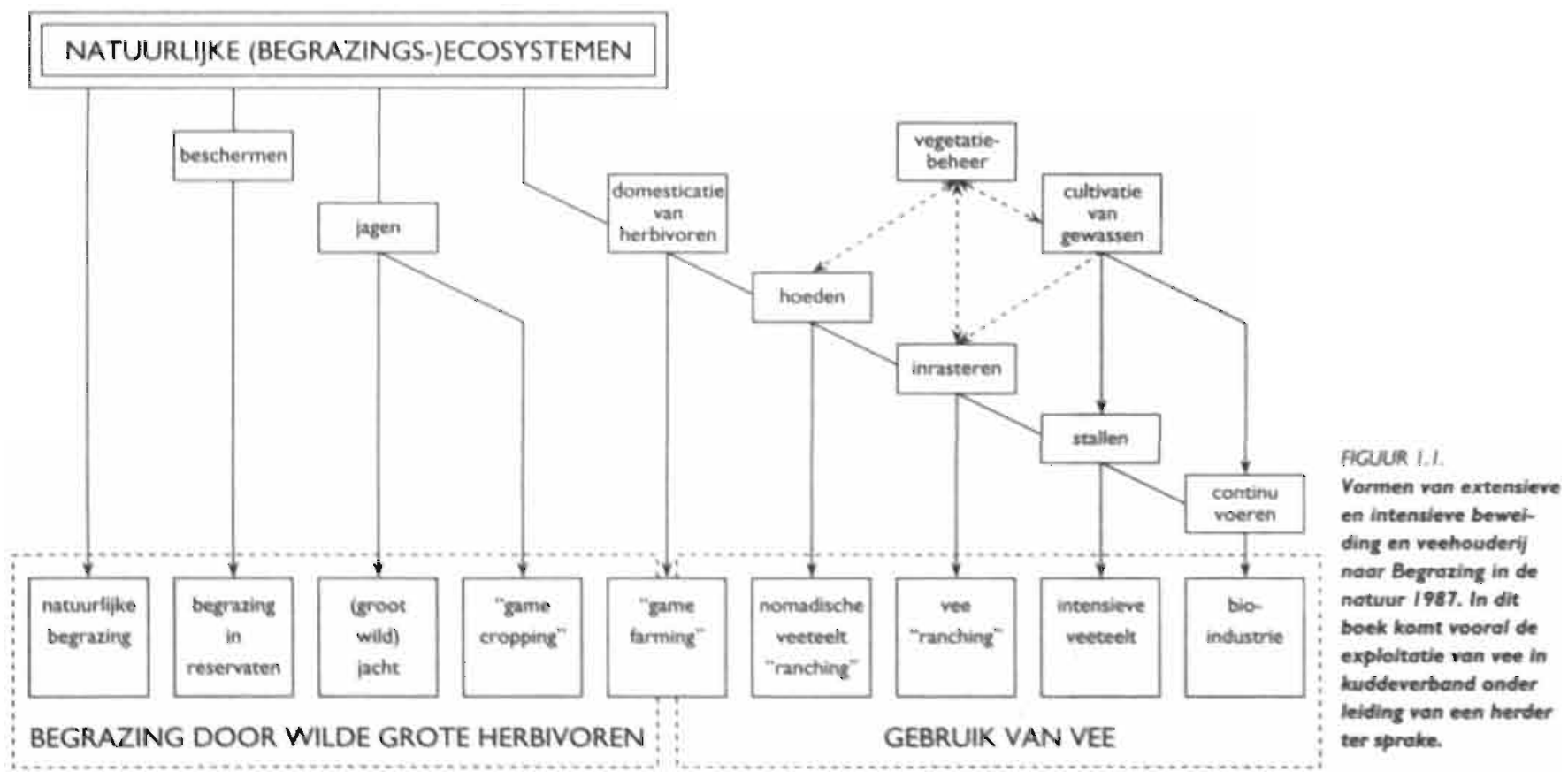




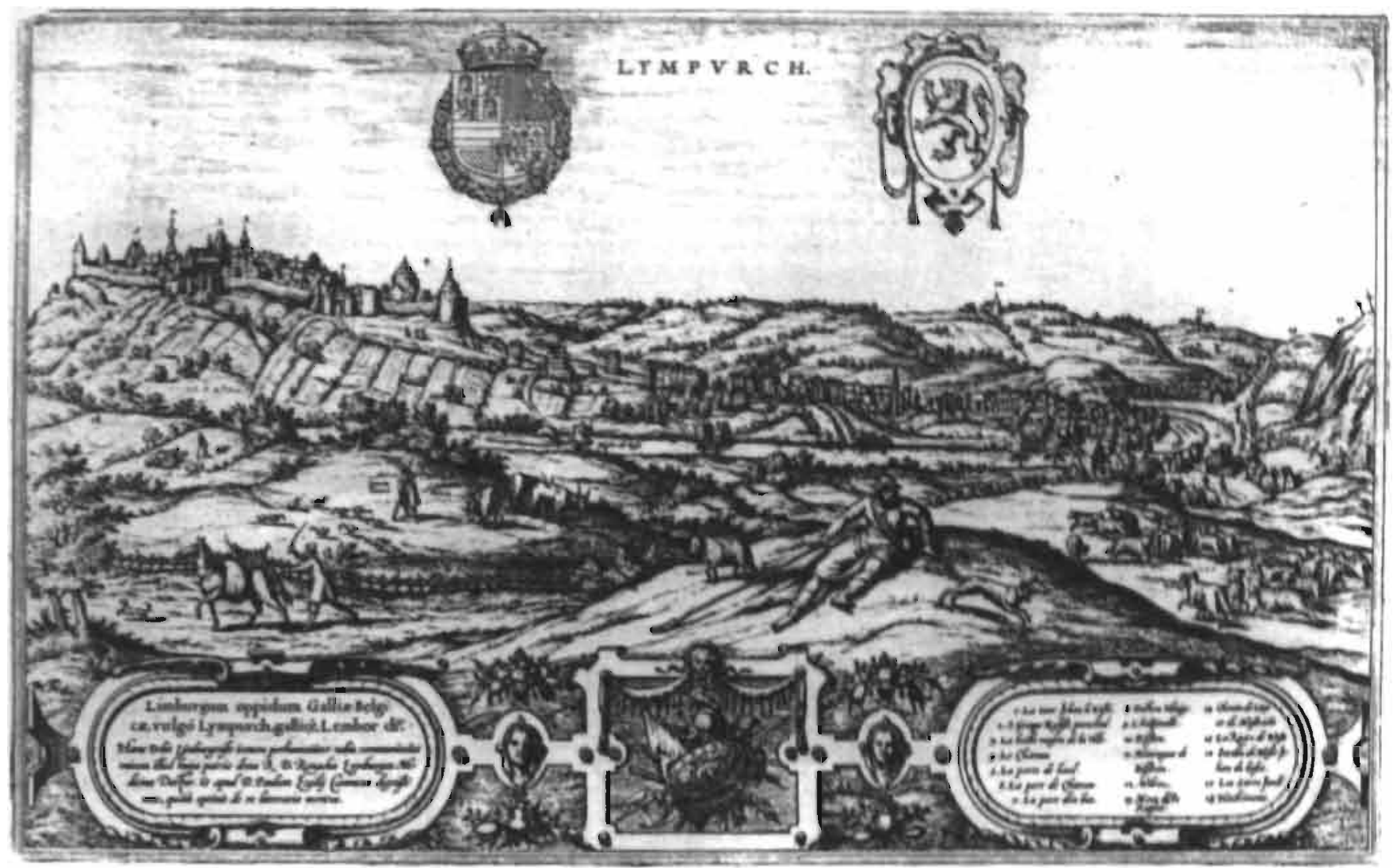

FGUUR 1.2. Extensieve beweiding rond de stod Limbourg rond 1620. Gravire Archief L G. O,G. Moastricht. Weiden met hagen ontbreken. Losiopend vee wontt bewaakt door herders. Akkers en tuinen op de achterizond zijn door hagen of muurtjes omgeven om te voorkomen dat het vee daor schade aanricht.

herstelden zich al na enige jaren. Dit onderwerp vormt één van de thema's uit deel II. Andere thema's van deel II hebben betrekking op de flora en vegetatie van veedriften, braakliggende akkers, die net als de schrale graslanden door beweiding worden beïnvloed. Deel III schetst de mogelijkheden voor de uitbreiding van de methode van de extensieve beweiding voor het gebied van onderzoek.

Het eerste deel van dit boek behandelt extensieve beweiding in het verleden binnen het gebied van onderzoek, dat in figuur 1.7 wordt aangegeven en waarop in het laatste deel van dit inleidend hoofdstuk nader wordt ingegaan. Het materiaal waarop deel I zich baseert, wordt gevormd door heerdgangindicatieve toponiemen, die in hoofdstuk 2 uitvoerig worden omschreven. In dit inleidend hoofdstuk kunnen zulke toponiemen kort worden aangeduid als een groep van "veldnamen", die te maken hebben met de voormalige weidegang van de dorpskudde onder leiding van een herder. Om de lezer op voorhand een indruk te geven van het grote belang van toponiemen voor de interpretatie van het voormalige landschap van een gebied, volgt hieronder een concreet voorbeeld van de interpretatie van één toponiem met verstrekkende gevolgen voor het inzicht in het landschap, waarop die naam betrekking heeft.
2.1 Nederlandse of Vlaamse reizigers die via de A4 de Nederlands-Duitse rịksgrens even terı noorderi van Aken passeren, worden daar attent gemaakt op borden langs de snelweg met de tekst "Autobahnkreuz Verlauteriheide", Die attentie geldt vooral voor de komende affsplitsingen van de A4 naar Belgiè en Nederland. Weinig, reizigers realiseren zich de betekenis van het laatste deel van de tweede sannenstelling, heide, een "gemeenschappelijke graasplaats, die voornamelijk door schapen in kuddeverband wordt benut".

Een heide op dit punt, waar internationale snelwegen elkaar kruisen? Een grotere tegenstelling tussen de letcerlijke betekenis van de

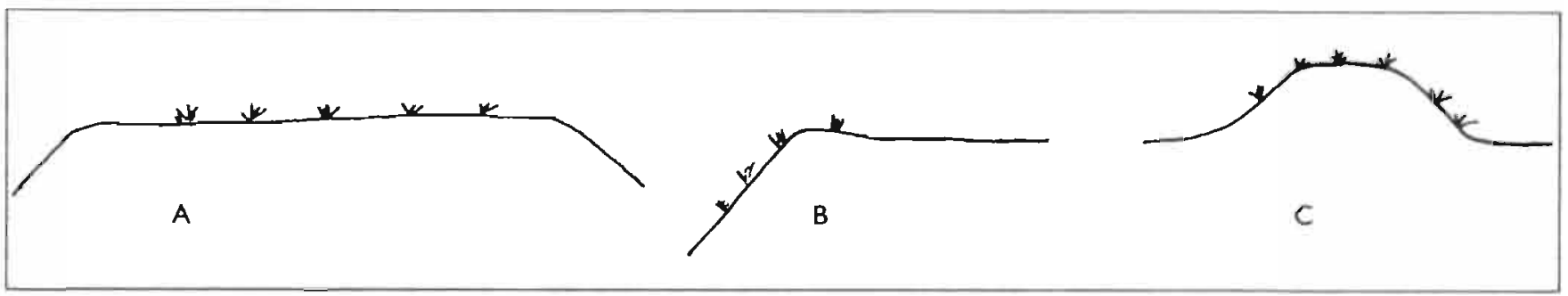

FGUUR 1.3. Drie geomorfologisch verschillende heiden in Zuid-Limburg plateauheide (A), plateaurandheide (B) en plateaukopheide (C) noor HiLLEgers 1980 . Slechts enkele plateaurandheiden xijn in Zuid-Limburg gespaard gebleven. Dank zij hun soortennjikjom, die aan kalkhoudende badems is gebonden, worden deze ook wel "kalkgraslanden" genoemd en bezitten ze nu de status "notuurreservoat". 
FIGUUR 1.4.

Scheper met kudde op de Dolsberg bij Gulpen rond 1920. De foto geefit een karakterisviek beeld van een plateaurandheide.

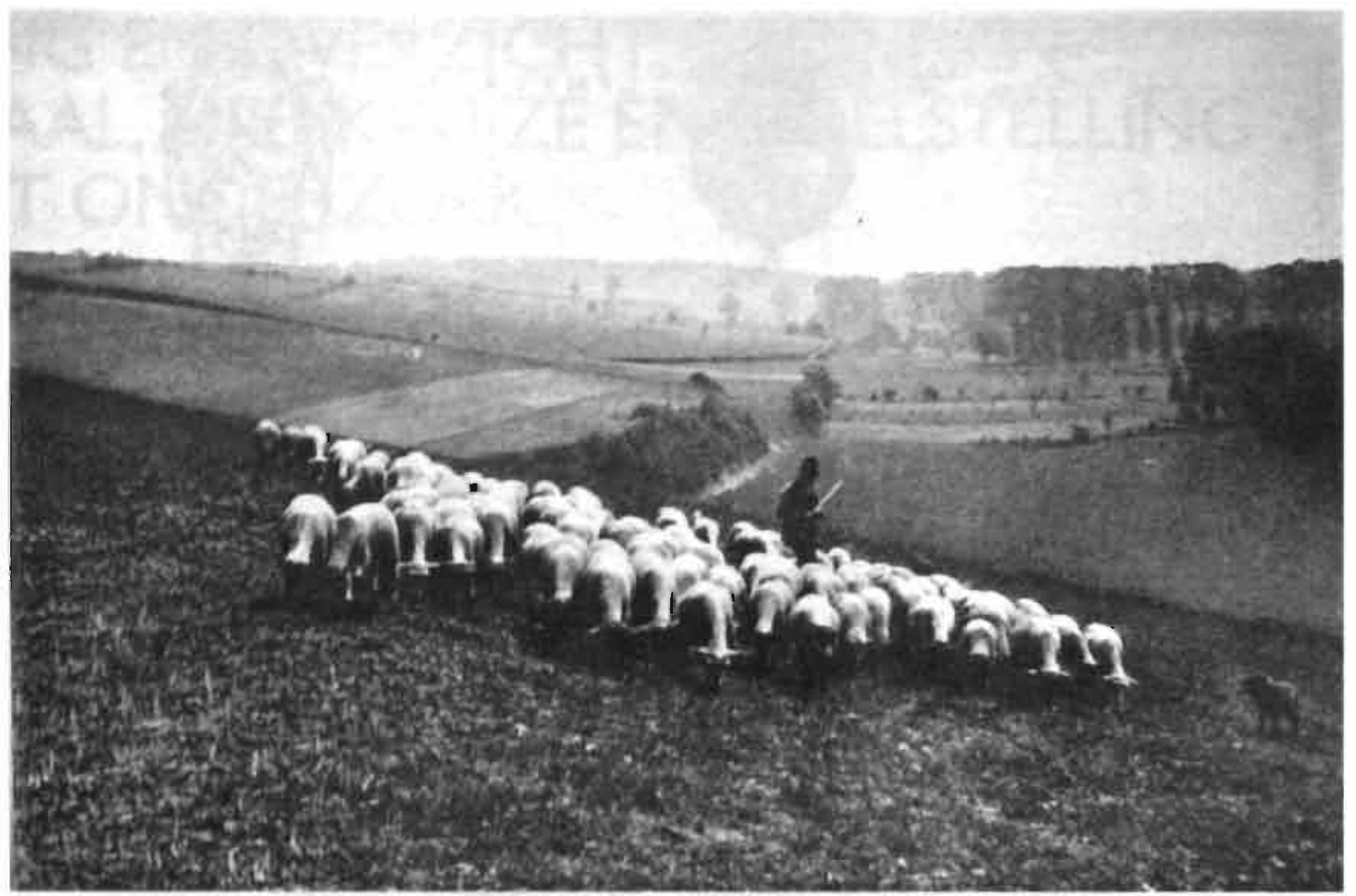

naam van deze plek en de actue! situatie ter plaatse is nauwelijks denkbaar. is het mogelijk dat op deze plek, waar internationale drukte zich vermengt met schreeuwende reclameborden, luidruchtig verkeer en industrie eens een "grote, stille heide" lag, waar, volgens het bekende liedje, "de herder met zijn kudde eenzaam dwaalde"?

Een heide in de Nederlands-Duirse grensstreek? Inderdaad waren eenzame heiden en uitgestrekie moerassen bij voorkeur gebieden waar doorheen lacer grenzen werden getrokken. Daaryan zijn vele yoorbeeiden bekend. '

Heiden in Zuid-Limburg? Zeker, elke Zuidlimburger kan er diverse opnoemen: in het gebied tussen de Graethei in het noorden, de Brunssummerhei in het oosten, de Mescherhei in het zuidwesten en de Panneshei bij Vaals in het zuidoosten liggen vele tientallen heidenamen."

Maar het zijn toch alleen namen voor dorpen of bossen, geen paars gekleurde vlakten waar, zoals op de zandgronden van Brabant en Drenthe, schaapskudden graasden? Dat is wel zo, maar de term heide betekende oorspronkelijk een droog schraalland in het bezit van de gemeente, dat door de dorpskudde werd beweid. Vandaar dat de Zuidlimburgse heidenamen ook op hellende delen van het landschap betrekking hebben en, als gevolg van een andere bodem dan zand- grond, een ander vegetatiedek droegen dan de door de sciort struikheide (Calluna vulgaris) in de bloeitijd paars gekleurde zandvlakten uit Drenthe (zie figuur 1.2). Bovendierı zijn vele heiden in de loop van de tijd onherkenbaar yeranderd in woonwijken, bossen, bouwlanden enzovoort, maar bleven hun naam heide houden. ${ }^{3}$

\subsection{Het woord Veriautenheide op het} verkeersbord is een goed voorbeeld van een toponiem. De wetenschap die deze namen als object van studie voor haar rekening neemt, is de toponymie. Tot toponiemen worden niet alleen de plaatsnamen gerekend in de gebruikelijke zin van het woord, dat wil zeggen de namen van menselijke nederzetcingen, maar ook namen voor percelen, namen voor landschappelijke eenheden of territoria met een nog groter oppervlak. In bredere zin behoren ook namen van straten en wegen hiertoe en zelfs die van waterlopen of -plassen van enige omvang en blijvende aard. Deze laatstgenoemde categorieẽn staan officiee! in de toponymie bekend als respectieveliik "hodoniemen" en "hydroniemen".

De toponymie is een taalkundige wetenschap; in deze studie wordt een bepaalde groep toponiemen vooral vanuit een landschapsoecologische invalshoek benaderd. Dit is in wezen een biologische benadering. Het onderwerp van studie betreft bovendien niet een geisoleerd toponiem, maar een complex daarvan dac, landschapsoecologisch gesproken, binnen hetzelfde kader valt.

Een dergelijk complex van toponiemen met cenzelfde landschapsoecologische achtergrond zou bijvoorbeeld kunnen bestaan uit een serie veldnamen voor akkers, afkomstig uit een bepaalde regio, of uit reeksen toponiemen die met bossen of weideplatsen te maken hebberı. De genoemde landschapseiementen hebben of hadden immers een duidelijk omschreven functie in het voormalig agrarisch-economisch gebruik van het landschap.

Het bestudeerde complex van toponiemen in het eerste deel van deze studie betreft heerdgang-indicatieve coponiemen, genoemd naar de rondgang van de heerd (een kudde onder leiding van een herder) op het grondgebied van een gemeente. Het al eerder genoemde toponiem Verlautenheide is daarvan eveneens een goed voorbeeld. Momenteel betrekking hebbend op een "Autobahnkreuz"., is het tevens de naam van een gehucht dat al rond 1800 bestond. De Tranchotkaart, daterend uit het begin van de vorige eeuw. ${ }^{4}$ geeft hieromtrent informatie: het gehucht Verlautenheid bestaat uit een grote hoeve en enkele kleinere behuizingen die rond een smal driehoekig pleintie zijn gelegen. Op het pleintie ligt een grote dorpspoel. De zuidelijke en westelijke omgeving van het 


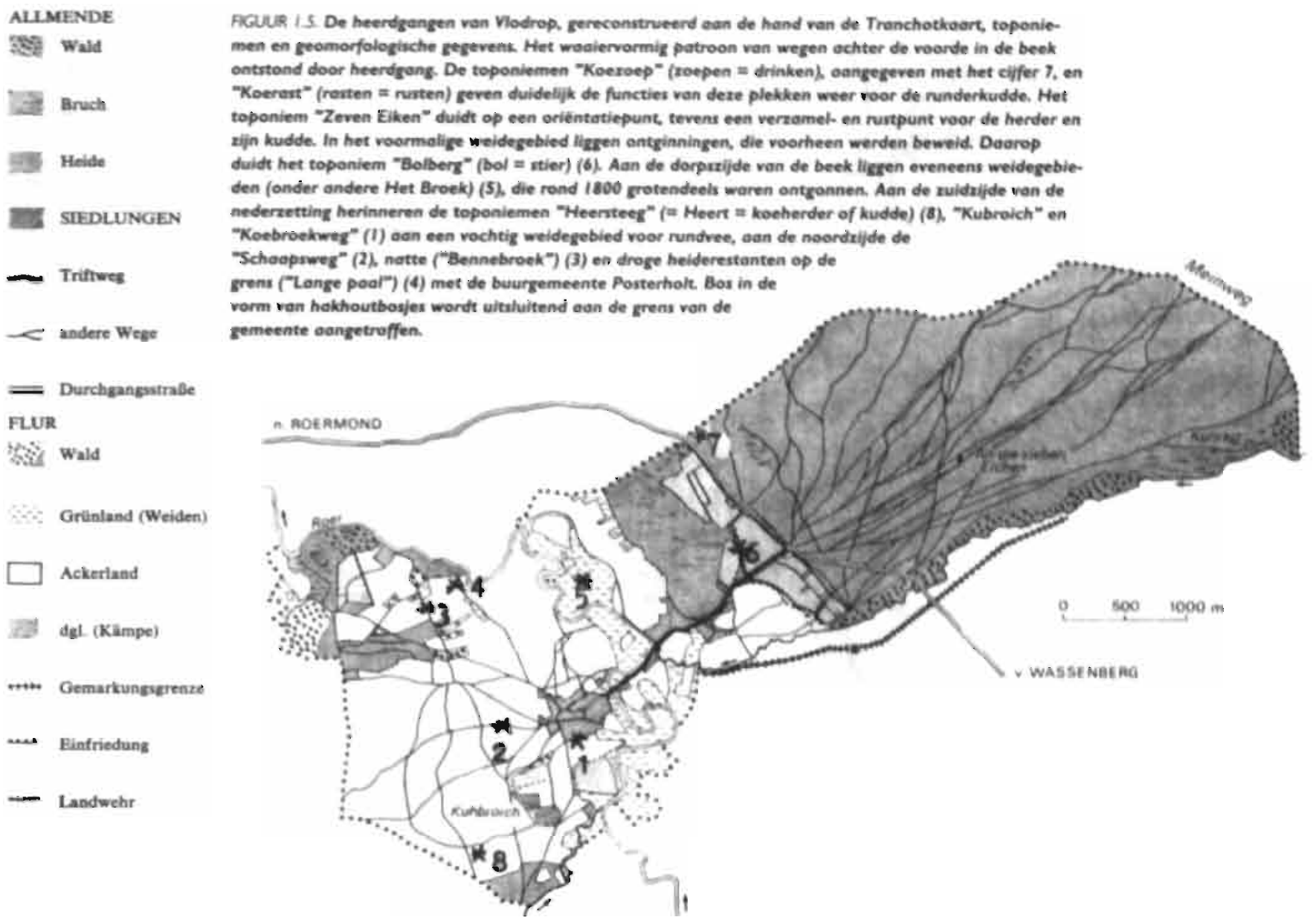

gehucht Verlautenheid bestaat uit een plateaurandheide met hier en daar verspreide begroeiing van struiken. Diverse groeven aan de plateaurand, waar kiezel en zand werd gewonnen, duiden op het onvruchtbare karakter van deze plateaurandheide (zie figuur 1.3 en 1.4) en tevens op de gemeenschappelijke rechten van een groep bewoners op dit gebied. Dergelijke nederzettingsvormen met de daaromheen gelegen gronden zijn uit vele delen van Europa bekend; ook in Zuid-Limburg komen ze voor. De in de omgeving van Verlautenheid gelegen nederzettingen Bochholzerheide en Bahneheide dateren uit de late middeleeuwen en zijn karakteristieke ontginningsnederzettingen. ${ }^{5}$

Er zijn behalve het woord heide meer benamingen voor graasplaatsen in toponiemen bewaard; bekend zijn onder andere beernd, broek en ooi, minder bekend zijn onder andere breul en pas. ${ }^{6}$ Afgezien van graasplaatsna men zijin er karakteristieke namen voor de wegen, waarlangs de kudde zich verplaatste tussen de nederzetting, waar het vee door de herder werd verzameld, en de weidegronden. Wegnamen als veestraat of gansbaan spreken voor zich, maar een groenstroot of een mes(t)weg verdienen toch enige toelichting. ${ }^{7}$ Een derde groep van heerdgang-indicatieve toponiemen heeft betrekking op de namen voor het verzamelpleintie binnen de nederzetting, wạar de herder 's morgens, voordat hij uittrok naar de: weidegronden, het vee verzamelde."

2.3 Om de juiste verklaring van een veldnaam te vinden, moet men zich eerst vergewissen van de betekenis van het woord of de delen daarvan. Het probleem begint meestal als een taalkundig verschijnsel, waarbij de oudste schriftelijke, vermelding en latere versies een rol spelen. Uit deze gegevens kan de taalkundige een poging ondernemen de oorspronkelịke betekenis van het toponien te doorgronden. Veel nederzettingsnamen zijn op deze wijze onderzocht." Kennis van het lokale dialect en zijn klankwetten is tevens een voorwaarde. Een reeks van dialectwoordenboeken. ${ }^{10}$ historische idioomcompilaties " ' en etymologische woordenboeken ${ }^{12}$ kunnen bij deze eerste stap van de analyse behulpzaam zijn. Soms zijn bepaalde woorden in toponiemen het onderwerp geweest van uitvoerige taalkundige studie, bij- voorbeeld dries, waarvan de resultaten in etymologische vakliteratuur zijn gepubliceerd. ${ }^{13}$ Voorts moet de toponymist een grondige kennis bezitten van gelijkluidende veldnamen elders in de streek. Dit zijn veldnamen die per regio of zelfs per gemeente op een verschillende wijze schriftelijk zijn weergegeven, maar die een opvallende overeenkomst vertonen wat betreft hun uitspraak. Nu eens kunnen deze worden gedefinieerd als waarschijniijke: fonetische varianten, dan weer als mogelijke symonymen. Hierbij moet worden uitgegaain van de gedachte, dat deze gelijkluidende veldnamen in het verleden een vergelịkbare betekenis bezaten; voor de ontwerpers en de gebruikers van toponiemen hadden deze benamingen een bepaalde betekenis, die momenteel niet of minder duidelijk kan zijn. Gelijkluidende veldnamen kunnen in diverse bronvermeldingen worden aangetroffen; alfabetisch gerangschikte registers van topografische kaarten vormen een belangrijike bron van informatie, " maar ook kadastrale kaarten, ${ }^{15}$ dorpsmonografieèn en gedecailleerde kaarten zonder register vermelden zeer veel toponiemen.

Een volgende stap die de toponymist dient te 


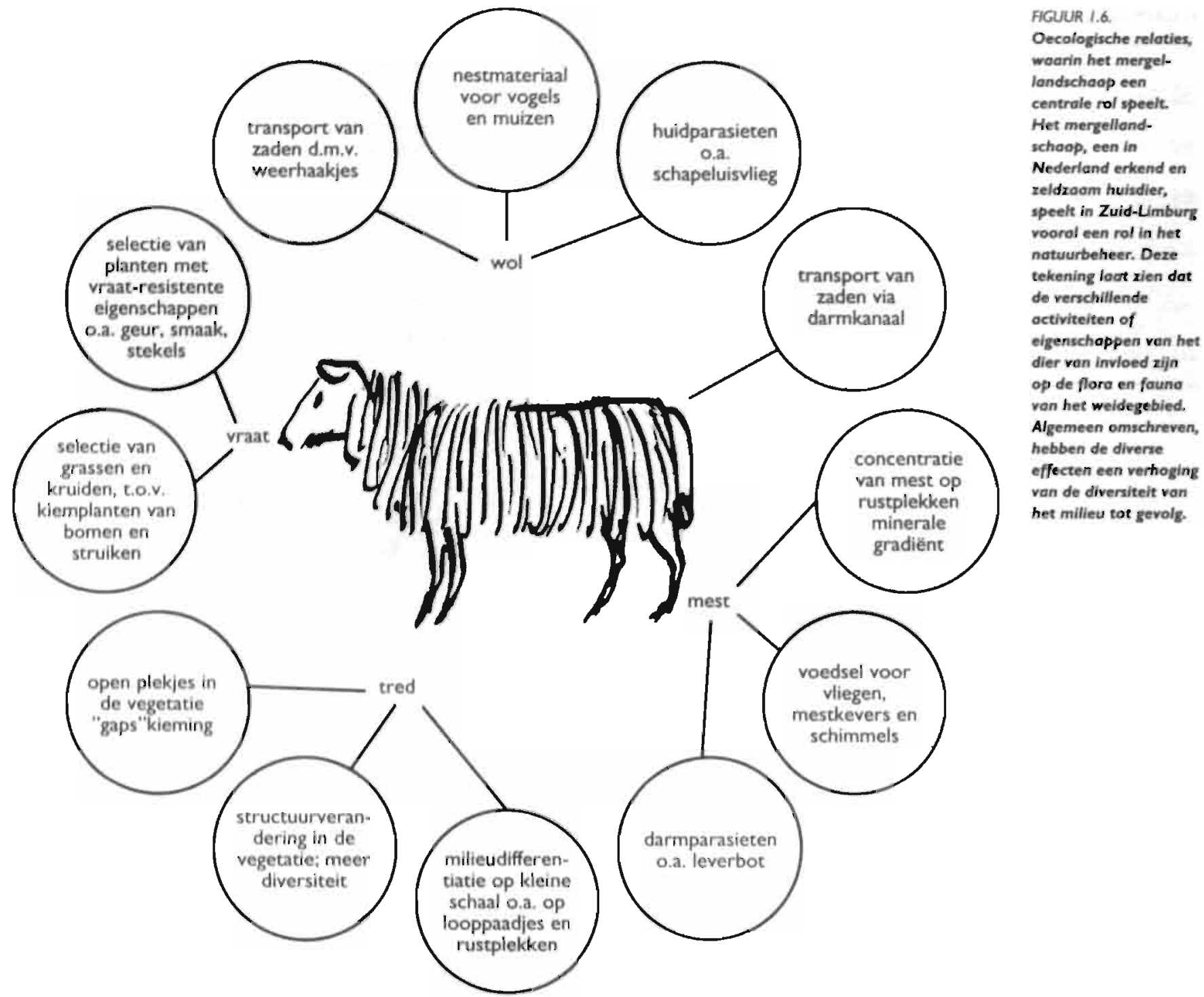

andernemen om een sluitende verklaring van de betekenis van zijn bronnenmateriaal te geven, is een zorgvuldige lokalisatie van gelijkluidende toponiemen, waarvan de beteke$\mathrm{nis}$ in een hypothetische fase verkeert, op kaarten die andere informatie verschaffen dan alleen de huidige topografie. Vooral de oudste historische kaarten van het gebied van onderzoek " mer de daarop aangegeven vormen van landgebruik, maar ook gedetailleerde kaarten die informatie geven met becrekking tot het relief en de bodem, spelen een belangriike rol bij het analyseren van de betekenis van heerdgang-indicatieve toponiemen. Op deze wijze kunnen bepaalde toponiemen, waarvan de betekenis onduidelijk was, worden ingepast in een heerdgang-kader en verkrijgen een nieuwe functionele betekenis. Wanneer een groot aantal heerdgang-indicatieve toponiemen binnen een nederzetting wordt aangetroffen, kunnen zelfs de heerdgangen per nederzetting worden ge- reconstrueerd (zie figuur 1.5).

De voor dit onderzoek meest belangrijike kaartenserie is die van Tranchot uit het begin van de vorige eeuw. Door nauwkeurigheid, detaillering en grote variatie in de legenda vormen deze kaarten prachtig studiemateriaal yoor historisch-oecologisch onderzoek. Aanvullende informatie ten aanzien van de betekenis van bepaalde toponiemen is verkregen door vergelijking van de lokatie, waarop het toponiem betrekking heeft met andere kaarten dan die van. Tranchot. Deze kunnen dateren uit de periode vóor Tranchot, maar zijn in dat geval minder nauwkeurig, niet vlak-dekkend, zoals de Ferrariskaarten, of hebben slechts betrekking op kleine delen van het gebied yan onderzoek, zoals bijvoorbeeld de gemeentekaart van Simpelveld uit 1580, van Rolduc en omgeving uit circa 1776, van Swalmen uit 1774 en van Jabeek uit circa 1700. Voor een vergelijking uit de periode na de Tranchotkaarten is gebruik gemaakt van, in chronologische volgorde, de Grote Historische Atlas van Nederland uit deperiode 1838-1857, de Kuyperkaarten uit de periode 1860-1865, de Chromotopografische Kaart des Rijks uit de periode 1890 1924 en tenslotte een aantal vlak-dekkende kaarten die dateren uit de periode na 1924 . Met behulp van dit kaartmateriaal is retrospectief, retrogressief en chronologisch onderzoek mogelijk. Deze methodieken hebben respectievelijk betrekking op het zoeken naar een verklaring voor de aanwezigheid van relicten in het huidige landschap, het zich verplaatsen in de tijd en met behulp van het kaartbeeld het landschap trachten te analyseren en het weergeven van een historische ontwikkelingsgang in het landschap vanaf een bepaald tijdstip in het verleden naar het heder. ${ }^{17}$ van aard. De oecoloog bestudeert, algemeen 
RGUUR 1.7 .

Het gebied von onderzoek, het ruldelijk deel van de Nederlandse provincle Limburg en de doaraan grenzende. delen ran BelginchLimburg en Duitalond.

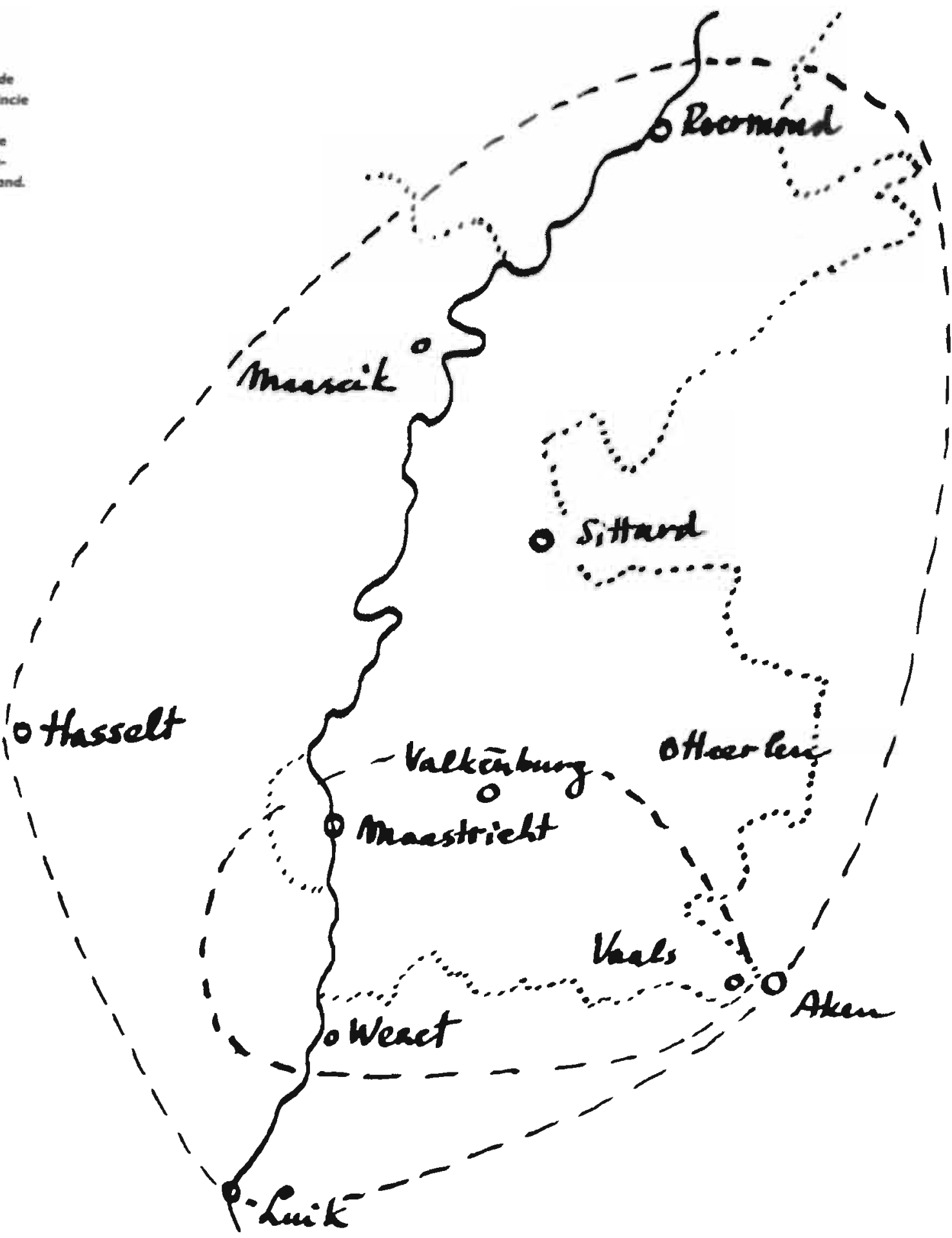

gesproken, relaties in de natuur. Dit kan één relatie zijn, bijvoorbeeld een voedselrelatie tussen één of meer soorten planten of dieren, maar er kunnen ook verscheidene samenhangende relaties worden bestudeerd. De meest eenvoudige bestaat uit de betrekking tussen twee soorten, bijvoorbeeld de afhankelijkheid van de eikegalmug en de soort die haar voedsel verschaft, namelịk de eik. Meestal bestudeert de oecoloog de betrekkingen tussen meer soorten, zoals schaap-mens-grasland-relaties (zie figuur 1.6), of een graep van verwante soorten, bijvoorbeeld de rol van mieren in een bepaald graslandtype.

Het aantal typen van relaties in de oecologie is al aanzienlijk en de complexiteit van het netwerk van betrekkingen neemt nog veel meer toe naarmate het studiegebied rijker wordt aan soorten. Dit is zeker het geval in het heidebiotoop, voor zover dat nog plaatselijk intact is. Ter illustratie: de Bemelerhei, momenteel een natuurreservatịe van amper 6 ha, telt alleen al minseens 300 soorten bloemollanten en een onbekend veelvoud daarvan aan sporeplanten, meer dan 50 sogrten gewervelde dieren en een eveneens onbekend veelvoud daarvan aan ongewervelden. ${ }^{18}$ Het aantal relaties daartussen is zeer groot en slechts een fractie is onderzocht. Desondanks bestaar de indruk dat er ten aanzien van de oecologische kennis van heiden in Zuid-Limburg, geobotanisch gedefinieerd 


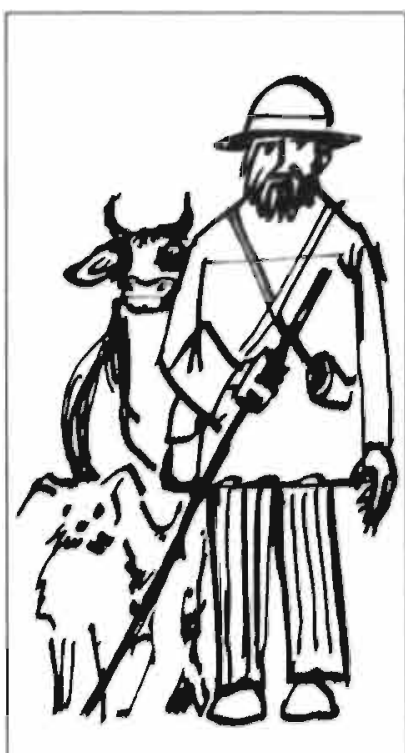

FIGUUR 1.80 De "heert" of koeher der. De karakteristieke ottributen van dexe dorpsfunctionaris tijn een algnoalhoom, vervaordigd uit een rote runderhoorn, een tas voor mondvoorraad en drank en een stok of staf. Schets von de "schweitxer" Willem Dolmans ult Meorssen, clrco 1910.

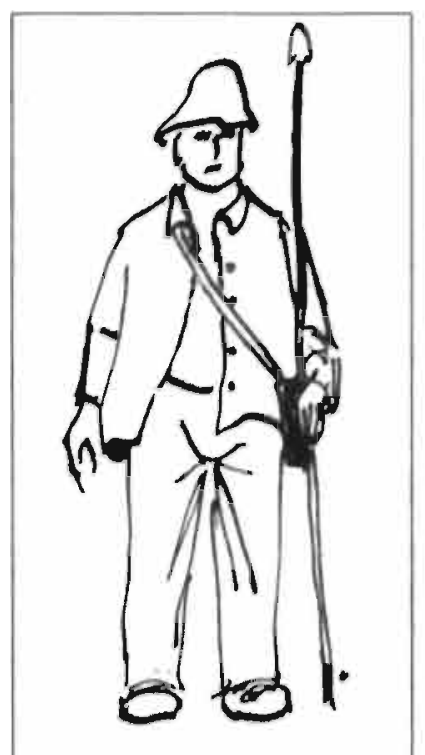

FGUUR I.8b Dr "schoper" of schaopherder. Zijn karakteristieke ottribuut bestend uit een stor. voorzien ven een schople, waormee oardluiten of stcentjes noor ofdwalende schopen konden worden gegooid. De hond reageerde op deze octle ein dreef het schoop terug noor de kudde (zie HuLegens $1982 \mathrm{c}$ ). Schetir van Wum Vroom, de loatste scheper van Bemelen, noor een fote uh 1970 (zie Hulegens 1984a, p. 16).

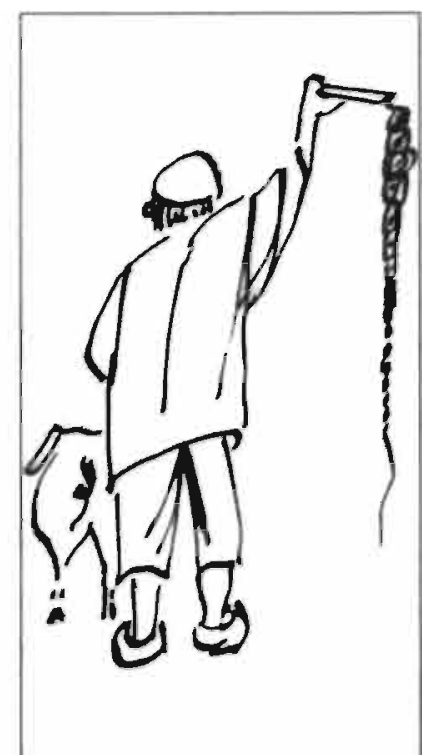

FIGUUR I.8C De "swreen", "verkeslonis" of varkenshoeder met zijn vervaarlijke rweep, bestoande uit een hort handvat en een uit leren lussen vervoardigd bewegend deel. Twee derzelijke xwepen xijn door een toeval bewaard gebleven (zie Huscias 1989 ). Schets noor een apbeelding uit de negentiende eeuw door een Moastrichese illustrotor (xle YAN DEN ABseELE, in This al vont Vercken 1988, p. 224).

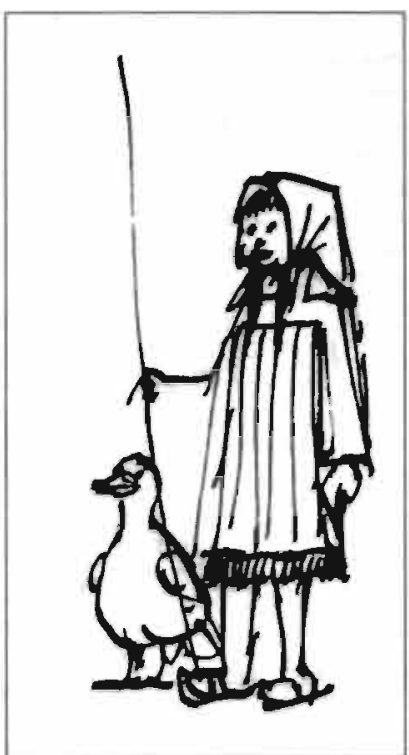

FIGUUR 1.8d" "Gawzelieske" vergelijk het Duitse Gänzelieschen -, het ganxenhoedstertje, is bekend uit de volksverhalen. Het rtadje Wezet (Vise) houd de herinnering aon haor en hoar ganzen levend. als kalkgraslanden en daaraan verwante droge schraallandtypen, heel wat bekend is. Het aantal titels van geschriften betreffende één enkel droog schraalland in de Euregio, bijvoorbeeld de Sint-Pietersberg, bedraagt momenteel $980 . .^{19}$ Desondanks mag worden gesteld. dat er nog vele hiaten in de oecologische kennis ten aanzien van dit biotoop bestaan. De bijdragen van de schrijver aan de oecologie van de heide, gepresenteerd in deel II van dit boek of eerder gepubliceerd, moeten dan ook in dit licht worden bezien. Slechts één oecologische techniek, die werd gebruikt bij de hoofdstukken 10 en 14, verdient een korte toelichting: het maken van een vegetatie-opname. Deze bestaat uit het afbakenen van een representatief deel van een vegetatie, het opstellen van een soortenlijst van alle daarin aanwezige plantesoorten en het vervolgens door middel van cen cijfercode aangeven hoeveel exemplaren van die soort er voorkomen of welk percentage van het proefvlak deze bedekken.

Met behulp van deze gestandaardiseerde methode kunnen vegetaties onderling worden vergeleken om bijvoorbeeld hun graad van verwantschap te berekenen. ${ }^{20}$ De naamgeving van plantesoorten volgt Heukels en
Van der Meijden, die van zoogdieren Van den Brink en die van vogels Peterson en anderen.

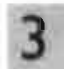

Tot slot van dit inleidend hoofdstuk nog enige opmerkingen ten aanzien van de begrenzing van deze studie, die niet alleen betrekking heeft op het gebied van onderzoek. maar tevens op de inhoud. Vervolgens wordt kort ingegaan op het doel van deze studie. Het. centrale deel van het gebied van onderzoek omvat het Mergelland; dat deel van de Nederlandse en Belgische provincie Limburg waar plaatselijk kalkhoudende gesteenten aan de oppervlakte komen. Daaromheen gelegen delen van de Nederlandse provincie Limburg, van de Belgische provincies Limburg en Luik en een klein deel van de dee!staat Nordrhein-Westfalen in Duitsland zijn tevens betrokken in het hele onderzoeksgebied, dat globaal een gebied omvat tussen de steden Roermond in het noorden, Hasselt in het westen, Luik in her zuidwesten en Aken in het zuidoosten (zie figuur 1.7). Niet zonder reden wordt dit gebied recent aangeduid met de terrn Euregio. letterlijk uit het. Griekse $\mathrm{eu}=$ goed en de oorspronkelijk uit het Latijn afkomsitige term regio $=$ koninkrijk of landstreek, warbij duidelijk, wordt vooruit- gelopen op een Europese gedachte om dit zeer oude kernland van Europa een model te laten zijn voor het toekomstige Europa zonder grenzen.

De inhoudelijke begrenzing van dit werk betreft één bepaalde vorm van extensieve beweiding, namelijk de heerdgang. Zoals blijkt uit figuur 1 . I bestaan er op wereldschaal diverse vormen van weidegang. Binnen Nederland worden daarvan momenteel twee vormen in het kader van het natuurbeheer toegepast. Een vorm, die bijvoorbeeld in het bekende natuurreservaat De Oostvaardersplassen wordt toegepast, vindt plaats binnen cen raster, zonder herder, met minstens twee soorten herbivoren en in een groot gebied. De andere vorm vindt plaats zonder raster, met een herder en een kudde die slechits uit éen socri herbivoor bestaat en die een gebied beweidt met een betrekkelijk geringe omvang. Alleen de laatstgenoemde vorm van extensieve, beweiding vormt de voortzetcing van de traditionele heerdgang (zie figuur 1.8 a tot en met $d$ ), die in dit boek ter sprake kome. Het doel van deze studie is drieledig, overeenkomstig de driedeling in de ondertitel "Verleden, heden en toekomst". Deel l'geeft inzicht in de betekenis van de ex- 
tensieve beweiding in het verleden. Die betekenis wordt geschetst aan de hand van toponiemen, die op de voormalige heerdgang betrekking hebben. Het blijkt dat de betekenis dusdanig groot is dat, ofschoon weinigen zich dit realiseren, tal van huidige straatnamen en veldnamen in elk dorp de herinnering aan de voormalige heerdgang levend houden. Bovendien kan het huidige patroon van wegen en bebouwing in de oude kern van bijna elke nederzetting deels worden herleid tot een patroon van veewegen en verzamelplaatsen. Zelfs kan de ontginningsgeschiedenis van het gebied van onderzoek globaal worden geschetst aan de hand van het verschijnsel van de voormalige heerdgang.

Deel II behandelt actuele oecologische thema's, waarin telkens extensieve beweiding aan de orde komt. Het zal de lezer duidelijk worden, dat deze methode van beheer van delen van het Zuidlimburgse landschap een voortzetting is van het traditionele beheer en goede garanties biedt voor herstel van "verwaarloosd" natuurgebied. De hoofdstukken van deel II zijn twee aan twee gekoppeld. De oneven genummerde hoofdstukken behandelen algemene oecologische thema's, het daaropvolgende even genummerde hoofdstuk is daarvan een afgeleid detailonderwerp.

Deel III beslaat éen hoofdstuk. Hierin wordt uiteengezet dat de methode van de extensieve beweiding een belangrijke rol zal gaan spelen in het beheer van natuurgebieden. " bescheiden rol die deze methode momenteel speelt, zal in de toekomst moeten worden uitgebreid door onder andere het stichten van meer kudden onder leiding van herders, die behalve natuurreservaten ook wegbermen begrazen, evenals overhoeken, groenstroken, bossen gedurende de winter, braakliggende akkers en andere grazige vegetaries die aan de produktiesfeer zijn onttrokken. Alleen op deze wijze kan een halt worden toegeroepen aan het ernstige verlies van diversiteit in flora en fauna sinds het einde van de Tweede Wereldoorlog. Zelfs verarmde graslanden kunnen met behulp van deze methode worden hersteld of veranderd in bloemrijke graslanden met de daarbij beho. rende soorten vlinders en andere fauna-elementen. De praktijk heeft geleerd dat het kan, ondanks drijfmest, zure regen en anderefactoren die het milieu momenteel bedreigen. De fase van het experiment is voorbij; herintroductie van de extensieve beweiding in bepaalde natuur-en recreatiegebieden binnen de Euregio is nu een politieke keuze.

\section{NOTEN}

1 De Brunssummerheide en de moerassige boorden van de Rode Beek vormden een natuurlijke grens tussen Duitsland en Nedertands-Limburg, de Peel scheidde Brabant en Limburz, het Oostermoer de provincie Groningen en Duitstand enzovoort

2 Zie Hulucers 1980 en tabel 1.

3 Zie tabel 1.

Zie Lust van kaarten.

Zie Renes 1988

Zie hooldsruk 2

Zie hoofdstuk 5 en 6

Zie hoofdituk 3 en 4

9 Zie onder andere De Vues 1958 en 1971. VAN VurN 1969 , Grsstunc 1960 , Mansion 1935 en Bejens et at 1991, die raakvlakken van het onderzoek naar veldnamen met andere wetenschapsdisciplines dar taslkunde en historie (onder andere agronomie. reografie, biologie) belichten.

10. Men raadplege de woordenboeken van de dialecten van Aken, Maastricht, Roermond, Gronsveld, Kerk. rade. Sitcard en Valicenburg (respectievelijk HikMANes 1970, ENotrous 1955, KATs 19eS, jasuns 1979. AMKNEurz et at. 1987, Scrulatho 1979 en Donuen (928)

11 Zie Kunen 1975, Venwys et at 1855-1941

12 Zie De Vhass 1958 en VAN Vun $198 \%$

13 In onder andere Mededelingen van de Vereniging. voor Naamkunde te Leuven en de Commisie voor Nasmkunde te Amsterdam

If Zie Topografischeatiassen (met registers), vermeld in de List van kaarten.

15. in het archief van het Social Historisch Centrum te Mastricht berust een verzameling kadastrale kaar ten van landmeter Stroom, wasrop xeer veel toponiemen zijin vermeld.

16. De belangrijkste historische kaarten vanhet onderzoeksgebied zịir, in chronologische volgorde: de Ferrariskaart, daterend van hes einde van de achetiende eeuw, de Tranchockaart uit her begin van de negentiende ceuv, de zogenaamde militairo kaart (zie Hal). de gemeentekaarten uit hec midden van de negentiende eeuw en de eerste topografische kaarters, daterend van de periode 1890.1924. Zie List van kaarten

17 Zie RENESi $1986, p$ i 13

if HILLEERS 1984a.

19 VAN SCHAIK 1983

20 Deze merhode wordt uitwoerig besproken door WESTHOFF en VAN DER. MAMREL Zie Clessification of plant communities 1976. MELTZER EN WESTHOH 1944 en LONDO 1975 ,

21 Zie tevens HILIFGERS 1990 


\title{
HEERDGANG-INDICATIEVE TOPONIEMEN
}

\author{
pastor, pastoor, pâtre, pâturage, pas, pesch... \\ heide, hei, fietje, fitje, Fé, hedsche... \\ feert, Koefwert, fierd, Hirt, fierder, heertweg...
}

I

Het eerste deel van de samenstelling heerdgang, ook wel als heer( $t$ ) of heerde geschreven, is in de Germaanse talen en in sommige delen van het Romaanse taalgebied een synoniem voor kudde. Vergelijk het: Engelse herd en her Duitse Herde voor kudde. De daarvan afgeleide woordvorm herder is Nederlands. In het Duits heet deze functionaris Hirt, in het Waals' is hierdt een koeherder. De huidige Nederlandse schrijftaal kent het woord heert niet meer, maar sommige dialecten nog wel: meeheer is Drents voor hulpscheper, ${ }^{2}$ kooheert is koewachter of koeherder. De laatste variant is uit onder andere Zuid-Limburg bekend. ${ }^{3}$ In de Belgische Kempen sprak men van een heerdgang. Ofschoon de woordvorm heerdgang in de Belgische Kempen ook de betekenis had van "een gehucht met de daaromheen gelegen gronden, waar de bewoners het recht bezaten daarop een kudde met een herder te laten grazen", is de meest gebruikelijke bete-

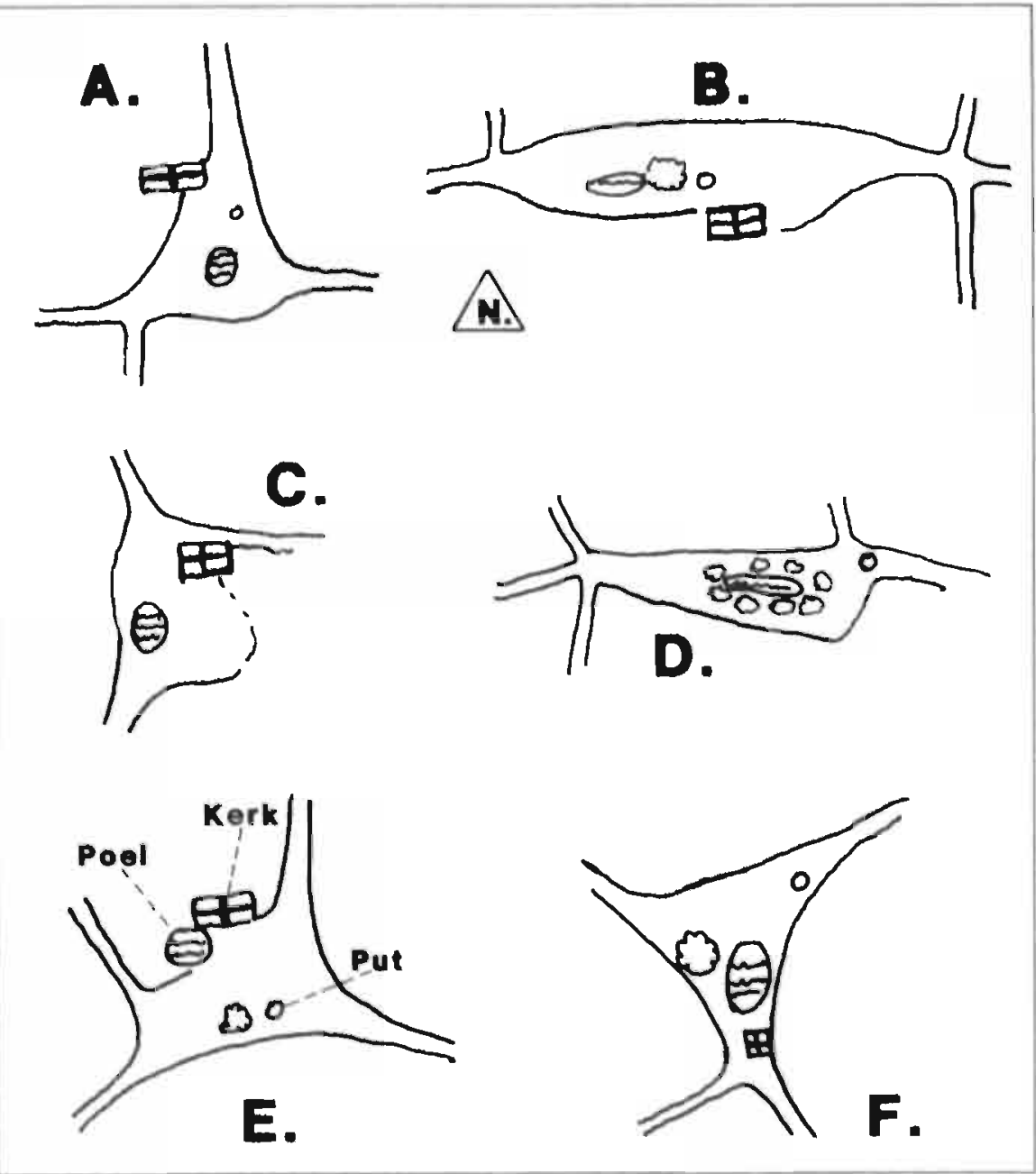

FGUUR 21, Vormrariaties van het dorpspleintje in verband met de vee

verzamelende functie. De hier afgebeelde pleintjes van Eckelrade (A), Codier en Keer (B), Jabeek (C), Bahneheide (D), Margraten (E) en Termaar (F) zljn geschecsit noar de Tranchotkaart of naar de Historische Atlas.

kenis van heerdgang "de dagelijkse rondgang van een herder met zijn kudde binnen de gemeente". ' Deze studie hanteert dit begrip uitsluitend in die laatste betekenis.

Binnen het huidige Noordwest-Europa met uitzondering van Lapland in het hoge noorden, is de zuiver pastorale bedrijfsvoering met het daaraan gekoppelde nomadisch bestaan verdwenen. Het houden van vee is er verbonden met zowel een agrarische bedrijfsvoering als een sedentair bestaan. Slechts hier en daar, met name in de bergen van Centraal-Europa, komt nog een vorm voor die met de Franse term "transhuman$\mathrm{ce}^{\text {"5 }}$ wordt aangegeven. Een dergelijke migratie van een kudde onder leiding van een herder die tweemaal per jaar wisselt tussen een winterbeweiding in het laagland en een zomerbeweiding in de bergen, is in Zuid-Limburg en omgeving onbekend. Hoogstens kan worden gewezen op de telkens eenmaal per jaar terugkerende trek van schaapskudden vanuit Noord-Limburg naar de markten van Parijs tijdens de vorige eeuw. ${ }^{6}$

In het gebied vari onderzoek was de dagelijkse heerdgang beperkt tot de eigen gemeente en stond mede in dienst van de landbouw. Deze vorm van veehouderij kwam hier algemeen voor. In de agro-pastorale bedrijfsvoering, het zogenaamd gemengd bedriif, werd vee vooral of ook om de mest. gehouden. Daartoe: werden de dieren gedurende de nacht opgestald. Mest en gier, vermengd en vastgehouden door stalstrooisel en in een. later stadium op het bouwland uitgespreid, bepaalde grotendeels de opbrengst van het akkerareaai.

Tijdens de periode van de geschiedenis van de landbouw, waarin het gemengde bedrijf noodzaak was, kan een tweetal fasen worden, onderscheiden met betrekking tot de wijze van veeteelt. In de eerste fase kende men uit. sluitend de gemeenschappelijke heerdgang. onder leiding van dorpsherders, naar gemeentelijke weidegronden. In de latere fase wordt elk type vee ondergebracht in particuliere standweiden of in andere afgesloten 
ruimten en verblijft daar zonder herder. Onder heerdgang-indicatieve toponiemen die uit die eerste fase stammen, ressorteren veldnamen in de brede zin van het woord, die in verband staan met de dagelijkse rondgang van de kudde onder leiding van de herder. De heerdgang verliep als volgt's morgens vroeg verzameide de herder de dorpskudde op een bepaalde open plaats in denederzetting, vervolgens trok hij uit via veedriften, die, voor zover ze binnen de nederzetting en het daaromheen gelegen akkerareal lagen, waren omzoomd met hagen of andere veekeringen. De bestemming van de heerdgang werd gevormd door de vitgestrekte weidegronden, gelegen binnen het grondgebied van de nederzetting: de grenzen van de dorpsgemeente mochten uiteraard niet worden overschreden. Daar verbleef de kudde gedurende een groot deel van de dag, niet alleen om voedsel op te nemen, maar ook om op vaste plekken te rusten. In de late namiddag keerde de kudde onder leiding van de herder terug naar de nederzetting, waar de kudde op een centrale plaats werd gedrenkt alvorens de beschutting van de stal op te zoeken. ${ }^{7}$

2.1 De in de volgende paragrafen gebruikte indeling der heerdgang-indicatieve toponiemen berust op het hierboven geschetste verloop van de heerdgang. Eerst worden de in toponiemen vastgelegde verzamelterritoria in de nederzetting besproken, dan komen de synoniemen voor veedrif- ten en vervolgens voor weideplaatsen aan de orde. Tenslotte vormt een restgroep van toponiemen een aparte vermelding. Deze duiden op verschillende veekeringen rond tuinen en akkers, die de gewassen tegen vraat door vee moesten beschermen. Onder de restgroep ressorteren tevens namen van grensmarkeringen en andere oriêntatiepunten voor de herder in het beweide gebied. Drenk-toponiemen sluiten de restgroep van heerdgang-indicatieve toponiemen af. Het punt van vertrek van de heerdgang bestaat uit een omheinde ruimte, gelegen in de kern of aan de rand van de nederzetting en met een naar één of meer zijden taps toelopend oppervlak, dat het naar buiten drijven van de kudde vergemakkelijkt." De ideale yorm is een driehoekig of spoelvormigpleintie, waaraan op elk punt een afsluitbare veedrift ontspringt. Dergelijke pleinties zijn uit meerdere Europese landen bekend. In Engeland spreekt men van green, in Duitsland van Anger, in Brabant van opstal, heuvel of ploots, in Noordoost-Nederland van brink. In ZuidLimburg komt dit toponiem niet voor: ze heten hier bies(t), dries, plats, plei of, naar een andere functie van het pleintie, markt ${ }^{10}$

Uit toponiemen, literatuur en afbee!dingen is verder bekend, dat deze dorpspleintjes met een vee verzamelende functie konden worden afgesloten door beweegbare klaphekken, valhekken of andere constructies, waardoor het vee niet zonder toezicht van de herder hetpleintje kon verlaten. Wei kon het vee vrijelijk gaan drinken aan een op het plein gelegen poel (zie figuur 2.1). ${ }^{11}$

De tweede categorie van heerdgang-indicatieve toponiemen bestaat uit veedriften en hun synoniemen. Deze routes beginnen op het dorpsplein en eindigen in het beweide gebied. Veedriften en hun synoniemen komen in toponiemen van het onderzoeksgebied frequent voor in de vorm van collectiefaanduidingen, bijvoorbeeld veestroat of als anduiding per diersoort, bijvoorbeeld schaopsweg. Men treft ze ook aan in de vorm van samenstellingen, waarin de naam van een beweid territorium wordt gecombineerd met een route-aanduiding, bijvoorbeeld heideweg. In deze gevallen blijkt de driftunctie onmiddellijk en ondubbelzinnig uit de naamgeving van de betreffende weg (zie figuur 2.2). Er zijn echter ook veedriften, waarvan de naam niet op een directe wijze samenhangt met de driftunctie. Een voorbeeld uit deze categorie secundaire veedriftnamen zijn de groenstroten en -wegen. ${ }^{12}$ De term groen is hier waarschijnliịk synoniem voor groenland, een term die in het huidige Limburgse taalgebruik in onbruik is geraakt, maar vroeger werd gebruikt om permanent grasland aan te duiden. Andere secundaire veedriftnamen hebben betrekking op hun karakteristieke vorm, profiel of substraat van de weg, die een voormalige heerdgang veronderstelt.

2.2 Tot de categorie secundaire veedriftnamen behoren onder andere de mest-

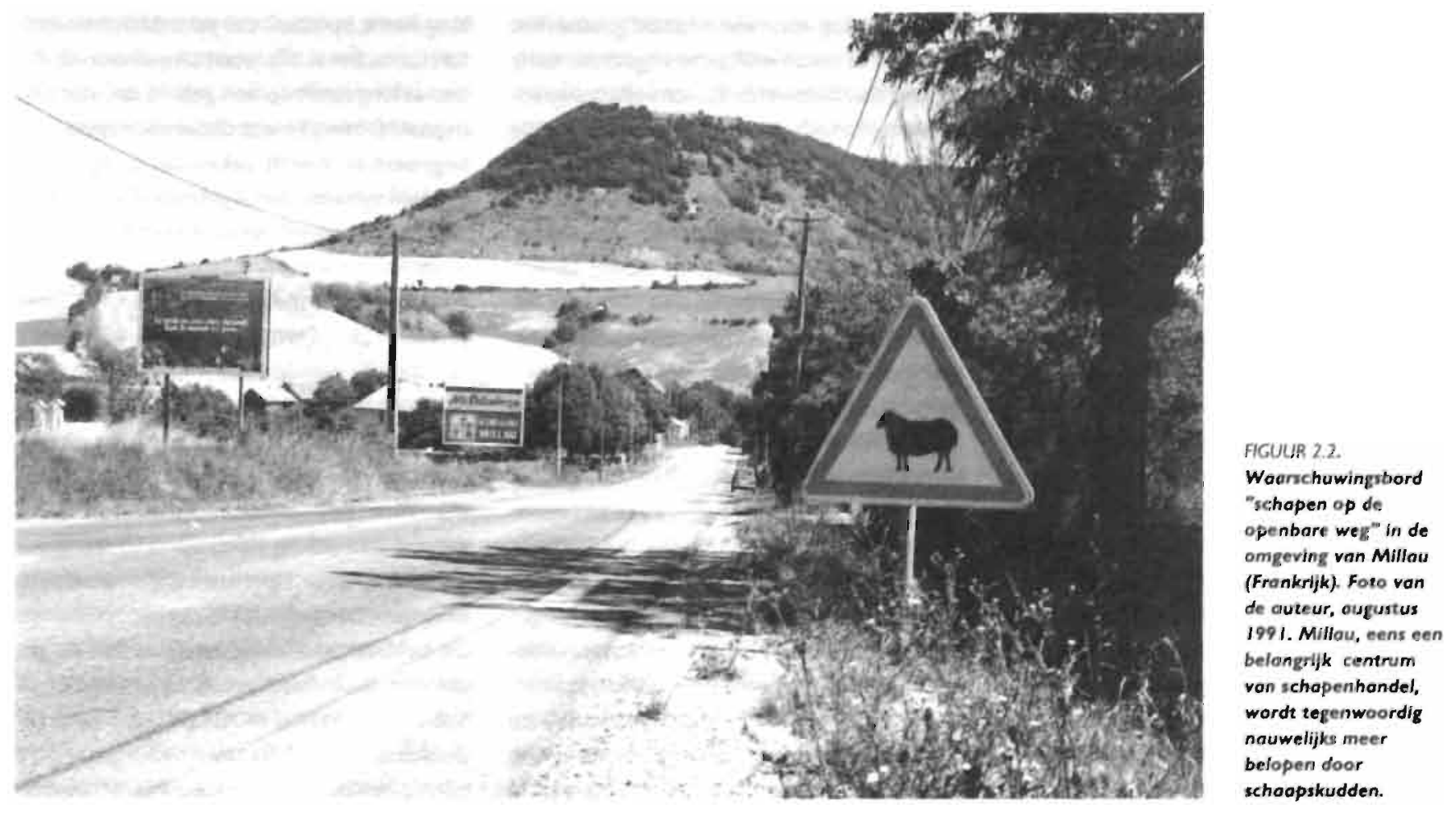




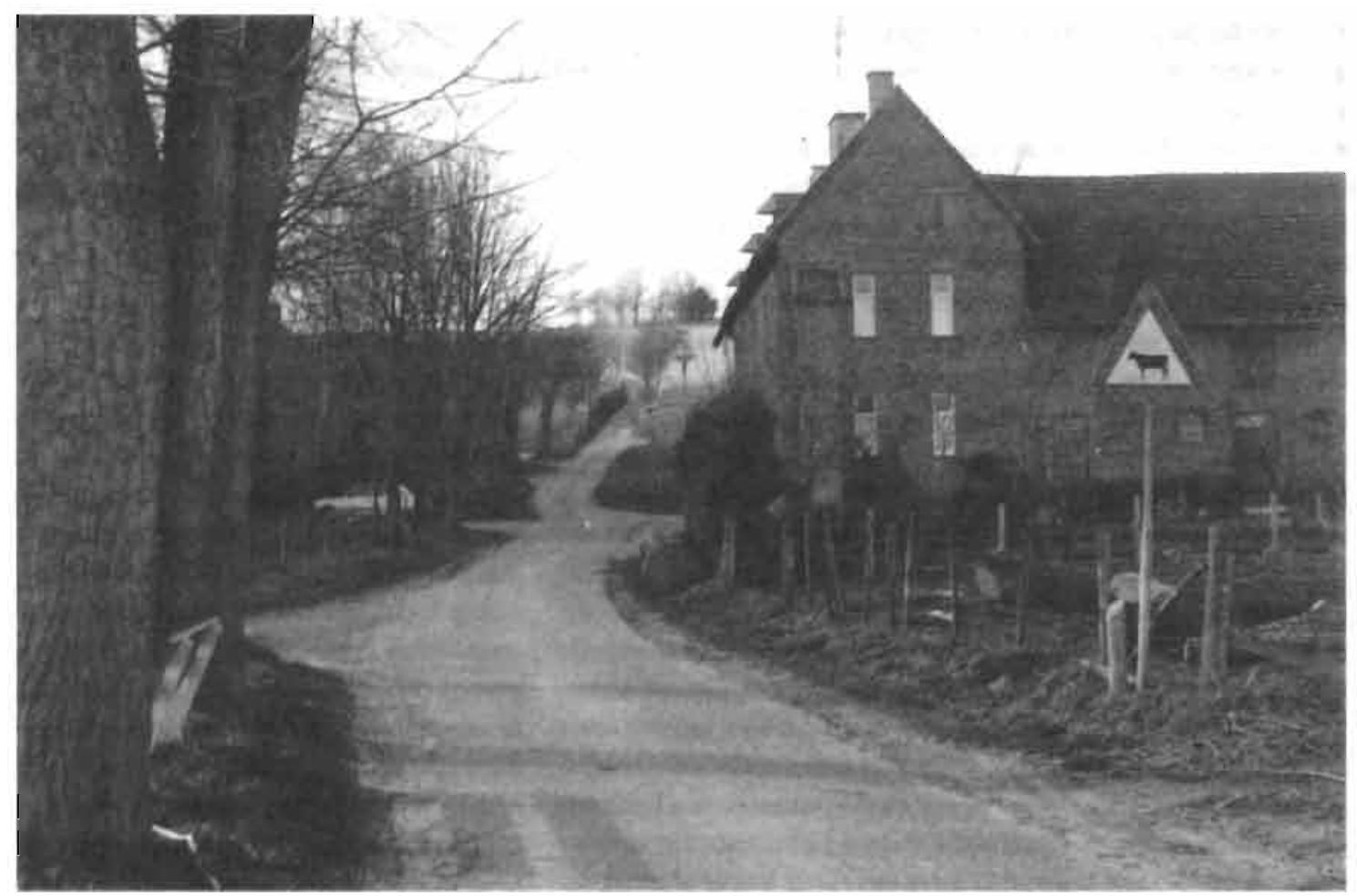

FIGUUR 2.3.

Holle weg met:

verkeersbord

"loslopend rundvee"

bij/ hoeve "De Bek" te

Gujpen. Foto van de

auteur, september

1989. De dagelijise

heerdgang, in dit geval

naar de Guipenerberg

is mede verantwoorde-

lijk geureest voor het

ontstaan van holle

wegen in Zuid-

Limburg. Het bord

heeft op dit moment

nouwelijks meer een

functie.

wegen en hun synoniemen die hun naam te danken hebben aan de door kleur, geur en omvang karakteristieke runderuitwerpselen op de veedrift. ${ }^{13}$

Een volgende groep secundaire veedrifinamen heeft betrekking op de karakteristieke omzoming docr hagen of andere veekeringen die moesten voorkomen dat de kudde kon binnendringen in moestuinen, boomgaarden of akkers. Het toponiem haogstraat en synoniemen daarvan komen algemeen voor in her gebied van onderzoek. Holle en brede wegen zijn tevens ideale veedriften. De steile randen, vaak met bomen of struikgewas begroeid, voorkomen het ontsnappen van een dier uic her kuddeverband (zie figuur 2.3). Brede wegen vergemakkelijken het drijven van de kudde. Uit vroegere reglementen ten aanzien van de wegbreedte kan worden afgeleid, dat veedriften tot de breedste categorie wegen in het verleden behoorden. " Zowel de vorm als de aanzienlijke breedte. waren dusdanig karakteristiek, dat deze eigenschappen de namen van dergelijke wegen bepaalden.

Op de plaats waar de veedrift uitmondde in het beweide gebied ontstond een waaiervormig wegenpatroon; het vee kon hier in het beweide gebied letterlijk zijn eigen gang gaan. Bedoeld waaiervormig patroon van wegen. op oudere kaarten duidelijk herkenbaar, is: vaak nog zichtbaar in het huidige wegenpatroon van bepaalde nederzettingen. In de to- ponymie staat dit punt soms geboekstaafdals einde.

\subsection{Net als de namen voor veedriften} zijn benamingen voor beweide gebieden frequent vertegenwoordigd in toponiemen. ${ }^{15}$ In raalkundig opzicht vallen de namen voor beweide territoria in twee groepen uiteen. Eén groep omvat in een samenstelling zowel de. naam van een gedomesticeerde herbivoor als de, aanduiding voor een bepaa!d gebied met een min of meer uniforme vegetatic, zoals bijvoorbeeld koeweide. Een tweede groep toponiemen. die betrekking heeft op beweide delen van de dorpsgemeente, is niet samengesteld. Deze woordvormen، zoals bijvoorbeeld beemden en het toponiem Op de Koo, hebben dezelfde betekenis als de eerste groep, nameliik weideplaatsen.

Gedomesticeerde herbivoren worden in samengestelde toponiemen vaak collectief ạangeduid, zoals in veeweide, soms ook per soort (schoopsbroek), per leeftijdsklasse van een soort (lammerdel) of per geslacht van een soort (koekamp). Met name voor het rundvee zijn er vele varianten.

Het schaap wordt in toponiemen van het gebied van onderzoek minder frequent genoemd dan de koe. Zeldzamer zijn toponiemen, waarin het woord geit voorkomt. Paarden worden eveneens zelden in toponiemen met name genoemd. Een aparte categorie vormen de begraafplaatsen voor het vee: in deze toponiemen komt het element paard meer voor:

Ook namen van andere soorten vee dar bovengenoennd, met name varkens en ganzen, komen voor in coponiemen die betrekking hebben op weidegronden. Het is een aanwijzing dat ook deze dieren onder leiding van eer herder buiten de nederzetting werden geweid.

De laatse categorie toponiemen, die betrekking heeft op door dorpskudden beweide territoria, bevat of bestaat uit een woord, dat betrekking heeft op een gebied dat met een bepaalde, min of meer uniforme vegetatie is: begroeid en wordt gekenmerkt door een bepaald agro-pastoraal gebruik. De substantiva broek, beemd, ooi en weerd, die vaak in toponiemen voorkomen, zijn indicatief yoor zowel grazig-kruidige vegetatietypen, gelegen in beek- of rivierdalen en geven tevens: aan dac hier destijds beweiding in kuddeverband plaats vond. Hetzelfde gelde voor enkele andere substantiva, zoals breul, pas en eng. Deze termen komen uitsluitend in toponiemen voor. Toponiemen waarvan de woordinhoud betrekking heeft op drogere, voor beweiding door rundvee minder geschikte biotopen, bevatten de elementen hei of dries. Ze hebben betrekking op delen van de gemeente, die buiten het overstromingsbereik van beken of rivieren zijn gelegen. Zelfs toponiemen, waarin de substantiva bos of berg. zijn opgesloten, kunnen duiden op bewei- 
FRUUR 2.4

Dorpaplein met poel te Heer in 1670 . Tekening ron fosude de Grave. Centroal ligt de drenk de moestuinen slin omgeven door een veekering de vegetatie op het plein is spadarnoom en bomen verlenen schadurw. De overeenkomit met Drentse brinken is oprallend.

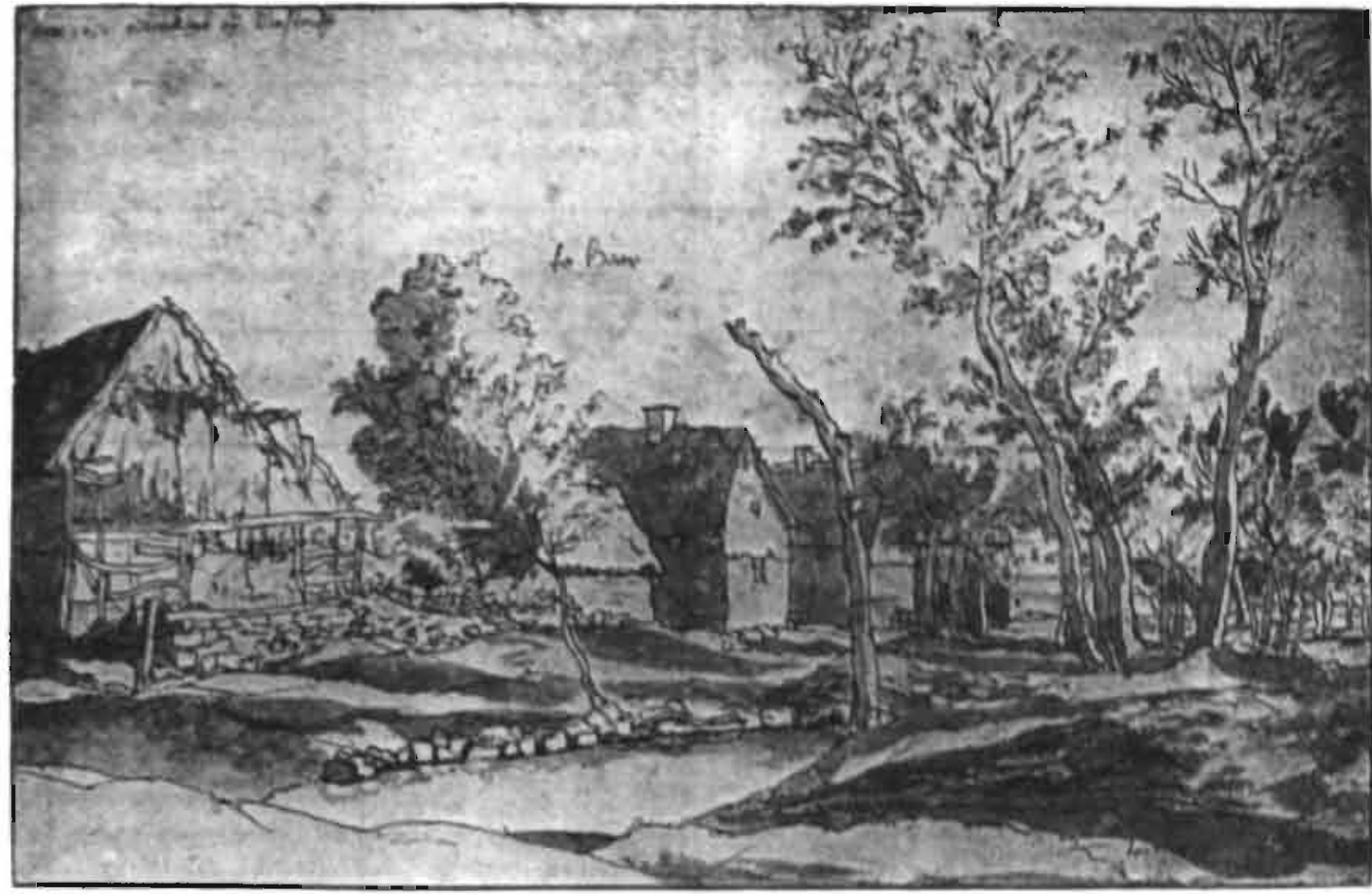

ding; bossen werden destijds, met name in de winter, beweid en met berg wordt in toponiemen een plateaurand aangeduid die, ongeschikt voor landbouw vanwege de steile hellingshoek, vaak als droog schraalland werd benut.

Beweide gebieden zijn overigens ook op een andere wijze te lokaliseren dan alleen door af te gaan op de betekenis van het lokale toponiem. Gedetailleerde kaarten geven hieromtrent informatie: weidegebieden waren meestai gelegen op de schraalste gronden, in delen van de gemeente die 's winters overstroomden of een steile hellingshoek bezitten en voor de landbouw ongeschikt waren.

2.4 Tenslotte dienen wij aandacht te besteden aan een groep van woorden, die in toponiemen voorkomt en die informatie biedt over de organisatie van de heerdgang. Hieronder vallen drie categorieën: namen van veekeringen en de daarbijbehorende mobiele afsluitingen, oriëntatie- en rustpunten in het weidelandschap en de namen voor drenken. 16

Tot diep in de middeleeuwen was het akkerareaal van de gemiddelde nederzetting geringer van omvang dan het groenland, waaronder alle permanent beweide gronden vielen. Alle akkercomplexen, boomgaarden en moestuinen waren omheind om te voorkomen dat het daarbuiten lopende vee daarin schade kon berokkenen (zie figuur 2.4). In principe waren veekeringen dus bedoeld om het vee buiten te sluiten. Die situatie is momenteel omgekeerd. De ingangen der nederzettingen en akkercomplexen konden worden afgesloten met beweegbare sluitingen. die bekend staan onder de naam volder, veken, grindel, klop of goar. In toponiemen komen deze klap- of draaihekken voor onder de dialectische varianten youwer, vouwer, falder, grindel of gryndel, flap, clap, garen of varen. Ook de term barrier heeft betrekking op een afsluiting, maar hier gaat het vermoedelijk om een tolhek. Valders konden op minstens drie plaatsen worden opgesteld: ter afs!uiting van het dorpspleintje, van een akkercomplex en van de toegangswegen tot de nederzetting. daar, waar de bebouwde kom begint (of eindigt). In toponiemen werd deze plaats aangeduid als eind. Aangezien er meer einden in een nederzetting konden voorkomen, werd elk eind voorzien van een adjectief dat ofwel de richting bepaalde van de weg ofwel de naam bevatte van een bewoner var, het eind. Zowel binnen als buiten de nederzetting bestonden de omheiningen van erven en moestuinen uit doornige struiken, een vlechtwerk van takken en palen of stapelmuren. In toponiemen komen de eerste voor onder de naam haag, de tweede als tuin. Veekeringen rond akkercomplexen, met name tussen akkers en permanente weideplaatsen, zoals heiden, waren meestal breder, voorzien van greppels en begroeid met een ondoordringbaar struweel. Dergelijike wildgroven of landgraven zịn bekend van de Graetheide en de
Brunssummerheide. ${ }^{17}$ De in toponiemen voorkomende woordvorm graof heeft niet altijid een veekerende functie, soms diende zilj (tevens) als grens, waterlossing of om bodemerosie tegen te gaan.

Her in toponiemen vee! voorkomende element kump, met als varianten comp, kemp en als diminutief kem( $p$ )ken, heeft everieens met een afsluiting te maken. Tegen woor dig wor. der kampen gezier, als ontgirn ingen met. een akkerfunctie, die waren omgeven door een veekerende afsluiting. De binneri het onderzoekssgebied in een sarnenstelling voorkomende kamp-toponiemen kunnen dit bevestigen.

2.5 Toen de periode van de "Rodungen" ep de plateaus was afgesloten, omgaven uitgestrekte groenlanden, in vegetatiekundig opzicht gekarakteriseerd als kalkgraslander., heischrale graslanden en grazige heider, de nogkleine ontginningssnederzettingen, waarvan de bijbehorende akkercomplexen relatief beperke van omvang waren. Hier en daar zullen in de uitgestrekte. groenlanden, met name op steile hellingen en op de grens van de gemeente, bosrestanten zijn gespaard in de vorm van hakhoutbosies met of zonder overstaanders, enkele solitaire bomen of enig struweel. De grenzen van de gemeente waren aanvankelijk nog vaag, maar bij een toenemende bevolking en een stijgende beweidingsdruk ontstond een dringender behoefte aan nauwkeurige grensafbakening die 


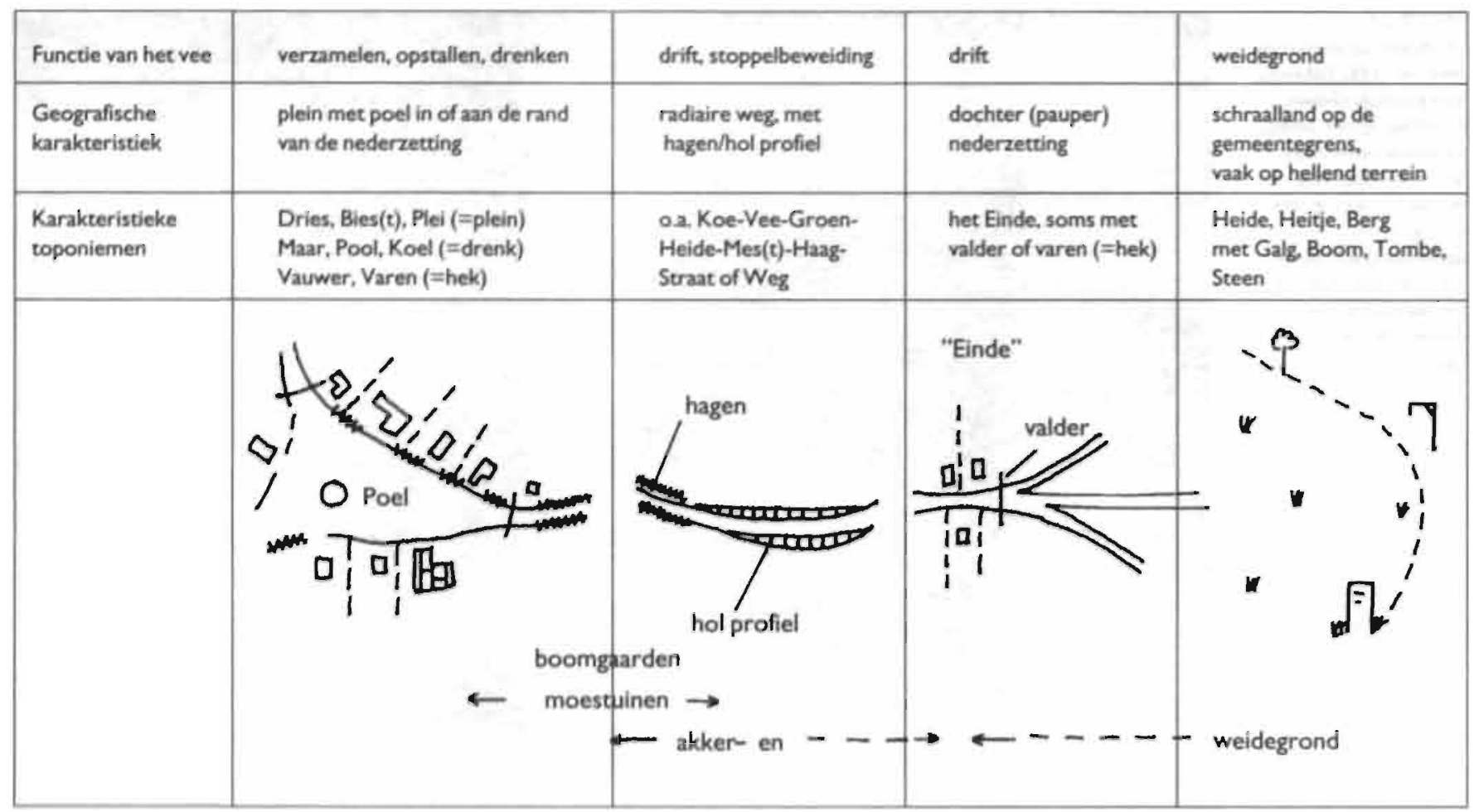

FGUUR 2.5. Schema van een heerdgang op grond van toponiemen en kaarten. De heerdgang Begint en eindigt op het dorpsplein, waaraan een drenh is gelegen. Via veedriften, omxoomd' met hagen of voorzien van een hal profiel, passeert de kudde het moestuin- en akkerareaal van de nederzetting en komt in het beweide gebied, woorvon de grenxen xijn gemarkeerd.

een oplọsing moest bieden voor de grẹnsgeschillen, totstandgekomen door wederzijdse grensoverschrijdingen met weidend vee. In archieven bewaard gebleven processtukken over beweidingsrechten in de periferie van de gemeerite geven hiervan een duidelijk beeid. "Dergelịke grensmarkeringen zijn onder vele gedaanten in toponiemen vastgelegd; het zijn de benamingen voor al of niet behouwen grensstenen, eventueel gekleurde palen of aarden heuvels. De laatste staan in de toponymie bekend onder de naam tom(me), waarvan een aantal van Gallo-Romeinse oorsprong is. Vaak speelden galgen tevens een rol van in het landschap duidelijk zichtbare bakens op de grenzen van het ene naar het andere rechtsgebied, dat in alle gevallen met gemeentescheidingen șamen viel. Levende grenspalen, in de vorm van bomen, boomgroepen of hoog opgaande struiken. konden, in tegenstelling tot grensstenen, niet zonder schade worden verplaatst. Solitaire bomen in een open landschap behoeven noodzakelijkerwijs niet altijd grensbomen te zijn; ze kunnen ook karakteristiek zijn voor wegkruisingen, maar net als grensbomen verschaften zij tevens beschutting aan de herder en zijn kudde tijdens bepaalde weersomstandigheden.
Het hierboven geschetste beeld is bewaard gebleven in diverse vormen, onder andere in toponiemen; de rode-nederzettingen en andere hout-namen op de plateaus herinneren aan de voormalige bossen; de zeer talrijke veld-namen hebben betrekking op de eveneens voormalige beweide groengronden, die pas in een latere tijd zijn omgevormd tot akkers. Niet minder talrijk zijn de in toponiemen vastgelegde grensbakens en geïsoleerde bomen, die met name voor de dorpsherders een orièntatiefunctie in het landschap vervulden.

2.6 Drenknamen die de woordvorm drenk bevatten, zijn weliswaar zeldzaam. maar andere benamingen voor plaatsen waar het vee kon drinken, zijn talrijk in toponiemen vastgelegd.

De centrale drenkplaats voor de dorpskudde in de nederzetting $\mathrm{kwam}$ al eerder ter sprake. Een zeer oude naam voor dit element in de heerdgang binnen het onderzoeksgebied is maar. Diverse kleinere plateaunederzettingen ontlenen er hun naam aan, Waarschijnlijk zijn de maren van een halfnatuurlijke oorsprong; de meeste toponiemen met de woordvorm kuil of poel zijn gegraven waterbassins. Tijdens de negentiende eeuw had vrijwel elke grote hoeve, gehucht of buurtschap zijn eigen drinkpoel. Uit diezelfde periode dateren tevens de vele poelen in de standweiden. In de stroomdalen fungeerden bepaalde gemakkelịk toegankelijke plaatsen in beken of rivierties als drenk. Een typische naam voor een drenk in toponiemen is zoep. Aan de rand van het onderzoeksgebied heeft een ven of vlos (vergelijk het Noordnederlandse toponiem fles) voor de kudde dezelfde functie.

\section{3} Uit de hierboven genoemde series toponiemen kan zowel het dagelijks proces als het patroon van de heerdgang per nederzetting worden afgeleid tot een model. De heerdgang (zie figuur 2.5 ) begint op een dorpspleintie met een meest driehoekige of spoelvormige plattegrond, aangeduid als bies( $t)$, dries, plats of plei. Daar ligt de dorpspoel, een maar, poel of drinkkuil die als veedrenk fungeert. De wegen die op het plein ontspringen, kunnen worden afgesloten met beweegbare hekwerken, aangeduid als vouwer, valder, voren, grindel of klap. Hoewel de meeste wegen als veedriften kunnen fungeren, is de belangrijikste drift geografisch bepaald. Er zijn vele synoniemen voor de veedriften in toponiemen bewaard gebleven. Een tweede groep 
synoniemen van veedriftnamen bevat de woordvorm mest, de naam van een veekering of noemt een hoedanigheid van de weg die met heerdgang in verband staat. Aan de rand van de nederzetting, vaak aan het begin van het weidegebied, ligt een plek waarop vaak een eind-toponiem, soms in gezelschap van een valder-toponiem en enige bebouwing in de vorm van keuterijen, betrekking heeft. Deze plek kan uitgroeien tot een nieuwe nederzetting. De besternming van de drift wordt gevormd door een beweid gebied, dat meestal gemeentelijk eigendom is en aan het begin daarvan kan vaak een waaiervormig wegenpatroon worden aangetroffen. Aan de rand van de uitgestrekte weidegronden. waarvan de calrijke namen betrekking hebben op een bepaalde geografische ligging en een specifiek pastoraal gebruik, liggen grensmarkeringen, rust-en oriëntatiepunten voor de herder en zijn kudde. Langs veedriften liggen verscheidene door gemeentelijke functionarissen onderhouden drenken. De grootste drinkpoel ligt op het dorpsplein.

Het patroon van veedriften blijkt in beekdal. nederzettingen te verschillen van dat der plateaunederzettingen. In de eerstgenoemde situatie staan zij haaks op de hoogtelijnen in het dal: de dreef voor het rundvee daalt af in de richting van de jaarlijks overstroomde graslanden langs de beek, de andere veeweg stijgt omhoog, richting plateau, en bereikt dat meestal via een holle weg. De plateaurandnederzettingen bezitten een radiair patroon van veedriften

Op grond van bovenstaande gegevens kunnen heerdgangen per nederzetting worden gereconstrueerd.
NOTEN

GUANOCACNE 1880

TUMUN 1985

Nissen 1977 en Sanceins et al. 1980, p. 86.

Moumans in Meatins 1984, a 301

Buscranke 1978

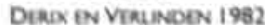

Beatrs 1975. HuLiaks EN REuTEN 1978 en Dr Smor 1981

8 Zie onder andere Beats 1975, BNINKENaOKK 1981 en LNINEN 1966

9 STEGH 1985, p. 50

10. Zie hooldstruk 3

II Zie hoofdatuik 4

12 Zie hootdituks

13 Zie hoofdstuk 6 .

14 HekKIR etal. 1981, p. 23 en KenoIN 1926, p. 201.

15. Zie cabel 2.3

16 Zie tabel $24,2.5$ en 2.6

17 Zle Revas 1998. pp. 137.140.

I8 Grenugeschillen in verband met beweidingrechten zijn bekend van onder andere Sittard (ONMMUs. 19a6). Geleen (Scouninemuxres 1983), Valkenburg (Wutres 1968), Eche (Wutros 1926) en Heer (VAN DE VENNE 1957) 


\title{
BIES(T)-TOPONIEMEN
}

\author{
"De Koeherder begon 's morgens op de Bies met het verzamelen \\ van de koeien..., Glies op een floorn..., (ging) via de... Veestraat... \\ met zijn beesten... naar de Koeheide..., 's avonds (nam hij)... de \\ terugweg..."
}

Heerdgang in Berg rond 1900 I $^{\prime}$

Het toponymisch element bies(t) komt in het dekzandengebied ten westen van de Maas, dat wil zeggen in de huidige provincies Brabant en Limburg aan weerszijden van de grens tussen Nederiand en Belgié, vrij algemeen voor. Bovendien wordt het element bies $(t)$ hier ook in samengestelde toponiemen aangetroffen, onder andere met -heuvel,-veld, -donk en hoek. De markante geografische posities van deze bies(t)-toponiemen in het vlakke en oorspronkelijk venige landschap, met name van de diverse bies(t)heuvels en biesdonken (donk = heuvelrug), hebben weinig twijfel opgeroepen over hun functionele betekenis in het verleden. ${ }^{2}$ Het zijn verzamelplaatsen voor rundvee, gelegen op hogere en drogezandkoppen in een lager gelegen, voch. tig weidelandschap. Sommige bies $(t)$-toponiemen zijn, wat hun betekenis betreft, geèvolueerd tot pleinties in agrarische nederzettingen, andere zijn in her stadium van hun primaire betekenis gebleven: een iets hoger gelegen deel van een uitgestrekt weidegebied, waar rundvee zich van nature verzamelt om te rusten.

Het toponymisch element bies, dus zonder $t$. komt in het gebied van onderzoek, waarvan het Nederlands deel van Zuid-Limburg de kern vormt, minder algemeen voor dan op de Kempische zandgronden. ${ }^{3}$ De simplexvormen hebben uirsluitend betrekking op pleintịes in nederzettingen. Samenstellingen met heuvel of -donk zịn in Zuid-Limburg onbekend; toch hebben deze pleintjes hier, net als in Brabant, gefunctioneerd als verzamelplaatsen voor rundvee.

De betekenis van het toponymisch element bies(t) wordt in de historisch-geografische $\mathrm{li}$. teratuur onbesproken gelaten. Dit hoofdstuk gaat hier wel nader op in. Allereerst worden de verschillende betekenissen van bies(t) besproken. Vervolgens komt de historisch-geografische ligging van bies ( $(t)$-toponiemen aan de orde en tenslotte wordt een aan- tal argumenten opgesomd, die voor de opvatting pleiten dat het element bies ( $t$ ) in toponiemen op grond van historisch-geografische en geobotanische argumenten geen betrekking kan hebben op bies of de pluralisvorm biezen, een verzamelnaam voor een groep van enige plantesoorten met opvallende rechte halmen.

2.I Deverschillende dialect-woordenboeken, etymologische en historisch-taalkundige woordenboeken' geven minstens vier verschillende betekenissen voor het substantief bies.

Wanneer in het dialect sprake is van het materiaal voor bepaalde stoelzittingen of van de halmen van de plantesoorten waruit dit werd vervaardigd, dan wordt de pluralisvorm beeze of bieze gebruikt. Andere varianten worden in de dialectische idioomcompilaties niet genoemd.

Vervolgens komt bies voor in de betekenis van de eerste melk van een koebeest na de geboorte van het kalf. Er zijn geen fonetische varianten bekend. Meestal gebruikt men de samenstelling biesmellek. Overigens komt deze term met dezelfde betekenis ook voor in het Nederlands, maar wordt hier voorzien van een eind- $t$.

Als aanduiding voor (koe)beest komt bies(t) of bees $(t)$ in de huidige dialecten binnen het gebied van onderzoek algemeen voor.

\subsection{Hieronder wordt enig commentaar} geleverd op het dialect-substantief bies in de betekenis van plantaardig materiaal, bestaande vit de halmen van biezensoorten, dat in onder andere stoelmatten wordt verwerkt. Er komen in Nederland minstens 44 plantesoorten voor, waarvan de Nederlandse naam de woordvorm bies bevat. ${ }^{5}$ Deze soorten behoren tot verschillende genera, onder andere Juncus (Bies). Scirpus (Mattenbies) en Eleocharis (Waterbies). Dialect- en volks- kundig gezien zịn er slechts twee categorieën van Linneaanse soorten bekend vanwege hun massaal, maar plaatselijk, voorkomen en. hun onvertakte, taaie en rechte halmen, waardoor zij als vlechtmateriaal kunnen worden benut. De eerste soort is de bekende Mattenbies (Scirpus lacustris) met een halmlengte van meer dan een meter. Van dit materiaal werden de bekende Genemuidermatten gemaakt, die in West-en Midden-Nederland werden verhandeld. Binnen het gebied van onderzoek komt de Mattenbies sporadisch voor langs de Maas. Voor zover bekend, werd dit materiaal in Limburg niet verwerkt. Van de tweede soortengroep, waartoe een driecal Juncus-soorten kan worden gerekend, met een halmlengte van minder dan een meter, is het gebruik eveneens onbekend. Eiders in Noordwest-Europa werden de halmen daarvan op een ambachtelijke wijze verwerkt tot stoelzittingen. Echter. binnen het onderzoeksgebied heeft de tradi. tionele boerenstoel een houten zitting. ${ }^{6} \mathrm{De}$ bedoelde drie luncus-soorten (0. conglomeratus. J. effusus en J. inflexus) zijn weliswaar niet zeldzaam, maar komen en kwamen toch nergens zo massaal en aspectbepalend voor. dat zich hierop een huisindustrie kon baseren. Alleen al op grond van deze gegevens, die laten zien dat zowel de plant als het materiaal daarvan voor de plattelandsbevolking in Zuid-Limburg nauwelijks een rol speelde, lijkt het onwaarschijnlijk dat het toponymisch element bies met het plantaardig materiaal met dezelfde naam iets van doen heeft. Deze gegevens gelden overigens niet voor gebieden buiten Zuid-Limburg "

3. Een geografische indeling van de sa= mengestelde bies(t)-toponiemen kan eveneens informatie geven over de betekenis van het element biest. Deze indeling is gebaseerd op de geomorfologische en geografische positie: van de samenstelling en van de histo- 
AGUR 3 .

Het dorpaplein "Op de Byes" te Schimmert natar de Tranchot: kade. De Byes, momenteel Bies ( $I$ ), is de tot een pleintie verbrede hoofdutreat. De huidige namen Meerntroot (2) en Vouerstroot (3) herinneren aen een veedrenk en oon hekwerken, die de wegen rond het plein konden afstuiten.

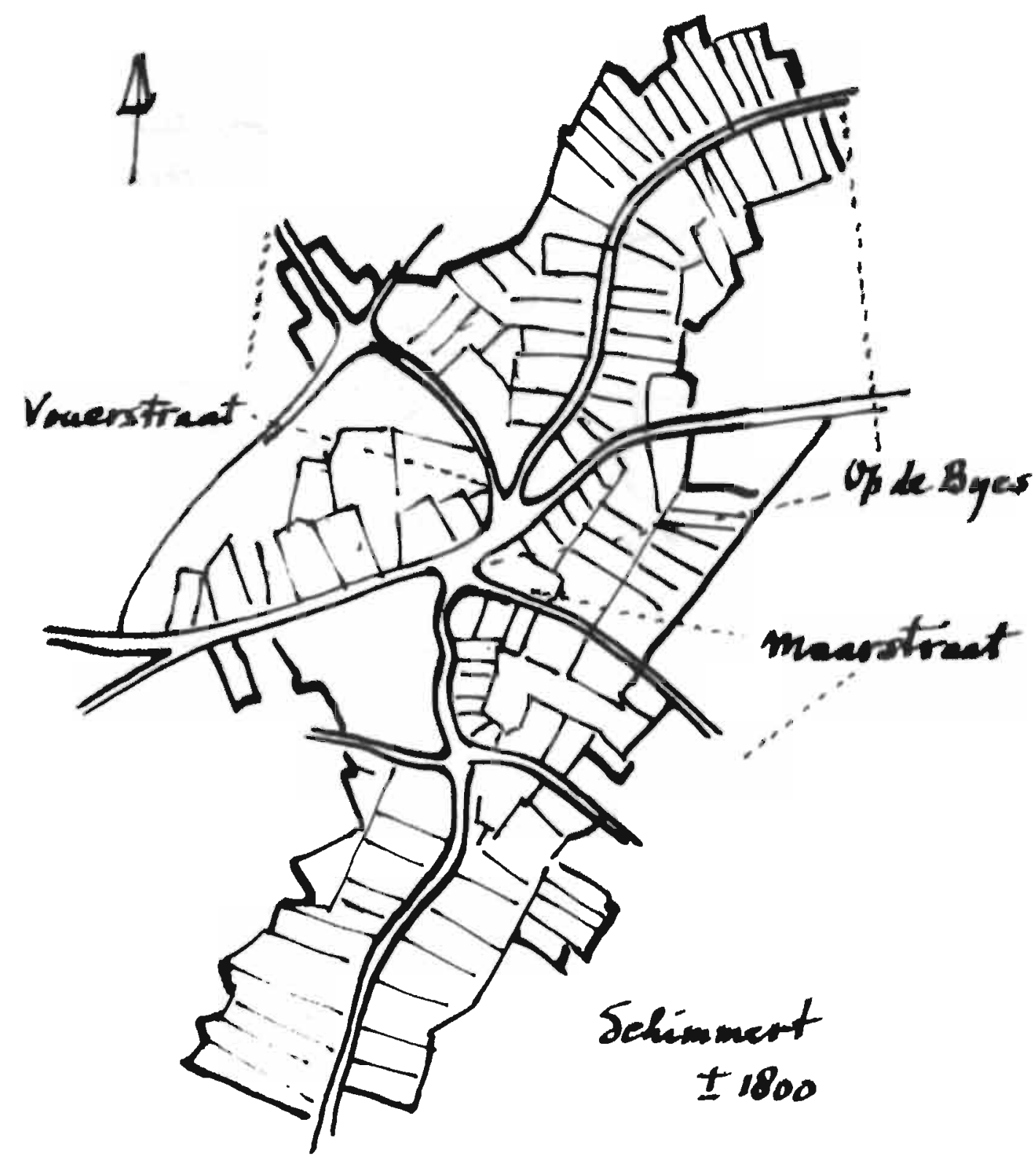

risch-landschappelijke betekenis van het tweede deel in de samenstelling. Het bies(t)toponiem wordt op deze wijze geplaatst in het kader van het historisch-oecologisch landschapsgebruik. ${ }^{8}$

In dit onderzoek zijn 48 bies(t)-toponiemen betrokken uit het gebied van onderzoek en 68 van daarbuiten. ${ }^{9}$ Ze hebben betrekking op geografische delen van het landschap, die uiteenvallen in vier categorieën: (1) pleinties binnen een nederzetting, (2) weidegebieden buiten een nederzetting, (3) bepaalde wegen en (4) poelen. In een historisch-oecologisch kader geplaatst, is hun functie duidelijk: de dorpspleintjes blijken veeverzamelplaatsen te zijn, met name voor rundvee, de gebieden buiten de nederzetting typische weideplaatsen voor rundvee, de wegen veedriften en de poelen veedrenken.

In de onderstaainde paragrafen worden deze categorieën besproken, het: eerst voor zover ze binnen her gebied van onderzoek zịn gelegen, daarna voor zover ze elders zij̣n gelegen.

De simplexvorm "Op" of "A gen Bies". "Bies" of "Byes", bekend van Berg. Heythuysen, Schimmert, Schiriveld, Sint-Martensvoeren en Moelingen, heeft betrekking op tot pleinties verbrede straten in of aan de rand van de nederzetting. Drie van de hierboven genoemde dorpspleintjes, worden hieronder nader besproken.

3.2. Het centrum van de plateaurandnederzetting Schimmert, vermoedelijk vlak na het jaar 1000 ontstaan, ${ }^{10}$ bestond rond 1800 uit een langgerekt pleintje, waarop een zestal wegen uitmondde. De tot een plein verbrede hoofdstrat heet momenteel Op de Bies. De Tranchotkaart vermeldt "Byes" bij dit deel van Schimmert en "Byesserveld" als een akkercomplex, dat daarbij hoort (zie figuur 3.1). Geomorfologisch gezien, vormt de verbrede hoofdstraat een deel van een ondiep dal, waarin zich periodiek oppervlaktewater kan verzamelen. Een kaart uit 1868' I beeldt hier een waterstroompje af, dat stroomalwaarts in de aangrenzende gemeente Beek de Vloedgraal wordt genoemd. Een zijstraat van het pleintje heet momenteel Maarstraat: de term moar verwiįst naar de verbreding van dit waterstroompje tot een poel. Tegenover de Maarstraat, aan de overkant van het pleintje, ligt de Vouerhofweg. 


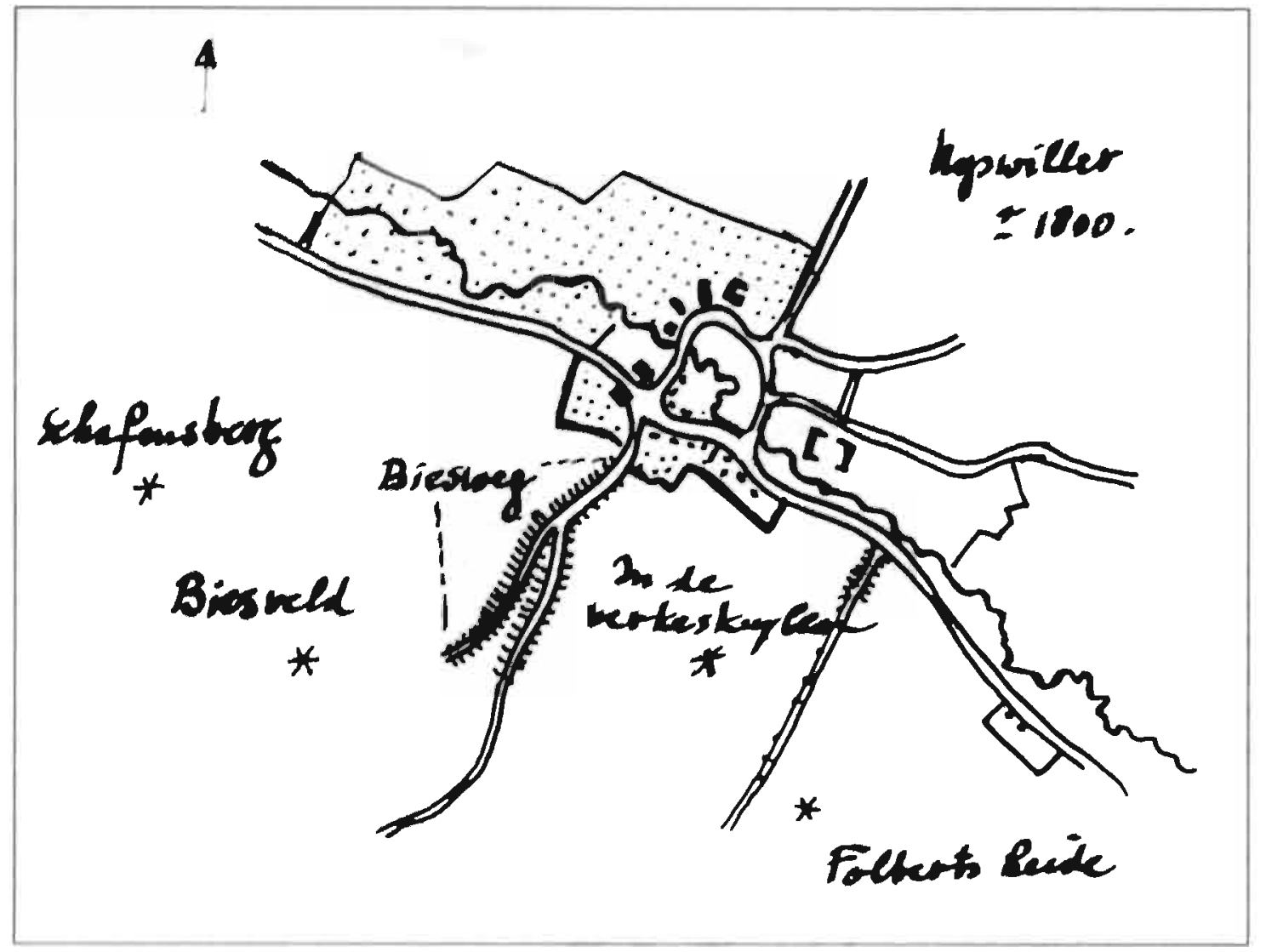

FIGUUR 3.2

De Blearwet het

Bliesveld en ondere

heerdjong-indicotiere

toponiermen in

Nijswiller noar de

Tranchotkaort De

Biesweg met een hol proflel verbindt het

Biesveld en de

Schofensber (=

Schoopsberg) (I),

beweide territoria, met

de dorpskern. Op

dezelfde heuvelnus

liggen Folbertsheide

(2) en De Verkenskuy-

Ien (3). Hier hebben

eens runderen,

schapen en varkens

onder leiding van

herden gegraasd. De

boomgoarden en

huiskavels zijn door

hagen omsloten om te

voorkomen dat de

kudden er schade

konden aanrichten.

waaryan de naam verband houdt met een vouer of valder, een weg afsluitend hekwerk, hoogstwaarschijnlijk destij]s het, pleintịe afsluitend.

De middeleesuwse kern van de plateaurandnederzeting Berg bestond in de vorige eeuw ult een tot een pleintje verbrede weg, die tot op heden Op de Bies wordt genoemd. Hieraan lag de inmiddels afgebroken kerk, een drinkpoel en een waterput. In de zestiende eeuw heerte de weg, die het verlengde vormt van het pleincje en de kartste yerbinding vormt met weidegronden in het dal van de Geul, de Pinckensteghe. De naam pink verwijst naar jong rundvee. Deels is dit een holle weg; naar vorm en betekenis een typische veedrift. De vee verzamelende functie van het pleintje scaat historisch vast; via de Veestraat kon de koeherder de Koeheide berei. ken. ${ }^{12}$

De kern van de laat(1)-middeleeuwse nederzetting Heythuysen is gesitueerd op de hoge oever van de Tungelroyse beek. Het dorps. plein Op de Bies is via de Biesstraat rechtstreeks verbonden met de graslanden langs de beek. ${ }^{13}$

De hierboven vermelde gegevens maken duidelijk, dat de simplexvorm van het toponiem bies betrekking heeft op het in de: liceratuur en uit afbeeidingen bekende laat-mid- delesuwse dorpsplein, warvan de elementen poel, put, valder en de voortzetting in een veedrift naar beweide territoria wijzen op de toenmalige heerdgang van rundvee. ${ }^{14}$

3.3 De overige bies(t)-toponiemen in het gebied van onderzoek leveren de volgende gegevens op: een tweetal archaisch aandoende samenstellingen zijn "Byestmael" en "Op ene Biestert": ${ }^{15}$ De historisch-oecologische betekenis van het eerste toponiem als "weideplaats voor het rundvee aan de grens van de gemeente" (maal = grens), is zeer waarschijnlijk: het gebied waarop dit toponiem betrekking heeft. ligt aan de ggrens van de gemeente, nabij de plateaurand, op onvruchtbare gronden en viakbij een nog bestaande plateaurandheide. Het rweede toponiem "Biestert" kan op grond van dezelfde historisch-oecologische: argumenten "weideplaats voor rundvee" ( aard $=$ weide) ${ }^{16}$ betekenen

De overige bies-toponiemen in deze categorie indiceren in elk geval beweide territoria. Dit geldt voor -berg (3x), -bos, -broek, -veld en weide $(2 x)$. Hierbii moet worden opgemerkt. dat ook bossen destijds werden beweid ${ }^{17}$ en dat de oorspronkelijke betekenis van veld ${ }^{1 \mathrm{a}}$ een weideplaats is.

De woordvorm bies komt in het gebied van onderzoek tenminste 14 keer yoor in een samenstelling met een route-aanduiding, 20 als -weg ( $4 x)$, -straat ( $3 x)$, -gots (= steeg) en -wol (telkens Ix). ${ }^{19}$ In enkele gevallen kan worden aangetoond, dat een dergelijke route vertrekt vanuit een dorpspleintje en uitmondt in weidegebieden (zie figuur 3.2). In andere gevallen heeft deze route eenzelfde richting als een daarbij gelegen veedrift of vormt het bies-toponiem een onderdeel van een heerdgang:

Vier keer komt bies voor in combinatie met een aanduiding voor water, zoals -bron. poel, -maar (=: poel) en-beek. ${ }^{20}$ Vermoedelijk ontlenen deze toponiemen hun historisch-oecologische betekenis eerder aan een drenk voor rundvee dan aan een voor de agrarische bedrijfsvoering onbelangrijke plantesoort. Het toponiem "Bisfalder" kan niet anders dan met heerdgang in verband staan; een laatachttiende-eeuwse plattegrond van het dorp Swalmen laat vier van deze veekerende valders zien. Het Bisfalder ligt aan her begin van een Mistweg, een mestweg, die uitmondt in de Blesweerd, een typisch weidegebied voor rundvee, gelegen in het overstromingsgebied van de Maas (zie figuur 3.3 en 3.4).

Nederzettingsnamen voor solitaire hoeven of zeer kleine buurtschappen als Bissen, Bishem, Biessen of Biessenhof, zouden kunnen 
FGUUR 3.3.

Schema van de nederzetting Swolmen met de bies-toponiemen "Alen Mirfalder" en "Bierweerd" volgens de Swaber. keare uit 1774 noar Geroeds en Cunters 1983. De nederzetting war omgeven door een "dorpstuin", woarin vier valders of veldpoorten lagen. Hun voornaamite functie stond in verband met de dagelijkse heerdgang. Het Binfalder (I), de Veltpoort (2), het Gevaren (3) en Honturalderen (4) vormden afsluitbare openingen in de "dorpstuin", ven omheining, rond de nederzetting. De vier belangrijkate. veedriften ontaluiten de vochtige graslanden langr de Maas en de droge wreidegronden op de heide op strategische en oymmetrische wijze.

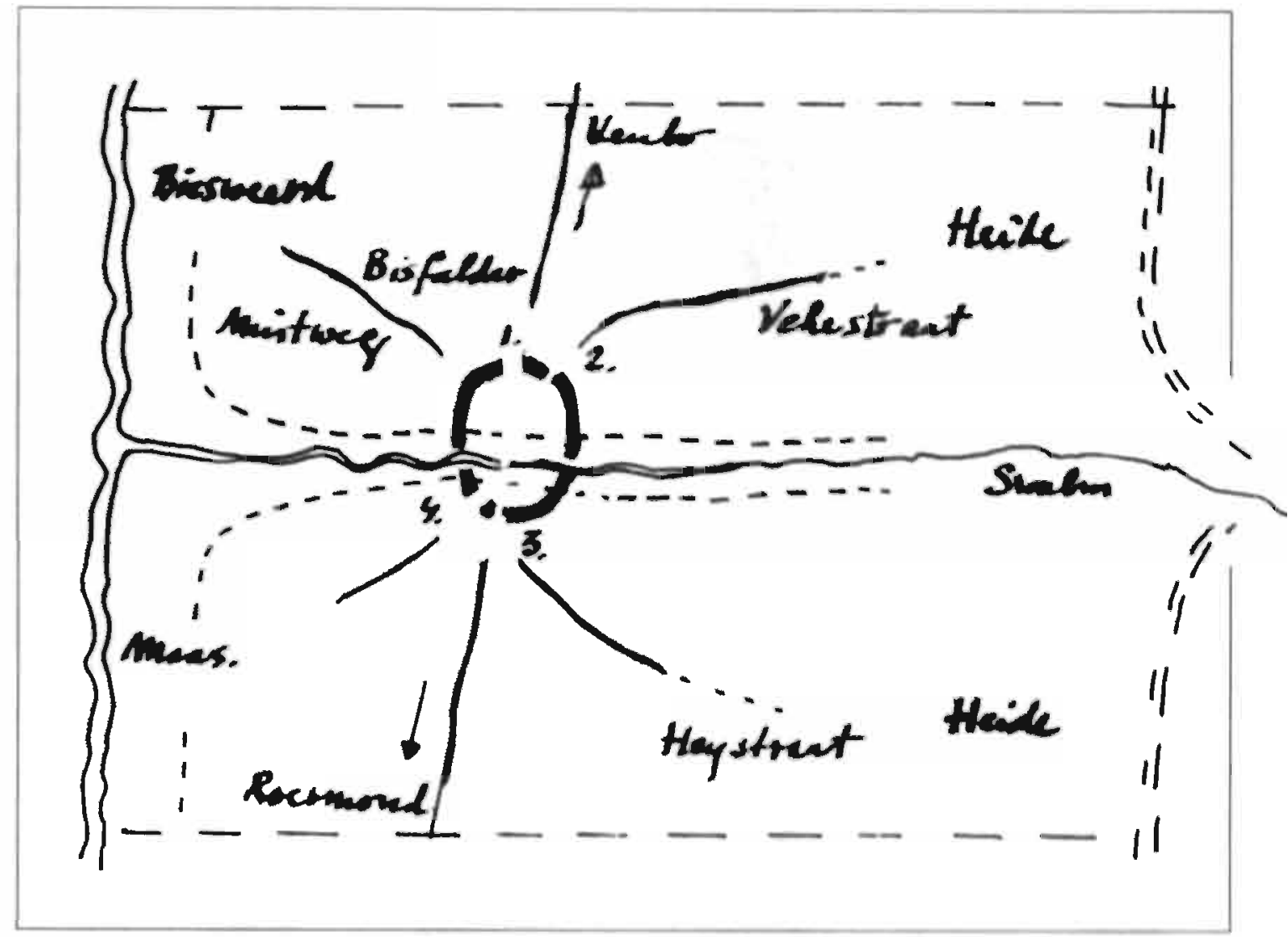

samenhangen met het bezitten van meer rundvee dan gewoonlijk; hun geografische ligging is bepaald tot beekdalen. Mogelijk lag in het oorspronkelijke bedrijf de nadruk op veehouderij, zoals dat voor onder andere een "vee-uithof' het geval was. Mogelijk was de oorsprong van die nederzetting een rust- of weideplaats voor rundvee, waarop later cen vee-uithof werd gesticht. Om deze veronderstelling te toetsen, zou een onderzoek moeten plaatsvinden naar de oudste schriftelijke vermeldingen van deze solitaire hoeven in historische bronnen.

3.4 Buiten het gebied van onderzoek komt het element bies $(t)$ als eerste deel van een samengesteld toponiem regelmatig voor. In verband met hun betekenisverklaring is het belangrijk te weten, dat de geografische lokaties waarop deze samengestelde bies(t)toponiemen betrekking hebben, in dezelfde vier categorieën worden verdeeld als hierboven genoemd, namelijk pleinties, weideplaacsen, wegen en poelen. ${ }^{21}$

Alleen al in de Nederlandse provincie Noord-Brabant kunnen minstens tien nederzettingen worden aangewezen, waarvan de kern uit een pleintje bestaat, gelegen op het vlakke deel van een heuvel, die opduikt vanuit een lager gelegen landschap. In deze pro- vincie liggen zes Bies(t)heuvels, een drietal Biesdonken (donk = zandrug), een drietal gehuchten die de simplexvorm "Bies(t)" dragen en een drietal pleintjes die waren gelegen buiten de stadswallen van kleinere steden. Ook deze "plaatsen", een andere aanduiding voor dergelijke pleintjes en de daaromheen liggende bebouwing in Brabant, staan bekend onder de naam Bies( $t$ ). Analoog met Biestheuvel, maar buiten Brabant gelegen, is waarschijnlijk Bieshorst (horst $=o p$ duiking in het landschap).

In de Belgische provincie Limburg liggen drie kleine nederzettingen, waar Bieswegen hun oorsprong vinden op het dorpsplein en uitmonden in voormalige weidegronden.

De hierboven genoemde bies(t)-toponiemen indiceren heerdgang.

\subsection{Twee biest-toponiemen in steden} verdienen een gedetailleerde beschriịving om de betekenis van biest te achterhalen. In het Belgisch-Brabantse Mechelen wordt een binnen de middeleeuwse stadsomwalling gelegen pleintje momenteel Biest genoemd. Dit plein gaat aan een zijde over in de Koestraat, aan de andere zijde in onder andere de Veemerkt. Tussen 1348 en 1643 droeg het bedoelde pleintje de naam Corte Biest Later werd de naam verkort tot Bist of
Biest, toen de Langhe Biest in Sint-Jansstraat werd veranderd. ${ }^{22}$

In het Belgisch-Limburgse Sint-Truiden lige het gehucht Ter Biest aan de buitenzijde van de stadswal. Momenteel heeft Ter Biest niet alleen betrekking op een brede weg, die de stad verlaat in noordoostelijke richting. waaraan de Veemarkt is gelegen, maar ook op een aan die brede straat gelegen gehucht. waarvan het kerkje uit 1420 dateert. Het daar gelegen kasteel, een waterburcht uit 1627 . draagt eveneens de naam Terbiest. ${ }^{23}$

Bovenstaande historisch-oecologische gegevens, in combinatie met her feit dat de stadjes Weert en Venray eveneens een Biest in hun oude kern herbergen, wettigen het vermoeden dat de biest-toponiemen in of aan de rand van steden als verzamelplaatsen voor rundvee hebben gefungeerd. Dat op dergelijke pleinen in een latere periode het bijeenbrengen van rundvee in verband kwam te staan met handel en slacht, is daarbij van secundaire betekenis.

\section{6} men, waarvan het laatste deel van de samenstelling, een beweid territorium, gelegen buiten de nederzetting, inhoudt, zijn buiten het gebied van onderzoek talrijk. Genoteerd werden, in alfabetische volgorde, -oard, -ak- 


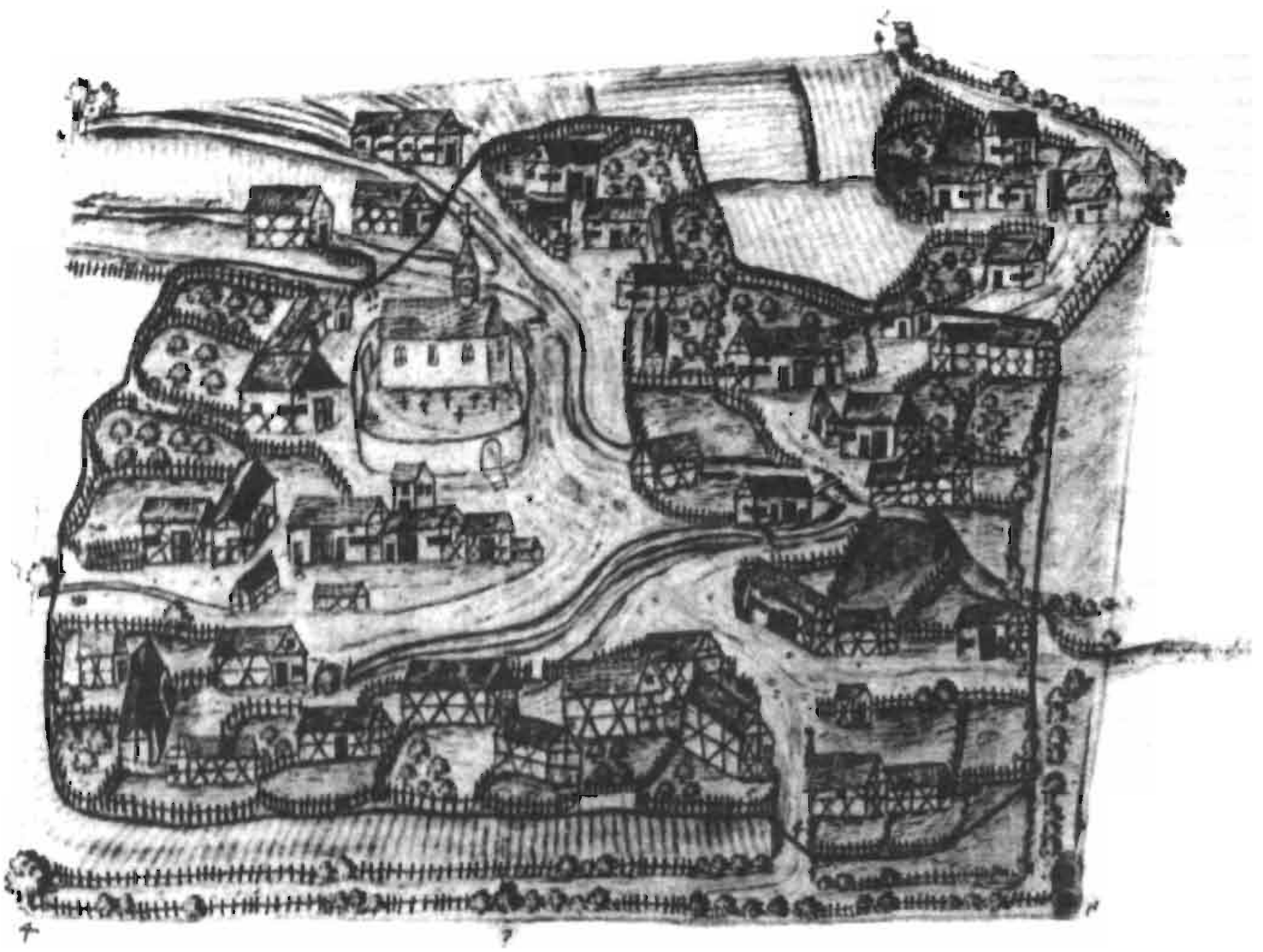

FFGUR 3.4. Schematische tekening van gen middeleeuws dorp met: diverse veekeringen naor Rbsener 1985. Nederzetting, moestuinen on boomgoerden sijn ongeven door veekeringen. De toegangswegen, eveneens omroomd' met veekerende hogen en staketsels, kunnen dooi valders (bij 4) worden afgesloten. De dorpskerk met het ommuurde kerkhof ligt aan een driehoekig plein. Houtskeletbouw domineert.

ker, -beemd, -blok, -bos (3x), -dries, -euwsel (8x), -haor, -hoek, -kamp (2x), -maat of -mede (2x), -mars, -mortel, -pas, -ploot, -polder, -veld $(10 \mathrm{x})$, -weerd en -weide. Dit zịn substantiva die op landschappelijke eenheden betrekking hebben, waaryan het vegetatiedek voor beweiding door onder andere rundvee in aanmerking kwam. Zelfs akkers, en driessen konden tijdens hun braakperiode worden beweid. Voorbeelden van bies(t)-routes zijn -straat (8x), -weg, -dijk en -brug. ${ }^{24}$

in de geraadpleegde toponymische bronnen van gebieden buiten Zuid-Limburg, die hoofdzakelijk nederzettingen en de namen van wegen, straten en waterlopen opsommen en de overige veldnamen niet vermelden, zijn slechts enkele bies(t)-hydroniemen aangetroffer: een kuil, een -put, een -ven en een -maar. ${ }^{25}$

Opmerkelijk zijn de attestaties "biesthof". 26
Het lijkt onwaarschijn!lijk dat deze hoeven zijn vernoemd naar een bepaalde groep van plantesoorten, die voor de stichter of uitbater van die hoeve van generlei betekenis was. Een vee-uithof als synoniem is veel waarschijnlijker.

4. 1 Het staat vast dat men al in de zestiende eeuw de term biest kende in de betekenis van pleintje. ${ }^{27}$ Ook daarna: een achttiende-eeuwse woordenlijst geeft als synoniem "groote plaats" en "markt", In die betekenis als plein kwam biest nog voor in het begin van de twintigste eeuw in een enkel Zuidlimburgs dialect. ${ }^{2 a}$

In de historische agro-pastorale bedrijfsvoering fungeerde de biest als plaats van her dagelijks vertrek en terugkeer van de dorpskudde, destijds voornamelijk bestaande uit rundvee.
Uit onderzoek naar de historisch-geografische ligging van een groot aantal samengestelde biest-toponiemen en de betekenis van het tweede deel van de samenstelling, is voorts vastgesteld dat er vier categorieën samenstellingen zijn. Dat zijn de reeds genoemde dorpspleinties met een vee verzamelende functie, weidegronden, veedriften en veedrenken.

4.2 Taalkundigen beschoưwen de veronderstelling, dat het toponymisch element bies(t) en het substantief (koe) bees(t) etymologisch samenhangen als onjuist; biest zou een "Kollektivbildung mit Dentalsuffix" zijn, primair betekenend "plaats waar biezen groeien", secundair een pleintje. ${ }^{29}$ Ten aanzien van de betekenisverklaring van de toponymische woordvorm bies(t), bestaat er zowel bij taalkundigen als bį̣ historisch-geogra- 
fen enige twijfel, maar op grond van landschapsoecologische en botanische argumenten is het heerdgang-indicatieve karakter evident, anderzijds kan de betekenis van diverse bies-toponiemen onmogelijk, zeer onwarschijnlijk of sleches twijfelachtig betrekking hebben op soorten van het verzamelbegrip "bies"

Wat betreft de betekenis van bieze-toponiemen zijn de meningen van taalkundigen en biologen gelijkluidend.

\section{NOTEN}

I Curssens et al. 1981, p. 282.

Renes 1995, pp. 102-103 en 51zEG 1985, p. 50.

Zie tabel 3.1. nr I-8 en tabel 3.2.

Zie noot 9 tot en met 12 van hooldstuk 1 .

HILXKES EN VAN DCA MIIIDEN 1984

Mondelinge mededeling C. Esen te Kelmond.

Zie rabel 3.4.

Zie hooldatuk 1. paragraaf 2.3

9 Zie tabel 3.

10 Rents 1988, p. 254

11 Kumba 1981.

12 C.arssens er al. 1981 , pqe 88,154 en 282

13 Zie cabel 3.1, nr 3.

14 Zie onder andere Hikkia etal 1981. ROANE 19aS. Reves 1988 en Boers 1975.

15 Zie cabel 3.1, ar 39 en 40

16. Linoemans 1946

i7 JaWSeN EN VAN De Westeanco 19a3, pp. 35-46.

I8 Livotruns 1946, p. 9 en volgende

19. Zie rabel 3.1, nr 21-33.

20 Zie cabel 3.1, w 34.37.

21 Zie tabel 3.2

22 VAN CASTra 1901, p. 46 en volgende

23 Limburg 1986, p 66

24 Zie cabel 3.2, nr 47.55

25 Zie tabel 3.2. no 56.59

26 Zle abel 3.2, ar 70-72.

27 KILINN 1975.

28 DOMMEN 1928

29. Schomaus 1966, p. 94 


\section{DRENK-TOPONIEMEN}

\section{"... Geekjes zijn het ... zenuwstelsel van het menselijkoccupatiepatroon." I}

1

Water is yoor de mens en zijn huisdieren van vitaal belang. Het ligt echter buiten het bestek van dit hoofdstuk, dat de drenk als onderwerp heeft, de fysiologische functies van water toe te lichten: welkan aan de hand van een drietal voorbeelden uit de toponiemenvoorraad van het onderzoeksgebied, hieronder nader toegelicht, worden aangetoond dat de aanwezigheid van water een factor van doorslaggevende betekenis is geweest voor het ontstaan van permanente nederzettingen in het bestudeerde gebied.

Tijdens dit proces hebben de beken en rivieren, die het gehele jaar door water bevatten, een belangrijke rol gespeeld: de oudste serie nu nog bestaande nederzettingen in ZuidLimburg liggen in stroomdalen. Zif dateren uit de Romeinse periode of viak daarna. Hun namen bevatten veelal Romaanse elementen. Plateaunederzettingen daarentegen, waar meri was aangewezen op stilstaand water dat zich in poelen verzamelde, dragen uitsluitend Germaanstalige namen. De talrijke rode-namen op de plateaus dateren uit de hoge of late middeleeuwen. De historische fasering van nederzettingsnamen illustreert het vitale belang van water.

Een tweede voorbeeld van de vitale functie van water betreft het voorkomen, onder andere in toponiemen, van specifieke dialectnamen voor bepaalde typen van watervoor- raden, waarvoor in het Nederlands geen synoniemen bestaan. De lokaties waarop deze namen betrekking hebben, worden uitsluitend aangetroffen op de waterarme plateaus. Zij hebben een belangrijke rol gespeeld in het proces van permanente vestiging. Hieronder wordt: dit: nader toegelicht.

Geomorfologisch onderzoek wijst uit dat een komvormige depressie op een plateau, waar zich periodiek water verzamelt, voor. komt in toponiemen als maar, een trogvormige depressie als zouw en een diep ingesneden depressie met water als sjlont. Een maar heeft het aanzien van een poel met een wisselende waterspiegel. Een zouw lijkt tijdelijk een zwak stromende beek. Zị mondt niec uit in cen ander beeksysteem. Een sjlont wordt gevormd door een diepe geul, voorzien van een bron en cen beekje met een lengte van slechts enige tientallen meters. Een ziep heeft betrekking op een kwelzone in een helling met een daarbij behorend kort waterstroompie, terwijl een sjprunk een puntbron voorstelt. De directe omgeving van een moor, een zouw of een sjprunk is uitermate geschikt voor menselijke vestiging: minstens zeven nederzettingen en evenzoveel dorpspleintjes op plateaus in het gebied van onderzoek heten naar die centrale poel Ter Maar, kortweg Maar. $M(h)$ eer of zijn daarvan afgeleid. ${ }^{2}$ Ook de andere dialecttermen voor watervoorra- den komen regelmatig voor in de oude kernen van plateaunederzettingen.

Een derde voorbeeld uit de toponiemenvoorraad van het gebied van onderzoek, dat laat zien hoe belangrijk de aanwezigheid van water is voor menselijke vestiging, wordt gevormd door de namen van een drietal buurtschappen binnen de huidige nederzetting Vlijtingen en rond de centraal gelegen, maar inmiddels verdwenen poel, die wordt gevormd door de lokale verbreding van een zouw (zie figuur 4.1). De naam van deze poel wordt momenteel gebruikt als aanduiding voor het gehele daaromheen gelegen dorpspleintje Op de Mheer. Dit deel vormt de oudste kern van de nederzetting Vlijtingen. Stroomopwaarts van de zouw ligt het buurtschap Ophem, momenteel de Ophemmerstraat, stroomafwaarts het gehucht Neerhem, momenteel de Erhemmerstraat. ${ }^{3}$ Dergelijke opposities tussen Ophem-Neerhem, waarbij eventueel het toponiem Euverhem (= aan de overzijde van de beek) aan toegevoegd kan zijn, komen meer voor in het gebied van onderzoek. Het zijn tevens heemtoponiemen die uit de Merovingisch-Karolingische periode dateren. Omdat de betekenis verband houdt met de geografische ligging ten opzichte van de oudste kern aan een waterplaats, moet de Mheer van Vlijtingen een respectabele leeftijd bezitten.

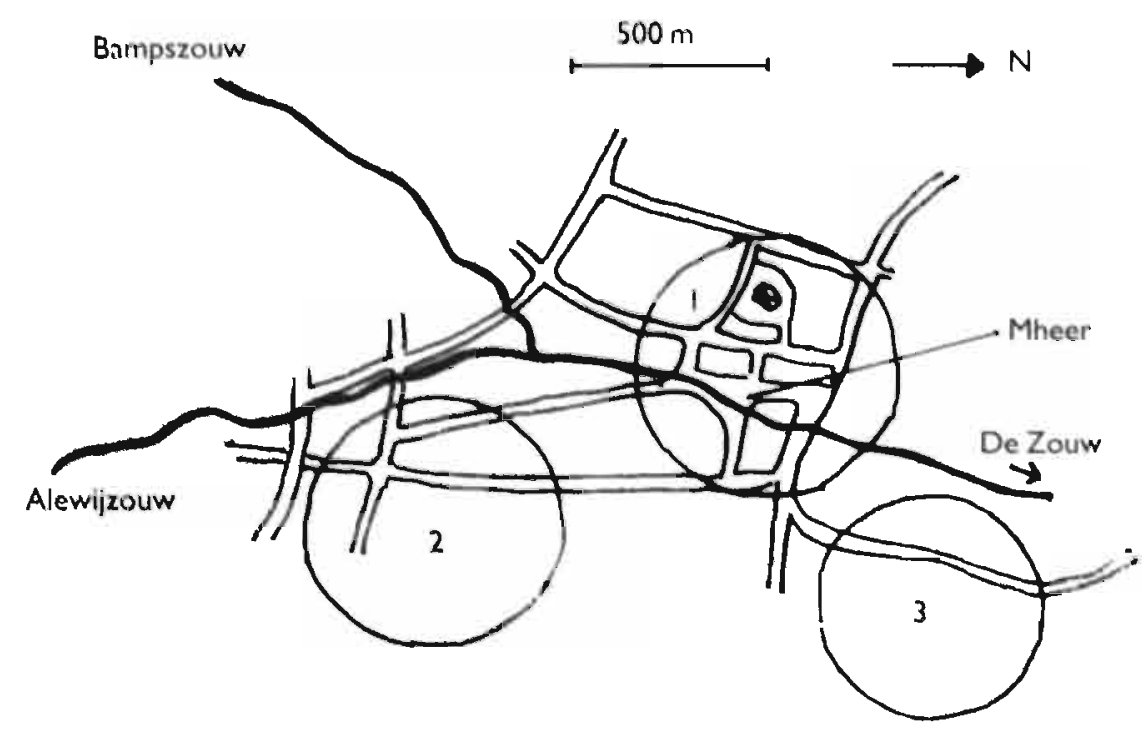

FIGUUR 41

De ligging van de drie woonkernen

"Mheer" (1). -Ophem" (2) en "Neerhem" (3) van Vlijtingen ten opxichte van het beekje de "ZOUW" nOar HACKENG 1982. De namen van de drie woonkemen van de nederzetting Vlijtingen houden verband met het water van de beek. De centraal gelegen dorpspoel, een "maor" of "meer", wrerd gevoed door een beekje dot tijdelijik water bevatte en "zouw" werd genoemd. Momentee! heet het hele plein "Mheer" (1), de poel isi inmiddels gedempe. Stroomopurearts van het beekje ligt de neterxettingskern "Ophem" (2), nu "Oppemmerstraac", stroomafivaarts ligt "Neerhem" (3), momenteel Erhemmerstraat. Omdat dere oppositie-toponiemen het element "heem" (= huis) bevotten en op grond daarvan vermoedelijit wis de' vroege middeleeuwen dorteren, moet de oude kern rond de Mheer van vobr die tijd stammen. 
2.1

De gegevens van dit hoofdstuk hebben betrekcking op stilstaande wateren; drenken aan beken of rivieren zijn weinig in topo. niemen vastgelegd, omdat het vee overal langs de beek kon drinken. Op de waterarme plateaus zijn daarentegen veel waternamen in toponiemen bewaard gebleven. Een eerste bespreking geldt de naam maor of meer. Deze woordvorm is van toepassing op de karakteristieke dorpspoel, die in vrijwel iedere nederzettingskern in het gebied van onderzoek, zeker op de plateaus, destijds een vitaal onderdeel vormde van de agro-pastorale bedrijfsvoering (zie figuur 4.2). Naast moor bestaan andere benamingen voor stilstaand water bevattende bodeminzinkingen. zoals pool en koel (zie figuur 4.3 en 4.4). Omdat deze twee substantiva frequent voorko. men en bovendien vaker in samengestelde toponiemen beward zijn gebleven, vormen pool-en koel-toponiemen een tweede thema in dit hoofdstuk.

In taalkundig opzicht heeft het substantief maar in de Noordwesteuropese talen een interessante betekenisevolutie doorgemaakt: het Duitse Moor betekent een dorpspoel, maar tevens een dode rivierarm en een met. water gevulde vulkaankrater: het zijn stilstaande wateren van een kleinere omvang dan een Nederlands meer. Het Duitse Meer is onze zee en omgekeerd, terwijl het Franse en $W$ aalse mare onder andere een dorpspoel betekent. Hun mer is onze zee.

Binnen het gebied van onderzoek heeft de toponymische woordvorm maar een oostelịke en meer een westelijke verspreiding; wat hun betekenis betreft zịn beide termen synoniem voor dorpspoel. De maar/meer-toponiemen geven weinig informatie over hun

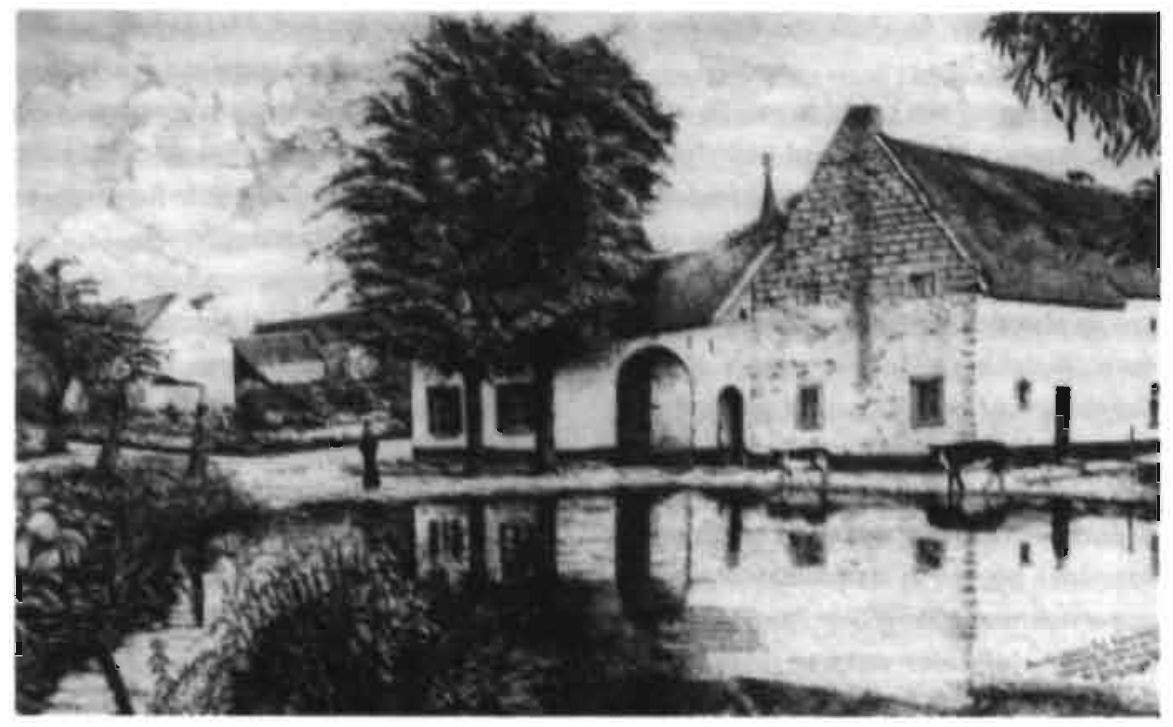

FGUUR 4.2. De "Schene Poel" van Berg. Tekening van Ber Schols naer

Cuassens et al. 1981. De poel werd rond 1955 gedempt het pleintye heeft de noam behouden.

functies in het verleden: de meeste zijn sim. plexvormen en slechts een viertal is samengesteld met een dierennaam. De talrijke poel-en koel-toponiemen, die hieronder aan de orde komen, geven daarover meer inlich. tingen.

\section{2}

Het dialectsubstantielf pool, hetzelfde woord als het Nederlandse poel, geeft aan dit vitale onderdeel van de nederzetting meer inhoud dan het maor-toponiern. Poelen zijn zowel in de dialecten als in de algemene voertaal van het onderzoeksgebied met regenwater gevulde ondiepten van een beperkte omvang. De levensduur varieere van enige uren tot vrị wel permanent. Voor poel-toponiemen ${ }^{4}$ geldt evenwel het laatste.

Tot voor kort bezat elke nederzetting op he: platteland meerdere poelen: een lijst van gemeentepoelen uit 1837 van Waubach vermeldt er 24 en in het nabijgelegen gehucht Groenstraat lagen er destijds $15 .^{\text {a Alleen al }}$ in de kleine kern Margraten lagen rond 1900 vier gemeentepoefen. ${ }^{6}$

Naast de gemeentepoelen die langs de openbare wegen en meestal binnen de nederzetting waren gelegen, bezaten grote hoeven meestal eeri private holpoel. Tevens diende elke standweide noodzakelijkerwijs een drinkpoel voor het vee te bezitten.

Tijdens de negentiende en tijdens het begin van de twintigste eeuw moet de poelendichtheid in het onderzoeksgebied bịzonder hoog ziinn geweest. Op basis van eerı poeleninventarisatie in het. Mergelland in 1960 was de poelendichtheid nog ongeveer vier per vier-

FIGUUUR 4.3.

De "Schone Poel" van Berg, afgebeeld op een ovale schotel van het servies "Boerenhoeve", vervaardigd door de, aardewerkfabriek "Societe Céramique" te Maastriche rond 1920. De affeelding op de schotel is via een gravure naar een foto vervaardigd door $A$. Sonneville. De afgebeelde hoeve is een realistische weergave van de nog bestaande hoeve, genaand "Voor gen Os". Ook de torenspits van de kerk op de achtergrond is herkenbaar als die van het Inmiddels afgebroken kerkje van Berg. Hoewel er in Berg tot 1930 een schaopskudde onder leiding van een herder bestond, is het echter niet zeker dat de hier afgebeelde herder met hond en kudde ook op de boerderi] zijn kudde staide, onder andere omdat het bouwsel woarin de schapen verdwijnen duidelijk als een schuur te herkennen vah. Yermoedeliik is de kudde met herder een romantische toevoeging van de Illustrator die geheel past in de sfeer van de tijd, woarin het serviesgoed werd vervaardigd en in de mentaliteit yan diegenen, waarvoor het servies was bedoeld.

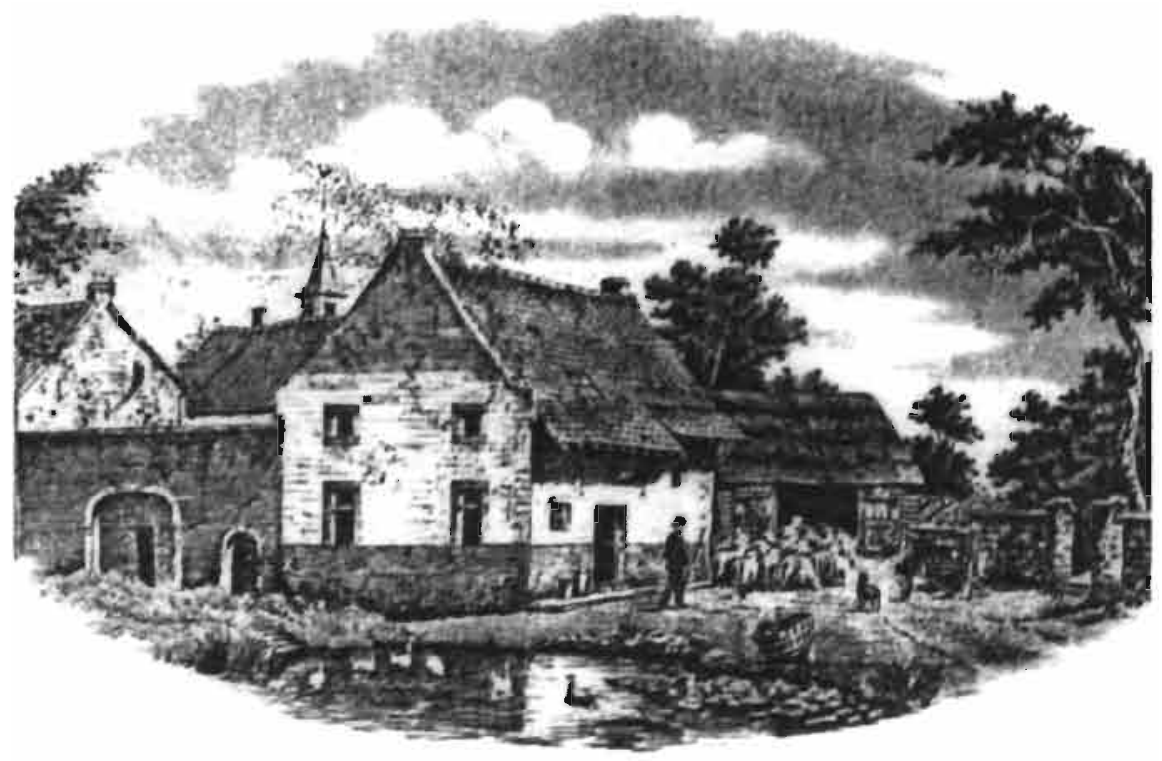


kante kilometer. In 1980 was daar nog de helft van over: ${ }^{7}$

Wat hun ligging ten opzichte van de dorpskern, omvang en trofiegraad betreft, is de variatie aanzienliịk. Uit de lijst van poel-toponiemen kan worden afgeleid, dat een aantal daarvan typische dorpspoelen waren; ze lagen op pleintjes binnen de nederzetting. Andere zijn als hofpoel te bestempelen; ze lagen dichtbij en op het grondgebied van een grote hoeve. Een derde type was buiten de nederzetting gesitueerd, meestal in standweiden. Beperkt van omvang waren de talrijke, vaak naamloze poelen in standweiden met een oppervlak nauwelijks groter dan tien vierkante meter. Hofpoelen variéren tussen tien en honderd vierkante meter, terwijl dorpspoelen een nog groter oppervlak besloegen. De Schone Poel van Berg bijvoorbeeld had een oppervlak van minstens 300 vierkante meter (zie figuur 4.2 en 4.3).

Schoon, dat wil zeggen voorzien van helder. zuurstofrijk en voor menselijke consumptie geschikt water, waren deze poelen zeker niet. Integendeel, alleen al op grond van additie-betekenissen mag worden aangenomen, dat het water was verontreinigd met onder andere dierliike mest; de in samenstellingen met pool of koel genoemde waterdieren en -planten (onder andere eenden, padden en kroos) indiceren voedselrijke, zuurstofarme en modderige milieus. Desondanks vormden deze waterbekkens voor hec onderzoeksgebied zeer karakteristieke landschapselementen, die geschikte voortplantingsbiotopen boden aan een aantal soorten amfibieèn, waarvan het voortbestaan momenteel ernstig wordt bedreigd (zie figuur 4.4).

2.3 Etymologisch zijn de substantiva koel in toponiemen en dialecten en het $\mathrm{Ne}$ derlandse kuil nauw verwant; beide termen duiden op bodeminzinkingen. In twee opzichten zịnn er echter betekenisverschillen. Een koel kan een omvangrijk oppervlak omvatten; "koel" betekent ook kolenmijn en tevens

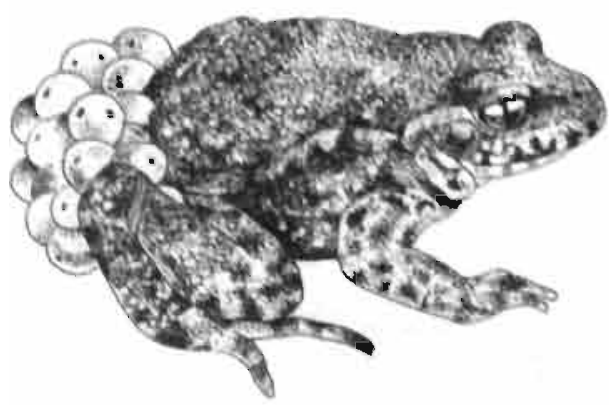

"elke gegraven groeve". Het tweede en derde verschil betreft de wijze van ontstaan en de latere functie; koelen zijn antropogeen van oorsprong, kunnen met regenwater blijvend gevuld raker en als drenk gaan fungeren, bij kuilen is dat niet noodzakelijk.

De talrijke koel-toponiemen, ${ }^{\text {" }}$ voor zover zij in het verleden een drenkfunctie vervulden. hebben het $z$ waartepunt. van hun geografische verspreiding in het oostelijk deel van het onderzoeksgebied. In het westeli $k$ deel, met name in het Belgisch deel van Limburg, is koel als toponiem in de betekenis van een waterhoudend bekken onbekend.

Er bestaan slechts enkele simplexvormen van het koel-toponiem. Eén daarvan, Koulen, is een gehucht. Talrijke composita geven in het eerste deel van hun samenstelling overvloedige informatie over de ontstaanswijze en de functie van de gegraven koel. De winning van delfstoffen, leem, mergel, zand, stenen, kiezel, klei, steenkool en ijzer(oer) worden met name in toponiemen genoemd. Eveneens met een vooropgezette bedoeling gegraven, zijn de prijekoelen, begraafplaatsen voor krengen, en de wolfskoelen, vangkuilen voor wolven" (zie figuur 4.5). Deze begraafplaatsen hebben met het element water niets uit te staan.

De drie volgende functies van een koel hebben wel op de een of andere manier te maken met water. De drenkfunctie van een koel ligt voor de hand; vee wordt in samenstellingen vaker genoemd. Secundair is hun betekenis als reservoir voor bluswater, maar ook die functie is begrijpelijk; tot diep in de negentiende eeuw waren de meeste bouwsels op het platteland immers uiterst brandbaar vanwege hun strodak en houten skelet. Brandpoelen en brandkoelen worden in dorpsreglementen genoemd en hun onderhoud was een gemeenschapsplicht. ${ }^{10}$

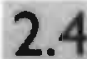
Minder bekend dan de functie van drenk en bluswaterreservoir is de functie van de dorps-

\section{FGUUR 4.4}

Kargkteristieke veepoelbewoners: de vroedmeesterpod en do geelbuilkvuurpad. Tekeningen van $\boldsymbol{R}$ Willocka.

De vroedmeesterpod dankt $x$ lin noam gan het feit dat de mannetjes de eisnoeren van het wijfle overnemen, dexe om hun achterpoten wikkelen en pas het water opzoeker, wanneer de eitjes op het: punt stoan om vit te komen. De geel gevlekte onderzilde van de geelbulkvuurpad fungeert als woarschuwing padden schilnen heel vies te smaken. poel met betrekking tot het conserveren van hout. Dit gold niet alleen voor het constructiehout voor vakwerkskeletten, ${ }^{11}$ maar ook voor wilgetenen die in ondergedompelde toestand gedurende een lange periode hur soepelheid bleven behouden. ${ }^{12}$ Wilgetenen speelden destijds een belangrijke rol als binden vlechtmateriaal.

De namen van dieren die als eerste lid in samengestelde koel-toponiemen worden genoemd, kunnen in minstens drie groepen worden verdeeld. De numeriek belangrijkste wordt gevormd door veenamen. Mogelijk is een drietal "Heerkuilen"13 te beschouwen als afgesleten heerdkuilen en synoniem voor veedrenk; een verklaring die uitgat van de (lands)heer lige bepaald minder voor de hand. Een tweede groep noemt waterbewoners (onder andere eend, kikvors en bloedzuiger) en een niet aan water gebonden vogelsoort; met name de zwaluw, die alleen de modder van de poelrand gebruikt om zijn nest te maken. Een derde groep van diernamen die met koel zijn samengesteld en in toponiemen zijn vastgelegd, omvat gravers (onder andere konijn, das en vos), die door hun graafactiviteiten mogelijk de primaire veroorzakers van de bodeminzinking ziịn geweest. Voor diverse "Wolfskuilen" is de verklaring "vangkuil" voor dic gevreesde en fel bejaagde dier zeker juist.

De namen van plantesoorten die met koel zijn samengestuld, duiden op houtige pionierssoorten met een volksnaam of op een het water geheel bedekkende waterplant. Andere koel-toponiemen geven, blijkens de betekenis van het woord waarmee zij zijn samengesteld, onder andere hun ligging aan bij een

karakteristiek landschapselement, bijvoorbeeld een bepaalde boom of een bepaalde weg. De overige poelen koelnamen die in het

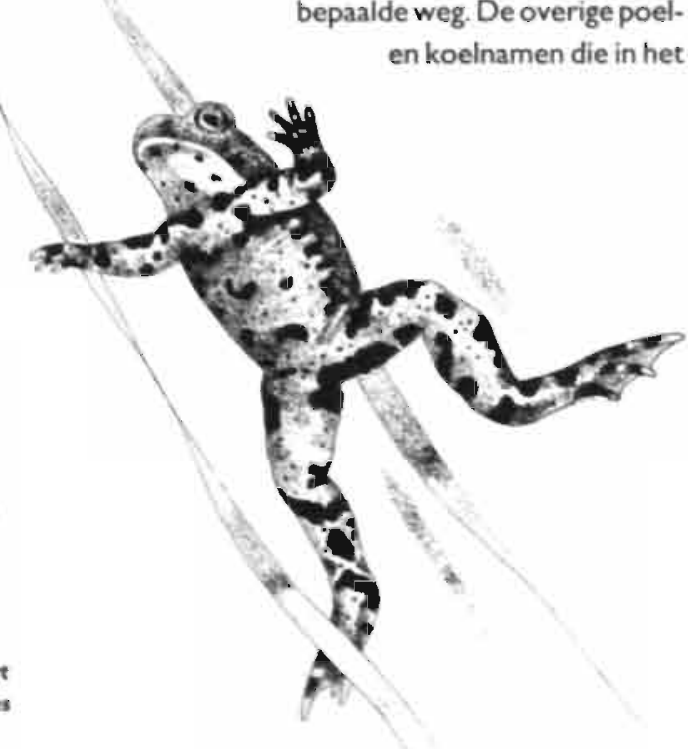




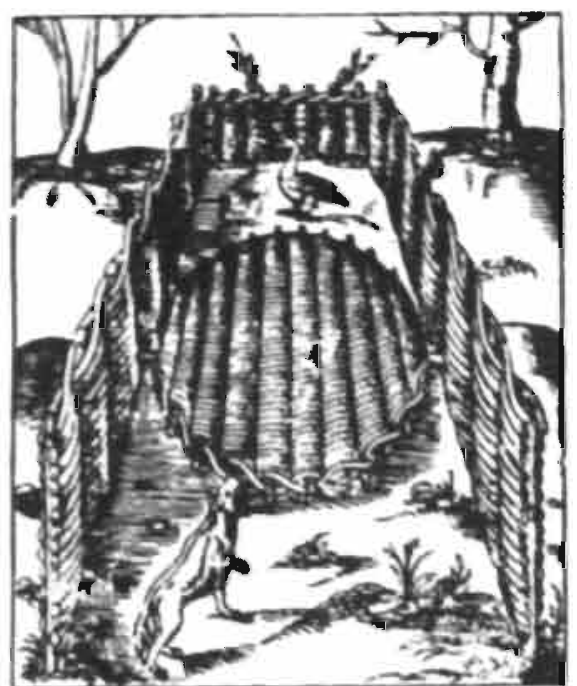

FGCUR 45. Een wolfskuil, noar een afbeelding wit SCHRijnemuareas 1986. Met behulp van een levend lokoos, een klapmechaniume en een diepe kuil werden wolven gevangen. Hoewel de wolf vrijwel in geheel Europa is uitgeitorven, leeft zijn naam in vele toponiemen voort.

gebied van onderzoek zijn aangetroffen, zijn moeilijker te duiden.

\section{3}

Het substantief drenk geeft de heerdgang-indicatieve functie in toponiemen hec meest duidelijk weer; drenken is immers het causatief van drinken en betekent dus letterlijk "doen drinken". Uiteraard wordt hier het doen drinken van vee bedoeld.

Binnen hec onderzoeksgebied zijn weinig drenk-toponiemen aangetroffen. Daarvan zijn er enkele gelegen aan stromend water: de rest heeft betrekking op poelen.

Minstens zo doorzichtig als drenk zijn de toponiemen "Koezoep" en "Kooywater". Dumpel is etymologisch identiek met het Hoogduitse Tümpel (= poel).

Afgezien van de al besproken namen voor stilstaande wateren met een drenkfunctie, zijn er nog enkele substantiva die in toponiemen voorkomen en waarvan de betekenis een stilstaand water inhoudt, namelijk "wijer", "ven" en "vlas". " Het eerste betekent ofwel een opgestuwde en lokaal verbrede beek bij een watermolen ofwel een kasteelvijver. Met een ven, plaatselijk in toponiemen "vin" en "vlas" genoernd, elders in Nederland "vles" of "fles", wordt een heidemeertje bedoeld. Incidenteel zullen deze stilstaande wateren ook weleens als drenk zijn gebruikt, maar uit toponymische samenstellingen blijkt dit niet. geeft van alle waternamen de duidelijkste in- formatie over diens betekenis voor de dorpskudde. Drenken kunnen zowel aan stromend water als aan stilstaand water zijn gelegen, In beweide graslanden langs beken en rivieren moeten zeer veel functionele drenken heb. ben gelegen: Op de sterk water doorlatende plateaubodems is oppervlaktewater een zeldzaamheid. Daarom zijn er op de plateaus meer drenk-indicerende toponiemen gevormd en bewaard gebleven. Het meest karakteristieke voorbeeld is het maar/meertoponiem. de oorspronkelijke naam voor een halfnatuurlijk regenwaterbassin, waaromheen een nederzetting kon ontstaan. In een latere fase van de geschiedenis van die woonkern wordt de naam voor de dorpspoel toegepast voor de open plek rond de poel of zelfs voor de hele nederzetting gebruikc. Het feit dat minstens zes nederzettingen zijn vernoemd naar de centraal gelegen maar of meer en minstens net zoveel nederzettingen een centraal gelegen pleintie met de naam moar bezitten, toont niet alleen de vitale functie aan van de dorpspoel, maar zou tevens een indicatie kunnen zijn voor de hoge ouderdom van het woord in die betekenis.

De meeste poelen en water bevattende kuilen danken hun ontstaan aan bewust graafwerk en dateren hoogstwaarschijnlijk uit een latere periode. Dat laatste geldt zeker voor de kleine drinkpoelen in standweiden. Tegen het einde van de negentiende eeuw is de poelendichtheid in het gebied van onderzoek zeer groot (zie figuur 4.6). Vanaf die tijd ver-

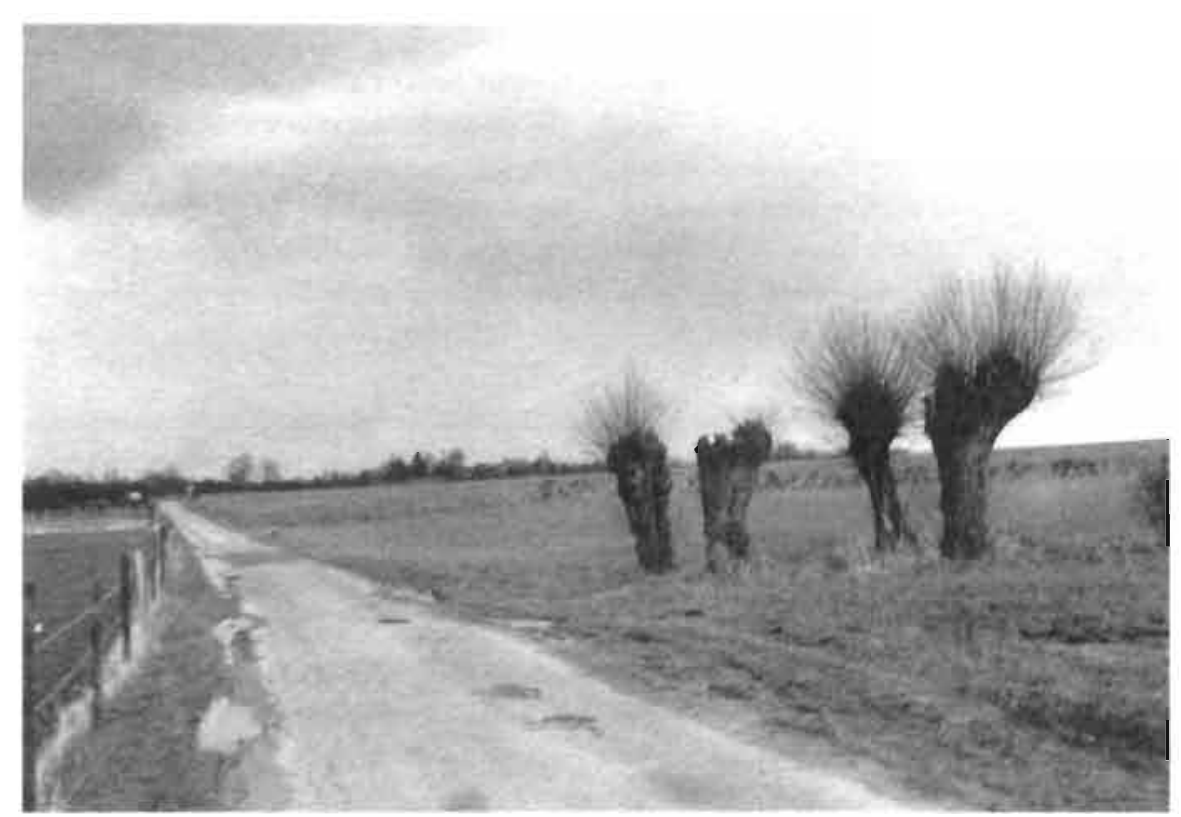

FIGUUR 4.6. Eein voormalige drinkpoel voor het vee, omgeven door knotwilgen, in een standweide tussen Bergenhuizen en Terlinden. Foto van de auteur, februar 1989. De plaats van deze voormalige poel wordt nog verraden door de oanwezigheid von de vier knotwilgen, die de poel tegen uitdroging moesten beschermen. dwijnen de grote dorpspoelen en andere gemeentepoelen; rond. 1950 hebben nogveel standweiden een drinkpoel. Sinds. 1980 worden de nog overgebleven exemplaren wettelijk beschermd, niet alleen vanwege het feit dat deze kleine landschapselementen karakteristiek zijn voor het plateaulandschap, maar ook omdat zij een aantal met uitsterven bedreigde diersoorten kunnen herbergen. Deze en nieuw gegraven dan wel gerestaureerde poelen worden momenteel onderhouden door gemeenten overkoepelende organisaties.

\section{NOTEN}

KNAMEN 1972 p. B

2. Zie abel 4.I. Fen typische zoun ligt in Vijtingen, ver. gelijk Hacxiva 1962, een slont in Meerssen, vergelijk Das etal 1977 en een syprunk te Margraten, ver. gelijk Heidendal in Bijdrage tot de historie van Margraten 1983.

1 Zie tabel 42

5 Goossens EN Gituen 1972. p. 298

6 Bijdrage tot de historie van Margraten [983, pp. 17]. 175

7 Kaart "Inventarisatie poelen" in het Nationaal Land schap Mergelland, juli 1987, Uitgave Natuur, Milieu en Faunabeheer, Archief N.M.F., Maastricht. Zie ook VAN DER BUND 1964

8 Zie tabel 4.3.

9 SCHRUNEMAKERS 1986.

10 Phil IPPENS 1983, p. 290

II HLLEgens 1987.

12 Zie tabel 43 , no 79-83

I4 Zie tabel 44
3 Hacking 1982 en figuur 4.1

I3 Zie tabel 4.3, nr 27-29. 


\title{
GROEN-TOPONIEMEN
}

\author{
Grampa, wet geer neet boe de Greune weeg ligk? \\ Meh, jungske, wetst te dat neet? \\ Dee ligk oonder de kooi heure start.
}

Een oud Maastrichts kinderraadsel.'

In Dittmaiers "Rheinische Flurna. men"2 worden van het toponiem Griner Weg de volgende betekenissen aangegeven: 1) "Grasbewachsener Weg... meist torlaufend... zum Viehhuten freigegeben... 2) mancherorts der Leichweg... 3) aufgegebener alter Weg, der zugewachsen ist: mehrfach Romerstrasse":

Het is vooral de laatste betekenis, die veel lokaal actieve toponymisten, dat wil zeggen zij die de toponiemen van slechts eeen nederzetting beschrijven en verklaren, heeft aan. getrokken. Diverse in Zuid-Limburg voorkomende groen-hodoniemen zijn veelal beschouwd als met gras overgroeide, verlaten wegen, die in de Romeinse tijd een belangrijke verkeersfunctie hadden.

"De hardnekkige neiging van de menselijke geest om de dingen ouder te maken dan ze zijn" heeft lokale historici en toponymisten vaker parten gespeeld. Deze uitspraak met een algemene strekking kan met enkele voorbeelden worden geillustreerd. Devoor ZuidL.imburg zo karakteristieke vierkante hoeve met binneriplaats is niet direct af te leiden van de Romeinse villa met atrium, ' Onze "mergelgrotten" blijken niet Romeins, maar hoogstens Romaans, dat wil zeggen middeleeuws van oorsprong. . De vele "kampen" in toponiemen zijn geen Romeinse legerplaatsen. maar laat-middeleeuwse, door hagen omgeven akkers't en de sporen van een Romeinse centuratio in Zuid-Limburg blijken een illusie. $^{7}$

Ook de Romeinse oorsprong der groen-hodoniemen wordt in de recente toponymische literatuur ernstig betwijfeld. Schrijnemakers $^{\mathrm{B}}$ wijst op een verschil tussen enerzijds groene wegen en anderzijds groene stroten. Hij komt tot de conclusie dat alleen de laatste van interlokale betekenis kunnen zijn geweest en mogelijk van Romeinse oorsprong zijn; groene wegen stellen daarentegen onbeduidende veldwegen voor en dateren uit een betrekkelijk recente periode. Molemans ${ }^{9}$ heeft onlangs in uitvoerige toponymi- sche beschriịvingen en voorzichtig gestelde verklaringen veel groen-hodoniemen uit Belgisch-Limburg van topografische details: voorzien: ze monden uit in bossen, beemden of heiden. Nergens vermeldt hij deze wegen als Romeins van oorsprong.

Dit onderzoek poogt, in navolging, van bovengenoemde auteurs, de in Zuid-Limburg talrijk voorkomende groen-toponiemen te. plaatsen in een landschaps-oecologisch kader, waarbij richting, doel en oorsprong in samenhang met het omringende landschap en het agro-pastorale gebruik daarvan worden onderzocht. Vanuit dit verband wordt gepoogd een betekenisverklaring te geven.

\section{2}

Afgezien van de combinaties met -straat, -weg en -wegsken, komt het adjectief groen. groene of groenen meermaals voor als eerste lid van een toponymische samenstelling. Als tweede lid werden genoteerd: ${ }^{10} \mathrm{dal}$, rein (= grens), boord (= zoom of grens), borg (= berg!), beemden, hei, veldje en graof (= berm).

Blijkens bovenstaande gegevens, die delen van het landschap voorstellen die niet worden geploegd, heeft het adjectief groen in de. toponymie betrekking op (permanent) grasland. Dit waarschijinlijk in tegenstelling tot akkerland, dat periodiek. wordt geploegd en dus regelmatig een andere kleur dan groen heeft.

In elk geval heeft de Nederlandse term groenland en het Hoogduitse equivalent daarvan. Grinland, ${ }^{11}$ in de historische agronomie algemeen ingang gevonden en betekent hier "grasland" of, meer specifiek, "grasland langs waterlopen in gebruik als hooilanden met nabeweiding dan wel uitsluitend als beweide gronden". De betekenis van het substantief groen in Zuidlimburgse toponiemen sluit hier volledig op aan.

Binnen het onderzoeksgebied kan een tweetal geomorfologisch sterk van ellkaar verschillende groenlandtypen worden onderscheiden, die echter in één opzicht met elkaar overeenkomen, nameliị vanwege hun ongeschiktheid als akker. Tot het eerste type behoren vochtige en produktieve graslanden langs waterlopen. In de toponymie staan deze. bekend onder de namen broek, beemd, pas, breul en dergeliịke, die als akker ongeschikt waren vanwege hun periodieke overstroming. Het tweede type groenland is gesitueerd op de steile plateauranden en is om die reden ongeschikt voor landbouw. In de Zuidlimburgse toponiemen staan deze groenlanden bekend onder de benamingen hei of berg. Omdat de meeste groen-toponiemen zijn gelegen in alluviale situaties, zijn dit de groengronden bij uitstek.

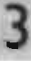

Binnen het kader van deze studie is het onmogeliịk de 28 Zuidlimburgse groenstraten en de 43 groen(e) wegen in hun geografisch en sociaal-historisch kader te plaatsen. ${ }^{12}$ Slechts enkele groenstraten en -wegen worden hieronder vitvoerig besproken. Van de overige groen-toponiemen worden deze historisch-geografische gegevens in de vorm van een tabel beknopt weergegeven (zie ta. bel 5).

Dank zij enige gedetailleerde kaarten uit de achttiende en negentiende eeuw van het gebied rond Kloosterrade, momenteel beter bekend onder de naam Rolduc, en dank zij de uitvoerige beschrijving van dit gebied door Schrijnemakers, ${ }^{13}$ kan een duidelijk land-

FiGUUR 5.1

De Groenstradt of

Kloosterveeweg van de abdighoeve Kloosterrode (Rolduc), ofgebeeld op de Tranchotkoart. De Groenstradt stond destijds bekend onder de noam Kloosterveeweg en verbindt de verestallen van de abdighoeve met diverse typen van beweide gronders, onder andere heiden, beemden en bossen. 
210 $2=-2 x^{2}$

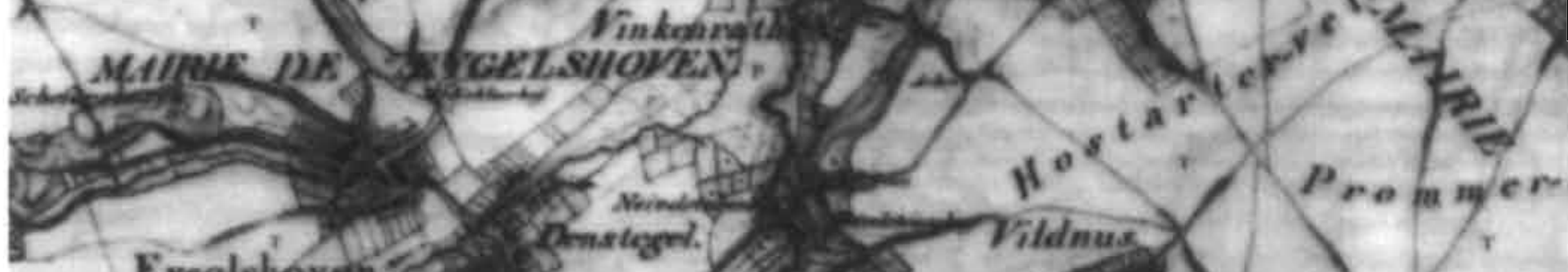

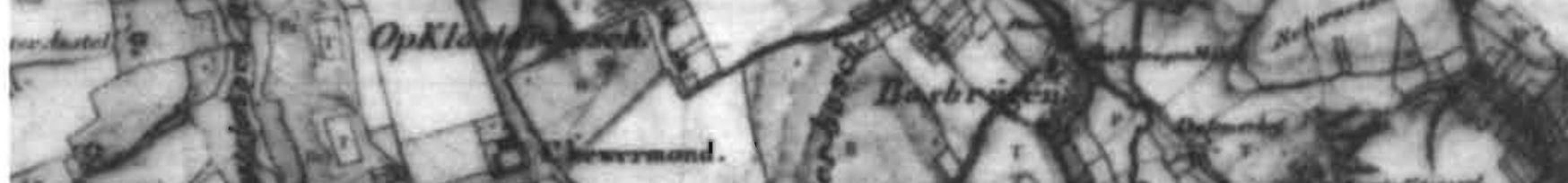

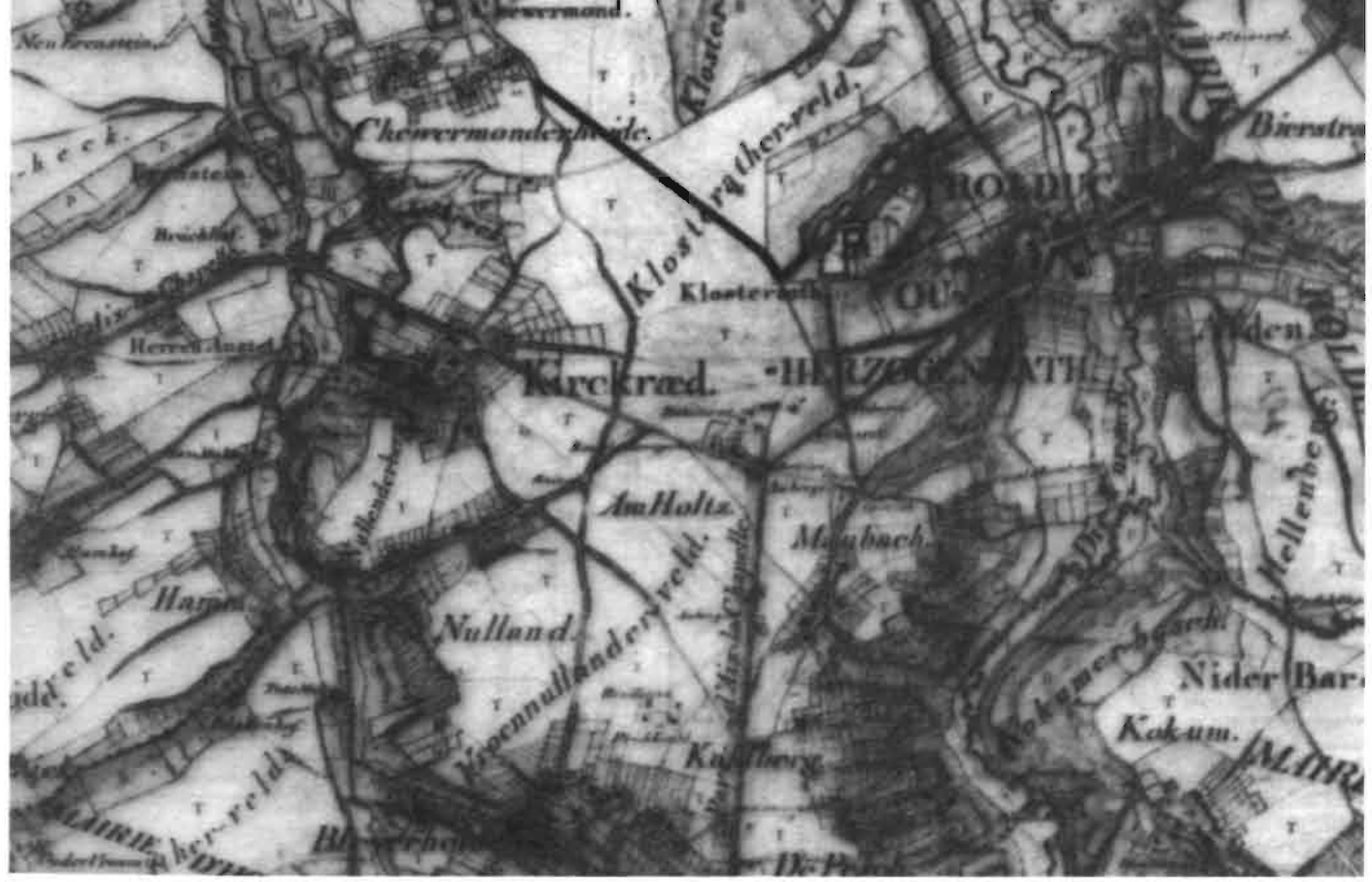




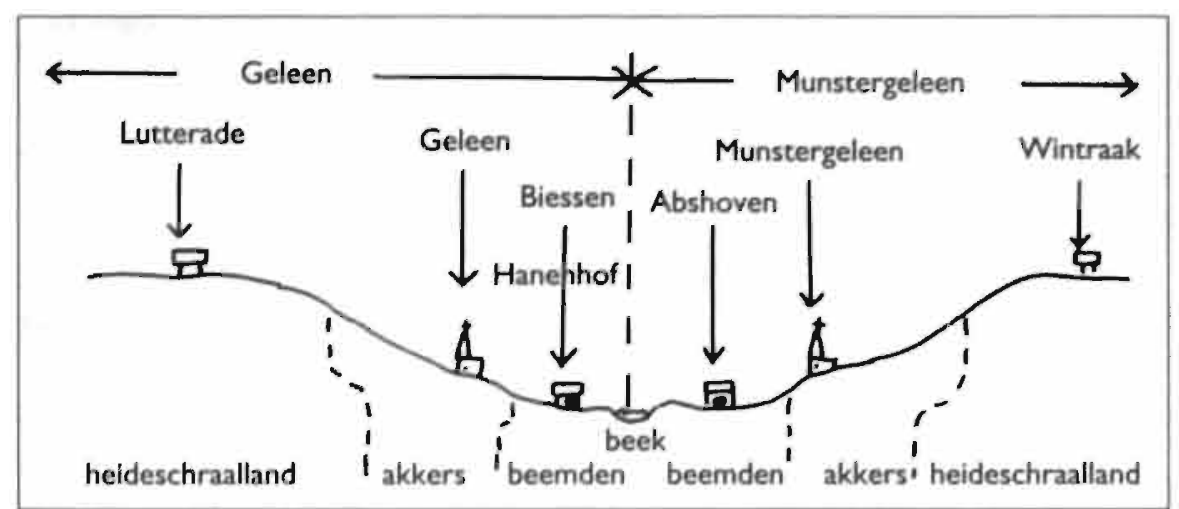

HGUUR 5.2. De symmetrie van twee beekdainederzettingen: Geleen en

Munsterneleein net hun satellietnederzettingen in het dal van de Geleenbeek.

D. beak vormt de scheiding tussen twee symmetrische londschappen, die op identieke wije werden beheerd.

schaps-oecologisch beeld worden geschetst van een groenweg.

Een gedetailleerde kaart, daterend uit de jaren 1775-1776 vermeldt "Grünen Weg" als de naam yan de weg die, komend vanuit, de abdijhoeve, kaarsrecht naar het noordwesten verloopt (zie figuur 5,1), De functie van het gebouwencomplex, waar deze "Grünen Weg" begint, wordt op een andere kaart nader gepreciseerdals een grote schapenstai en (runder)stallen. De kaarsrechte weg wordt. echter op deze kaart als de Kloosterveeweg aangeduid.

De ligging en de bestemmingen van deze groenweg, alias veeweg van de abdijhoeve, kunnen op de Tranchotkaart uit 1805 nader worden bestudeerd. De weg in kwestie verdeelt het plateau van Kloosterrade in twee gelịke helften. Hị passeert, komend vanuit de hoeve, eerst het akkercomplex Klosterratherveld, waar na de oogst beweiding kon plaatsvinden en komt aan een viersprong met: een "Lindebaum". Dit is een oriêntatiepunt. Vanuit dit punt verloopt een weg, naar het westen die uitmondt in het Teutelbroek, volgens de Tranchotkaart een complex van zowel vochtige (broek)graslanden langs de Anselerbeek als van droge, heischrale graslanden op de plateauranden. De momenteel nog overgebleven restanten van deze vegetatietypen, met name die van de Peschbeernden langs de beek, zijn bijzonder soortenrijk en indiceren een langdurige extensieve beweiding. " Overigens, ook het toponiem Peschbeemden verraadt de voormalige beweiding in kuddeverband. ${ }^{15}$ Vanaf de viersprong noordwarts verenigt de "Grünen Weg" zich met de Koestraat en mondt uit in "Chèvrennonterheide", een toponiem dat, wathet eerste deel van die samenstelling ook moge betekenen: ${ }^{16}$ op (voormalige) beweiding in kuddeverband betrekking heeft. Zowel ten noorden als ten oosten van de viersprong liggen bossen, respectievelijk Op den Klosterbosch en Klosterbosch, beide omgeven door hagen, behalve op die punten waar de wegen deze bossen aansnijden. Ook bossen werden (periodiek) beweid.

De bovengenoemde. "Grünen Weg" is een duidelijk voorbeeld van een heerdgangroute
FIGUUR. 5.3

Groen-toponiemen by Geleen, aangegeven op de Kuyperkoart uh 1869. De Groenstrat van Lutterade vormt de verbinding tussen de nederzetting en de grasianden langs de beek. Hier lag een drenk. De Groenstraot van Geleen vertindt everseens het dorp met graslanden langs de Geleenbeek. De Groene weg ten noordeosten van Geleen is gelegen in de omgeving van een historisch bekende veeroute: die vanuit Munstergeleen noar de Graethei.

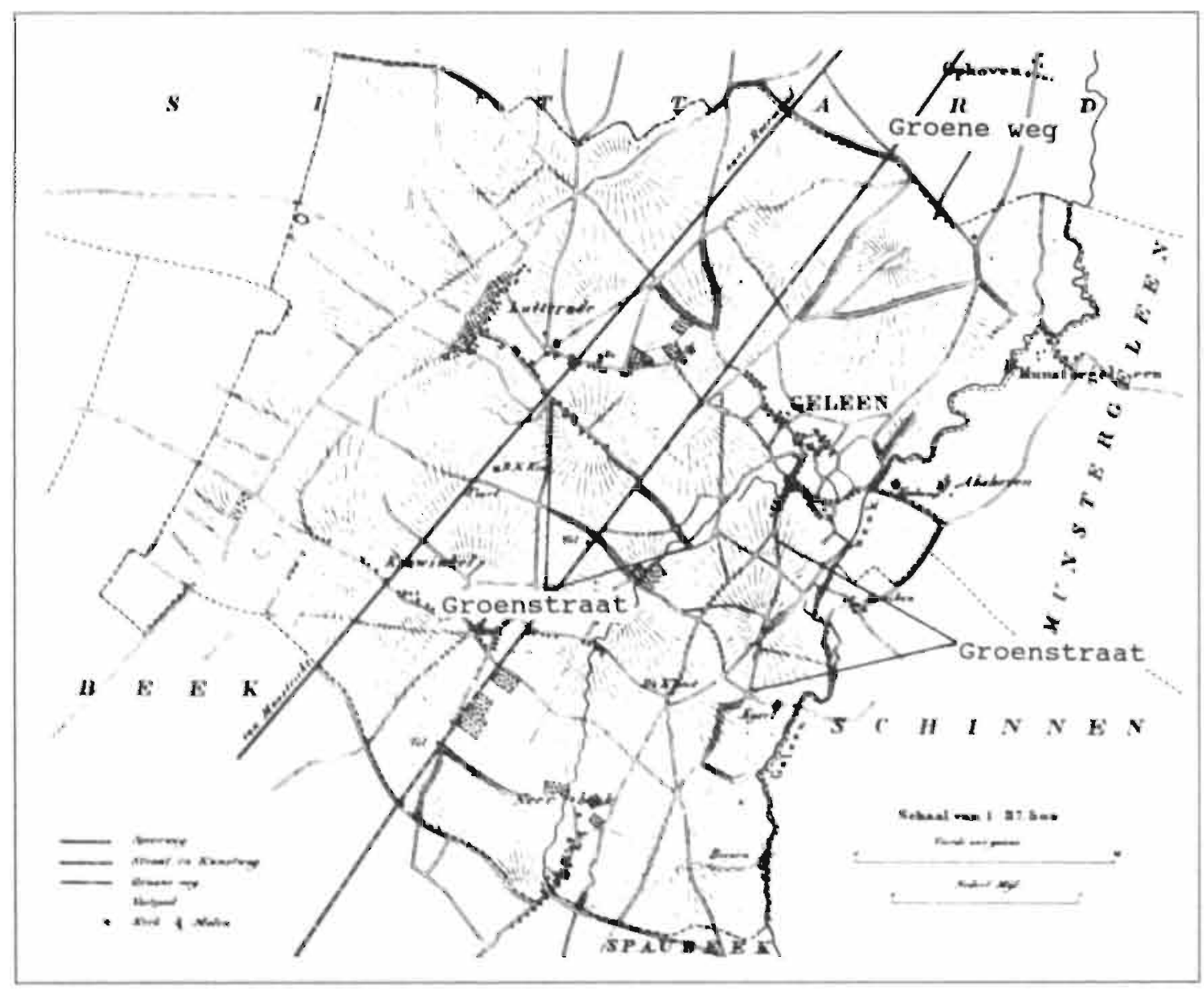


vanuit de abdij van Kloosterrade die op een strategische wijze alle landschapseenheden bestrijkt die voor beweiding in aanmerking komen en die zijn gelegen binnen het rechtsgebied van de abdii.

4. I In een monografie over de nederzetting Munstergeleen ${ }^{17}$ wordt informatic verschaft over vier groenstraten en twee groenwegen. Aan deze zes groen-hodoniemen kan nog een groenweg worden toegevoegd, die door de landmeter Stroom wordt opgegeven. I"

Alvorens deze successievelijk te bespreken. lijkt het nuttig een overzicht te geven van het landschap rond Geleen en Munstergeleen. Landschaps-oecologisch gezien, vormen de gemeenten Geleen en Munstergeleen elkaars spiegelbeeld. De woonkernen bevinden zich op het middenterras van de Geleenbeek, die wordt omzoomd door vochtige beekdalgraslanden. Plateauwaarts liggen drogere gronden die eveneens werden beweid: de zogenaamde heiden en bergen. Op de Geleense kant van het beekdal lag tot en met het begin van de negentiende eeuw de legendarische Graethei, aan de Munstergeleense kant de Hondskerkerberg met plateauranduitlopers naar het noorden en zuidwesten. Beide gemeenten omvatten, afgezien van de vroegmiddeleeuwse dorpskernen voorzien van een kerk, woonkernen van latere corsprong. zoals de ontginningsnederzettingen Lutterade (= kleine ontginning?) en Wintraak, benevens eenzaam gelegen hoeven in het dal van de Geleenbeek. De bewoners van al deze kernen maakten op identieke wijze gebruik van de delen van het landschap: de matig vochtige, nooit overstroomde en vruchtbare dalgronden rond de nederzetting waren bestemd voor de graanproduktie; de vochtige, periodiek overstroomde graslanden langs de beek fungeerden als hooilanden en weideplaatsen voor het rundvee. De droge schraallanden op de plateauranden aan de periferie van de gemeente waren eveneens weideplaatsen, maar meer geschikt voor schapen dan voor rundvee (zie figuur 5.2).

4.2 De binnen de grenzen van dit gebied gelegen groenstraten laten zich in dit landschaps-oecologisch kader als volgt karakteriseren (zie figuur 5.3 en 5.4).

De Groenstraat van Geleen, al in 1378 genoend, vormt de voortzetting van de Dorp. straat en verbindt de dorpskern met: bewei- de gronden langs de beek. Deze Groenstraat vormt, gezien haar richting, oorsprong en eind, zeker een heerdgangroute, maar zou tevens een interlokale weg kunnen zijn, omdat zij over een lang traject het beekdal volge. 19

De Groenstraat van Lutterade is, net als die van Geleen, de voortzetting van de Dorpstraat maar "gaat niet verder terug dan de Middeleeuwen", 20 De straat vormde de directe verbinding tussen de nederzetting Lutterade en het beekje, dat de dorpen Beek en Neerbeek van hun naam voorziet. Daar konden de Lutteraders hun vee drenken. De Groenstraat van Lutterade was volgens de Tranchotkaart met hagen afgezet.

De toponiemen Drenkstraat, Groenstraat (bij de hoeve Abshoven in Munstergeleen, vermeld door landmeter Bollen in (745) $)^{21}$ en Groene weg liepen vanaf de Geleenbeek bij Abshoven in elkaars verlengde in oostelijke richting. Vanuit Abshoven kon men via de Drenkstraat het water van de beek en de daar gelegen vochtige graslanden bereiken en via de Groenstraat en Groene weg de drogere graslanden van de plateaurand. De heerdgangen van Lutterade en Abshoven zijn elkaars spiegelbeelden: een drenk aan de

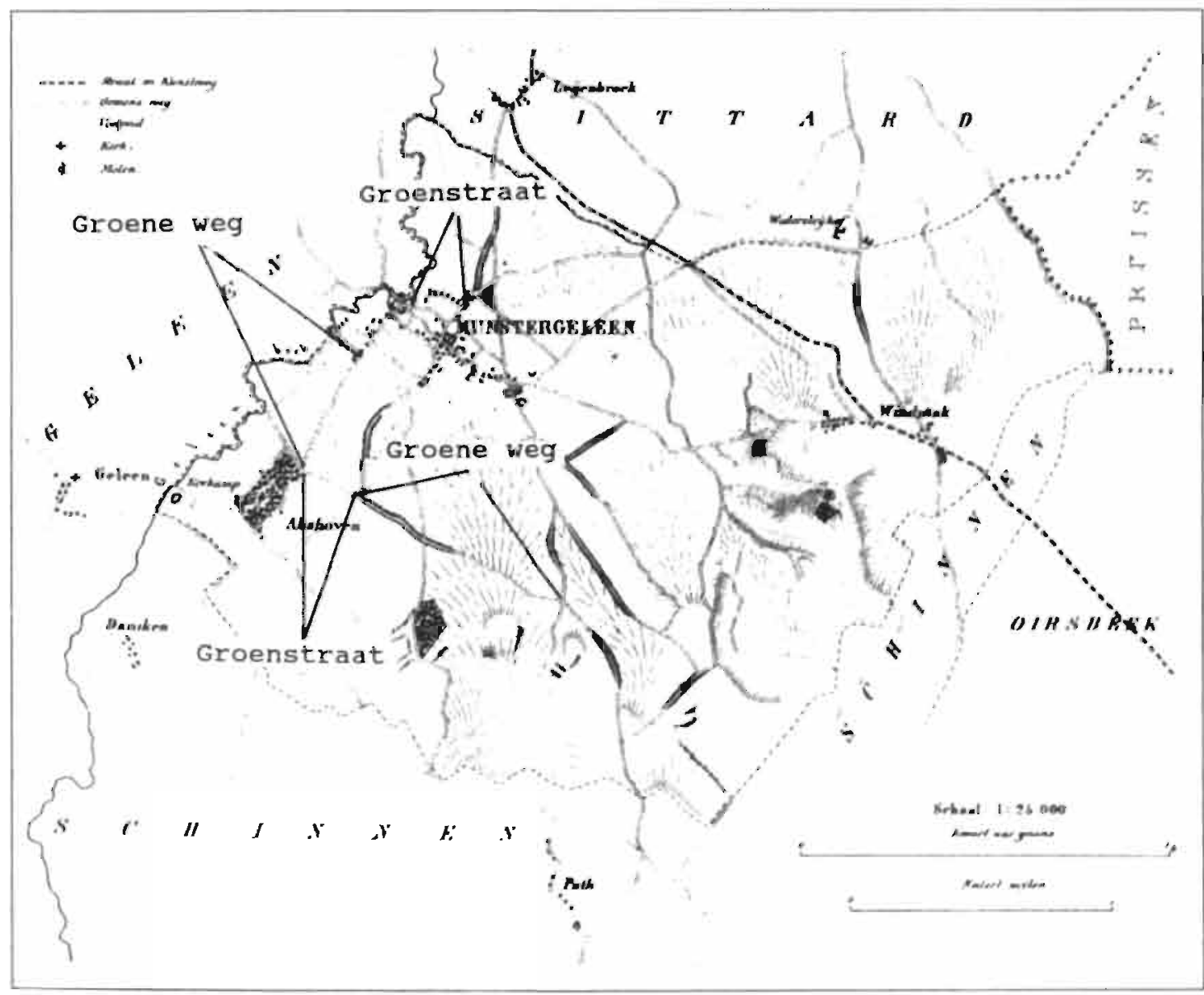

FIGUUR S.A

Groen-ioponiemen bl] Munstergelean, adngegeven of de Kuyperkaart wit 1869. De Groenseraat ran Munsturgeteen vormt ees verbinding tussen het dorp en de trasianden langs de beek De Groenstraat eni de Groene weg van de herenhoeve Abshoven lopen in elkaars vertengde. De route verbindt de hoeve met woidegronden op de ploteourand aan de periferie van de gremeente en met de beenden langs de Geleenbeek. Een andere Groene weg, tussen Abshoven en Munstergeleen, loopt door het dal van de beek 
FIGUUR 5.5.

Groenstraten en -wegen rond de vesting Moostriche, ingetekend op de Cherrolierkeart uit 1748 noar VAN EAMEN at at. 1985. De groenutraten en -wegen hebben een radiair vertoop.

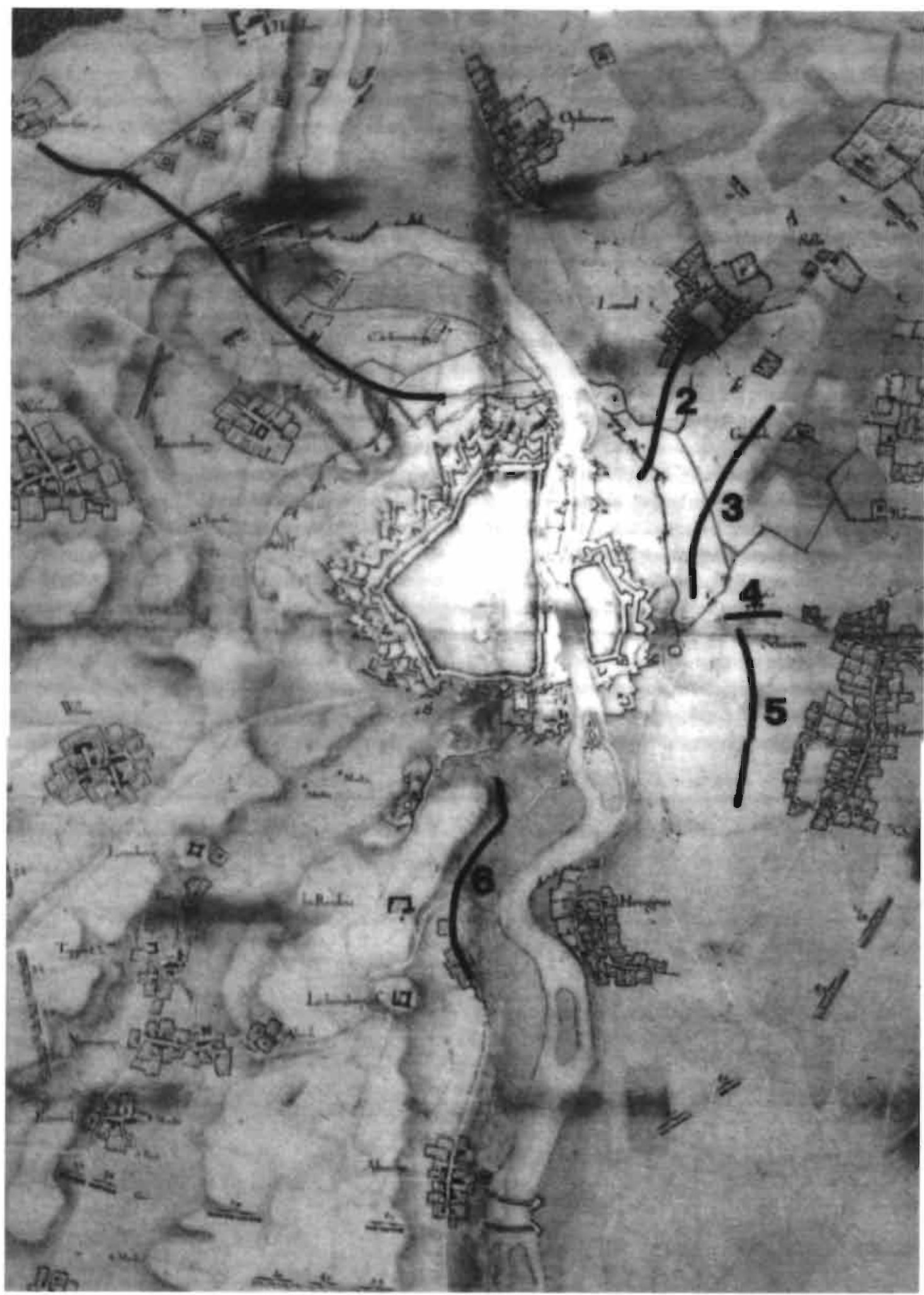

beek, een route waaryan een dee! Groenstraat heet, haaks staat op de hoogtelijnen van het dal en die eindigt aan de plateauranden, war droge graslanden voorkomen. Tevens schịnt de Groenstraat van Abșhoven een deel te zijn geweest van het traject Maastricht-Tuddern-Heinsberg. Dit deel werd in de middeleeuwen en nog lang daarna de (Maas)Trichterweg genoemd.
De Groenstraat van Munstergeleen is volgens Schrijnemakers ${ }^{22}$ "een straat in de oude kom van Munstergeleen die in onze tijd willekeurig aan de vroegere Kladderstraat is gegeven": De naamsverandering lijkt toch niet helemaal willekeurig. In de eerste plaats vormde de bedoelde straat de verbinding tussen de kern van de nederzetting en de groengronden langs de beek, zodat kan wor- den gesproken van een functioneel juiste naam in landschaps-oecologisch opzicht. Die functionaliteit blijkt voorts uit de naam van een verder gelegen verlengstuk, de nader te bespreken Groene weg van Munstergeleen en de opvallende symmetrie met de Groenstraat in Geleen. In de tweede plaats lijkt de omzetting van "Kladderstraat" naar "Groenstraat" toch wel zinnig het dialectische klod- 
ACUUR 5.6.

De Groenstraat van Linne in relotie tot heerdgong-indicatieve toponiemen in dezelfide gemeente. Deze Groenstrad begint in de kern en vertokt zich in de Veestroot, die noar groenland ( $=$ grasland $)$ langs de Maes verloopt, en in de Breestraat (heerdgangwegen behoorden tot de breedute cotegorieên van dorpowegen), die de Linnerhel ob einddoel heeft.

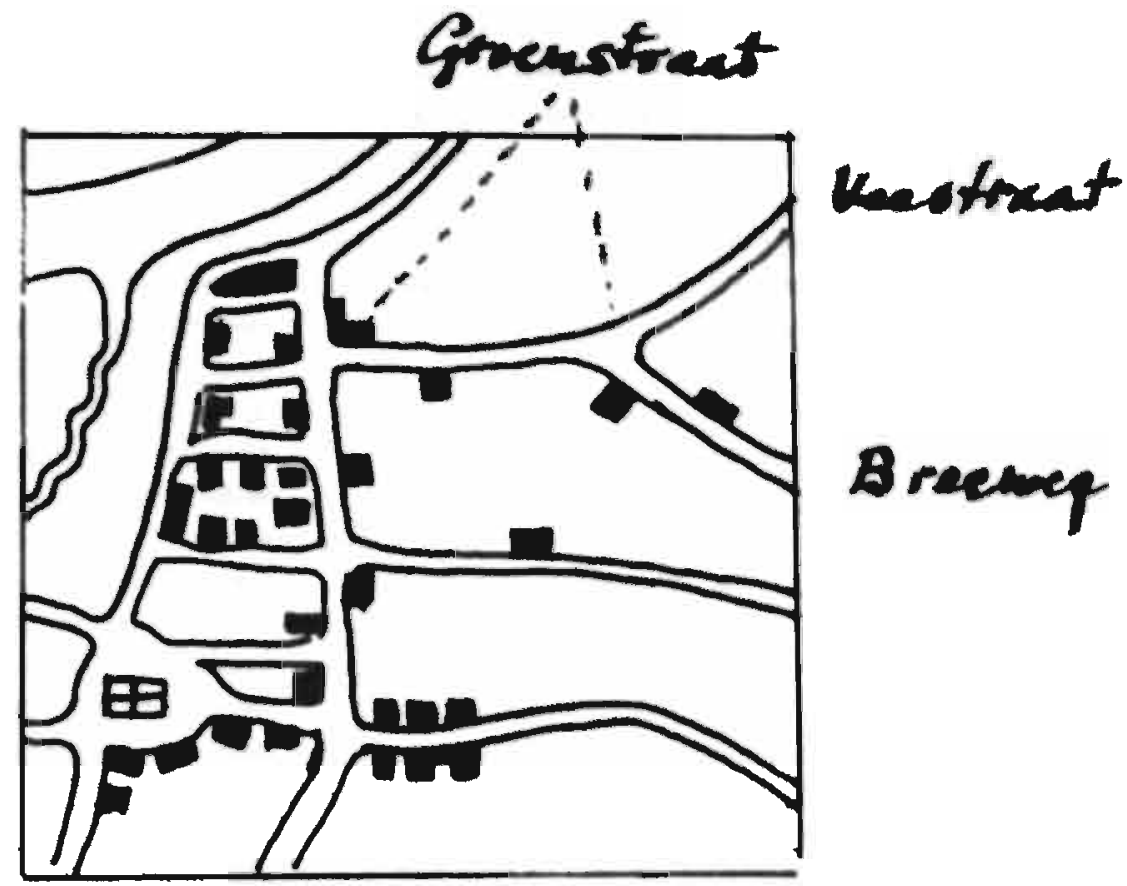

der is een term die kan worden vergeleken met het Nederlandse klodder en klodderen. termen die kunnen worden geassocieerd met modder of rundermest. De "Kladderstraat" was waarschijnlijk synoniem voor "Meststraat" en als zodanig tijdens het begin van deze eeuw, toen de heerdgang was verdwenen, "rijp" voor vervanging. ${ }^{23}$

De Groene weg van Abshoven, een veldweg, "draagt die naam al eeuwen" 24 en vormt een deel van de verbinding tussen de hoeve in het dal, de akkers hogerop en nog verder de plateaurand, waar, zoals overal elders in Zuid. Limburg, schrale graslanden hebben gelegen. Over een aanzienliịk deel van zijn traject is deze Groene weg een holle weg. Min of meer parallel aan de bedoelde Groene weg, die van Abshoven komt en naar de schrale graslanden langs de plateaurand voert, ligt een andere heerdgangroute. Deze met hagen omzoomde, deels holle weg, komt vanuit Munstergeleen en heeft, net als de Groene weg van Abshoven, zijn eindbestemming in de schrale graslanden op de plateaurand.

De Groene weg tussen Abshoven en Munstergeleen bij de vroegere Keerbeemd en de molens, heette in 1659 Kerckwegh. ${ }^{25} \mathrm{De}$ wegverbindt de hoeve met de parochiekerk, maar loopt vlak langs en parallel met de beek. waar vele toponiemen, zoals "Keerbeemd. Drenk, Koekamp, Koebrug en Veewei" op de voormalige functies van deze laaggelegen groengronden wijzen. Beide namen voor de weg in kwestie zijn dus functioneel in landschaps-oecologisch opzicht.

De Groene weg op de grens van Geleen en
Sittard lijkt een onbeduidende veldweg, die over een afstand van nog geen honderd meter de gemeentegrens vormt tussen de genoemde gemeenten. Deze weg bevindt zich precies op de plaats, waar men de ligging van een zeer oude veeroute zou mogen verwachten, namelijk tussen Munstergeleen en de Graethei. Het op zijn minst uit de vroege middeleeuweri stammende dorp Munstergeleen wạs nameliịk één van de 14 kerspelen. die beweidingsrechten bezaten op de uitgestrekte plateauheide, die Graet werd genoemd. Net als bij de overige 13 kerspelen moet er een directe veeroute zijn geweest tussen het. kerspei Munstergeleen en de centraal gelegen Graethei. Een kaart van de Graethei, vervaardigd door Krings ${ }^{26}$ en gebaseerd op toponiemenonderzoek, geeft deze situatie weer. De hierboven vermelde Groene weg maakt het totale aantal van 14 veewegen compleet. Op een andere toponiemenkaart van dezelfde Graethei wordt op precies dezelfde plek wel een Veeweg vermeld. ${ }^{27} \mathrm{Er}$ is bovendien nog een argument om te veronderstellen dat het hier om een deel gaat van de oeroude veeroute van Munstergeleen naar de Graethei, namelijk de holle vorm van de weg, geattesteerd door de huidige benaming "Mooliweg", hetgeen duidt op de lange en van steile kanten voorziene vorm van een baktrog $(=$ moolj $){ }^{28}$

4.3 De onduidelijkheid rond de diverse kris-kras verlopende groenstraten en -wegen bij Geleen en Munstergeleen wordt pas opgelost nadat de patronen zijn gesitueerd in een geografisch en landschaps-oecologisch kader. De oudste nederzettingskernen in het gebied. Geleen en Munstergeleen، bezitten beide een groenstroat, die als een heerdgangroute voor de dorpskudde van rundvee te beschouwen is en de kern van de neder. zetting verbindt met graslanden langs de beek. De later gestichte dochternederzettingen op het hoger gelegen plateau en in het lager gelegen beekdal, respectievelijk Lurterade en Abshoven, hebben binnen de grenzen van de gemeente dezelfde weiderechten als de moedernederzetting. De functionele namen vooi hun heerdgangroutes zijn kopieen van die van de moedernederzetting. Differentiatie in -straat en -weg is waarschijnlijk het gevolg van verschillen in gebruik; voor doorgaande routes wordt -straat, voor niet doorgaande routes wordt -weg gebruikt. In een nog latere periode, wanneer de heerdgang verdwijnt; vervaagt de betekenis van de tot dan gebezigde heerdgang-indicatieve toponiemen.

Diezelfde tendenzen doen zich voor bij de groenstraten en -wegen rond Maastricht, die in de volgende paragraaf worden besproken.

\section{5} Sinds de bouw der stadsomwallingen in de middeleeuwen tot aan de sloopervan tijdens de: tweede helft van de vorige eeuw, bestond de directe omgeving van de vesting Maastricht uit open, niet geakkerde gronden. Talriịke afbeeldingen uit die periode kunnen dit illustreren. ${ }^{29}$

De aanwezigheid van een grazig, vrijwel boomloos gebied rond de stad was niet alleen 
het gevolg van een bepaalde verdedigingstactiek van de vesting, die voorzag in een groot open schootsveld voor de muren van de vesting. Ook de perjociiek sterk fluctuerende stand van het Maaswater, yooral in het winterhalf,aar, had een grondgebruik tot gevolg, waarin voor akkerbouw geen plaats was, veeteelc werd toegepast, en waar uitsluitend grassen en kruiden voorkwamen die tegen periodieke, inundaties en begrazing bestand zijn. Deze "wilde" groenlanden betekenden voor de boeren, of liever voor hun vee, welkome weidegronden. Vanuit hun nederzettingen rond Maastricht dreven zij hun vee via vaste routes naar deze gronden. De vijf Maastricht straalsgewijs omgevende groenstraten eri-wegen stellen dan ook geen uitvalswegen voor vanuit de stad, maar vormen de verbindingen tussen de agrarische nederzettingen rond de stad en de uitgestrekte, 's winters overstroomde groengronden buiten de stadsornwallingen.

Vanal het midden van de vorige eeuw verloren de toen nog bestaande zes groenwegen of -straten rond Maastricht hun oorspronkelijke functic. Hun mamen werden vervangen: slechts één groenstroat heeft de naamsverandering overleefd, maar deze loopt nu dwars door een woonwijk, die uit het begin van de twintigste eetiw dateert. De nummers van de hieronder vermelde serie groenstraten en wegen komen overeen met die van figuur 5.5 . 1) De "Groenstraar" van Lanaken, momentee! "Lanakerstraat", verbond het dorp met de "Grote en Kleine Oo"30 een "ool" of rivierdalgrasland aan de westoever van de Maas ten noorden van de stad. Dit is momenteel een industriegebied.

2) De "Groenstraat" van Limmel, momenteel "Dolmansstraat", verbond Limmel met de graslanden op de oostoever van de Maas ren noorden van Wijck. waar woon wijken en fabrieksgebouwen de plaats innemen van de oorspronkelijke weidegronden voor de dorpskudde van Limmel. ${ }^{31}$

3) De uit de richting Amby of Rothem komende "Korte en Lange Groenstraat", min of meer overeenkomend met de huidige "President Rooseveltlaan", mondden uit in demoerassige graslanden langs het beekje de Kanjel ten noordoosten van Wijck. ${ }^{32} \mathrm{De}$ Tranchotkaart vermeldtaldaar "pat.", dat wil zeggen påturage, graslanden. Dit waren gemeenschappelijk beweide groengronden.

4) De "Groenstraat" van het buurtschap Scharn, vermeld op de Tranchotkaart, is gesitueerd ten oosten van de Duitse poort in de Wiịcker stadsmuur, waar tot ongeveer 1900 regelmatig overstromingen plaatsvonden als gevolg van hoge waterstanden van de Maas. Deze "Groenstraat" is nu een deel van de "Scharnerweg".

5) De "Heerder Groenweg" (destijds. "Koystraat"), waarvan twee van elkaar geïsoleerde delen nog bestaan, verbond de hierboven vermelde laagte in het Maasdal ten oosten van Wijck met het dorp Heer. Mogelijk is deze weg synoniem met de in 1588 vermelde "Gruynstraat" van Heer. ${ }^{33}$

6) Aan de Maastrichtse kant van de Maas lag tenslotte de "Groenstraat" van Sint-Pieter. tegenwoordig de "Burgemeester Ceulenstraat", die het dorp verbond met graslanden langs het riviertje de Jeker, dat de Maastrichtse stadsmuur aan de zuidzijde begrensde. ${ }^{34}$ Het voormalige dorp Sint-Pieter is thans geheel met de stad vergroeid.

6.I Het onderzoek naar de landschapsoecologische context van de overige groentoponiemen in Z'uid-Limburg, waarvan de resultaten hieronder worden samengevat, moet worden gezien als de voortzetting van dat van Molemans en Schrijnemakers, die ervan uitgaan, dat niet alleen taalkundige of historische, maar ook geografische en geomorfologische gegevens, zoals oorsprong. richting en bestemming en dergelijke van groen-hodoniemen, gekoppeld aan gegevens betreffende het voormalige, agro-pastorale gebruik van landschapselementen, inzicht kunnen verschaffen in de oorspronkelijke betekenis van toponiemen.

Hetgeografisch begin van wegen, waarvan de naam de woordvorm groen inhoudt, is meestal gelegen in een woonkern, dat wil zeggen een dorp, een gehucht of een grote hoeve. Met stellige zekerheid kan dit worden aangetoond voor $70 \%$ der groenstraten en voor $78 \%$ der groenwegen. Van het restant ontbreken voldoende gegevens orn dit te kunnen stellen, dan wel geldt dat hieromtrent onduidelijkheid bestaat.

Voor groene. wegskens (in totaal slechts zes binnen het gebied van onderzoek) ${ }^{35}$ geldt dat de helft begint in een woonkern. Wanneer het gaat om het beginpunt in dorpen of gehuchten, dan betreft het ofwel een pleintje: soms driehoekig. soms een langwerpige rechthoek, waaraan de kerk of de kapel, de dorpsput en de dorpspoel zijn (of waren) gelegen, ofwel is de groenstroot (of weg) de voortzetting van een belangrijke straat in het dorp.
Het einddoel of de bestemming van wegen die het element groen in hun naam bevatten, bestaat (of bestond) uit beweide territoria. Deze regel geldt voor minstens $80 \%$ der verzamelde groen-hodoniemen. In de overige situaties kan het einddoel van de weg, een beweid territorium, niet worden vastgesteld. omdat de ligging van het groen-hodoniem niet meer is na te gaan ofwel, omdat het einddoel op de oudste topografische kaart niet als groenland wordt: aangegeven. Dit is het ge. val bij een zestal plateaunederzettingen. Men mag aannemen dat de groenlanden van deze plateaunederzettingen al vóór 1800 waren omgezet in akkers. De meeste "Groene wegskens" eindigen in de periferie van de gemeente; slechts in één geval kon daar een heide worderi gesitueerd.

Wat betreft de geografische voortzetting kan het volgende worden opgemerkt. In veel situaties vormt de groenstroot of -weg slechts een deel van de volledige heerdgangroute (zie figuur 5.6). Hij verloopt tussen de nederzetting en de weidegronden. Er kan een ander heerdgang-indicatief hodoniem aan voorafgaan of erop volgen, zoals een hol(le)bree-(brede), haog-, mestweg of -stroat. Deze zijn door hun vorm, breedte, aanwezigheid van veekerende hagen of uitwerpselen karakteristieke heerdgangwegen. In enkele gevallen is een veeweg of koestraat zelfs het synoniem voor of het vervolg van een groen-hodoniem

Inzake de geomorfologische situering is het opvallend dat minstens $32 \%$ van de wegen in kwestie min of meer twars staat op de hoog. telijner, dat: wil zeggen dat ze stijgen of dalen. Deze regel geldt voor nederzettingen die in de dalen liggen en niet voor die op de plateaus. Die reden ervan is gelegen in het feit, dat twee groengrondtypen te onderscheiden zịn, die wat hun ligging betreft ofwel hoger ofwel lager zijn gelegen dan de nederzetting in het dal, te weten de vochtige beemden langs de beek en de plateaurandheiden.

6.2 Ondanks het feit dat groenstraten en -wegen weleens, worden verwisseld, meent Schrijnemakers ${ }^{36}$ verschillen waar te nemen tussen beide hodoniemen; de eerste zouden "bestraat", dat wil zeggen verhard zijn. Zij kunnen interlokale routes voorstellen en van een respectabele ouderdom zijn. Groene we gen daarentegen zijn onverharde, meestal doodlopende veldwegen en slechts van lokale betekenis.

Het is weinig zinvol deze wegen te onderzoe- 
ken op hun bestrating. Oudere kaarten geven geen of onvoldoende uitsluitsel over het materiaal van het vroegere wegdek. Wel kunnen ze worden vergeleken wat betreft hun voorkomen in grote of kleine nederzettingen, hun positie ten opzichte van het interlokale wegennet en hun ligging ten opzichte van de woonkern. In sommige gemeenten komt de naam voor een route met daarin de term groen twee keer voor, dat wil zeggen er komt aldaar dan zowel een Groenstraat als een Groenweg voor. Dit verschijnsel brengt informatie aan het licht aangaande eventuele verschillen in betekenis tussen beide hodoniemen.

Uit de bovenstaande gegevens die in tabel 5 zijn vermeld, kan het volgende worden geconcludeerd: de primaire betekenis van het adjectief groen in een toponiem houdt verband met "groengronden". Dit zijn weidegronden waar het vee, meestal onder leiding van een herder, werd gehoed. Groenstraten en-wegen zijn routes van nederzettingen naar groengronden en dus heerdgang-indicatief. Een groenstraat kan in een aantal gevallen tevens samenvallen met een deel van een interlokale weg, zijnde ẹn doorgaande verbinding tussen een aantal nederzettingen. Dit zou het geval kunnen zijn voor de "Groenstraat" van de gemeenten Berg, Born, Geleen en Ubach over Worms. De "Groenstraat" van Ubach over Worms is tot een straatdorp uitgegroeid. ${ }^{37}$ In de meeste gevallen vormt de groenstraat geen deel van een veronderstelde, oude, interlokale route. Geen enkele groene weg valt samen met een dergelijke route.

Groenstraten komen meer voor in oude dorpen, dat wil zeggen nederzettingen voorzien van een kerk in 1800 , dan in gehuchten. Bijgroen(e) wegen is die situatie juist andersom. Groenstraten behoren vaak tot het wegenpatroon van de dorpskern. Groenwegen zijn meestal perifeer in de gemeente gelegen. Wanneer in een woonkern zowel een groenstraat als een groenweg voorkomt, dan is de -straat belangrijker voor het lokale verkeer en vormt naast de verbinding van de kern met de groengronden, tevens een verbinding met een andere gemeente. Die doorgaande functie heeft de groene weg niet. Groene wegskens zijn perifeer gelegen in de gemeente; het zịn vaak doodlopende wegen.

Samenvattend mag worden gesteld dat in de serie groenstraat, -weg en -wegske de eerstgenoernde naast de primaire functie van een heerdgangroute, tevens een secundaire func- tie als transportweg voor goederen of personen kan (of kon) vervullen. Bij groene wegen is deze secundaire functie nergens uit af te leiden; bij groene wegskens, op grond van hun perifere ligging, vrijwel' uit te sluiten.

\section{NOTEN}

1 Bovens 1988.

2 Dirmuer 1963, p. 95.

3 Scosuperuktks 1965, ip. 93

Hexocen 194\%-1946, p. 30 en volgende.

VAN WISTREENEN 1988

VAN DE BHOEK 1961,pp, 68.70

Renes 1988, pp. 38-39.

SCrenentmakins 1965, p. 93.

Molemuns en Paulussen 1976. p. 73 en Molemans EN METTENS I984, p. 303

10 Zie tabel 5

11 Rosenim 1995, $p$. 146

12 Zie tabel 5.1,5.2 en 5.3

13 SCHannerakins $1984 \mathrm{~b}$

14 Henruns et al 1983

is Zie hoofdstuk 2

16 De eerste verklaring van het toponiem Chevremomt luidt, letteriilk vanuit het Frans, "keiteberg". Een andere verklaring gaat vit van "chavey", een holle weg. Zie Tumatias 1962

17 Scomentmakres 1965

I8 Zie cabel 5. 1, nr 6, 16. 20 en 21 en tabel 5.2, nr 28, 29 en 30 .

19 Schapatmakins 1965

20 Scrinintmakes 1965

23 Scouputmakins 1965

22 Sorimnimakins 1965

23 Zie hoofdstuk 6

24 SCHimnarakens 1965

25 SCodentemakres 1965

26 KMUNGS 1976. p. 90

27 Zie figuur 8 ?

$2 n$ Het Duitse "Mulde" is onder andere ẹn gootvor mige verdieping in het landschap

29 Zie ondes andere VAN ERMEN Et al, 1985

30 VAN BOMMEL 1976

31 BLONOEN 1933, p 56

32 BLONOEN 1933, 56

3.3 VAN DE VENNE 1957 en hoofdstuk 6.

34 BLONDEN 1933, p. 51

3.5 Zie tabel 5.3 .

36 SCMRUMNEMAKERS 1965

37 SCHOBAEN 1958 


\title{
MES/MIS-TOPONIEMEN, HEERDGANG OF KERKGANG?
}

\author{
"En sal fij pagter gehouden zijn soo veel beesten of vee te fiouden \\ dat alle stroije aldaer geconsumeert en tot mesz gemaekt word."
}

Artikel 10 urt het pachtcontract van een laathof te Margraten van 14-10-1784.'

1.1 Veldnamen kenmerken zich onder andere door hun regionaal beperkt, mondeling gebruik, een lage frequentie van het schriftelijk gebruik en kunnen eeuwenoud zijn. Deze gegevenheden hebben er soms toe geleid, dat er opmerkelijke verschillen zijn te constateren tussen de gesproken en de geschreven vormen van een veldnaam. De verschillen zijn weleens dusdanig groot, dat er betekenisverschillen kunnen ontstaan tussen de gesproken en de geschreven vorm. Een enkel voorbeeld: het element mes in het toponiem "Mesweg", regionaal uitgesproken als "mèsweech", zal in de gesproken vorm bij de gebruiker van het regionale dialect onmiddel!ijk herkend en vertaald worden als "mest", terwill de niet-dialectspreker het element mes associeert met een instrument om mee te snijden.

Een tweede valkuil voor toponymisten die op zoek zijn naar de betekenis van hun studiemateriaal, wordt gevormd door een ander verschil tussen de schriftelijke en mondelin-" ge weergave van een woord dat in een toponiem ligt opgesloten. Dit probleem ligt in de beperktheid van het aantal lettertekens die tot de beschikking van een schrijver staan. waardoor hij niet in staat is het woord fonetisch exact weer te geven. Ter illustratie: de dialectische aanduiding voor het Nederlandse substantief mest kan op een grove wijze fonetisch worden weergegeven als mes, meis of mees, maar de klinker wordt in het westelijk deel van Zuid-Limburg minder gesloten uitgesproken dan in de weergave mes en zou kunnen worden genoteerd als mès, eventueel als mis, of, zoals in het Hoogduits. Mess of Mesz, terwijl in het oostelijk deel van ZuidLimburg de klinker lang wordt gerekt en in de schriftelijke vorm mees of meis, eventueel meys kan worden genoteerd. Kortom, subtiele klankverschillen bemoeilijken de juiste schriftelijke weergave, waardoor de becekenis van het grondwoord dat in toponiemen voorkomt, niet meer duidelijk is, met name voor diegenen die niet op de hoogte zịn van de regionale dialecten. ${ }^{2}$

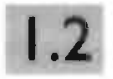

Een derde probleem bij een verklaring van de betekenis van begrippen in topo. niemen schuilt in de betekenisevolutie van het begrip als zodanig. Het dialectwoord mès kan daarbij weer als voorbeeld dienen. $\mathrm{Na}$ dat de heerdgang ophield, verdween de mest van het straatbeeld en werd in de vorm van stalmest opgeslagen, die vervolgens door kunstmest werd vervangen. Drijfmest is de huidige vorm van het agrarisch nevenprodukt "mès", een woord dat in de loop van de tijd. een duidelijke betekenisverschuiving doormaakt.

Het substantief mès betekent in veel dialecten van het onderzoek ook de dagelijkse of wekelijkse eucharistieviering in de kerk; de. twee woorden zijn homoniem, dat wil zeggen ze worden op dezelfde wijze uitgespro. ken en geschreven, maar verschillen wat betreft hun betekenis.

Ofschoon de evolutie van mès in de zin van "kerkelijke eredienst." ongetwijfeld op een later tijdstip in de geschiedenis begint dan dat van de eerste betekenis, geldt ook dat voor dit begrip de inhoud van de betekenis in de loop van de tiijd verschuift van een alledaags gebeuren, dat door velen werd bezocht, naar een zeldzaam evenement, waaraan slechts weinigen deelnemen. De langzame verschuiving van de inhoud van de twee homoniemen is van invloed geweest op de begripsverwarring, die in deze tijd is ontstaan.

In elk geval zijn, zoals hierboven is viteengezet, de regionale uitspraak, de schriftelijke weergave. de historische en geografische context en de betekenisverschuiving in de loop van de tijd factoren, die bij de interpretatie van toponiemen een belangrijke rol spelen.

Dit hoofdstuk zal zich in dit brede perspec- tief met mes/mis- toponiemen bezighouden. Eerst volgt een: taalkundig overzicht van het substantief mès, zoals dat wordt gebruikt in de Zuidlimburgse dialecten, dan komen mestwegen, onmiskenbare heerdgangen dus, aan de orde. Vervolgens worden eerst mis- en meswegen besproken, die vroeger als mestwegen werden geschreven. Daarna volgen andere mes/mis-toponiemen die, onder andere vanwege hun geografische positie in het landschap, onmogelijk iets met een kerkgang te maken kunnen hebber. Dic hoofdstuk eindige met een cultuurhistorisch overzicht van heerdgang en kerkgang en de betekenis van toponiemen die daaraan kunnen worden gekoppeld.

.3 in de inleiding van dit hoofdstuk. kwamal ter sprake, dat de dialecttermen mès of mees, identiek met het: Nederlandse mest. niet alleen variëren wat betreft de regionale uitspraak in het gebied van onderzoek, maar ook dat de in het: Nederlands gebruikte let.tertekensi niet in staat zijn om de nuances in de klinker juist weer te geven. Dit probleem deed zich voor aan diegene, die voor het. eerst in de geschiedenis de mondeling over-geleverde namen op schrift zette. De negen-. tiende-eeuwse scribent had de keuze ofwel de dialectbenaming om te zetten in standaard Nederlands of Hoogduits ofwel de dialectische vorm weer te geven met behulp van de. hem ter beschilkking staande lettertekens, dan wel door middel van een extra medeklin. ker aan te geven dat de daaraan voorafgaande klinker kort moest worden uitgesproken. een methode die ook in het Hoogduits gebruikelijk is. Op deze wijze ontstonden respectievelijk de "vertaling" mest- of mistweg. de fonetisch weergegeven mis-, mes-, meis-. meys- ent mees-toponiemen en de van een extra medeklinker voorziene mesz- en messwegen. Al de hierboven opgesomde varianten zijn in de toponiemenvoor- 


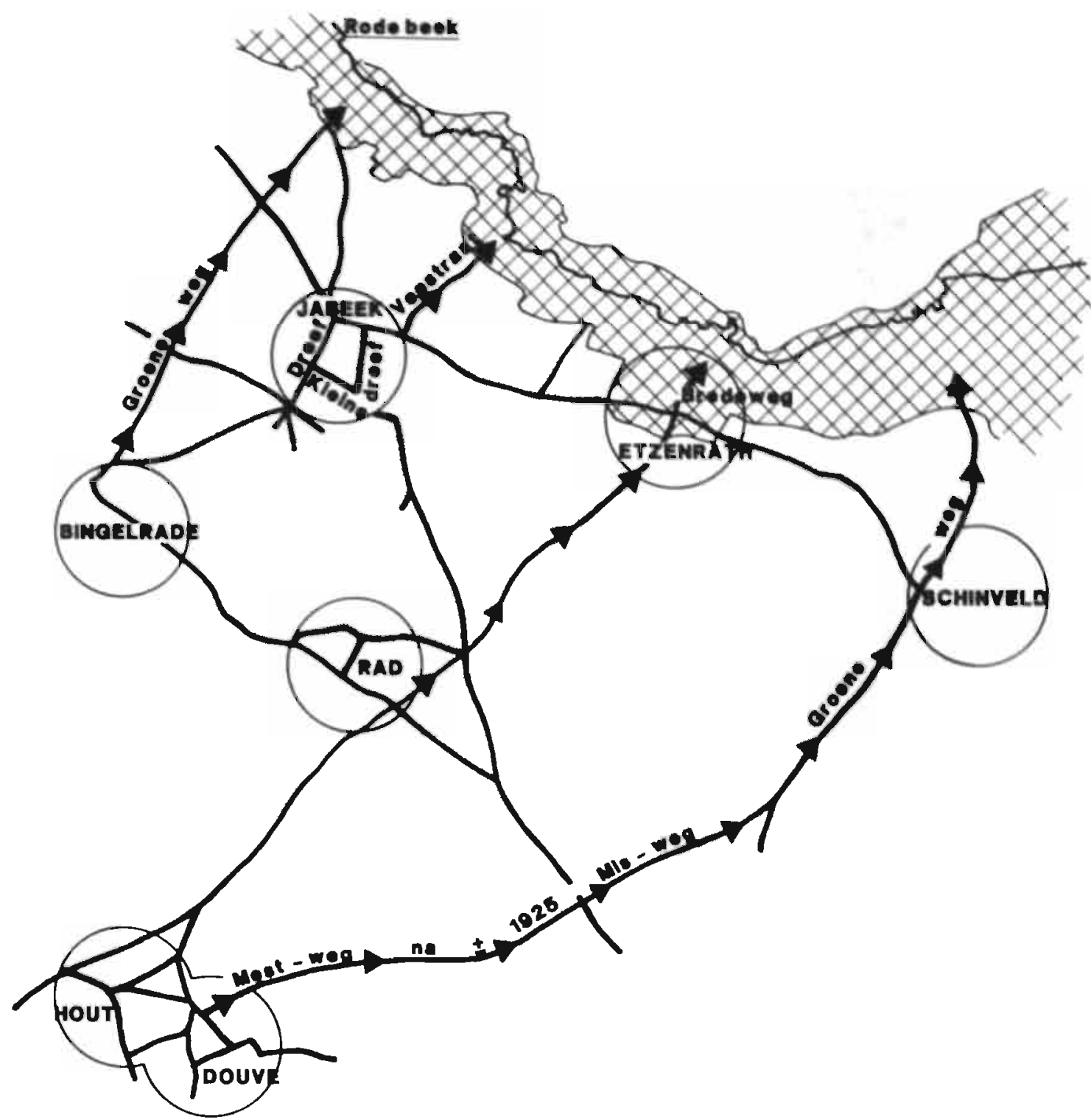

FQUUR \&I.

De Mert Misweg ram Merkelbeek en andere heerdgangroutes in het dal van de Rode Beek. gesitueerd op een detall van de

Tranchotkoart uit 1806. Huidige en vroegere straatnamen herinneren aon de oude veedriften vanuit de nederzettingen of het ploteau noor de veidegronden in het dal. Dix xijn, gesitueerd op een detail van de Tranchotkaart wit 1306: de Groene weg. van Bingelrade, de Veestraot, Dreef en Neine dreef ran jobeek, de Brede weg van Etrenrade ef! diens verlengde, de Masutrichserweg van

Roth met een hol profiel, de Groene weg ven Schinveidi en Merkelbeek eni de Mestweg van Houe, doarna Misweg en Oude Minweg genoemd. Len deel van de huidige Misweg en het gehele troject van de huidige Oude Misweg in 1925 no Mertweg genoemcl. tussen de nedernetting Hout en Schinveld slook oan bij dr huldige Groene weg van Sehinveld, die eindigue in de ultgestrekte groesilanden oasn de Rode Besk.

raad van het onderzoeksgebied aangetroffen.

\section{1}

"Mest-" of "mistwegen", het laatste is de Hoogduitse variant van het eerste, komen voor zowel binnen het gebied van onderzoek als in de daaraan grenzende delen van Belgie ${ }^{3}$ en Duitsland. " Vroeger werden "mistwegen" frequenter aangetroffen dan thans: de dorpsplattegrond van Swalmen uit 177 ' 4 vermeldt vijf "mistweghen", die van het nabiigelegen Asenray uit 1766 twee.s Ook in Echt en Hillensberg kwam een "mistwegh" voor. ${ }^{6}$ Op de huidige plattegronden van deze dorpen zijn ze vervangen door andere namen. Van de gemeente Linne werd in 1766 "den mestwegh" opgegeven, die nadien niet meer werd vermeld. ${ }^{7}$ De "MestStrasse" te Millen bii Sittard, vermeld op de Tranchotkaart, gaat over in de "Viehstrasse". Beide straatnamen zijn veranderd. Te Ubach over Worms bestond het toponiem "Aan de
Mestweg", de weg zelf werd als "Meszwegh" aangeduid. Aan het begin daarvan lag de dorpspoel. ${ }^{8}$ Te Benzenrade heette een dergelijke veepoel de "Meestkoel". De in 1925 nog als. "Mestweg" genoemde route in Merkelbeek heet later "Misweg". In Zuid-Limburg bestaat er nog maar één "Mestweg", een in het buitengebied van Schin op Geul gelegen veldweg. ${ }^{10}$

In alle bovengenoemde wegnamen komt (of kwam) dus het substantief mest of mist voor. Beide termen zijn, naar respectievelijk het officièle Nederlands en het Hoogduits, correcte vertalingen van de namen van wegen, die in het plaatselijk dialect een iets andere schrijfwijze zouden hebben gehad. Momenteel zijn deze mestwegen op één na allemaal verdwenen.

Ondubbelzinnige synoniemen van mestwegen bestaan echter nog wel, maar hun oorspronkelijke betekenis is verzwakt. Zo wijzen
"Flatter-, Kladder-, Klater-, Vuil- en Drekstraten of -wegen" 11 eveneens op de aanwezigheid in vroeger tijden van uitwerpselen op die delen van het dorpswegenpatroon, waarlangs de (koe)heerde dagelijks letterliik haar spoor trok, hetzij naar het groenland langs de beek, hetaij naar de droge graslanden op de hellingen van de plateaus, die als heiden of bergen bekend stonden. De in deze samenstellingen genoemde termen missen in het huidig taalgebruik de gevoelswaarde van een meststraat.

\subsection{Er is een aantal directe aanwijzingen} dat ook mes- en miswegen of andere varianten zonder $t$ eertijds mestwegen (met $t)^{12}$ waren. Het hierboven aangehaalde voorbeeid van de tegeliịkertijd naast elkaar voorkomende toponiemen "Aan de Mestweg" en "Meszweg" in Ubach over Worms kan dit illustreren. 


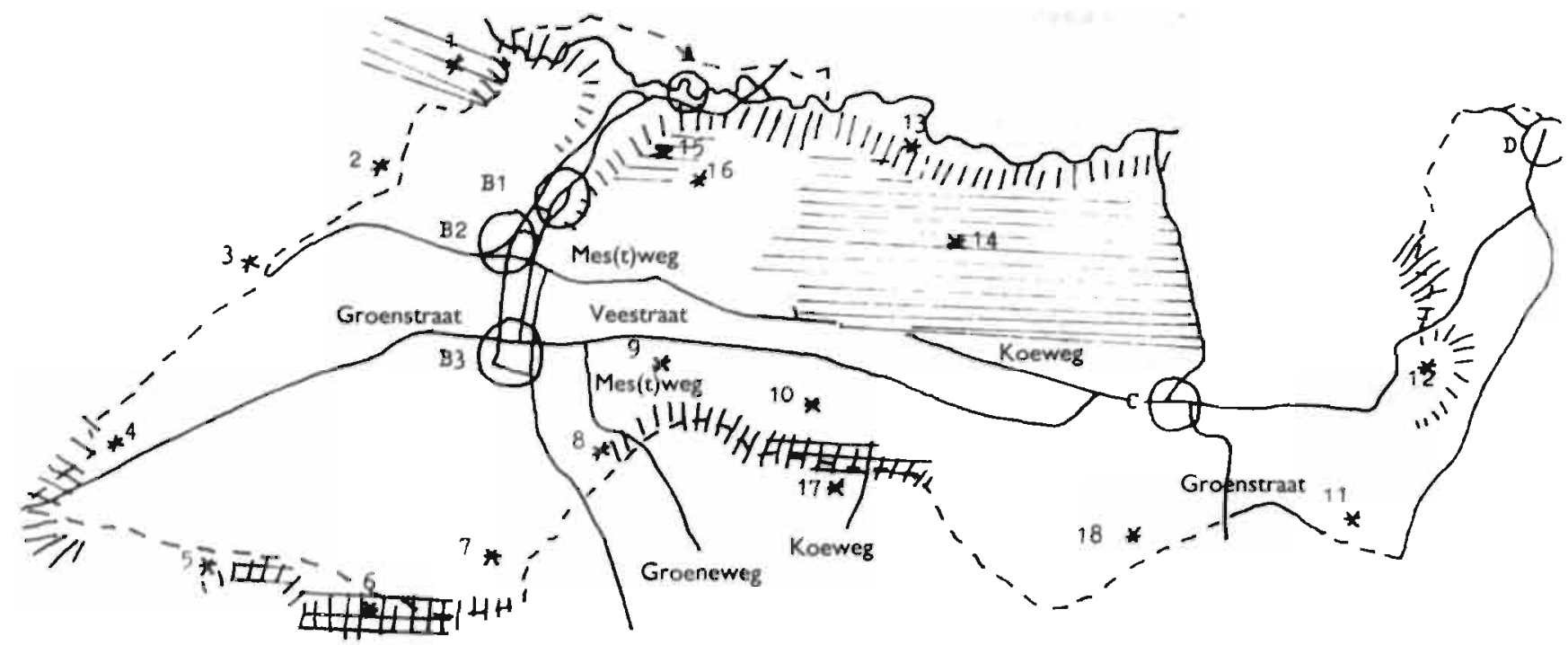

FIGUUR 6.2 Mes(t)-toponiemen in de gemeente Berg gesitueend op een topografische kaort utt 1850, in relotie tot de voormalige heerdgangen in dexe gemeente. De gemeentegrenxen van Berg zijn met een onderbroken lijn aangegeven, Binnen de gemeente liggen de woonkernen Geulhem (A), Vilt (C), de Plonkert (D) en drie kernen van Berg (BI, B2 en B3). Do kern BI is gelegen rond het pleintje "Op de Bles", A2 rond het pleln "de Schone Poel". Elke karn ls met den of twee wegen, die een heerdgang-lndicacleve naam bexitten, varbonden met een deel van hat areaal schroallond (horizontaal gearceerd) binnen de gemeente. Beholve de Grote hel (= Berger- en Vilterhal) (14), lagen er meerdere schraallanden langs de grenzen op de plateauranden: Meerssener- (1) en Koyerheide (2), Ravens dries (3) en Gemeynen dries (4), 't Hotje (5), Bemelerhel (6), Meerkoul, een drenk (7), Mestberg of Mesberg (8), Kleine heide (9), Biljorheide (10), Biestmoel of Byesuerborn, Bismer, Byessemer ( $=$ koemaor, -bron of -grens?) (II), Koberg of Cauberg (= koeberg?) (12), Wolfodries (13), Geulhemmerheide (15), Wippertse helde (16), Op den Dries (17) en Vilterheide(weg) (18). Ook de nederzetting Terblljt bezat weiderechten op de plateaurand en was met deze weidegronden via heerdgangwegen verbonden.

In een aantal geografische sicuaties vormen "mes-" of "miswegen" aantoonbaar delen van cen gemeentelijke heerdgang of waren in het verleden als mestwegen bekend: de huidige "Misweg" van de gemeente Merkelbeek. op de stafkaart van 1925 nog als "Mestweg". aangeduid, loopt vanuit de nederzetringskern Hout-en-Doeve in een noordoostelijke richting, mondt uit in de "Groenstrat" en eindigt in de rond 1800 nog bestaande, uitge. strekte graslanden langs de Rode Beek (zie figuur 6.1).

De nu niet meer bestaande "Meszwegh" of "Mestweg" te Ubach over Worms met, de daaraan gelegen "Meesepool" in het dorpscentrum, heeft dezelfde richting als de wel nog bestaande "Veeweg", die de verbinding vormde tussen het dorp en het deel van de hei, die tegenwoordig "Brunssummerhei" heet en waar eertijds ook de bewoners van Ubach over Worms weiderechten bezaten. De "Blijer Mesweg" vormt weliswaar éen van de verbindingen tussen Terblijt (zonder kerk) en het kerkdorp Berg. maar doorsnijdt tevens de tussen beide nederzertingen gelegen beweide territoria "Mesberg" (ook geschreven als "Mestberg") en de "Kleine Heide" (zie figuur 6.2).

In dezelfde gemeente Berg bestaat nog een
"Mesweg", ook als "Meesweg" bekend, die een deel vormde van de heerdgang tussen de oude kern van Berg en de "Grote Heide". Parallel hiermee en eveneens het dorp met de heide verbindend, verloopt de "Veestraat". Via beide wegen bereikt men het kerkloze gehucht Vilt, destijds "Veld" genoemd, gesticht op een deel van de "Grote Heide".

lets dergelijks doet zich voor ten aanzien van de "Mesweg" te Eys, die via de beemden langs de beek het gehucht Overeys verbindt met het kerkdorp. Uit de namen "Vilt", destijds "Veld", en "Overeys" blijkt dat deze gehuchten satellietnederzettingen zijn; het ene is gesticht op het veld, aan de rand van de voormalige heide, het andere stroomopwaarts en aan de overzijde van de beek in de eveneens beweide beernden. Wellicht, zijn de genoemde "meswegen" primair als mestwegen te beschouwen en zịn zij pas in een latere periode geassocieerd met een kerkgang.

\section{3} Veel Zuidlimburgse hodoniemen bevatten de term haog of de pluralisvorm hogen. Deze veekeringen langs de wegen in of bij de nederzettingen moesten immers voorkomen dat de dagelijks passerende kudde schade zou berokkenen aan gecultiveer- de gewassen. Tot ver in de nieuwe tijd waren veekeringen immers meer bedoeld om het vee buiten het omheinde gebied te houden dan daarbinnen, zoals dat nu het geval is. De verplichtingen tot onderhoud en herstel van veekeringen zijn uitvoerig uiteengezet in calrijke Wijsdommen, gemeentelijke reglementen opgetekend sedert de late middeleeuwen. In deze context past het toponiem "Meshaag" bij Munstergeleen ${ }^{13}$ en de toponiemen "Holter Meszweg" en "Achter de. Hagen" bij Hulsberg.

De huidige "Meishagerstraat" te Munstergeleen - het toponiem "Meyshagen" komt al in middeleeuwse bronnen voor - ligt nagenoeg op dezelfde plaats waar de Tranchotkaart uit her begin van de negentiende eeuw het toponiem "Meisag" situeert. In dit gebied worden twee parallel verlopende holle wegen afgebeeld, die de verbinding vormen tussen het dorp aan de beek en de plateaurand waar, zoals oiveral in Zuid-Limburg, schrale graslanden lagen.

Blijkens dezelfde kaart is ook de huidige: "Mesweg" te Hulsberg omzoomd met hagen. De kadastrale benaming langs dit deel van de: Mesweg luidt "Achter de Hagen". De weg. vormt de verbinding tussen de laaggelegen nederzetting en het plateau. In de late mid- 


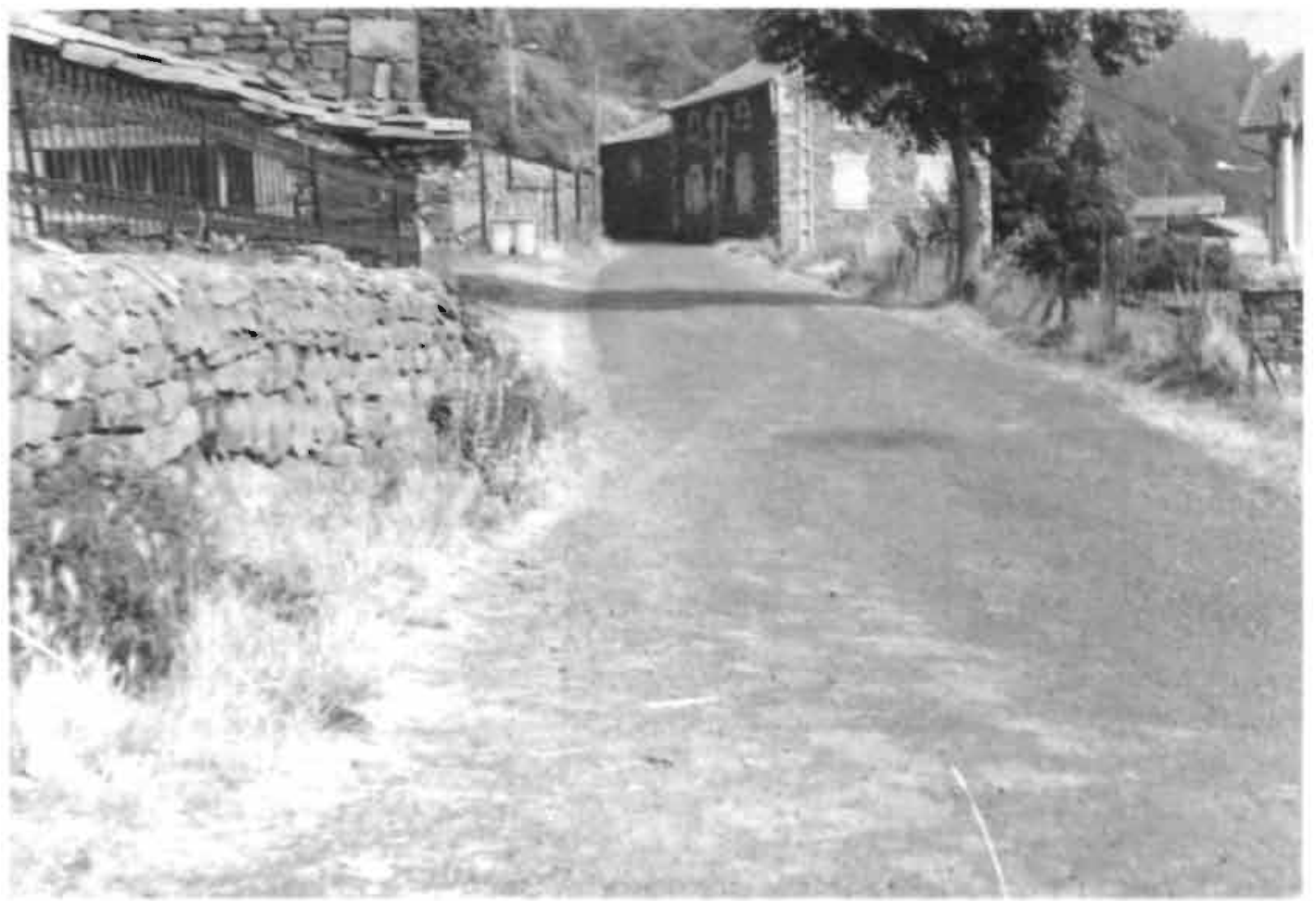

PGUUR 63

Een mertweg te St. Privot (Auvergne, Frankrilk). Foto van de auteur, juli 1989 . In ruidelijke delen van Europa a het vernchiliniel heerdgang via de openbare weg plaatselijk nog geen zeldraamheid. Niet alleen de mest wan runderen op het wegdek is doarvan een sichtbear bewilh, maar ook flore wan de wegrand. In Nederland is de heerdgang met rundree allang rerieden sijd, alleen sommige straotnamen, roals de Veewreg. herinneren ean die voormalige functie van dorprwegen. Ook Mestwegen waren bekend, maar die aamen werden om begrijpelijke redenen vervangen door andere namen of veranderden int Mirwegen. Want wie wil er nu nog ean een "vtrontweg" wonen?

deleeuwen stond de weg bekend als de "Holter Meszweg". Twee argumenten pleiten verder voor "een mestweg van de nederzetting Holt" (= Hulsberg): de schrijfwijze mesz in het toponiem is dezelfde die voor mest werd gebruikt. Daarnaast speelt het argument van bosbeweiding een rol. Beweiding door rundvee van de op het plateau aanwezige bosrestanten was regel. Na verdere degradatie werd dit voormalige bos gerooid en de nederzetting Arendsgenhout gesticht. Die naam verwijst zowel naar de stichter als naar het voormalige bos. Primair lijkt de "Holter Meszweg" dus een veedrift: in een latere periode, na de ontginning van het bosgebied waarop een nederzetting ontstond, werd de voormalige mestweg gebruikt als de verbindingsweg tussen de dochternederzetting en het kerkdorp, uiteraard voor kerkgang gebruikt en geïnterpreteerd als een misweg.

\section{4} In het voorafgaande werd betoogd dat mes/mis-toponiemen hun betekenis ontlenen aan mest en dus als heerdgang-indicatieven moeten worden opgevat. In het onderstaande wordt uiteengezet, dat er een negatief verband bestaat met mis in de betekenis van een kerkdienst, zoals door diverse auteurs werd yerondersteld.

Op de eerste plaats zijn de huidige mes/mishodoniemen merendeels geen verbindingswegen tussen kerkdorpen en de daaronder ressorterende gehuchten zonder kerk. Daar waar dat wel het geval lijkt te zijn, zoals te Berg-Vilt. Berg-Terblijt, Eys-Overeys en Huisberg-Arendsgenhout, zou de oorspronkelifke veewveg later, behalve als yeedrift, tevens als kerkpad kunnen zijn gebruikt tussen het moederdorp (met kerk) en de dochternederzetting (zonder kerk), gesticht op de voormalige gemene weidegronden.

Op de tweede plaats moet het argument worden vermeld dat mes/mis-wegen worden gekenmerkt door een aanzienlijke wegdekbreedte en een omzoming met hagen, die eerder passen bij heerdgangwegen dan bij een kerkgang, die meestal te voet plaats vond. Als regel zijn kerkwegen smal. Het is typerend dat binnen het gebied van onderzoek wel kerkstegen en kerkpoden zijn aangetrof. fen, maar geen misstegen of mispaden. Bovendien ging men vroeger niet alleen ter kerke om daar de miș biị te wonen; ook met anderewoorden aangeduide diensten speelden in het sociale leven een rol van betekenis.

Tenslotte geeft de inhoud van een aantal samenstellingen met mes of mis aan, dat hier onmogelijk sprake kan zijn van een kerkdienst; bedoelde delen van de samenstellingen blijken betrekking te, hebben op ofwel beweide territoria (-berg en -winckel, het laatste in de betekenis van een afgelegen hoek in de gemeente) ofwel heerdgangroutes (-haog. -weg, -gats en -grubbe) of veedrenken (-poel. kuil).
5 Het zou te ver voeren hier een gedetailleerd overzicht te geven van twee met elicaar in verband staande historische processen, die: hebben geleid tot een onjuiste interpretatie van de mes/mis-toponiemen, name. Hijk de dalende omvang en afnemende betekenis. van de heerdgang en de daarmee samenhangende verschuivingen in de waarde. ring van het produkt, dat de akkers vruchtbaar diende te houden. Hier wordt yolstaan met cen summier overzicht (zie figuur 6.3). $\checkmark$ anal de late middeleeuwen en het begir van de nieuwe tijd verdwijnt geleidelijk de gemeenschappelijke dorpskudde, bestaande uit grootvee onder leiding van de heert (koeherder) en kleinvee onder leiding van de scheper (schaapherder). De privatisering van de oorspronkelijke beweide gemene gronden en de introductie van braakgewassen zijn daarvan de belangrijkste oorzaken. Tussen I 500 en I 800 werd de "Flurzwang" geleidelijk afgeschaft en zijn de dorpskudden, weidend op de stoppelvelden en nog resterende groengronden, een zeldzaam verschijnsel geworden. Even later worden de driesgronden permanent in cultuur gebracht en de ge. mene gronden bebost. Zij werden van beweiding uitgesloten. Tegen het einde van de vorige eeuw resteerden nog slechts enkele schaapskudden in plateaurandnederzettingert en in de dorpen aan de zoom van laaglandheiden, terwijl rundvee in kuddeverband alleen nog voorkwam in het Maasdal en in de. 


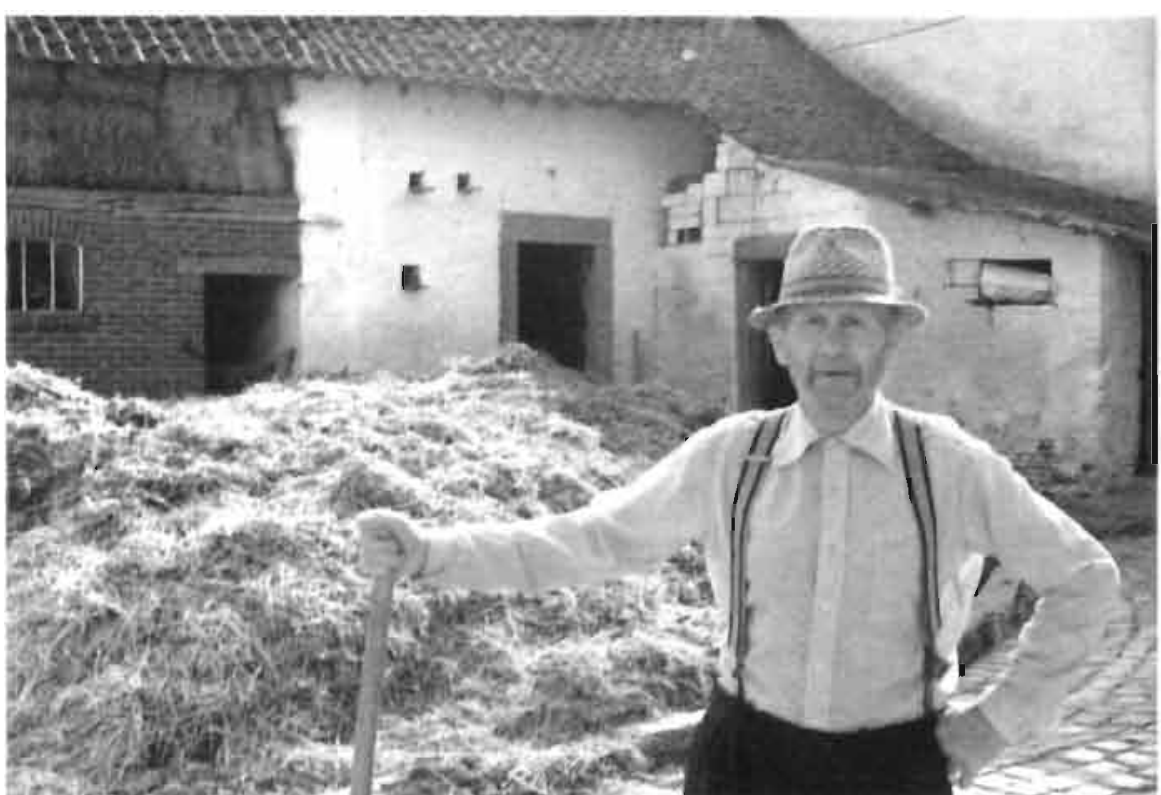

bovenloop van het Geuldal. Even na 1900 valt het doek voor de heert en enige decennia daarna dat voor de scheper.

Gedurende vele eeuwen vormde dierlijke mest, eventueel vermengd met en vastgehouden door afgestorven plantaardige bestanddelen, vrijwel de enige toevoeging op de akkers. Tijdens de niewwe tijd werd het gebruik daarvan geïntensiveerd en steeds vaker werden substituten aangewend in de vorm van stadsafval en produkten van industrièle herkomst. " Het einde van de vorige eeuw bracht de synthetische kunstmest, die een enorme revolutie betekende in de agrarische bedriffsvoering, maar waarvan de effecten pas op grote schaal zichrbaar werden na de eerste helít van deze eeuw. Het gemengd bedrijf, met zijn vanzelfsprekende mestvaalt direct voor de voordeur, is momenteel definitief vervangen door een vorm van bio-industrie, die gigantische mestoverschotten produceert, deze als drijfmest onzichtbaar opslaat in gierkelders, deponeert in centraal gelegen, maar aan het oog onttrokken mestbanken of geruisloos en onzichtbaar laat verdwijnen via het riool. Onoplosbare mestproblemen. waarvan de zure regen er slechts éen is, kenmerken de Zuidlimburgse landbouw van na 1970; mest is van een zegen een vloek gewarden.

Tegen de achtergrond van deze gegevens viel er bij de plattelandsbevolking een verschuiving te constateren in de attitude ten aanzien van mest. Met het verdwijnen van de uit- werpselen op de oude heerdgangwegen werden de mestwegen op een voor de hand lig. gende wijze vervormd tot, of abusievelijk geassocieerd met. miswegen en vervolgens als kerkpaden geìdentificeerd (zie figuur 6.4). In het bovenstaande werd de stelling geproneerd dat mes'mis-toponiemen en -hodoniemen moeten worden geassocieerd met mest, in de betekenis van dierlịke uitwerpselen (met name van koeien in kuddeverband) en dus als heerdgang-indicatieven moeten worden beschouwd.

Met grote waarschijnlijkheid kon worden aangetoond dat een associatie met een mis in de betekenis van "kerkdienș" in de meeste gevallen moet worden verworpen. Kerkhodoniemen (Kerkwegen, -straten, -paden en-stegen) zijn in het gebied van onderzoek wel geattesteerd. Naar analogie daarvan zouden om diverse redenen alleen mispoden. stegen of -wegjes kunnen voorkomen; van deze groep is uit het gebied van onderzoek slechts één voorbeeld bekend. ${ }^{15}$

De identificatie met de voornaam "Meys", een verkorting van Bartholomeus of Remigius, is onwaarschijnlijk. ${ }^{16}$ Hetzelfde geldt voor de verklaring van "Mis(t)weg" als "ein gerneinschaftlicher, zwischen den Anliegern sich erstreckender Feldweg zum Mistfahren benutzt". Maar deze verklaring uit het Rijnland ${ }^{17}$ gaat wel uit van het begrip mest. dat aan de bașis ligt van de in dit hoofdstuk behandelde groep van toponiemen.
FIGUUR 6.4.

Boer Meers uht Zussen (Belgie), in 1990 trots poserend voor de mexthoop op de binnenplacts van xijn hoeve, gelegen in de omgeving van de Misweg destijds Mestweg. Voor hem (en zjin voorouders) was de geurige mesthoop vlak voor zijn voordeur cen teken van wretroart Hoe hoger de hoop, des to meer "brood op de plank". De huidige bla-industrie warstelt met de problemen van de mestoverschotten. overbemesting mestquota, zure regen en grondwaterverontreiniging. Tegen deze achtergrond is de ormzetting van Mertwegen naor M/swegen heel begrijpelljk.

\section{NOTEN}

I Bijdrage tot de historie van Margraten 1983, p. I45

2 Zie onder andere NOTTEN 1974. p. 20.

3. MOLEMANS EN PAULISSEN 1976, onder andere p. 66 en. Molemans en Merzens 1982, p. 234.

1 DitTMAarer 1963, p. 205.

5 Geraeos en Custers ! 983 en tabel 6.1

6 WELtens 1923 en VROMEN 1972

NISSEN 1977

8. Zie tabel 6.1

9 Zie tabel 6.3, nr 4

10 In het Gerendal (gemeente Schin op Geul), zie SAN

11 Zie tabel 6.2

12 Zie tabel 6.3.

13 Zie tabel 6.4

14 JANSEN 1982a, p. 289

15. Dit is het "miswegie" te Vlijtingen, een voetpad tussen het gehucht Laefelt en het kerkdorp Vhijtingen. Zie HACKENG 1982.

16. HARTMANN 1986, p. 133.

17 DitTMANE 1963, p. 205. 


\section{DRIES-TOPONIEMEN EN HET DRIESLAGSTELSEL}

\section{"Oeck driessen, dye gebroecken weerden ende geackert ende beseet met fruchten, al sullicken laet men een jaer onvertfiient- dicht int hardt koeren ende een jaer int soemerkoeren ende daernae geven sij thienden als anderen, dye XIe gerff."}

Van de opbrengst van driesen behoeven voorlopig geen tienden te worden betaald: cen stimulans tot ontginning.'
Ofschoon de term dries in oude Nederlandse teksten wel voorkomt, is hij in het huidige Nederlandse taalgebruik allang verdwenen. In de dialecten van de Zuidlimburgse plattelandsbevolking komt de term dries wel nog voor. De betekenis van dries is "brakk", in de zin van "braakliggend land" of een "perceel slechte grond dat voorlopig alleen voor beweiding in aanmerking kome". Om die reden zijn toponiemen, waarin het element dries voorkomt indicatief voor heerdgang: braakliggende gronden werden niet omheind en konden door het vee onder leiding van een herder worden beweid.

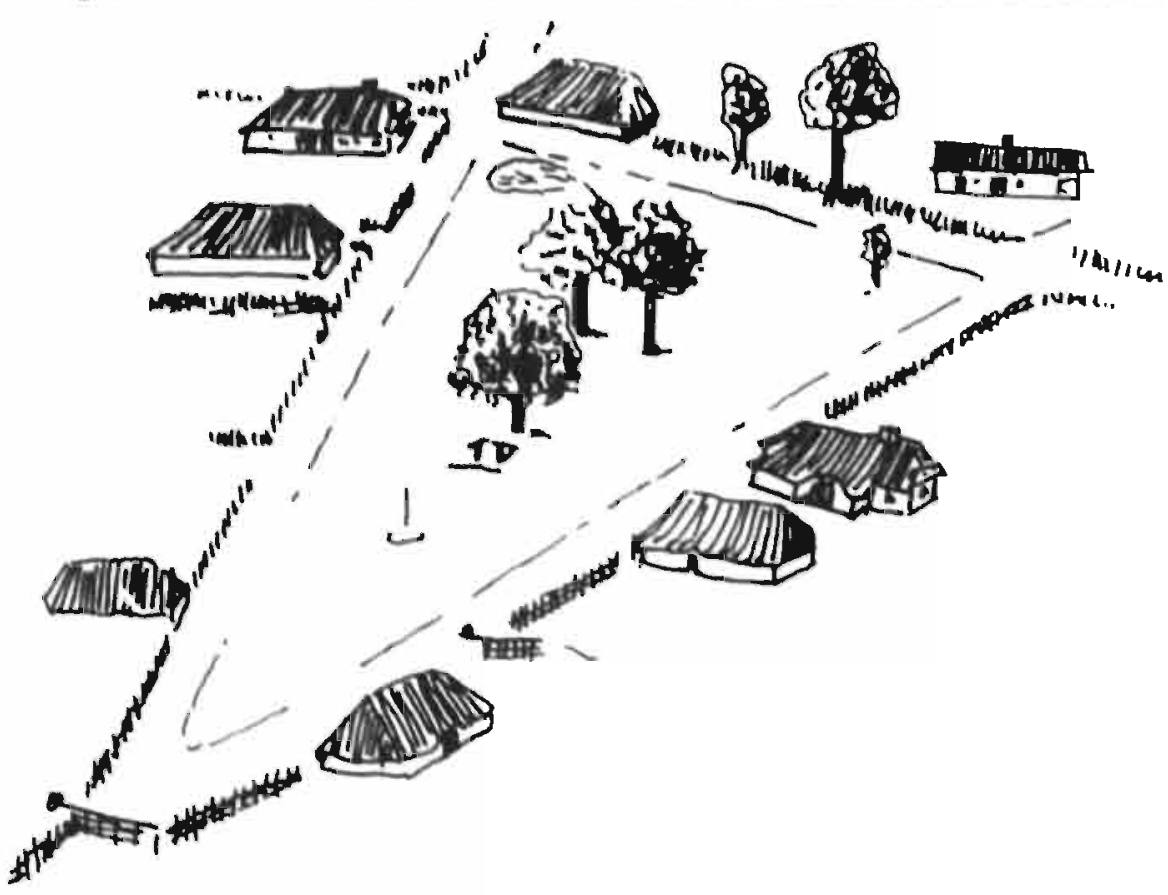

FGUUR 7.1. De dries als dorpsplein met drinkpoel on afsluitbare hekken, onder andere in gebruilk als verzamelplagts voor de dorpskudde, gereconstrueerd in het openluchtmuseum Bokrijk. Ofschoon in veel dorpspleintjes van nu de drinkpoelen on hekken xijn verdwenen, is de roormolige functie von het pleintje als verramelplaats voor de kudde nog goed herkenboar. In Bokrijk xijn dere elementen wel oonwexig.
Het dries-toponiem komt veel voor in het gebied van onderzoek en heeft niet uitsluitend betrekking op onvruchtbare gronden. Ook dorpspleintjes en percelen grond aan de buitenzijde van stadsmuren lagen "dries" en werden met, deze term aangeduid.

Dit hoofdstuk houdt zich niet alleen bezig met de agro-pastorale betekenis van het eeuwenoude woord dries in Zuid-Limburg en in gebleden daaromheen; ook het agronomische begrip drieslogstelsel, dat pas in de vorige eeuw werd geîntroduceer d, komt aan de orde. Juist in verband met dries in de betekenis van "braak" zou men zich kunnẹn ạfvrạ- gen of een rotatiestelsel met een daarin opgesloten brakperiode niet meer de essentie raakt van elk rotatiestelsel in de landbouw dan een stelsel, gebaseerd op een cyclus van precies drie jaar.

2. I Het aantal dries-toponiemen binnen het gebied van onderzoek is relatief hoog: van de 160 enkelvoudige of samengestelde: dries-toponiemen binnen het onder. zoeksgebied aangetroffen, ${ }^{2}$ betreft het merendeel $(65 \%)$ territoria of percelen die ver buiten de kernen varı nederzettingen, meestal aan de rand van voormalige heiden zijn gelegen. In een aanta! gevallen ( $8 \%$ ) vorme de dries een pleintje in of aan de rand van een nederzetzing (zie figuur 7.1). Heel zelden (2\%) duidt het dries-toponiem een perceel aan, dat is of was gelegen aan de buitenzịjde van een middeleeuwse stadsmuur (zie figuur 7.2). Vaker, dat wil zeggen in $12 \%$ van het aantal gevallen, heeft het dries-toponiem betrekking op een hoeve of een groepje huizen. die ver buiten een dorp mer kerk zị̣n gelegen (zie figuur 7.3).

Het valt op dat "driesen", gelegen op een grote afstand van nederzertingen, vaak grenzen aan destijds permanent beweide territoria, die als "heiden" bekend staan. In deze gevallen zijn zij gesitueerd op de plateaus. Een dergelijke ligging geldt niet alleen voor ZuidLimburg, maar ook in Drenthe zijn "drieslanden" karakteristiek voor de periferie van de es en vormen ze, ruimtelijk gezien, een overgang van de oude landbouwgronden naar de heide. Het waren gronden die slechts incidenteel in cultuur werden gebracht. Ter illustratie kan een tweetal kaarties dienen van de ligging van een aantal driesen in de gemeenten Nijswiller en Ubach over Worms (zie figuur 7.4 en 7.5). 
Daar waar "driesen" zijn gesitueerd in alluviale delen van het onderzoeksgebied, geldt eveneens de regel dat deze territoria in agrarisch-economisch opzicht van marginale betekenis waren. Dergelijke in de stroomdalen gelegen "driesen" komen slechts zelden voor. Dedries binnen een nederzetring is een pleintie, warvan de vorm (driehoekig, vierkant of langwerpig), de oppervlakte en de ligging ten opzichte van de kern van de nederzetting (in of aan de rand ervan) weinig essentieel lijken te zijn, eigenschappen die ook bil de goed onderzochte dorpspleintjes uit Noord-Nederland van weinig belang bleken. Essentieel zijn wel, evenals bij de Noordnederlandse brinken, de volgende onderdelen: een poel, beweegbare afsluitingen ten behoeve van de dorpskudde, een kapel of kerkje, de dorpsput en een beplanting van bomen, binnen het onderzoeksgebied meestal uit lindebomen bestaande. Dergelijke pleinties, afgezien van dries ook bies(t), plots, pley of, elders, heuvel of brink ${ }^{3}$ genoemd, ${ }^{\text {' } z i j n ~ b i n n e n ~ h e t ~ g e b i e d ~}$ van onderzoek karakteristiek voor nederzettingen op de plateaus.

Met name in het zuidoosten van het gebied van onderzoek komen diverse driesen voor als aanduidingen voor een groepje huizen of een enkele grotere hoeve. Vermoedelijk zijn deze driesen als "Einzelhöfe" op te vatten. gesticht op de voormalige gemene weidegronden. Hun wijze van ontstaan is dan waarschijnlijk analoog met de meer binnen het onderzoeksgebied voorkomende "Heiho. ven"s of paupernederzettingen, gesticht vanuit een moederdorp, zoals bijvoorbeeld "Heerlerheide".

In bodemkundig opzicht variëren "driesen", voor zover het territoria buiten de nederzettingen betreffen, zeer sterk: hun substraat: kan bestaan uit grove dekzanden (eolische afzettingen uit het Pleistoceen). grinden of zanden (fluviatiele sedimenten uit het Pleistoceen), vuursteeneluvia (uitgeloogde, oorspronkelijk mariene sedimenten uit het: Krijt) dan wel zanden of grinden van Tertiaire oorsprong. In één opzicht komen deze "driesen" in hoge mate met elkaar overeen. namelijk hun marginale agrarisch-economische betekenis voor de vroegere agrarische landbouw.

\section{2} allereerst globaal worden verdeeld in simplex-en compositavormen. ${ }^{6}$ Tot de eerste groep behoren bijvoorbeeld "Op den Dreesi", "Ten Driessen" of "Dreeske". De tweede groep, de samenstelling, is interessanter, omdat het adjectief of substantief dat met dries een samenstelling vormt, inlichtingen kan verschaffen omtrent de hoedanigheid van de "dries". Tevens geeft het bestaan van diminutief- dan wel compositavormen binnen één gemeente aan, dat aldaar vroeger meer driesen voorkwamen. Op grond daarvan mag men aannemen, dat het aantal daarvan binnen die gemeente (en dus in het hele onderzoeksgebied) groter was dan het aantal dat in deze studie is verwerkt.

Samenstellingen met de namen van planten of dieren komen regelmatig voor. In de serie gedomesticeerde dieren wordt het schoap. de schraalheidsindicator bij uitstek, vaker genoemd dan andere gedomesticeerde herbivoren. Composita met niet-gedomesticeerde dieren (onder andere hoos, wolf en roaf) zouden kunnen wijzen in de richting van een extensief beheer op deze perifeer gelegen gronden. De in samenstellingen genoem * de vogelsoorten, alle zaadeters, leggen een verband met een zeventiende-eeuws synoniem voor een dries, denigrerend als "vogelwey" " aangeduid. Driesen waren rijk aan onkruiden. De genoemde plantesoorten in samenstellingen met dries indiceren een extensieve beweiding, een cultuur van hakhout of braakgewassen, die karakteristiek zijn voor onvruchtbare, stenige gronden. Samenstelingen van dries met aanduidingen voor een slechte bodemkwaliteit, zoals zuur, mager. stenig of droog, zijn typerend.

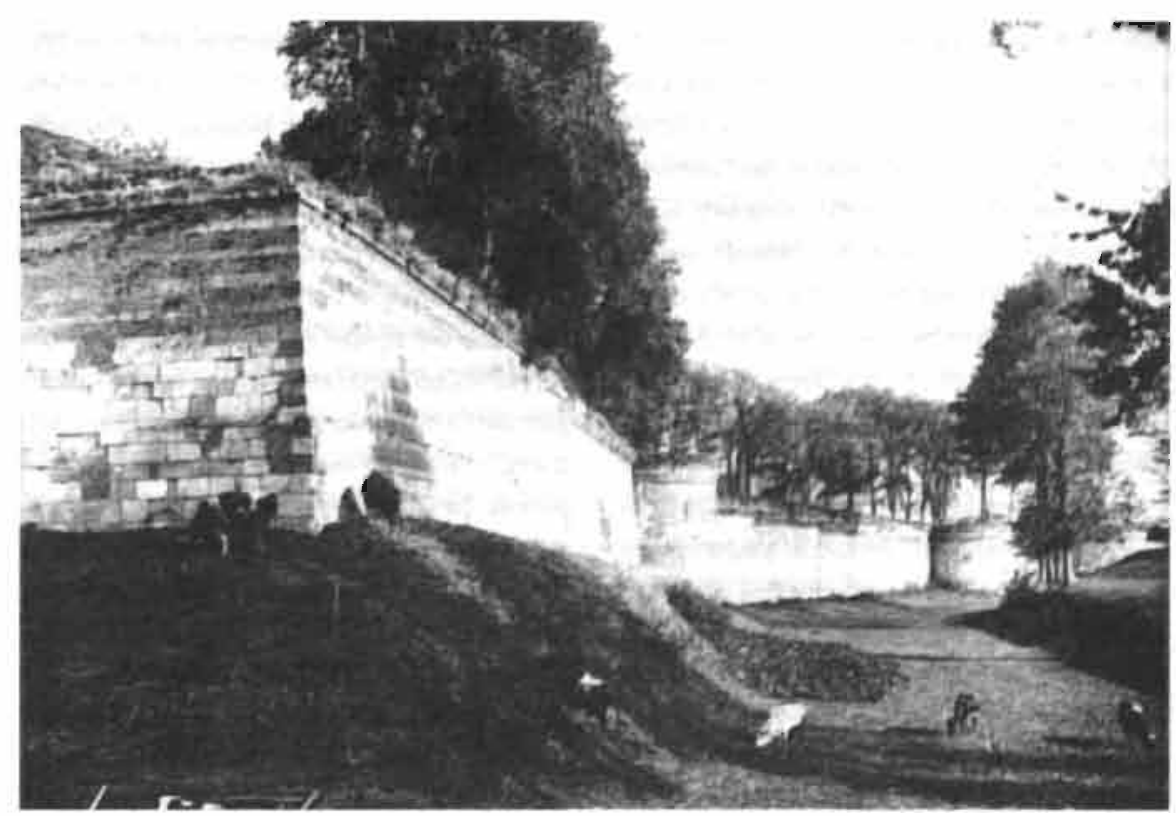

FGGUV 7.2. De dries als aanduiding voor braaklizgende grond aan de buitenzijde van de stodsmuur, onder andere in gebruik als weide- en marktplaots voor vee. Om strategische redenen moest het gebied rond de vesting boomloos $\mathbf{2} / \mathrm{jn}$. Evenmin kon hier okkerbouw worden bedreven, moar deze braak(= dries)liggende gronden werden wel beweid.
2.3 Een volgende serie bepalingen in composita $^{8}$ duidt op eigendomsverhoudingen; de term gemeen of behorende tot de nederzetting $X$ in samenstellingen met dries. wijst op het oorspronkelijke, gemeenschappelijke bezit van deze in landbouwkundig. gronden, De samenstellingen waarin kerkelijke en overheidsinstanties (kerk, klooster, heer, gemeente of hun functionarissen (koster, gemeentebode, kapelaan) en instellingen (schutterij, armenbestuur) worden genoemd, wijzen in diezelfde richting; het is bekend dat deze functionarissen en instanties bij de geleidelijke privatisering van de gemene gronden een deel daarvan in eigendom dan wel in erfpacht ontvingen."

Hetzelfde geldt voor dries-toponiemen, die betrekking hebben op een alleen gelegen hoeve of een gehucht; waarschijnlijk moeten deze worden opgevat als geprivatiseerde ontginningen op de voormalige gemene gronden. De meeste driesen, als aanduiding voor een hoeve of gehucht, zijn dan waarschijnlijk analoog met de meer bekende heihoeven en gehuchten met de naam heide. Uit de betekenis der composita in dries-toponiemen blijkt duidelijk een zekere schraalheid van het substraat; driesgronden waren te onvruchtbaar om vrijwel permanent te worden benut als landbouwgrond en moesten daarom regelmatig braakliggen. Wel werden zij benut als weidegrond voor de dorpskudde onder leiding van een herder tijdens opzicht marginale en of perifeer gelegen 
de braakperiode en na de oogst van het om de zoveel jaar geteelde graan. Tevens blijkt dat driesen oorspronkelijk veelal tot de gemene gronden behoorden.

Niet alleen blijkt de landschaps-oecologische betekenis van de driesen uit de samenstellingen, waarin het element dries in toponiemen voorkomt. Historische aantekeningen, afkomstig uit het gebied van onderzoek en daarbuiten, laten weinig twijfel bestaan over de marginaliteit van de "driesen". Het blijken "...braakliggende gronden, spaarzaam begroeid met ruw gras en eigendom van de gemeente. De arme mensen die geen eigen weiland hadden konden hun vee tegen een kleine pacht op driessen laten grazen. De weg die naar deze gemeene weideplaatsen voerde, heette van oudsher Vijehweg of Veeweg". Elders vermeldt dezelfde bron: ${ }^{10}$ "...gebruikt als weideplaats voor het hoornvee.... voor schapen en geiten", "...bergachtige gedeelten waar de grond bedekt was met stenen, ...voor bebouwing weinig geschikt" en "...voor bebouwen te slegt, hoogstens kunnen zil dienen om dennebomen daarin te zaayen". Volgens een andere bron " is een dries "een veld dat minder geschikt was voor de landbouw en meestentijds braak lag. Het was gemeenschapsgrond en alle mensen konden er hun vee, koeien, schapen en geiten op laten grazen waarvoor meestal een kleine vergoeding gevraagd werd. Na enige tijd te hebben braakgelegen, werd de grond bewerkt en rogge verbouwd",

De volgende omschrijvingen van "driesen" hebben betrekking op gebieden rond ZuidL.imburg. De omschrijuving van een dries uit het nabijgelegen Rijnland komt geheel met de Zuidlimburgse overeen. Het is een "zeitweise beackertes, nun aber for mehrere Jahre unbebautes, brachliegendes, minderwertiges, ausgewonnenes Ackerland, mit einer spärlichen Grasnarbe bewachsen, deshalb als Weide dienend oder zum Heuer". ${ }^{2}$

Een veel minder uitvoerige definitie uit de Belgische Kempen luidt: "een benaming voor grasland, waarop men (gemeenschappelijk) vee mocht drịven". ${ }^{13}$ en uit de Nederlandse Kempen: "nu en dan eens gescheurd en nadat die eens of 2 jaar met rogge, 1 of 2 jaar met boekvveit zijn gesaait geweest. worden die met haver en klaver gesaait en blijven dan weder dries liggen". 4

Zowel uit dries-toponiemen als uit (historische) omschrijvingen van driesen blijkt dat dit woord synoniem is met "braak", waarop gemeenschappelijke beweiding plaats vindt en die vervolgens, na het breken van de zode

FIGUUR 7.3.

Dries als hoevenaam en entginningsnederzetting gesticht op perifeer in de gemeente gelegen schraalland (driesgrond). Diverse cenzoam gelegen hoeven danken hun noam aan de driesgronden, waarop zij werden gerticht. Voor de noom "Heidehoeve" geldt hetzelfde.

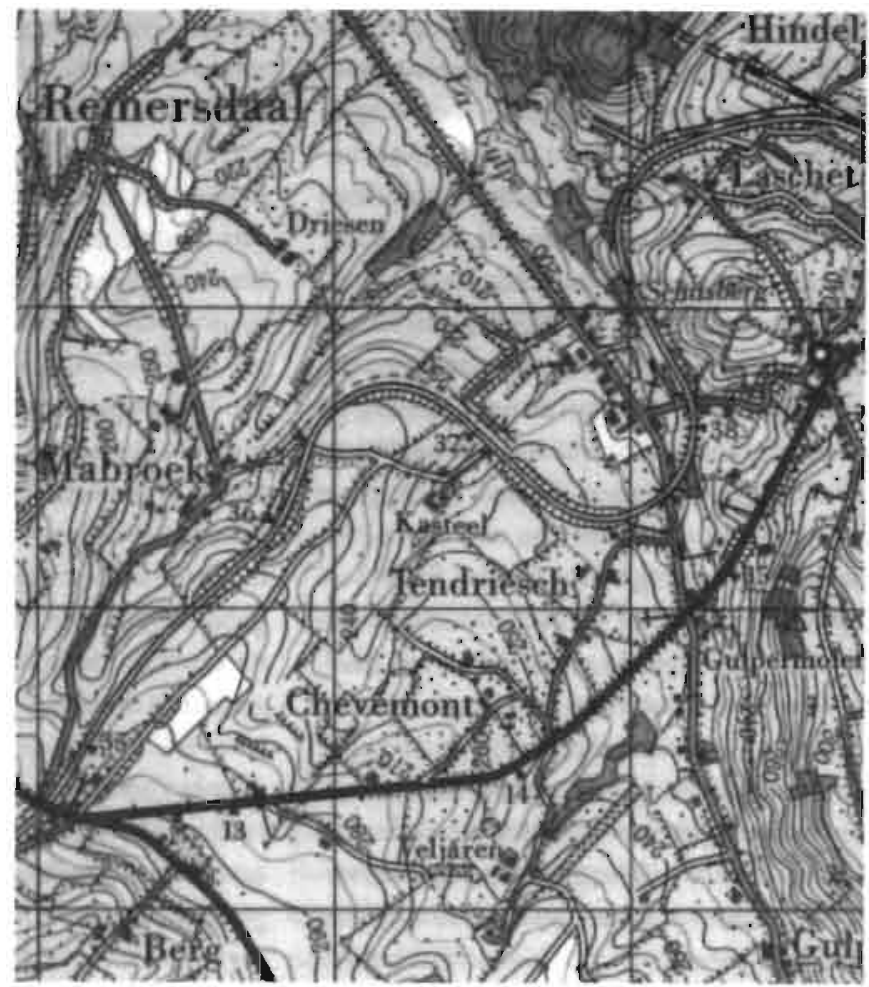

door de ploeg, wordt. afgewisseld met een periode waarin het perceel als bouwland fungeert Nergens wordt in de cyclus weidelandakkerland melding gemaakt van een periode van drie jaar; kennelijk is de lengte van de braakperiode afhankelijk van de natuurlijke vruchtbaarheid van het perceel.

\section{1} Landbouwhistorici hebben nooit. verband gelegd tussen de termen dries in de betekenis van "braak" en rotatiestelsels; het drieslogstelsel is een "historisch landbouwsys. teem dat een cyclische rotatie inhield van twee graanjaren en een braakjaar". De term moest, zijn afgeleid van het telwoord drie en het substantief slag. Een slag zou zoiets als een "groot perceel" moeten betekenen; het drieslagstelseli zou een systeem zị̣n van drie percelen die elkaar in de loop van drie achtereenvolgende jaren cyclisch zouden opvolgen met eenzelfde gewas: wintergraan, zomergraan en braak. In het onderstaande wordt, na een analyse van de termen dries, slag en drieslagstelsel, onderzocht of er een ander verband zou kunnen bestaan dan dat van het telwoord drie en het substantief slag in de betekenis van "een perceel".

De boerenterm dries is ongetwijfeld zeer oud, mogelijk zelfs van Keltische oorsprong. ${ }^{13}$ Sinds de negende eeuw is de term bekend onder de schrijfwijze thriusca. Daarna wordt hij in andere vormen, waaronder trisc, drisc en dries, regelmatig aangetroffen in Vlaamse, Nederlandse en Duitse geschriften.
In Walloniè en in sommige delen van Frankrijk komt dries voor als trieu, tri of triche. ${ }^{16}$ in het huidige Nederlands blijkt de term echter uitgestorven of zeer verouderd, maar in diverse Zuidlimburgse dialecten wordt het woord dries, tot op heden, alleen maar door boeren gebruikt. ${ }^{17}$ In toponiemen van Noordwrest-Europa komt dries regelmatig voor.

De betekenis van deze oude agrarische term met een enorm verspreidingsgebied heeft uitvoerige discussies uitgelokt. Enerzijds geven diverse icfioomcompilaties van zowel his. torische als huidige Noordwesteuropese talen ${ }^{18}$ en dialecten het idioom dries op en stellen het synoniem "periodiek braak" voor in de betekenis van "rustend land", dat eventueel door onder andere schapen kan worden beweid. Het zijn "inculte" gronden die periodiek onder de ploeg vallen, in toponiemen worden deze braakliggende en beweide gronden nader gepreciseerd als weinig produktieve akkers, tot bouwland omgezette schrale graslanden, dorpspleintjes waar onder andere de heerdgang begint en eindigt en percelen gelegen aan de buitenzijde van stadsomwallingen die om diverse redenen braakliggen. Ook dit onderzoek wijst duidelijk aan, dat de grondbetekenis van de term dries synoniem is met een bepaalde vorm van "braak".

Nu wil het geval dat al in de Capitulare de villis sprake is van rotatieplicht met daarin een. brakperiode. Moet men die rotatie identifi. 


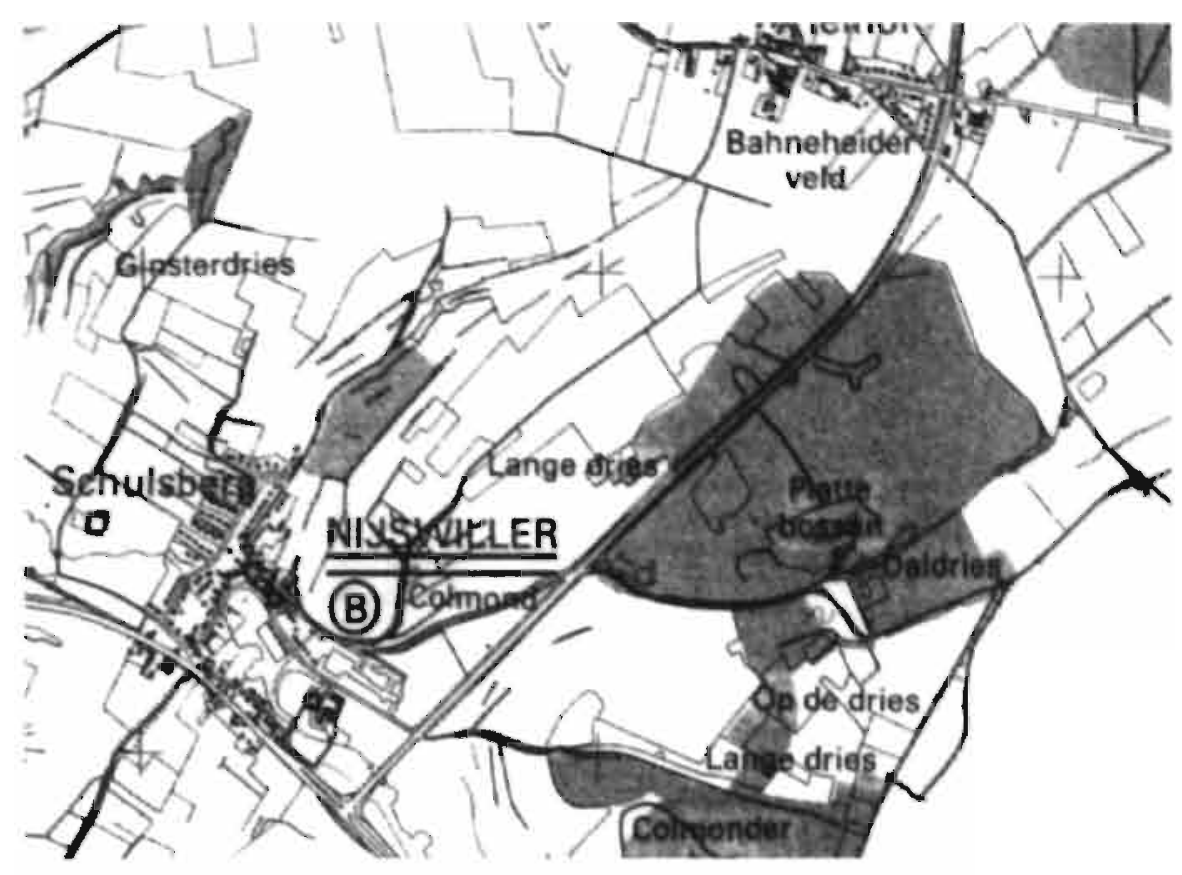

FGUUR 7.4 De ligging van een aantal dries-toponiemen turuen heide en bos (grijs) en landbouwgrond (wit) bij Nijwwiller, volgens ReNes I993.

ceren met een cyclus van drie jaar, waarvan er één een brakajaar is, zoals landbouwhistorici gewoon zijn te doen? Of is die verplichting bedoeid om gronden periodiek braak (dries) te laten liggen, alvorens deze opnieuw met een graangewas te bezaaien? Gezien de grote variatie aan substraatgebonden vruchtbaarheid in het gebied, waarover de Capitulare rechtsgeldigheid bezat, lijkt dit een stelling die door oecologen zou kunnen worden verdedigd.

In elk geval hebben taalkundigen, historici en toponymisten naar een woordverklaring gezocht, die de term dries in verband moest brengen met het telwoord drie. De etymoloog Gysseling ${ }^{19}$ poneerde in 1952 de stelling, dat de oude vorm thriusca een "gesubstantiveerd telwoordcollectief' voorstelt en dat dus de toponymische woordvorm dries primair een driehoekig dorpsplein of een driesprong van wegen zou betekenen. Een dries als derde deel van akkerland zou volgens dezelfde auteur secundair zijn. ${ }^{20} \mathrm{Het}$ omgekeerde van de laatste stelling werd echter door de historicus Lindernans ${ }^{2 i}$ verdedigd, maar ook hij ontkende evenmin dat er een betekenisverband bestond tussen het telwoord drie en de oude boerenterm dries. Dittmaier ${ }^{22}$ deed dit pertinent wel: zijn "Driesch" is geen deel van een drieslagstelsel, maar van een tweeslagstelsel en kan dus niets met het telwoord drie te maken hebben. Förste komt na uitvoerig onderzoek tot de. zelfde conclusie. ${ }^{23}$ In 1975 herroept Gysse- ling zijn eerder voorgestelde etymologie en sluit zich bij die van Förste aan. ${ }^{24}$

Samenvattend mag worden gesteld dat de term dries een zeer oud en een in Noordwest-Europa wijd verspreid begrip voorstelt, dat in de loop van de negentiende eeuw in de Nederlandse en andere Noordwesteuropese cultuurtalen in onbruik geraakte, verdween en slechts in plaatselijke dialecten op het platteland nog wordt gebruikt. Degrondbetekenis van de oude boerenterm dries is "braak". Een betekenisverband met het telwoord drie, dat gedurende een lange periode verwarring in de Nederlandse vakliceratuur heeft gesticht, moet worden uitgesloten.

\subsection{Ook agronomen hebben getracht} om het telwoord drie en rotatiestelsels waarin een braakperiode voorkwam, met elkaar in verband te brengen. De dringende behoefte om een in her Nederlands gestelde vakterminologie te ontwerpen, heeft hen daarbij parten gespeeld.

Het was W.H.C. Staring, de grondlegger van de agronomie in Nederland, die de termen drie, slog en stelsel voor het eerst in een onderling verband heeft gebruikt. In 1858 schrifft hij, sprekend over onvruchtbare. Drentse heidegronden: "Eerst bij enen verbeterden landbouw is men in staat om hier ook andere landbouwprodukten te telen, maar het zoogenoemde stelsel in drie slagen. waarbij tweemalen rogge en eenmaal boek- weit elkander opvolgen, is tot dusverre voor deze gronden algemeen in zwang ". 25

Ten aanzien van dit citaat moet worden opgemerkt, dat Staring de samengestelde woordvorm drieslagstelsel niet gebruikz jook niet elders in dit werk uit 1858 ) en bovendien dat de betekenis daarvan geheel anders is dan wat daar later onder werd verstaan. Het rotatiesysteem dat door Staring werd bedoeld en onlangs door Bieleman vitvoerig is onderzochc, kan functioneel beter worden omschreven als een tweeslagstelsel, ${ }^{26}$

Pas de bewerker van de tweede druk van Starings werk, waaraar bovenstaand citaat is ondeend en dat in 1878 verscheen, ${ }^{27}$ nam de samenstelling drieslagstelsel op in het register, waardoor de term als een zelfstandige eenheid is gaan functioneren.

In 1860 verscheen Starings "Schoolkaart", waarin het begrip dries/agstelsel in de legenda van een kaart wel voorkomt. ${ }^{21}$ De betekenis die Staring daaraan koppelde, was echter veel ruimer dan van het "stelsel uit drie slagen", dat hij in zijn boek vit 1858 beschrijft. De Schoolkaart vermeidt als drieslogstelsel: "het bouwland voor 2/3 of geheel, met rogge, voor 1/3 met boekweit; woeste gronden voor mestbereiding, en dikwijis nog voúr schapenhouderij van de Drenische, Veluwsche en Kempische rassen; de weiden niet bemest": Op dezelfde pagina vermeldt Starings Schoolkaart bovendien de term driesfand in de betekenis van "braakliggend land".

3.3 Uit bovenstaande gegevens valt af te leiden, dat Staring aanvankelijk een zekere schroorn bezat ten aanizien van het gebruik van de rerm drieslagstelsel; in 1858 gebruikte hị een "stelsel in drie stagen" en daaronder verstaat hij "een rotatiesysteem op een perceel met twee jaar graan en een jaar boekweit", Enige jaren daarna gebruikte hij de term dries/cgstelsel als synoniem voor "een regionaal landbouwsysteem dat zich kenmerkt door een viertal grondgebruikstypen die zeer uiteenloperi wat betreft hun exploitatiewijze, namelijk bouwland met cen permanente cultuur van rogge, bouwland met rogge en boekweit in de verhouding $2: 1$, de door schapen begraaste heide, en het niet bemeste schraalland". Slechts éen van de genoemde typen kent een driejarige cyclus, de overige een permanent gebruik. Het driesland, dat Staring kende in de betekenis van braakland, was, weliswaar gebonden aan een cyclisch gebruik, maar niet eén van drie jaar. Concluderend: Starings tweede omschrijuing van het drieslogstelsel is identiek met het uit 


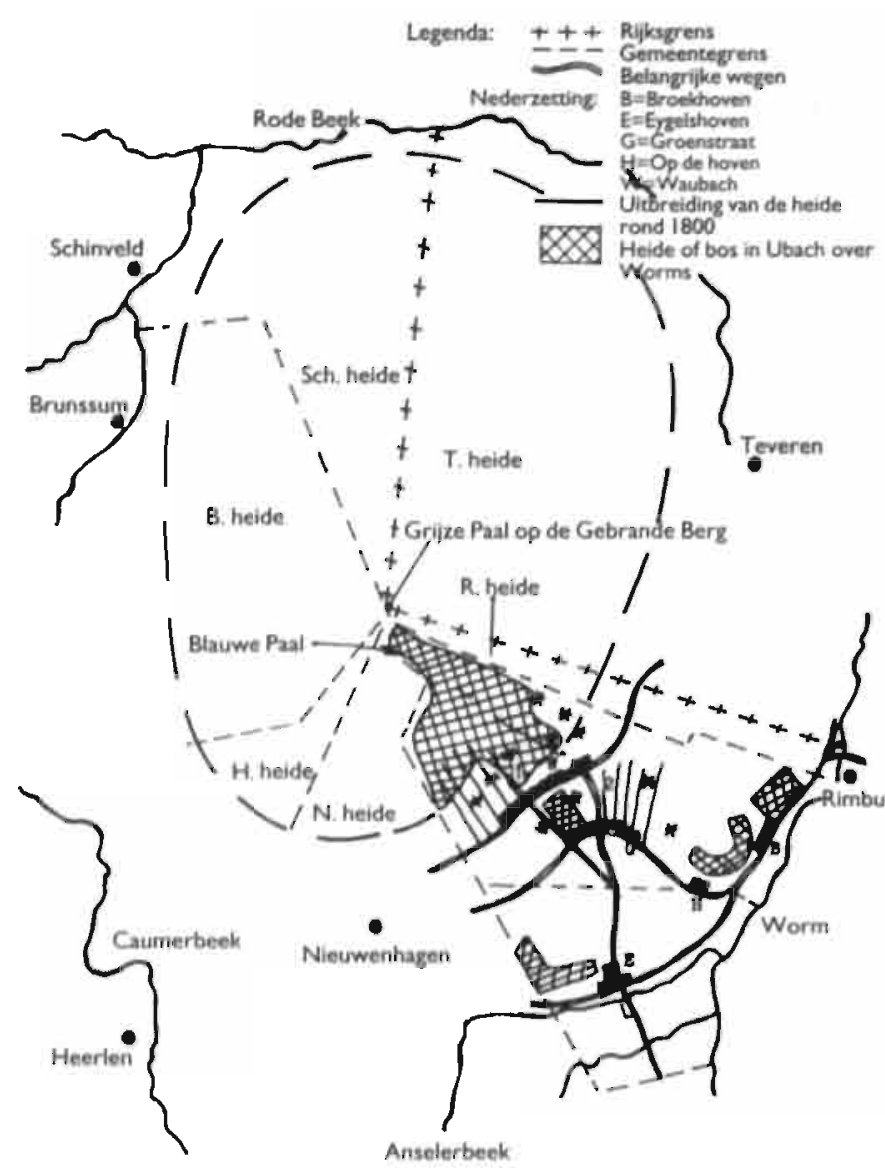

Iater onderzoek bekende potstalsysteem van de diluviale zandgronden met hun essen, heiden. schraallanden en driesgronden.

Het is dan ook duidelijk dat latere agronomen grote problemen ondervinden bij het incerpreteren van Starings definities van het "stelsel in drie slagen" en het "drieslagstelsel", die identiek zouden moeten zijn aan de termen "assolement triennal", "three-yearly crop rotation" (= three course rotation) en "Dreifelderwirtschaft", die inmiddels uit buitenlandse literatuur bekend waren.

Blink schreef dan ook in 1902:29 "Het drieslagstelsel werd in latere eeuwen van karakter gewijzigd door de invoering van boekweit, zegt Staring..., welke als zomervrucht het braakjaar kon vervangen ". Ongetwijfeld doelde Blink op de al eerder vermelde passage van Staring, toegankelijk gemaakt door het register van de bewerker van de tweede druk van Starings "Voorheen en thans, opstellen over Neerlands grondgesteldheid" : In de definitie van Blink is, afgezien van de drieparige duur, de afwisseling van wintergraan en zomergraan ook het braakjaar essentieel. In deze zin komt de Nederlandse term wel overeen met "assolement triennal" en "Drei-
FIGUUR 7.5 .

De ligging von een
twoolftal dries-

toponiemen in de

gemeente Ubach over

Worms in relotie tot

de heide, het

bouwland en de kem

van Ubach over

Worms noor gegevens

van onder andere de

Tranchotkoort. Binnen

de gemeente Uboch

over Worms liggen,

volzens GOOSSENS

1981 , twoalf dries-

toponiemen. Hun

ligeing wordt enerzi/ds

bepoald door het

substraat, dat door

Goossens wordt

omschreven als

"randig schraal" tot

"kJexelig onvrucht-

baor", onderzijds door

het toenmalige

bodemgebrulk als een

"gemeenschoppelijke

weideplaats voor het

vee, periodiek benut

als ropke-akker". Rond

1800 logen deze

driesgronden in een

boog om de nederzet-

ting Wouboch en

Groenstraat tussen de

mor nime ontomnman

heide en de permanen-

te akkercomplexen.

\section{felderwirtschaft".}

Dit landbouwsysteem, dat door niemand minder dan door Karel de Grote zou zijn gepropageerd, zou gedurende vele eeuwen, vanaf de vroege middeleeuwen tot aan het begin van de nieuwe tijd, in geheel Europa ten noorden van de Alpen vrijwel het enige landbouwsysteem zijn geweest. ${ }^{30}$

Uit recent onderzoek ${ }^{31}$ is echter gebleken. dat er ten aanzien van deze stelling zoveel uitzonderingen bestaan, dat er ernstig moet worden getwijfeld aan de algemene geldigheid daarvan. Wel essentieel in de twee, drie tot twaalf jaar durende "slagenstelsels" is de braakperiode als de noodzakelijke rustperiode van de akker, waarop de mest van het weidend vee en de opnieuw gevormde humuslaag van de braakvegetatie weer voldoende garanties scheppen voor de oogst van een volgend graangewas.

Daarnaast bestaat de term driesland, die al door Staring werd gebruikt in de betekenis van periodiek braakliggend land, een term die door Roessingh ${ }^{32}$ en Bieleman ${ }^{33}$ nader wordt onderzocht en gepreciseerd en aanleiding vormt tot de introductie van de nieuwe term "driesstelsel".
De betekenisevolutie van het historischagronomisch begrip drieslagstelsel samenvattend, mag worden gesteld dat er sprake is geweest van een aanzienlijke begripsverwarring. De term heeft aanvankelijk, dat wil zeggen tijdens de laatste helft van de vorige eeuw, minstens twee betekenissen, heeft vervolgens in het begin van deze eeuw betrekking op een driejarige rotatie zonder braak en betekent tenslotte een rotatiesysteem, waarin de braakperiode essentieel blijkt te zijn en waarin de duur van de cyclus alsook de volgorde en de soortensamenstelling van de daarbinnen geteelde gewassen een minder belangriike rol spelen. Naast het agronomisch begrip drieslogstelsel bestaan momenteel de termen driesland en driesstel$\mathrm{sel}$, die tot op zekere hoogte wat hun betekenis betreft met elkaar in verband staan.

3.4 Net zo weinig als het telwoord drie in de term drieslagstelsel zinnig en essentieel blijkt te zijn, geldt dat voor de term slag. Logischerwijs zou dit synoniem moeten zijn met "perceel" en een deel moeten zijn van een akker. In toponiemen zou dit begrip zeker bewaard moeten zijn gebleven. Maar zelfs de gebl vecutera Linutermans, "sie net toponymisch verschijnsel dries en het agronomisch systeem drieslogstelsel met elkaar in verband trachtten te brengen via het telwoord drie, moesten concluderen dat de term slog in Vlaanderen ontbrak en dat inen daarvoor zood gebruikte. In Nederlands-Zuid-Limburg, zou het aldaar veel voorkomende toponiem gewande ${ }^{35}$ daarvoor in aanmerking kunnen komen, in Duitsland de term Zeige ${ }^{36}$ in Belgisch-Zuid-Limburg gebruikt een gezaghebbende auteusi ${ }^{37}$ de term driehoevenstelsel als synoniem voor drieslagstelsel en zou de term hoeve het gemis aan slog compenseren.

Viveliswaar geeft een middeleeuwse idioomlijst. ${ }^{34}$ van de 21 betekenissen van het substantief slach, er één op in de betekenis van "perceel", maar deze betekenis is zeer vaag. heeft niet uitsluitend betrekking op een deel van een akkercomplex en zou bovendien te maken kunnen hebben met een "aanslag", dat wil zeggen een perceel waarover belasting moest. worden betaald.

Momenteel komt de term slag wel voor als onderdeel van een begrip uit de huidige landschapsoecologie. Men spreekt van een slogenlandschap, waarmee een weidelandschap. in de veenstreken wordt bedoeld dat door elzenhagen in lange stroken is geparcelleerd. ${ }^{39}$ Bedoelde afscheidingen tussen "opstrekkende percelen" werden periodiek "ge- 
slagen", dat wil zeggen geicapt en onder andere als brandhout benut. Het is mogelijk dat Staring de term slog. die met name in Zuidwest-Drenthe werd gebruilkt, in een ander verband heeft toegepast.

Het is, gezien het bovenstaande, niet ondenkbeeldig dat de via of door Staring in de agrarisch-historische literatuur geïntroduceerde term drieslagstelsel is ontleend aan een bestaande boerenterm dries en de werkwoordsvorm liggen, synoniem voor het werkwoord broakliggen. Mogelijk ontstond pas op de schrijtafel van historici en agronomen de (abusievelijke) koppeling tussen het telwoord drie en het substantief slag, mede onder invloed van de buitenlandse termen "Dreifelderwirtschaft", "assolement triennal" en "three crop rotation". Voor deze, in wezen correcte termen, omdat zij zijn opgebouwd uit termen die duidelijk met elkaar in verband staan, kent het Nederlands immers geen synoniem, omdat de betekenis van slog in de samenhang met drie en stelsel een onduidelijke term is. Niettemin heeft de term drieslogstelsel en de daaraan naar analogie gevormde twee, vier-enzovoort-stelsels, vaste posities, veroverd in de agronomische literatuur. De betekenis is duideliik vanuit de termen: het zijn rotatiestelsels met een bepaalde opeenvolging van geteelde gewassen. Bij de term drieslagstelsel gaat het vooral om een historisch rotatiestelsel, een jaar wintergraan, een volgend jaar zomergraan en een derde braakjaar.

Gezien vanuit de huidige kennis van zaken omtrent middeleeuwse en post-middeleeu'wse landbouwsystemen lijkt de koppeling "dries" en "liggen", als synoniem voor "braakliggen", veet zinniger dan de koppeling "drie" en "slag", omdat de periode van de braak afhankelijk was van de natuurlijke vruchtbaarheid van het perceel. De term "driesligstelsel" heef: dan eveneens bestaansreche.

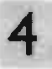

In het algemeen mag worden gesteld, dat zowel de omvang der dries liggende gronden, zijnde dat deel van het akkerareaal dat jaarlijks braak lag, alsook het belang daarvan als weidegrond voor het vee, vanaf de vroege middeleeuwen tot in de nieuwe tijd steeds verder afneemt om uiteindelijk in het begin van de twintigste eeuw te verdwiinnen. Tijdens de vroege middeleeuwen is aan de veeteeit in West-Europa een belangrijker rol toebedacht dan aan de landbouw; de graancultures waren niet alleen beperkt van omvang, maar werden ook zeer exten- sief bedreven. Het gehele landbouwareaal, waarvan jaarlijks tenminste de helft braak lag. werd door de dorpskudden onder leiding van herders beweid. Dit landbouwsysteem kan als een tweeslagstelsel worden beschouwd; functioneel gezien verdient de term "Feldgraswirtschaft" de voorkeur. *

Door een bevolkingstoename, ingezet tijdens de Karolingische periode en manifester vanaf het begin van de hoge middeleeuwen, ontstaat een stiigende behoefte aan meer voedsel, dat in eerste instantie door het verbouwen van meer graan moest worden geleverd. De akkerbouw werd geintensiveerd door een verkorting van de braakperiode; het drieslagstelsel, een rotatiesysteem van een jaar wintergraan, een jaar zomergraan en een derde jaar braak, werd plaatselijk geinstitutionaliseerd en bleef gedurende de gehele middeleeuwen éen van de meest toegepaste landbouwsystemen in veel delen van Europa ten noorden van de Alpen. Op deze algemene regel bestaan echter diverse uitzonderingen en afwijkingen.

Tijdens de late middeleeuwen ontstaan vanuit dichtbevolkte en in landbouwkundig op: zicht geavanceerde gebieden, waaronder Vlaanderen, nieuwe landbouwtechnieken, die door onder andere de toepassing van potstalbemesting, verbetering van de grondbewerking en verbouw van braakgewassen het drieslagstelsel verlengen tot meerjarige rotaties, waardoor de braak werd verminderd en de dorpskudden in omvang afnamen. Zeker vanaf de nieuwe tijd wordt het vee steeds meer ondergebracht in geprivatiseerde standweiden of op stal gevoerd. Alleen op de meest marginale gronden, die bovendien waren gelegen aan de periferie van de gemeente, wordt nog de braak toegepast, " waar de resterende schaapskudden nog enig voedsel konden vinden. In het dichitbevolkte en relatief vruchtbare deel van Nederlands Zuid-Limburg verdwijnt de braak definitief in de loop van de negentiende eeuw. Pas daarna worden de grazers in kuddeverband afgeschaft.

Tegen deze achcergrond is het langzaam verdwijnen van het taalkundig element dries in de officièle taal en in dialecten alsook her blij. ven bestaan in toponiemen goed verklaarbaar. Omdat de primaire betekenis van dries; te weten "braak", nauwelijks meer van toepassing is in de negentiende-eeuwse landbouw en geheel yerdwijnt in de eerste helft van de twintigste eeuw, sterft het woord dries uit en blijft als een taalkundig fossiel achter in toponiemen.

\section{NOTEN}

1 JANSEN DE LIMREN 1976, p. 426.

2 Zie tabel 7.

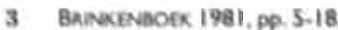

4 ReNes 1988, p. 88. Renes 1985, p. 103 en STuch 1985, p. 50.

5 Er zin verschillende "Hei(de)hoeven," in Zuid-Lim. burg het zịn eenzaam gelegen onginningsboerderijen, gesticht op voormalige heiden, bijvoorbeeld te Amby, Hulabergen Brunsum. Vergelijk ReNes 1988. p. I 10. Ook buiten Zuid-Limburzkomen deze "Ein. zelhote" voor, vergetijk Renes 1985, p. 103

6 Zie tabel 71 tot en met 7.5 .6 .

7 De term "vogelwey" is hier denigrerend bedoeld Zie Rotshotcx 1973, p. 36.

$8 \quad$ Zie tabel 7.5.3

9. Kinnos 1976

10. Goossens 1981, pp. 297 en 345

11 Rarvin 1985, p.52

12 DitTmark 1963, p.54

I3 LINOEMANS 1946, p. 116

14 Couns EN Kereunas 1987, pp. 22.23

15. Linoeruws 1951,p. 19

16 Lindumans 1951,p. 19 en GHANDGAGNe 1880

17 Zie noot 10 van hoofdstuk I

I8 KuLIN 1975, De Vhes 1958, VIMDAM 1976, ViRwus etal. 1855-1941 en VAN Dau 1976

19 Grsuecing 1952, p. 50

20 GrnseiNG wordt in zijo mening gestasfd door Di vos 1952, p. 56

211 Lindomans 1951 en 1952, respectievelipk pp. 23 en 90

22 Dirtmath 1960 , p. 726

23 Fonst 1966

21 Grssunc I975

25 STAUNG 1858, p. 90.

26. BIELEMAN 1987, p. 580

27 STARING 1878, p. 91.

28 STARING 1860.p, 4

29) Bunic 1902.p.94.

30 ZADOKs in Inleiding tot de oecalogie 1985, p. 381 ,

31 BifLEMAN 1987, p. 574 en volgende. HACKEVG 1982. Mertens in Aigemene geschiedenis der Nederlan. den 198 1-1982. Dervilu 1988 en SuCHER VAN BATH 1960 .

32. Roessingh in Algemene geschiedenis der Nederlar. den 1981-1982, deel 8, pp. 42-50.

3.3 BILLEMAN 1987

31 Lindemans, J. 1951 en 1952 en Linotmans, P 1960

35. POELMAN in Het Landschap van Zuid-Limburg 1987.

36 BIELEMAN 1987, p. 580

37 Bemers 1975.p. 161.

38 Verwils ecal 1855-1941.

30 ZONNEVELI 1985.

40) DitTMAEK 1960, p. 722

11 Hilizgens 1980. 


\title{
I HEERDGANG EN ONTGINNINGSGESCHIEDENIS, O EEN SCHETS VAN DE PROCESSEN EN PATRONEN VAN DE HUMANE OCCUPATIE IN ZUID-LIMBURG
}

\author{
"De $\mathcal{N}$ ederlandse historisch-geografen heb6en dit deel van \\ Nederland (= Zuid-Limburg) nog maar weinig onderzocht. "I
}

De bovenstaande opmerking suggereert, dat er over de ontginningsgeschiedeniș van dit dẹel vạn Nederlañ nog maar weinig zinvals te vermelden valt. Die conclusie zou onjuist zijn; vooral in de laatste jaren is door diverse, niet-historisch-geografisch onderlegde auteurs vrij veel materiaal bijeengebracht op grond waarvan een schets van de ontginningsgeschiedenis van Zuid-Limburg kan worden opgeste!d. In dit hoofdstuk worderı deze gegeyens, door archeologen, historici, taalkundigen en biologen verzameld, tot een symthese gebundeld.

Na een grove schets van de geomorílogie van het gebied van onderzoek en de afbake. ning van het historisch proces van de ontginning daaryan, wordt in de tweede paragraaf nader ingegaan op taalkundige gegevens, die het proces van de ontginning relatief kunnen dațeren. Een andere reẹs van țaalkundige gegevens is bruikbaar bij de reconstructie van het oorspronkelijk patroon van de nederzettingen. De derde paragraaf behandelt gegevens uit biologisch onderzoek, voor zover deze van belang zịn voor een reconstructie van de ontginning. Onderzoek van laagsgewijs in de bodem bewaard gebleven stuifmeel geeft inzicht in de verschuiving van de floristische samenstelling van de vegetatie vóór en na de ontginning.

Ander biologisch onderzoek betreft veranderingen in structuur en floristische samenstelling van de vegetatie onder invloed van diverse vormen van heerdgang, die in de loop van het historisch ontginningsproces elkaar hebben opgevolgd. Verder zịn vegetatiereconstructies uit de ontginningsperiode mogelijk op grond van onder andere toponiemen en ongestoorde bodemprofielen. Voorts wordt uitvoerig ingegaan op de humaan-oecologische betekenis van de vier belangriịkste landschapstypen voor de mens. die in de loop van de ontginning een wisselende rol hebben gespeeld. Tevens wordt kort ingegaan op de rol die het vee speelde in het ontginningsproces en de technische apparatuur waarover de ontginner kon beschikken.

Afgezien van kaartmateriaal van zeer uiteenlopende aard levert de geografie gegevens op met betrekking tot lokaal voorkomende bodemtypen en hun gebruik door de ontginner en zijn nakomelingen. De natuurlijke produktiviteit van deze ontginningsgronden vormde immers de basis voor het succes van de ontginning.

Een laatste bijdrage tot de ontginningsschets van Zuid-Limburg wordt aangedragen door destudievan nederzettingsvormen, dienauw aansluiten bij gegevens uit de sociale geografie.

De afșluitende paragraa vạn dit hoofdstutuk legt verband tussen het patroon van het ontgonnen gebied en het proces van de ontginning.

\section{2}

Zuid-Limburgmaakt deel uit van de rand van een geologisch oud en gevarieerd massief, dat grenst aan het Noordwesteuropese laagland. In plaats van "heuvelachtig" kan Zuid-Limburg beter worden omschreven als een "tafelland", bestaande uit een afwisseling van stroomdalen (= dalbodems) en plateaus. Geologisch gezien zijn de dalbodems jong. Oppervlaktewater is daar permanent aanwezig in de vorm van beken en rivieren. De plateaus zijn geologisch veel ouder. voor zover met löss bedekt vruchtbaar en relatief droog. Permanent aanwezig oppervlaktewater is niet voorhanden. De oppervlakte der plateaus varieert nogal; het kleinste beslaat een oppervlak van enkele vierkante kilometers, het grootste van enkele tientallen vierkante kilometers. De overgangen van stroomdalen en plateaus bestaan meestal uit steile hellingen, waar diverse zeer oude gesteenten kunnen dagzomen. Behalve stroomdalen zijn er oak droogdalen, die slechts periodiek water afyoeren. In komvormige depressies aan het begin van een droogdal op het plateau kan zich onder gunstige omstandigheden oppervlaktewater verzamelen. De droogdalen fungeren als natuur!ijke verbindingern tussen de stroomdalen en de plateaus. De omgeving van de poel in de komvormige depressie lijkt een gunstige plaats voor vestiging.

Elk plateau in Zuid-Limburg kent zijn eigen geschiedenis, maar het verloop is in grote lifnen voor alle plateaus hetzelfde (zie figuur 8.1). Eerst worden de beekdalen die het plateau begrenzen gekoloniseerd. Het met bossen bedekte plateau zelf is op dat moment niet bewoond, maar wordt wel benut (fase A). Droogdalen worden ontginningsassen. Pas wanneer de dalen een bepaalde dichtheid van bewoning kennen, neemt de exploitatiedruk op de plateaus toe; de plateaubossen degraderen door selectieve kap en overbeweiding tot schraallanden (fase B). Vervolgens ontstaan vanuit moederdorpen in het dal dochternederzettingen op de randen van het plateau, met name daar waar zich water in poelen verzamelt. Daarna wordt, afhanketiijk van de lokale omstandigheden, het plateau in radiair verlopende segmenten opgedeeld. waarvan het aantal gelijk is aan het aantal moedernederzettingen in de dalen. Grote delen van het schraalland op de plateaus zijn dan tot bouwland omgezec. De ontginnings. geschiedenis is op dat moment in grote lijnen afgesloten (fase $\mathrm{C}$ en D). Hoogstens kunnen daarna op kleine schaal nog enige restanten worden ontgonnen (fase $E$ ).

Elk plateau kent echter zịn eigen ontginningsgeschiedenis in detail, afhankelijk van onder 
andere zijn grootte, vorm, bodem, watervoorziening, rechtspositie van zijn kolonisten enzovoort. De ontginningsgeschiedenis van Zuid-Limburg valt daarom uiteen in een geschiedenis per afzonderlijk plateau.

I.3 Het begin van de ontginningsgeschiedenis van een bepaald gebied behoeft niet te worden gezocht bij de eerste bewoning ervan. Zuid-Limburg werd minstens sedert 250.000 jar tijdens de prehistorie bezocht door nomadiserende jagers en voedselverzamelaars. Deze culturen hebben het milieu niet in die mate beïnvloed, dat er van een ontginning kan worden gesproken. De eerste landbouw en veeteelt bedrijvende culturen voldoen wel aan die voorwaarde. maar het is de vraag of de Bandkeramiekers. de eerste bewoners uit Zuid-Limburg met een agro-pastorale economie en een min of meer sedentaire levenswijze, een zodanig blijvende en voldoende grootschalige ontginningsstructuur hebben veroorzaakt, dat daarin het begin van de ontginningsgeschiedenis van Zuid-Limburg moet worden gezoche ${ }^{2}$ In elk geval blijkt uit archeologisch onderzoek niet, dat de volkeren en culturen die de Bandikeramiekers opvolgden deze vroegste ontginningen consolideerden of hebben uitgebreid.

Het staat echter wel vast, dat op het moment van de verovering van het onderzoeksgebied door de Romeinen, een halve eeuw vóor het begin van onze jaartelling, de ontginningsge- schiedenis al was begonnen; de inheemse bevolking bezat een agro-pastorale economie en bewoonde min of meer permanente nederzettingen. Toch wordt de periode die begint met de bezetting en de daaropvolgende kolonisatie door de Romeinen niet alleen beschouwd als het begin van de historie, maar tevens als het begin van de ontginningsgeschiedenis." Vanwege de bevolkingsafname in de laat-Romeinse tijd kan een herbegin van de ontginningsperiode ook worden geplaatst in de latere Merovingische periode, In elk geval blijkt, dat in het oostelijk deel van het onderzoeksgebied de nederzettingen in de beekdalen zich sinds het midden van de zevende eeuw uitbreidden. In de Karolingische tijden of kort daarna begon de exploitatie-

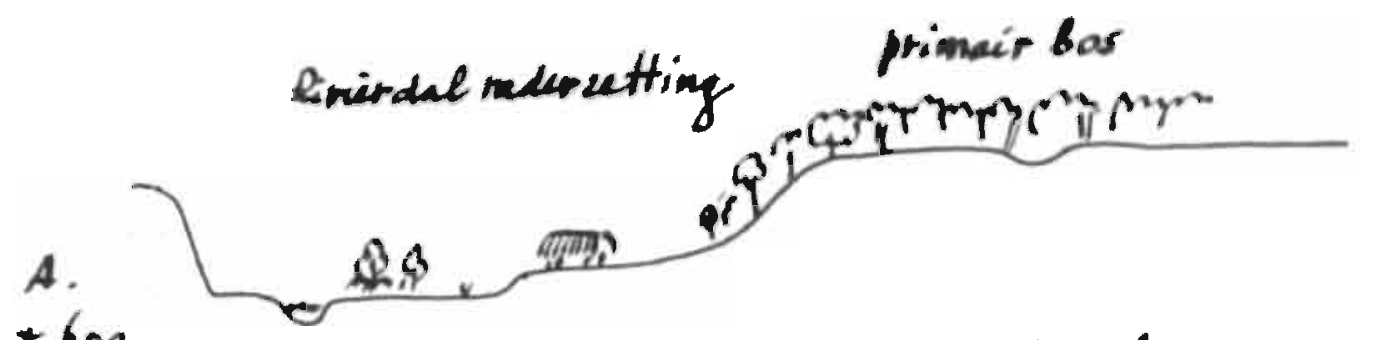

B.

$\pm 800$
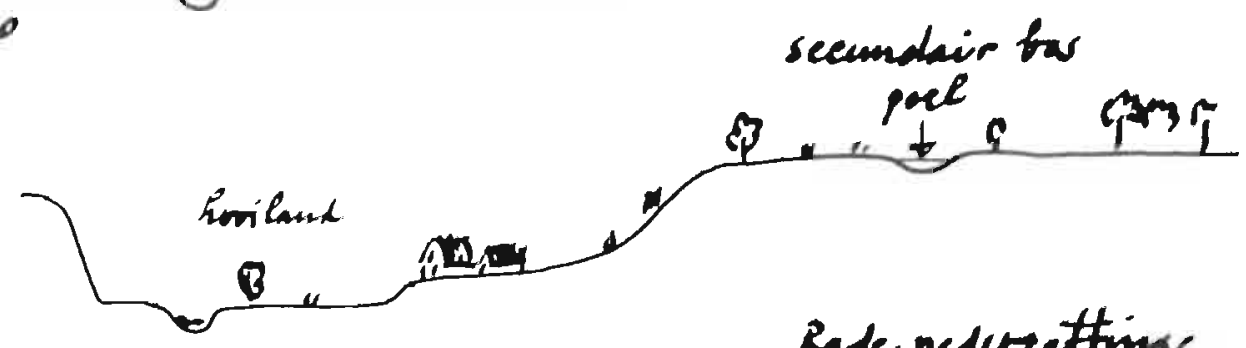

Rade nederzetting

hoide

c.

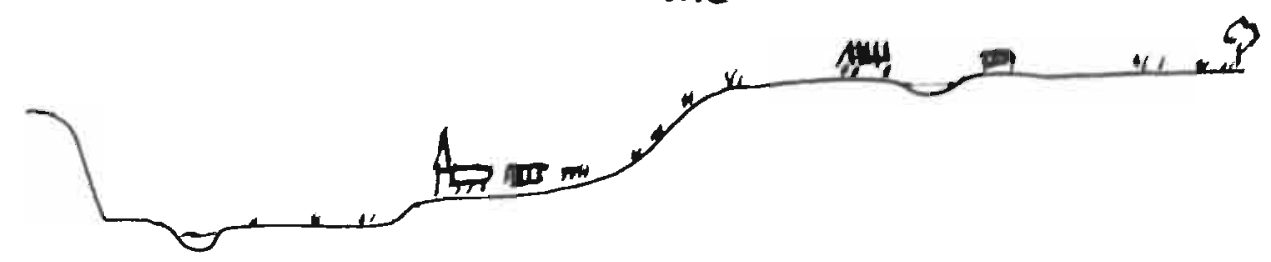

\section{$\pm 1100$}

$\mathcal{D}$.

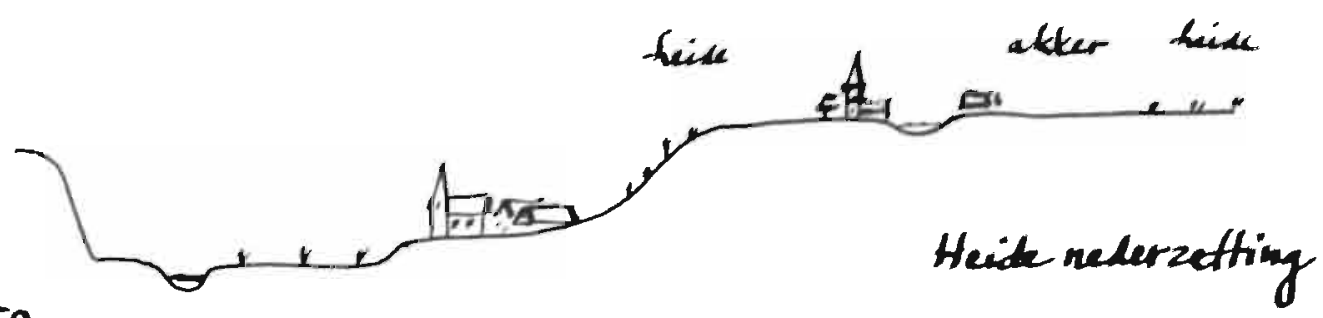

$\pm 1250$

$\epsilon$.

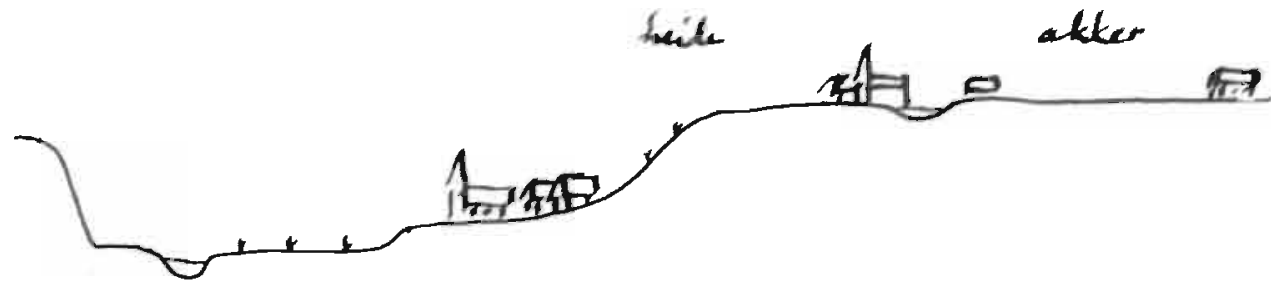

FIGUUR 8.1.

Fasen uit de ontginningrgeschiedenis ran een deẹl van ZuidLimburg (schematisch). Fase A De nederzetting op de hoge oever van de rivier: Fase B: De vroenhef is tot een keine nederzetting: uitgegroeid. Op hiet punt woar de heerdgangroute het ploteau bereikt, onestaot een poel, de "mear", cen roor de dorpskudden vitaol punt.

fase $C$ : In de omgeving van de maor ontstadt een boshoevenederzetting.

Fose D: De dalnederzetting verdicht zich en de boshoeveneder zetting groeit ait tot een "rode"-dorp. Fose E: Ontginringsboerderijen worden gesticint aan de platecurand of aan de rand van het dorpsareaal. 


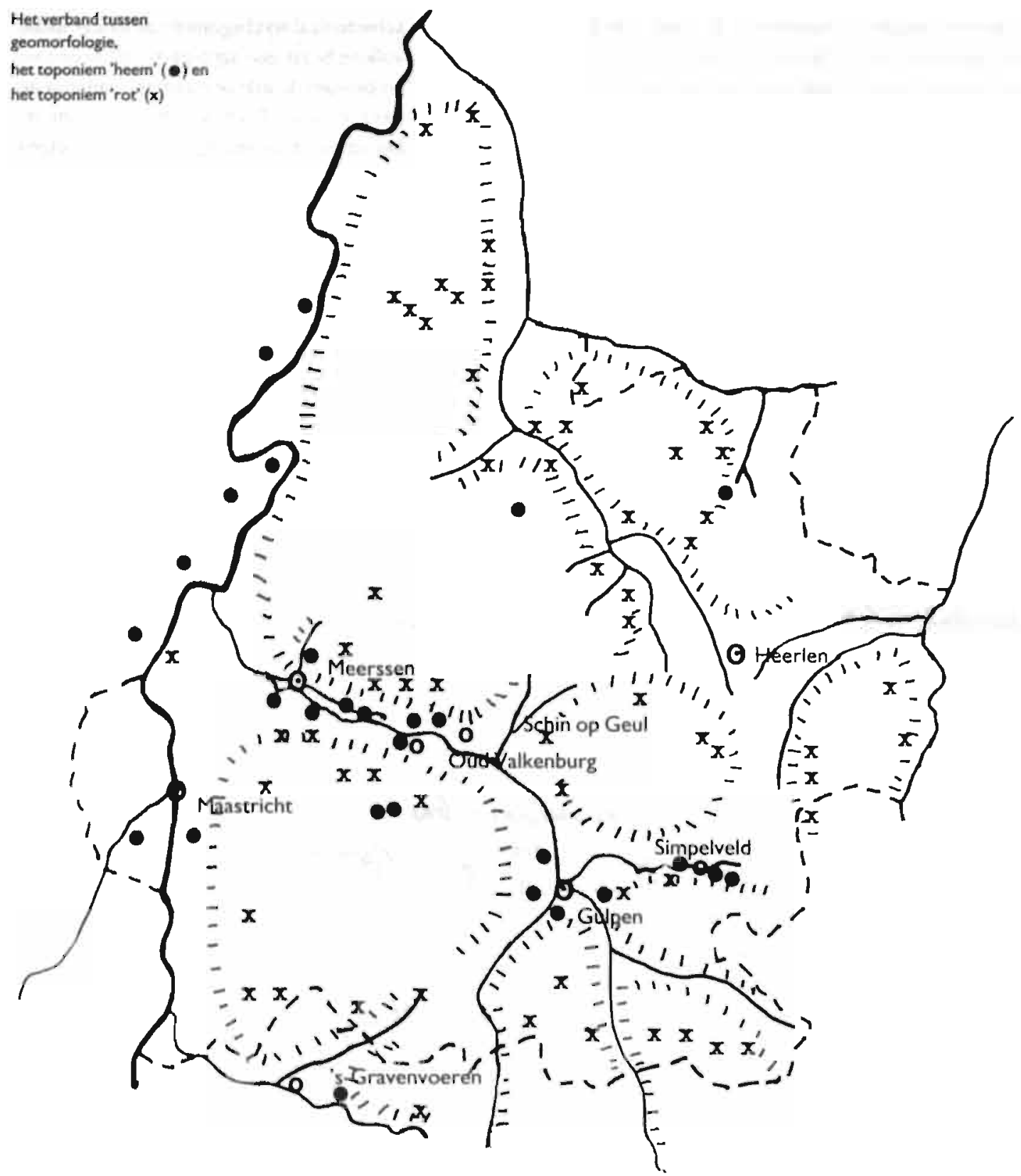

FIGUUR 8.2

Het verband tussen de nederzetringsgeschiedenis, reomorfologie en toponiemen. De oudste historische nederzettingen (GalloRomeins) liggen in de rivierdalen. Hun namen zijn deels of geheel Romaans. De dooroprolgende generutie van nederzettingen (MerovingischKorolingisch) liggen eveneens in de beekof rivierdalen. Hun Germaanse namen kunnen het suffix "hem" (= heem) bevotten. Ook de "rot" (= rode, rade)nederzettingen $z i / n$ Germaans, maar liggen op de plateaus en doteren uit de periode van de grote ontginningen tussen 1100 en 1300. De nomen van de heemen rot-nederzettingen worden vermeld in tabel 7.6 . druk op de plateaus toe te nemen. Eveneens kan worden aangetoond dat tijdens de elfde eeuw in sommige delen van Zuid-Limburg nederzettingen ontstaan op de plateaus. Het einde van de periode van de ontginningen is net zo min op een exact tijdstip te fixeren als het begin. Formeel eindigt die met het verdwijnen van het laatste restant "oerbos" ten gunste van cultuurgrond, maar dit moment is niet precies aan te geven: onder andere omdater binnen het onderzoeksgebied, met name op de hellinger, bossen voor ontginning zijn gespaard vanwege hun functies binnen de agrarische bedrijfsvoering. Als gevolg daarvan hebben deze hellingbossen hun oorspronkelijk "oerbos"-karakter verloren en dragen al sinds enige eeuwen een zoge- naamd halfnatuurlijk karakter:

Gewoonliịk neemt men aan, dat het verzadigingspunt van de oecologische expansie rond het einde van de dertiende eeuw werd bereikt, hetgeen tevens het einde betekende van de periode van de grote ontginningen in Zuid-Limburg.

\section{I Taalkundige gegevens met betrek-} king tot de ontginningsgeschiedenis worden onder andere door de toponymie aangedragen. De toponymie is een relatief jonge loot van de linguistiek: haar studiemateriaal bestaat voornamelijk uit namen van nederzettingen, maar ook uit. die van geïsoleerde boerderijen, percelen (veldnamen in engere zin), wegen en waterlopen. Via een taalkun- dige ontleding is de toponymist onder andere in staat zịn materiaal relatief te dateren. in ziịn proefschrift "Romaans in Limburgse plaatsnamen " oppert Tummers ${ }^{4}$ de these, dat diverse van Limburgs, oudste, nog bestaande nederzettingen Romaanstalig zijn. Geomorfologisch gezien worden deze plaatsnamen gekenmerkt door hun ligging op de hoge, dat wil zeggen niet overstroomde oevers van beken en rivieren. Vlakbii stromend water liggen sok, nederzettingen met een Romaans-Germaanse naam, meestal bestaande uit een Germaanse (persoons) naam en een Gallo-Romeins suffix, zoals Beutenaken, Slenaken en Etenaken. Mogelijk behoort tot deze reeks ook het bij Broekhem gelegen "Loesak". Aanzienlijke delen van de rivier- 


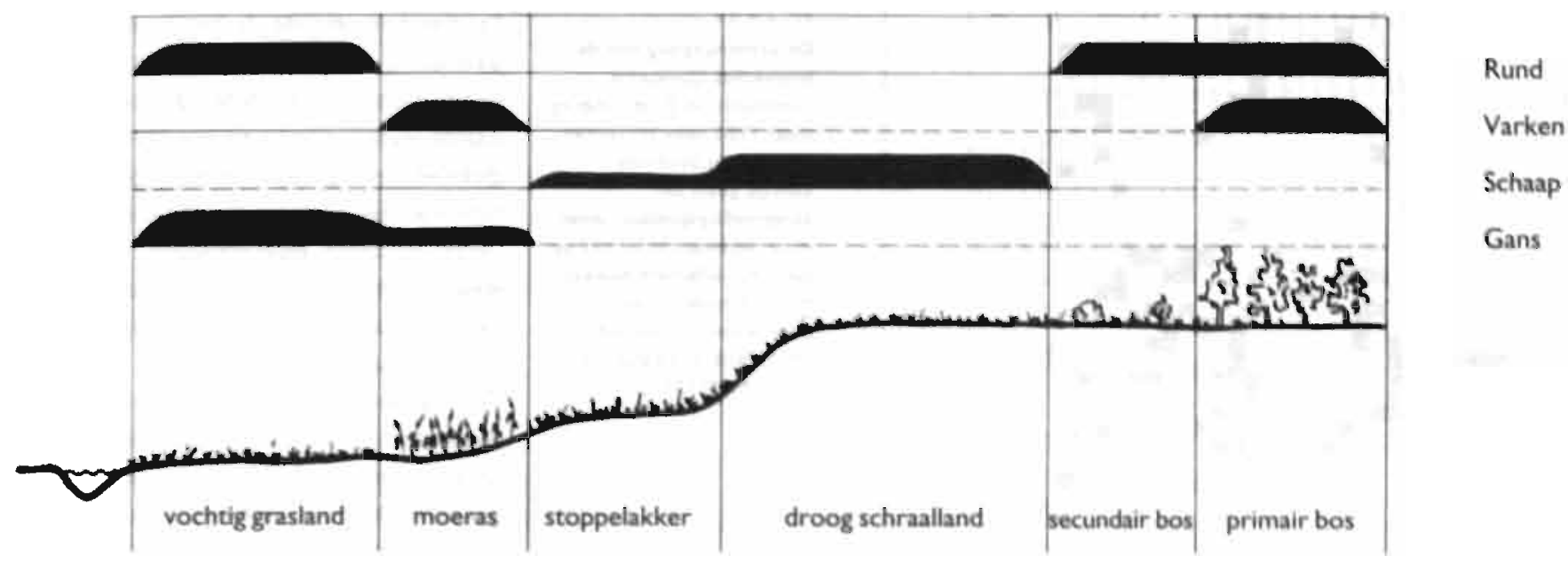

FGUUR 8.3. Favoriete weideplootsen von enige grote herbivoren, die in kuddeverband werden gehouden in een Zuidlimburgs beekdel naar Hiusges 1990 , Runderen, schapen, varkens en ganxen verichillen van elkaar wat betreft hun veedselstrotegie; elke soert heeft eigen weidegronden.

en beekdalen moeten daarom al voor de volksverhuizing in cultuur zijn gebracht. Nederzettingen met een volledig Germaanse naam dateren van na de volksverhuizing. Een van de bekendste en oudste groepen van Germaanse nederzettingsnamen betreft het "heem"- of "heim"-suffix. De talrijke "heem". namen, meestal afgesleten tot "hem", liggen binnen Zuid-Limburg geclusterd rond centra van Merovingische of Karolingische activiceit' (zie figuur 8.2).

Een volgende categorie nederzettingsnamen dateert uit de tweede middeleeuwse ontginningsgolf, beginnend in de elfde eeuw. Hiertoe behoren de talrijke nederzettingsnamen die duiden op de aanwezigheid van "bos". Dit betreft niet alleen de meeste namen met het element "hout" (hols, holt, huls), "hees", "stok" of "bos", die waarschịnlijk een bepaald bostype voorstellen, maar vooral de "rode"-nederzettingen, die op al dan niet geleidelijk gerooid bos wijzen. Vrijwel alle "bos"-nederzettingsnamen liggen op de plateaus. De talrijke rode-toponiemen omkransen de plateaus (zie figuur 8.2). Uit spaarzame bronnen en decailstudies is bekend, dat de rode-nederzettingen te beschouwen zijn als "dochter"- of "satelliet"-nederzettingen, gesticht vanuit een "moeder"-dorp in het dal, ?

Een laatste categorie nederzettingsnamen, vermoedelijk daterend uit de late middeleeuwen of de nieuwe tijd, is voorzien van het suffix "heide", voorafgegaan door een toen al bestaande nederzettingsnaam, zoals bijvoorbeeld Heerlerheide of Bochholtzerheide. Ook werden er in deze tijd geisoleerd gelegen "Heidehoeven" gesticht. ${ }^{\mathrm{B}}$
2.2 Het onderzoek naar heerdgang-indicatieve toponiemen," dat in de hoofdstukken 1 tot en met 7 werd gepresenteerd en dat voornamelijk bestond uit het rubriceren en in kaart brengen, heeft aangetoond dat een verrassend hoog aantal veldnamen in het gebied van onderzoek in dit opzicht een fossiele betekenis heeft; beweiding door vee in kuddeverband moet vroeger, in tegenstelling tot nu, een belangrijke rol hebben gespeeld. Maar voor een juiste interpretatie van deze gegevens, met name voor de rol van het vee in het ontginningspoces, moeten andere hulpwetenschappen worden geconsulteerd. Deze rol is vooral weggelegd voor de oecologie. Deze tak van de biologie geeft onder andere informatie ten aanzien van vegetatieveranderingen die door weidend vee worden veroorzaakt, van de speciale rol van elke soort herbivoor, van de verschillende effecten veroorzaakt door variatie in beweidingsdruk en in de periode waarin beweiding plaats vindt enzovoort. Juist deze gegevens zijn voor een reconstructie van de ontginningsgeschiedenis van biịzonder belang. In de volgende paragraaf wordt daarom de bij̣drage van de biologie aan de ontginningsgeschiedenis apart aan de orde gesteld.

3. I De biologie heeft bijdragen geleverd aan het algemene beeld van de ontginningsgeschiedenis van het studiegebied door met name te wijzen op de effecten van beweiding door vee. Veranderingen in het areaal en de soortensamenstelling van het bos in de loop van de tijd zijn voor een belangrijk deel toe te schrijven aan activiteiten van de mens. maar vooral door diens vee.

Uit palynologisch onderzoek (de studie van subfossiel stuifmeel, bewaard gebleven in moeras- of veenafzettingen) blijkt dat na de periode van de Romeinse overheersing het areaal bos in Zuid-Limburg toenam om vervolgens weer nagenoeg te verdwijnen in de hoge middeleeuwen. Aan de hand van de pollendiagrammen kan ook worden vastge. steld, dat er na het jaar 1000 sprake is van een steeds sneller verlopende afname van boomstuifmeel ten gunste van graanstuifmeel. ${ }^{10}$ Voor een belangrijk deel zijn deze veranderingen toe te schriiven aan bosbeweiding. Recente vegetatiekundige studies betreffende de effecten van begrazing door grote herbivoren op zowel de structuur als de soor. tensamenstelling van plantengezelschappen, laten zien dat bossen door overbeweiding degraderen tot schrale graslanden." "De diversiteit aan levensvormen van deze graslanden blijkt onder andere een functie van de tijd. Dientengevolge moeten de om hun soortenrijkdom bekendstaande kalkgraslanden eeuwenlang beweid zijn geweest. Wan. neer op kalkgraslanden de beweiding wordt gestaakt, ontstaat, via een aantal cussensta. dia, een soortenarm bos. Herintroductie van beweiding brengt de oorspronkelijke en rijke soortensamenstelling van het droge schraalland terug.

Fysiologisch onderzoek naar de spijsverteringswijze van verschillende gedomesticeerde grazers leert dat varkens, runderen en schapen in dit opzicht van elkaar verschillen. Voedselstrategie en -biotoop blijken soortspecifiek: vandaar dat elke soort in het ontginningsproces een andere rol kriggt toebedeeld ${ }^{12}$ (zie figuur 8,3). De snelheid van bosdegradatie blijkr dus mede afhankelijk te zijn van de soort grazer en de begrazingsdruk. ${ }^{13}$ 

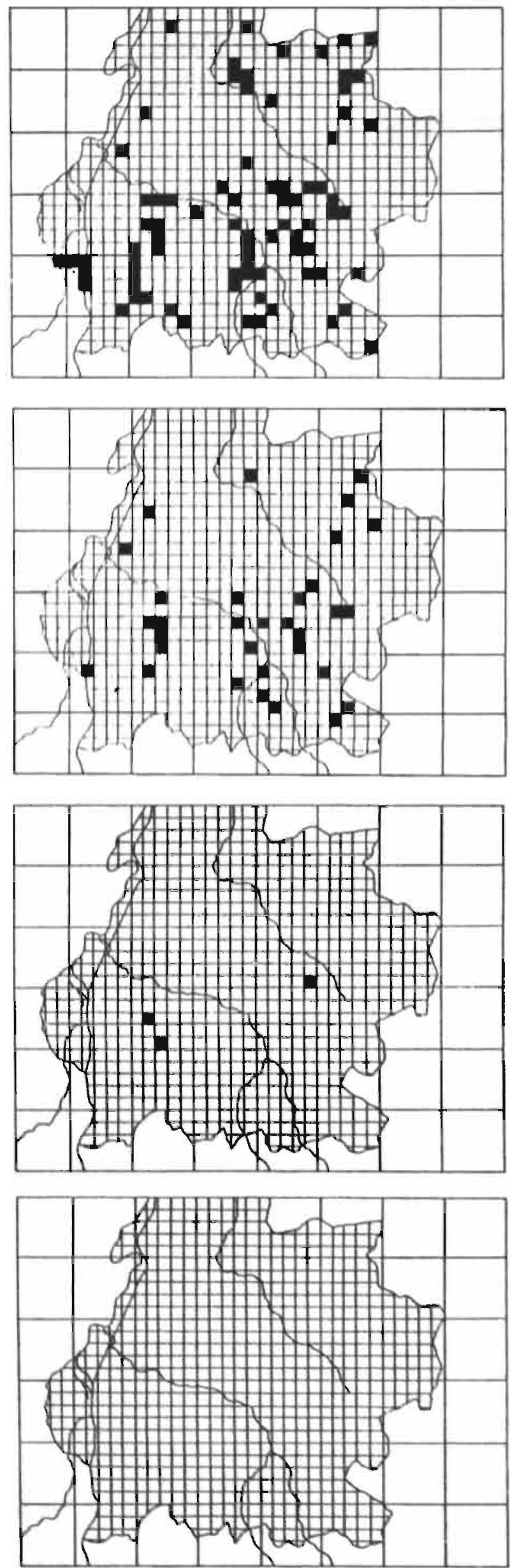

FIGUUR 8.4.

De achteruitgang van de jenevertes Juniperus communis) in Zuid-Limburg sindu 1900 naar HULEGES 1985a. Het bovenste koortje geteft het verspreidingspatroon weer in de periode 1900-1925 op basis van kilometerhokken, het daaronder stoande kaarte voor de periade 1925-1950, het volgende voor 1950-1975.
Studies betreffende de mechanismen van overleving van plantesoorten in begraasde oecosystemen vullen deze inzichten aan; bepaalde levensvormen en overlevingsstrategieën verlenen groepen plantesoorten, typerend voor beweide graslanden en struwelen, "vraatresistente" eigenschappen. " De overweldigende soortenrijkdom van deze oecosystemen is dan ook door een lange co-evolutie totstandgekomen.

Gedragsonderzoek naar de activiteiten van wilde grazers in kuddeverband laat zien, dat de kudde een dagelijkse cyclus doormaakt. gekenmerkt door vaste gedragspatronen, zoals zich verplaatsen, grazen, rusten en drinken. Bij de gedomesticeerde nakomelingen van deze runderen of schapen die in kuddeverband worden gehouden, is dit gedragspatroon weinig veranderd. ${ }^{15} \mathrm{Op}$ grond van nieuwe inzichten in de botanische oecologie zijn vegetatiereconstructies mogelijk van inmiddels geheel veranderde delen van het gebied van onderzoek op basis van historische vermeldingen van inmiddels verdwenen plantesoorten. Dank zij de opgaven van bepaalde soorten in een reeks van jaren op de Sint-Pietersberg bii Maastricht, kan een duidelijk beeld worden geschetst van de vegetatiegeschiedenis van dit gebied. Ook worden weleens plantesoorten in toponiemen genoemd, die vegetatiereconstructies mogeliik maken. Een voorbeeld is de jeneverbes (Juniperus communis), een schraallandindicator, in toponiemen voorkomend onder de naam "wrakel" of "wachelder"16 (2ie figuur 8.4).

Deze nieuwe gegevens, kunnen niet alleen de in 2.1 geschetste ontginningsgeschiedenis bevestigen, ze geven eveneens inzicht in het proces en het patroon van de ontginning van het gebied van onderzoek.

3.2 Bovendien heeft de door biologen geïntroduceerde oecologische denkwịze op historici, geografen en vele anderen invloed uitgeoefend en hen geholpen bij een meer algemene interpretatie van processen en patronen van humane occupatie. De modellen van het "Waldviehbauerntum", de "Heidewirtschaft", het "Esch-Driesch-model" en het: "concentrișch nederzettingsmodel van Von Thünen", die in de ontginningsgeschiedenis van geheel Noordwest-Europa een rol spelen, zijn in feite oecologische modellen die, zoals hieronder zal blịken, eveneens toepasbaar zijn in het gebied van onderzoek. Hieronder worden deze oecologische modellen nader toegelicht.

Het "Waldviehbauerntum"17 vertegen- 


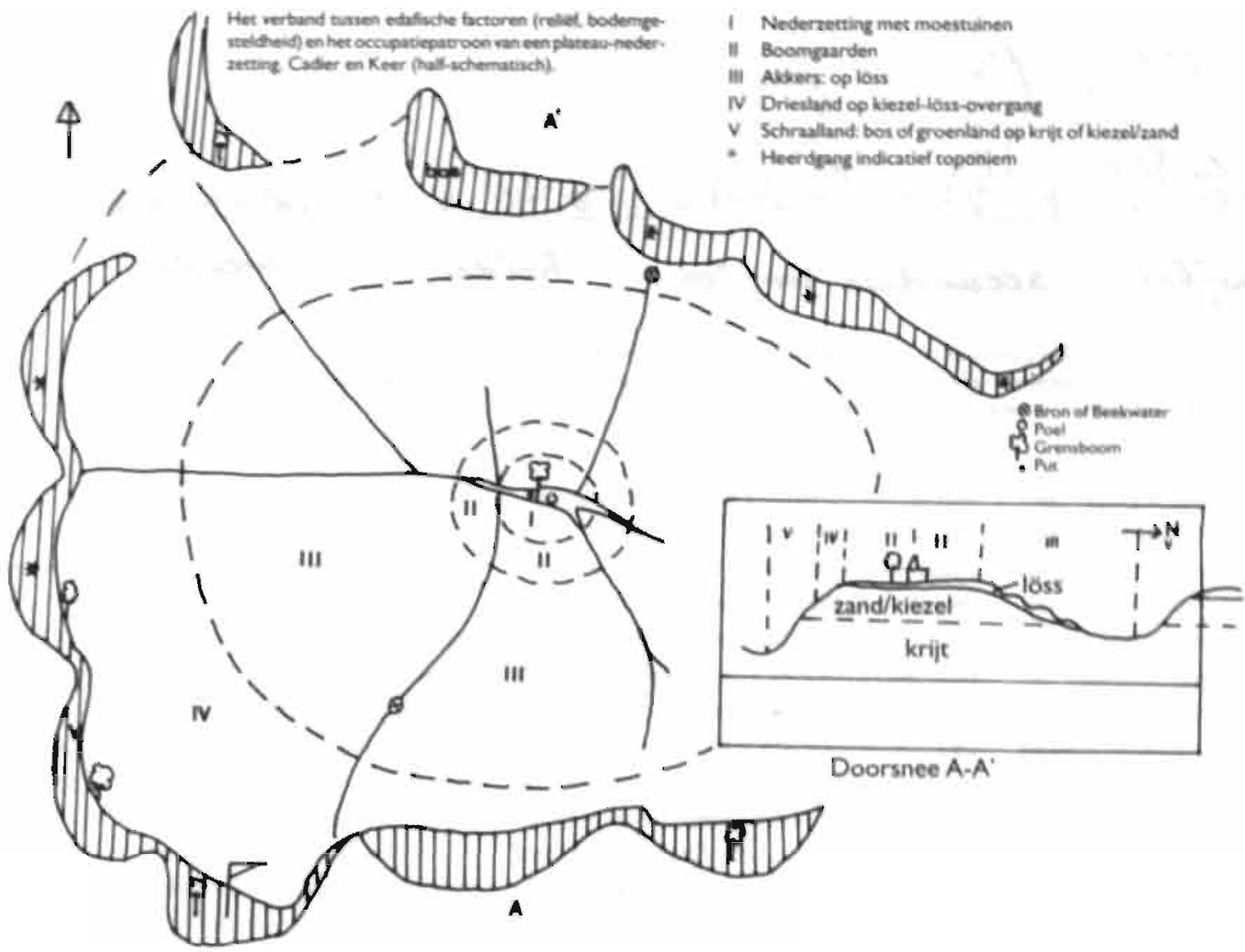

FIOUUR \&.S.

Ligging grondgebruik en nederzettingspotroan van de gemeente Codier en Keer noar onder andere de Tranchotkaart In het centrum van het vruchtbare, met lös bedekte middendeel van het plateau ligt de dorpskem, een tot een pleintye verbrede straot met een poel, beschaduwd door de dorpalinde. Vanuit het plein ontspringen wegen naar de randen van het ploteau, waor onvruchtbaarder gronden voorkomen. Hier liggen periodieke landbouwgronden: de driesen. Aan de periferie van de gemeente, gemarkeerd doer grensbomen, op de voor landbouw ongeschikte hellingen sijn droge schraallanden en bossen gelegen. woordigt een oude fase in het proces van de ontginning: het primaire bos is dan het belangrijkste leefmilieu voor de mens en zijn vee. Varkens, maar ook runderen vinden in dit biotoop vrijwel het gehele jaar door voedsel. De jacht in het bos en het verzamelen van bosprodukten zijn voor de menselijke economie van wezenlijk belang.

De "Heidewirtschaft"1" lost het "Waldviebauerntum" af. Het is gebaseerd op het droge schraalland, de degradatiefase van het bos. Schapen, maar ook runderen, passen in dit model. De mest van de kudden wordt benut om het vruchtbaarheidsniveau van het landbouwareaal op peil te houden.

In het. "Esch-Driesch-model"19 is het areaal aan bouwgrond aanzienliijk toegenomen ten koste van het schraalland. Door het, regeimatig braak laten liggen van een groot deel van het bouwland kan, dank zij onder andere groenbemesting, graan worden geteeld. In dit model bestaan de weidegronden voor de schapenkudden voornamelijk uit braakliggende akkers.

Het nederzettingsmodel, opgebouwd uit concentrische ringen met een naar de periferie toe afnemend gebruik door de mens, is in Nederland vooral bekend geworden door onderzoek naar het Drentse esdorp tijdens de vorige eeuw. ${ }^{20}$ De gradiënttheorie van
Van Leeuwen, toegepast in de vegetatiekunde, staat hiermee in verband. ${ }^{21}$

Op grond van de ligging en betekenis van toporiemen geldt dit model tevens voor een groot aantai Zuidlimburgse nederzettingen (zie figuur 8.5). Het, idee dat tijdens de ontginningsgeschiedenis de intensiteit van het gebruik der "ringen" verschuift in de richting van de periferie van het model, levert een aanzienlijke bijdrage tot het inzicht van het gehele ontginningsproces.

Biologisch onderzoek kan kennelijk zowel een aanvullende als een fundamentele rol spelen bij de interpretatie van de ontginningsgeschiedenis van Zuid-Limburg. De aanvulling heeft betrekking op de reconstructie van historische plantengezelschappen, het verklaren van bosdegradaties onder invloed van gedomesticeerd vee enzovoort. Een meer fundamentele rol komt tot uiting in de oecologische modellen van de nederzetting en de daaromheen gelegen en door de bewoners van die nederzetting beïnvioede landschappen of delen daarvan. Dit laatste aspect verdient een verdere uitwerking.

3.3 Hieronder wordt kort ingegaan op enkele thema's uit de humane oecologie. De betreffende thema's hebben enerzijds betrekking op vier biocoenosen, met name bos, heide, hooiland en bouwland, die door de mens ten behoeve van zichzelf, van zijn vee of docor zijn vee in de loop van de ontginnings. geschiẹdenis zilfn geéxploiteerd. Anderzijds hebben de thema's betrekking op een aantal technieken en methoden, dat in dezelf́de periode door de mens in deze biocoenosen werd toegepast. De bedoeling van deze schets is om aan te geveri dat de ontginningsgeschiedenis moet worden beschouwd als cen stapsgevvijs verlopend proces, waarbij de introductie van een nieuwe techniek veranderingen tot stand brengt in relatie tot de mens, diens vee en het geèxploiteerde milieu. Omdat over het wisselend gebruik voor het vee van bos, heide, hooiland en akker in de loop van de tijd nieuwe gegevens zijn verzameld, lijkt het nuttig om een overzicht te geven van de verschillende wijzen van de huma. ne exploitatie van deze vier belangrijkste delen van het landschap, die in de directe omgeving van elke nederzetting binnen het gebied van onderzoek waren gelegen.

Gedurende de yroege middeleeuwen spee!de het bos in de economie yan de toenmalige bewoner een grote rol.22 Die betekenis wordt samengevat in de termen " $W$ aldviehbauerntum" en "Wald-Weide"'. Bosbeweiding, met name door zwijnen en rundvee in kuddeverband, was regel; de jacht en het ver- 


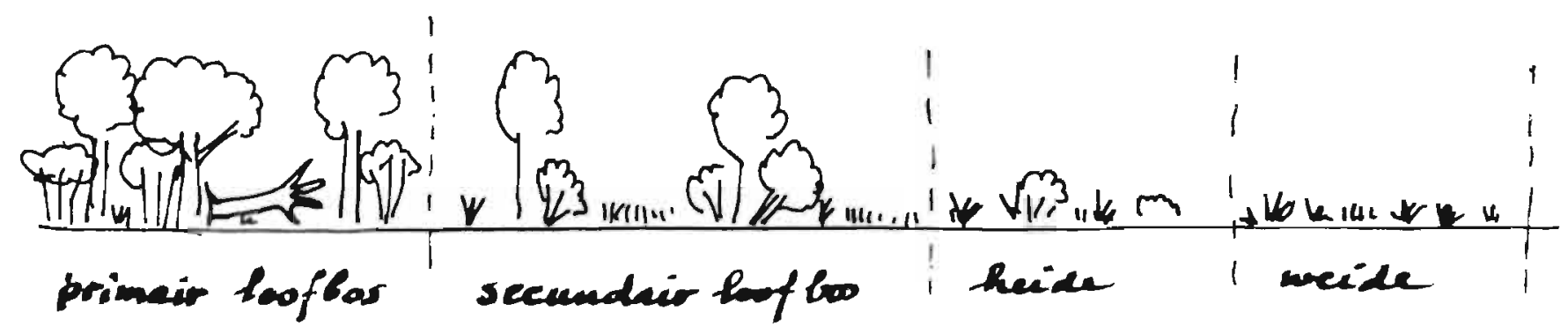

AGUUR 8.6. Degradatiestadia van primair loopas (climaxrtadium) via helde (degradatiestadium) tot weide onder invloed van bewelding. Overmatige bosbewelding door gedomesticeerde herbivoren heeft uiteindelijk de totale ofbraok van bos tot gevolg. De helde wordt door onder andere het gebrulk van mest tot weide omgezet.

zamelen van bosprodukten, afgezien van brandhout en constructiehout, speelden een belangrijke rol in de voedselvoorziening en behoefte aan kleding. Door overexploitatie gedurende het einde van de vroege en het. begin vari de hoge middeleeuwen daalde het areaal bos a anzienlijk; bewciding door gedomesticeerde herbivoren in kuddeverband en selectieve houtkap leidden tot een steeds verder gaande degradatie van het bos, waar: uit op den duur via een aantal tussenstadia uitgestrekte schraallanden (heiden) ontstonden (zie figuur 8.6). De jacht of "oogst" van dierlijk voedsel eindigde met de eliminatie van alle grote wilde herbivoren, terwijl de laatste fase van dic beheer werd afgesloten met het verbod van beweiding door gedomesticeerde grazers. Via zowel het ene als het andere proces ontstonden in de loop van de late middeleeuwen en het begin van de nieuwe tijd bossen met vrijwel uitsiuitend een hout leverende functie. Deze bossen bestonden voornamelijk uit "Niederwa!d" (hakhoutbos) en "Mittelwald" (een hakhoutbos met "overstaanders", bomen die constructiehout leverden).

Door toepassing van de "Wald-Weide"-economic, waar de reelt van varkens een belangrijke plaats inneemt, verkirigt de eik (Quercus robur an Q. petraea) een dominante positie vanwege zijn kwaliteiten als voedselpro. ducent voor de varkens, alsmede als leverancier van constructiehout voor de lokale bouwtrant ${ }^{23}$ en van looistof. De beuk (Fagus sylvatica) en de linde (onder andere Tilia cordata) nemen in aantal af door selectieve kap. vanwege hun kwaliteiten als leveranciers van respectievelijk branthout en wintervoedsel voor rundvee.

In het begin van het tweede millennium werden de plateaus plaatselijk ontginningsrijp als. gevolg van overexploitatie door beweiding en selectieve kap. Bos bleef everiwel noodzakelijk voor de lokale economie en werd bewust instandgehouden op de plateauran-. den op ruime afstand van de inmiddels gestichte nederzettingen.

Tegen her einde van de middeleeuwen resteerden nog slechts enkele bossen, waarvan het totale areaal slechts enkele procenten bedroeg van de totale oppervlakte van ZuidLimburg. Bossen werden nog aangetroffen op steile plateauranden en onvruchtbare plateaudelen. Hun functie was beperkt tot de produktie van hout. Bosbeweiding werd aan strenge regels gebonden. Deze situatie bleef voortbestaan tot diep in de negentiende eeuw. Bosbeweiding verdween geheel. Sinds de: overheid de gemeenschappelijke bossen overnam en grote oppervlakten gedegradeerde bosșen en schraallanden, de zogenaamde "woeste gronden", tot produktiebossen omvormde, werd de produktie van hout de enige functie van het bos in Zuid-Limburg. Pas na 1950 werd rekening gehouden met een recreatieve functie.

3.4 Het begrip "heide" mag geen misverstanden wekken. Daarmee wordt niet bedoeld: de in de nazomer paars gekleurde Calluna-heide, bekend van de arme zandgronden uit oostelijk en zuideliịk Nederland, ${ }^{21}$ maar wel: een droog schraalland, begroeid met een lage, soortenrijke vegetatie van kruiden, grassen en enige struikjes, waarin plaatselijk en bepaald door de zuurgraad van de bodem, Calluna vulgaris (struikheide) kon voorkomen. De heide was het gemeenschappelijk eigendom van de lokale gemeenschap, waar de kudde onder leiding van de dorpsscheper regelmatig $\mathrm{kwam}$ weiden. Ook kalkgraslanden of krijthellinggraslanden, begrippen die afkomstig zijn uit de geobotanie. stellen functionele heiden voor. Hun aanwezigheid binnen Nederland is tot een deel van Zuid-Limburg beperkt. ${ }^{25}$ Het ontstaan en het voortbestaan van dit biotoop is gekoppeld aan beweiding door grote herbivoren. Tijdens de prehistorie was het areaal heide ten opzichte van bos binnen het gebied van onderzoek te verwaarlozen, maar het nam toe naarmate de bevolkingsdruk en de daaraan gekoppelde beweidingsdruk steeg. Ook in de vroege middeleeuwen was het areaal heide nog beperkt van omvang. Daarna ging de heide het areaal bos verre overtreffen. ${ }^{26}$ De juiste omvang is moeilijk te schatten. omdat heide in de tijd en in de ruimte tussen bos en akker in staat: braak(dries)liggende akkers evolueren immers tot schraalland, terwijl bossen door overbeweiding tot heide degenereren. Kunstweiden of standweiden, zoals we die nu kennen, bestonden destijds niet.

Vermoedeliik heeft het heide-areaal zijn grootste omivang gekend tijudensi en vlak na de laatste fase van de middeleeuwen; grote delen van de plateaus, met narne langs de randen daarvan, moeten tussen 1450 en 1700 ermee bedekt zijn geweest. Pas vanaf 1800 kan, op basis van kaartmateriaal, een nauwkeuriger beeld van de omivang van het heideareaal worden geschetst: diverse plateaudelen en andere, relatief onvruchtbare gebie-derı waren er nog door bedekt, zoals de uitgestrakte Graethei (zie figuur 8.7) en de heide van Echt en Brunssum, maat ook aan de randen van de vruchtbare plateaus heeft elke gemeente dan nog zijn eigen heide met een beperkte omvang. De langzame opruiming van het gemeenschappelijk bezit, formeel eindigend met de introductie van de Franse wetgeving, heeft ertoe bijgedragen dat de resterende gemene schraallanden langzaam maar zeker werden geprivatiseerd of aan de overheid toevielen, die deze. "woeste" gronden vaak in produktiebossen omzette. De overgebleven snippers, ongemeen rijk aan flora en fauna, raakten pas in de tweede helft van deze eeuw in handen van natuurterrein beherende instanties. Ze werden toen tot natuurreservaten verklaard. Door het uitblijven van beweiding (het traditionele beheer door middel van schapenkudden was inmiddels gestaakt), veranderde zowel de struc- 


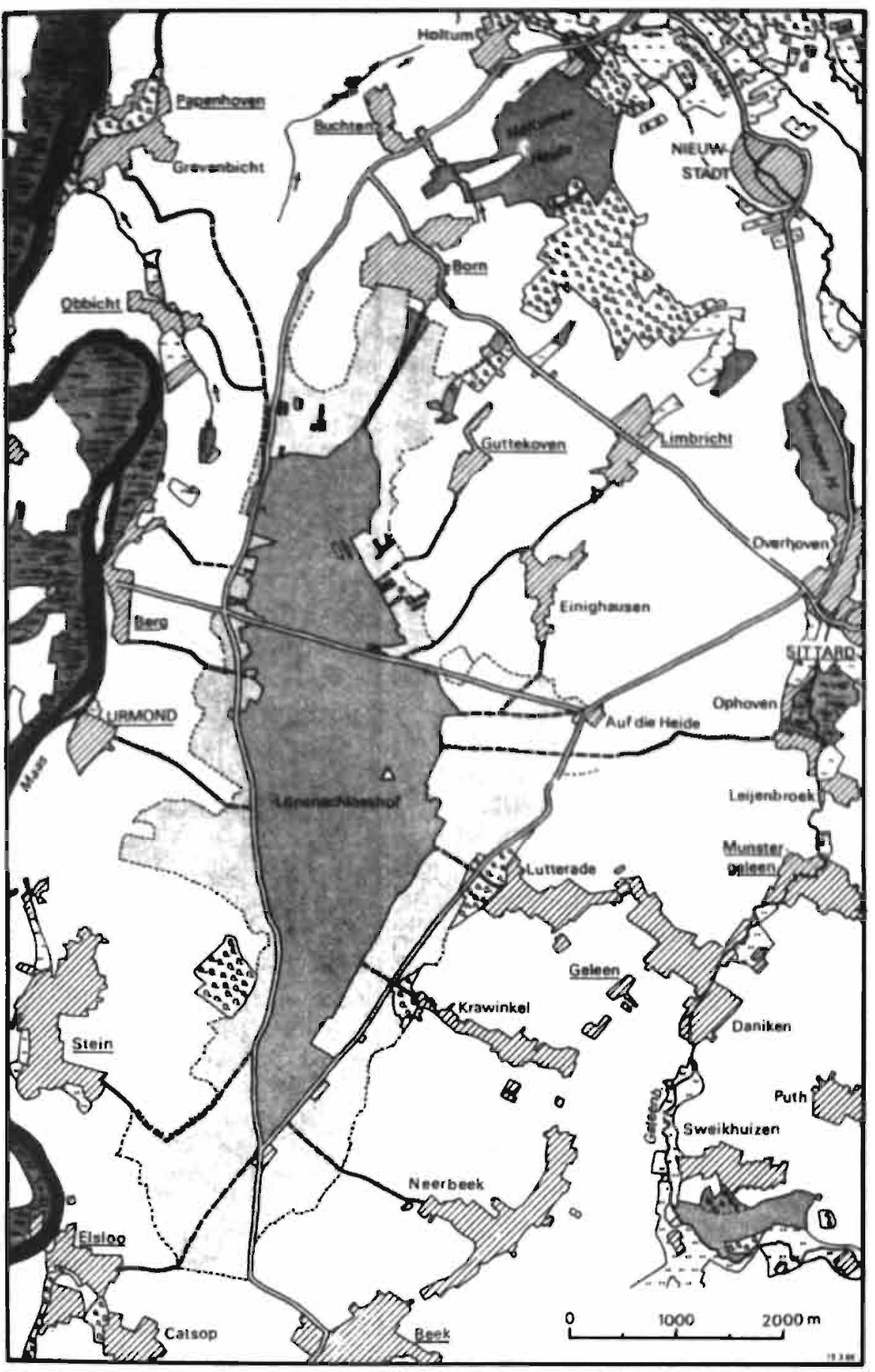

FIGUUR 8.7. Het plateau van de Graetheide in 1800 noar KaINGs 1976. De kaart geeft op cen xeer illustratieve wijxe het belang van de heerdgang weer voor de ontginningsgeschiedenis. Vanuit de amringende dorpen vertrekt telkens een heerdgongroute naar het centroal gelegen weidegebied. Tevens is duidelijk te zien dat het heideoreal in de loop van de achttiende eeuw is

tuur als de soortensamenstelling van de heidevegetaties, maar door herintroductie van de periodieke begrazing vanaf 1980 kon de oorspronkelijke vegetatie van de tot natuurmonumenten verklaarde heiderestanten weer worden gerestaureerd.

De rond midzomer gemaaide, kruidenrijke graslanden op vochtige dalbodems ontstonden kort na de ontginning van de beekdalen. Dalbodems zijn vruchtbaar, niet alleen door hun gunstige vochthuishouding, maar ook omdat het achtergebleven slib na de winteroverstroming als natuurliike meststof fungeert. Hun produkt, het hooi, vormde het wintervoedsel voor het vee. Hooi was essentieel in de agrarische bedrijfsvoering van de nederzettingen in de stroomdalen, aangezien hierdoor werd bepaald hoeveel stuks vee kon overwinteren. ${ }^{27}$ Het areaal hooiland, waarin overigens ook nabeweiding plaats grasland, gemeenschappelijk gebruikt

Weide

ontginningen uit de $18 \mathrm{e}$ eeuw

Tes landweer (voormalige grens van het cultuurland)

-.. veẹdrift

bouwland

$\because \because$ grasland. individueel gebruikt

$\therefore$ bos

nederzetting (ind. tuinen en huisweiden)

belangrijke weg

vond, in de toponymie van Zuid-Limburg bekend onder de namen "beemd", "broek". "pas" of "breul"," was rond de stroomdalnederzettingen relatief groot. De verst van de stroomdalnederzetting gelegen vochtige graslanden werden uitsluitend beweid.

Vanaf de vroege middeleeuwen tot aan het einde van de vorige eeuw vormden de hootlanden vooir de boeren in de dalen een gewaar deerd bezit, waaraan plotseling een einde kwam door de introductie van kunstmest. Ook de niet door het rivierslitı bemeste graslanden konden sinds diẹ wintervoẹdsel produceren. Devoormalige hooilanderi werden omgezet in standweiden, populierplantages of, na drainage, in bouwland.

Op de plateaus ontbrak het hooiland nagenoegals gevolg van de afwezigheid van oppervlaktewater en de grote waterdoorlatendheid van het plateausubstraat. Tijdens de beginfase van de plateaukolonisatie kon het vee in de winter nog genoeg roedsel vinden in de bossen, op de uitgestrekte heidevelden en braakliggende akkers. Naarmate bossen, heidevelden en drieslanden in de hoge middeleeuwen verdwenen, moest het areaal bouwland het winteryoedsel leveren voor het vee, aanvankelijk door weidegang in kuddeverband op stoppelakkers en driesgronden, later in de vorm van braakgewassen en andere landbouwprodukten: die op stal werden gevoerd.

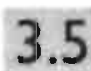

Geen enkel biotoop heeft zich in de loop van de Zuidlimburgse geschiedenis zo sterk gewijzigd wat betreft ligging, areaal. 
FGUUR 8.8.

De ploeeaus von ZuldLimburg noar RENES

1988. De meerte plateaus xijn genoemd noar de belangrijkste doarop gelejen nederzetting.

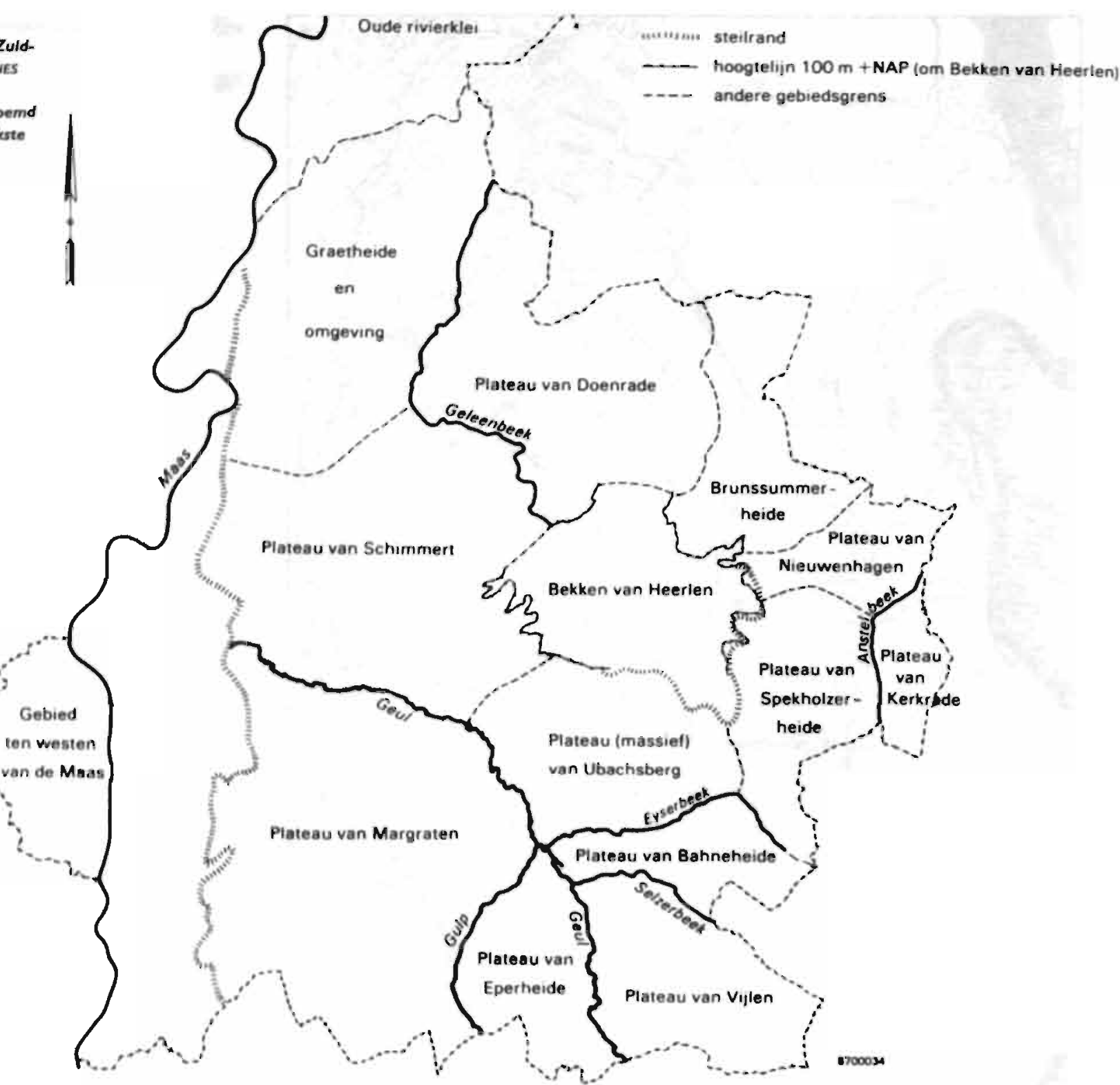

socrtensamenstelling en wijzen yan bewer. king als de akker. Over de prehistorische graanakkerįes van de eerste boeren. de Bandkeramiekers, is veel bekend: het waren door "Brandrodung" ontstane, in het bos: gelegen, uiterst kleinschalige perceeltjes met een polycultuur van diverse granen en andere broodgewassen. Zelfs de onkruidflora van deze bosakkerties, is bekend. $\mathrm{Na}$ uitputting. bleven ze in gebruik als weidegrond. ${ }^{29}$

Grootschaliger yan omvang was de landbouw en veeteelt van de Romeinse "villae", die, zo wordt aangenomen, tevens produ. ceerden yoor de grens, bewakende legioenen. ${ }^{30}$ Hun landbouwgronden lagen voorall op de zacht glooiende hellingdelen buiten het overstromingsbereik van de rivier. Mogelijk. hebben de Romeinen graansoorten en varieteiten (en de daarbijbehorende onkruiden) vanuit het zuiden geïmporteerd.
Tijdens de vierde eeuw nam het areaal bouw. land sterk af als gevolg van de successievelijke verwoesting van de Romeinse villae, om pas weer in de laat-Merovingische en vroeg. Karolingische periode opnieuw toe te nemen. Daarna volgde een nieuwe breuk. Pas in de tiende en elfde eeuw ontstonden op diverse plateaus nederzettingen, waaromheen aanvankelijk kleine, later grotere akkercomplexen waren gelegen. Slechts voor een deel van Zuid-Limburg is het proces van de toename van het akkerareaal in grote lijnen bekend. ${ }^{31}$ Tot ver na de middeleeuwen bleef de akkerbouw een roterend systeem, waarin de braak hier en daar aanvankeliịk misschien zelfs de helft van het areaal landbouw. grond besloeg, In de nieuwe tijd werd, tijdens. een proces van minstens twee eeuwen, de wilde braak verkort en vervolgens gecultiveerd, onder andere door de introductie van zogenaamde braakgewassen. De braak verdween definitief in de loop van de negentiende eeuw. Geleidelijk aan voltrok zich ook een verschuiving in het teeltplan en de geteelde gewassen. Vanaf het einde van de zeventiende eeuw verloren menggranen, peulvruchten en spelt aan betekenis ten gunste van tarwe. rogge en gerst.

De eerste voldoende gedetailleerde topografische kaarten, daterend rond 1800 , schijnen tevens een beeld te geven van een al drie. tot vier eeuwen bestaande situatie: meer dan $70 \%$ van Zuid-Limburg werd ingenomen door landbouwgronden, die voornamelijk granen opleverden. Pas in de twintigste eeuw werd dit beeld grondig gewijzigd. ${ }^{22}$

De hierboven aangeduide landschapseenheden bos, heide, hooiland en akker zijn voor de huidige waarnemer scherp begrensde ve. getatietypen met een verschillend gebruik. In 
het verleden was dat zeker anders. Zowel in de tijd als in de ruimte bestonden er tussen deze vegetatietypen allerlei overgangen. Tussen bos en heide bestonden gradiénten met verspreide boomgroei en struweel van houtige soorten. Tussen heide en akker lagen de meerdere jaren braakliggende driesgronden, die eventueel met loofhout konden worden beplant en tot een hakhoutbos uitgroeiden. $\mathrm{Na}$ een drainage konden hooilanden worden omgezet in akkers of, door niet meer te hooien, in broekbossen veranderen. In de ruimte bepaalde de beweidingsdruk de structuur van een houtige vegetatie: een geringe druk levert een loofhoutbos, een iets hogere druk een dwergheestergemeenschap.

3.6 De economie van het rurale ZuidLimburg is zeker vanaf de middeleeuwen en zeer warschijnlijk vanaf de prehistorie tot in de tweede helft van deze eeuw een agro-pastorale geweest: landbouw en veeteelt waren nauw verweven. Elk agrarisch bedrijf was per definitie een gemengd bedrijf.

In verband met de rol van het vee tijdens de ontginningsgeschiedenis van het gebied moet op een aancal facetten van de veeteelt wor. den gewezen. Op de eerste plaats werd he: vee destijds in kuddeverband gehouden. Onder leiding van de sween, heert en scheper, specifieke namen voor de hoeders van varkens, runderen en schapen, zwierven de kudden dagelijks door de "gerneynte". ${ }^{33}$ Afhankeliịk van plaats en tijd verdwenen deze dorpsfunctionarissen geleidelijk vit het Zuidlimburgse landschap. Daarnaast moet worden vermeld, dat begrazing door vee in kuddeverband op den duur bepaalde delen van het dorpsterritoir "rijp" maakte voor de ploeg. Voor Zuid-Limburg gold, dac beweiding van de plateaus vooraf ging aan de ontginning daarvan tot landbouwgrond. Voorts bezat elke soort herbivoor karakteristieke. weideplaatsen: varkens prefereerden bossen en moerassen, schapen droge, grazige en kruidige vegetaties en rundvee gedijde zowel in de genoemde biotopen, maar vooral in vochtige graslanden. Bovendien was de beweidingsdruk bepalend yoor de snelheid, waarmee plantengezelschappen konden veranderen wat betreft structuur en soortensamenstelling; bossen degradeerden door een voortdurende beweiding, via een aantal tussenstadia, tot heiden.

Tenslotte moet nog worden gewezen op een belangrijk bijprodukt van de veeteelt; mest en urine, vastgehouden en vermengd met stro en opgespaard in de potstal, leverden een belangrijke bijdrage aan de produktiviteit van het landbouwareaal. In verband met de transportproblemen van stalmest kon de potstal pas optimaal worden gebruikt na de introductie van de mestkar, een technisch geavanceerd vervoermiddel. Voordien is mogelijk gebruikgemaakt van het recht van valte, waarbij de dorpskudde 's nachts binnen een perk op een bepaald perceel verbleef. Elke volgende nache werd een ander perceel bemest.

3.7 Naast de biologie leveren ethnologie en archeologie inzicht in het proces van de ontginningsgeschiedenis van Zuid-Limburg. Dit geldt met name voor de technische hulpmiddelen van de ontginner, die door samenlevingen eiders in de wereld worden gebruikt of die, welke als bodemvondst uit het gebied van onderzoek bekend zijn. Tijdens een bepaalde fase in de prehistorie werd landbouw bedreven met pootstok en hak; de ploeg is in zijn meest elementaire vorm een combinatie daarvan, die wordt voortbewogen door een trekdier. Met een dergelijke primitieve ploeg, het eergetouw, voorzien van een houten, stenen of metalen punt en voortbewogen door een span trekdieren. konden slechts percelen met een beperkte omvang en een min of meer vierkante vorm worden bewerkt. Bovendien moest diagonaalsgewijs worden geploegd, omdat het eergetouw de aarde niet omkeert. ${ }^{34}$ Een belangrijke vernieuwing vormden daarom het keerbord aan de ploeg en de haam voor het trekpaard. Pas na de introductie daarvan, tussen de achtste en tiende eeuw, ontstonden de zogenaamde langakkers en konden grotere percelen worden geploegd. De snelheid van ploegen werd vooral door paardentractie gunstig beìnvloed. ${ }^{35}$ Ossen en zelfs koeien voor ploeg of kar bleven echter incidenteel in gebruik tot in het begin van de twintigste eeuw.

De zware mestkar, geschike voor het transport van mest, is een post-middeleeuwse constructie. De natuurliịke groenbemesting van de braak kon nu vervallen. ${ }^{36}$ Het gebruik van vuur als ontginnings- en bemestingsmethode geraakte in onbruik. ${ }^{37}$

Het materiaal (vuursteen of metaal) en de vorm van het oogstgereedschap (oogstmes. sikkel en zicht) had belangrijke gevolgen voor bijvoorbeeld het na de oogst resterende deel van het gewas en de stoppelbeweiding. $\mathrm{Na}$ een sikkeloogst kwam ongeveer twee derde deel van de biomassa van het gewas op de akker ten goede aan de begrazer, na een oogst met behulp van cen zicht nauwelijks een derde. ${ }^{\text {aa }}$

4.1 Topografische kaarten. ${ }^{39}$ chronologisch gerangschikt en in voldoende mate gedecailleerd, geven veel informatie inzake patronen en processen van ontginning. De oudste, bruikbare serie overzichtskaarten van het gebied dateert echter uit het begin van de negentiende eeuw, een moment waarop de ontginningsfase van het gebied allang voorbij was. Uit vroegere perioden is wel kaartmateriaal voorhanden, bijvoorbeeld de Ferrariskaarten daterend uit het einde van de achttiende eeuw, maar zil geven slechts delen van het gebied weer.

Toch schijnt de eerder genoemde kaartenserie door Tranchot-Von Muffling een beeld te geven van de laat-middeleeuwse situatie in Zuid-Limburg; voornamelijk op grond van deze kaart kon Krings een beeld schetsen van de veranderingen in het landgebruik van de Graethei. ${ }^{40}$ een plateauheide. gelegen tussen de Maas en de Geleenbeek. Ook van de Mein. weg. een andere heide in het gebied van onderzoek, zijn inmiddels veel historische gegevens bekend.

Geologische, geomorfologische en pedologische kaarten, totstandgekomen in de tweede helft van deze eeuw. geven uitvoerige informatie: inzake bodem en terreingesteldheid. Gekoppeld aan de huidige kennis inzake bodemvruchtbaarheid en andere agrarisch-economische kwaliteiten van de op hun legenda's voorkomende eenheden, vormen deze kaarten huipmiddelen bij de reconstructie van het voormalig agrarisch gebruik van de gronden. Op deze wijze kon bijvoor. beeld een heidetypologie worden opgesteld aan de hand van geologische en toponymische gegevens. 4

Bodemkundig onderzoek heeft geleerd dat het bodemgebruik, bijvoorbeeld als grasland, van invioed is op de structuur van het bodem. profiel. De aanwezigheid van een bepaalde inspoelingslaag indiceert langduriggebruik als grasland. Op deze wijze zouden ook voormalige schrallandboderns in kaart moeten worden gebracht, hetgeen plaatselijk is gebeurd. ${ }^{12}$ Geomorfologische kaarten brengen niet-natuurlijke (of tevens door agrarisch gebruik gevormde) terreinoneffenheden in beeld, zoals graften, landweren, poelen, groeven en holle wegen. Ook mag men veronderstellen, dat de aanwezige droogdalen of "grubben", die vanuit de stroomdalen langzaam omhoogstiigen naar de plateaus, hun holle vorm tevens te danken hebben aan ero- 
sie, veroorzaakt door de dagelijkse heerdgang en het transport van goederen. Waarschijnlijk functioneerden ze tijdens de occupatie van het achterland als "ontginningsassen" of "ontginningsrichtingen"., "s Ook ligt het voor de hand te veronderstellen dat de komvormige depressies, die het begin van een droogdal op het plateau markeren, als "natuurlijke" regenwaterbekkens ${ }^{4}$ fungeer. den, die tevens ideale drenkplaatsen waren voor de kudde. Zeer waarschijnilijk ontstond hier vlakbij de nederzetting.

\subsection{Het bovenstaande gegeven sluit} aan bij de studie van nederzettingsvormen. een thema uit de historische geografie. Recent onderzoek heeft aannemelijk kunnen maken, dat er binnen het beschreven gebied minstens twee typen van agrarische nederzettingen bestaan, namelijk straatdorpen en brinkdorpen (= dries- of maardorpen). ${ }^{45}$

Straatdorpen zịn in stroomdalen gesitueerd. De straat loopt parallel aan de beek of rivier. Ze dateren uit de vroege middeleeuwen en bezitten vaak een kerkje van Romaanse oorsprong en meestal cen versterking, die later uitgroeide tot een burcht. Een centraal gelegen plein met een drinkpoel ontbreekc. De drenk ligt aan het stromende water:

Brinkdorpen liggen op de aan oppervlaktewater arme p!ateaus, meestal aan de rand daarvan en bezitten eén of enkele pleinties (dries, plats, plei of bies $(t)$ genoemd) met daaraan een poel (drenk, maar, pool of koel genoemd), een dorpsput en een kapel of kerkje van hoogstens gotische oorsprong. ${ }^{46}$ Het pleintije fungeerde onder andere als verzamelplaats voor de dorpskudde." "Brinkdorpen missen een versterking. Rode-nederzettinger zijn typische brinkdorpen. ${ }^{\text {II }}$

Door middel van retrogressief onderzoek van kadastrale data, een onderwerp uit de sociale geografie, heeft Hartmann ${ }^{19}$ onlangs de ontginningsgeschiedenis van een deel van Zuid-Limburg kunnen ontrafelen. Het westelijk deel van het plateau van Margraten blijkt tijdens de elfde en twaalfde eeuw te zijn gekoloniseerd vanuit nederzettingen in het Maasdal. In detail is bekend dat de nederzetting Breusterbos door zeven kolonisten, afkomstig uit Breust, in 1157 is gesticht. Oorspronkelijk vertoonde Breusterbos een oast-west-orièntatie met cen dorpspoel op een langwerpig pleintie, de huidige Maarstraat. Vermoedelijk geldt dit principe ook voor andere nederzettingen op het plateau. die zich in de loop van de dertiende en veertiende eeuw verdichtten en uitgroeiden.
Kadastrale kaarten speelden ook een rol in het onderzoek van Renes; bepaalde perceelscheidingen met een lang verloop en een richting haaks op de ontginningsas worden door Renes ${ }^{50}$ beschouwd als de oorspronkelijke begrenzing van het ontgonnen kavel. Een reeks van dergelijke naast elkaar gelegen kavels yormde een "Waldhufe"-nederzetting, die in een later stadium kon evolueren tot een brinkdorp.

De historische geografie leverde een wezenlịke bijdrage aan de huidige kennis inzake de ontginningsgeschiedenis van Zuid-Limburg. Alleen al op basis van topografische kaarten kon de ontginningsgeschiedenis van enkele plateaus worden gereconstrueerd. Voor een ander plateau kon dit mede gebeuren aan de hand van kadastrale gegevens. De resultaten van het onderzoek naar nederzettingsvormen onderstrepen de verschillen tussen de stroomdalnederzettingen enerzijds en die op de plateaus anderzijds. Tussen beide nederzettingsvormen blipken "genetische" betrekkingen te bestaan.

5. I In het voorafgaande is aannemelijk gemaakt, dat de ontginningsgeschiedenis van Zuid-Limburg een proces is geweest, dat primair was gekoppeld aan het geomorfologisch patroon van dit gebied, dat in wezen is opgebouwd uit dalen met permanent stromend water en plateaus zonder oppervlaktewater (zie figuur 8.1). Aanvankelijk werden de rivier-en beekdalen gekoloniseerd en vervolgens gebeurde dat ook met de plateaus vanuit de dainederzettingen. Het staat vast dat grote delen van de dalen al tijdens de Romeinse periode in cultuur waren gebracht door mensengroepen, die nederzettingen bewoonden die nu nog bestaan. Door achtereenvolgende bevolkingstoenamen gedurende de middeleeuwen werd men gedwongen nieuwe nederzettingen te stichten op de plateaus, waar inmiddels door beweiding en selectieve kap de aanwezige bossen sterk waren gedegradeerd. Het areaal bouwland breidde zich sterk uit ten opzichte van het areaal schraalland. Een minimum aan bos. bleef bestaan op hellingen en andere delen van het gebied, die voor landbouw ongeschikt waren. Voor de meeste plateaus was. dit proces tegen het einde van de middeleeuwen een feit. Daarna ontstonden hoogstens. nog enige kleine heidenederzettingen. De. serie tekeningen in figuur 8.1 geven hiervan een gedetailleerder beeld.

Het hierboven geschetste globale ontginningsverloop betekent geenszins, dat dit pro- ces zich overal in dit gebied gelijktijdig en met dezelfde snelheid voltrok. Integendeel, elk plateau en elk dal kent zijn eigen, specifieke ontginningsperiode, zijn eigen tempo en zijn eigen ontginners (zie figuur 8.8 ). Van slechts enkele plateaus of plateaudelen zijn deze gegevens in grote lijnen bekend en in het onderstaande worden deze kort samengevat.

5.2 De ontginningsgeschiedenis van het plateau van de Graethei, gelegen tussen de Maas, Geleen- en Keutelbeek is globaal opgehelderd; vanuit de nederzettingen in de stroomdalen werd dit vruchtbare gebied. aanvankelijk een uitgestrekt bos, dat het bos van de Graet werd genoemd, door overbeweiding in de Graetheide veranderd, kort na 1800 verdeeld en vervolgens ontgonnen. De door $\mathrm{Krings}^{\mathrm{51}}{ }^{\mathrm{g}}$ gereconstrueerde heerdgangwegen lopen vanuit de op beweiding en andere exploitatievormen rechthebbende 14 kerspelen, die in de stroomdalen zijn gelegen, straalsgewijs richting centrum van de Graethei. Dat dit gebied niet eerder dan vóór de negentiencle eeuw werd ontgonnen, is waarschijnlijk het gevolg van het, feit dat de rechthebbende 14 kerspelen gezamenlijke exploitatierechten bezaten, maar niet tot verdeling: mochten overgaan (zie figulur 8.7). Het kaartbeeld van de Graetheide uit het begin van de vorige eeuw vertegenwoordigt fase $C$ van figuur 8.1.

Het direct ten zuiden van de Graethei gelegen deel vars het centrale plateau werd veel eerder dan I 800 ontgonnen. Een belangrijke rol hierin speelde waarschijnlijk de proostdij van Meerssen in het dal van de Geul, van waaruit een aantal Frankische heem-nederzettingen plateauwaarts werden gesticht: en vervolgens (na 1000) een aantal rade-nederzettingen op het plateau. In het oosten liggen op. het plateau een aantal hout-nederzettingen, die aansluiten bij het in de zeventiende eeuw deels gekapte Ravensbos, waarvan een restant tot op heden is overgebleven. "Heide"-toponiemen liggen op en aan de rand van het plateau, ver van nederzettingen verwijderd.

5.3 Het, westelijk deel van het plateau van Margraten werd vanuit het Maasdal ontgonnen. ${ }^{52}$ Er bestaan moeder-dochter-relaties tussen Heer en Cadier, Gronsveld en Eckelrade, Eijsden en Sint-Geertrudisrade (= Sint-Geertruid), Breust en Breusterbos. Het oostelijk deel werd vanuit het Geul- en Gulpdal gekoloniseerd. Er bestaan eveneens relaties tussen Wijlre, 't Rooth en 't Reutie, Gut- 
pen en drie maar-nederzettingen op het plateau. Gulpen en Reijmerstok. In het zuidelijk deel van het plateau zijn er eveneens relaties tussen moederdorpen in het dal van de Voer en dochternederzettingen op het plateau. ${ }^{33}$ Nadat het vruchtbare middendeel van dit plateau tijdens de middeleeuwen was ontgonnen, verschoof het areaal heide en bos naar de minder vruchtbare randen. Hier liggen alrijke heide-toponiemen. De nog aanwezige hellingbossen schijnen zeer oud te zijn. Op het plateau liggen twee zeer oude nederzettingen: Honthem en Weisden, mogelijk gesticht voor 1000 . Zij zijn gesitueerd op plaatsen, waar ook nu nog stromend water voor. komt, hetgeen elders op het plateau niet het geval is.

Het onvruchtbare plateau van Eperheide werd warschijnlijk laat ontgonnen; alleen in het noordelijk deel komt een "heem"-toponiem voor, dat vóor 1000 vanuit Gulpen is gesticht. Er is een moeder-dochter-relatie tussen Gulpen en Landsrade, Slenaken en Heijenrath en tussen Epen en Eperheide. In het begin van de negentiende eeuw waren nog grote delen van het plateau en de hellingen met bos en heide bedekt. Daarvan resteren momenteel alleen hellingbossen. Het kaartbeeld van dit plateau uit het begin van de vorige eeuw komt overeen met fase $C$ van figuur 8. I: dat van het plateau van Vijlen met fase $A$.

Het laatstgenoemde, eveneens onvruchtbare plateau met centraal daarop de "Villener Boesj", het gemeenschappelijk eigendom van de "Zeven Rotten", kleine nederzettingen die als een krans rond Vijlen liggen, bleef tot aan het begin van de twintigste eeuw een complex van bossen en heiden, waarop de bewoners van de zeven rotten exploitatierechten bezaten. ${ }^{3 t}$ Tot ongeveer 1900 werd in dic boscomplex nog een extensieve beweiding door runderen toegepast.

\section{4}

Het kleine plateau van Bahneheide en Bochholtz werd in de twaalfde eeuw vanvit Simpelveld ontgonnen. ${ }^{5.3} \mathrm{Pas}$ in de late twaalfde eeuw nam de bewoning op Bahneheide toe tot het niveau van een gehucht. Rond 1800 lagen er nog enkele heidevelden in de omgeving van de ontginningsnederzettingen Bahneheide en Bochholtzerheide, waarvan de plattegronden het klassieke patroon van een ontginningsnederzetting hebben bewaard.

De ontginningsgeschiedenis van het sterk geaccidenteerde plateau van Ubachsberg is onduidelijk. Aan de randen liggen diverse rode-nederzettingen. De hoogste en tevens meest onvruchtbare delen van het plateau droegen tot in de negentiende eeuw een heidevegetatie. De nederzettingen op het plateau kenmerken zich door een wezenlijk andere plattegrond dan die uit het stroomdal van de Eyserbeek. De eerstgenoemde zijn brink-, de andere straatdorpen. ${ }^{36}$

Het naar verhouding zeer kleine plateau van Rode is een klassiek voorbeeld van een middeleeuwse ontginning. geìnitieerd door een kloostergemeenschap, waarover veel historische details bekend zijn. 3 ? Op het plateau liggen verschillende rode-nederzettingen. Rond 1800 lagen ook daar nog enige bossen en heiderestanten.

De lage kom in het landschap ten noorden van de lijn. Voerendaal-Klimmen mag niet als een plateau worden beschouwd. In dit laaggelegen gebied, waarin diverse beken stromen, ontbreken rode- en hout-namen.

Het ten opzichte van de rest van Zuid-Lim* burg laaggelegen en langgerekte plateau tussen de Geleen- en de Rode Beek wijkt sterk af van de eerder besproken plateaus. ${ }^{\text {sh }}$ Toch liggen er diverse rode- en hout-toponiemen. De nederzetting Raath zou op grond van de simplexvorm en de centrale ligging op dit plateau tot de oudste ontginningsnederzettingen kunnen behoren. De boorden van de Rode Beek waren tot diep in de negentiende eeuw omzoomd met uitgestrekte moerassige en venige graslanden. Van hieruit lopen heerdgangroutes naar de nederzettingen op de hoge oever van het dal.

\subsection{Heerdgang heeft een rol van door-} slaggevende betekenis gespeeld in het totscandkomen van het huidige landschap van het onderzoeksgebied. Uitgaande van een schaarse bewoning in de beekdalen tijdens de. vroege middeleeuwen, degradeerden de bossen op de plateaus en aan de randen daarvan tot droge schraallanden, die op hun beurt tot bouwland werden omgezet. Hier en daar. met name op de randen van de plateaus, bleef bos gespaard. Tegelijkertijd veranderen de dorpskudden van soortensamenstelling en omvang. De gemeenschappelijke heerdgang maakte tussen 1850 en 1950 plaats voor beweiding in private standweiden. Desondanks laat zich vaststellen dat het proces van ontginning per plateau telkens een ander verloop kent. Heerdgang bepaalde eveneens het patroon en de soortensamenstelling van de concentrisch rond de nederzetting gelegen vegetatieringen binnen de gemeente. Het model van het Drentse: esdorp geldt ook voor Zuid-Limburg.

Tenslotte bepaalde de heerdgang het patroon van de nederzetting, heţeen blijkt uit de resultaten van een studie naar de betekenis van gelokaliseerde toponiemen binnen hun geomorfologische en landschaps-oecologische context.

\section{NOTEN}

Hee Landachap van Zund-Limburg 1987, p. 85

2 Bures 1987 en De Groome IN Vrawus 1984, pp. 66-67.

3 RENEs 1988, p. 61 en rolgende

Tumens 1962

NoTtEN I985.

BLOK 1979, p. 132 en volgende

HAMTMUNa 1996, p. 173 en volgende.

Renes 1988. p. 107.

9 Zie hoofdstuk 2.

10 JANGS 1960

11 Huncres 1989 b

12. Hitucens 1983b

13 HiLcocos 1990

1) VAN DutvinvoOnde 1994

15 Vea 19a8. pp 110-132

16. Huscans 19a5a.

17 Venvort 1987'

1月. De Smot 1981 en Vavioet 1987

19. Ditmanen 1960 en Vinvoer 1987

20 De SMOI 198 !

21 VAN LIEUWWEN 1965

22. EUENaERG !982, pp. 73-379, BrCHMANN 1984, JaNSEN EN VAN DE WESTERINGH 1983 en BUIS 1985

23. HILIEGERS 1987

21 DE SMIOT 1981

25. WILEMS 1987

26. DE SMIOT 1981.

27. Pruns 1988

28i Zie hoołdstuk 2

29 BAKES 1987 . pp. 58-71.

30 WILEMS 1987

3) HARTMANN 1986

32 PHitups et al 1964, pp. 76-77

33 BeHETS 1975

34 ENINEN EN JANSSEN 1979, p. 32.

35 ENINEN EN JANSSEN 1979, PD. 133-134

36. Zie hoofdscuk 7.

37 BECHIMNN 1984, pp. $72-74$

38. ENINEN EN JANSSEN 1979, pp. 33 en 157

39 Zie List van kaarter:

40. KRINGs 1976, pp. I en 90-91.

41 HuLeEERS 1980.

12 HilleGers 19842.

43 RENES 1988, $p$ 70

11 Hendelux 1984 en Her Landschap van Zuid-Limburg 1987, p. 30

45 RENES 1988, p. 55 en SimONus 1975, pp. 65-69.

16. RENES 1988 , pp. $54-59$ en $85-90$ en Curpens 1976

47. HeKkeR et al. 1981 en RENES 1988, p. 88

18 Het Landschap van Zuid-Limburg 1987, p. 30 en RENES. 1988 , pp. $88-90$

(19) HaRtManin 1986

50 RENES 1988, pp. $81-84$

51 Kanics 1976

52 HARTMANH 1986, p. 173 en volgende.

53 ReNuES 1988, p. 71 .

54 JANSSEN DE LUMPENS 1976

55. FrañSSEN 1970

56 RENES, 1988, p, 67

57 SCHRUNEMAXES 19846

58 RENES 1988, pp. 65.66 


\title{
SCHRAALLANDEN, VOORMALIGE FUNCTIES EN HUIDIGE BEDREIGINGEN
}

\author{
"... Gloemrijkals de Alpenweiden..."
}

De oorspronkelijke boerenterm "schraalland", dat wil zeggen arm, in de zin van weinig produktief́ en onbemest cultuurland, heeft in de oecologie ${ }^{1}$ een toegevoegde waarde gekregen en betekent een door kruiden en grassen gedomineerd oecosysteern, waarin een "verschralend" beheer plaats vindt. De mens oogst dus alleen, direct of via zijn vee. de vegetatie of een deel daarvan en brengt er geen voedingsstoffen terug. Schraallanden waren overal in Europa onder diverse namen karakteristiek voor de voormalige agro-pastorale bedrijfsvoeringen; hun biologische rijkdom was zeer hoog en hun achteruitgang, gemeten zowel aan areaal als aan soortenaantal, alarmerend. ${ }^{2}$

Tot de bekendste Nederlandse voorbeelden van schraallanden behoren riet-en veenmoerassen, hooilanden en een grote variatie aan beweide graslandtypen, heiden en duingraslanden. Omdat schraallanden extensief wer-

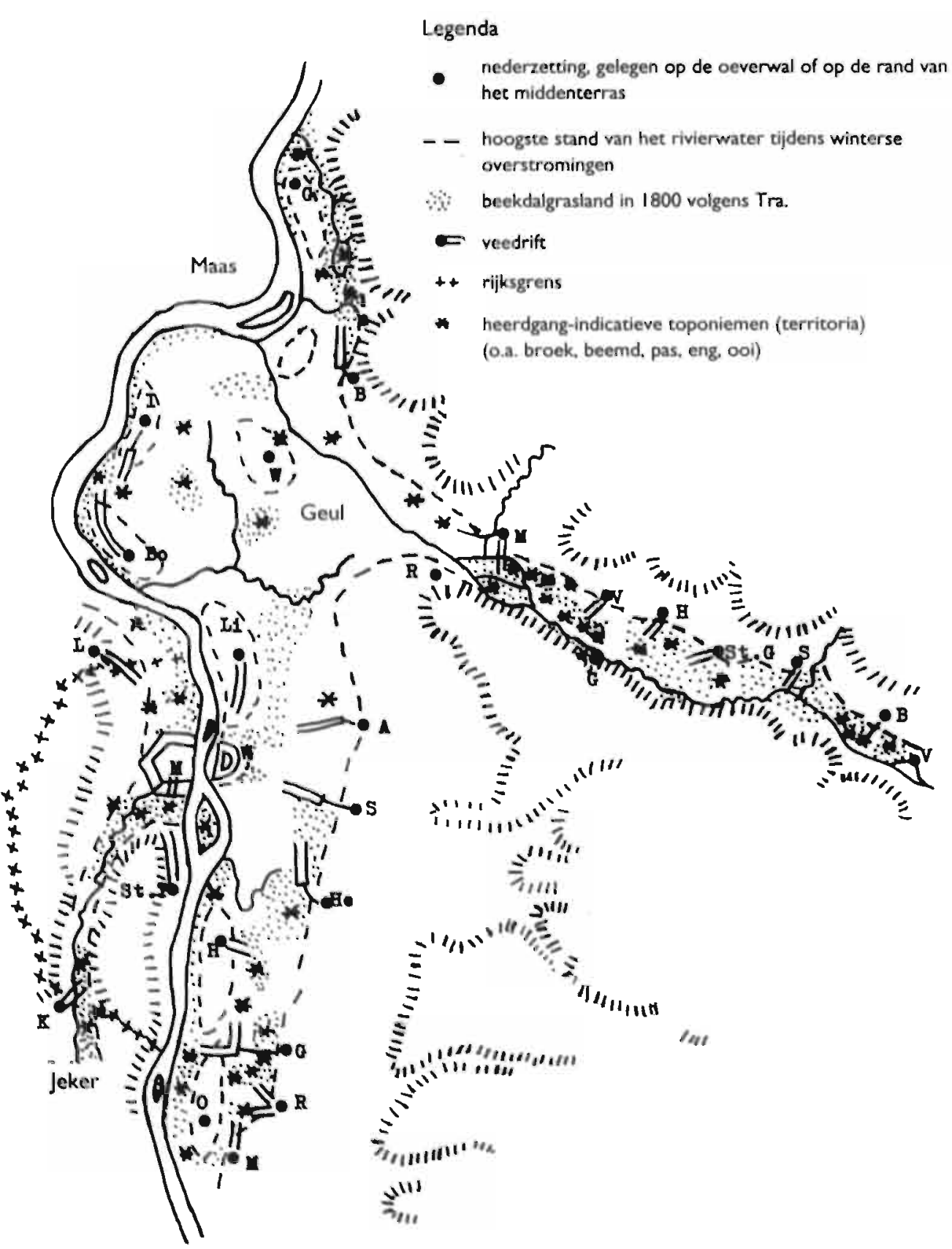

FIQUUR 9.1.

De (roormalige) verspreiding van natte schraallanden (= beekdalgraslanden) in het Maas-, Geulen Jekerdal blj Moastricht rond 1800 volgens de Tranchotkoart en de belangrijkste heerdgangroutes vanuit de nederzettingen en weidegronden op basis van toponiemen. Als gevolg van winteroverstromingen waren de loaggelegen gronden ongeschikt als bouwlond en uitsluitend in gebruik als hooilanden en weidegronden voor rundvee. Tot in het begin van deze ceuw vond beweiding in kuddeverband vanuit de nederzettingen plaots. De namen van de veedrifien vanuit de nederzettingen en weideplaatsen voor de kudden in de beekdalgraslanden kunnen dit gegeven illustreren. De betekenis van de letters is als volgt: voor het fekerdal: $K=$ Kanne SLP. $=$ Sint-Pieter voor het: Moosdal: $M=$ Megirland $0=$ Oost $R=$ Rijekhoit $\mathbf{G}=$ Gronsveld $\boldsymbol{H}=$ Heugem $H_{e}=$ Hear $S=$ Scharn $A=A m b y$ $U=$ Limmel. $\mathrm{Ml}=$ Maastricht $L=$ Lanaken Bo $=$ Borgharen $I=$ itteren $W=$ Weert $B=$ Bunde $G \equiv$ Geulle roor hell Geuldal: $M I=$ Meerssen $V=$ Yroenhof $G=$ Geulhem $H=$ Hourthem St. G. $=$ Sint-Gerlach $S=$ Strabeek $B=$ Broekhem $V_{a}=$ Volkenburg 
FCUUR 9.2. De verspreiding van droge schroallanden in Zuid-Limburg tijdens de negentiende eeurw op basis van onder andere toponiemen.

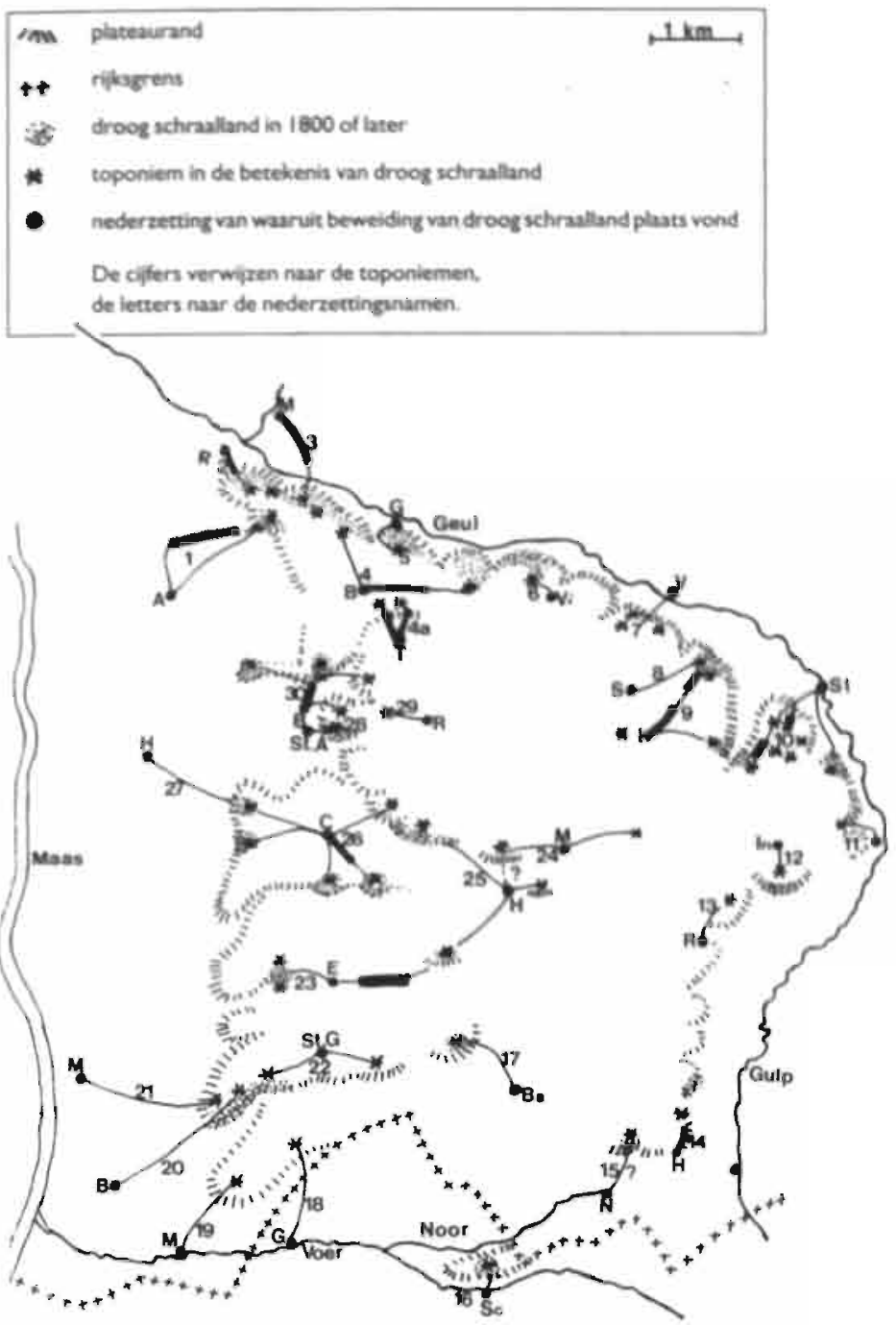

FIGUUR 9.2.2. Het ploteou van Margraten

\begin{tabular}{|c|c|c|c|c|}
\hline $\begin{array}{l}\text { 1. A } \\
\text { 2. } R\end{array}$ & $\begin{array}{l}=\text { Amby } \\
\text { = Rothem }\end{array}$ & $\begin{array}{l}\text { II. } G=\text { Gulpen } \\
\text { II. } \ln =\text { Ingber }\end{array}$ & $\begin{array}{l}\text { 21. M } \\
\text { 22. SeG. }\end{array}$ & $\begin{array}{l}=\text { Moorland } \\
=\text { Simt-Geertruid }\end{array}$ \\
\hline $3 . M$ & $=$ Mrersien & 13. $R=$ Rejignerstok & 23. $\mathrm{E}$ & = Eckelrade \\
\hline 4.8 & $=$ Berg: & 14. $H=$ Hoogerut: & 24. $M$ & $=$ Mergraten \\
\hline $4 a . T$ & $=$ Terblijt & I5, $\mathbf{N}=$ Noorbeek & 25. $\mathrm{H}$ & = Honthem \\
\hline 5.6 & $=$ Geulhem & 16. $S_{c}=5$ choppem & 26. $C$ & \# Codier \\
\hline 6. V & $=$ Vilt & 17. $B=$ Banholt & 27. $\mathrm{H}$ & a Hoer \\
\hline 7. $v$ & $=$ Volkenburg & 18. $G=3$-Gravenvoeren & 28. Si.A. & $=$ Sine-Antoniusbank \\
\hline 8. 5 & $=$ Sibbe & 19. $M=$ Mesch & 29. $R$ & $=$ Rooth \\
\hline 9. 1 & $=1$ Ixeren & 20. $B=$ Breust & 30. $\mathrm{B}$ & $=$ Bemelen \\
\hline
\end{tabular}

10. $5 t=$ Struch

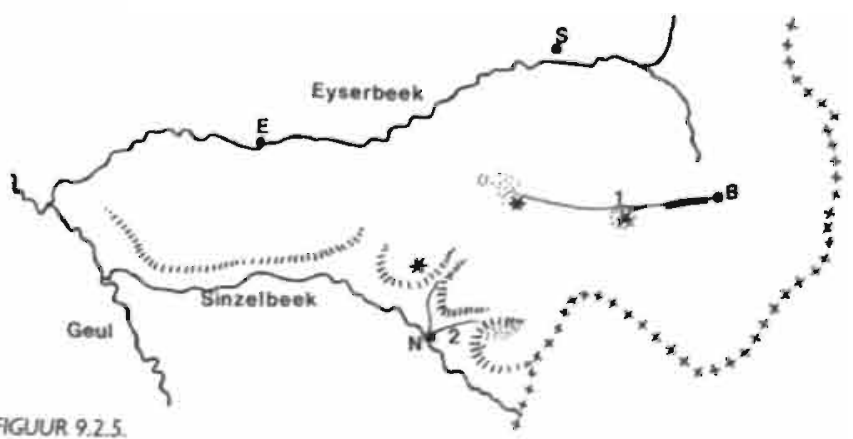

Het plateau von Bahneheide

I. $B=$ Bochholtz

2. $\mathbf{N}=\mathbf{N}$ ijswiller

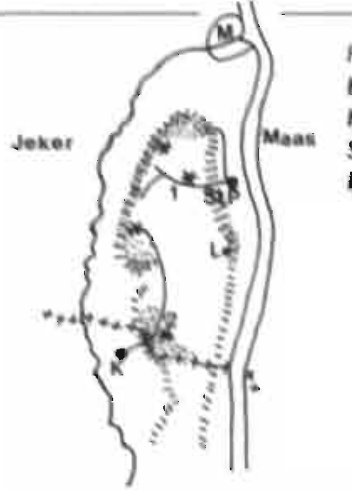

FGUUR 9.2 .1 .

Het pleteou van de St. Pietersberg

$K=$ Kanne:

St.P. $=$ Sint-Pleter

L = Lichtenberg

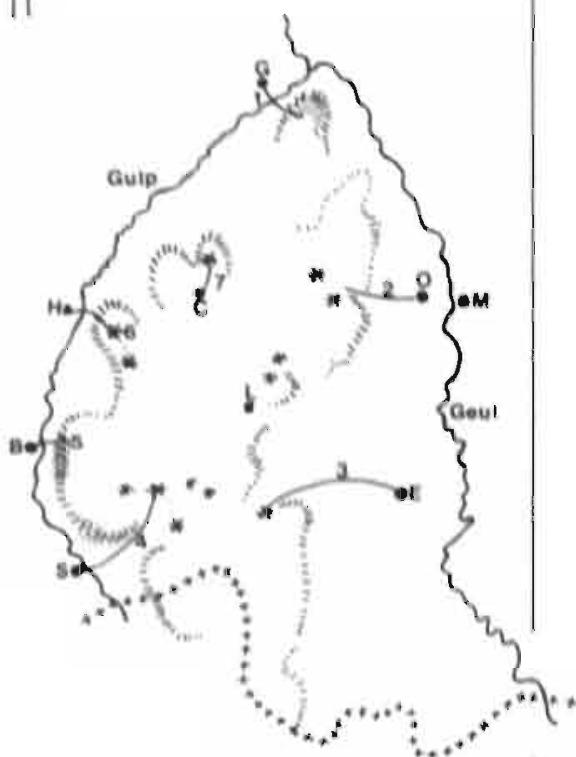

FGLIUR 9.23

Het plateou van Landsrade

I. $G i=$ Gulpen

2. $\mathrm{Cl}=$ Crergeul

3. $E=$ Epen

4. 5 = Sienoken

S. $\mathrm{B}=$ Beutenoken

6. $H=$ Houbender

7. $C=$ Crapoel

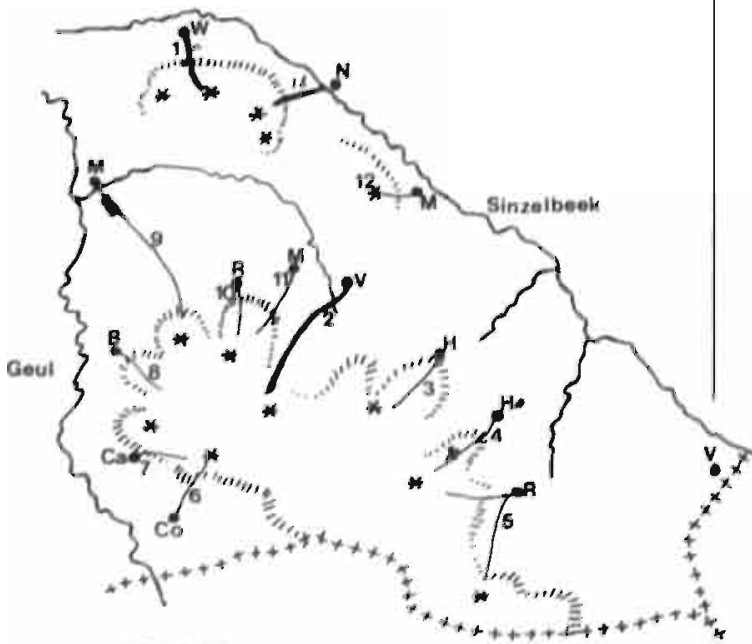

FIGUUR 9.2 .4

Het plateau van Vijlen

1a. $W=$ Wahlwiller $\quad 6 . \quad C_{0}=$ Cottessun

lb. $\mathbf{N}=$ Nifswille: 7. $\mathrm{Ca}=\mathrm{C}_{\mathrm{amerig}}$

2. $\checkmark=$ Vijlen $\quad$ 8. $\boldsymbol{B}=$ Bommerig

3. $H=$ Hories 9. $M=$ Mecheien

4. Ho $=$ Holset 10. $A=$ Roth

5. $\mathrm{R}=$ Raren $\quad$ II. $\mathrm{M}=$ Melleschet 


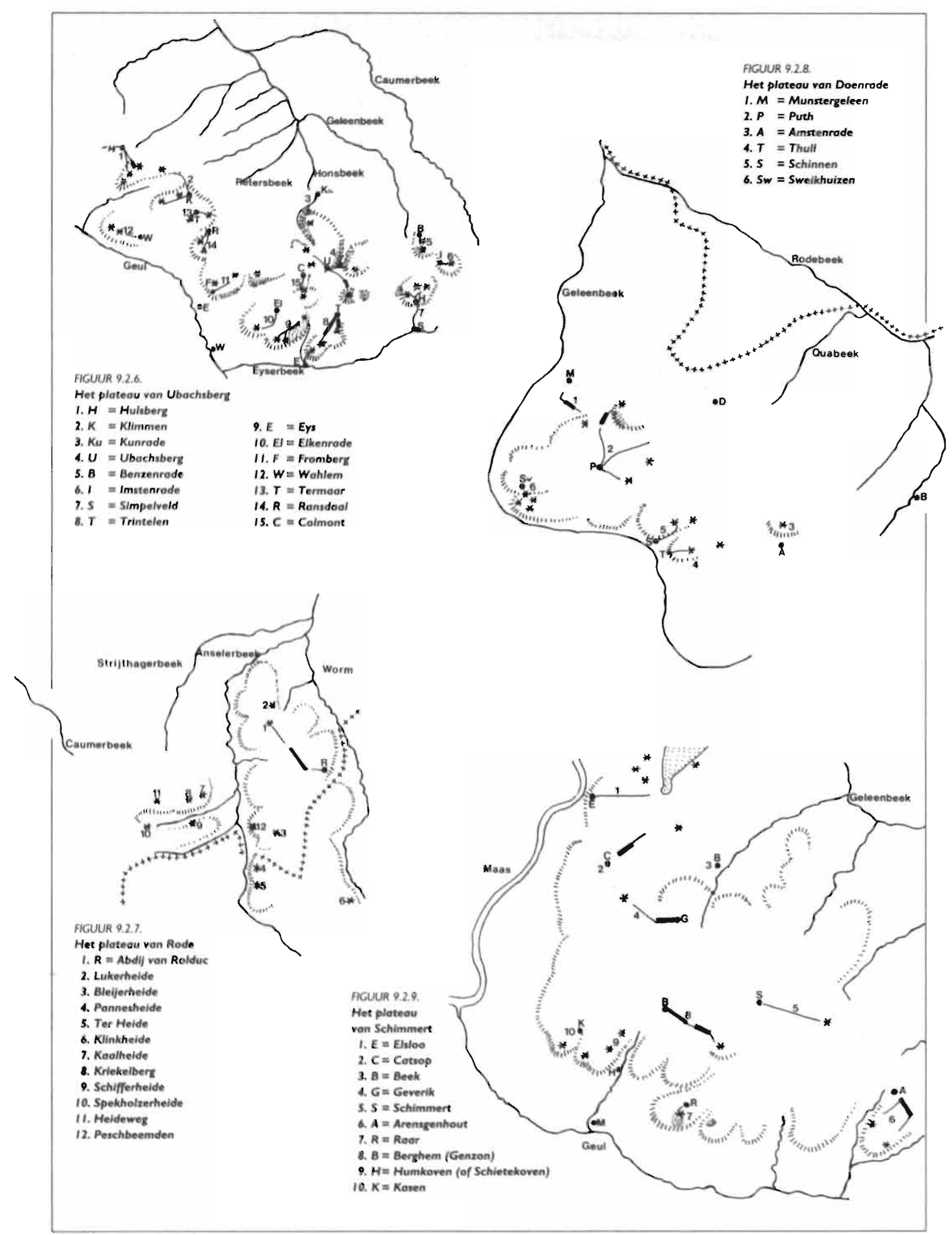




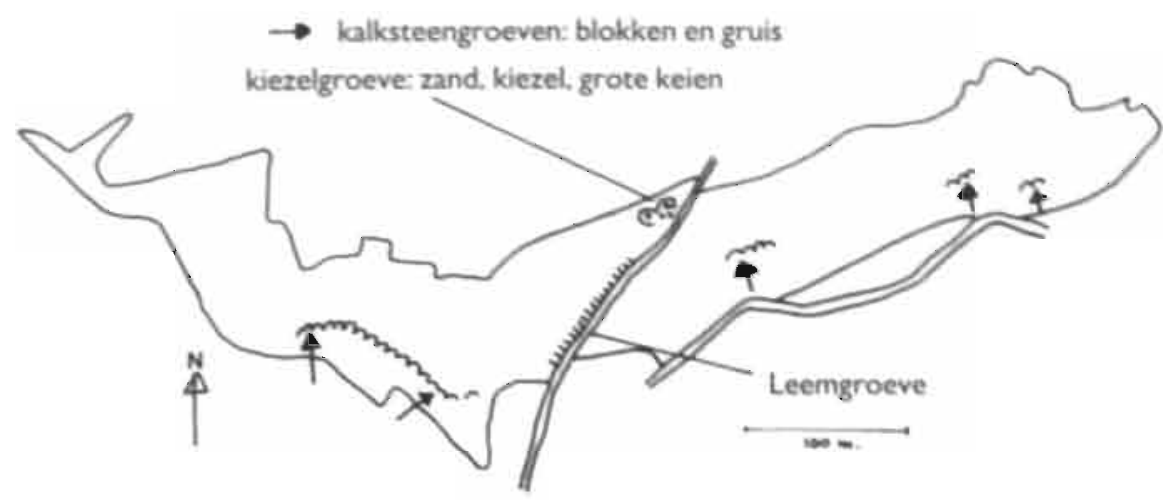

AGUUR 93 Delfrto/winning op de gemeentehel van Bemeien. Het vaste krijtgesteente werd ontgonmen in de rom van geradgde blokken. De ontginning vond plaots in de ondergrondve gangenstelseh van de Stroo-, Winckel- en Cluysberg en doteert uit de lote middeleeuwen. Los en uitgehakt mergeligruts werd ah een vorm van kurntmest benut. De kiezelgroeve leverde. afgerien van kiexel voor wegrerharding rand en srote keien op. In de leemgroeve aan de holle Molenweg werd materiaal redolven voor onder andere het bepleirteren van de wanden van de vakwerkhuiren.

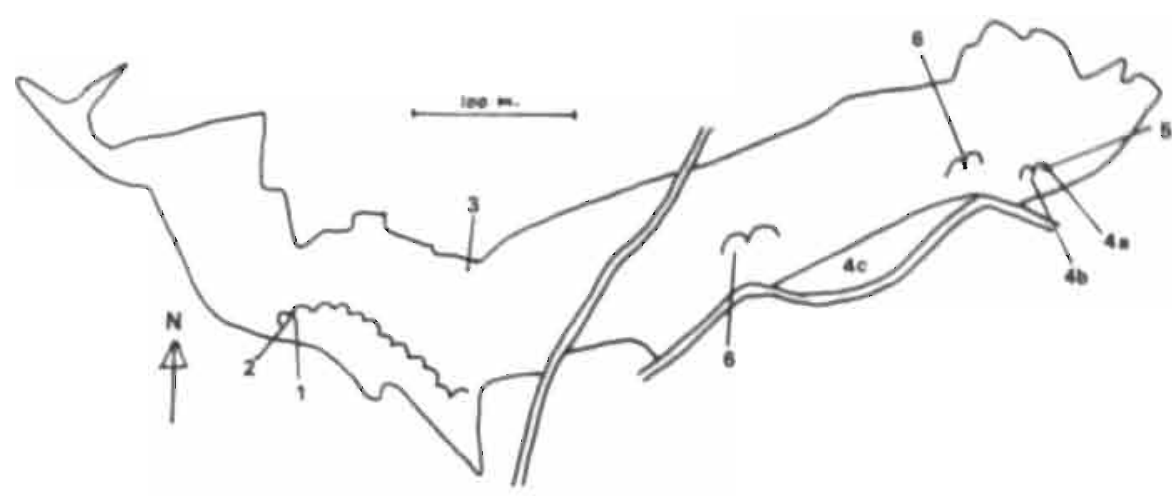

FCUUTR 9.4 . Nevenfunctier van de gemeentẹtei van Bemelen. In de brede ingongupartij van de Strooberg (1) konden arme boeren overtollig itro opulaan. In een ander deel van derelfde ingangspartij was de ichietschif van de lakale. schutteri) opgehangen (2). Op de top van de Strooberg (3) stand een galg opgesteld. Tot 1803 hebben in de grotwoning noast de Chysberg khizenaan gewoond (4a), een nobijgelegen ingang fungeerde als geitestal (4b) en op het akkertye (4c) verbouwden xil graan. De kleine moestuin ( $\$$ ) van de hluis heeft gefungeerd ab een begraafplost voor wreemdelingen en angedoopte kinderen. De ingangspartij van de groeve van de Winckelberg en de Cluysberg (b) heeft als dorprschan dienrigedaan.

den beheerd en, in vergelijking met de rest van het cultuurgebied waarvan zij deel uitmaakten, een hogere graad van "natuurlijkheid" bezaten, worden schraallanden ook wel tot "halfnatuurlijke" ${ }^{3}$ landschappen gerekend. Niettemin worden ze door menselijk handelen instandgehouden en kunnen ze desgewenst, door de voormalige beheertechnieken van toen weer toe te passen, ook worden gereconstrueerd.

Het is gebruikelijk om schraallanden in te delen in "droge" en "natte". Ook binnen het gebied van onderzoek is deze indeling toepasselijk, omdat ook hier de mens vanouds de zone tussen droog en nat bewoonde en bewerkte, waardoor de beide schraallandtypen ruimtelijk van elkaar werden gescheiden.

Binnen het kader van dit hoofdstuk kunnen de natte schraallanden slechts terzijde worden besproken; hun ligging is beperkt tot de stroomdalen van beken en rivieren. Ze staan in de toponymie bekend onder de aanduidingen "broek, beemd, ooi, weerd" enzovoorc. Ze werden destijds gehooid en nabeweid of alleen extensief beweid, meestal door rundvee. Figuur 9,1 geeft een beeld van de voormalige verspreiding van diverse natte schraallanden in het Maas-en Geuldal. Oecologische gegevens ten aanzien van dit biotoop binnen het gebied van onderzoek zijn schaars; de meeste waren al verdwenen voordat uitgebreid biologisch onderzoek kon plaatsvinden en de schaarse restanten zijn door eutrofièring van het oppervlaktewater dermate veranderd, dat hun huidige vegetatie nauwelijks meer representatief te noemen is voor de oorspronkeliịke vegetatie. ${ }^{5}$ Van de droge schraallanden binnen het gebied van onderzoek (zie figuur 9.2.I tot en met 9.2.9) is daarentegen vee! meer bekend; het nu volgend deel van dit hoofdstuk. heeft hierop betrekking.

\section{2}

De oudste en tevens belangrijkste functie van het droge schraalland, die al tijdens de prehistorie werd toegepast en ononderbroken tot en met het begin van de twintigste eeuw heeft geduurd, bestond uit. de voedselproduktie voor het weidende vee, met name voor schapen en rundvee. Vanaf de introductie van het potstalsysteem, dat in Zuid-Limburg tijdens de zestiende eeuw bekend raakte, werd aan de beweidingsfunctie een mest leverende functie gekoppeld. De mest van de kudde, opgespaard in de potstal, fungeerde vanaf die tijd als "de kurk waarop de. agrarische economie bleef drijven ". 6 De droge schraallanden werden vervolgens "woeste gronden" genoemd " toen diverse substituten voor potstaimest op grote schaal hun intrede deden. Het zal dan duideliigk zijn dat het substituut kunstmest het definitieve einde betekende van het droge schraalland. Naast de yoedsel en mest leverende functies heeft het droge schraalland in de loop van de tijd binnen het gebied van onderzoek een aantal nevenfuncties gekend. Eén daarvan bestond uit het verzamelen van plantaardig materiaal, dat door het weidend vee werd gemeden en dat yoor gebruik door de mens geschikt was, zoals bijvoorbee!d het verzamelen van "ginster", takken van de dwergheester brem (Cytisus scoparius), geschikt voor de fabricage van bezems of benut als stalstrooisel, "wachelder" of jeneverbes (Juniperus communis), waarvan diverse delen verschillende gebruikstoepassingen kenden $^{2}$ en de lange stengels van braam (Rubus div. species), die als vlechtmateriaal (onder andere voor bijenkorven) werden benut. Als stalstrooisel werd ook dor gras en de zoden van de dophei (Erica tetralix) gebruikt.

Belangrijker in economisch opzicht dan het verzamelen van plantaardig materiaal, dat door het weidend vee werd gemeden, was de delfstofwinning ${ }^{B}$ in het gemeente-schraalland. Karakteristiek voor Zuid-Limburg was de exploitatie van "mergel" in de vorm van kalkhoudend gruis, waarmee akkers werden bemest, of in de vorm van rechthoekige blokken, bestemd voor de bouw van boerderijen of kerken. Daarnaast werd op de gemeente- 


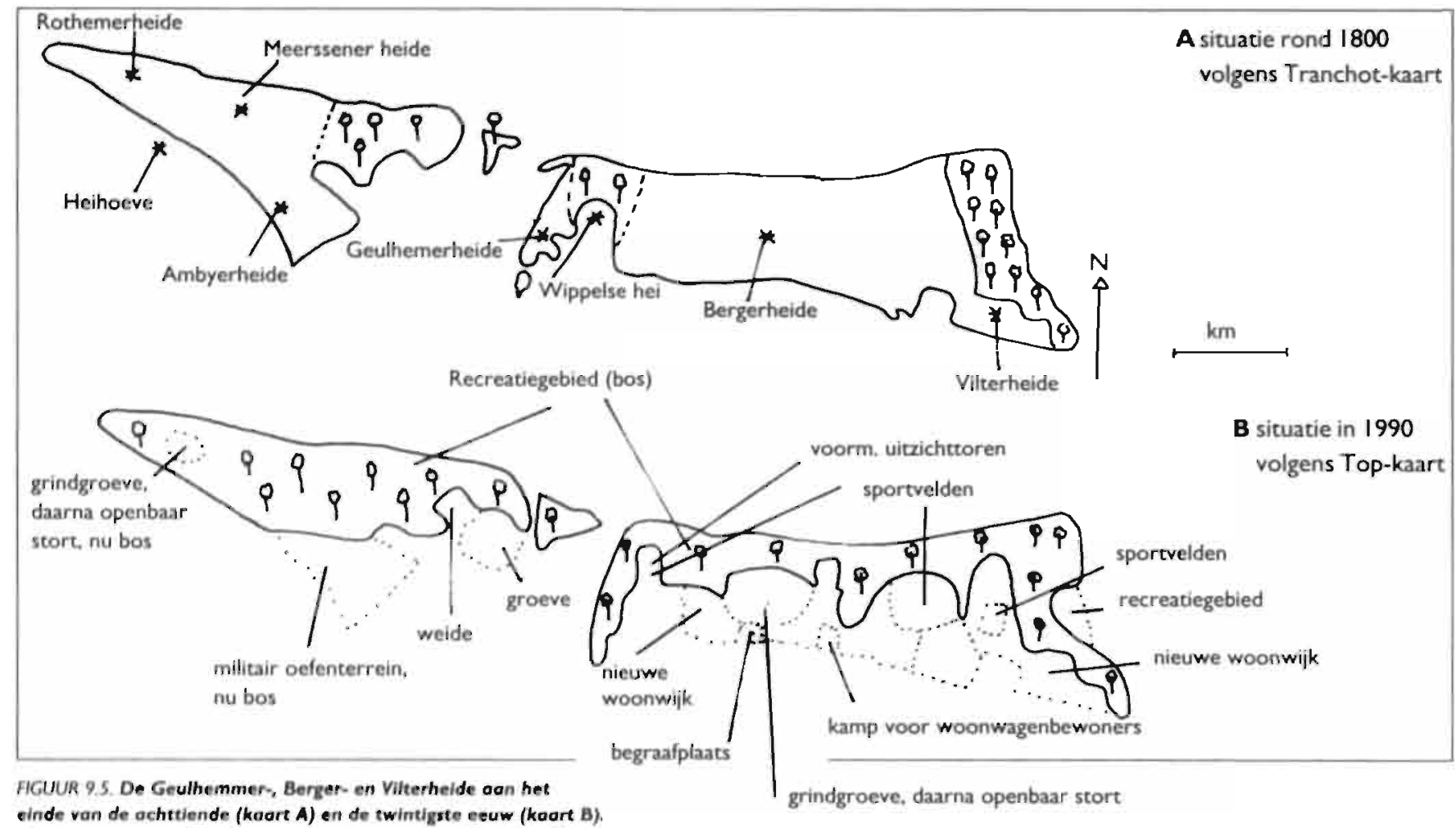

einde van de achttiende (kaart A) en de twintigste esuw (kaart B).

Van de oorspronkelijke vegetatie van droog scihraoliand bleef nietr over.

hei zand en grind gewonnen, dat een rol speelde als bouwmateriaal, materiaal voor wegverharding en -opvulling enzovoort. Grote stenen en keien werden benut als stalplaveisel of fungeerden in de vorm van "șiampstein" voor de ingang der schuurpoorren." Leem speelde een rol in de bouw van vakwerkhuizen. Vrijwel elke gemeente bezat destijds zijn eigen "mirgelskoel", "blokberg". "kiezel- of zavelkoel" en "leimkoel" binnen het gemeente-schraalland. De Bemelerhei. momenteel natuurreservaat, herbergt binnen haar grenzen deze vier typen groeven (zie figuur 9.3). Dergelijke kleine, momenteel niet meer geéxploiteerde groeven vormen juist door hun kleinschaligheid een bijdrage tot de variatie in het landschap. Alleen het biotoop van de gangenstelsels van de calrijke "blokbergen" is oecologisch nader onderzocht. Zij dragen in hoge mate bij aan de biologische diversiteit van de droge gemeenteschraallanden. ${ }^{10}$

Tevens vervulden de gemeenteheiden een aantal "sociale" functies. in dit verband moeten worden genoemd: schuilplaats in de gangenstelsels, begraafplaats voor diegenen die op het kerkhof bij de kerk niet mochten worden begraven, plaats van terechtstelling. oefenterrein voor de lokale schutterij en vestiging voor de dorpsheremiet. Voor de gemeentehei van Bemelen zijn deze functies nog aantoonbaar (zie figuur 9.4). In meer re- cente jaren vormde de gemeentehei een min of meer getolereerde speelplaats voor de dorpsjeugd. Dankzij deze herinneringen hebben vele oudere dorpsbewoners nog een grote affiniteit met hun gemeentehei.

\section{3} Uit diverse "Wijsdommen" en "Cleernissen". gemeentelijke voorschriften inzake het gebruik van bossen en schraallanden, die dateren uit de vijftiende tot en met de zeventiende eeuw, " is bekend dat deze iandschapselementen "gemeyn" waren, dat wil zeggen tot het gemeenschappelijk bezit der ingezetenen behoorden. Oorspronkelijk was de aanduiding "heide" synoniem met het gemeenschappelijk beweide droge schraalland. Vandaar de in toponiemen vastgelegde benaming "gemene-, gemeyne- of gemeentehei". Vaak wordt het toponiem "hei" voorafgegaan door de naam van een nederzetting. De aanduiding "hei" in toponiemen heeft dus een geheel andere betekenis dan "hei" in het huidige Nederlandse taalgebruik, waarmee doorgaans een door struikheide (Calluna vulgaris) gedomineerde vegetatie op mineraalarme zandgrond wordt bedoeld. ${ }^{12}$

Dezelfde Wiịsdommen en Cleernissen, die meestal uit verbodsbepalingen bestaan. geven tevens duidelijk aan dat er een overexploitatie plaats vond op de heide. De geschiedenis heeft geleerd, dat het areaal van de gemeenteheiden afnam, onder andere ten gun- ste van andere wijzen van gebruik dan de collectieve beweiding. Dit kan worden geillustreerd met de gemeentehei van Berg, die in de loop van de negentiende en twintigste eeuw werd opgeofferd aan kleinschalige ontginningen, die door de gemeente werden verpacht, en aan aanleg, en uitbreiding van gemeentelijke kiezel-en grindgroeven die in een latere fase werden gebruikt als openbare vuilstortplaats en motorcrosscircuit. Een ander deel werd voetbal- en sportterrein. $\mathrm{Er}$ kwam een begraafplaats, een zigeunerkamp. een nieuwe woonwijk van gemeentewoningen en een recreatiegebied, dat werd bebost. Van het oorspronkelijke beweide heidegebied met een omvang van rond 60 ha in 1803 bleef ruim een eeuw later niets over (zie figuur 9.5).

Een tweede factor die een belangrijke rol heeft gespeeld in de geschiedenis van de Zuidlimburgse gemeenteheiden, is hun economische marginaliteit, die door verschillende factoren werd bepaald. De eerste factor betreft de relatief grote afstand tussen de gemeenteheide en de dorpskern. De schraallanden vormden immers de meest perifere ring rond de nederzetting en de grote afstand tussen de nederzetting en het schraalland bepaalde het extensieve gebruik ${ }^{13}$ (zie figuur 9.6). Ook al zijn er uitzonderingen, de meeste schraallandrestanten worden aangetroffen op de grenzen van de (voormalige) ge- 
meenten.

Vervolgens was het de hoedanigheid van de gemeentehei als potentiele landbouwgrond. die een eventuele marginaliteit bepaalde. Alleen die delen bleven als droog schraalland in gebruik, die ofwel te steil waren voor landbouw ofwel door hun onvruchtbare substraat daarvoor ongeschilkt. Dit is tevens de verklaring voor het feit dat diverse droge schraallanden, die hun bestaan nog hadden weten te rekken tot in het begin van de twintigste eeuw, spontaan of opzettelijk zijn "verhout", dat wil zeggen in struweel of bos zijn veranderd.

Spontane verhouting is enerzijds het gevolg van de beeindiging van de traditionele begrazing, anderzijds het gevolg van een spontaan natuurlijk proces. Bewuste aanplant gebeurde vooral tijdens de crisisjaren. Figuur 9.7. handelend over de verandering van schraallanden in bossen tussen Bemelen en Margraten, kan dit illustreren.

$\checkmark a n$ de meer dan 60 gemeenteheiden die er binnen het onderzoeksgebied konden worden aangetoond, bestaat er nog slechts een drietal, waarvan de vegetatie in grote lijnen overcenkomt met de oorspronkelijke, met name de Bemelerberg, de Kunderberg en de Brunssummerhei, die dank zij natuur beschermende instanties indertijd werden aangekocht: en tot natuurgebied zijn verklaard. De overige droge schraallandrestanten zijn dusdanig klein van omvang, dat zij de term "gerneenteheide" niet meer verdienen of een andere voorgeschiedenis dan gemeenteheide bezitten.

4.I De droge schraallanden die op de Tranchotkaarten uit de periode 1803-1806 nauwkeurig zijn weergegeven binnen het gebied van onderzoek, kunnen globaal in twee groepen worden verdeeld; enerzijds zijn er enkele grote aaneengesloten complexen met een minimale oppervlakte van 100 ha, die door verscheidene nederzettingen werden geëxploiteerd, anderzijds zị̣n er tientallen kleine, meesta! lintvormige gemeenteheiden op of aan de rand van de plateaus, waarvan de oppervlakte maximaal enige ha bedraagc Dit zijn gemeenteheiden die door maar eeen gemeente werden gexploiteerd.

Van de aaneengesloten schraallanden zijn de Graethei en de heide van Echt momenteel volledig ontgonnen en de "Villener Boesi"' geheel bebost. Alleen van de heide, waarop de bewoners van Brunssum, Schinveld en enige andere gemeenten exploitatierechten bezaten, is een deel gespaard gebleven; dit deel

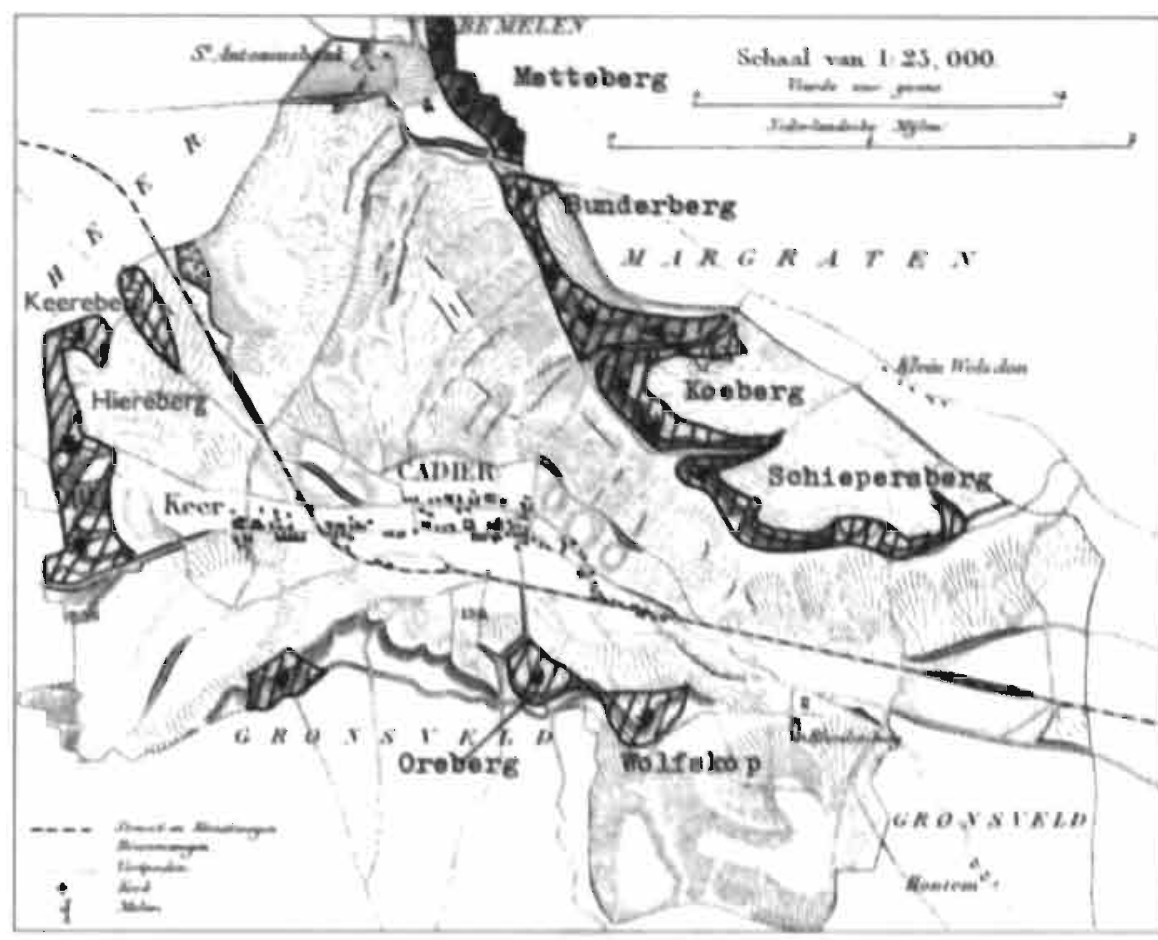

FGUUR 9.6. De perifere likging van een aantal droge schraallanden in de gemeente Cadier en Keer: Situotie rond 1800. De perifere ligging was mede bepalend voor de marginale betekenis van de gemeenteheiden.

bezit de status van natuurreservaat. ${ }^{14}$

Geografisch gezien liggen de alrijke kleine gemeenteheiden min of meer regelmatig verspreid. Op de grotere plateaus is de ligging gebonden aan de randen daarvan; alleen op hec kleine plateau van Ubachsberg en Bahneheide liggen (of lagen) de șchraạallanden centraal en geïsoleerd.

Eerder onderzoek naar de geomorfologie en geografie van de in de negentiende en de in het eerste kwart van de twintigste eeuw nog aanwezige droge schraallanden, wees uit dat er drie typen te onderscheiden zijn: plateauheiden, plateaurandheiden en plateaukopheiden ${ }^{15}$ (zie figuur 9.8). Van het type plateauheide resteert nog één voorbeeld: de Brunssummerheide; van het cype plateaukopheide eveneens nog één voorbeeld. en wel de Vrouwenheide. Deze heide heeft zijn oorspronkelijk vegecatiedek echter verloren. Van het derde type is er tot op de dag van heden een tiental bewaard gebleven, waarvan de Bemelerberg, de Wrakelberg, de Kunderberg en de Laamheide in het. Gerendal het oorspronkelijke schraallandkarakter het best hebben bewaard. Alleen de Bemelerberg en de Kunderberg zijn yoormalige gemeenteheiden.

De bodemsamenstelling van de hierboven omschreven schraallandtypen is uiterst gevarieerd; ze omvatten vrijwel alle in Zuid-Limburg voorkomende bodems. Een opvallend gegeven is echter dat loss, het meest voorkomende en zeer vruchtbare bodemtype in Zuid-! imburg, weinig is vertegenwoordigd in huidige schraallandreservaten, terwijl kalkhoudende sedimenten juist frequent aan de oppervlakte komen. Vandaar de aanduiding "krijthellinggraslanden" als synoniem voor de in het Mergelland gelegen droge schraallanden. Dat deze naam onvolledig is, kan worden aangetoond door de aanvezigheid van diverse andere niet-kalkhoudende gesteenten binnen de grenzen van huidige schraal. landreservacen, zoals vuursteeneluvium, tertiaire en kwartaire zanden en grinden en col. luviale bodems. In één opxicht komen al đie genoemde bodemtypen met elkaar overeen: voor landbouw en veeteelt zijn ze van een zeer marginale betekenis door hun perifere ligging, hun onvruchtbaar substraat, hun hellend oppervlak of een combinatie van deze factoren.

Afgezien van hun variatie aan bodemtypen vertonen de restanten droge schraallanden die de status natuurreservaat bezitten nog andere zeldzame eigenșchappen van hun substraat als gevolg van hun ouderdom als gras. land. Hierdoor zjjn in de loop van de tijd onder andere merkwaardige inspoelingshorizonten ontstaan. Alleen hez schraalland van de Bemelerberg is in dit opzicht nader onderzocht en bleek een "museum" voor bodem kundigen. ${ }^{16}$ Waarschijnlijk geidt deze kwali- 


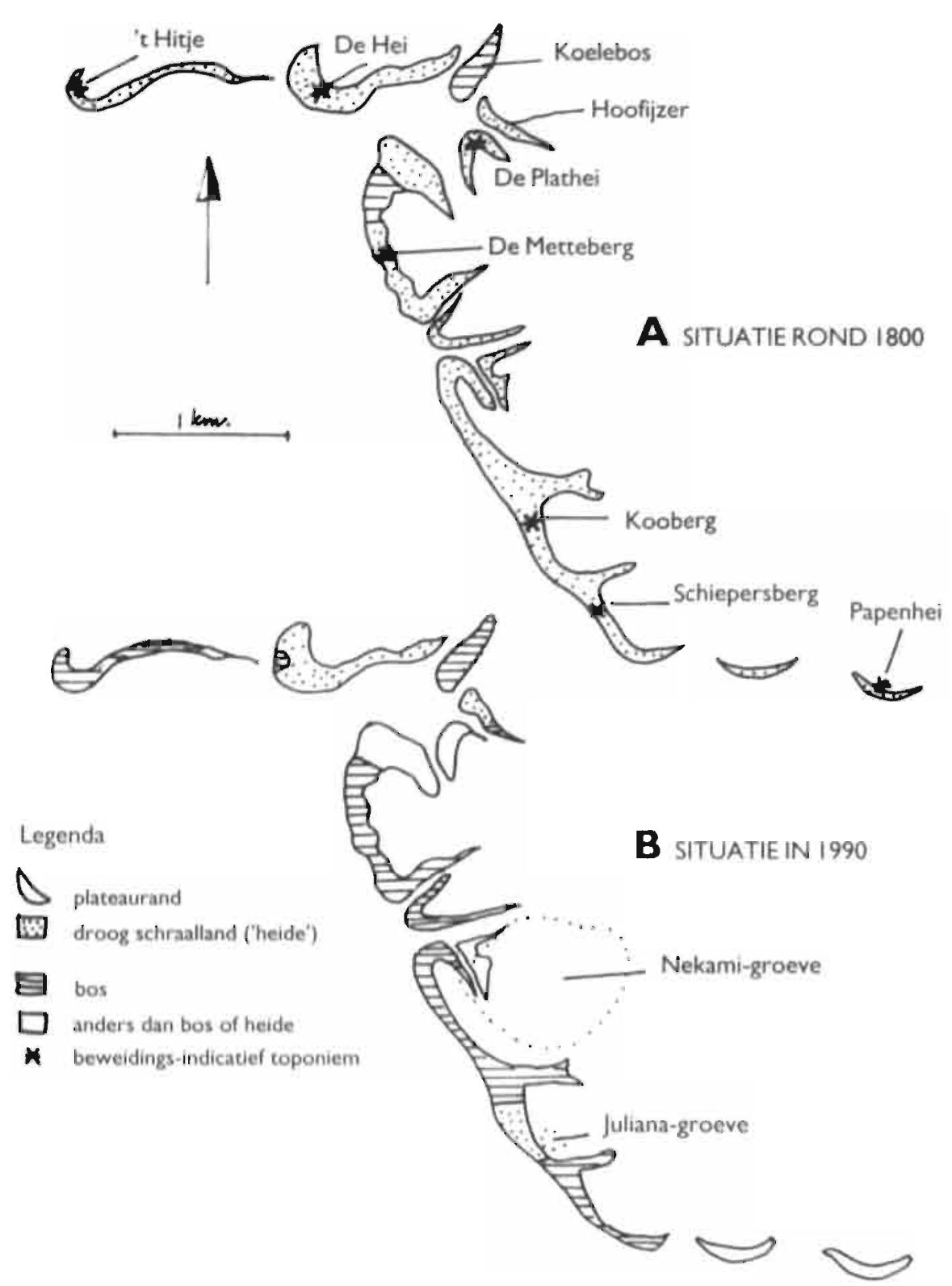

FGUUUR 9.7. De verhouding schraalland en bos tussen Bemelen en Margraten in respectievelijk I800 en 1970. De verandering van droge schroallanden in bos is het gevolg van het beetindigen van het traditionele beheer (beweiding door schopen in kuddeverband) en het spontaan verbossen van de hellingen.

ficatie evenzeer voor andere droge schraallandreservaten; toch zijn enkele, met name de Wrakelberg en de Wijle-akkers, ontstaan uit een "dries" en hebben zij in het verleden als bouwland gefungeerd.

4.2 Vrijwel alle drogeschraallandreservaten liggen op steile hellingen; de benamingen "krijthellinggraslanden", "plateaukop-" en "plateaurandheiden" spreken voor zich. Dit gegeven is het gevolg van een historisch proces, waarbij de vlakke en minst steile delen van het schraalland in de loop van de tijd een ander agrarisch gebruik dan weidegrond hebben gekregen. Alleen dat deel van het oorspronkelijk schraalland dat voor een ander gebruik volledig ongeschikt was, dat wil zeggen het meest hellende deel, bleef als schraalland in gebruik en kon vervolgens vanaf het midden van deze eeuw door natuurterrein beherende instanties worden verworven.

De meeste reservaten bezitten een zuidelijke expositie, Ook dit hangt samen met het marginale karakter van het gemeenteschraalland: op zuidelijk geéxponeerde hellingen, waar meestal humusloze bodemtypen dagzomen, is de verdamping hoog door de directe instraling van de zon. Het bodemmilieu is ter plaatse zeer droog en de groeimo- gelijkheden van het gewas dientengevolge zeer beperkt. Kortom, de voor landbouw of veeteeit meest waardeloze delen van het schraalland verwierven in een latere fase de status van natuurreservaat.

De consequenties ten aanzien van het huidige en toekomstige beheer van de zozeer verspreid gelegen schraallandreservaten, hun relatief kleine oppervlak, hun langwerpige. spoel- of lintvormige omtrek en situering op een helling zijn duidelijk; de randeffecten die uitgaan van het omringende agrarische cultuurlandschap, waar op een bio-industriele wij̨ze wordt geproduceerd, zịn immers des te groter naarmate de oppervlakteverhouding tussen (overbemest) cultuurland en schraalland groter wordt (zie figuur 9.9).

Met name is het probleem van de inspoeling van meststoffen vanaf het plateau in de richting van het lager gelegen schraalland zo groot, dat de karakteristieke flora (en fauna) van de hogere hellingdelen op korte termijn drijgt te verdwijnen; een schrale graslandvegetatie maakt plaats voor een weelderige: zoom van (drijf)mest-indicatoren, zoals onder andere brandnetels. ${ }^{17}$ Bovendien bestaat: in alle reservaten het probleem van de isolatie; vergelijkbaar met eilandjes (van diversiteit) in. een oceaan (van monotoon cultuurland), doen zich zeker op korte termijn genetische verarming en verregaande inteelt. gevolgd door uitsterven voor bị die organismen, waarvoor het cultuurland een onoverkomelijke barrière vormt. Deze processen zijn al enige decennia aan de gang en kunnen aan de hand van goed gedocumenteerd feitenmateriaal worden gestaafd. Een voorbeeld is de jeneverbes (Juniperus communis). die als uitgestorven moet worden beschouwd, ${ }^{18}$ het andere betreft struikheide (Calluna vulgaris), die gevaar loopt te verdwijnen. ${ }^{19}$ Beide soorten waren destijds algemeen en zịnn zeer karakteristiek voor droge schraallanden. Gealarmeerd door deze processen van genetische verarming bestudeert het Rijksinstituut voor Natuurbeheer de populaties van enige andere bedreigde soorten in Zuidlimburgse schraallanden en zoekt naar mogelijkheden om dit proces te stoppen.

\section{5} Het bovengenoemde "museale" karakter van de bodemtypen geldt in een nog hogere mate voor de flora en fauna van de droge schraallanden. Met name over de flora en de vegetatie bestaat op dit moment voldoende kennis om deze terreinen te rekenen tot de soortenrijkste en meest stabiele oe- 
MCUUR 9.8

De grogrofische vorm

van een oantel

schroallandreservaten.

Hun loncrereikte vorm

hangt samen met de

rteilheid van het

terrein en is daardoor

zeer kwetubear voor

randeffecten, die

uitgoan van het

erboven gelegen

cultuurland. Yeel

droge schroallanden

bebben bovendien een

ruldelizke exponitie.

hetgeen bijdroogt aan

de onvruchtbaarheid

van het gebied.

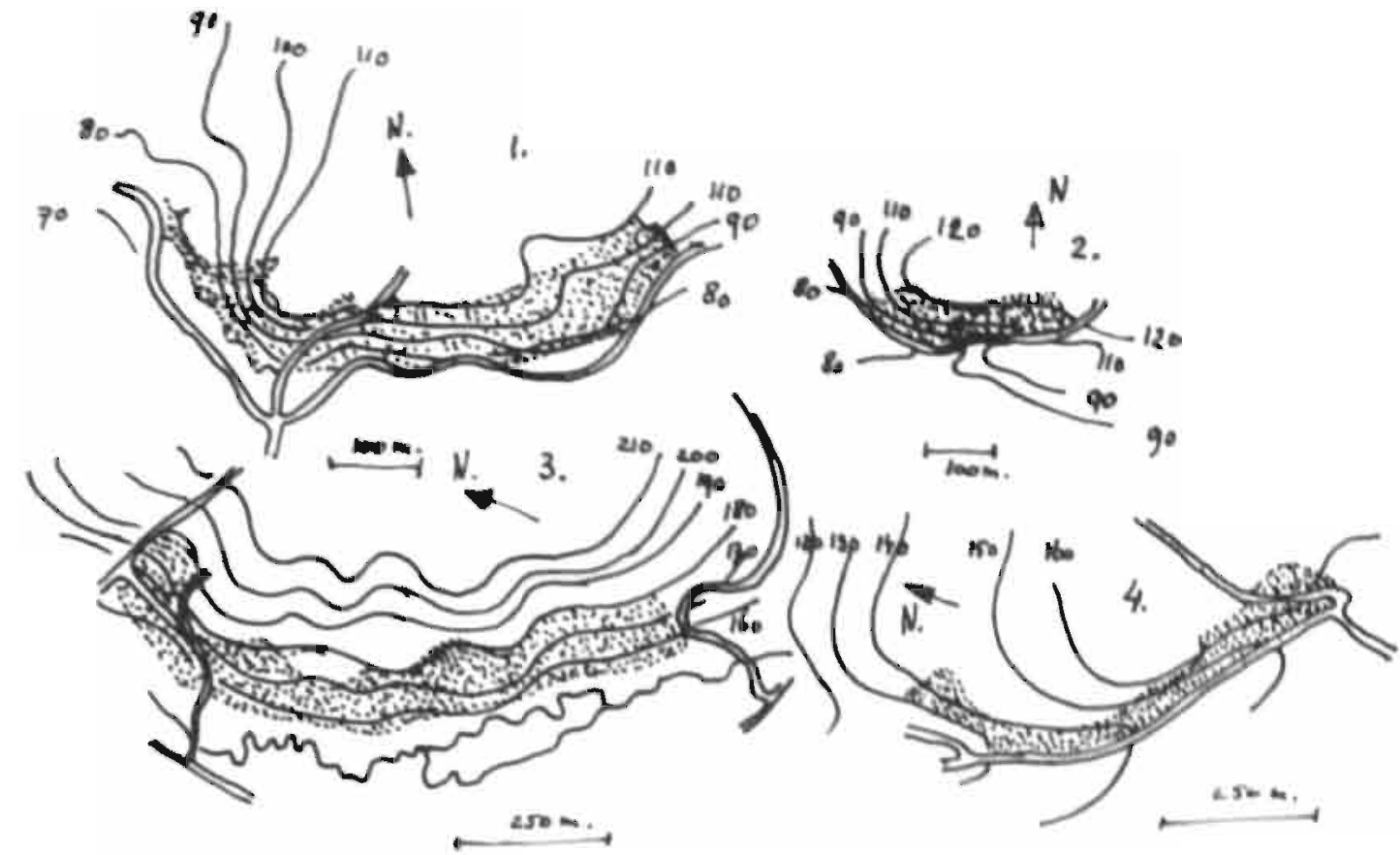

cosystemen van West-en Centraal-Europa.

Deze uitspraak is gebaseerd op vele publicaties, zowel van wetenschappelijke als van populaire aard, "Voor een belangrijk deel is dit te danken aan de aanwezigheid van een uiterst interessante en in brede lagen van de bevolking bekende soortengroep, namelijk die van de orchideeën, ${ }^{2 !}$

De huidige kennis van het plantendek betreft niet alleen de taxonomie der soorten, florastatistiek en syntaxonomie; vooral in de laatste jaren is er door de Rijksuniversiteit van Utrecht veel oecologisch en oeco-fyșiologisch onderzoek gedaan. Ook andere wetenschappelijke instituten hebben een grote belangstelling voor dit soortenrijke oecosys. teem. De resultaten van dit onderzoek zị̣n in tientallen doctoraalscripties en in een vijftal dissertaties vastgelegd. ${ }^{22}$

De Zuidlimburgse schraallandreservaten trekken niet alleen de belangstelling van wetenschappelijke onderzoekers; jaarlijks be. zoeken, vele duizenden de voor het publiek toegankelijke schraallandreservaten. Dat geldt: met name voor het orchideeènrijke schraallandreservaat in het Gerendal. ${ }^{23}$

Ofschoon er al relatief veel bekend was omtrent de karakteristieke faunistische elementen in bepaalde schraallanden, heeft er onlangs een grootschalig onderzoek plaatsgevonden naar de evertebratenfauna van dit oecosysteem. ${ }^{24}$ De resultaten van dit grootschalig onderzoek van de laatste jaren heb. ben onder andere geleid tot een symposium. dat met name aan het behoud en het beheer van kalkgraslanden en de daarbij aansluiten- de droge schraallanden was gewijd ${ }^{25}$ Sinds dit symposium bestaat er dan ook een algemene consensus ten aanzien van het beheer van de droge schrallanden, dat via een ex. tensief en periodiek begrazingsbeheer met mergellandschapen moet plaatsvinden. Het hiștorișch ondẹrzọek naar het voormalig beheer van de schraallanden is voorai vanuit de behoefte aan een adequaat beheer ontstaan; de tot voor kort gebezigde beheer. technieken (maaien, maaien en afvoeren van de vegetatie, branden en nietsdoen) leverden viteindelijk een negatief resultaat op.

Het historisch onderzoek naar het yoormalig beheer van schraallanden begon met het op schrift stellen van de ervaringen van de laatste scheper van Zuid-Limburg en met het veilig, stellen van het lokaal voorkomende schapenras. ${ }^{26}$ In 1979 werden weer voor het eerst na ongeveer een halve eeuw deze schapen ingezet op een Zuidlimburgs droog schraalland. Dat gebeurde zowel op de Bemelerberg als in het Gerendal. De resultaten van dit extensieve beheer met mergellandschapen waren dusdanig positief, dat in de loop van 1983 tot 1989 dit beheer in vrijwel alle in het gebied van onderzoek gelegen droge schraallandreservaten opnieuw werd geintroduceerd.

\section{1} Algemeen gesproken kunnen de invloeden die het voortbestaan van het oecosysteem van de droge schraallanden binnen de huidige reservaten in gevaar brengen. worden verdeeld in externe en interne bedreigingen. Het eerstgenoemde complex van factoren betreft invloeden die uitgaan van activiteiten, die buiten het reservaat plaatsvin. den en waar de eigenaar dan wel de feitelijke beheerder geen invloed op kan uitoefenen. Tot dit complex behoren de invloeden die hun oorsprong vinden in de omringende bioindustrie en het daarmee samenhangend fe. nomeen van de zure regen. Tot de reeks van interne bedreigingen kunnen worden gerekend: de door de beheerder gebezigde wilize of wijzen van beheer en de door de beheerder al of niet toegestane recreatiedruk.

Kwalitatief en kwantitatief vormt de bio-industrie de grootste bedreiging van het schraalland: beide systemen staan immers lijnrecht tegenover elkaar. Het ene is gebaseerd op een overmaat aan voedingsstoffen en diverse grove en steeds wisselende verstoringen van het biotoop, waarmee slechts én soort, het geteelde gewas, is gebaat. Het andere systeem dankt zijn waarden aan "schraalheid" van het substraat, wat betreft nutriènten en aan slechts een verstorende. maar constante factor, nameliịk extensieve beweiding.

Om bedreigingen die uitgaan van de bio-industrie te beperken, kunnen slechts twee maatregelen worden genomen: areaalvergroting en buffering van de huidige reservaten. De richting van de areaalvergroting zal, aangezien de meeste schraallanden op hellingen zijn gelegen, een zijwaartse en een plateauwaartse moeten zijn. Alleen reservaten met een minimumareaal van enige tientallen ha zullen in de toekomst een kans van overleven hebben. Buffering, dat wil zeggen het 


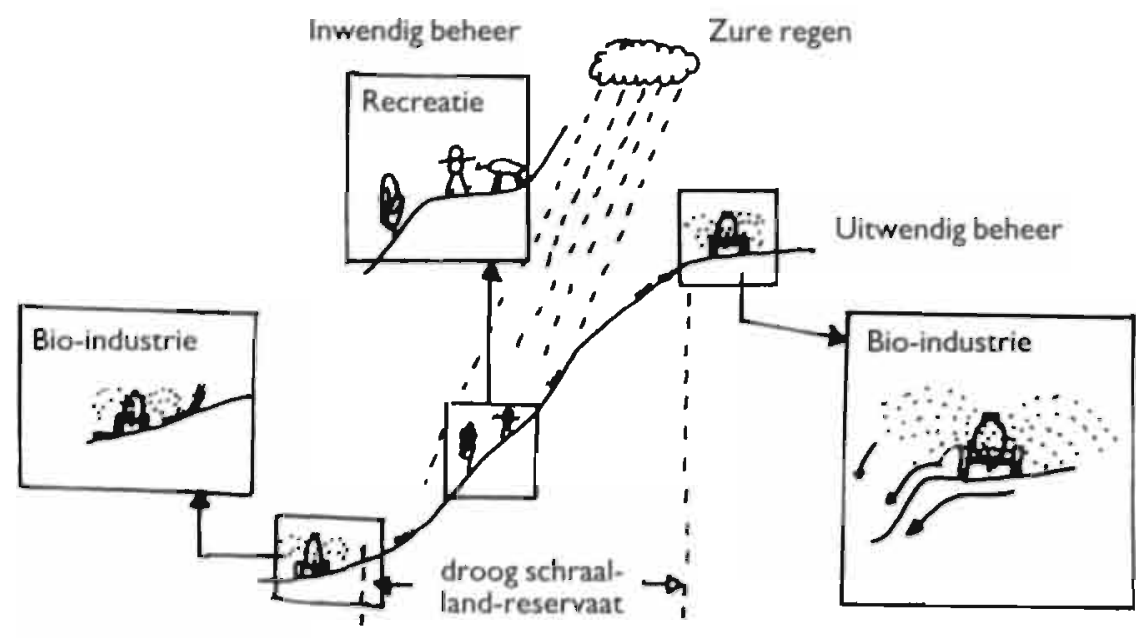

FGUUR 9.9. Een nantal bedreigingen van droge sehraollonden. De belangrijkste bedreiging op dit moment wordt gevormd door de inbreng van drijfmest vanaf de plateaurand. Ook laterale Inspoeling van meststoffen en bestrijdingsmiddelent is geconstoteerd. Doomoast is het complex zure regen van invloed.

Overmatige en illegale recreatie in voor het publiek gesloten reservoten komt eveneens voor.

aanleggen van bufferstroken in de vorm van stroken korte vegetaties, het cultuurland begrenzend met een houtwal of haag, moet op het plateau totstandkomen. Hierbij moet worden gedacht aan een minimale strookbreedte van $50 \mathrm{~m}$.

Een tweede bedreiging, die tevens voor een deel teweeg wordt gebracht door de bio-industrie, wordt gevormd door het complex zure regen. Dit complexe verschijnsel, waarvan de effecten op het droge schraalland uitvoerig zijn bestudeerd, kan worden vergeleken met een extra bemesting van met name stikstof. ${ }^{27}$ Proefondervindelijk is aangetoond, dat de effecten daarvan tot nog toe te bestrijden zijn door een wat hogere beweidingsdruk toe te passen gedurende de periode van de groei van die grassoort, die maximaal profiteert van de ongewenste stikstoftoevoeging door de neerslag. Zelfs kunnen cultuurgraslanden, die in het nabije verleden werden bemest en onder andere daardoor hun diversiteit aan soorten grotendeels verloren, door middel van een verschralingsbeheer met behulp van begrazing door mengellandschapen worden omgevormd tot soortenrijke graslanden.

6.2 Interne bedreigingen kunnen voortvloeien uit het gevoerde interne beheer. Vanafhet moment dat schraallanden de status van natuurreservaat verkregen, zijn er door de beherende instanties tijdens de eerste jaren van hun bestaan drie vormen van beheer toegepast, te weten: nietsdoen, bran- den en maaien. Deze drie vormen van beheer zijn uitvoerig onderzocht; ${ }^{28}$ hieronder wordt volstaan met een summiere toelichting.

Nietsdoen leidt in de meeste gevallen binnen een periode van 10 tot 30 jaar tot een volledige biotoopverandering; een soortenrijk en stabiel schraalland verandert via een aantal karakteristieke tussenstadia in een soortenarm en instabiel struweelbos. Om die reden moet deze vorm van beheer worden afgewezen.

Het branden van de droge biomassa in het. vroege voorjaar voorkomt weliswaar opslagen struweelvorming. maar bevordert het ontstaan van een soortenarme grasmat. Ook. voor diverse fauna-elementen van schraallanden is deze vorm van beheer fataal. Alleen tijdens, de beginfase van de restauratie van een zeer verwaarloosd schraalland of wanneer beweiding om de een of andere reden (nog) niet kan worden toegepast, kan een voorzichtig brandbeheer tijdens het vroege voorjaar plaatsvinden: dit geldt met name voor wegbermen.

Hec maaien van droge schraallanden stelt een historisch onjuiste beheervorm voor, maar is het enige alternatief voor extensieve beweiding. Vooral in de beginfase van de restauratie is maaien en afvoeren van de biomassa in de top van het groeiseizoen een methode om verschraling te versnellen. Maaien en afvoeren kan wel worden ingesteld en blijvend toegepast als onderdeel van het beheer van driesakkers.
Extensieve beweiding is de historisch juiste beheervorm. Hierbii moet worden gedacht aan beweiding in kuddeverband onder leiding, van een herder. In het verleden betrof de kudde meestal schapen. Het is op grond van waarnemingen in her buitenland en op grond van aanvijzingen uit de toponiemen-voorraad waarschijnliịk, dat plaatselijk ook enige geiten in de schaapskudde meeliepen. Toponymisch nawijsbaar zijn eveneens diverse "koebergen" en "koeheiden"; dit neemt niet weg, dat de favoriete weidegronden voor het. rundvee op de dalbodems waren gelegen.

De extensiviteit van de begrazing van de droge, schrale graslanden blijkt verder uit de jaarcyclus van begrazing. Uit historisch onderzoek. geldend voor de tweede helft van de vorige eeuw en het eerste kwart van deze eeuw, bleek dat gedurende twee periodes per jaar, te weten in hetvoorjaar en de nazomer, de schrale grasianden niet werden beweid, omdat tijdens de eerstgenoemde periode de produktievere wegbermvegetaties voor de kudde beschikbaar waren. Tijdens de tweede periode, in de nazomer, werd stoppeibeweiding van het uitgestrekte akkerareaal toegepast. Beweiding van de droge schraallanden vond dus plaats in de voorzomer vanaf een moment dat hier de groei van grassen en kruiden had ingezet tot het moment waarop de akkers werden geoogst. verder gedurende de herfist tot en met de winter; wanneer de stoppelakkers ingezaaid en voor beweiding niet toegankelijk waren. ${ }^{20}$ Vermoedelịjk bestond deze vorm van extensieve beweiding van de schraallanden al veel eerder dan 1850.

In verband met de hierboven aangehaalde periodieke en aan bepaalde seizoenen gebonden beweiding, zal de beheerder moeten streven naar een soortgeliịke beweidingsvorm, die in het verleden plaats vond, hetgeen betekent dat een jaarrondbeweiding. met een beweidingsdruk. van I, 5 schaap per ha, een vuistregel die door het Rijksinstituut. voor Natuurbeheer werd gehanteerd, moet worden afgewezen. Onderzoek heeft uitgewezen dat een seizoensbeweiding met een hoge beweidingsdruk in de voorzomer. voorafgegaan en gevolgd door een periode waarin geen beweiding wordt toegepast, en een winterbeweiding met een lage beweidingsdruk de beste resultaten oplevert. In verbạnd hiermee moet de beheerder om de kudde voldoende voedsel te garanderen tijdens de periode dat het schraalland niet kan worden beweid, zorgen voor zogenaamde parkeergraslanden. Dit kunnen uiteraard 
gewone, dat wil zeggen cultuurgraslanden zijn, maar ook percelen grasland die zijn bestemd tot omvorming naar schraalland, wegbermen of braakliggende akkers.

6.3 Een andere vorm van inwendig beheer bestaat uit het reguleren van houtige opslag. De groei van volwassen bomen wordt door vraat van schapen niet belemmerd. voor jonge exemplaren geldt dit wel, maar specifieke basteigenschappen bepalen de mate van de schade. Kiemplanten van bomen overleven een normale beweidingsperiode niet. De aanwezigheid van volwassen bomen in schraalland is het gevolg van het voormalig beheer. Zij kregen een kans tijdens de periode dat een "nietsdoen"-beheer werd toegepast. Door beschaduwing van hun omgeving met de daarmee gepaard gaande buffering van temperatuur, licht-en waterhoeveelheden op de bodem ontstaat een microklimaat. waarin de karakteristieke soorten van het droge schraalland ontbreken. Het afgestorven blad bedekt de bodem, verhindert onder andere kieming van eenjarige soorten in het voorjaar en veroorzaakt eveneens een milieu, warin de karakteristieke schraallandsoorten ontbreken. Wanneer dit milieu zou moeten worden uitgedrukt in een oppervlaktemaat, dan kan worden gesteld dat de horizontale kroonprojectie, vermenigvuldigd met een factor twee, een oppervlak potentieel schraalland onttrekt, aan het totale schraallandreservaat. Aangezien de huidige schraallandreservaten zeer klein van oppervlakte zijn, moeten volwassen boinen binnen een schraallandreservaat als ongewenst worden beschouwd. Door kappen, ringen of knotten kan de beheerder hun negatieve invloed reduceren.

Struwelen. voor zover ze al bestonden tijdens de periode van de traditionele beweiding, kunnen zeer soortenrijk en biologisch waardevol zijn. In de meeste gevallen zijn de bestaande struwelen in de reservaten opgebouwd uit een soort die begrazingsresistent is. Deze soortenarme struwelen dateren uit de periode, dat een nietsdoen-beheer werd toegepast en zijn relatief jong. Een lage begrazingsdruk voorkomt weliswaar een hori. zontale uitbreiding van het struweel, maar is niet in staat een verticale groei te belemme. ren. Bovendien kunnen in het centrum van het struweel bomen tot ontwikkeling komen. die het karakter van het schraalland negatief beïnvloeden. Dergelijke ontwikkelingen doen zich echter zeer langzaam voor en kunnen desgewenst door de beheerder worden gereguleerd. Het oppervlak aan struweel binnen een schraallandreservaat mag niet hoger worden dan vijf procent van hec totale opperviak. $^{30}$

Diverse invloeden die van de recreatie uitgaan, kunnen negatief zijn; de beheerder heeft de mogelijkheid het reservast volledig voor recreatie te sluiten dan wel gedeeltelijk open te stellen. Een volledig verbod sluit ech. ter ongewenst bezoek niet uit; per dag wordt, bij wijze van voorbeeld, het voor het publiek gesloten gedeelte van het natuurre. servaat "De Bemelerberg" gemiddeld minstens eén. keer illegaal betreden, zelfs wan. neer het gebied door een professionele bewaker regelmatig wordt bezocht. De eventueel toegebrachte schade varieert aanzienlijk: van betreding tot vandalisme. In de voor het publiek toegankelijke delen is de recreatiedruk zeer hoog; op zon- en feestdagen heeft het voor het publiek toegankelijke deel van de Bemelerberg een recreatiedruk te verwerken van dertig personen per ha. In de toekomst zullen, gezien de grote publieke belangstelling voor deze schraallandreserva. ten, voorzieningen moeten worden getroffen. Dit is alleen mogelijk, wanneer de reservaten aanzienlijk worden uitgebreid.

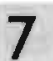

Vanwege het extensief beheer, uitgevoerd op een constante wijze en geduren de een lange periode, zijn schraallanden overal in Europa te karakteriseren als "halfnatuurlijke" oecosystemen, die niet alleen rịik zị̣n aan natuurhistorische, maar eveneens aan cultuurhistorische waarden. Het areaal schraaliand is dramatisch afgenomen, even. als de biologische kwaliteit van de overgeble. ven restanten. Binnen het gebied van onderzoek zijn echter nog diverse schraallandres. tanten overgebleven. Deze worden als natuurreservaten en tevens als cultuurrelicten instandgehouden. Ondanks de vele bedreigingen, waarvan de zure regen en de bedreigingen door de bio-industrie de belangrijkste zị̣n, heeft onderzoek uitgewezen, dat een restauratie van deze soortenriike oecosystemen mogelijk is door middel van de herintroductie van het traditionele beweidingsbeheer door schapen. Zelfs soortenarme graslanden kunnen op deze wijze aanzienlijk winnen aan biologische kwaliteit. In de nabije toekomst zal het evenwel noodzakelijk zịn de huidige schrallandreservaten te vergroten en deze onderling, via schaapskudden te verbinden.

\section{NOTEN}

Inleiding tot de oecologse 1985, pp. 522.567

2 Zie onder andere Euinath 1982, pp. 615-623 en WOLKINCER IN PLANK 1981

3 Westuroff et al 1970.1973, deel I. pp. 60-80 Zie hoofdstuk 2.

MuLder En. CORTENRMA 1990

De SMet 1981.

Hiuncres 1985a

8 Raoemake in Deltstoffen in Limburg 1989

9 Limminuinc 1978-1985, deel 3, pp. 22-23

101 Ontdek het Mergelland 1978, pp. (41.157.

11 Habers 1891.

12. De SMMOT 1981

13. Zie hoofdutuk 10

14. VAN OER MANT 1983

15. Hurcerrs 1980 .

16. Hiucotes 1994 a

17 Huiscens 1984

I8 Himates 1985a

19 Hicions 1982a

20 De belangripkste liceratuur inzake katiuraslanden wordt vermeld door. Wiums 1987, pp. 39-42

21 KnEutz 1987 en 1992 en Hitucans 1989 a.

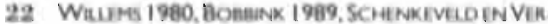
KuAR 1984, Dr KHOON 1990 en Van TOONEN 1989

23. Bossinhor 1980

20 Auxima 1983

25. Symposium kallograstanden 1983

26. Hitucins 19856

27 Bosienk 1989

24i Zie onder andere WiLims 1983 en 1987

29. Hitucins En Reuren 1978.

39 Hiugres 19890 


\title{
HET THERO-AIRION IN LIMBURG
}

\author{
"...een miskend wereldje van miezepieters."
}

Het. Thero-Airion is de wetenschappelijke naam van een tot NoordwestEuropa beperkte groep van associaties, die men "verbond" noemt. De term is deels afgeleid van de genusnaam "Aira", waartoe twee kleine, eenjarige grassoorten behoren. die in hoge mate karakteristiek zijn voor de bedoelde plantengemeenschap. Het andere deel van de samenstelling "Thero-Airion" houdt verband met het Griekse woord "theros", dat "vluchtig" of "kort levend" betekent. Diverse kensoorten bezitten een zeer korte levenscyclus, die zich tot het voorjaar beperkt. In het Nederlandse synoniem van het Thero-Airion komt de naam voor van éen van de hierboven vermelde grassoorten: zilverhaver. Vandaar de naam Zilverhaververbond.

Het Thero-Airion wordt aangetroffen op zeer droge, mineraal-, kalk- en humusarme zanden en grinden.' Dit zijn bodemtypen die. afgezien van de duinstreek in West-Nederland, in de zandgebiecien van Oost- en ZuidNederland te vinden zijn.

In het Mergelland, het deel van de provincie Limburg ten zuiden van de lijn MeerssenHeerlen en tevens het kerngebied van deze studie, zijn de hierboven omschreven bodems en de daarop voorkomende vegetaties zeldzaam en beperkt tot de kiezel- en zandhoudende randen van de plateaus. Vandaar dat hier de standplaatsaanduiding "kiezelkopvegetatie" als een synoniem voor het TheroAirion zou kunnen worden gebruikt. Voor de het Mergelland omringende gebieden is deze aanduiding echter onjuist.

Behalve op de hierboven omschreven kiezelkoppen komen zeer lokaal verwante vegetatietypen voor langs zandige schouwpaden van spoorlijnen, emplacementen, kiezelgroeven en dergelijke.

Ofschoon de floristische samenstelling van het Thero-Airion binnen het gebied van onderzoek lokaal kan variëren, is het patroon en de structuur van de vegetatie onder optimaal beheerde omstandigheden vrijwel identiek. Her bestaat voornamelijk uit een mozaìekpatroon van verspreid voorkomende graspolletjes met hier en daar rozetplanten en dwergstruikjes met houtige stengels. Op de daartussen gelegen open plekken groeien gedurende het voorjaar minuscule bioemplanten, mossen en korstmossen.

Deze plantengemeenschap is aan de aandacht van de vegetatiekundigen ontsnapt. mogelijk omdat het Thero-Airion binnen het gebied van onderzoek șlechts fragmentair, dat wil zeggen onvolledig, zou zijn ontwikkeld, te sporadisch zou voorkomen of op de bovengenoemde standplaatsen een te geringe omvang zou bezitten. Waarschijnlijker is dat de extreem vroege bloei en ontwikkeling van deze plantengemeenschap in de maanden maart en april de oorzaak vormde van het gegeven, dat het Thero-Airion in het Mergelland niet werd opgemerkt; voor de meeste vegetatiekundigen begint het veldwerk immers pas in mei. De hier gepresenteerde stu.

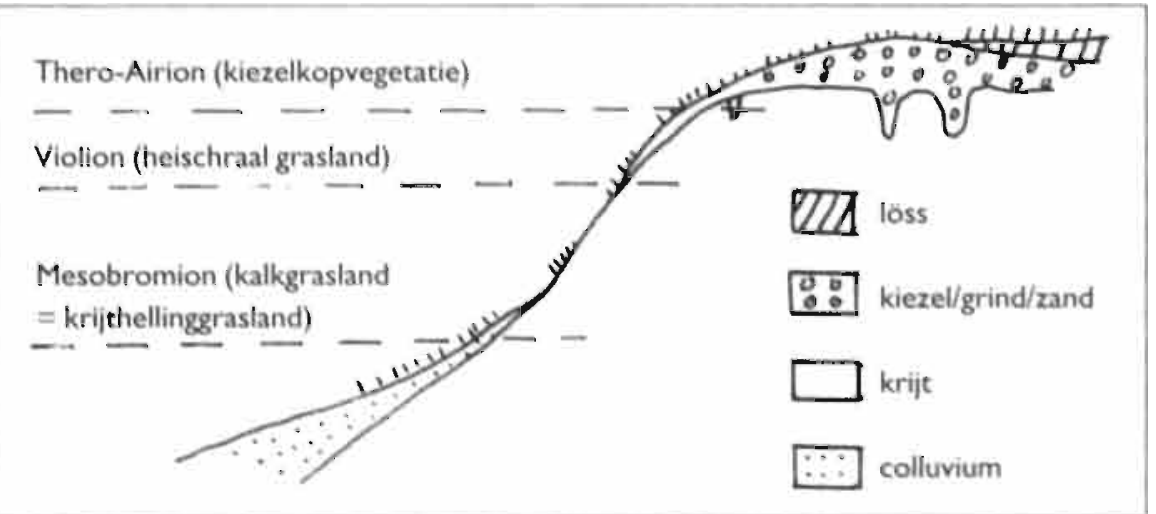

FIGUUR 10.1, Geologisch profiel van cen Zuidimburgse plateaurand met de doarop voorkomende groslandtypen. Er kunnen vier plantengemeenschoppen worden onderscheiden die, afrexien van het verschil in hun soortensamenstelling, eveneens verschillen in hun substrage.

die geeft daarom voor het eerst een overzicht van deze om verschillende redenen bijzondere plantengemeenschap in en rond het Mergelland.

De meeste groeiplaatsen van het Thero-Airion in het Mergelland zijn gelegen binnen natuurreservaten, die als droge en schrale, dat wil zeggen onbemeste, graslanden bekendstaan. Omdat dergelijke schraallanden deels kalkriike bodems bezitten en op hellingen zijn gelegen, spreekt men van "kalkgraslanden"'- of "krijthellinggraslanden", die vanwege het vaak massaal voorkomen van onder andere soorten orchideeën en andere spectaculair bloeiende planten uniek voor Nederland zịnn.

Een aantal krijthellinggraslanden was al in een vroeg stadium van de geschiedenis van de floristiek en vegetatiekunde, dat wil zeggen vóór 1960" onderwerp van uitgebreide studies. De onderzoekers gingen destiijds echter voorbij aan plantengemeenschappen, die een ander substraat dan "kalk" bewortelden. Het heideschraalland in Zuid-Limburg dat op kalkarme grinden en zanden voorkomt, werd pas in de jaren zeventig uitvoerig onderzocht en beschreven. ${ }^{3}$ De onderhavige studie van het Thero-Airion, oftewel de vegetatie van de kiezelkoppen op de plateaurand van het droge schraalland, vormt het derde en tevens het laatst onderzochte en beschreven vegetatietype van het droge schraalland in ZuidLimburg (zie figuur 10.1).

2 Diverse gebeurtenissen en omstandigheden yormden na. 1978 evenzoveel aanleidingen om een overzicht te geven van het Thero-Airion in de provincie Limburg. In de eerste plaats is er in de periode 1978 tot 1983 een aantal kensoorten van het Thero-Airion (her)ontdekc. Omdat het hier een zevental, voor Zuid-Limburg uitgestorven gewaande, soorten bloemplanten betrof waarvan opgaven uit de periode 1930 tot 1960 ontbreken, heeft deze herontdekking een belangrijke rol gespeeld in de diagnose van deze voor Limburg niet. of nauwelijks beschreven plantengemeenschap, De betreffende soortenlijst werd al eerder gepubliceerd. " In de tweede plaats heeft de herintroductie van het traditioneel beheer van droge, schra- 


\begin{tabular}{|c|c|c|}
\hline Klasse & Orde & Verbond \\
\hline $\begin{array}{l}\text { Sedo-Scleranchea } \\
\text { (volyens Korneck in } \\
\text { Oberdorfer 1978) }\end{array}$ & 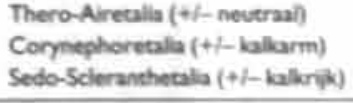 & $\begin{array}{l}\text { Thero-Airion } \\
\text { Commephorion Koeterion } \\
\text { Alysa-Sedion }\end{array}$ \\
\hline $\begin{array}{l}\text { Koelerio-Corgnephoretea } \\
\text { (volyens Westhoff en } \\
\text { Den Held I975) }\end{array}$ & $\begin{array}{l}\text { Cornephoretalia } \\
\text { Sedo-Scleranthealia }\end{array}$ & 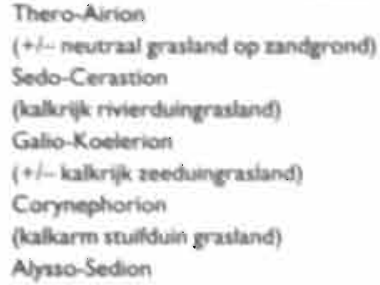 \\
\hline
\end{tabular}

ACUUR 10.2. Symtaxonominche indeling van de Klase der Sedo-Scleranthea rolgens KonntCK noar Süddeutsche Pflanzengesellschaften 1987 en volgens WESTHOF en DEN HELO naar WESTHOF EN DEN HEL 1975.

le graslanden, te weten extensieve beweiding metmergellandschapen sinds 1980 in natuurreservaten waar coena (= elke abstracte vegetatie-eenheid, ongeacht het criterium volgens hetwelk deze is onderscheiden) van het Thero-Airion voorkwamen, ertoe geleid dat deze vegetatietypen zich duidelijker gingen manifesteren, dat wil zeggen hun areaal en karakteristieke soortensamenstelling breidde zich uit en de structuur van de vegetatie veranderde aanzienlijk naar aanleiding van het gewijzigde beheer. Ook deze veranderingen werden al eerder in het kort beschreven en gepubliceerd. ${ }^{\mathrm{J}}$

Voorts bleek dat plantengemeenschappen van het Thero-Airion slechts gedurende een korte periode, die vroeg in het vegetatieseizoen is gelegen, kunnen worden bestudeerd. Tegen het einde van de meimaand zijn immers al diverse kensoorten van de syntaxa van het Thero-Airion uitgebloeid en bovengronds zelfs verdwenen. Dit heeft eerder onderzoek bemoeilijkt, omdat andere typen van schraallandvegetaties pas vanaí die tijd gaan bloeien en dan eerst voor bestudering optimaal zijn.

Vervolgens hebben de gegevens die worden vermeld in "Plantengemeenschappen in $\mathrm{Ne}$ derland" $" 6$ inzake gerneenschappen die tot het Thero-Airion worden gerekend, de diagnostiek van deze plantengemeenschappen in Zuid-Limburg bemoeilijkt, enerzijds door onduidelijkheden in de beschrijving, anderzijds door het ontbreken van gegevens wat betreft het voorkomen van bepaalde gemeenschappen van het Thero-Airion in het Krijtdistrict. In de paragrafen 3.1 en 3.2 wordt dit nader toegelicht.

Tenslotte heeft een tweetal recente publicaties met betrekking tot nieuwe inzichten op methodisch gebied ${ }^{7}$ en het beschikbaar stellen van een oude vegetatie-opname uit ZuidLimburg sen verhelderende bijdrage geleverd bij het interpreteren van het door de schrijver tijdens het begin van de jaren tachtig verzameld feitenmateriaal, dat in deze studie bijeen is gebracht.

\section{1} In de onderstaande alinea's worden de resultaten en conclusies besproken van een literatuurstudie inzake het Thero-A $\mathrm{A}$ rion, zoals dat binnen Nederland voorkomt. Korneck, de meest recente bewerker van

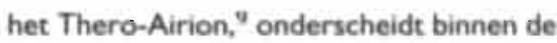
klasse der Sedo-Scleranthetea (een aantal plantengemeenschappen van droge, schrale en humusarme substraten) een drietal orden. Westhoff en Den Held onderscheiden binnen Nederland eveneens een drietal orden, maar hun benamingen verschilien ten dele. Als één van de indelingscritreria ter onderscheiding varı plantengemeenschappen hanteren beide handboeken de gevoeligheid van hun kensoorten voor het Ca-gehalte in hun substraat: één soortengroep komit voor op kalkrịike, een andere op kalkarme bodems en de derde groep verkeert in een middenpositie. Dit criterium wordt door Korneck gebruikt bij de indeling op het niveau van de orde, door Westhoff en Den Held bij de indeling op̣ verbondsniveau (zie figuur 10.2). Het verschillend $\mathrm{Ca}$-gehalte van de bodem, waarop de verschillende plantengemeenschappen zo duidelijk blijken te reageren, ${ }^{16}$ kan in Nederland tevens fungeren om een geografische scheiding tot stand te brengen in de onderscheiden plantengemeenschappen op verbondsniveau. Het zeeduingrasland op kalkrijke bodems, wetenschappelijk bekend als het Galio-Koelerion, beperkt zich binnen Nederland tot het meest westelijke deel. Het rivierduingrasland komt voor op matig, kalkrijke substraten en het SedoCerastion in centraal en zuidelijk Nederland. Het Thero-Airion, een type grasland van lemige zandgrond op neutrale tot kalkarme bodems in het binnenland, wordt voornamelijk aangetroffen in diluviaal Nederland, terwijl het Corynephorion uitsluitend voorkomt in volledig ontkalkte stuifzandgebieden in oos.telijk en zuidelijk Nederland.

Op een fijne geografische schaal toegepast, lijkt de factor van het Ca-gehalte, dat van doorslaggevend belang blijkt te zijn voor het al of niet voorkomen van bepaalde plantengemeenschappen in Nederland, een minder belangrijke rol te spelen; binnen het in Zuid. Limburggelegen natuurreservaat "De Bemelerberg" komen zowel zeer kalkrijke als kalkarme bodems naast en door elkaar voor. Beide bodemtypen zijn vrijwel humusloos en uiterst droog. Diverse elementen uit de hierboven vermelde Galio-Koelerion-, SedoCerastion-, Alysso-Sedion- en Thero-Airionsyntaxa komen hier dan ook naast en door elkaar voor. Deze voor Nederland uitzonderlijke situatie doet zich, behalve op de Bemelerberg, ook nog voor op een aantal andere plaatsen in het Mergelland. " Dit gegeven heeft het onderzoek moeilijk gemaakt. maar onderstreept tevens het belang van de Zuidlimburgse natuurreservaten voor wetenschappelijk onderzoek en steunt de opvatting van. Van Leeuwen, dat kleinschalige gradienten oecologisch zeer belangrijk zijn.

\subsection{Westhoff en Den Held onderschei-} den binnen het Thero-Airion vier associaties. ${ }^{12}$ Daarvan is er én karakteristiek voor de duiner. De drie andere associaties zijn beperkt: tot het pleistocene deel van Nederland. De betreffende vier associaties worden hieronder kori gekarakteriseerd. De duinassociatie, het Airo-Cariceturn arenariae, beschreven door Westhoff, Van Leeuwen en Adriani in 1962, kenmerkt zich onder andere door een geslotenheid van het vegetatiedek, een zekere soortenarmoede en het uitsluitend voorkomen van Aira praecox op een ontkalkt, zandig substraat. Westhoffen Den Held achten het waarschijnilijk dat het Airetum praecocis Krausch 196.7 de binnenlandse vicariant (= nauw verwante vegetatie-eenheid die de ander geografisch uitsluit) is van het Airo-Caricetum arenariae, dat wil zeggen de beide gezelschappen zijn nauw verwant: maar sluiten elkaar geografisch uit.

Oberdorfer geeft een uitvoerig overzicht van het Airetum praecocis binnen Centraal- en Zuid-Duitsland. ${ }^{13}$ In zijn tabellen komen enkele opnamen voor uit de Eifel, een aan Limburggrenzend gebied. Opgrond van deze gegevens is het voorkomen van het Airetum praecocis in Limburg zeer waarschijnlijk. Vooruitlopend op de resultaten van het veldwerk - vergelijk paragraaf 4 -, kan worden 


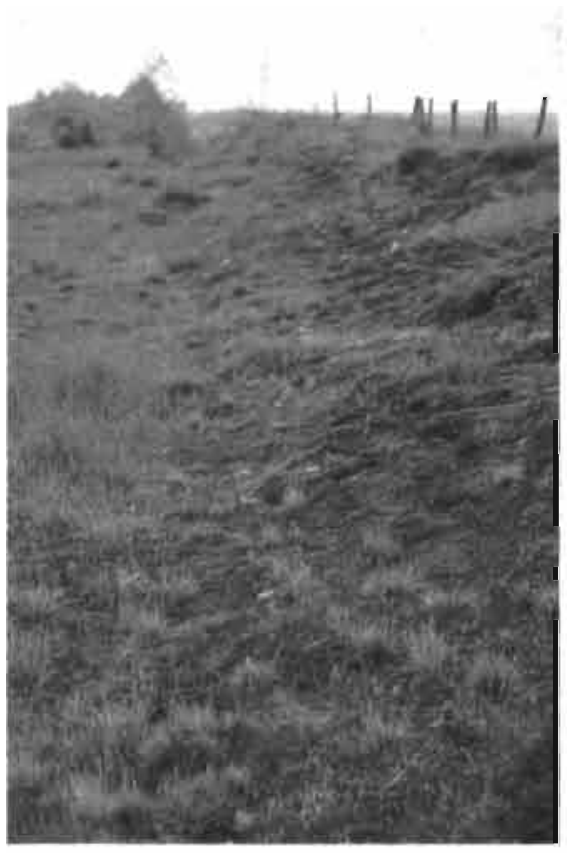

vermeld dat zulks inderdaad het geval is. Omtrent de eerste gemeenschap in het pleistocene deel van Nederland, het Ornithopodo-Corynephoretum, heerst wat onzekerheid volgens Westhoff en Den Held. De betreffende associatie werd beschreven door Passarge in 1960 op basis van gegevens uit Noord-Duitsland van enigszins anthropogeen beïnvloede, open, kalkarme en zandige graslanden. Er zijn weinig Nederlandse gegevens vañ bekend. De associatie zou een vicariant kunnen zijn van her Vioio-Corynephoretum, beschreven door Westhoff in 1943 en 1947, een type duingrasland dat bin. nen het Waddendistrict van Nederland voorkomt en waarvan wel voldoende opnamemateriaal voorhanden is. De laatstgenoemde associatie ressorteert echter niet ander het Thero-Airion, maar onder het Galio-Koelerion. Dit verbond dat al eerder ter sprake kwam, is beperkt tot graslanden in duinlandschappen langs de kust. Op basis van deze gegevens is de positie van het Ornithopodo-Corynephoretum binnen het Thero-Airion onzeker.

Ook tit een andere opmerking van Westhoff en Den Held blijkt dat de syntaxonomische positie van het Ornithopodo-Corynephoretum ter discussie staat. Op pagina 149 vermeiden de schrijvers: "het Spergulo-Corynephoretum wordt niet opgevolgd door soortenriịkere Corynephorus-gemeenschappen als het Ornithopodo-Corynephoretum zoals men wel eens ten onrechte veronder. stelt...". Kennelijk zijn er auteurs die de betreffende associatie in een ander verbond dan het. Thero-Airion willen onderbrengen, met

FIGUUR 10.3.

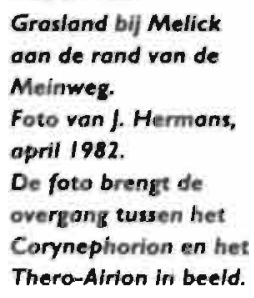

Grasiand bij Melick

aan de rand van de

Meirnweg.

Foto van f. Hermans, opril 1982.

De fota brengt de overgang tusen het Corynephorion en het Thero-Airion in beeld.

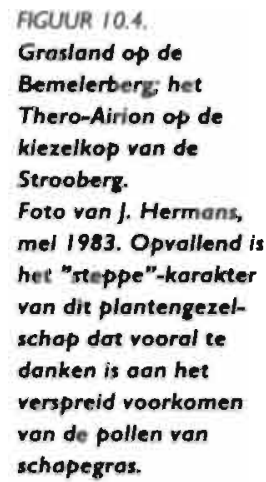

name; het Spergulo-Corynephorion.

Vooruitiopend op de resultaten van het veldwerk - yergelijk tabel 9.1 tot en met 9.5 -, kan worden gesteld dat er binnen het gebied van onferzoek lokaties zijn waar vloeiende overgangsscadia zijn te onderkennen tussen coena van het Thero-Airion en het Spergulo-Corynephorion (zie figuur 10.3).

3.3 Eenderdeassociatie van het TheroAirion binnen de Nederlandse riịksgrenzen, die door. Weschoff en Den Held wordt vermeld, is het Agrostietum tenuis Hueck 1931 em. Arndt 1956. Deze plantengemeenschap is in 1979 door Hennekens en Schaminée 14 beschreven van de plateaurand op de Bemelerberg: ze kamt evenwel ook elders op Zuidlimburgse plateauranden voor. De naamgevende soort. Agrostis tenuis, sinds kort veranderd in A. capillaris, heeft hier in alle opnamen een opvallend hoge bedekkingsgraad en gedraagt zich vergelijkbaar met Brachypodium pinnatum, een grasșoort waaraan on. langs zeer virvoerige studies zijn gewijd. ${ }^{15} \mathrm{De}$. huidige dominantie van beide soorten in droge schraallanden van Limburg, waarop geen actief beheer van toepassing was, laat zich verklaren door te stellen dat beide grassoorten beschikken over morfologische en fysiologische adaptaties om, door ondergrondse uitiopers, zich sterk horizontaal uit te breiden en daardoor andere plantesoorten te verdringen. De dominantie van de beide soorten gramineeèn is verder in de hand gewerkt door een langdurig beheer van "nietsdoen "in combinatie met het verschijnsel zure regen. Volgens de hierboven genoem-

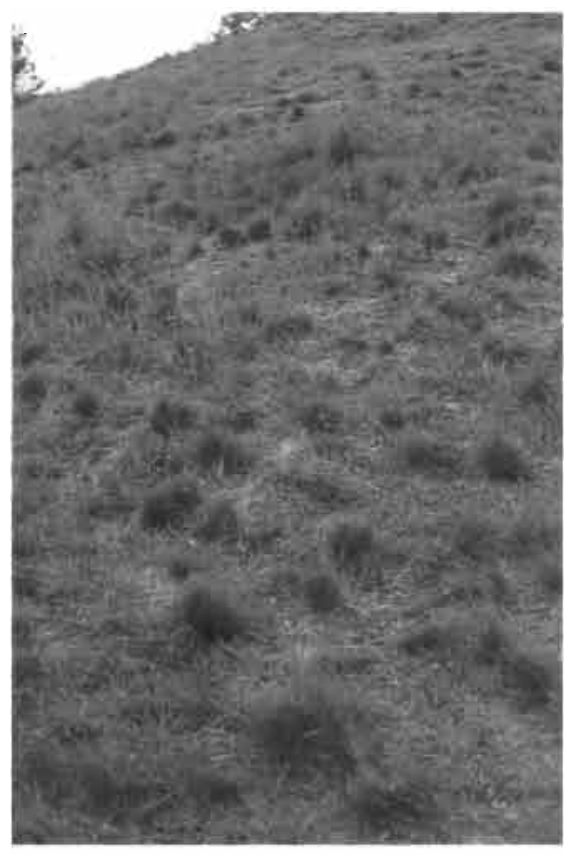

de studies geldt dit in elk geval voor Brachypodium pinnacum. De genoernde factoren verklaren de soortenarmoede van het Agrostietum tenuis; de opmerking van Westhoff en Den Held, dat deze plantengemeenschap een vervangingsgemeenschap is van een andere associatie van het Thero-Airion en op licht: nitraathoudende gronden voorkomt. sluit hier goed bij aan. De begrazingsexperi. menten, onder andere op de Bemelerberg. hebben inderdaad kunnen aantonen dat het Agrostietum tenuis met zijn "vervilte" struc. tusur en relatieve soortenarmoede na enige jaren verandert in een open, mozaiekrijke en soortenrijkere vegetatie, die te boek staat als het Festuco-Thymetum serpylii R. Tx. (1928) 1937.

Onntrent deze vierde en laatste associatie van het Thero-Airion binnen Nederland bestaat eveneens verwarring en onduidelijkheid. Westhoff en Den Held ${ }^{\mathbf{1} 6}$ geven voor her Festuco-Thymetum serpylli vier synoniemen. die elkaar deels overlappen en niet volgens de regels van de syntaxonomie zijn beschrever,. De naamgeyende: kensoort. Thymus serpyllum, wordt in één van de synoniemen vervangen door Thymus pulegioides, die el. kaar in bepaalde delen van Nederland (onder andere in Z'uid-Limburg) vitsluiten. Voorts beweren Westhoff'en Den Heid dat het Festuco-Thymetum serpylli in Nederland algemeen zou voorkomen. Het Krijtdistrict, waarbinnen het Mergelland valt, komt niet voor in de lijst van districten, waarin het Fes. tuco-Thymethum serpylli vrij algemeen voorkomt. Toch is er een opname van de westhelling van de Sint-Pietersberg bij Maas. 
tricht van Westhoff uit 1950 bekend, die op grond van zijn soortensamenstelling tot het Festuco-Thymetum serpylit moet worden gerekend (vergelijk tabel 9.1. opname 12).

Opvallend is voorts dat het Festuco-Thymetum serpyllien diens subassociaties, die door Westhoff uitvoerig zijn beschreven tussen 1939 en 1946, ${ }^{17}$ zijn gebaseerd op relatief oude data en dat meer recent, dat wil zeggen na 1980, beschreven vegetaties van droge schraallanden in Limburg wel tot het TheroAirion konden worden gerekend, maar niet tot een associatieniveau herleid. Dergelijke floristisch verarmde en in een andere structuur overgegane vegetatietypen worden momenteel als "rompgezelschap" betiteld. ${ }^{18}$ Dit zou er op kunnen wijzen dat het Festuco-Thymetum serpylli in zijn klassieke vorm. dat wil zeggen daterend uit de periode vóor 1946, uit Nederland (en zeker uit Zuid-Limburg) is verdwenen. De oorzaken daarvan liggen vermoedelijk in een gewijzigd beheer sindsdien, zoals andere vormen van beweiding, introductie van kunstmest of herbiciden en gewijzigde atmosferische deposities (zure regen).

Vooruitiopend op de conclusies van het veldwerk in Limburg - vergelijk paragraaf 4 -, kan inderdaad worden vastgesteld dat de huidige kiezelkopyegetaties van de plateauranden langs her Maas- en Jekerdal afwijken van het klassieke Festuco-Thymetum serpylli (zie figuur 10.4).

\subsection{Hieronder worden de literatuurge-} gevens uit het aan Zuid-Limburg grenzende buitenland kort samengevat.

Van het Ardense Maasgebied, rond Han sur Lesse, wordt door Thill ${ }^{19}$ een vegetatic beschreven, die hij aanduidt als "la pelouse xerophile à Potentilla argentea et Trifolium striatum". Deze plantengemeenschap wordt niet alleen bepaald door dezelfde edafische en microklimatologische factoren, maar ook door een groot aantal gemeenschappelijke soorten en eenzelfde structuur, als die welke gelden voor de kiezelkopvegetaties van het Nederlandse deel van het Maasdal ten zuiden van Maastricht.

Lebrun c.s. plaatsen de "pelouse xerophile à Potentilla argentea et Trifolium striatum" (Potentilleto-Trifolietum striati Lebrun) echter binnen het Mesobromion. Alleen nader onderzoek zou deze kwestie kunnen oplos. sen.

Van het Duitse grensgebied met Zuid-Limburg wordt het Thero-Airion uitvoerig door Korneck ${ }^{20}$ besproken. Hij onderscheidt een viertal associaties waarvan er cén, het soortenrijke Airo caryophyllea-Festucetum ovinae Tx. 1955, identiek is aan de kiezelkopvegetatie van de plateauranden van het Maasen jekerdal ten zuiden van Maastricht. Een interessante bijzonderheid in zijn tabellen van deze plantengemeenschap is de presentie van. Moenchia erecta, een soort die in 1942 voor het lastst in Zuid-Limburg werd waargenomen. ${ }^{21}$ Hoewel Moenchia erecta in Nederland wordt beschouwd als een begeleidende soort voor het Mesobrometum, het kalkgrasland, is het echter waarschijnlijker dat zij hier haar oecologisch optimum bezat in het Thero-Airion. Deze opvatting sluit aan bij die van Tuxen. ${ }^{\text {Iz }}$

Eveneens van Duitsland, maar specifiek van de Sötenicher Kalkmulde in de Eifel, een gebied dat op ongeveer $80 \mathrm{~km}$ vanaf de grens met Zuid-Limburg is gelegen, stamt een beschrijving van het Thero-Airion door Schumacher ${ }^{23}$ Evenals Korneck onderscheidt hiin een viertal associaties, waarvan het Airo caryophyllea-Festucetum ovinae zeldzaam voorkomt. Schumacher geeft een opname, afkomstig van de rand van een steengroeve te Vussem. Bij een bezoek aan deze steengroeve bleek nog een kensoort varı de hier. boven vermelde associatie present te zijn, die in de opname van Schumacher ontbrak, na. melijk Aira praecax. Met deze vermelding worden de overeenkomsten tussen de Zuidlimburgse en Eifelse standplaarsen van het Airo caryophyllea-Festucetum ovinae nog eens extra onderstreept. ${ }^{24}$ Van het Franse kustrgebied ten noorden yan Normandië heeft Wattez ${ }^{23}$ uitvoerig enige vegetatietypen be. schreven, die tot het. Thero. Airion zouden behoren. In dit ge. bied werden twee pioniervegetaties van yoormalige zand-en grindgroeven onderzocht en beschreven, waarvan de eerste duideliike overeenkomsten vertoont met de door Aira praecox gedomineerde vegecaties van de Nederlandse duingebieden, terwijl de andere pioniervegetatie overeen komemet door soorten uit het genus Vulpia gedomineerde typen. In Zuid-Limburg wordt dit laatste type vooral aangetroffen op en langs schouwpaden van spoorlijnen (vergelijk tabel 9.2). Gezien het feit dat Vulpia-soorten zich in de loop van de laatste decennia hebben gevestigd of sterk uitgebreid, met name langs spoordijken en spoorwegemplacementen, maar ook in schrale graslanden, lijkt het zeer waarschijnlijk dat er binnen het Thero-Airion een voor Nederland nieuwe plantengemeenschap kan worden beschreven.

\section{1} Hieronder volgen de resultaten en conclusies van het veldwerk in Limburg wat betreft verspreiding, abiotisch milieu, structuur, soortensamenstelling en beheer van enige coena van het Thero-Airion.

De resultaten zijn vastgelegd in de tabellen 9.1 tot en met 9.5. van de bijlagen. Ten aanzien van de interpretatie van de hierin vermelde gegevens past enig voorbehoud. Het aantal opnamen per lokaliteit varieert slechts van én tot drie, hetgeen voor een uitvoerige statistische analyse onvoldoende is. De opnamen zijn vaak beperkt van omvang. meestal $2 \times 2 \mathrm{~m}$, zodat de kans bestaat dat een opname niet voldoet aan de eisen van het minimumareaal. Afgezien van de kjeinschaligheid van coena van het Thero-Airion, zijn deze binnen het onderzoeksgebied betrekkelipk zeldzaam. Desondanks geeft het hieronder vermelde overzicht van 3 | vegetatieopnamen een overzichtelijk beeld van een voor Limburg en omgeving karakteristiek en om verschillende redenen bijzonder vegetatietype.

Ten aanzien van de geografische verspreiding van de coena van het Thero-Airion kan worden vastgesteld, dat zil diffuus over het gehele onderzoeksgebied voorkomen (zie figuur

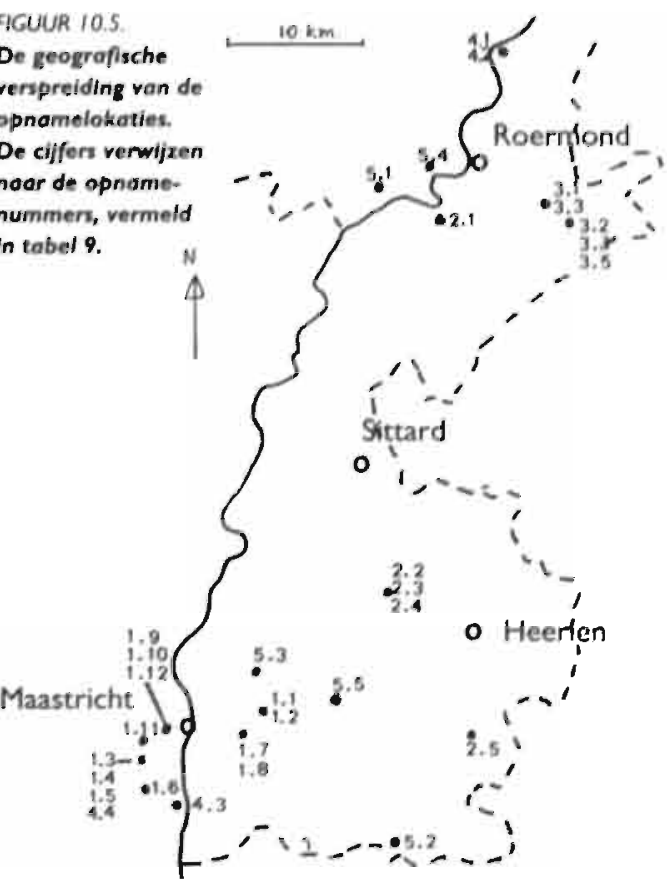




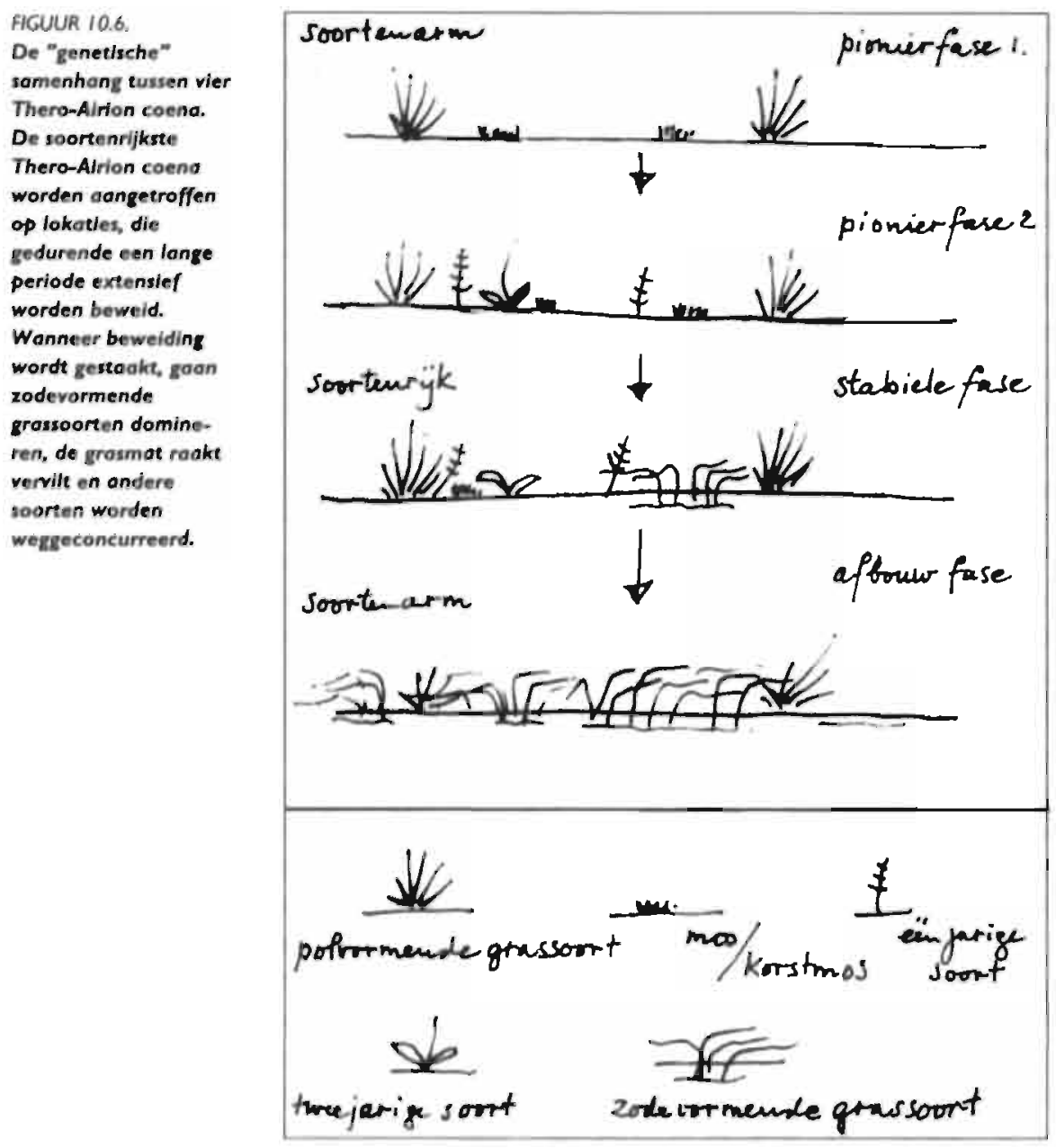

10.5). Niettemin zijn er minstens vier concentratiegebieden aan te wijzen, met name in graslanden op de plateauranden van het Maas- en Jekerdal in Zuid-Limburg, zowel op Nederlands als op Belgisch grondgebied, langs spoorwegen in het gehele gebied van onderzoek, op een enkel rivierduingrasland in Midden-Limburg en op een aantal zandgebieden in (voormalige) heidelandschappen. Tot de laatstgenoemde groep behoren onder andere plaatsen op de Brunssummerheide, de Melickerheide en de Beegderheide. De opnamelokaliteiten Meerssen (zie tabel 9.5. nr 3) en Cottessen (zie tabel 9.5, nr 2) vallen buiten dit kader:

Vooral in Zuid-Limburg is het huidig voorkomen van coena van het Thero-Airion een zeldzaamheid. Bovendien is het totaal oppervlak per groeiplaats meestal zeer beperke van omvang, variërend van 10 tot hoogstens 500 vierkante meters.

Sommige factoren van het abiotisch milieu van de standplaats kunnen sterk wisselen. andere zijn constant. Voor het bewortelde substraat geldt, dat de korrelgrootte varieert van stuifzand tot kiezel. De geologische herkomst van de bodem is zeer verschillend. 20
Hẹt humusgehaltẹ, hẹt water vasthoudend vermogen, de trofiegraad en het kalkgehalte zijn vermoedelijk laag. In een groot aantal lokaliteiten lijkt een zekere mate van bodemverdichting duidelijk een rol te spelen.

De expositie van opnamen op een hellende ondergrond is meestal zuidwaarts. Naar het noorden geèxponeerde standplaatsen zijn niet aangetroffen.

$$
4.2
$$
gezelschappen varieert aanzienliijk: er zijn vier typen te onderscheiden, waartussen overgangen bestaan (zie figuur 10.6). Het eerste type wordt gekenmerkt door een laag bedekkingspercentage, minder dan $65 \%$. Het aandeel van de eenjarige soorten, de zogenaamde annuellen (groep $C$ van tabel 9.1) in het vegecatiedek is hoog, dat van de polvormende en zodevormende overjarige grassen (groep A en B van tabel 9.1) laag, terwiil de dwergstruiken (groep G van tabel 9.1) ontbreken. Het tweede type vertoont een mozaiekpatroon, dat wil zeggen heeft een horizontale afwisseling van diverse levensvormen, maar het vegetatiedek is open. dat wil zeggen hier en daar zijn onbegroeide plekken in het vegetatiedek. zichtbaar. Het derde type bezit de hoogste mozaikdiversiteit en is tevens het meest soortenriijk. Het vegetatiedek. is vrijwel gesloten. Het vierde vertoont nauwelijks, een mozaiekpatroon; annuellen ontbreken nagenoeg. De groep van de zodevormende gramineeën is dominant; het vegetatiedek is volledig gesioten en plaatselijk zo dicht, dat van een "viltige" grasmat sprake is (zie figuur !0.6).

De "genetische" samenhang van de vier onderscheiden structuurtypen, dat wil zeggen de wijze waarop zij uit elkaar ontstaan, wordt. in grote lijnen bepaald door de factoren tijd en begrazing: structuurtype I vertoont alle kenmerken van een pioniersstadium. Bij type 2 is de kolonisatieperiode afgesloten. Zonder begrazing ontwikkeltzich een gesloten vegetatiedek. Type 3 vertegenwoordigt de begraasde vorm, die zich in de tijd min of meer stabiliseert als gevolg van het: feit dat alle soorten binnen elk patroontype op de een of andere wijze begrazingsresistente eigenschappen bezitten (zie figuur 10.6). Structuurtype 4 wordt beschouwd als de afbraakfase. Door onder andere het uitbliijven van beweiding gaan de zodevormende gramineeèn domineren en verdringen op deze wijze eerst alle annuellen en mossen, vervolgens de meeriarige rozetten en tenslotte alle dwergheesters.

In floristischch opzicht vallen vooral de kiezelkopvegetaties; van de plateauranden in het Maas-en Jekerdal op door hun hoge soortdiversiteit en een groot aantal zeldzame soorten. Het laatste geldt met name voor de groep van de annuellen, zoals de beide Aira's, Desmazeria rigida, Filago minima, Vicia lathyroides, Vulpia bromoides, Holosteum umbellatum en Myosotis stricta. De perenne soorten Trifolium scabrum en Potentilla argentea zịin uitsluitend van coena van het Thero-Airion bekend (zie figuur 10.7).

Inmiddels zijn uit de kiezelkopvegetaties waarschijnlijk verdwenen: Ornithopus perpusillus, Moenchia erecta en Spergularia segecalis (zie figuur 10.8).

4.3 De vegetaties der kiezelkoppen behoren tot het Airo-Festucetum ovinae Tx. 1955. Deze conclusie is gebaseerd op grond van de volgende argumenten: de hoge presentie en abundantiecijfers van de kensoort Festuca ovina, de hoge trouwgraad van de beide Aira-șoorten en andere annuellen en de presentie van andere levensvormen (zodevormende gramineeèn, moskussens, (half)parasieten, rozetplanten en dwergheesters). 


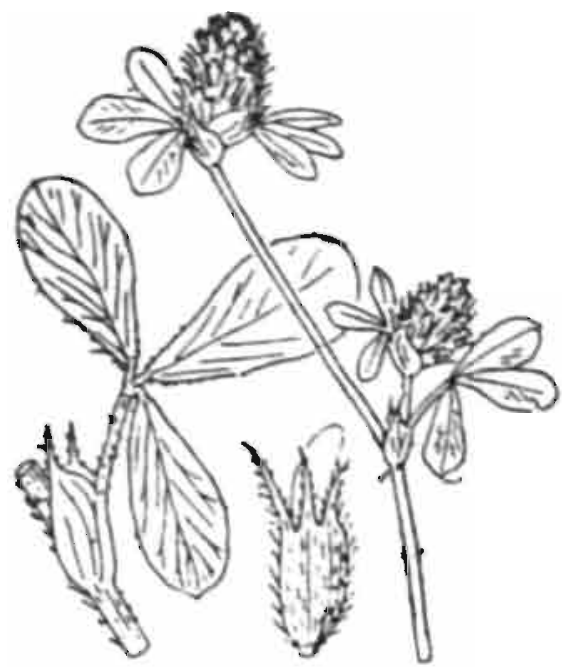

Trifolium striatum.

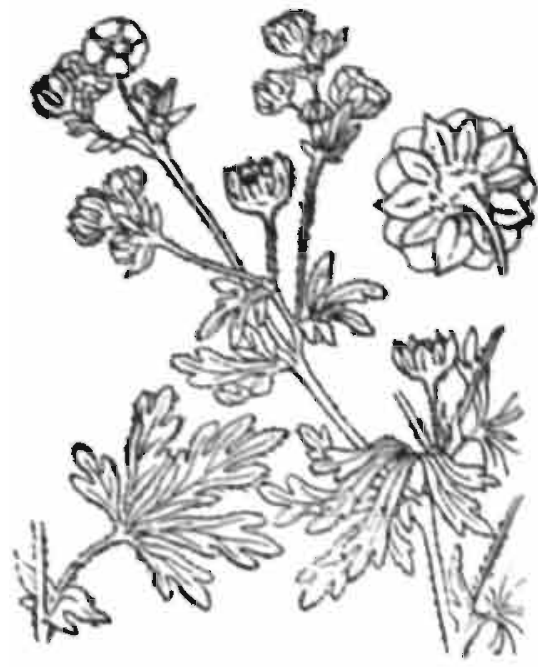

Potentilla argentea.

FGUUR 10.7. Twee herontdekte kensoorten ven het Thero-Airion noar Hiukis 1911. Gestreepte klover (Trifolium striatum) en viltgonxerik (Potentillo argenteo) zijn herontdekt, woar extensieve begraxing door schopen weer werd toegepast.

waarvan het soortenbestand weliswaar wisselt, maar waarvan het mozaiekpatroon telkens het aspect bepaalt.

Ook de opnamen van spoorwegen en spooremplacementen, verzameld in tabel 9.2. zijn tot de bovengenoemde associatie te reke. nen. Ze zijin echter minder soortenrijk, ze vertonen een minder duidelijk mozaiekpatroon en bepaaide levensvormen ontbreken. Ze verschillen van de kiezelkopvegetaties door de presentie van beide Vulpia's. Deze gezelschappen zijn jong en als pioniervegetaties te karakteriseren.

De opnamen, verzameld in tabel 9.3, laten overgangen zien met het Spergulo-Coryrie- phorion. Ze onderscheiden zich duidelijk van het Airo-Festucetum ovinae en well door de presentie en abundantieciffers van de kensoort Corynephoros canescens en door de presentie van de differentiérende soorten Teesdalia nudicaulis en Crnithopus perpusilus. Bovendien verschilt het substraat (vastgelegde stuifzanden) aanzienlijk van dat van de kiezelkopvegetaties. Dit vegetatietype komt ook voor op de: Brunssummerheide, maar werd daar niet nader onderzocht.

De opnamen, verzameld in cabel 9.4 , laten eveneens, overgangen zien, onder andere naar het Sedo-Cerastion. In deze rivierduingraslanden (opname I en 2) en open krijthel- linggraslanden, op plaatsen waar tevens tertiaire zanden dagzomen (opname 3 tot en met 5), komen diverse $\mathrm{Ca}$-indicatoren voor. zoals Sedum sexangulare, Sedum album, Saxifraga tridactylites en Erodium cicutarium. Dit zijn, met uitzondering van Erodium cicutarium, kensoorten van het Sedo-Ceras. tion.

De restopnamen van tabel 9.5 laten soortenarme begroeiingen zien. De soortenarmoede is te verklaren, doordat zij pioniersstadia vertegenwoordigen (opname 1, 3 en 5) ofwel door de hoge bedekking van de zodevormende grassoort Agrostis capillaris (opname 4), die door een grote concurrentiekracht in staat is andere soorten te doen verdwijnen. In elk geval is er in alle overige opnamen sprake van een zekere ruderalisatie. veroorzaakt door tred (opname 4), tred en recreatie (opname I en 5) en het gebruik van kunstmest (opname 2). Vermoedelijk bewerken deze activiteiten een verhoging van het stikstofgehalte van het substraat.

\section{4}

Hoewel het onderzoek naar de fy. siologische kenmerken van de kiezelkopvegataties als geheel of van bepaaide soorten daarvan in het bijzonder, buiten het kader van deze studie valt, is het evident dat dit vegetatietype moet beschikken over yoor Nederlandse maatstaven extreme aanpassingen ten aanzien van zijn waterhuishouding.

De droogteresistentie kan niet alleen worden afgeleid uit de met het blote oog zichtbare morfologische eigenschappen van de individuele soorten, maar tevens uit het oecologisch gedrag,van de kiezelkopvegetatie gedu-

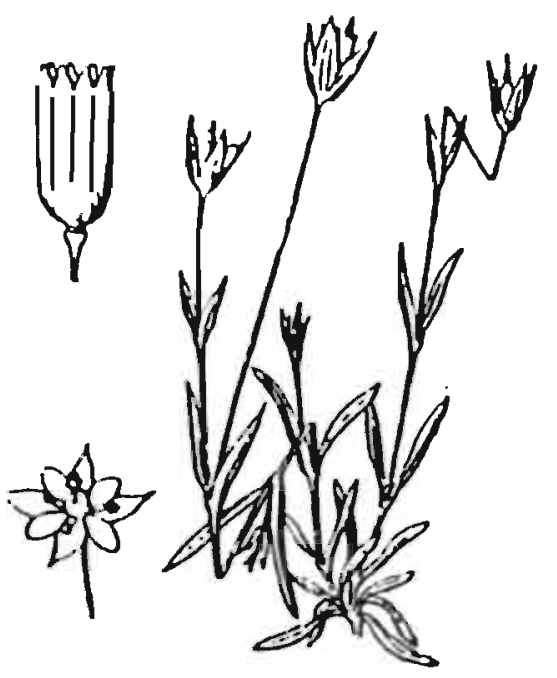

Moznchla erecta.

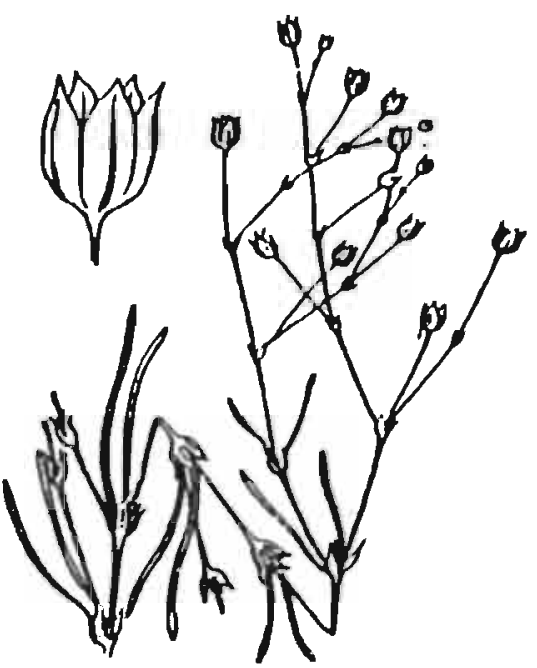

Spergularla segetalls.

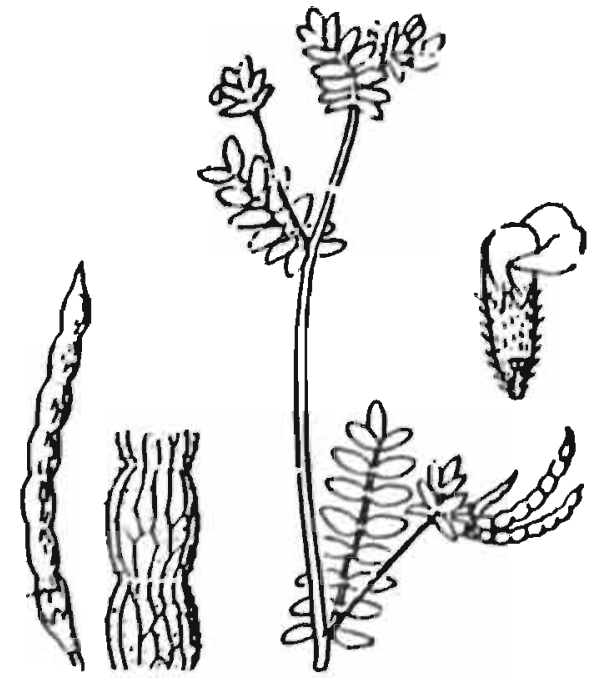

Omithopus perpusillus.

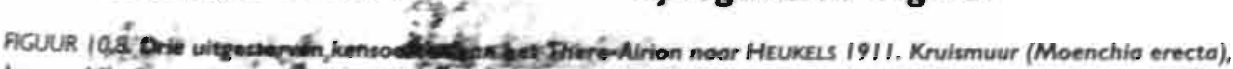

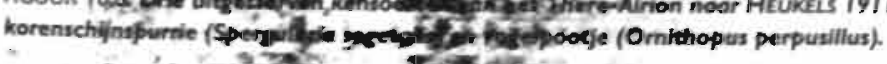




\begin{tabular}{|c|c|c|c|c|c|}
\hline $0 \stackrel{\text { bled }}{0}$ & "betplaut" & nilt op thed & 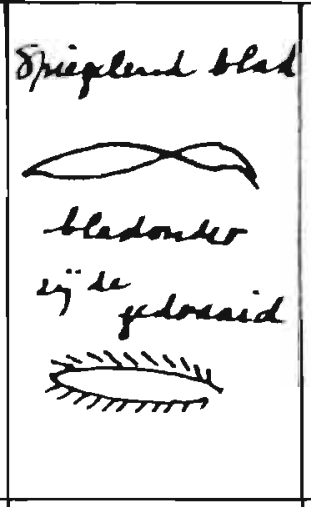 & 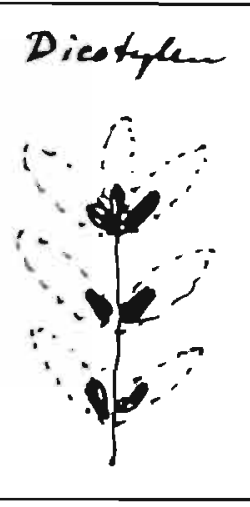 & $\begin{array}{c}\text { mons estylen } \\
\vdots \\
\vdots \\
\vdots \\
\vdots \\
\vdots \\
\vdots \\
\vdots\end{array}$ \\
\hline & Sucoulen tie & & Sichtreferie & \multicolumn{2}{|c|}{ Micrefflli } \\
\hline 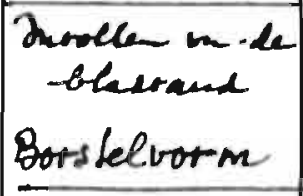 & $\begin{array}{l}\text { Unettip slap } \\
\text { in thad } \\
\text { enstengel }\end{array}$ & $\begin{array}{l}\text { Belering } \\
\text { howet } \\
\text { hellthy } \\
\text { not. }\end{array}$ & 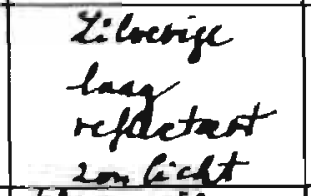 & \multicolumn{2}{|c|}{$\begin{array}{l}\text { Reducte bet } \\
\text { Hed oprerolat }\end{array}$} \\
\hline Fepturee onime & Sedewer eare & Filagp minima & $\begin{array}{l}\text { ther pilos. } \\
\text { Potent arg. }\end{array}$ & eqtiven reop & Agrotes. \\
\hline
\end{tabular}

\begin{tabular}{|l|l|l|l|l|}
\hline & 1 \\
\hline Pronit
\end{tabular}

FGUUR. 10,9. Morfologische adaptaties met betrekking tot het beperken van vochtverlies door verdamping (droogte-resistentie) bif een aontal kensoorten van het: Thero-Airion. Voor de verkdaring van de termen vergelijke men de tekst van dit hoofdstuk.

rende het jaar: de periodiciteit van groei en bloei vindt, in tegenstelling tot de meeste plantengezelschappen in Nederland, plaats gedurende een weetal fasen. De eerste vindt plaats in het vroege voorjaar, de tweede in het najaar. Gedurende de zomer-en wintermaanden verkeert de kiezelkopvegetatie in een zekere rust. De vooriaarsbloei van de annuellen valt het meest op: de najaarsbloei wordt gekenmerkt door het geel van diverse bi-annuelle soorten.

De als droogteresistentie op te vatten mor- fologische adaptaties zịn zeer gevarieerd per groep van levensvormen (zie figuur 10.9). De soortengroep der polvormende gramineeèn. groep A van cabel 9 . I, bezit opgerolde bladeren. De met stilstaande lucht gevulde holte beperkt een overmatige verdamping. De zodevormende gramineeên, groep B van tabel 9.1. vertonen minder duidelijke aanpassingen die verlies van water voorkomen. Mogelijk heeft de bladbeharing van Luzula campestris een dergelijke functie, evenals de reductie van het totale bladoppervlak bij het opvallend smalbladige gras Agrostis capillaris. Groep $C$ van cabel 9.1 , de annuellen, overieven de zomerse droogte als zaad, terwill enkele vetplanten uit deze groep een zekere reserve aan vocht in hun weefsels opslaan. De mossen van groep $D$ van tabel 9.1 vertonen een duidelijke periodiciteit gedurende hun jaarcyclus. Alleen in het yoor-en najaar zijn ze de gehele dag actief. Gedurende extreem droge zomerdagen is hun fysiologische activiteit beperkt. Dank zij het bezit van speciale hygroscopische cellen kunnen ze atmosfe- 
risch water opnemen. De in aantal beperkte soortengroep van de parasieten en hemiparasieten vertoont eveneens een duidelijke periodiciteit. Van de hemiparasieten rondt de ene soort (Rhinanthus minor) haar cyclus af in het voorjaar, de andere (Euphrasia stricta) in de nazomer. In dat seizoen heeft ook de parasiet Cuscuta epithymum zijn optimum.

De bi-annuelle en perenne soorten van groep F en G zijn dank zij hun uitgebreid wortelstelsel in staat langer te profiteren van een regenbui. Daarnaast vertonen ook de bovengrondse delen veel morfologische aanpassingen die vochtverlies beperken. Beharing van het blad verstrooit het zonlicht en vermindert de verdamping. De onderzijde van het blad van Hieracium pilosella draait zich gedurende een droogteperiode om haar lengte-as, bezit een licht reflecterende opperhuid en kan op deze wijze lange droogteperiodes overbruggen. Ook de reductie van het totale bladoppervlak, hetzij door het aantal bladeren te reduceren (en de stengel deels de bladfuncties te laten overnemen), hetzij door reductie van het oppervlak per blad, voorkomt overmatig vochtverlies. Het eerste komt onder andere voor bij de bezembrem (Cytisus scoparius), het tweede bil struikheide (Calluna vulgaris). Hetzelfde ge!dt voor een zichtbaar en voelbaar wasachtig laagje op alle bovengrondse delen, omgekrulde of ineengerolde bladeren. De overige aanpassingen zijn alleen microscopisch waarneembaar of fysiologisch aantoonbaar; maar ook zonder verdere hulpmiddelen dan alleen het blote oog kan men bij talrijke soorten uit deze gemeenschap een grote variatie aan mechanismen waarnemen, die ten dienste staan van het voorkomen van vochiverlies.

\section{5}

Het beheer van kiezelkopvegetaties en andere plantengemeenschappen die onder het Thero-Airion ressorteren, dient te bestaan uit een extensieve beweiding met schapen of begrazing door wilde konijnen. omdat de verschillende effecten van hun begrazing minder grove verstoringen in het milieu van het Thero-Airion veroorzaken dan de veel grotere herbivoren, zoals paarden of rundvee. Een lichte graad van betreding door mensen en de eventueel daarmee gepaard gaande eutrofiëring door recreatie lijkt vooralsnog niet schadelijk. Kiezelkopvegetaties in omheinde reservaten, waarin periodiek een hoge begrazingsdruk door schapen voorkomt, lopen het gevaar te eutroof te worden, omdat de schapen deze droge milieus als rustplekken verkiezen en relatief grote hoeveelheden mest achterlaten. Het beheer van plantengezelschappen van het Thero-Airion op spoordijken en -emplacementen of in verlaten grindgroeven is problematischer; een hoge begrazingsdruk door wilde konijnen toelaten, lijkt vooralsnog de enige manier om het voortbestaan van deze vegetatietypen voorlopig te garanderen. Het mechanisme van het begrazingsbeheer met mergellandschapen berust op selectie van de grazer. ${ }^{27}$ De karakteristieke soorten van het droge schraalland - en dus ook van het Thero-Airion - zijn tot op zekere hoogte begrazingsresistent. De polvormende grassen zijn hard, taai en bevatten waarschijnlijk grote hoeveelheden cellulose; de zodevormende grassen worden positief geselecteerd; de zode blipft daardoor onder andere open voor de annuelle dwergen. Dergelijke "nanistische" $2 \mathrm{at}$ levensvormen zijn overigens typerend voor schapenweiden. Open plekken worden eveneens bezet door rozetsoorten, waarvan de op de vlakke bodem gedrukte bladeren voor de plukkende schapelippen onbereikbaar zijn. Van de houtige dwergstruiken worden alleen de zachte toppen geconsumeerd; deze soorten ontwikkelen zich tot buitige structuren.

\section{5}

Plantengemeenschappen die tot het Zilverhaver-verbond behoren, komen in Zuid-Limburg sporadisch en kleinschalig voor op uiteenlopende, maar extreem droge en kalkarme standplaatsen. Vooral de zogenaamde kiezelkopvegetaties die op de plateauranden van het Maas- en Jekerdal vrijwel alleen in natuurreservacen zijn aan te treffen, kenmerken zich door een grote soortenrijkdom en een opvallend mozaïekpatroon. Sommige soorten die tot het verbond van Zilverhaver behoren, zijn in het Mergelland viterst zeldzaam en komen slechts in dit vegetatietype voor. Patroon, structuur en soortensamenstelling vertonen een duidelịke samenhang metzowel het abiotisch milieu als met de wijze van beheer. De aanpassingen die de individuele soorten bezitten zowel ten aanzien van de vochthuishouding als begrazing, zijn bijzonder opvallend en verdienen nader te worden bestudeerd.

Het onderzoek naar het Thero-Airion in Limburg, waarvan het zwaartepunt zich concentreerde op begraasde vegetaties van de kiezelhoudende randen van de plateaus in het Mergelland, vormt de afsluiting van een reeks van vegetatietypen die eerder werden beschreven, met name het kalkgrasland (Mesobromion) en het heischrale grasland (Vio- lion). Dit drietal plantengemeenschappen vormt samen de hoofdstructuur van alle droge schraallanden in het Mergelland, waarvan de restanten, onder andere vanwege hun overweldigende soortenrijkdom, tot natuurgebied zijn verklaard.

De restauratie en het verdere onderhoud van dit om diverse redenen bijzondere en interessante vegetatietype. dient te geschieden door extensieve beweiding door mergellandschapen.

\section{NOTEN}

1 Westron EN DEN Heto 1975. p. ISI

2 Wuins 1989.

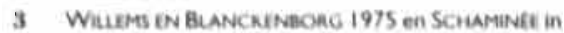
Hitutcens 1984a, pp. 23-25

- Huscans 1986

5 Hurcans $1983 b$

6. Westhom en Den HeLo 1975

7 Srroma EN Westrion 1987 en Bunkrun 1968 De eerstgenoemde publicatie geeft een verhelderend betoog betreffende de genese van schrale grasiandvegetaties in relatie tot het beheer Tevens worden in deze publicatie enige nieuwe syntaxonomische begrippen geintroduceerd, die van toepassing bleken op Zuidimburge Thera-Airion coena De tweede publicatie geet nieuwe insichten in het begrip minimumareas Zie ook Scourtinfer et al 1991.

a De betreffende oprame (tabel 91, nr 12) door Westholf dateert wit 1950 en werd opgenomes op de westelijke plateaurand van de Sint-Pietersberg bij Mastricht De lolatie van de opname is inmiddels sterk veranderd: de genoemde soorten Omithopus perpusillus en de beide Aira soorten komen in het gethed niet meer voor

9 EULANERG 1982.p 638 en KOHNECK in Suddeutsche Pflanzengesellschaften 1987.pp. 13-31

11. ElLENBERG 1982, p. 638.

11 Onder andere op de Hierebergen Schiepersberg bif Cadier en Keer

12 WESTHOFE EN DEN HELO 1975.

13. KORNECK in Suddeutsche Pflaniengesellischaften $198 \%$.p. 23

14 HENNEKENS EN SCHAMINGE in HILIEEER 1984 .

I5 BoBaink 1989 en DE KROON 1990.

16. WETHOH EN DEN HFW 1975, p. ISI

17 MeLtzer et al. 1940

18 STKORA EN WESTHOFt 1987 en SCHAMINEE et al. 199 !

19 THLL 1964, pp. 36-37

20 KORNACK in Süddeutsche Pflanzengeselischałten 1987, pp 13.31

21 Atas van de Noderlandse flora 1985-1989, deel 1. p. 148 :

22 Kiausch 1986, pp. 74 en 76. 8lijkens de gegevens van Krausch doet zich dezelfde parallelle situatie voor ten aanzien van Moenchia erecta in Brandenburg als in Zuid-Limburg vór 1960 opgegeven als kensoort van het Thero-Airion, daarna verdwenen. Zie ook hooldstuk 12

23 SCHUMACHER 1977, pp. 106-108

24 De excursie vond plaats op 06.07 .1982

25 WATTEZ 1977.

26. Onder andere terciaire zanden en grinden, kwartajre dekzanden, carbonische feisteen, zanden en steengruis van onbekende herkomst en geologische ouderdom.

27 VAN DUIVEN OORDE 1984

28 Letterligk "dwergachtig", vergelijk HARANT EN jas. kY 1987,p. 258. 


\title{
ALGEMENE OECOLOGIE VAN HET DRIESLAND
}

\author{
"... Les chardons et autres plantes voraces qui les \\ (jachères) couvrent ordinairement."
}

In hoofdstuk 4 werd aangetoond, dat de fundamentele betekenis van de oude boerenterm "dries" synoniem is yoor "braak". Gronden of percelen waarop de term dries van toepassing was, lagen ofwel permanent braak en werden benut als weideplaatsen of veeverzamelplaatsen, zoals dorpsbrinken, percelen aan de buitenzijde van de stadsomwalling en stenige gronden die ongeschikt waren voor de ploeg. Driesland kon ook tijdelijk braakliggen. Daarna werd de braakperiode afgewisseld met een periode. waarin de verbouw van een landbouwgewas, meestal rogge, plaats vond. In het nu volgend hoofdstuk wordt de dries volgens de laatste betekenis gedefinieerd als een periodiek braakliggend perceel, waarop na de braakperiode èen of meer jaren graarı werd verbouwd. Afgezien van de rotatie braak-graanbraak enzoyoort was beweiding door vee in kuddeverband essentieel, zowel in het braakjaar als, na de oogst van het graan in de vorm van stoppelbeweiding. Minder essentieel was de duur van de braakperiode of het antal graanjaren: dit hing af van de vruchtbaarheidsgraad van het perceel, waarop de rotatie werd toegepast en verschilde van perceel tot perceel.

De term "braak" verdient enige toelichting. De huidige betekenis daarvan, dat: wil zeggen "niet produktief", geldt niet voor het verleden. Op de eerste plats was de braak immers een noodzakelijk weidegebied voor de dorpskuddde. Voorts fungeerde de vegetatie van het driesland als bemesting voor de daaropvolgende graanoogst ofwel in de vorm van groenbemesting, die door de ploeg met keerbord tot stand werd gebracht, dan wel de door het vee omgezette vorm daarvan, die ter plaatse werd achtergelaten. Tenslotte fungeerde de beweiding van braak en stoppel tevens als een wijze van onkruidbestrijding; vraat, voorkomt of beperkt de bloei. zaadzetting en uitbreiding van de braakvegetatie.

Het driesland, gekenmerkt door een karakteristiek en hierboven omschreven agro-pastoraal gebruik, kan tevens in een algemene en meer op het landschap betrokken zin worden omschreven als een deel van de "cultuursteppe" rond de nederzetting. De term "cultuursteppe" doelt enerzijds op uitgestrekte graanculturen, weidend vee en menselijke. bedrifvigheid bij het ploegen, zaaien en oog. sten, anderzijds op een open, vlak of zwak goivend en weids landschap, waarin natuurlijk aandoende clementen als onkruidrijke graanvelden elkaar afwisselen met braaklanden en stoppelveiden, waaropgrote herbivoren in groepsverband worden gehoed (zie figuur (I.I).

In elk geval is dit oecosysteem, dat binnen het. onderzoeksgebied al sinds het neolithicum। op kleine schaal bestond en dat zich vooral sinds de hoge middeleeuwen sterk heeft uitgebreid wat betreft areaal en soortensamen. stelling, vanaf de introductie van de intensieve vecteelt tijdens de tweede helft van de twintigste eeuw vrijwel geheel verdwenen. De al eerder genoemde Tranchotkaarten uit het begin van de negentiende eeuw geven een duidelijk beeld van de cultuursteppe die, met name op de plateaus, het landschap van ZuidLimburg domineerde.

Het is niet eenvoudig om het verschil te schetsen tussen de drieslanden en de rest van de cultuursteppe, omdat tussen beide termen slechts graduele verschillen bestaan. Wat betreft de ligging binnen de gemeente ligt het driesland aan de periferie, dat wil zeggen tussen de permanente schraallanden of bossen en de permanente bouwlanden dichtbij de nederzetting. Deze ligging is identiek met die uit Drenthe, waar het driesland tussen de heide en de es was gelegen. Driesland werd niet voorzien van stalmest; groenbemesting na de braakperiode en de achtergebleven mest van het weidende vee volstonden voor een volgende oogst van rogge of een ander weinig eisen stellend graangewas. De omvang van het areaal driesland omvatte, voordat het gebruik van stalmest werd geintroduceerd, het gehele areaal landbouw. grond voor zover dat met granen was ingenomen. Nadien daalt het areaal driesland; alleen de meest perifere, onvruchtbare en niet met stalmest; voorziene delen van het areaal aan bouwgrond blijven tiijdens de negentiende eeuw als driesland in gebruik. $\mathrm{Na}$ de intro-

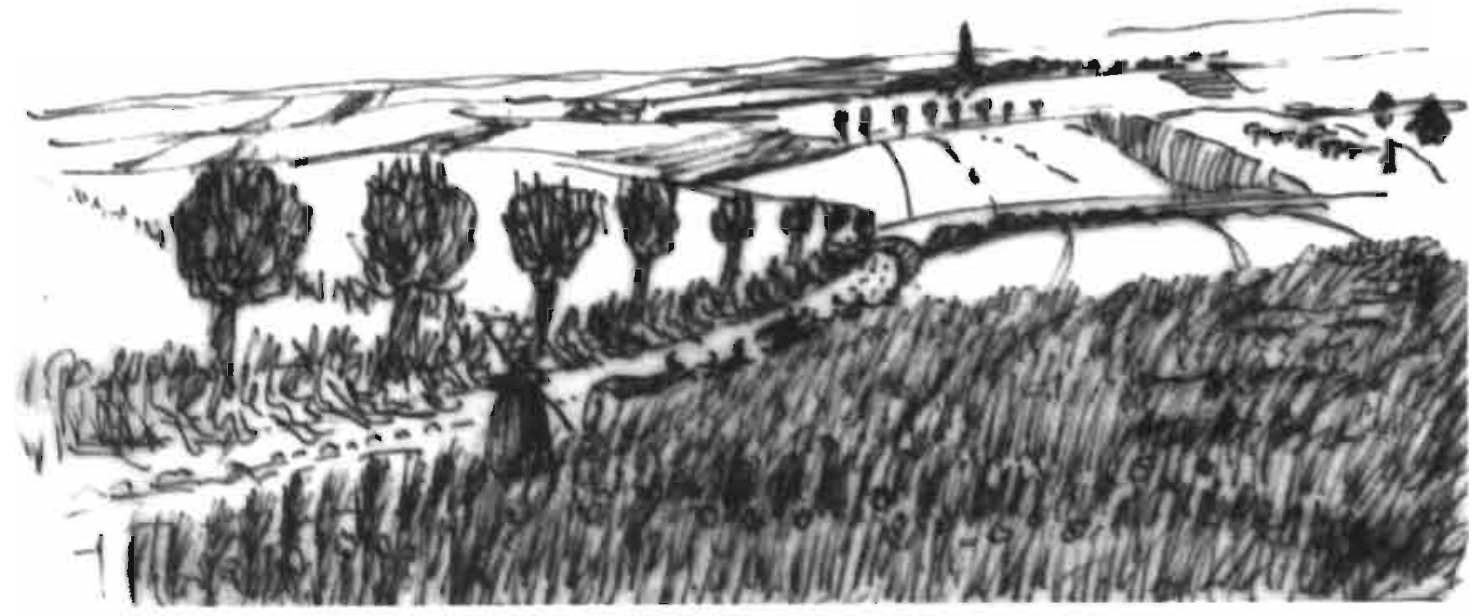

FGUUR 11.1. Een beeld van de cultuursteppe in Zuich-Limburg rond 1850. Het golvende: plloteoulandschop is in kleine percelen opgedeeld; een teelt van grainen domineert Op een brede, deels holle veldweg beplont met knotwiligen, loope de koeheert met rijn kudde tervg noar de nederzetting. Een schoopsikudde onder leiding ran de scheper bewreidt de stoppelvel. den De groanschoven zijn voorlopig opgetort in ronde korenmijten. 

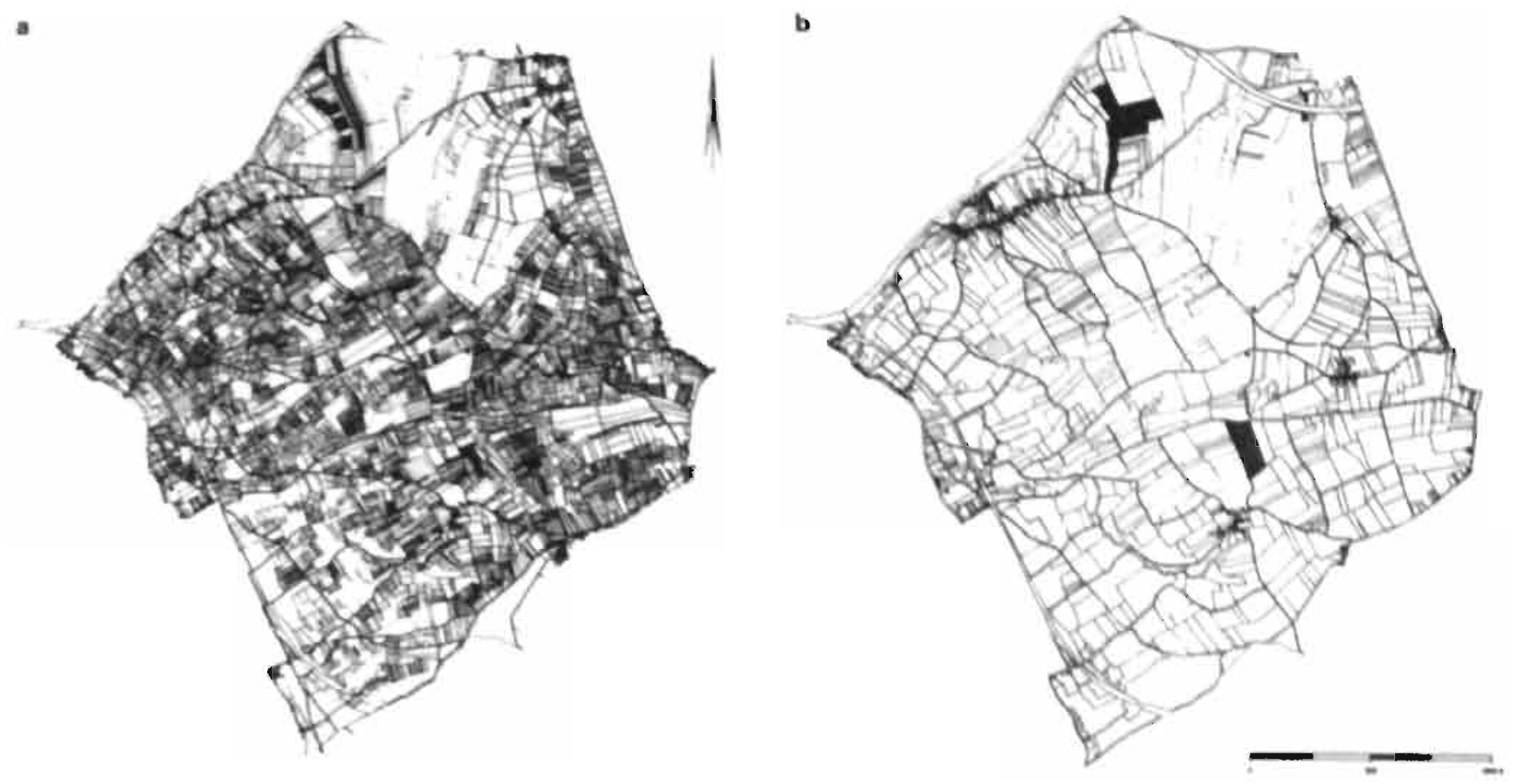

FGUUR 11.2. Parcellering vódr en na ruilverkaveling. Kadastrale indeling van het Ransdalerveld vobr en na de ruilverkaveling naer ReNEs 1988. Niet alleen xijn de individuele percelen in oppervlak toegenomen, ook veel kJeine landscheptelementen, roals groften, veldwegen, poelen en overhoeken, sijn verdwenen.

ductie van kunstmest rond het begin van de twintigste eeuw verdwijnt het driesland definitief.

In de tweede paragraaí van dit hoofdstuk worden de belangrijkste antropogene factoren besproken, die het driesland in de loop van haar evolutie hebben beìnvloed en daardoor medebepalend zịn geweest voor de soortensamenstelling van zijn vegetatiedek; alleen die soorten organismen met een bepaalde levensstrategie kunnen in een dergelijk door de mens gestoord milieu overleven. Dit is het thema van de derde paragraaf. Tevens wordt ingegaan op de vegetatiekundige aspecten van het cultuursteppegewas par excellence: het wintergraan en de daaraan gebonden onkruidflora.

Vervolgens worden enige gecultiveerde braakgewassen besproken die, ofschoon zij de biologische diversiteit van de dries als oecosysteem aanzienlijk hebben vergroot, uiteindelijk bijdroegen aan het einde van de wilde braak.

Tenslotte wordt in de laatste paragraaf van dit hoofdstuk gepleit voor een plaatselijk behoud, respectievelijk herstel van de dries op grond van cultuurhistorische, biologische en educatief-recreatieve argumenten.

2.I Elk oecosysteem wordt gekarakteriseerd, afgezien van de floristische samenstelling van haar vegetatiedek en de daarvan afhankelịke diersoorten, door een specifiek abiotisch milieu. Niet alleen bepalen de van nature aanwezige abiotische factoren, zoals bodem-, water-, licht- en luchtkwaliteiten, her vegetatiedek en de daarvan afhankelijke fauna. Ook zijn de invloeden van belang, die uitgaan van menseliike activiteiten. Grondbewerking, bemesting, betreding, begrazing en de wijzen en technieken van exploitatie van het gecultiveerde gewas bepalen in hoge mate het milieu van de cultuursteppe.

In de onderstaande paragrafen wordt een overzicht gegeven van de belangrijkste antropogeen bepaalde invloeden op het milieu van de cultuursteppe, gezien vanuit het perspeccief van de tijd. Achtereenvolgens komen aan de orde: areaal, oppervlak en vorm, assortiment aan gewassen, "shifting cultivation", grondbewerking, het gebruik van vuur en andere wịzen van bemesting, weidegang en nevenprodukten van en op driesland, waarop braak- en graanjaren elkaar regelmatig afwisselden.

Vanaf de prehistorie tot nu neemt het gemiddelde oppervlak van zowel een graanakker als van het met graan beteelde areaal van een nederzetting toe met een factor van ten minste 50 , terwijl de vorm van de graanpercelen zich wijzigde van klein en oval naar groot, rechthoekig en langwerpig.

De prehistorische graanakkertjes van de Bandkeramiekers en de raatakkers van het
Celtic field-type bezitten slechts een opper. vlak van minder dan één ha: ${ }^{2}$ de huidige akkers beslaan vala meerdere hectaren. Deze sterke coenarne van de gemiddelde perceelgrootte is onder andere mogelijk gemaakt door technische innovaties van het land. bouwgereedschap, met name dat van de ploeg en de tractie daarvan. De toename kreeg een exponentieel verloop na 1950 , toen de bio-industrie het gemengde bedrijí ging vervangen.

Tot in de vroege middeleeuwen bezaten graanakkers een min of meer afgeronde vorm als gevolg van het gebruik van het eergetouw, een primitief ploegtype waarmee niet alleen overlangs, maar ook dwars en diagonaalsgewijs moest worden geploegd. Vanaf de vroege middeleeuwen ontstaan smalle akkers, die vele malen langer zijn dan breed; dit als gevolg van een nieuw ploegtype. dat werd voorzien van een vast keerbord dat de geploegde zode omkeert, ${ }^{4}$ hetgeen bijeen eergetouw niet mogelijk was. Vanaf het moment van de introductie van het keerbord kan de omgekeerde zode als groenbemesting fungeren.

Tot voor kort overheerste in het gebied van onderzoek de lange en smalle vorm der percelen. Andere factoren dan de ploeg met keerbord, die deze vorm hebben beinvioed, zijn hun wijze van ontstaan uit boshoeve-ontginningen, ${ }^{5}$ de wiịze van erfdeling en, met: 
FIGUUR 11.3. Rotatiecycll met enige braokgewassen. De lengte van de brookperiode is vooral afhankellik van de natuurlijke vruchtbaarheld van het perceel. Diverse braokperioden en braakgewassen konden worden benut om een daaropvolgende roggeoogat te goranderen. $O_{p}$ "rotland" duurde de cyclus het langry; de bouwperiode werd afgewisseld met een hakhoutperiode van 12 tot 20 jaar. Op "schiffelland" duurde de cyclus korter. De as van de in brand gestoken roden fungeerde als mest. "Heiland" werd geploegd. De ondergeploegde zode fungeerde als mest. "Driesland" lag den of enkele joren braak voordat het met xaadgoed werd besteld, tenwijl "esland" (dexe term komt in Zuid-Limburg niet voor). donk $x$ y een regelmatige bemesting met stalment, elk joar als bouwland werd gebrulkz. Diverse braokgewassen konden in dexe cyell warden Ingepart om de notuurlijke vruchtbaarheid van de bodem te verhogen. Het braakgewas diende als veevoer.

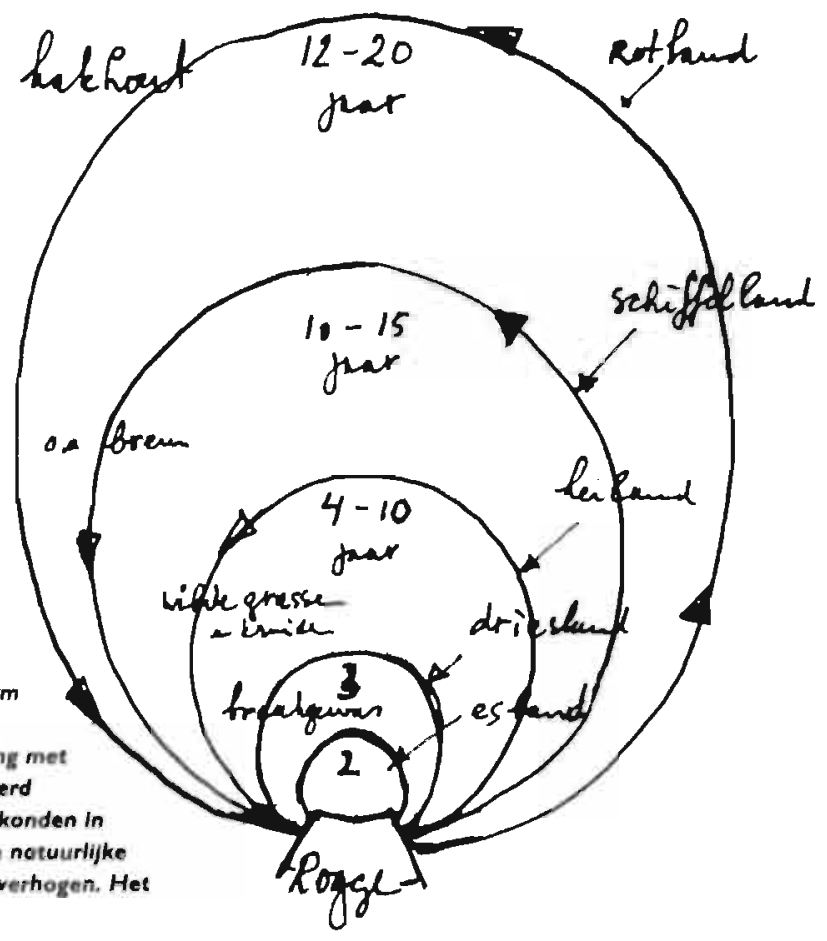

name op hellingen, de wijze van ploegen parallel met de hoogtelijn. Men mag aannemen dat de voor Zuid-Limburg zo karakteristieke geterrasseerde alkers met tussenliggende graften op deze manier tot stand zijn gekomen. ${ }^{\circ}$

De huidige bio-industrie ondervindt nogal wat hinder van de vaak smalle en kleine par. cellering. Vooral veel graften zijn in de loop van de laatste decennia genivelleerd in het kader van rullverkavelingen en private herinrichtingen met de bedoeling perceelvergroting tot stand te brengen. Deze activiteit veroorzaakte cen serie van negatieve neveneffecten (zie figuur 1!.2).

Het assortiment aan landbouwgewassen blịkt al tijdens de prehistorie verrassend groot te zijn, blijf min of meer constant gedurende de middeleeuwen, stijgt vanaf het begin van de nieuwe tijd opnieuw door de introductie van een aantal braakgewassen en daalt vervolgens zeer sterk; de huidige akkerbouw kent hoogstens nog een vịftal cultuurgewassen. Tevens daalt in de laatste fase, algemeen gesproken, de variatie aan plantesoorten op een akker. Hierbij moet niet alleen worden gedache aan onkruiden; ook graanakkers waren vaak "polyculturen", dat wil zeggen uit meer dan één soort graan bestaande culturen.

Tijdens de prehistorie werden niet alleen graansoorten, verwant aan de huidig bekende vier granen, tarwe, gerst, haver en rogge, verbouwd, ook momenteel in onbruik geraakte graansoorten, zoals eenkoorn. em- mer, spelt en gierst. (respectievelijk. Triticum monococcum, T. dicoccum, T. spelta en $\mathrm{Pa}$ nicum miliaceum), "onkruidgranen", zoals dreps (Bromus secallinus), oliehoudende gewassen (onder andere Papaver spec.) en de zaden van Chenopodium-soorten speelden

Ook in de periode van de Romeinse overheersing werden vooral broodgranen verbouwd, een tendens die zich in de middeleeuwen voortzet. Vele soorten graanonkruiden dateren uit de beginperiode van de geschreven geschiedenis. ${ }^{8}$

\section{2}

Vanaí de nieuwe tijd wordt in toenemende mate onder invloed van de successen van onder andere de Vlaamse landboum en de propaganda van het Frans bestuur na de Revolutie, de traditionele wilde braak geleidelijk vervangen door de culcuur van een groot aancal braakgewassen. ${ }^{9}$ Deze braakgewassen waren meestal inheemse soorten, die op deze wijze werden gecultiveerd. Door de introductie van braakgewassen nam de diversiteit aan landbouwgewassen sterk toe. Tevens werden toen diverse handelsgewassen geintroduceerd, zodat de achtriende en negentiende eeuw zijn gekenmerkt door de grootste diversiteit aan landbouwgewassen in de geschiedenis van het onderzoeksgebied; het gaat om ongeveer 40 verschillende soorten. Dit aantal neemt tijdens de eerste helft van de twintigste eeuw snel af: de huidige incensieve landbouw kent in hoofzaak een rol als broodvrucht. ${ }^{7}$ slechts een drietal oorspronkelijke braakge- wassen: maìs, bieten en aardappels. De term braakgewas is op deze soorten niet meer van toepassing.

Zowel uit archeologische als ethnografische bronnen is bekend dat akkercomplexen, toebehorend aan een bepaalde nederzetting. zich in de tijd en in de ruimte konden verplaatsen. Soms hield deze "shifting cultivation" een verplaatsing in van de nederzetting. Tussen deze vorm van zwervende landbouw en de sedentaire landbouw, waar zowel de nederzetting als het daarbijbehorend akkercomplex op één locatie zijn gefixeerd, lag een roterend systeem van een ofwel zich verplaatsende woonkern rond een blijvend akkercomplex ofwel een vaste woonkern en een zich verplaatsend akkercomplex. Dergeliike systemen zịn bekend van gebieden buiten het gebied van onderzoek. ${ }^{10}$

Rotaciesystemen waarin én of meerdere braakjaren zijn opgesloten, kunnen als vorm van zwervende landbouw worden beschouwd, zeker wanneer het oppervlak van het rustende, "dries."-liggende land een veelvoud is van het. "winnende" land (zie figuur 11.3). In het drieslagstelsel is de rotatie terug. gebracht tot drie jaar en vindt plaats op drie delen van het akkercomplex. Het verdwijnen van de wilde braak door de introductie van braakgewassen betekent dan het einde van de zwervende landbouw.

Een geschikt zaaibed voor graanzaden vereist een aantal bodembewerkingen, die in de loop van de geschiedenis in toenemende mate totstandkomen door technisch gecompliceerder wordende hulpmiddelen en werkwijzen. Graafstok, hak en vuur vormen het belangrijkste instrumentarium van de prehistorische boer uit de steentijd. "i Pas in de ijzertijd verschịnt de met runderen bespannen ploeg met een metalen punt, maar zonder keerbord. Tijdens de vroege middeleeuwen verschijnt een verbeterd ploegtype, bespannen door een paard en voorzien van een keerbord dat de zode omkeert: ${ }^{12}$ Op deze wijze kan groenbemesting totstandkomen. die zo karakteristiek is voor alle vormen van driestigstelsels.

Aanschaf en onderhoud van paard, ploeg en andere werktuigen die in dienst staan van de grondbewerking of transport. en die door tractie worden voortbewogen, veronderstellen een zekere welstand van de boer. De in de "Wijsdommen"13 genoemde "ploegers" bezitten, in tegenstelling tot de daarmee in samenhang genoemde "keuters" zonder dit kapitaalintensieve instrumentarium, meer rechten binnen de dorpsgemeenschap. 


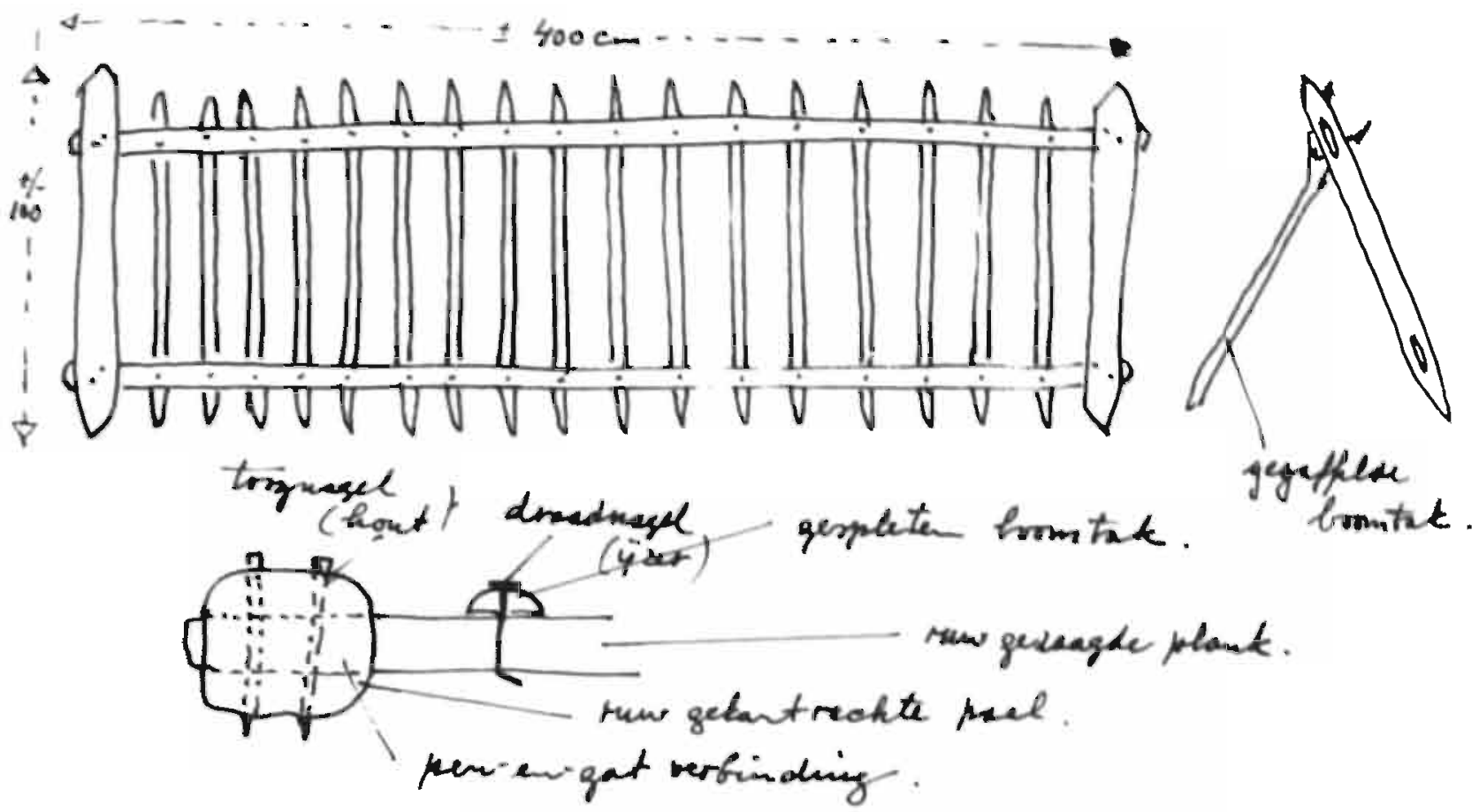

ACUUR II.4. Voaltehek voor een kudde schopen uit de Zexere-vallei in Portugal. De canstructie besteot uit gespleten stokken en grof gekantrechte palen die door middel van pen-en-got-verbindingen zijn verbonden. Het opretten gebeurt met behulp van regaffelde stokken. Zestien van dexe hekken vormen een vierkant, waarin de kudde 's nochts wordt gestald. Tekening van de schrijrer, jull I9a7.

Dit zou onder andere de verklaring kunnen zị̣n voor het gegeven, dat de braak bij keuterbedriịven en in onvruchtbare streken langer bleef bestaan. "

\subsection{Ontginnen met behulp van vuur is} een oude, wijd verbreide, maar primitieve landbouwtechniek, waarbij de asbestanddelen als meststof fungeren. ${ }^{15}$ Deze methode is bekend van de eerste boeren in het gebied van onderzoek en is ongetwijfeld nog toegepast tijdens de ontginningsperioden van de middeleeuwen. Een speciale vermelding verdienen twee brandtechnieken, die bekend zijn van gebieden die grenzen aan het onderzoeksgebied en die ook in Zuid-Limburg zouden kunnen zijn toegepast, namelijk de "veenbrand"16 en het "schiffelen". ${ }^{17}$ Het eerste vond plaats in vochtige heiden ten gunste van de boekweitteelt, het tweede, bekend uit de Eifel, in droge heiden of ruige graslanden. Beide technieken berusten op het losmaken van de zode, die te drogen wordt gezet en daarna in brand wordt gestoken. Mogelijk speelde alleen het schiffelen een rol in driesligstelsels.

Alleen schepers hebben tot in de twintigste eeuw nog gebruik gernaakt, van vuur ter verbetering van de weidegronden; opslag van houtige gewassen en verruiging van de hun permanent ter beschikking staande weidegronden werd daardoor voorkomen. ${ }^{1 \text { " }}$
Vergane delen van planten, bedekt en vermengd met aarde, leveren een geschikt kiemen groeisubstraat voor granen. De ontbindende en vochthoudende humusbestanddelen voorzien de zich ontwikkelende graanplant van zowel mineralen als water en de kruimelige bodemstructuur draagt zorg voor een gunstige doorluchting. Uiteraard moet worden voorkomen, dat er kieming optreedt van zaden die afkomstig zijn uit de zaadbank van de braakvegetatie; dergelijke kiemplanten beconcurreren de jonge graanplanten. Evenzeer moet worden voorkomen, dat de vegetatieve delen van meerjarige plantesoorten uit de braakvegetatie opnieuw uitlopen. Door een regelmatige beweiding van de braak, door tijdig, voldoende diep en zoda. nig te ploegen dat de zode wordt omgekeerd. kan de heropslag van braakvegetatie worden onderdrukt, waardoor een volgende graanoogst mogelijk wordt.

Zowel het driesligstelsel als het drieslagstelsel profiteren optimaal van de hierboven geschetste vorm van groenbemesting. Ze zijn toegepast cijdens die periode in de agrarische ontwikkelingsgang, toen beweiding door vee in kuddeverband op de wilde brak en op de stoppel regel was en toen de ploeg met een keerbord werd gebruikt.

Al in de prehistorie werd verband gelegd tussen de aanwezigheid van mest van het vee en het opbrengst verhogend effect daarvan op een volgende graanoogst. Echter, een landbouwsysteem, geheel gebaseerd op de potstal dateert van een veel latere: periode. Dit systeem, veronderstelt immers niet alleen een potstal waar urine en feces van opgestalde dieren worden vermengd en vastgehouden door stro of ander bindmateriaal, maar tevens stalvoer, de daarmee verband hou. dende verbouw van braakgewassen en transportmogelijkheden van het geoogste braak-. gewas naar de stal en van de bewerkte mest in omgekeerde richting. Dit vervolmakte potstalsysteem zou cen Vlaamse uitvinding zijn geveest, welke zich vanaf de zestiende. eeuw in snel tempo over Nocrdwest-Euro-. pa verspreidde. ${ }^{19}$ Het werd vooral bekend door laat-negentiende-eeuwse beschrijvingen van landbouwsystemen, voorkomende: op de arme zandgronden in dit gebied, waar met name de potstallen van de schaapskudden de noodzakelijke mest opleverden voor de cultuur van rogge op de essen, de zogenaamde eeuwigdurende roggeteelt. ${ }^{20} \mathrm{De}$ maximale uitbreiding van de Calluna- en Ericaheiden op deze gronden tijdens de achttiende en negentiende eeuw zijn het directe gevolg geweest van het potstalsysteem. buitengewoon zware en moeilịk hanteerbare substantie, veronderstelt onder andere een technisch geavanceerd transportmiddel. 
De mestkar of "sjlaag"-kar, zo genoemd naar het ingewikkelde neerklapmechanisme van de bak, was in de late middeleeuwen onbekend en verschijnt pas tijdens de zeventiende eeuw. ${ }^{21}$

Stalmest komt eerst dan ter beschikking. wanneer voldoende stalvoer in de vorm van braakgewassen kan worden aangeboden. Uit bovenstaande gegevens zou kunnen worden afgeleid, dat de "bloeiperiode" van de driesligstelsels begint met het tijdstip. waarop de ploeg met keerbord wordt geîntroduceerd en eindigt op het moment, waarop de cultuur van braakgewassen de wilde braak geheel heeft vervangen. Grofweg komt deze periode overeen met die van de hoge en late middeleeuwen.

Sinds de late middeleeuwen werd, vooral in dichtbevolkte gebieden en rond de steden, in toenemende mate gebruik gemaakt van afvalprodukten van min of meer industriële herkomst. Aanvankelijk komen deze ten goede aan hoveniersbedrijven aan de stadsperiferie, later worden ze op grote schaal gebruikt in agrarische bedrijven op het platteland. De negentiende eeuw brengt de guano en het: thomasstakkenmeel, het begin van de twintigste eeuw de kunstmest en vanaf 1960 de drijfmest, een produkt van bio-industriele herkomst.

In toenemende mate veroorzaken industrietle meststoffen ontregelingen en storingen in de min of meer gesloten kringloop van het gemengde bedrijf, hetgeen zich onder andere inanifesteert in eeri versnelde afname van de mest leverende en tot de dorpsgemeente behorende schraallanden. De voorheen uitgestrekte heiden, beemden en andere schrale graslanden kunnen vanaf dan op grote schaal worden ontgonnen en geprivatiseerd. Pas in deze eeuw ontstaan door het gebruik van deze bio-industriele produkten, waaronder ook biociden ressorteren, verontreinigingen yan het grondwater.

Binnen het onderzoeksgebied werd een meststof al in een zeer vroeg stadium benut die, evenals industriele produkten. van buiten het gesioten systeem werd betrokken. Dit was "mergel", een kalkhoudend en betrekkelijk licht materiaal, dat als gruis of poeder op de akkers werd uitgestrooid. Het gebruik ervan werd al vermeld door Romeinse geschiedschrijvers en bleef in zwang tot in het begin van de twintigste eeuw, ${ }^{22}$

Vanaf de prehistorie tot nauwelijks een halve eeuw geleden was heerdgang op akkers een vertrouwd, alledaags en noodzakelijk verschịnsel. De kudden troffen hier na de

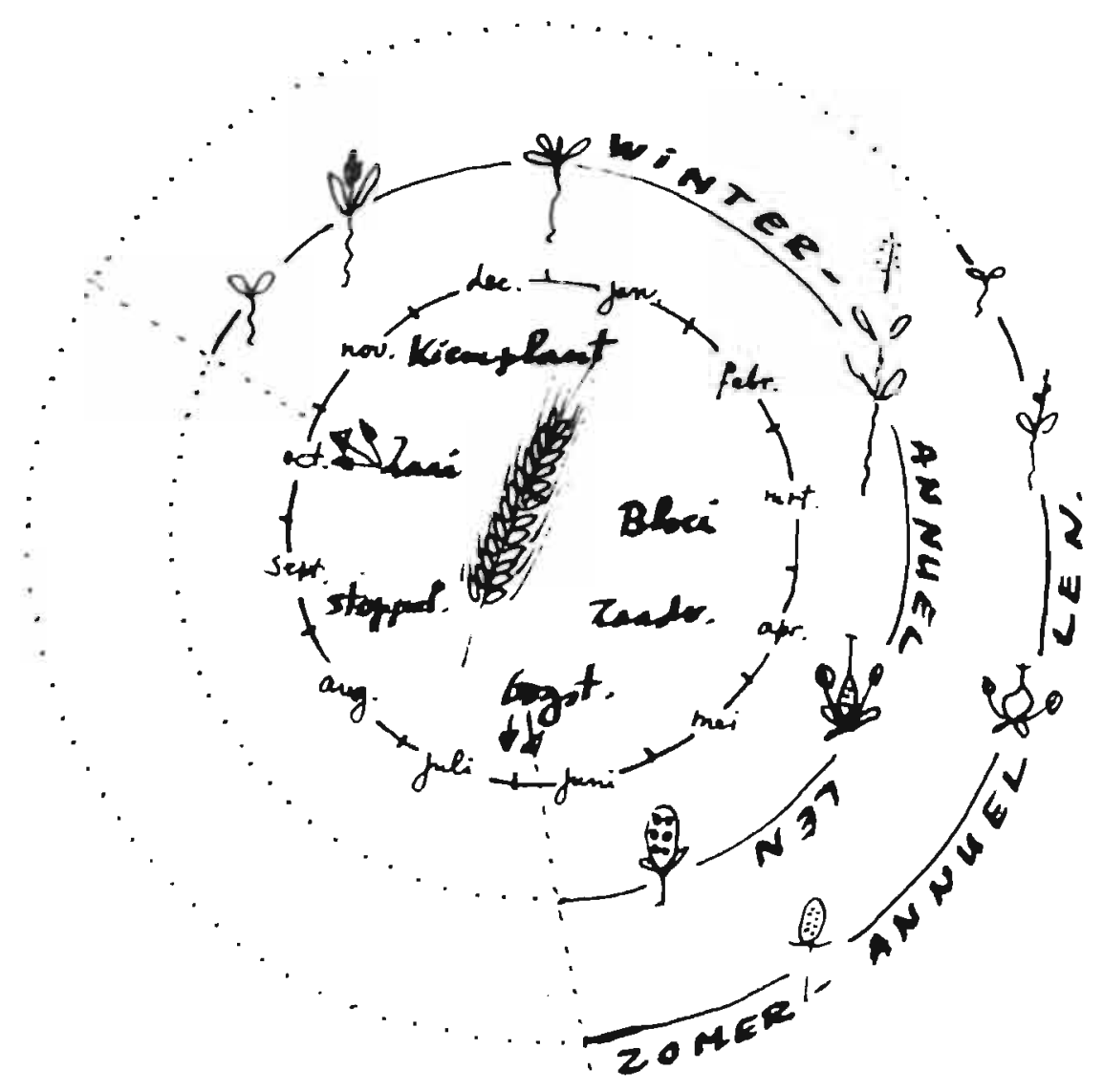

FIGUUR 11.5. Schema van de joarcyclus van een wintergraan (rogge) met de daarbij behorende categorieën van cenjarige graanakkeronkruiden. Dit scheino geeft een beeld van de levenscyclus van de groanplant (binnenste cirkel) on de doarmee synchroon verlopende cyclus von een winterannuel (middelste cirkel) en een kortere cyclus van cen zomerannuel (buitenste kwort cirkel).

oogst volop voedsel aan, waarvan, volgens de Wijsdommen. ${ }^{23}$ eerst de varkens, dan de koeien en renslotte de schapen konden pro. fiteren. Tevens werd door beweiding een groot gedeelte van het onkruid vernietigd, dat immers een bedreiging vormde voor een volgende graanoogst. Het onkruid werd op deze wijze omgezet in mest, die ter plaatse achterbleef. Zelfs op de pas ingezaaide wintergraanakkers werd tot in het begin van deze eeuw de schaapskudde even getolereerd: de afgebeten halm stoelde later met meerdere scheuten uit, waardoor een dichter gewas ontstond met een hogere opbrengst. ${ }^{24}$

Sinds het begin yan de nieuwe tijd verdwenen om diverse redenen de kudden meer en meer van de akkers: het beroep van varkens. hoeder stierf uit in de loop van de zeventiende eeuw, ${ }^{23}$ dat van de koeherder of heert in de vorige eeuw en dat van de scheper in de eerste helft van deze eeuw, ${ }^{26}$ In het drieslig. stelsel vervulde de heerdgang een essentiéle rol: drieslanden fungeerden als extra weidegrond en het grazende vee onderdrukte de groei van het onkruid in de komende graanakker. Tevens werd het onkruid omgezet in mest, die een volgend graanjaar ten goede kwam. Van dit laatste gegeven hebben onze voorouders, zeker weet gehad: het recht van "vaalte" dat het overdag op de akkers na de oogst weidende vee 's nachts werd ingeperkt op een bepaald perceel. De nachtelijk geproduceerde mest kwam ten goede aan een volgend cultuurgewas. Het is vrijwel zeker dat dit systeem, dat onder andere uit Frankrijk en Drenthe werd vermeld en logischerwij̣s voorafgaat aan het transport van mest per kar, ook binnen het onderzoeksgebied voorkwam (zie figuur 1 I .4).

In het verleden leverden graanakkers meerdere produkten dan brood en bier. De pro. duktie van stro was destijds belangrijk. Wijsdommen en vroege pachtcontracten ${ }^{20}$ maken ons attent op de economische waarde van stro, dat als dakbedekking, constructiemateriaal in de vakwerkbouw, bind-, opvul-. afdicht- en poetsmiddel werd gebruike. Vooral in de vorm van mestbinder speelde 


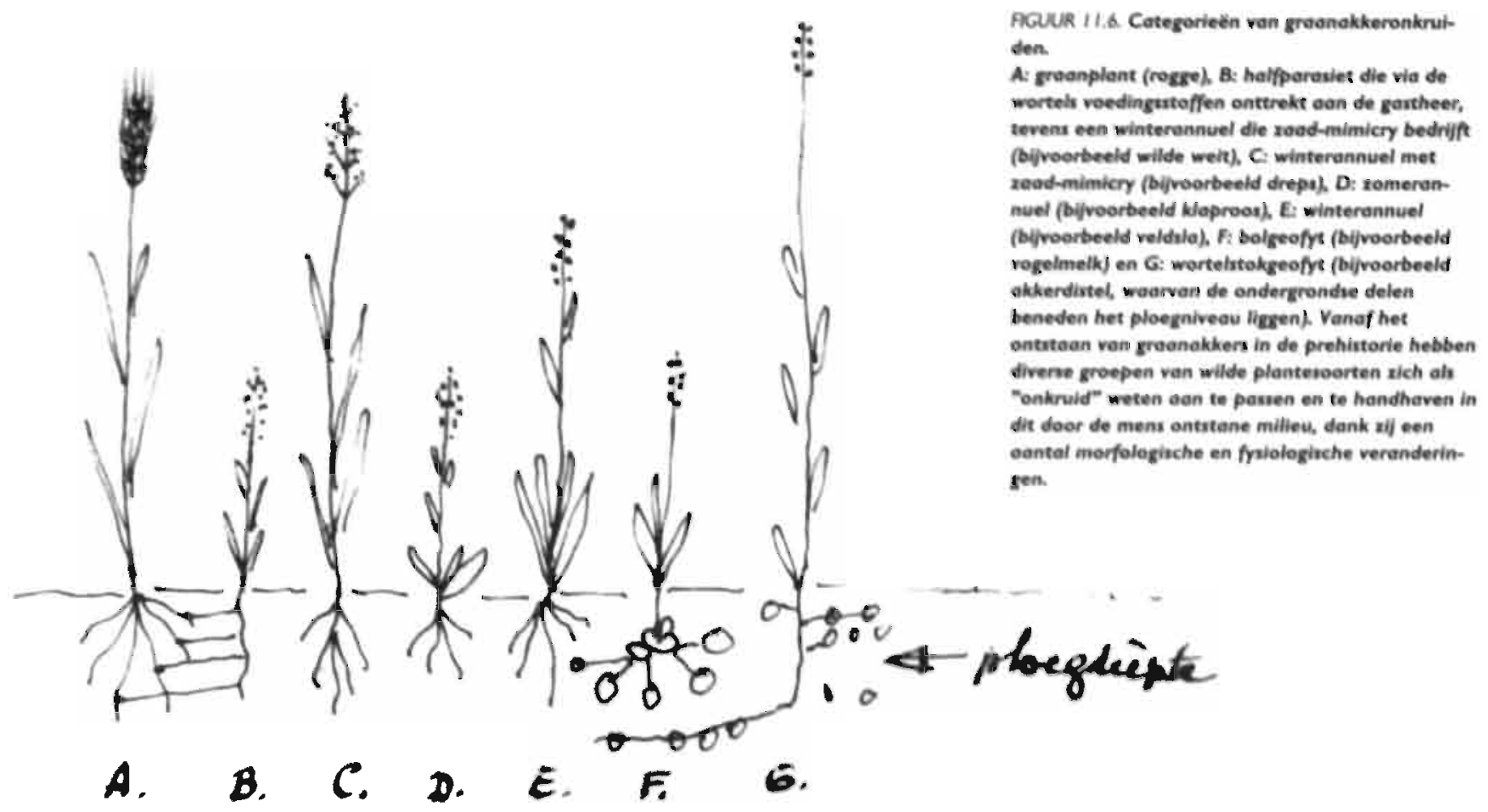

stro een onmisbare rol in de gesloten agrarische bedrijfsvoering. Stro mocht het bedrijf niet verlaten. Stroresten en de daarin nog aanwezige restanten van onkruiden, eventueel versneden met hoogwaardiger voedsel, vormden een belangrijk wintervoedsel voor het op stal staande vee. De braak en de akker na de oogst fungeerden als weidegrond. Bepaalde, veel voorkomende graanonkruiden, zoals bijvoorbeeld korenbloemen (Centaurea cyanus), werden gewaardeerd als honingleveranciers, andere onkruiden waren als "veldsla" (onder andere Valerianella spp.) geschikt voor menselijke consumptie of speelden een rol bij folkloristische gebruiken of religieuze feesten. ${ }^{30}$ Bij het verdwijnen van de braak en de teelt van granen zijn deze nevenfuncties komen te vervalien.

\section{I Het milieu van drieslanden laat zich} kort typeren als een steppemilieu, waar, als gevolg van een ijle en lage vegetatie, licht. wind en neerslag tot op het niveau van het substraat hun invloed uitoefenen. Periodiek verstoren zeis of sikkel, ploeg, eg, tred en vraat van weidend vee de structuur en soortensamenstelling van de vegetatie alsook de bodemtoplaag. Aan al deze storende factoren zullen soorten organismen zich moeten aanpassen, willen zij zich kunnen handhaven in dit milieu. Zij dienen een bepaalde overlevingsstrategie te volgen.

Van de drie door Grime ${ }^{31}$ onderscheiden vormen van levensstrategieèn die voor planten gelden, komt er een tweetal in aanmerking, namelijk de "ruderale" en "stress-tolerante" strategie.

Tot de eerste categorie, afgekort als R-strategie, behoren kortlevende, eenjarige kruiden en grassen, waarvan de levenscyclus gelijk is aan of korter van duur is dan het gecultiveerde wintergraan. $\mathrm{Z} i j$ kiemen dus op hetzelfde moment als, of zelfs iets later dan het cultuurgewas. Dergelijke kortlevende soorten, zogenaamde therofyten, kiemen ofwel vóór de winter, bloeien vroeg en zịn yóór de aanstaande zomer al geheel afgestorven, ofwel kiemen vlak na de winter en hebben al zaad geproduceerd bij de oogst van het cultuurgewas. Ze worden respectievelijk winter- en zomerannuellen genoemd (zie figuur II.5).

Tevens kan men een groep van soorten onderscheiden, die haar levenscyclus synchroniseert met die van de granen en waarvan bovendien het zaad in grootte, vorm en gewicht op dat van de granen lijkt. Ook de bloeiwijze van deze "zaad-mimicry" bedrijvende akkeronkruiden bevindt zich op hetzelfde niveau als dat van de granen, waardoor de kans dat hun zaden in het graanzaaigoed terechthomen aanmerkelijk wordt vergroot. Tot deze categorie graanonkruiden behoren onder andere bolderik (Agrostemma githago), dreps (Bromus secalinus) en mogelijk akkerdravik (Bromus arvensis), de vroeger algemeen voorkomende klaproossoorten (Papaver div. spec.) en korenbloem (Centaurea cyanus). Hur vruchthalmen werden tegelijkertiịd met die van de granen geoogst en hun zaden bieven aanwezig in het zaaigoed en in het voor consumptie bestemde graan.

Een derde groep van therofyten, met name die van de halfparasieten, ${ }^{32}$ is in staat haar levenscyclus aanmerkelijk te verkorten door deeis voedingsstoffen te onttrekken aan de wortels van de graanplanten. Binnen het onderzoeksgebied kwamen minstens vilf soorten halfparasieten voor in graanakkers, alle afkomstig uit de familie van de Scrophulariaceae. Van één soort werd zaad-mimicry ver. ondersteld.

In tegenstelling tot de graanakkerruderalen zijn de stress-tolerante graanakkeronkruiden gekenmerkt door meerjarigheid, een lage zaadproduktie, een ondergrondse opslag van reservevoedsel en tevens door het bezit van vegetatieve delen, die na een eventuele beschadiging door ploeg of eg levens. vatbaar blijven en op deze wijze verspreid raken of die door het bezit van toxische stoffen door het op de akkers weidende vee niet worden gegeten.

Tot de stress-tolerante categorie behoort vooral een aantal bolgewassen, meestal Liliaceae, die als de bijbelse "leliën des velds" uit het mediterrane gebied bekend zijn. Binnen het gebied van onderzoek zijn de fraai ogen. de, maar voor het vee toxische vuurlelie, 


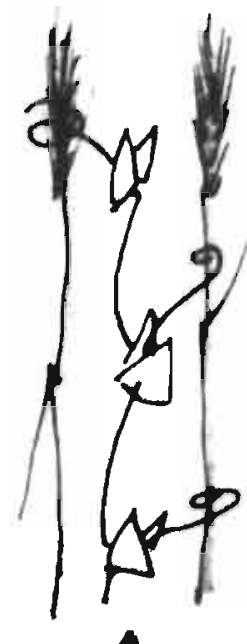

A.
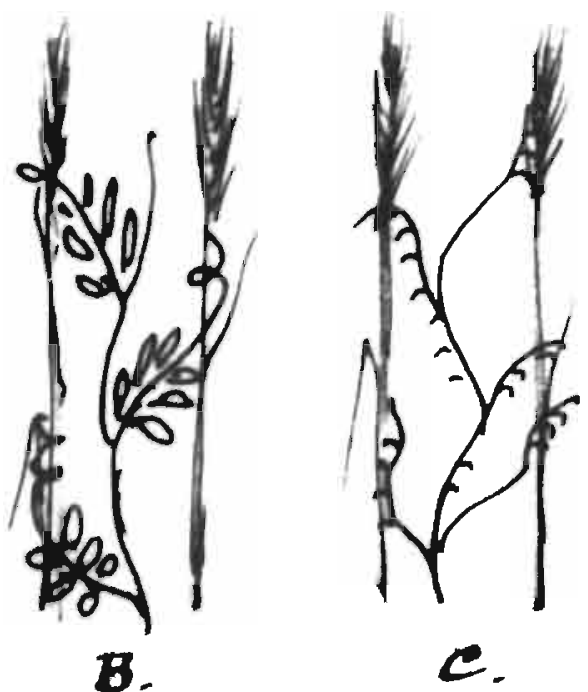

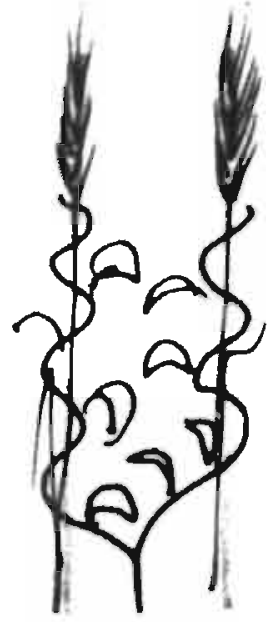

$\boldsymbol{D}$.

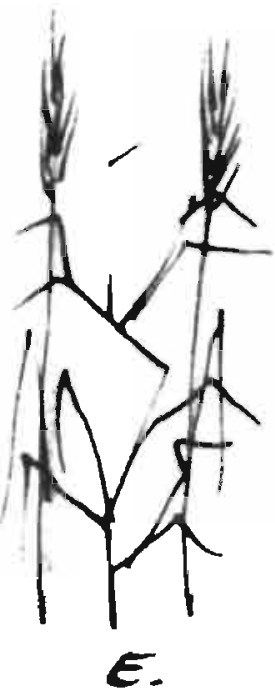

FGUUR [1.7. Yoorbeeiden van steunmechanismen bi) enJge soorten groonakkeronkruiden. Diverse steunmechanismen, ontstaon uit verschillende morfologische delen vain de plant, verlenen veel graanokkeronkruiden de mogelijkheid om maximaal van het xonlicht te profiteren. A: nookte lachyrus met rank, die bestoot uit de hoofdnerf van een blad, B: ringelwikke met ranken, die bertaan uit de verlengde hoofdnerf van het blod, $C_{\text {: }}$ kleefkruld inet hookjes oan alle boivengrondse delen van de plant, $D$ : akkerwinde met windende stengels en $E$ : korenbloem met sterk vertakte stengels die tegen de graanholmen steun vinden.

vogelmelk, kuifhyacint, wilde tulp en akkergeeister (respectievelijk Lilıum bulbiferum, Ornithogalum umbellatum. Muscari comosum. Tulipa sylvestris en Gagea villosa) vrijwel uitgestorven. ${ }^{33}$ Sommige wortelstokgeofyten blijken echter haast onuitroeibaar. ondanks het gebruik van herbiciden. Een voorbeeld daarvan is een grassoort, die wordtgekenmerkt door een uitgebreid wortelstokkenstelsel en bekend staat onder de naam kweek (Elymus repens), in diverse Zuidimburgse dialecter "peume" genoemd. De droge wortelstokken werden als wintervoer voor schapen benut ${ }^{34}$ (zie figuur 1!.6).

\subsection{Veelgraanakkeronkruiden worden} morfologisch gekenmerkt door hun weinig scleromorfe bouw; hun lange, slappe stengels vinden steun aan de hen omringende graan- halmen. Andere soorten vertonen nog verdergaande aaripassingen, zoals; het bezit van windende stengels, rankende bladspitsen, in ranken veranderde steunbladeren of zijn geheel bezet met teruggekromde stekeltjes, die het omlaag vallen verhinderen (zie figuur (1.7).

Ook uit de morfologie van hun zaden of vruchten blijken adaptaties aan het ijle en lage vegetatiedek van de graanakker. De wind speelt ook in de cultuursteppe een belangrijke rol als vector voor het transport van zaden. Tevens komt bij een aantal soorten exozoöchoor of endozoöchoor transport voor; eeuwenlang, werden immers de stoppelakkers door onder andere schaapskudden beweid $^{35}$ (zie figuur 11.8).

Karakteristiek voor graanonkruiden is voorts het groot aantal zaden, dat door een
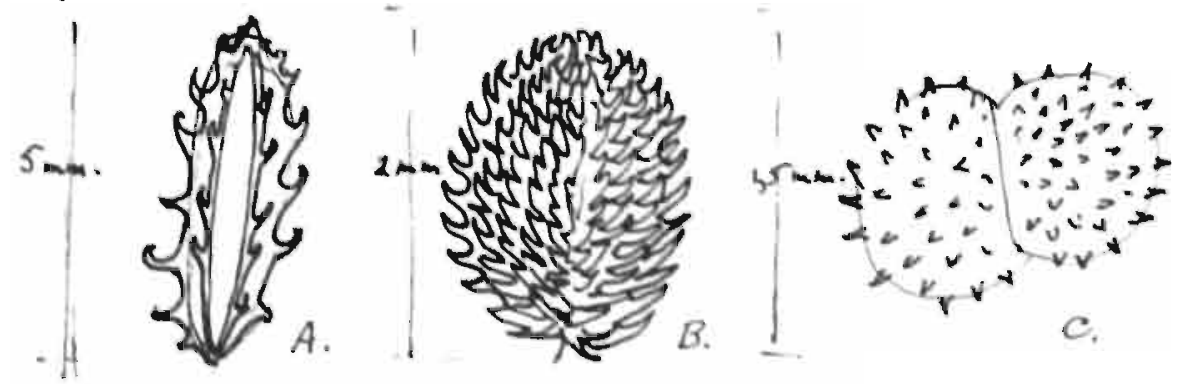

FGUUR | I.8. Wijze von verspreiding van graononkruiden door middel van vormvariatie van de xaodhuid. Meer dan de helft van de soorten graanakkeronkruiden in de cultuursteppe laten hun xaden of vruchten door de wind of door het op de akker weidend vee verspreiden. Op de tekening drie voorbeetden van raden die zich vio de wol van schopen laten vervoeren: A: doomrood, B. wilde peen en C: kleeforuid.

individu kan worden geproduceerd en de langdurige kiemkracht per zaad. Onderzoek in Zuid-Limburg heeft uitgewezen dat op een graanakker. die minstens 30 jaar als grasland was gebruikt, een complete onkruidgemeenschap van graanakkers op kalkriịke gronden ontstond.

In zekere zin weerspiegelt de indeling van de flora in relatie tot het abiotisch milieu en de bewerking daarvan volgens vegetatiekundige criteria eveneens een bepaalde vorm van levensstrategie. Bepaalde plantesoorten komen immers in vaste combinaties voor, die karakteristiek blijken te zijn voor een bepaald milieu, op te vatten als een samenspel van factoren van abiotische aard, bijvoorbeeld het kalkgehalte van de bodem, en van biotische aard, onder andere de wijze van bodembewerking door de mens. Zo onderscheidt men onkruidgemeenschappen van winter-en zomergranen op kalkrijke en kalkarme bodems en gemeenschappen van hakvruchten en braakgewassen. ${ }^{36}$ Het zal duidelijk zijn dat de vele aanpassingen wat betreft levensstrategie en de daarmee samenhangende morfologische en fysiologische eigenschappen van de talrijke wilde levensvormen, die karakteristiek waren voor de cultuursteppe, niet in enkele tientallen jaren zijn ontstaan. Integendeel, met dit proces zịn eeuwen gemoeid. Het is echter triest te moeten constateren, dat deze levensgemeenschappen op het punt. staan te verdwijnen; daarmee verdwijnt tevens een belangrijke hoeveelheid oecologisch studiemateriaal. 


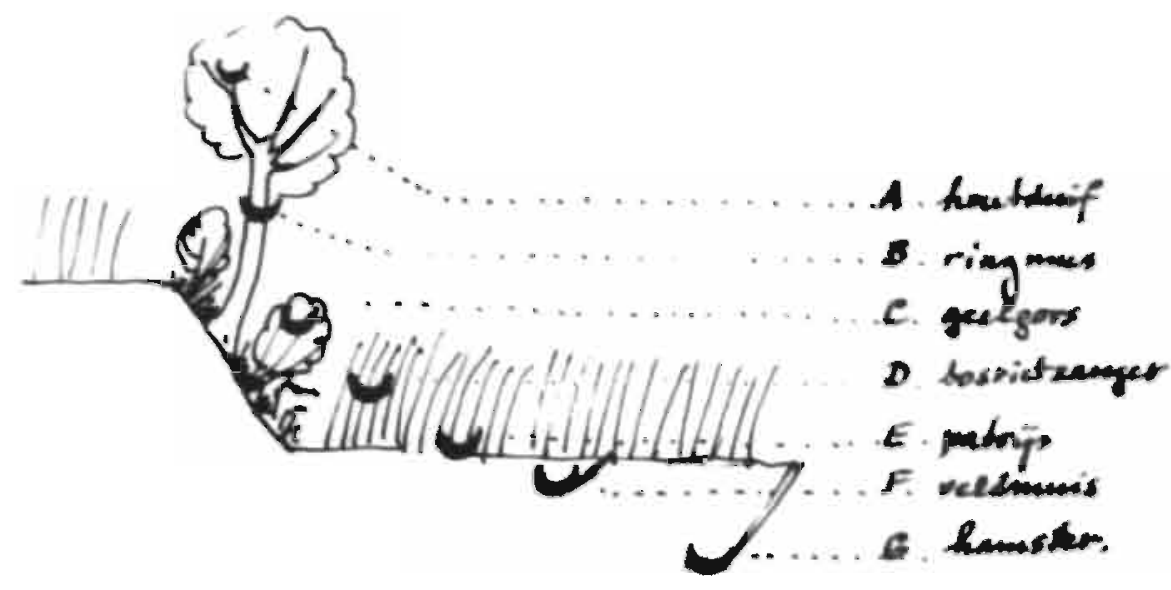

3.3 Niet alleen de "wilde" flora, maar ook de "wilde" fauna van de driesgronden moet beschikken over diverse adaptaties aan het milieu van de cultuursteppe (zie figuur 11.9). Voor herbivore zoogdieren liggen deze vooral in het uithoudingsvermogen, snelheid van voortbeweging, een goede schutkleur of in het vermogen tot graven. waardoor ondergrondse schuilmogelijkheden kunnen worden geschapen.

Vanaf de prehistorie tot en met de vroege middeleeuwen zullen de toen nog algemeen voorkomende grote herbivoren (herten en wilde zwijnen) de kleinschalige graanakkers als fourageerbiotoop hebben benut. De uit geschreven bronnen bekende wildgraven, met doornig struikgewas beplante wallen al of niet in combinatie met greppels rond de akkercomplexen, ${ }^{37}$ waren destijds noodzaak en het "heerlijk" jachtrecht niet alleen een recht, maar zelfs een verplichting voor de heer.

Voor kleinere herbivore zoogdieren biedt de cultuursteppe nog steeds, of tot voor kort, voldoende voedsel en dekking om hier tijdelijk dan wel permanent te verblijven. Typische, oorspronkelijk uit het mediterrane of uit het pontische gebied afkomstige, graan belagende kleine herbivoren zijn de binnen het onderzoeksgebied steeds zeldzamer wordende haas, de eveneens zeldzame en momenteel wettelịk beschermde hamster, het nog algemeen voorkomende konijn en enkele muizensoorten (respectievelijk Lepus europaeus, Cricetus cricetus, Oryctolagus cuniculus en onder andere Microtus arvalis en Micromys minutus). Van hun schadelijke activiteiten in graanakkers is in het verleden meermaals melding gemaakc ${ }^{3 a}$

Een veel grotere belaging door predatie van zoogdieren ging, zeker in het verleden, uit van vogels. Dit zijn dieren die door hun grote actieradius, snetheid, wendbaarheid en neiging tot zwermvorming in staat zijn om effciènt het zich plotseling aandienende voedselaanbod van de dries te benutten.

Bepaalde soorten waren en zijn deels nog regelmatige en dagelijkse verschijningen op de cultuursteppe. Specifieke vogelnamen komen voor in dries-toponiemen. ${ }^{30}$ Een uit 1777 daterende aantekening stelt een bepaalde dries binnen het onderzoeksgebied spottend synoniem met een "vogelweyde": destijds aanzieniiịk zịnn geweest.

Min of meer permanent in de cultuursteppe verblijvende soorten kunnen worden omschreven als. "loopvogels". Dit zijin verschijningen op stevige, lange poten, een matig lange hals, een korte, harde snavel en een snelle vlucht. Zị bezitten de mogelịkheid om vanuit een verticale positie te starten. Typișche loopvogels bezitten een schutkleur en baltsen met visuele signalen, die buiten de paartijd onder de schutkleur yerborgen blijven. Het zịn primair zaadeters, die tịjdens gunstige seizoenen dierlijke kost ${ }_{\text {" }}$ meestal ongewervelden, tot zich nemen.

Karakteristieke loopvogels van het onderzoeksgebied zijn de zeldzaam wordende patrijs, fazant, de momenteel haast uitgestorven kwartel en het inmiddels vitgestorven korhoen (respectieveliajk Perdix perdix. Phasianus colchicus, Coturnix coturnix en Lyrurus tetrix). Vroeger of vlak buiten het onderzoeksgebied komen of kwamen in de cultuursteppe voor: griel, kwartelkoning en de grote en kleine trap (respectieveliịk Burhinus oedicnemus, Crex crex. Otis tarda en Otis tetrax). Een aantal van de hierboven genoemde soorten zijn trekvogels.

Wegtrekkend is ook een aantal kleinere oogstschade door vogels op driesland moet
AGUUR 11.9. Broed(nest)biotoop van enige soorten zoogdieren en vogels ran de cultuursteppe. De horisontale geloagdheid van het milieu werd optimaal benut; in huldige groanokkers komen de meeste van de hier vermelde soorten niet meer voor.

Loag A wordt benus door diverse grote soorten vogels, onder andere de torenvalk en de houtduif in open nesten; holenbroeders, loog B, roaks de ringmus, de steenuil en de holenduif, broeden in geknotte bomen, terwijt het struikgewas, laag C, nestgelegenheid biedt aon diverse kleine soorten vogeh, onder andere de geelgork. De nerten van de bosietranger en de dwergmuir zijin opgehangen aan de graenhatmen. Op de grond, loag $E_{\text {, in een }}$ open nest broeden de leeuwerik en de patri/s. tenwill veldmuizen een cenvoudig nest in de grond. loag $F$, groven. De hamster bouwt een zeer. secompliceerde en diep gelegen burcht met voornadkemers in lagg $G$.

soorten zangvogels, zoals leeuweriken, gorzen en piepers die op de bodem broeden en in hoofdzaak een dierlijk dieet hebben. Een aparte plaats wordt binnen dit milieu ingenomen door de bosrietzanger (Acrocephalus palustris) die bovengronds, dat wil zeggen in samengebonden roggehalmen nestelt, zich vitsluitend met insecten voedt en er alleen gedurende het broedseizoen voorkomt. Deze soort was vroeger algemeen in rogge. akkers, maar komt momentee! niet meer voor

Uitgestorven zịin ook de bodem bewonende roofvogels, waarvar, de grauwe kiekendief (Circus pygargus) als dagroofvogel en de velduil (Asio flammeus) als nachtelijke jager plaatselijk in graanvelden of op braakliggende akkers als broedvogels binnen het gebied van onderzoek voorkwamen.

3.4 Diverse andere vogetsoorten kennen de cultuursteppe slechts ais voedselbio. toop en broeden elders. In de oogsttijd doen zij zich te goed aan het rijpe graan en onkruid. zaden. Typische zaadeters zij̣n duif-en gorsachtigen, vertegenwoordigd met respectievelijk vijf en viẹ soorten. Historișch interes. sant in dit verband is een vermelding van het "ius columbari" voor de kasteelhoeve Li. beek. " Dit heerlijk recht bepaalde dat de betreffende hoeve aan minstens 200 duiven onderdak diende te verschaffen. Dit gebruik was zeker niet alleen tot de hoeve Libeek beperkt; tot ongeveer 1950 behoorde de "doevesjlaag", een broedhok van een simpele constructie, tot het standaard hoevemeu. bilair.

Tijdens of vlak na iedere grondbewerking ontstaan opnieuwr gunstige fourageermogelijkheden voor vogels, niet alleen voor zaadeters, maar ook voor carnivore en omnivo. 


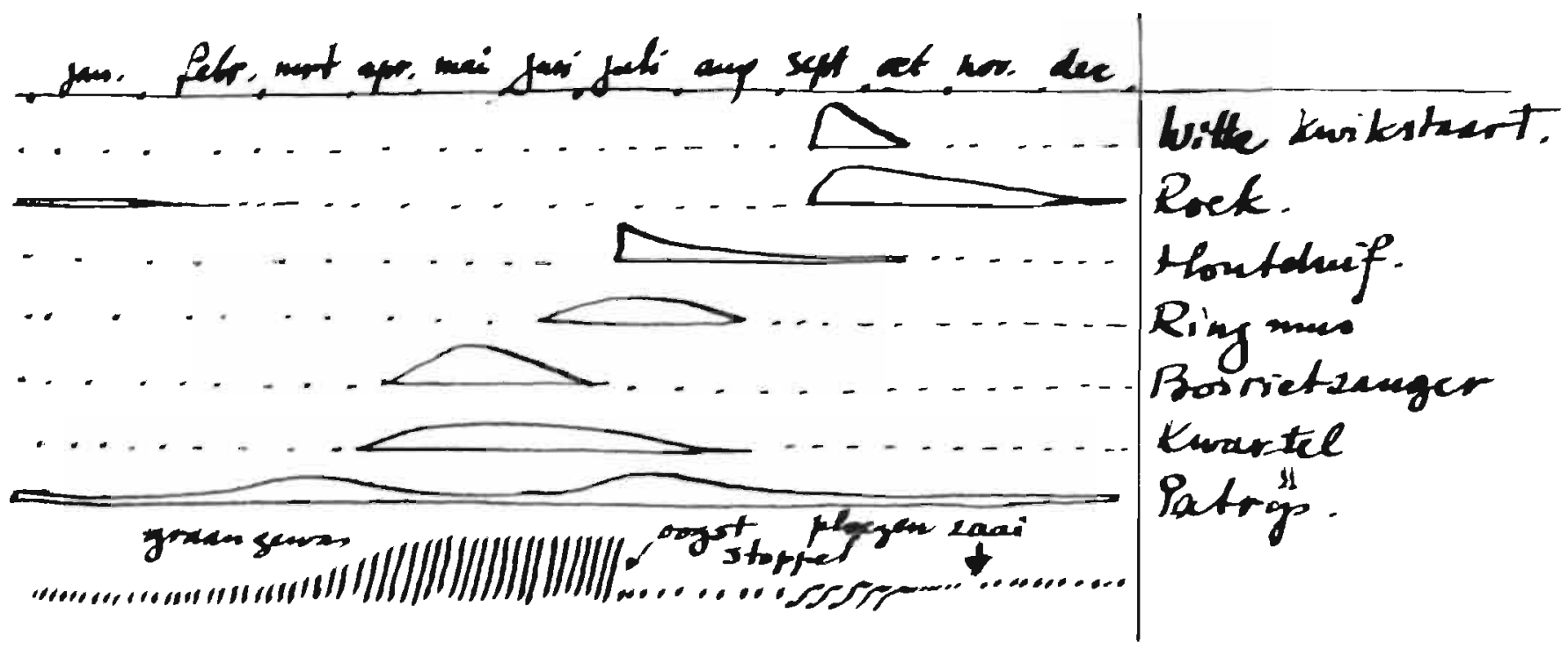

HGUUR 11.10 De benutting als voedselblotoop door vozelsoorten van de verschillende door de cultuur bepaalde vormen van het driesland. Het driesland biedt voor weinig vogelsoorten voedsel voor het gehele jaar; voor de meeste soorten geldt dot $x i j$ hier alleen gedurende cen bepoalde tijd van het jaar voedsel kunnen vinden. Dexe periode is afhankelljk van de door de mens bepaalde uiterllike vormen van het driesland (bovenste horizontale kolom) die per maand kunnen verschillen (in letters aangegeven). De patrljs is een standvogel, terwijl de kwartel een trekvogel is. De bosrietzanger is een inselkteneter, die vroeger in graanvelden broedde. De ringmuit en de houtduif zijn xaodeters, die viak na de oogst veel roorkomen, terwij! de rack en de witte kwikstoart met nome bil en vlak na hat ploegen veel voodsel aontreffen.

resoorten. Een voorbeeld van een insectivore soort is het "akkermenneke" of witte kwikstaart (Motacilla alba), die de ploeger constant begeleidt (zie figuur $1 !, 10$ ).

De omnivore kraaiachtigen, waartoe de roek, de zwarte kraai, de torenkraai en de inmiddels uitgestorven raaf (respectievelijk Corvus f́rugilegus, $\mathrm{C}$. corone, $\mathrm{C}$. monedula en C. (orax) behoren, zijn in hoge mate karakteristiek voor de cultuursteppe. Hun algemene of specifieke benamingen "kra(o). cra. kraw, daol (specifiek voor torenkraai) en raaf' komen regelmatig voor in toponiemen. De eveneens omnivore kieviet (Vanellus vanellus) en meeuwesoorten (Larus, div, spec.) missen een dialectnaam; hun voorkomen op de vers geploegde akkers is van een recente datum.

De winterperiode vormt een tijd van rust voor de cultuursteppe. Alleen dan yertoonden zich incidenteel twee, door hun grootte opvallende vogeisoorten op de verlaten ak- kers: de grote trap (Otis tarda), een wintergast uit Midden-Europa en de kraanivogels (Grus grus) op hun trek van of naar hun broedgebieden in het noorden. Nog in het begin van de vorige eeuw kwamen wolven, in toponiemen genoemd, ${ }^{21}$ regelmatig voor. De laatste Nederlandse wolf werd in 1845 in het Zuidlimburgse Schinveld geschoten. ${ }^{12}$ Verreweg de meest geziene en zeker voor de mens belangrijkste diersoorten van de driesgronden waren gedomesticeerd. De frequentie van de in toponiemen genoemde soorten vee weerspiegelt de beweidingsdruk van het veld: de verhouding rundvee, schapen, paarden, varkens en ganzen, in toponiemen met "dries" voorkomend, is als 6:6:1:1:1. ${ }^{33}$ Het destijds algemeen voorkomende beeld van de schaapskudde, weidend op de stoppelakkers, is een belangrijk thema geweest van de schilderkunst van de romantiek en heeft de uitvinding van de fotografie ruimschoots overleefd.

4. I Betreffende de onkruidvegetatie van de wilde braak, die een onderdeel vormde van een cyclisch systeem waarin graanverbouw werd afgewisseld met een braakperiode, is weinig bekend. "' De belangrijkste oorzaak van dit kennisgebrek is, dat de vegetatiekunde ałs wetenschap pas in de twintigste eeuw tot ontwikkeling kwam, toen de wilde braak in Noordwest-Europa al nagenoeg was verdwenen

Hoogstens kan uit een enkele historische aantekening worden geconcludeerd, dat op driesgronden plaatselijk meerjarige en begrazingsresistente soorten konden domineren. Zo spreekt een landbouwverslag met betrekking tot de wilde braak, daterend uit het einde van de achttiende eeuw, ${ }^{45}$ over ".. les chardons et autres plantes voraces quiles couvrent ordinairement". Ook andere oecologische groepen dan meerjarige distelsoorten, zoals bijvoorbeeld die van de hemiparasieten en bolgeofyten moeten destijds algemener versprcid zijn geweest op driesgronden dan in onkruidrijke graanakkers uit het begin van de twintigste eeuw. "1"

Ondanks het gebrek aan informatie inzake de flora en vegetatie van de, voormalige driesgronden kunnen, op grond van recent: successie-onderzoek op verlaten akkers binnen het onderzoeksgebied, ${ }^{17}$ enige wetmatigheden worden opgesteld ten aanzien van zowel de floristische samenstelling als van het verloop van de vegetatiesuccessie op driesgronden:

1. Tijdens het eerste jaar na de braak domineren therofytische, concurrentie gevoelige soorten die successievelijk worden vervangen door meerjarigen om uiteindelijk te wvorden verdrongen door houtige soorten.

2. Aanvankelijk heeft de vegetatie van de braak findien gelegen op kalkriike grond en indien de laatste grondbewerking heeft plaatsgevonden tijdens de zomer) een Caucalidion-inslag, die na enige jaren yerschuift in de richting van een Mesobromion (kalkgrasland) met duidelijke invloeden van het Trifolion en het Arrhenaterion. Al vroeg in de successie verschijnen houtige șoorten; een gesloten vegetatiedek verhindert echter een massale opslag van struiken, maar uiteindelijk is na enkele decennia de braak veranderd in een mozaijek van ruig grasland en struweel.

3. De floristische diversiteit bereikt zijn hoogtepunt pas na enige jaren; opmerkelijk zijn in dit stadium de aanwezigheid van diverse orchideeënsoorten, die in late- 
re stadia van de successie weer verdwijnen. 4. Om verschillende redenen verdient het aanbeveling de successie in het orchideeênrijke stadium te fixeren door het toepassen van een beheer dat uit bepaalde vormen van maaien, kappen of beweiden bestaat. Tot nog toe heeft een extensieve beweiding met mergellandschapen tot de beste resultaten geleid.

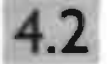

Zowel vanuit agrarisch-technisch als vanuit oecologisch standpunt gezien, worden de vanouds in Noordwest-Europa gecultiveerde granen verdeeld in zomer- en wintergraner. De eerste worden in het voorjaar gezaaid en nog datzelfde jaar geoogst, de tweede behoeven een fysiologisch bepaalde koudeprikkel om tot kieming te komen en moeten vóór de winter worden gezaaid. Ze zijn dus pas een kalenderjaar later oogstbaar. Door de tijdsverschillen, gelegen tussen het moment van de laatste grondbewerking voor de inzaai en het moment van de oogst, is er bij een zomergraan sprake van een korte periode van ongestoorde groei, bij een wintergraan is deze periode aanzienlipk langer. Deze verschillende tijdsfactor heeft een dusdanige invloed op de samenstelling van de onkruidflora van de beide graanculturen, dat in de vegetatiekunde ${ }^{48}$ wordt gesproken over Secalietea, dat wil zeggen onkruidgemeenschappen van wintergranen en van Chenopodietea, waartoe onder andere onkruidgemeenschappen van zomergranen behoren. Afgezien van de tijdsfactor is er nog de factor kalk, in het substraat differentièrend voor een weetal gemeenschappen binnen de Secalietea: kalkrijke wintergraanakkers herbergen een Caucalidion-, kalkarme een Aphanion-onkruidgemeenschap. Vooral Caucalidion-gemeenschappen zijn (respectievelijk waren) in hoge mate karakteristiek voor dat deel yan het onderzoeksgebied, dat momenteel Mergelland wordt genoemd. maar Aphanioni-gemeenschappen kwamen hier ook plaatseliịk voor. ${ }^{49}$

Bovendien is van het Mergelland, dat grotendeels overeenkomt met het door plantengeografen onderscheiden krijtdistrict, en het daaraan grenzende lössdistrict nog een plantengemeenschap beschreven, die kenmerkend was voor vochtige ploegvoren op wintergraanakkers. Deze gemeenschap was opgebouwd uit uiterst kleine, minder dan $10 \mathrm{~cm}$ hoge bloemplanten en mossen.

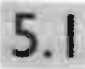

Al eerder werd gewezen op de teelt van de zogenaamde braakgewassen, die een belangrijke rol hebben gespeeld in de areaalafname van de driesgronden of het rustende land, tijdens de middeleeuwen de helft tot een derde deel van het cultuurland of het winnende land omvattend. In tegenstelling tot de plantesoorten van de wilde braak die onder de term "onkruiden" vallen, zijn braakgewassen gecultiveerde soorten. Aangezien het tijdstip van het begin van cultuur voor de meeste soorten braakgewassen slechts enige eeuwen geleden viel, is hun genotype door onder andere gerichte zaadselectie weinig. veranderd; spontane verwildering komt vaak voor. Bovendien zịn diverse braakgewassen. onder andere klaversoorten, oorspronkelijk inheems. De verbouw van braakgewassen heeft in wezen minstens drie functies: veevoer, het onderdrukken van ongewenste soorten en groenbemesting.

Aanvankelijk waren veel soorten braakgewassen, waaronder bladgroenten, leguminosen, wortels en knollen ressorteren, in cultuur rond de nederzetting in moestuinen en koolhoven. Primair werden ze daar geteeld voor menselijke consumptie. Hun teelt op akkers buiten de nederzetting en primair als veevoer schịnt echter een Vlaamse aangelegenheid te zijn. Vlaamse "driesbedrijven" ${ }^{\text {"5e }}$ bezaaiden sinds het begin van de zeventiende eeuw uitgeputte cultuurgronden met rapen, brem, maar vooral met klaver. De klaverakkers bleven daarna drie tot twaalf jaar als weidegrond in gebruik om vervolgens weer te worden omgezet in graanakkers:

Vlak na de. Franse Revolutie hebben met name Franse agronomische deskundigen zich ingezet om dit systeern, dat. de wilde braak produktiever moest maken, op grotere schaal te introduceren. Vanaf dan zịn voor het gebied van onderzoek uitvoerige gegevens beschikbaar betreffende de omvang en soortensamenstelling van de braakgewassen. Elke soort daarvan kent zijn eigen geschiedenis van opkomst, bloeiperiode en verval. ${ }^{51}$

Op de historische aspecten van de verschillende braakgewassen wordt niet nader ingegaan. Wel komen in het hieronder staande enige, oecologisch verwante groepen braakgewassen aan de orde en moet worden geconstateerd, dat van het totale assortiment van meer dan 40 soorten braakgewassen rond $1850 \mathrm{er}$ in 1985 nog slechts drie resteren, namelijk aardappel, biet. en mais. De term braakgewas voor deze op industriéle wijze verwerkte produkten is momenteel misplaatst.

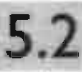

De meest karakteristieke en tevens oudste groep van braakgewassen behoort tot de familie van de Papilioraceae, ook vlirtderbloemigen of leguminosen genoemd. Soorten uit deze plantenfamilie zijn in staat atmosferische stikstof te binden en in ondergrondse organen op te slaan, waardoor zij een positieve invloed hebben op de bodemvruchtbaarheid. De bovengrondse delen leveren een uitstekend veevoer, onder andere door een hoog eiwitgehalte. Van sommige soorten zijn de zaden ook voor menselijke consumptie geschikt. Peuluruchten uit de genera Pisum, Phaseolus en Lens (respectievelijk erwten, bonen en linzen) zijn al uit de prehistorie van het onderzoeksgebied bekend. Historisch nawijsbaar zijn die uit de geslachten Cytisus (brem, dialectisch "ginster"), Lupinus (lupine), Medicago (twee soorten: luzerne, dialectisch "steinklee" of "iewige klee" en hopklaver), Melilotus (honingklaver). Onobrychis (esparcette), Ornithopus (serradella), Trifolium (minstens vier soorten klaver), Ulex (gaspeldoorn) en Vicia (minstens, twee soorten wikke). Bovengenoemde gewassen konden zowel vers als in de vorm van hooi worden gevoerd. Klaver gold als krachtvoer voor paarden. Koeien werden ook wel "aan de tuier", dat wil zeg. gen aangepaald "op de klaver" gezet. De omgeploegdestoppelvormde een uitstekende groenbemesting. Houtige soorten, onder andere brem, werden tevens als brandhout benut. Bremakkers zijn toponymisch navwijsbaar. ${ }^{52}$

Ook soorten uit andere plantenfamilies wverden als braakgewassen gecultiveerd; belang. rijk waren soortenı wit de genera Beta (biet). Brassical (onder andere kooizaad, knolraap, bladkocsl, stengelkool), Fagopirum (boekweit) en Solanum (aardappel). Minder belangriik. waren Bunium (aardnoot), Helianthus. (aardpeer), Daucus (peen), Pastinaca (Iwinzerwortel), Phacelia en Spergula (spurrie). De meeste van de bovengenoemde soorien vormen knollen, die als wintervoedsel voor het op stai' staande vee fungeerden. Aanvankelijk gold dat.zelfs yoor de aardappel. Boekweit werd echter uitsfuitend voor menselijke consumptie geteeld.

Elk braakgewas stelt specifieke eisen, niet alleen ten aanzien van hun agro-techniek, maar vooral ten aanzien van het bodemmilieu Speciale aandacht verdienen vooral die soorten, die op de meest. marginale gronden nog konden groeien, uiteraard zonder toevoeging van organische bemesting (zie figuur II, II). Tot de braakgewassen kunnen eventueel ook de zogenaamde handelsgewassen word'en gerekend; ze leveren produkten die min of 

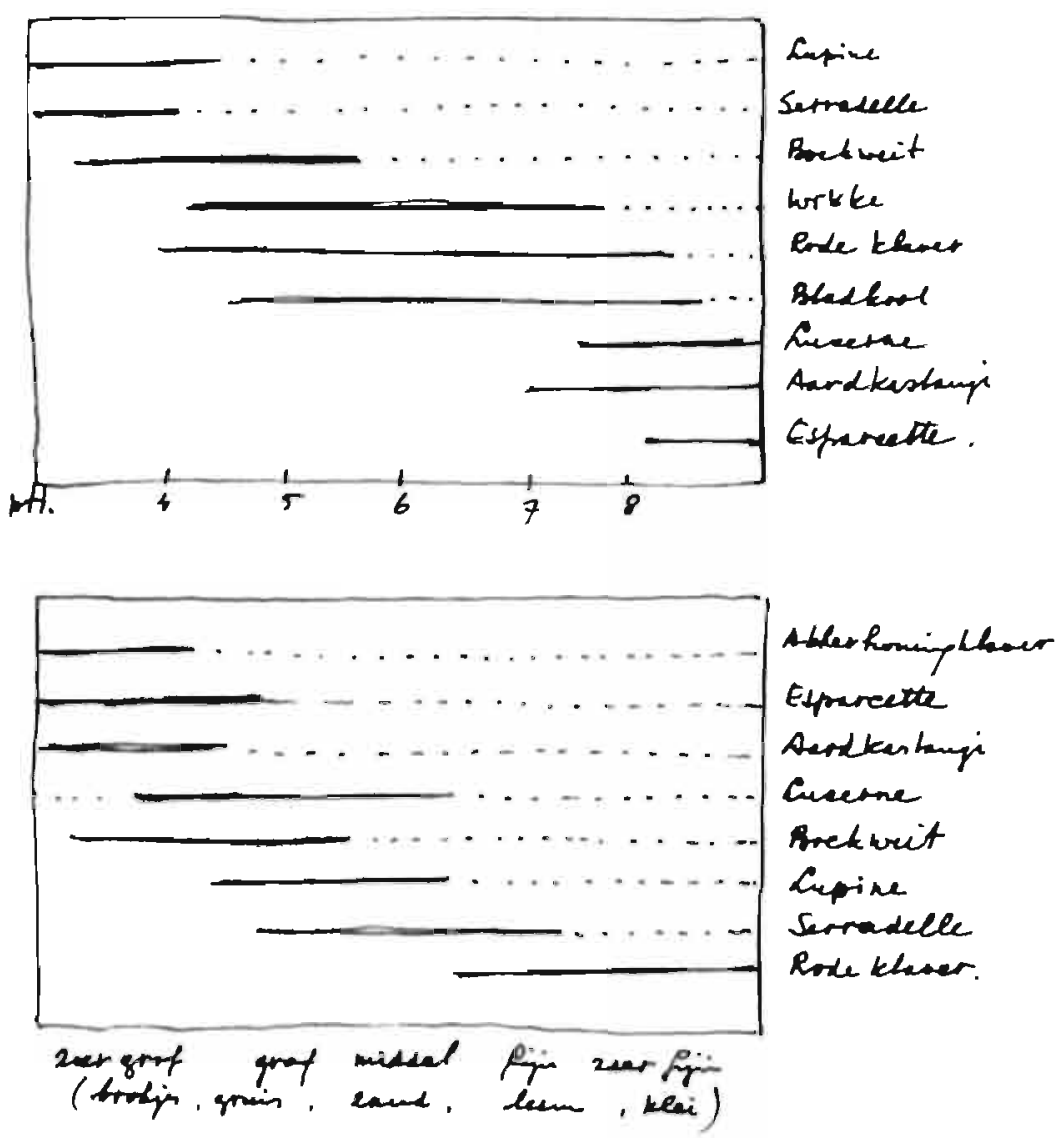

FGUUR 11.1/ De benutting win een sontal broakgewassen in relatle tot enige bodeintypen en hun igenschappen. De meeste broakgewassen bexitien symbiatische wortelbocterien, die stikstof in de bodem ofgeven en alleen al doardoor de bodemvruchtboarheid verhogen. Daarnaast betit elk soort brookgeuras eon voorkeur voor bepaolde bodemtypen. Door de grote variatie aan geteelde braokgewassen op kleine school waren drieslanden destijds zeer soortenrijk.

meer grootschalig buiten het agrarisch bedriff werden verwerke. Slechts een deel van deze gewassen kwam in aanmerking als veevoer. Hiertoe behoren oliehoudende gewassen, zoals Brassica napus (koolzaad), Camelina sativa (huttentut). Sinapis alba (witte mosterd) en deels Linum sativum (vlas). Vervoligens waren er verfstof leverende gewassen, zoals Isatis tinctoria (wede). Reseda luteola (wouw). Rubia tinctoria (meekrap) en vezels leverende gewassen, zoals Linum sativum (vias) en Cannabis sativa (hennep).

Bepaalde nevenprodukten van deze handelsgewassen, onder andere bladloof of het residu van de uitgeperste zaden werden aan het opgestalde vee als wintervoedsel aangeboden. Deze functie ontbreekt bij de teelt van Cichorium intybus (cichorei), Dipsacus fullonum (weverskaarde). Humulus lupulus (hop) en Nicctiana alata (tabak).

5.3 De onkruidflora van de braakgewassen, die na de mechanisatie van de landbouw tijdens de eerste helft van deze eeuw in rijen gezaaid en door middel van "hakken" geschoond werden van onkruid, wordt samengevat onder de term "hakvruchtenflo$\mathrm{ra}$ ". De daaronder ressorterende plantengemeenschappen behoren tot de PolygonoChenopodiecalia R. Tx et Lohm. 1950 em. J. Tx 1961, Een overzicht van deze onkruidgemeenschappen in Nederland werd eerder gepubliceerd; ${ }^{3 s}$ de onderstaande opmerkingen betreffen enige oecologische aanvullingen. Van de braakgewassen die niet in rijen werden gezaaid en waar een hakvruchtflora ontbreekt, is zo goed als niets bekend, wel is men op de hoogte van het bestaan van enkele soortspecifieke parasieten uit de familie der Orobanchaceae: Orobanche minor (klavervreter) kwam tot ongeveer 1960 regelmatig voor in klaver-en luzerne-akkers en $\mathrm{O}$. ramosa in tabak- en hennepculturen. ${ }^{54}$ Orobanche rapum-genistae was zeer waarschijnlijk vertegenwoordigd in bremdriesen, maar hieromtrent zijn geen gegevens bekend. Cuscuta epilinum (vlaswarkruid) woekerde op vlas, maar is inmiddels uitgestorven. ${ }^{53}$

Uit eigen waarnemingen en ongepubliceerde berichten, ${ }^{56}$ daterend uit de periode 1925 tot
1960, is bekend dat in klavervelden, meestal uit Trifolium pratense (rode klaver) bestaande, meerdere klaversoorten voorkwamen. zoals Medicago sativa ssp. sativa (luzerne), Medicago lupilina (hopklaver), Trifolium hybridum (basterdklaver), T. incarnatum (Franse klaver) en T. repens (witte klaver). Andere min of meer karakteristieke onkruiden in klaverakkers waren destijds Daucus carota (wilde peen), Galim mollugo (glad walstro), Silene vulgaris (blaassilene) en Picris echioides (dubbelkelk).

Diverse braakgewassen, met name de veel gecultiveerde rode klaver en koolzaad, produceren veel honing: hiervan profiteerden niet alleen de gedomesticeerde Apis mellifica (honingbij), maar ook vele soorten vlinders. Minstens vier soorten dagylinders, momenteel uiterst zeldzaam geworden, waren geheel afhankelijk van bepaalde braakgewassen. ${ }^{37}$

Hec verdwijnen van driesgronden, gedefinieerd als marginale landbouwgronden die zijn onderworpen aan een wisselbouw van granen en braakgewassen en waarop periodiek weidegang wordt toegepast, is op de eerste plaats te beschouwen als een cultuurhistorisch verlies. Niet alleen zijn veel oude landbouwgewassen verdwenen, die op de een of andere wijze de huidige mens van nu met name in ontwikkelingslanden van nut hadden kunnen zijn. Tevens zịn ook de oude, al vele eeuwen door de mens toegepaste agrarische technieken en methoden verdwenen, zoals onder andere wisselbouw en weidegang op akkers. Het verdwijnen van de driesgronden is daarnaast ook een landschappelijk verlies: de grootschaligheid, het beperkte assortiment aan gewassen en het gegeven dat gedurende de winterperiode de landbouwgronden niet zijn begroeid, verleent het huidige door de intensieve landbouw gedomineerde landschap een grote mate van monotonie en uniformiteit, die in schril contrast staat met het vroegere boerenland. Het zal duidelijk zijn dat de verliezen aan biologische diversiteit zeer groot zijn. Dat geldt niet alleen voor de cultuurgewassen op de driesgronden, zoals de verschillende soorten granen, een onbekend aantal rassen van granen en meer dan 40 soorten braakgewassen. Nog meer geldt dat voor tientallen soorten akkeronkruiden en de ook daarvan afhankelịke fauna-elementen, warvan er een aantal nota bene wettelijke bescherming geniet.

Zowel de in hun voortbestaan bedreigde en wettelijk beschermde das, de hamster alsook veel soorten vogeis en vlinders 
vinden in dit biotoop voedsel en beschutcing. Tenslotte zijn er economische verliezen te koppelen aan het huidige intensieve gebruik van de driesgronden, zeker wanneer men op lange termijn rekent. In tegenstelling tot de schrallheid van de voormalige driesgronden, worden deze momenteel zwaar bemest. De term "mest dumpen" is geheel terecht; een groot gedeelte van de hierin aanwezige nitraten verdwijnt via het grondwater, wordt elders opgepompt en als drinkwater benut. Volgens het principe van "de vervuiler betaale" moeten de zuiveringskosten van het drinkwater worden verhaald op de bio-industrie. Een tweede, eveneens nadelig effect betreft de zijdelingse afspoeling van de drijfmest naar op hellingen gelegen natuurgebieden, die op deze wijze in ernstige mate eutrofièren. Dit geidt met name voor de kiezelkopvegetaties op de plateauranden. ${ }^{\text {an }}$

Een derde economische verliespost heeft betrekking op het afspoelen van de bodem. toplaag door regenwater. Doordat bij het bio-industriele gebruik de bouwgronden op hellingen gedurende de winterperiode geen vegetatiedek dragen, spoelt bij elke regenbui een deel van de bodemtoplaag met het afstromende water mee. Deze vorm van bo. demerosie veroorzakt een keten van aanzienlijke schadeposten. ${ }^{59}$

6 In het dichtbevolkte Zuid-Limburg wordt het verschijnsel van de "sociale braak" vanaf ongeveer 1970 manifester; de periferie van de stedelijke agglomeraties wordt vanaf die tijd in toenemende mate onttrokken aan agrarische en industrièle functies en krijgt meer en meer betekenis als "groenzone", waarvan de belangrijkste functie wordt gevormd door dagrecreatie. Daarnaast kunnen sociaal braakliggende terreinen, met name in Zuid-Limburg, toeristische functies vervullen. De natuur-en cultuurhistorische waarden zijn vaak dermate hoog, dat ook educatieve functies een rol kunnen spelen.

Naast gebieden met een agrarisch verleden liggen aan de stadsperiferie tevens terreinen die een industrieel verleden gekend hebben en in aanmerking komen voor natuurontwikkeling of natuurbouw. Hieronder ressorteren uitgebate of anderszins, verlaten mergel-. zand- of kiezelgroeven, grindgaten, kleiputten, steenstorten en voormalige verdedigingswerken die door middel van bepaalde vormen van extensief beheer (onder andere extensieve beweiding) tot waardevolle natuungebieden kunnen worden ontwikkeld.

Gezien vanuit de hierboven uiteengezette problematiek is het absoluut noodzakelijk de driesgronden van de plateauranden te onttrekken aan hun huidig agrarisch gebruik en aan te wijzen als bufferzones van natuurgebieden. In het beheer van deze gronden kan begrazing door grote herbivoren (onder andere schaapskudden) een belangrijke rol spelen.

Binnen het onderzoeksterrein zijn er minstens vijf stadsagglomeraties aan te wijzen. waarvan perifere delen zich in de bovengenoemde richting ontwikkelen.

Voor Maastricht zijn dit de Sint-Pietersberg. ${ }^{60}$ waarvan de natuur- en cultuurhistorische waarden al in het begin van de vorige eeuw zijn onderkend, de voormalige vesting. werken en het natuurgebled bij Bemelen. ${ }^{61}$ Voor de agglomeratie van Heerlen-Kerkrade is het natuurgebied van de Brunssummer. heide ${ }^{62}$ van belang, terwill het complex van de Kunderberg en Putberg binnen het kader van de landschappelijke herinrichting aanzienlijk zal worden uitgebreid.

Het Meinweggebied ${ }^{\text {ta }}$ zal de belangrijikste groenzone worden voor het stadsgewest van Roermond; kleinere natuurgebieden zijn gesitueerd, ten zuiden en ten westen van de stad.

Rond Aken liggen reeds belangrịke natuurgebieden met een verleden dat sterk door menselijk handelen is bepaald. zoals de Witkensberg, de: Brenigerberg en het Aachener Wa!d en rond de stad Luik zouden naast de al bestaande natuurgebieden in het dal van de Ourthe ook voormalige steenstorten en -groeven tot natuurgebieden moeten worden ingericht.

Binnen het kader van de hierboven geschetste ontwikkeling past de herintroductie van de dries om economische, recreatieve, natuuren cultuurhistorische redenen. Het driesbiotoop is riik aan levensvormen en vormt, evenals de heide, kalkgrașland en hakhoutbos een cultuurrelict, dat als zodanig waardering. behoud en herstel behoeft. Om die redenen wordt dan ook gepleit voor een herstel en een verdere uitbreiding van het areaal driesbiotoop in het onderzoeksgebied.

\section{NOTEN}

1 FESTr 1950, cimat uit 1787

2 BAKEST 1990, p. 243

3. ENeNEN EN JANGSEN 1979, p. 32

4 ENNEN EN Juessen 1979, p 156 en Agrarische ge. schiedenis van Nederland 1986, p. 12

5. Reves 1988, p. 82

6 Ontek het Mergelland 1978. pp. 227-228

7 DE GNOOTH EN VERWEN 1984, pp, 38-40.
8 Welencenc 1986, p. 318

9 Pears et al. 1964. pp. 55.77 en Forr 1950

10 Baxcin. $1989, p$, 40

11 ENAEN EN JANSSEN 1979, p. 32

12 ENEITN EN JANSSEN 197\%, p. 32

13 Wereas 1926, p. 136.

14 Mondelinge mededeling Sjang Brouwers te Hont. hem. Zie ook Goossins 1981

15. De GRooth BN Verwus 1984, pp. 38-39

16 Westhion et al 1970-1973, deel 3. p. 41.

17 Sourucier 1977, p. 70 en De Srior 1991,pp. I4. 15

18: Wicums 1987, pp. 30-32

19 Lnoemuns $1960, p .101$

20 Dr Smiot 1981, pp. 11-30

21 Mededeling Prof. Dr.J.C.G.M. jansen te Masustricht

22 Ontdek het Mergelland 1978 , p. 149

23i VAN DE VININE 1957, p. 113

21. Huroens 1981 a

25i De wasrachijnlijk lastate vermelding van een var. kenshoeder uit het gebied van onderzoek dateert uit 1774 . Zie VAN DE VENNE, 1957, p. 113 en HiLucins. $1989 \mathrm{c}$.

26 Hucrous 1961 a

27 TuFAN 1985

286 Bassanase 1978 pp. 134.137

29 Rotanotck $[973$

30 Lemmenanc 1978-1985, deel 8. pp. 38.46.

31 Game 1978.

32 Hiucous $1981 \mathrm{~b}$ en Wrean et al 1985-1991, dee 3. pp. 226-237

33 Atlas van de Nederiandse fora 1985-1989, deel I pp. 143 en 149 (respectievelijk voor Litum bulbife rum en Muscari comosum), deel 2. pp. 155 en 305 (voor Gagea villosa en Tulipa nlvestris). Ornitheg. alum umbellatum komt weliswar nog wij alemeen voor, maar wordt niet mẹer in graanakkers aangetraffen

31 HiLfoEs 1981 a. p 127

35i HULGES 1985c

36 Westhorf EN DEN HeLo 1975, pp. 84.99

37' RENES 1988, pp. 137.140

3i. Peizers et al. 1986.

39) ROtaRotCK 1973.

iii JASPAR et at. 1972, p. 43

11 SCHAIPNEMAKens 1986

12. MSSELING EN SCHEYGRONO 1950, p. 321

(3) Zie tabel 7.5.1

11 De rond Maastricht actieve floristan uis het begin van de negentiende eeuw vermelden her milieu van de wilde braak niet als zodanig.

45, Fistr 1950, p. 59

46. Zie hoofstuk i?

17 HenNex.ENS et a! 1983

18. WESTHOF EN DEN HLL 1975 en SIrsINGH 1950

191 HIUFCERS 1984

50) Livotmuss 1960 en MeEkTEN in Algemene Geschie. denis der Nedertanden 1981-1982. p I5

51 Zie onder andere PHups et al. 1964, pp. 62-77

52. Onder andere Ginsterdries (Str) bij Wahlwiller. Brẹemakdeer (Str) bij Heer en Brẹemacker (Joni bi Sittard.

53 WESTHOF EN DEN HHO 1975

34 Wenor et al. 1985. 1991, deel 3, pp. 238-244

5. WeroAet al. 1985-1991, deel 3. pp. 117.118.

56 De Wever antekeningen, ongepubliceerd. Aanwe. zig in het archief van het Natuurhistorisch Genoot. schap to Mastricht.

57 Braakgewas afhankelipke dagvlindersoorten: gete en oranje lucernevlinder en klaverblauweje. Zie CAN. TER EN PHILIF 1983

58 HIUFGers 1984a, p. Ba

59) BemEMMNo in Bodemerosie 1988.

60 Vaw Scraix 1983

61 HUEGers $1984 a$

62! VAN DER MAST 1983

63 LENDERS 1983. 


\section{FLORA EN VEGETATIE VAN DE DRIESGRONDEN OP DE SINT-PIETERSBERG BIJ MAASTRICHT}

"Vele dezer Kulturen worden begeleid door een groot aantal
akkeronkruiden, waarvan sommige, wanneer ze in vollen bloei

zijn, een schilderachtig aanzien aan het bouwland geven en

inderdaad heb6en dan ook Kunstenaars van naam dit

landschap op het doek weergegeven; deze schilderstukken

hebben dan ookveel weg van een gekleurd dambord waardoor

velen wellicht aan de werkelijkheid twijfelen en het voor

fantasie houden."
De Sint-Pietersberg dankt zijn naam aan het dorp Sinc-Pieter bij Maastricht. Het is een "tafelberg", waarvan zowel het plateau als de hellingen onvruchtbare boderns bezitten. Op het plateau liggen slechts enkele grote hoeven, die in het verleden een extensieve graanteeit bedreven. De met droge en schrale graslanden bedekte hellingen en sommige delen van het plateau waren ongeschikt voor landbouw en werden evenals stoppelakkers en braakliggende gronden (= driesgronden) eeuwenlang door schaapskudden beweid. Hun mest maakte, aangevuld met stadsbeer, graanteeit op het plateau mo- gelijk.

Dank zij onder andere de grote variatie aan bodemtypen en het eeuwenlange extensieve beweidingsbeheer ontwikkelde zich hier een voor Nederlandse begrippen buitengewone flora en fauna. Hiervan is niet alleen vroeg in de geschiedenis van de floristiek en faunistick, maar ook regelmatig in latere tijd, verslag gedaan (zie figuur 12.1).

Op grond van deze floristische gegevens is het mogelijk de onkruidrijkdom van de graanvelden uit het verleden te analyseren en veranderingen in de soortensarnenstelling in de laatste twee eeuwen te volgen. Deze veran- deringen gingen gepaard met een groot verlies aan diversiteit van de flora, veroorzaakt door wijzigingen in de agrarische bedrijfsvoering. Tevens verdween een deel van de berg door afgraving ten behoeve van de cementindustrie.

Sinds kort bestaat er een volledig, nieuw beleid ten aanzien van het beheer van de SintPietersberg, die in 1977 tot natuurmonument is verklaard. In dit nieuwe beleid is bewust gekozen voor de herintroductie van de extensieve beweiding door middel van een trekkende schaapskudde, gekoppeld aan een extensieve verbouw van granen, omdat deze
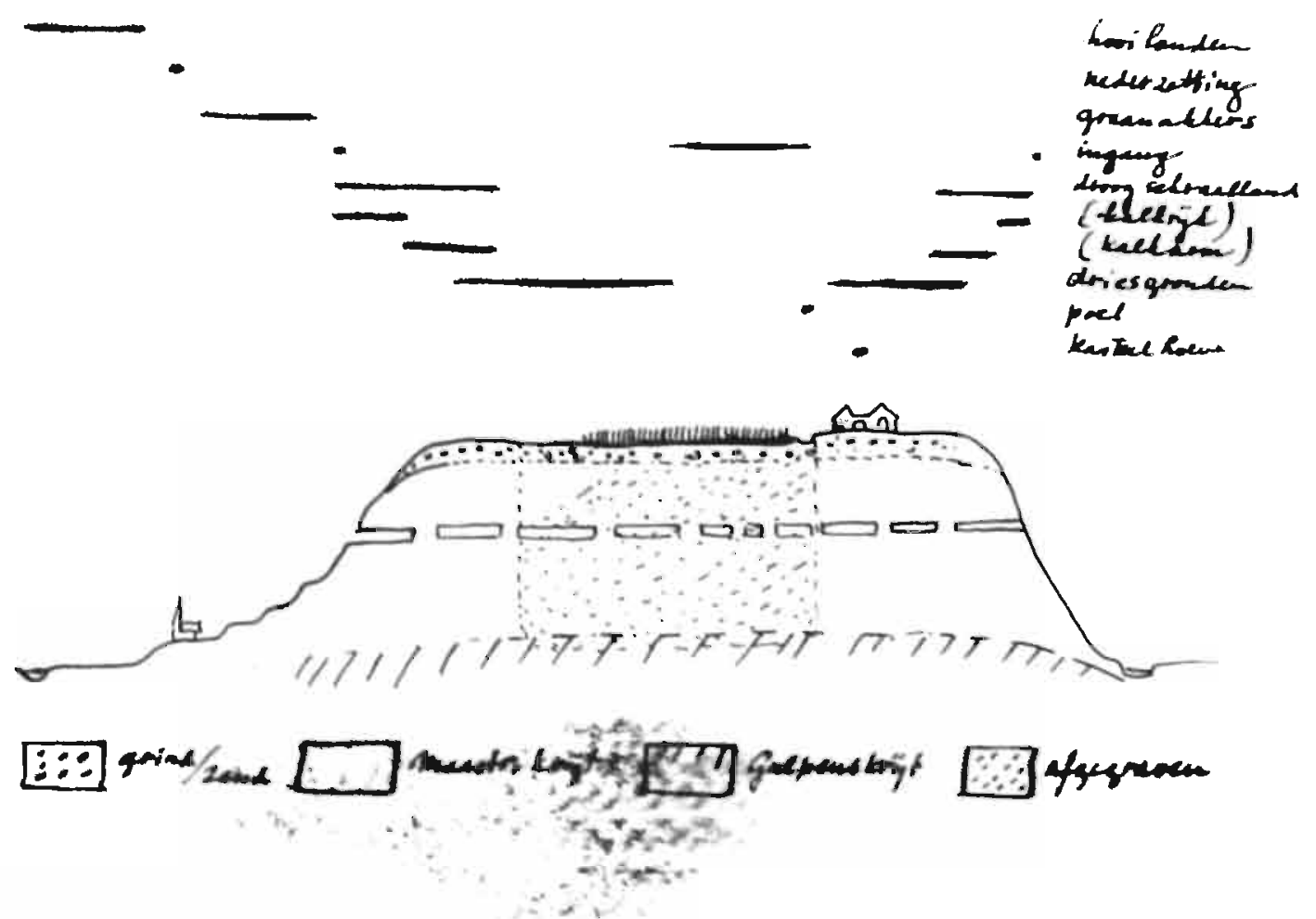

\author{
FIGUUR 12.1. \\ De Sint-Pietersberg. \\ Schemotische doorsnede \\ en grondgebruik rond \\ 1850. Het gestippelde \\ deel is: momenteel \\ ofgegroven ten behoeve \\ van de cemerreindustrie. \\ In feite is de Sint- \\ Pietiersberz geen berz \\ maar een plateau. De \\ steile randen zijn voor \\ landbouw ongeschiks; re \\ werden els droge \\ scihroellanden benut. \\ Ook de platecuranden \\ werden als zodanig benut \\ vanwege hun geringe \\ muclinbaarheid. Periodiek \\ werd' dit viait gelegen \\ driesland als bouwland \\ Benur. Alleen op het \\ centrale deel lais een dun \\ Hossdek, dat als \\ permonent bouwland \\ dichtbili the hoeve in \\ gebruik was.
}


traditionele vorm van beheer mede de basis vormde van de vroegere diversiteit en stabiliteit van schrale graslanden en driesgronden. Op kdeine schaal is sinds 1989 met deze wijze van beheer op de Sint-Pietersberg geêxperimenteerd; de resultaten daarvan zijn zeer hoopgevend.

\section{2}

De Sint-Pietersberg, deels op Nederlands, deels op Belgisch gebied gelegen, is geomorfologisch gezien geen berg, maar een smal plateau dat ingekdemd ligt tussen het dal van de Maas en dat van de jeker. Het Albert. kanaal vormt de geomorfologische zuidgrens. Het vlakke deel van de "tafelberg", met een oppervlak van ongeveer $350 \mathrm{ha}$, bestaat uit tertiaire zanden en grinden die hier met name op de randen van het plateau aan de oppervlakte komen. De steile hellingen naar de Maas en enige delen van de jekerdalhelling bestaan uit dagzomende krijtgesteenten. Deze zijn niet alleen vanwege hun hellingshoek voor landbouw ongeschikt, maar ook omdat hun kalkhoudende bodems sterk waterdoorlatend en dus erg droog zijn. Oppervlaktewater in de vorm van bronnen of beken ontbreekt op zowel het plateau als op de hellingen. Alleen op de lagere hellingdelen dicht biị de Maas of de Jeker, waar vochtiger en mineraäliijker bodems en oppervlaktewater binnen handbereik voorkomen; zijn de voorwaarden yoor landbouw en bewoning gunstiger, Op het plateau ontbreekt sinds de afgraving van het centrale gedeelte, de voor de rest van Zuid-Limburg zo kenmerkende en vruchtbare löss.

Door zijn ligging in de uițerște zuidoosthoek van Nederland, waar de inviloed van de Noordzee kleiner is en waar een meer continentaal klimaat heerst, is het lokale klimaat van de Sint-Pietersberg droger en zonniger dan in de rest van Nederland en het verschil tussen de gemiddelde zomer-en wintertemperaturen groter.

De geografische positie van de Sint-Pietersberg heeft een uitgesproken grenskarakter. Hij kan worden beschouwd als de meest noordelijke uitloper van de continentale middelgebergten, die uitsteekt in het vlakke Atlantische laagland. Via die natuurlijke toegangspoort van het Maasdal is de verbinding totstandgekomen tussen de Lage Landen aan de Zee en het Bourgondisch hart van WestEuropa. Aan die positie dankt de stad Maastricht aan de: voet van de Sint-Pietersberg haar epitheton "Yseren Stad" 2 en de berg ernaast de naam "plantengeografisch bastion $^{-3} \cdot 3$

AGUUR 12.2

De Sint-Pletenberg op de Ferroriakeort, rond 1780. De geschreven telusten op het plateou luiden: C(hatesu) de Neerenbergh, een rendivenen hoeve $(7)$. "Lavandegh Courv, $t$ de Recollets", mogelijk Slavante en Mlooster ron de Recolletten, "c. II de Lichtenberg". mogelijk de kapel van de Lichtenberg, "cho. de Lichtenbers". kanteelhoeve de Lichtenberz, "cha Carter", het inmiddeh verdwenen karteel Caenter, "cha et cabaret Le Sart", de inmiddels verdwenen hoeve en ultapanning Sart.
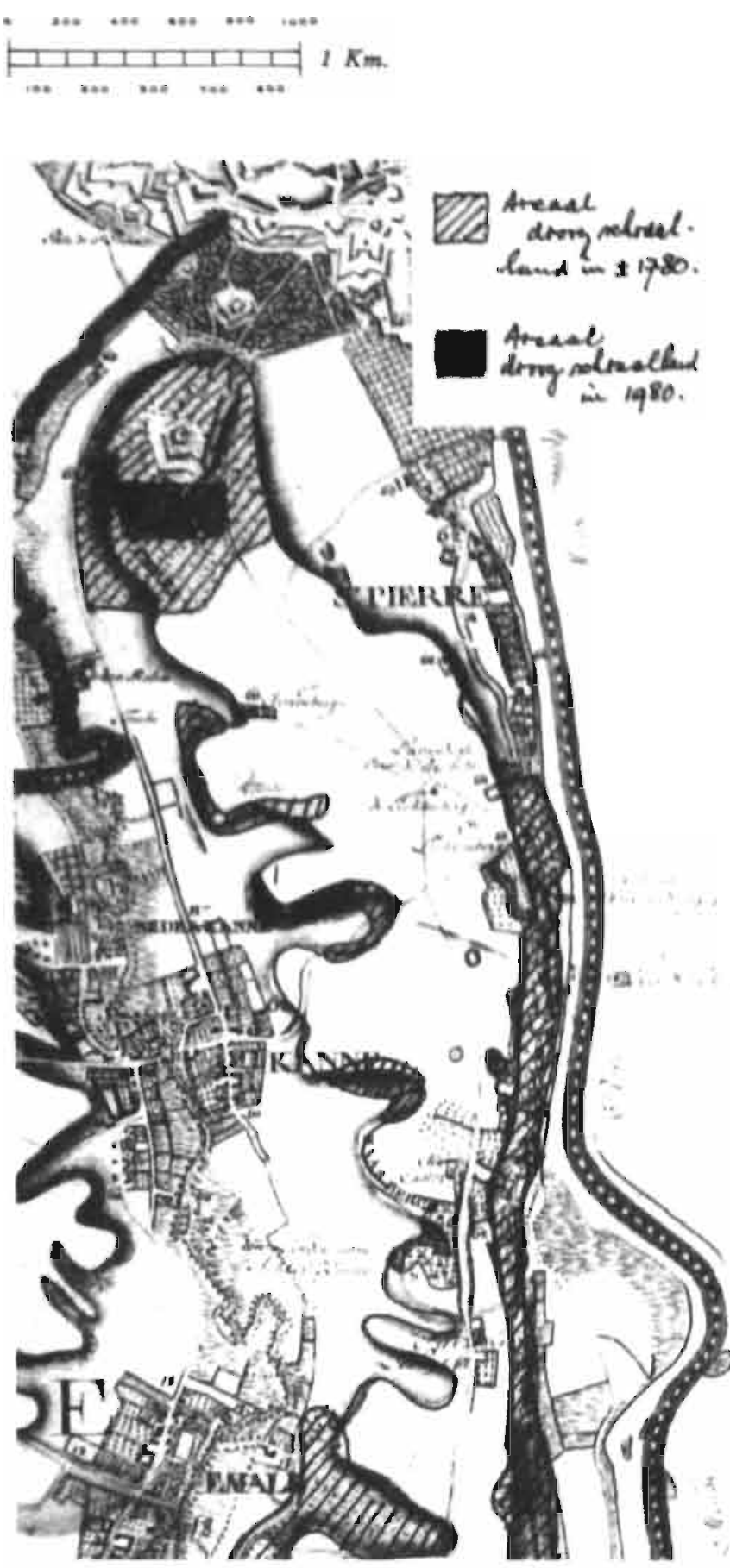

3.1

Tijdens de prehistorie is deze door de natuur gevormde doorgangsroute van Noord naar Zuid vaak door zwervende jagers bezocht: niet ver van hier bevinden zich de oudste bewijzen van menselijke bewoning op Nederlands grondgebied. ' Gedurende latere fasen van de prehistorie, toen sedentaire landbouwers en veetelers de plaats innamen van nomadische jagers en verzamelaars, werd het gebied min of meer permanent bewoond. Vanaf toen moet de natuurlijke climax-vegetatie van het gebied, dat wil zeggen bos, al zijn beïnvloed. In die richting wijzen de opgegraven restanten van bandkeramische nederzettingen, de cerste boerencultuur binnen Europa, waarvan de ouderdom worde geschat tussen 4000 en 2500 jiaar vóór het begin van onze jaartelling. ${ }^{5}$ De opgegraven metaalsmeltovens uit de ijzertijd aan đe voet van de Sint-Pietersberg veronderstellen een toenemend gebruik van hout als brandstof. ${ }^{6}$ Omdat deze sedentaire bevolkingsgroepen tevens veeteelt bedreven, mag men veronderstellen dat de vegetatie van de Sint-Pietersberg gedurende de laatste fasen van de. prehistorie al deels open, dat wil reggen boomloos was.

De veronderstelling dat het gebied deels 
FIGUUR 12.3 .

Schaopskudde met
herder op het plateau
van de Sint-Pleters-
berg- Foto uh 1920 .
Dezelfde herder en
kudde beweidde
eveneens de
voormallge vestingwer-
ken rond Moastricht
De foto geeft een
duidelljk beeld van het
oorspronkellike droge
schraalland op de rand
van het plateau.

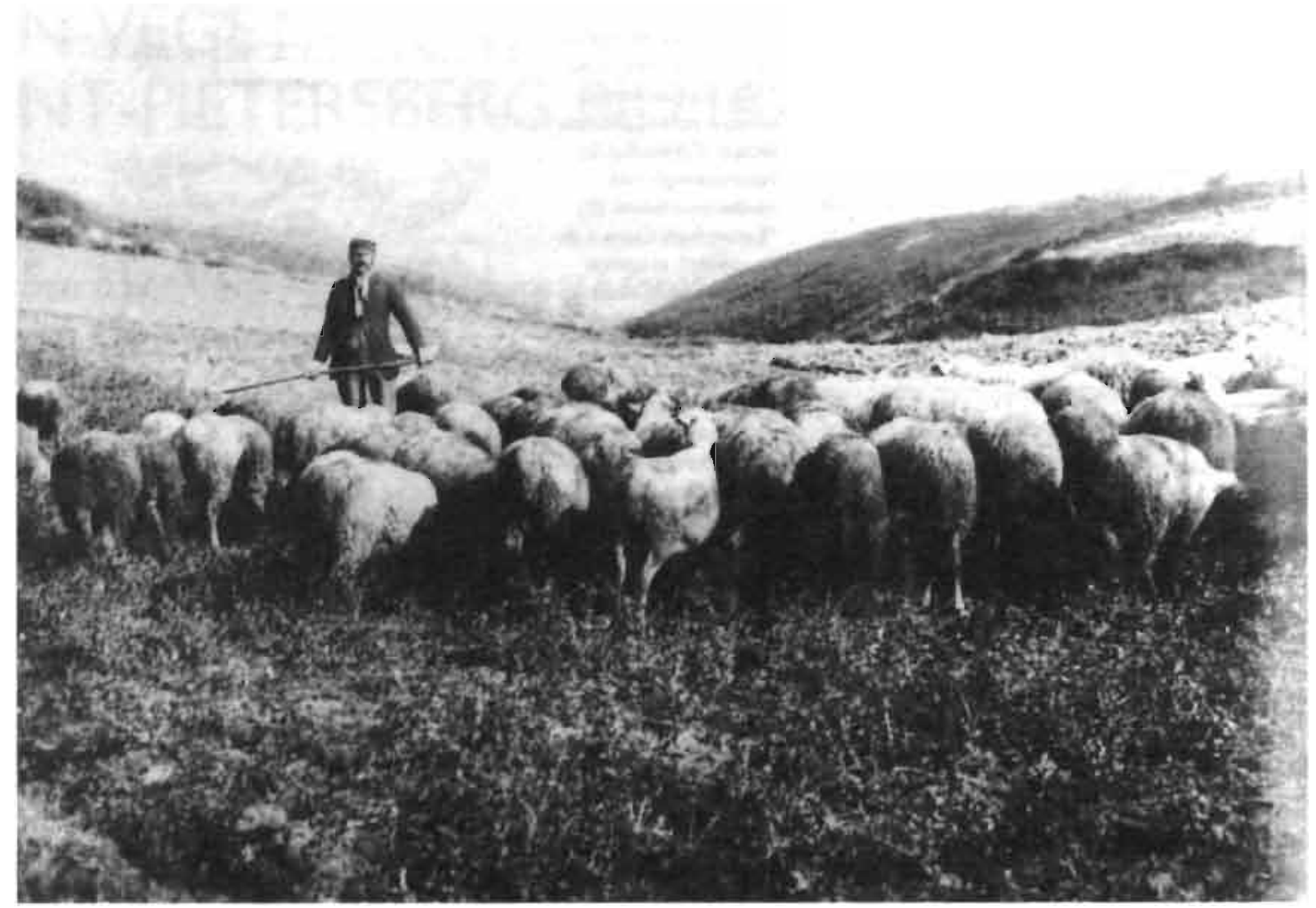

boomloos was tijdens de beginfase van de historische periode, wordt versterkt door eni= genederzettings-en veldnamen uit die periode. Op het plateau ligt dan een Romeins legerkamp, wạarvan de naam "castra" rechtstreeks verband schijnt te houden met hec uit de middeleeuwen daterende kastee! Caes. ter. ${ }^{7}$ Aan de voet van de berg ligr de in de Romeinse tijd al ommuurde vesting Maastricht. De nederzetzing Kanne in het dal van de Jeker bestaat dan evencens. Voorts liggen er rwee "Tombe"-toponiemen op de westelijke plateaurand van de Sint-Pietersberg," waarvan er éen met zekerheid te identificeren is met een "tumulus", een grafheuvel van Gallo-Romeinse oorsprong. Dergelijke op de plateaurand opgeworpen grafheuvels zijn "skyline"-monumenten en in een beboste omgeving ondenkbaar. Ook wordt cen R.omeinse oorsprong verondersteld van de toren van de Lichtenberg. Dergelijke wachttorens, ${ }^{\circ}$ waarop met behulp van vuur lichtsignalen werden doorgegeven, zijn bekend uit Zuid.Limburg, maar er bestaat geen archeologisch bewijsmateriaal voor de stelling dat de Lichtenberg uit die tijd dateert.

3.2 Uit de vroege middeleeuwen zijn geen directe gegevens bekend ten aanzien van de vegetatie op de Sint-Pietersberg. Maar omdat de stad vanaf de Romeinse tijd nagenoeg continu wordt bewoond en in omvang, toeneemt, is de aanwezigheid van primair bos in de onmiddellijke omgeving van Maastricht zeer onwaarschijnlijk. De aanwezigheid van secundair bos en heide op de SintPietersberg, gedegradeerd door selectieve kap en beweiding, ligt meer voor de hand. Vlak na het jaar 1000 begon de tweede ontginningsgolf in Zuid-Limburg. warin de eventueel nog beboste plateaus definitief in cultuurgionden werden omgezet. De toename van de vraag naar ander bouwmateriaal dan hout heeft vanaf de dertiende eeuw de kiern gelegd voor de exploitarie van mergel als bouwsteen voor stadsmuren en kerken. Van toen af waren de strategische belangen van de punt van het plateau en de economische belangen van de ondergrondse steengroeven vele malen belangrijker dan de agrarische. Met een aan zekerheid grenzende waarschijnlijkheid kan worden gesteld, dat vanaf de hoge middeleeuwen de Sint-Pietersberg. een vrijwel boomloos cultuurlandschap droeg.

Een cultuurtandschap, bestaande uit schraa!land, dat wil zeggen heide, graanvelden en de daarmee in verband staande braakliggende gronden, kan pas worden verwacht vanaf het moment dat aldaar hoeven zịn gesticht. Hun aancal, in relatie tot het oppervlak cultuurland van ruim $300 \mathrm{ha}$, is in de loop van de tijd opvallend beperkt gebleven. ${ }^{10}$ Hoewel er op het plateau in totaal vier, mogelijk vijf hoeven bekend zijn, hebben slechts twee hoeven vanouds het plateau geëxploiteerd. Dat zijn de kasteelhoeven Lichtenberg en Caester. waarvan de naam al in de elfde esuw wordt genoemd. Het kasteel Caester is verdwenen, de hoeve bestaat nog, evenals de ruine van de middeleeuwse burchttoren Lichtenberg en de daarbijbehorende hoeve. Een derde zeer oude hoeve is hoeve "Sart", waarvan het gebouw in de jaren viịftig verdween. De naam is Waals voor "rode" en lijkt gegeven aan een ontginningshoeve uit de hoge middeleeuwen, vergelijkbaar met de overige "rode"nederzettingen op de plateaus in Zuid-Limburg en de "sart"-nederzettingen in het daaraan grenzende Land van Herve, die dateren wit de ontginningsgolf in de elfde en twaalfde eeuw. Het grondgebied van hoeve Sart lag. buiten het gebied van het plateau. Hoeve Zonneberg, gelegen op de oostflank van de berg, is de kleinste en waarschịnnliịk jongste: hoeve. Het huidige gebouw dateert uit de negentiende eeuw. Mogelijk was een gebouw op het noordelijke deel van het plateau, genaamd "Neerenbergh", eveneens een hoeve (zie figuur 12.2).

Een karakteristiek element van elke hoeve is: de grote veepoel. Geen van de hierboven genoemde hoeven heeft zich in de loop van de tijd tot een nederzetting verdicht. Elders op de plateaus gebeurde dat wel. Uit deze gegevens laat zich voorzichtig vaststellen, dat 


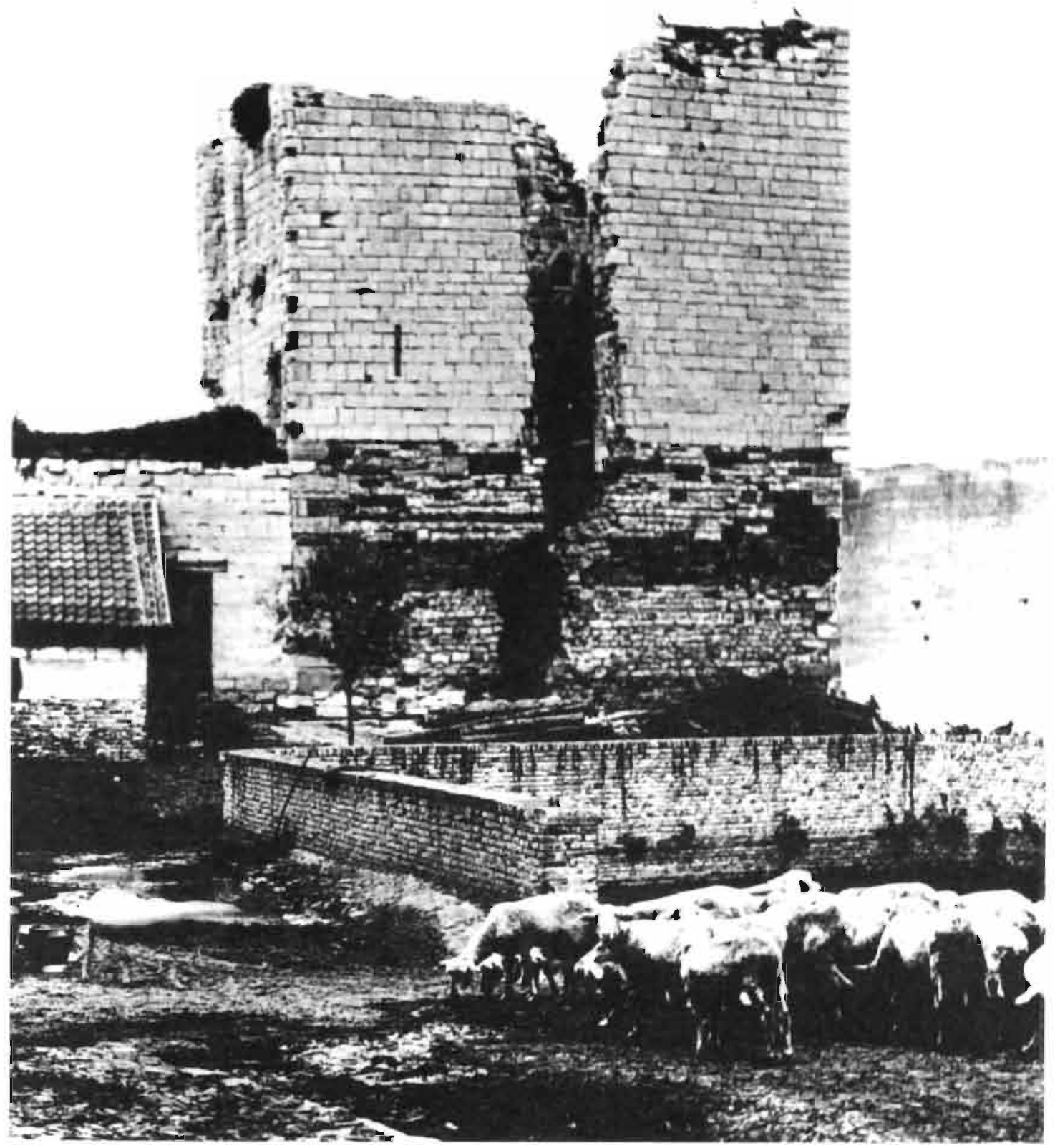

FGUUR 124

Schaopskudde op de Lichtenberg. Foto uit 1893. Venaf 1991 is er weer een hender met een trekkende kudde schepen aanwexig op de hoeve Lichtenberg.

slechts twee hoeven het plateau van de SintPietersberg hebben geëxploiteerd, hetgeen op een indirecte wijze aangeeft wat bodernkaarten direct weergeven, namelijk de geringe vruchtbaarheid van de plateaugronden. Een extensieve graanteelt met lange braakperioden door een gebrek aan stalmest is dan ook de meest waarschijnlijke vorm van exploitatie geweest.

\subsection{De eerste topografische kaarten.} voldoende gedetailleerd en met vermelding van diverse begroeiingseenheden die een duidelijk beeld geven van de vegetatie, zijn die yan Ferraris uit de periode !77!-1777 11 en yan Tranchot uit 1803-1820.12:

Vrijwel alle hellingen en plateauranden zijn dan bedekt met schraalland; op het plateau liggen zowel landbouwgronden als schraallanden, die op de Tranchotkaart bovendien als "pâturages" zijn aangegeven. Het areaal bos is beperkt tot een zeer smalle strook op de meest steile delen van de Maasdalhelling tussen de Lichtenberg en Caester. Gezien de aanduiding op de kaart bestond het meer uit verspreid liggend struikgewas dan uit bos. Ten zuiden van kasteel Caester ligt, eveneens. op de Maasdalhelling, het "Bois de Caester". dat als een parkbos yan het gelijknamige kas. teel kan worden beschouwd. Bij het gehucht Henisse was er nog een hakhoutbosje.

Uit dezelfde periode dateert een beschrijving van de plateaurand door Bory de St. Vincent. die de ongeveer $20 \mathrm{~km}$ lange Maasdalhelling tussen Hallembaye en het fort Sint-Pieter schildert als een heide, waar schaapskudden grazen en waar' schepers met hun kudden beschutting zoeken in de ingangspartijen van verlaten gangenstelsels. Afbeeldingen uit de negentiende eeuw bevestigen dit beeld.

De legenda van de beide kaarten geeft geen verschil aan tussen permanente landbouw- 
FGUUR 12.5. Restanten von het droge schraalland met de status notuurreservoot in 1988 op Beigisch en Nederlands grondgebied van de SintPletersberg.

De betekenis van de cijfers is als volgt:

1. Werthelling

2. Kannerhei

3. Poppelmondedal

4. Grasland bij de gremipalen

5. Grosland bij de Insnijding van het Albert-kanaol

6. Thier a lo Tombe

7. Thier des Vignes

sa. Thler de Lanaye

8b. Thier de Nivelle

9. Heyoule

10. Pachlouw

I1-12. Thier de Loen

13. Cóteau du Tunnel
Mastricht

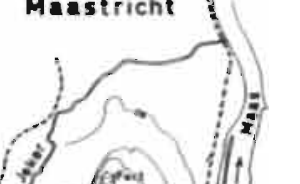
;

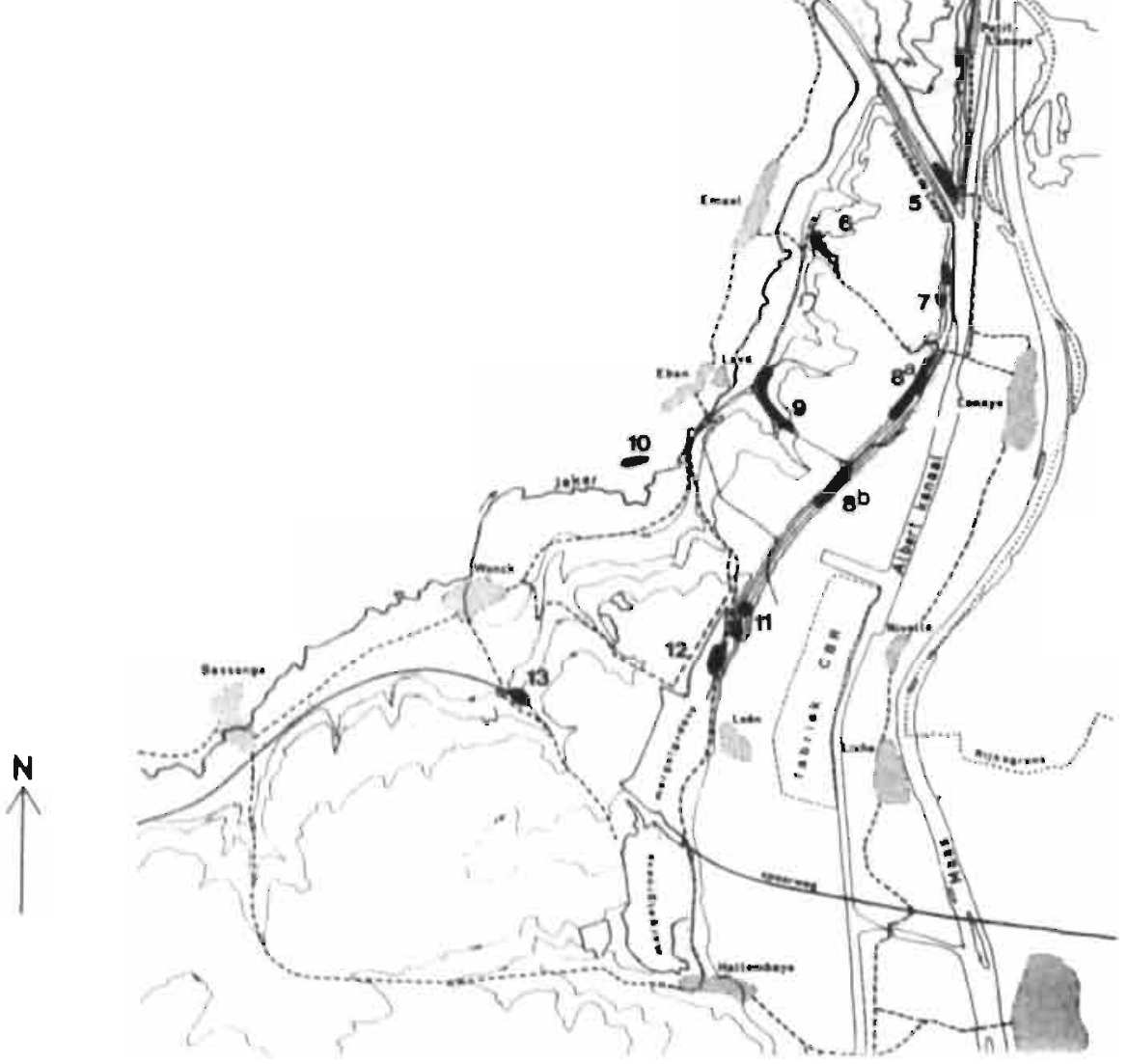

gronden en de frequent braakliggende landbouwgronden, de "driesen". Die zịn toponymisch wel anowijsbaar. ${ }^{\text {a }}$ Gezien de relatief́ slechte bodemkwaliteit, de ongunstige verhouding schraalland-bouwland, " de daaruit voortvloeiende tekorten aan mest en de lage hoevedichtheid op het plateau, moet de aldaar bedreven graanteelt extensief zijn geweest. Zeer waarschijnilik bleven vele percelen bouwland èen of meerdere jaren braakliggen al naar gelang hun vruchtbaarheidsgraad. Gecultiveerde braakgewassen. meestal klaversoorten en stoppelknollen. hebben in de loop van de achtriende en negentiende eeuw de wilde braak vrijwel geheel verdrongen. De teelt van granen bleef hoofd- zaak tot halverwege de twintigste eeuw.

Een reeks van topografische kaarten uit de periode 1860-1950 lạat zien, dat het plateau le hellingen en aanvankelijk zelfs op het plateau lag schraalland, terwịl de minder steile en vruchtbare hellingen bij de nederzettingen in de dalen werden ingenomen door boomgaarden en kleinschalige akkers. De dalbodems en hellingen werden geèxploiteerd vanuit de daar gelegen kleine landbouwbedrijven. Bij elke nederzetting in het dal behoorde een gemeenteheide, deels op de hellingen, deels op de plateaus gelegen, die door schaapskudden werd beweid (zie figuur 12.3). Op het plateau werd een extensieve werd beheerst door akkerbouw. Op de stei- graanteeit bedreven door een tweetal grote kasteelhoeven, waarvan er zeker één schapenteetr. in kuddeverband bedreef (zie figuur 12.4). Afgezien van schraallanden zullen de schaapskudden van de hoeven op het plateau, maar ook vanuic de dorpen in de dalen, tevens de uitgestrekte stoppelvelden en braakliggende akkers als weidegronden hebben benut. Hun rnest, opgespaard in de potstal en vermengd met stro van de graanakkers, vormde de basis van het landbouwsysteem. Vanaf het begin van de negentiende eeuw werd op de hoeve Lichtenberg het gebruik van stalmest aangevuld met stadsbeer, afkomstig uit Maastricht.

Vanaf 1920 verandert het hierboven geschetste bovengrondse beeld van de Sint-Pietersberg, dat eeuwenlang werd bepaald door agro-pastorale bedrijvigheden. Twee factoren zijn hiervoor verantwoordelijk: die van de industrie, met name de cementindustrie die her plateau vanuit hec Maas dal ging afgraven, en de introductie van de kunstmest in het agrarisch bedrijf. Dit produkt veranderde de aard van het gemengd bedrijf, waardoor zowel de schaapskudden verdwenen als de schraallanden en de brak overbodig werden. Via natuurlijke processen werden de schraallanden ruiger, voor zover ze niet al verdwenen waren door bewuste inplant van $\operatorname{bos}^{15}$ of werden vermalen tot cement.

De afname van het areaall driesland tussen 1800 en heden is met duidelijke cijfers vooralsnog niet aan te geven, omdat de Tranchotkaart het verschil tussen periodiek of permanent bouwland buiten beschouwing laat. Maar op vergelijkbare bodems elders in ZuidLimburg bedraagt het perceritage driesland rond 1800 ongeveer $30 \%$ van het oppervlak bouwland. Beter zijn wij geinformeerd over de floristische samenstelling van de graanakkers en het driesland van de Sint-Pietersberg tiịdens het begin van de negentiende eeuw. Met behulp van deze gegevens kan worden vastgesteld, dat in de loop van de negentiende eeuw de wilde braak geheel verdween ten gunste van de teelt van braakgewassen. ${ }^{16} \mathrm{~A}$ an de hand van opgaven van bepaalde plantesoorten, waarvan de oecologie momenteel goed bekend is en die tijdens de eerste helft van de negentiende eeuw in graanakkers op de Sint-Pietersberg yoorkwamen, kan het vermoeden worden geuit dat de wilde braak toen nog voorkwam.

Ten aanzien van de afname van het areaal schraalland vanaf het einde van de achttiende eeuw zijn wij nauwkeuriger geinformeerd, omdat de kaarten van Ferraris en van Tran- 


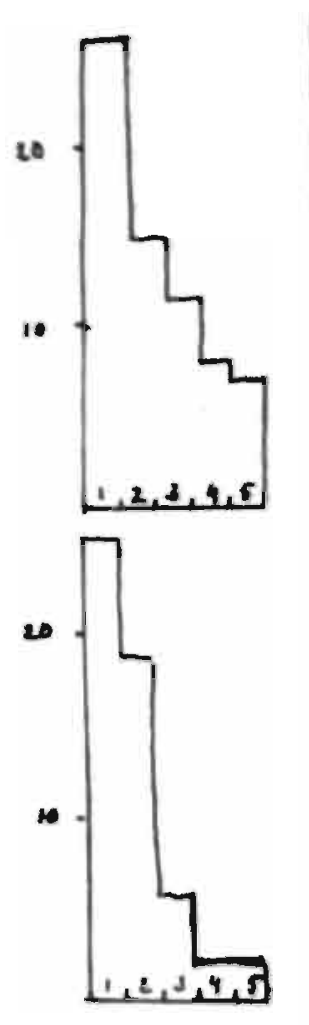

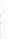
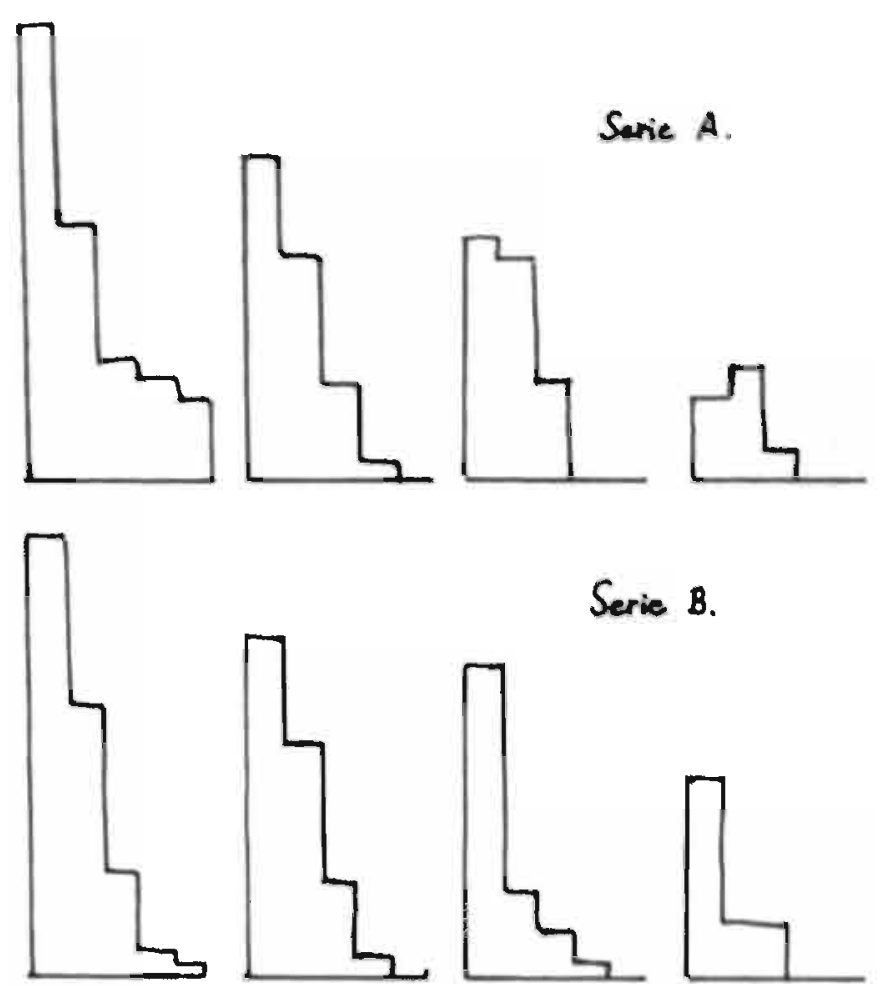

1828

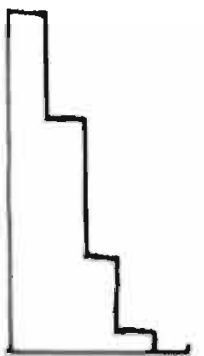

180 een bepaald gebied. Hun soortenlijsten bevatten aantekeningen over de verspreiding. de zeldzaamheid of standplaatsgegevens.

Uit de geschiedenis van de floristiek is bekend dat de Sint-Pietersberg een haast magische aantrekkingskracht heeft uitgeoefend op floristen; de oudste vermeldingen van plantesoorten door Lejeune." en zelf́s complete soortenlijsten van het gebied, zoals die van Bory de St. Vincent, ${ }^{18}$ dateren al uit het begin van de vorige eeuw. Deze oude lịsten werden door latere floristen aangevuld of van commentaar voorzien, onder andere door Franquinet en Dumoulin, ${ }^{19}$ rond het midden van de vorige eeuw. Tijdens het begin van de twintigste eeuw verrichtte De Wever uitvoerigonderzoek, waarvan de resultaten zijn vermeld in onder andere een monografie met de natuur en het milieu van de Șint-Pietersberg tot onderwerp, die door Van Schaik in 1938 werd geredigeerd. ${ }^{20}$ In 1964 werd de flora van de Sint-Pietersberg geinventariseerd door Traets. ${ }^{21}$ Tenslotte werd in 1983 de monografie van Van Schaik herdrukt en opnieuw van commentaar voorzien. ${ }^{22}$ Er zijn maar weinig gebieden in Nederland en Noordwest-Europa waarvan een dergelijk omvangrijk floristisch feitenmateriaal is opgebouwd.

Met behulp van deze gegevens, die een pe-
RGUUR 12.6. Stoofdiagrammen met betrekking tot de echterultgrang van de flora van de groonakken op de: Sint-Pietersberg. Serie A: op kalkarme bodems, serie B. op kolikrike bodems. De diogrammen zilin per serie chronologlich cerangachilkt. voor xover alj aijn voorzien van een jaartal en ziljn verdeeld in vertikale staafeenheden, genummerd I tot en met 5 . Het zijn de volgende oecologische groepen: 1 . winterannuellen, 2, somerannuel. len, 3. meerjarigen, 4. hemiparasieten en 5. geoffren.

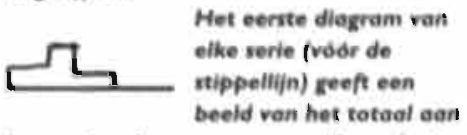
kenmerkende soorten greanakkeronkrulden, opgesplitst in de hierboven opgesom. de oecologische groepen voor groanakters op kallerijke en kalkarme bodems; hes zilja kensoorten en differentirende soorten voor het Aphanion en Caucalidion voigens Wesmow EN. Den HrLo 1975. Het jeartal onder het betreffende blokdiagram komt overeen met het aantal noorten groanokkeronkruiden, die in het betreffende jear voorkwamen op de Sint-Pietersberg. respectievelijk rolgens BonY ot ST, VINCENT 1821, DUMOUIN 1868, De Wrven 1918,

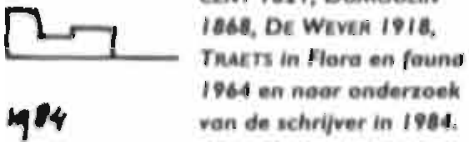

riode van bijna twee eeụwen beslaan en bovendien betrekking hebben op momenten die zich met een zekere regelmat in de tijd voordoen, wordt in de onderstaande paragrafen een historisch overzicht gegeven van de driesflora op de Sint.Pietersberg. Dit overzicht heeft op de eerste plaats betrekking op het aancal soorten en oecologische groepen yan graanakker- en braaklandonkruiden, die op de Sint-Pietersberg voorkwamen en die typerend waren voor dezelfide vegetacietypen elders in Nederland. Daarnaast is de zich wijzigende soortensamenstelling van dit biotoop op de Sint-Pietersberg in de loop van bijna twee eeuwen weergegeven. Het resultaat van dit zowel vergelijkend als historisch overzicht is weergegeven in de vorm vart een aantal staafdiagrammen (zie figuur 12.6).

De eerste twee staafdiagrammen van elke serie hebben betrekking op de vergelijking cussen de flora van de graanakkers op de SintPietersberg en op die, welke als Nederlandse standaard fungeert. Beide fora's zịn nagenoeg gelijk, dat will zeggen de flora van de graanakkers van de Sint-Pietersberg in het begin van de vorige eeuw beantwoordt aan het ideale en meest complete beeld van de flora van een Nederiandse graanakker. Dit complete beeld geldt. zowel voor graanakregistreren ook op andere wịzzen en vermelden andere gegevens betreffende de flora van 


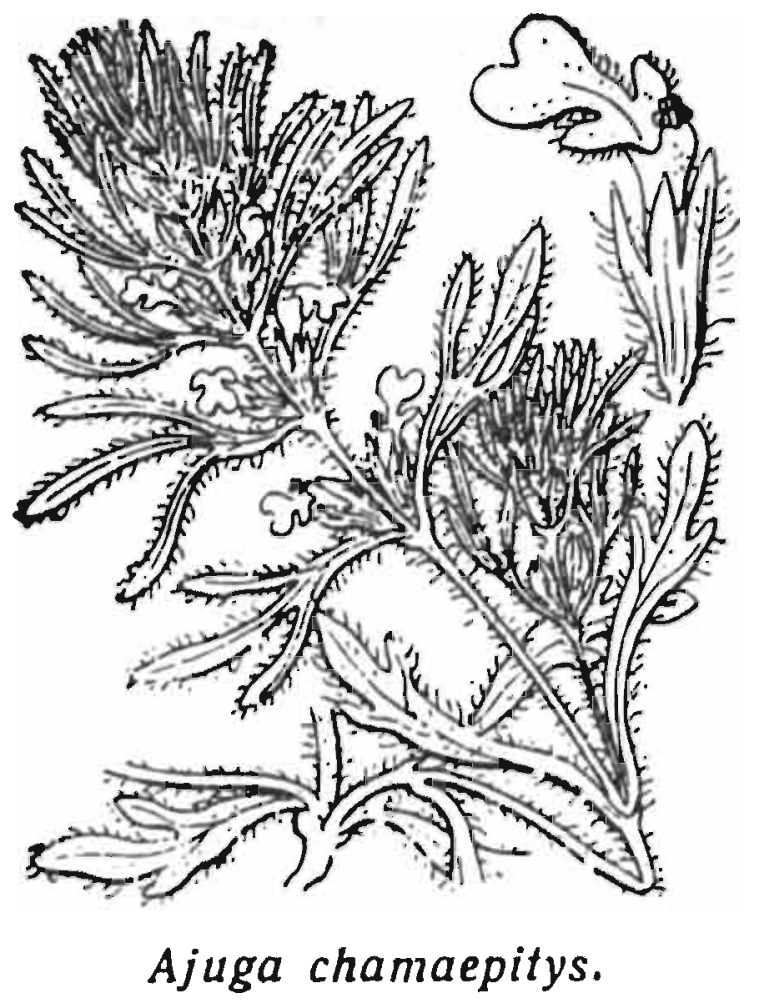

kers op kalkarme als voor die op kalkrijke gronden,

Het historisch aspect komt tot uiting in de staafdiagrammen die zij̣ voorzien van jaartallen. Niet alleen is er sprake van een spectaculaire achteruitgang van het aantal șoorten, met name tussen ! 938 en 1964, die ongetwijfeld te wijten is aan grote veranderingen in het boerenbedrijf na 1950. Ook is er sprake vari een duidelịike afname van een aantal categorieèn, met name de bolgeofyten en halfparasieten, ruim een eeuw eerder. Dit zou kunnen samenhangen met het definitieve verdwijnen van de wilde dries.

4.2. De onderstaande paragrafen vermelden enige oecologische gegevens van een drietal plantesoorten, die binnen Nederland vrijwe! beperkt waren tot driesgronden op de Sint-Pietersberg. ${ }^{23}$ A.kkerzenegroen, korenschịnnspurrie en kruismuur (respectievelijk Ajuga chamaepitys. Spergula segetalis en Moenchia erecta) waren eenjarige onkruiden van graanakkers of schrale graslanden die tijdens, de eerste helft van de twintigste eeuw op de Sint-Pietersberg en daarmee ook uit Nederland zijn verdwenen. Dit onderstreept. het unieke karakter van de Sint-Pietersberg. als "plantengeografisch bastion" voor Nederland; niet alleen geldt dit voor de flora van deschrale graslanden of de hellingbossen van dit gebied, ook de driesgronden van de SintPietersberg vormden een voor Nederland
FIGUUR 12.7

Habitus van

akikerzenegroen naar HEUKELS 1911. Een karalcteristieke soort van groanakkers op kalkrijke bodem, voor het eerst in $1838 \mathrm{en}$ het lootst in 1930 op de Sint-Pletersber oangetroffen. uniek biotoop, waarvan de aanstaande restauratie hoopvolle verwachtingen wekt.

Akkerzenegroen is een klein, dicht behaard en geel bloeiend plantie met liggende stengels die nauwelijks een vinger lang worden. De korte bloeiwiize met enkele zwavelgele lipbloemen verheft zich slechts enkele centimeters boven de grond (zie figuur 12.7). De soort heeft een mediterraan-continentale verspreiding in Europa en komt in zuidelijke delen van haar verspreidingsgebied niet alleen in graanvelden op kalkhoudende gronden voor, maar ook langs wegen en op stenige plaatsen met een spaarzame vegetatie. Zowel in de Benelux als in West-Duitsland en de noordelịke helft van Frankriị ${ }^{24}$ staat. akkerzenegroen bekend als een kensoort van het Caucalidion lappulạe, een plạntengemeenschap van onkruiden in wintergraanakkers. In de hierboven genoemde delen van Noordwest-Europa is akkerzenegroen sterk. in aantal afgenomen of plaatselijk geheel verdwenen.

Op de Sint-Pietersberg werd akkerzenegroen voor het eerst door Franquinet herkend in 1838 en voor het laatst in 1930 aangetroffen. De vindplaats is bekend; in de onmiddellijke omgeving daarvan liggen nog, steeds graanakkers op kalkrijke bodems. ${ }^{23}$ Tijdens die periode van bijna een eeuw leek. akkerzenegroen soms wel verdwenen; Dumoulin vermeldt in 1868 dat de soort al enige jaren niet meer is teruggevonden: De
Wever beweert in 1938 dat akkerzenegroen "al meer dan 50 jaar niet meer is terug gevonden". 26 Dit was voor De Wever overigens aanleiding om te veronderstellen, dat akkerzenegroen een uit cultuur ontsnapte en verwilderde soort zou zijn, die zich uiteindelijk in graanakkers niet kon handhaven. De veronderstelling, dat akkerzenegroen een gecultiveerde soort zou zijn die vanuit tuinen zou kunnen ontsnappen, is onwaarschijnlijk: inmiddels is uit buitenlandse gegevens bekend dat dit typische graanakkeronkruid binnen zijn gehele verspreidingsgebied sterk afneemt. Overigens is het gegeven, dat een bepaalde plantesoort na jaren van afwezigheid weer plotseling wordt gevonden, nog geen reden om te veronderstellen dat deze soort uit een cultuur zou zijn ontsnapt; uit de praktijk van het foristisch onderzoek blijkt telkens dat juist akkeronkruiden na jaren van afwezigheid plotseling weer worden aangetroffen op dezelfde vindplaats. Ongetwijfeld is dit een gevolg van de langdurige kiemkracht van hun zaden die, zoals onderzoek heeft uitgewezen, vaak decennia lang hun kiemkracht behouden. Voor akkeronkruiden is dit een gunstige eigenschap, die hen in staat stelt onder andere langdurige vruchtwisselingencycli op akkers te overbruggen. ${ }^{27}$

4.3 is eveneens een kleine plantesoort en valt door haar tengere bouw, die bestaat uit een bundeltje van draaddunne stengeltjes van amper $5 \mathrm{~cm}$ hoog, nauwelịks op. Het plantịe is voorzien van enige smalle blaadjes en kleine witte bloemetjes met een diameter van 2 $\mathrm{mm}$. In tegenstelling tot akkerzenegroen bezit korenschijnspurrie een mediterraan-subatlantische verspreiding, maar ze komt ook in de meer centraal gelegen delen van haar verspreidingsgebied zeldzaam voor, onder andere in graanvelden en op braakliggende, iil begroeide gronden. In West-Duitsland is korenschijnspurrie momenteel haast uitgestorven. In Nederland is dat zeker ${ }^{2 n}$ en in Belgiè is dat waarschịnnlịik het geval.

Behalve op de Sint-Pietersberg kwam korenschijnspurrie, voor het eerst in Nederland door Dumoulin vermeld van de Sint-Pietersberg, nog op andere plaatsen in Zuid-Limburg voor, De Wever vermeldt nog de gemeenten Heerlen en Sitzard en Wijck, het ten oosten van de Maas gelegen stadsdeel van Maastricht. Voor het laatst werd Korenschijnspurrie in 1939 bij Heerien gesignaleerd. Omdat een aantal van deze gemeenten niet: in het Krijtedistrict ligt, moet worden aange- 
nomen dat korenschijnspurrie niet aan kalkrijke graanakkers was gebonden. Uit nader onderzoek bleek, dat de soort zeer kieskeurig was en uitsluitend in vochtige ploegroren op lóssakkcers voorkwam, 20 Die kieskeurigheid, in combinatie met het gegeven dat huidige akkers nauwelijks meer een brakperiode kennen of in zulke gevallen met onkruidbestrijdingsmiddelen worden behandeld, is de meest waarschijnlijke oorzaak van haar verdwijnen in Nederland.

De recent door $W_{\text {eeda }}{ }^{30}$ voorgesteide naam "kruismuur" voor Moenchia erecta doet al vermoeden dat het hier om een kleine en weinig opvallende plantesoort gaat; de vele "muur"-soorten in Nederland zijn immers eenjarige, lage kruiden met kleine witte bloemetjes en een onopvallend uiterlijk. die bovendien veel op elkaar lijken (zie figuur 10.8). De geringe grootte en sterke gelijkenis van kruismuur met verwante dwergsoorten is dermate groot, dat zelfs een eminente botanicus als De Wever zich vergiste en enige exemplaren van kruismuur samen met enige exemplaren van vetmuur (Sagina apetala) op een herbariumvel plakte onder uitsluitende vermelding van de naam van de laatste soort $^{31}$

Op de Sint-Pietersberg groeide kruismuur onder andere op een droge, stenige weide vóorr het fort. ${ }^{32} \mathrm{Bij}$ die omschrijving past het begrip "dries" uitstekend. Op andere lokaliteiten in Zuid-Limburg is de groeiplaatsaanduiding "kalkgrasland" van toepassing. De Zuidlimburgse vegetatie-opnamen, waarin Moenchia wordt vermeld en die dateren uit de periode 1944 tot. 1950, laten er geen twijfel over bestaan dat kruismuur in het milieu van krijthellinggraslanden voorkwam. ${ }^{33}$ Voor Nederland wordt kruismuur dan ook als een kensoort van het Mesobromion beschouwd. Uit buitenlands opnamemateriaal blijkt echter dat kruismuur ook in een ander schraa! graslandtype, maar dan zonder kalk in de bodem, kon worden aangetroffen. ${ }^{34}$ Aangezien kruismuur op de Sint-Pietersberg en elders in Zuid-Limburg is verdwenen - de laatste vondst dateert uit 1950 -, kan dit syntaxonomische probleem niet. meer worden opgelost.

Aan de hand van deze "case"-studies laat zich vaststellen dat, afgezien van de schrale graslanden op de Sint-Pietersberg, ook het milieu van de aldaar gelegen drieslanden een voor Nederland zeer bijzondere flora herbergde, hetgeen de botanische waarde van de SintPietersberg nogmaals onderstreept. Omdat het hier akkeronkruiden betreft met een voor deze groep kenmerkende langdurige zadreserve in de bodem, waarvan een groot gedeelte van het akkerareaal niet is afgegraven en het gebied waar zij voorkwamen momenteel de status van natuurreservaat heeft gekregen, mag bil het continueren van het vroegere beheer worden verwacht dat deze soorten in de nabije toekomst opnieuw zullen verschijnen. In elk geval zal, wanneer het nieuwe beheer een hervatting zal zijn van het traditionele, de interessante en valk kleurrijke soortengroep van de graanakkeronkruiden nieuwe kansen krijgen.

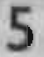

Nu de Sint-Pietersberg tot natuurmonument is verklaard en de algemene beheervisie ten aanzien van het bovengrondse deel is verschenen. ${ }^{35}$ zal een nieuw stadium aanbreken in de geschiedenis van het driesbiotoop op de Sint-Pietersberg. De belangrijkste consequentie van het nieuw te voeren beheer zal bestaan uit het herstel van de voormalige agro-pastorale bedrijfsvoering. waarbij één van de twee resterende bedrijfsgebouwen op het plateau zal gaan fungeren als exploitatiecentrum. Een grote kudde mergellandschapen met herder moet hierin worden gehuisvest. De huidige landbouw die op een bio-industriéle wijze wordt bedreven. zal plaats moeten maken voor een extensieve landbouw, in hoofdzaak bestaande uit een teelt van yoornamelijk wintergraan (rogge). Eventueel kunnen zomergranen en braakgewassen de teelt van wintergraan afwisselen. Het laten "dries."-liggen moet eveneens worden opgenomen in de vruchtwisselingscyclus. Uiteraard mogen deze percelen niet meer worden bemest.

Onderzoek in Zuid-Limburg heeft uitgewezen dat landbouwgronden, onttrokken aan intensief agrarisch gebruik, spontaan begroeid raken met een zeer gevarieerde vegetatie, warvan een groot aandeel van de soorten uit akkeronkruiden bestaat. ${ }^{36}$ De belangrijkste oorzaak van dit verschijnsel is, dat akkeronkruiden beschikken over een persistente zaadbank van meerdere decennia. De restauratie van driesgronden op de Sint-Pietersberg heeft. dan ook een grote kans van slagen, wanneer voormalige graanakkers weer extensief worden beheerd. Een braakperiode kan daar eventueel aan voorafgaan. Wanneer bovendien een schaapskudde wordt ingezet die het gehele graan- en brakkareaal in combinatie met. wegbermen, schrale graslanden en bosranden verbindt. dan kan op grond van een bepaalde verspreidingsstrategie van zeer veel plantesoorten worden verwacht, dat het vroegere beeld van de kleinschalige en buitengewoon kleurrijke drieslanden op de Sint-Pietersberg binnen enkele jaren een realiteit wordt.

\section{NOTEN}

I Deze opmerking is van A. de Wever en dateert uit 1938. Zie Van SCHak 1993, p. 253.

2 Morrinu 1974

3 Himuns in VAN SOOWK 1983, pp. 259-272

4 Rotanooss 1990, pe 73-81

5 Bacns 1987 , figuur 2. p. 17.

6 Mondelinge mededeling f. Felder

7 Dexe veronderstelling wordt al door Bory de St. Vincent geopperd en door Van Schaik herhaald. Zie VANDIR MNIEN 1978, p. 91 en VAN SCHAK et al 19 3. p. 339.

a Het toponiem "Thier a i Tombe" wordt vermeld door Mantis 1987; het andere tombe-toponiem lig: op Nederiands grondgebied. en wordt op de Stroomkaarten vermeld.

o RiNes 1988 en VAN SCHARK 1983. p. 340

10 VaN Hers 1979 pp 130.145

II Ferraribaart

12 Tranchotkaart

13 Schraalland indicerende toponiemen op het plareau van de Sint-Pieternberg Ganzendries (Tra), Grote en Kleine Pruys (" pierreusl w stenie, Tra, VH). De Hei van Sint. Pieter (fer) en Kannerhei (So)

i4 Op de Drentse zandgronden was de verhouding heide (schraalland) ten oprichte van bouwland als 7.5 I (zie Di Smot 1981. p. 24), dat wil regten om I fa landbouwgrond vruchtbaar to houden, was de mest van 5 tot 10 ha schraalland noodrakelijk. Op de Sint-Piectersberg was de verhouding schraallandbouwland nauwelijks I : !

15. Op dexe wije ontstond het Encibos op de westhelling.

16. Zie hooldstuk II en Vanoen Marun 1978, pp. 78. 80 en Fischea Eu HranonN 1987, pp 126-139

17 Lejeune ! $811-1813$

II BOAYOR ST VINCINT I821

19. Franguiner 1838 en Dumoutun 1868

20 VANSCHAYK 1983

21 TrARTs in Flora en fauna 1964

22 Van ȘCHAiK 1983

23 De Nederlandse verspreidingsgegevens worden vermeld in Atlas van de Nederlandse flora 1985 . 1989, deel I, pp. 47, 95 en 148.

21 De verspreidingagegevens voor het buitenland wor. den vermeld door VAN ROMPAEY EN DElyosac.4 1979 (verspreiding in Belgie en Luxemburg). FounNaEk 1961 (verapreiding in Frankrijk) en HAEupLE EN SCHONFELDE 1989 (verspreiding in West-Duitsland).

25 DumOULN 1868, pp. 12-13

26 De WeVER in VAN SCraix 1983, p. 255

27 Fenras. 1985, p. 37 en volgende.

28 Suddeutsche Planzengeselischaften 1985-1989. deel I, p. 95.

29 Sessinuch 1950 en WESTHOH EN DENHED 1975, p: 76.

30 WeEDa et at 1985-1991, deet 2, p 193.

31 Mondelinge mededeling E. Weeda:

32 DumOuUN IB68, p. 132

33 Diemont EN VAN DE VeN 1953, tabel I en p. is

34 Suddeutsche Pllanzengeselischatten 1987, p. 30

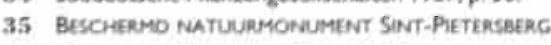
1992

36. Onder andere HenNexEN et al. 1983 


\title{
VEEDRIFTEN EN HUN VEGETATIES, REALITEIT EN RECONSTRUCTIE
}

\author{
"Erosion pastorale, vormontwikkelingen in de zuidlimburgse \\ nederzettingen."
}

1.1 Veedriften verschillen van "wissels", dat wil zeggen herkenbare paden van wilde dieren, omdat zị zịn ontstaan door gedomesticeerde dieren, die door hun bezitters vanuit een beschermde ruirnte naar of van hun weidegronden worden "gedreven". Toch zijn de verschillen tussen wissels, looppaden van vee, dreven en migratiebanen van kudden herbivoren eerder gradueel dan principieel van aard en is de herkenbaarheid daarvan afhankelijk van omvang en frequentie van het passerend vee en tevens van de tijdsduur waarbinnen zich dit proces afspeelt (zie figuur 13.1).

Vanaf het moment in het evolutieproces, dat in kudden levende herbivore zoogdieren grote delen van hun biotoop vrij hieiden van boomgroei en er open vlakten ontstonden, hebben grassen en andere kruidachtige plantesoorten in een coèvolutionair proces met die herbivoren de ontstane open vlakten kunnen koloniseren. ${ }^{2}$ Op diverse wijzen heb- ben zowel de soorten planten als de verschillende herbivoren zich weten aan te passen. Hierdoor ontstond, ook onder invloed van het klimaat, via radiatie en nieuwe soortvorming de veelvormigheid van organismen in boomloze, met kruiden en grassen begroeide milieus, die wij nu kennen onder de namen steppe, savanne, poesta, prairie, llano enzovoore. ${ }^{3}$ Binnen deze oecosystemen ontstor. den verschillen, die door grote herbivoren werden veroorzakkt bij drink-of schuilplaatsen, langs migratiebanen en druk bezochte wissels, waar zij zich langer ophielden dan elders, concentreerde zich meer mest en werd de bodem vaster aangedrukt. Hier in dit milieu ligt de oorsprong van de plantesoorten, die op een later tijdstip in de evolutie deel gingen uitmaken van de vegetatie langs veedriften.

Veedriften in de zin van migratiebanen, waarlangs nomadische stammen en hun vee zich regelmatig verplaatsten, zijn zeer oud. Uit de
Europese prehistorie is bekend, dat al tussen 7000 en 3000 jaar vóór het begin van onze jaartelling migraties van vee plaatsvonden, die ofwel vanuit de Pannonische laagvlakten de grote rivierdalen volgend ofwel vanuit het Middellandse Zeegebied via het RhôneMaasdal Noordwest-Europa bereikten. ${ }^{4}$ Elke nieuwe cultuurgolf gedurende de prehis. torie en tijdens het begin van de geschreven geschiedenis ging gepaard met grootschalige verplaatsingen van vee. Dat is bekend vanaf de tijd van de bandkeramiekers, ${ }^{5}$ de mensen van de bekerculturen" tot en met de komst van de Romeinen ${ }^{\text {? }}$ en de daaropvolgende periode van de grote volksverhuizingen.

Er is veel minder bekend van de ouderdom of de omvang van de jaarlijkse seizoenmigratie, die plaats vond tussen de winterweiden in het laagland en de zomerweiden in het hooggebergte. Dit moet een algemeen verschijnsel in Europa zijn geweest. Slechts in enkele gebieden rond de Midden- en Zuid-

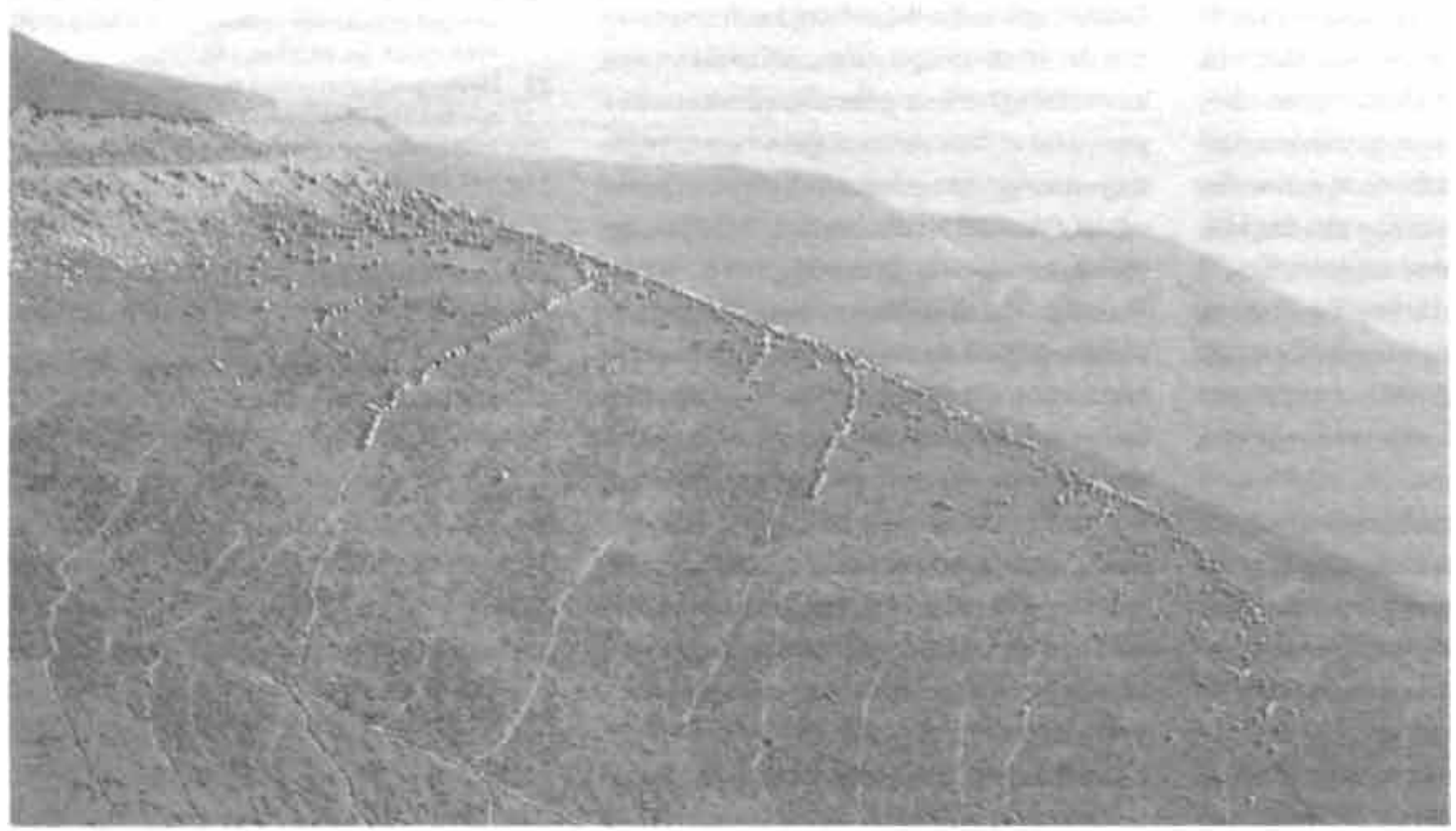

FIGUUR 13.1.

Door schoopskudden begroasde berghelling met poodjes in de Pyreneedin.

Foto van B. Graotsma, romer 1989, De looppoodjes van het ree op de helling. zogenaamde veetrappen, zijn als een netwerk van poraliel met de hoogtelijnen verlopende poden duidelijk herkenboar. In de dolen verenigen dexe poden zich tot bredere veedriften. 
europese gebergten, waar het verschijnsel van de "transhumance" nog steeds plaats vindt, zijn er nog functionele veedriften in het landschap aanwezig." Alleen hier kan de vegetatie langs deze eeuwenoude seizoengebonden migratiebanen nog worden bestudeerd.

1.2 Meer in detail zijn de migratiewegen bekend van middeleeuwse veeverplaatsingen vanuit fokgebieden naar delen met een hoge bevolkingsdichtheid." In Nederland hebben deze "ossewegen" hun sporen in het landschap achtergelaten. ${ }^{10}$ In Limburg zijn dergelijke periodieke en omvangrijke verplaatsingen van vee naar een grote markt nog tot diep in de vorige eeuw blijven bestaan. "

Vee kan een belangrijke rol spelen in het transport van zaden en vruchten van wilde planten via hun vacht of hun spijsverteringskanaal. Het is duidelijk dat met het vee tientallen plantesoorten kris-kras door Europa werden verspreid; op kleinere schaal gebeurde dat zeker tijdens frequente en aan vaste wegen gekoppelde veeverplaatsingen in elke Noordwesteuropese gemeente met heerdgang. Het vaste patroon van de heerdgang binnen de gemeente en de constant veriopende processen op heerdgangwegen verschaften de basis voor een stabiel milieu, warin zich een aantal plantesoorten kon handhaven en zich een vegetatie vormde met een min of meer constante soortensamenstelling.
Vegetatiekundig gesproken, ressorteren vegetaties van veedriften onder het Onopordion, het Wegdistel-verbond, genoemd naar een opvallend zilverkleurige en grote distelsoort, de wegdistel (Onopordum acanthium), die uitsluitend in dergelijke milieus voorkomt en als naamgevende kensoort fun. geert. Dit verbond is vooral in Centraal-Europa bestudeerd, toen veel veedriften nog functioneel waren, maar in Nederland, waar al tijdens de vorige eeuw het aantal functionele veedriften langzaam maar zeker afnam en vóór 1950 geheel verdween, kwam hetvegetatiekundig onderzoek te laat. Sommige kensoorten, zoals stinkende ballote (Ballota nigra) en bilzekruid. (Hyoscyamus niger), ${ }^{12}$ kunnen zich weliswaar nog handhaven in vergelijkbare milieus, een andere kensoort, zoals brave hendrik (Chenopodium bonus-henricus), is biinna uit ons land verdwenen. ${ }^{13}$ Voor de overige kensoorten van het Onopordion geldt dat, als zij zich binnen Nederland kunnen handhaven, zij straks tot een andere plantengemeenschap zullen moeten worden gerekend.

In de onderstaande paragrafen wordt, na een algemene beschouwing over de fysionomie van de veedrift, een drietal concrete veectriften met elkaar vergeleken; een voormalige veedrift in het gebied van onderzoek, een nog functionele veedrift in Frankrijk en een gereconstrueerde veedrift in een Duits openluchtmuseurn.
2 Zoals de term "veedrift" al aangeeft. wordt hiermee de route bedoeld. waarlangs de kudde 's morgens vanuit de stallen in de nederzetting naar de weidegronden werd gedreven en er 's avonds terugkeerde. Destijds gebeurde dit dagelijks. Heerd (koeherder), scheper (schaapherder) " sween (varkenshoeder) en het ganzenhoedstertje dreven de dorpskudden of die van grote hoeven naar de gemeenschappelijke gronden, die binnen de "gemeynte" en meestal aan de periferie daarvan waren gelegen. Het aantal veedriften per nederzetting varieerde al naargelang het aantal en de ligging der weidegronden. Veedriften bezitten meestal een radiair patroon; dit is binnen het gebied van onderzoek het geval bij nederzettingen op de plateaus. Nederzettingen op de dalhellingen worden gekenmerkt door een veedrift voor het rundvee dalwaarts en éen voor schapen die naar de plateaurand verloopt.

Wat betreft vorm, begrenzing. breedte en dergelijke zijn de volgende elementen karakteristiek: hun profiel is bij voorkeur "hol", dat wil zeggen de driftranden zį̣n voorzien van veekeringen in de vorm van levende of dode hagen, houtwallen, stapeimuurties, greppels of bermen In Zuid-Limburg hebben de holle wegen mede hun ontstaan te danken aan de eroderende werking van veehoeven in samenwerking met afstromend regenwater. De veedrift begint op een pleintje met een variabele vorm, waar een drenk is gelegen" " (zie figuur 13.2). Eén of meerdere afsluitingen
FIGUUR 13.2

Dorpspleinţe met veedrenk te St Privot (Auvergne, Frankrijk). De veedriften ( $\mathrm{nr}$ I en 2) xijn door muren of rotswanden begrensd. De drenk (3 en 8) ligt op een open pleintie. De stallen liggen langs een brede straat (4), waor ook cen "noodstal" (5) is opgerteld. Deze diende voor het beslaan van de hoeven van de trekossen (zie figuur 13.4). De vegetatie-opname (zie tabel 9.6.1) betreft een rtrook yan deze weg tussen $T^{*}$ en $7^{*}$.

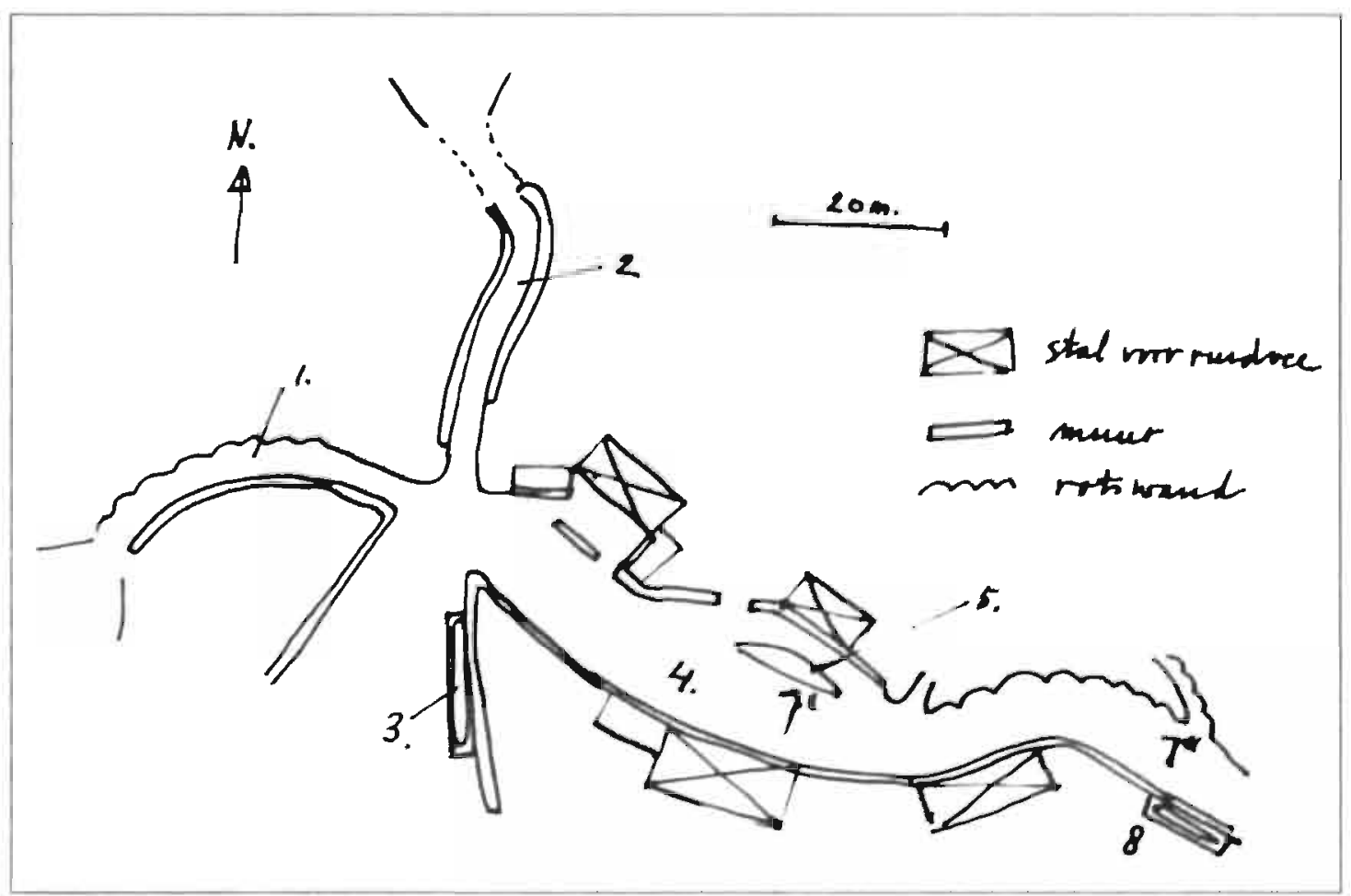




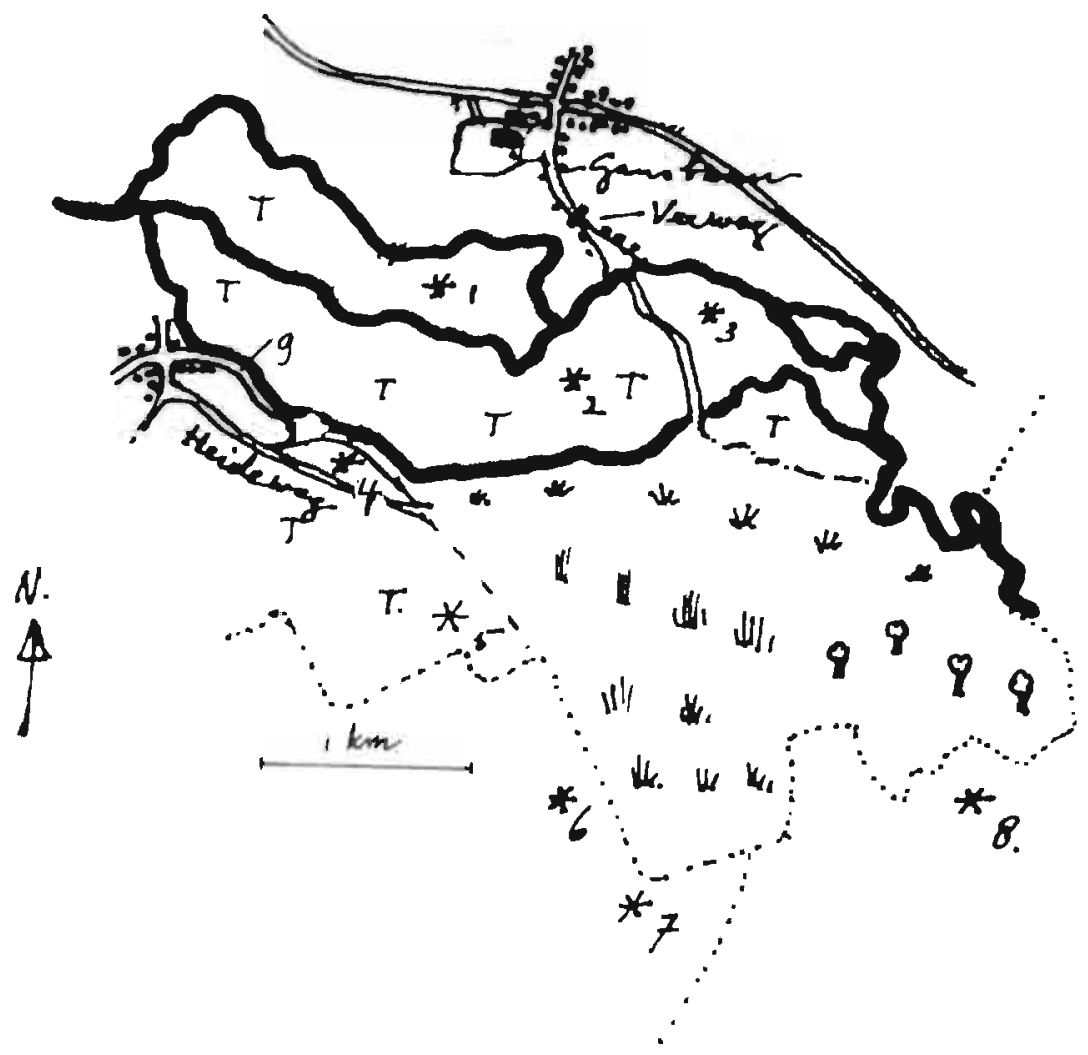

in de vorm van klap- of valhekken, die onder diverse namen bekend zijin, ${ }^{15}$ moesten ervoor zorgen dat het vee die route nam of dat perceel beweidde, dat door de herder werd gekozen. De breedte van de veedrift was aanzienlijk; ze behoorden tot de categorie van de breedste dorpswegen. 16 Wanneer begrenzingen van een brede veedrift ontbreken, is een laanbeplanting regel, bij voorkeur met knotwilgen; deze snelgroeiende boom leverde bovendien teen- en geriefhout. ${ }^{17}$

De drift mondt uit in beweide territoria. Vanuit dit punt waaieren diverse wegen uit, een patroon dat op de oudste topografische kaarten vaak goed te herkennen valt. De beweide territoria moeten destijds zeer omvangrijk zijn geweest en waren gemeenschappelijk bezic. Voor zover deze op de plateauranden of op de hellingen zijn gelegen, staan ze veelal bekend onder de naam "gemeenteheide". ${ }^{18}$ In de toponiemen zijn er veel bewaard gebleven. Voor zover ze in de beek- of rivierdalen zijn gelegen, worden ze in toponiemen aangeduid onder de namen "broeker" of "beemden", voorzien van een prefix dat uit een nederzettingsnaam bestaat.

Nederzettingen in stroomdalen bezitten in principe twee veedriften: de eerste daalt af en werd vooral door het rundvee benut, de tweede stijgt naar het plateau en werd vooral door de schaapskudden gebruikt. De omhooglopende veedrift heeft gedurende de kolonisatiefase in de vroege middeleeuwen mogelijk als een "ontginningsas" gefunctioneerd. ${ }^{19}$

Tenslotte wordt de veedrift gekenmerkt door een aantal daarlangs gelegen poelen: drenken, die door de gemeente werden onderhouden. De aanwezigheid van mest op de drift, vooral van runderen, is karakteristiek. Deze factor, gecombineerd met een zekere mate van bodemverdichting door de tred van het vee, heeft hier een karakteristiek vegecatiedek doen ontstaan, dat aan ten minste drie milieufactoren was aangepast: een grote mate van mineraalrijkdom van het bewortelde substraat als gevolg van mest op en aan de rand van het wegdek, een zekere tredbestendigheid met name voor die delen van de driftvegetatie, die de weg begrenzen en tenslotte een zekere bescherming tegen vraat door het vee, dat dagelijks de drift passeert. ${ }^{20}$ De genoemde milieufactoren veroorzaken bovendien een gradiènt die, gerekend vanaf het centrum van de weg. geleidelijk naar de randen afneemt:

\section{I De koeherder van Meerssen heet-} te Dolmanș. ${ }^{21}$ Maar niemand noemde hem zo: men zei "de schweitzer", 22 omdat hij als soldaat van het $Z$ witserse regiment bij de paus had gediend. Hij was gewond geraakt door een geweerkogel in zị̣n been en hinkte sindsdien. Na zijn eervol ontslag in Rome. kwam hii naar huis en kreeg van de gemeente een baantje als koeherder. Elke morgen
FIGUUR 13.3. De veedriften van Meerssen en het buurschap Rothem volgens de Tranchotkaort uit 1803 1820. Via de Gansbaan en de Veeweg werd het rundvee vanuit een centraal gelegen plein, de Marke, naar de weidegronden in het Geuldal gedreven De uitgestrekte weidegronden van het Gemeentebroek en de Meerssenerheide, aongegeven met een stippellijn, waren nond 1800 nog gemeenschappelijk berit. De toponiemen Benedenste en Bovenste Breulen ( $\mathrm{nr}$ I en 2) en de $O$ (3), die beweide graslanden indiceren, woren tijdens die periode al in landbouwgronden ( $T$ ) omgexet Het Gemeentebos, aangegeven met bossymbolen, wos waarschijnlijk van beweiding uitgesloten. Ook het buurschop Rothem, dat tot de gemeente Meerssen behoorde, bezot heerdgangrechten op deze gronden. De Geitenstraat (9) en de Heideweg herinneren hieroon. De toponiemen Schepersberg (4) en Rothemmerheide (5), Heihof (6), Ambyerheide (7) en Bergerheide (8) indiceren eveneens voormalige beweiding deels vanuit andere nederzettingen. Let op de brinkachtige verbredingen van de veedriften.

kwam de schweitzer naar de markt en blies op een grote hoorn van een stier. Die droegs hiij altijd bij zich. ${ }^{2.3}$ Dat was het signaal voor de boeren, die rond de Markt, langs de Volderstraat en de Kruisstraat woonden, om de staldeuren open te zetten. De beesten liepen "vanzelf" naar de markc. De schweitzer kende zeallemaal. Langzaam liepen alle koeien en hun kalveren langs de Gansbaan en de Veeweg naar het Gemeentebroek. Soms ging een koe aan de Geul' bij de brug, even drinken, ${ }^{24}$ maar als dat te lang duurde, zei de schweiczer "allèh" tegen zịn grote herdershond, die dan al blaffend de koe in de poten probeerde te biiten. De koe draaide zich dan om en liep weer met de andere mee. De hele dag bleef de schweitzer bij de kudde op het Broek aan de rand van de: Meerssenerhei, in de $\mathrm{O}$ en op de Breulen tot aan de Houthemmerbeemden. ${ }^{25}$ Rond het middaguur, wanneer de koeien gingen liggen in de schaduw van een boom of een. bosje of zomaar in het water van de Geul gingen staan om af te koelen als het: warm was, at de schweitzer zijn boterhammen op, die in krantenpapier waren gewikkeld. Koffie nam hij mee in een blauw geèmailleerd kruikje. Dat bewaarde hị in een schoudertas, ${ }^{26}$ Daar zat ook wolgaren in voor sokken, die de schweitzer zelf kon breien. Verder deed hij de hele dag niets dan alleen zij̣n pijp roken en zij̣n stok vasthouden. maar de mensen in het dorp zeiden dat hij ook. wel stroopte. 
RCUTR 13.4

Een deel van de

vendrift te St Privot

wir Allier. Foto van de auteur, zomer 1990.

Let op de veekerende

functie von muren en

rotreranden, de

vervallen noodrtal (in

Auvergne werden

oasen en relfi koeien

met hoeffirers

beslogen), de

mertplaikken op de

wer en de vegetotie

doorlange. De

manahoge dirtel links

in beeld is de

wogdistel, de

noomgerende

kensoort van het

Werdintel-verbond.

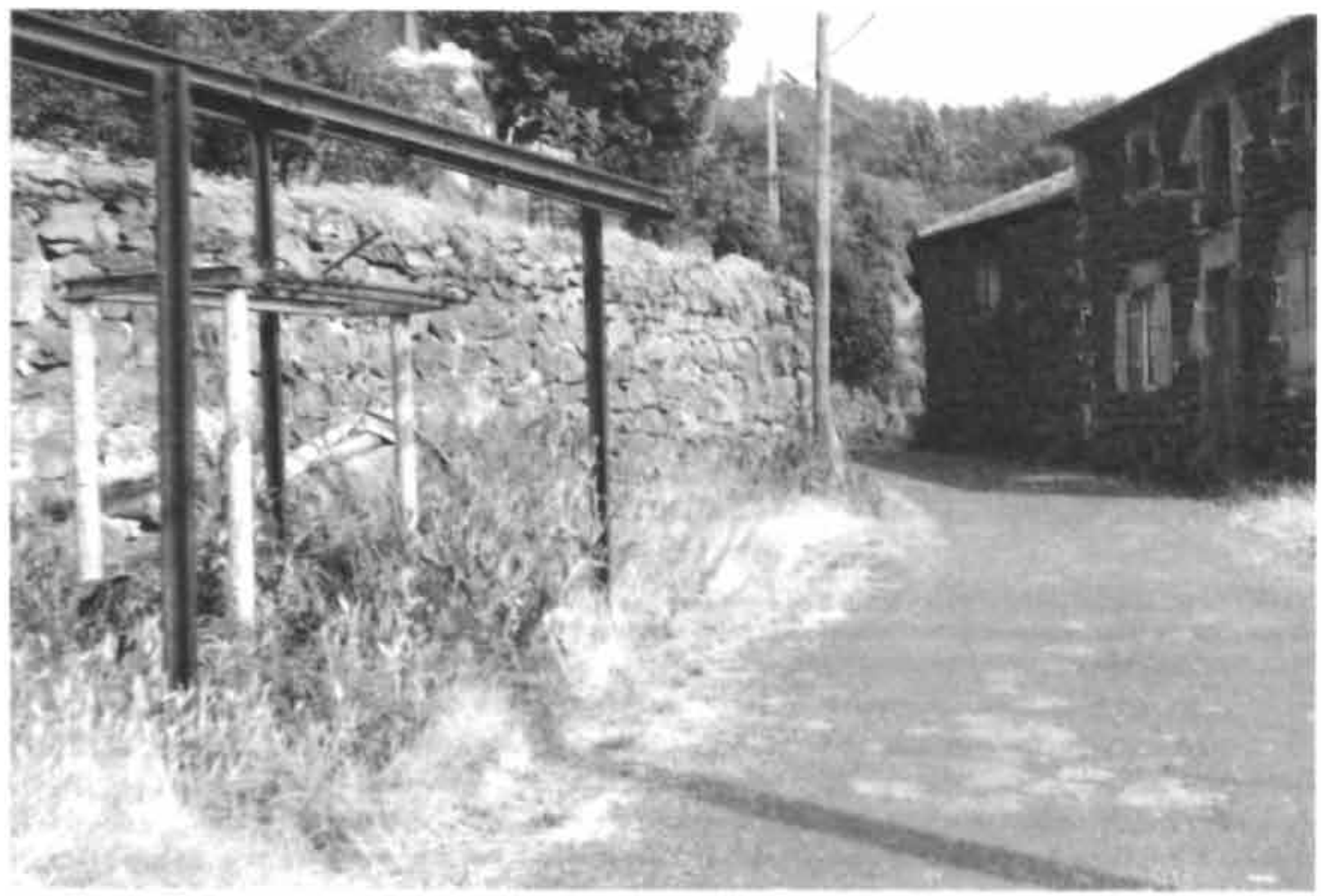

In de late namiddag zei hij weer "alleh" tegen zijn hond en die zorgde ervoor dat de kudde terug liep naar de markc. De schweitzer had geen horloge en toch was hij elke dag precies vóor het avondeten thuis.

\subsection{Het bovenstaande historische ver-} slag. dat betrekking heeft op de heerdgang. van Meerssen in Zuid-Limburg tussen 1910 en 1920, kan als model dienen yoor elke heerdgang binnen het gebied van onderzoek. De reconstructie van deze veedrift zou zonder het bovenstaande verhaal eveneens mogelijk zijn geweest. De huidige topografie, de namen van wegen en weideplaatsen, hun huidige lengte, breedte, begrenzingen en het voorkomen van een bepaalde flora kunnen de voormalige veedrift doen vermoeden; een historisch verslag is een duidelijker bewijs.

Bị nader onderzoek verraadt de actuele toestand in Meerssen de voormalige veedrift: de Markt is een ovaal plein, waarop destijds een poel lag en waarlangs aan de noord-en oostzijde de aaneengesloten bebouwing nog steeds het karakter draagt van een serie boerderijen. Dat geldt ook voor de aaneengesloten bebouwing van delen van de Kruisstraat, de Volderstraat, en de Kuileneindestraat. Gansbaan en Veeweg verlopen in elkaars verlengde en vormen de verbinding tussen de verzamelplaats voor het vee op de Markt en de weidegronden in het dal van de Geul. De veedrift daalt af, heeft deels een hol profiel (bovenste deel van de Gansbaan), een relatief breed wegdek en heeft een lengte van minder dan een kilometer. De begrenzing van de Veeweg bestaat uit een deel met steile bermen, aaneengesloten bebouwing en geschoren meidoornhagen. Zelfs de flora langs de Veeweg kenmerkte zich door een aantal opvallende soorten: tussen 1955 en 1985 werden langs de Veeweg, afgezien van diverse elementen uit tredplantgemeenschappen, ook enige, vrị zeldzaam voorkomende soorten uit het Wegdistel-verbond aangetroffen.

Historische bronnen vullen het ooggetuigeverslag aan en tevens completeren ze de recente gegevens die de voormalige heerdgang verraden. De toponiemen Gansbaan en Veeweg, waarvan de betekenis voor zich spreekt, zijn eeuwenoud, terwiil de toponiemen "In de O. Onderste en Bovenste Breulen. Op het Broek en Houthemmerbeemden" enige verklaring eisen: het zijn typische namen voor weidegronden langs rivieren. Voorts geeft de Tranchotkaart van rond 1800 veel informatie over de uitgestrektheid van de Meerssense weidegronden in het Geuldal (zie figuur 13.3).

Het bevolkingsregister van Meerssen verschaft de volgende informatie inzake de identiteit van de heerd: Willem Hubert Dolmans werd geboren op 21 december 1840 te Limmel, gemeente Meerssen en werd op 27 oktober 1924 in het bevolkingsregister van die gemeente uitgeschreven. Vermoedelijk overleed hij kort daarna in Maastricht. Hij was in dienst bij de gemeente Meerssen. Gedurende de zomermaanden was hij aangesteld als heerd, tijdens de winterperiode fungeerde hil als lantaarnopsteker. Bovendien was hij doodgraver en kantonnier. Een gemeentelijk document "Instructies voor den Koeherder te Meerssen", gedagtekend 16 mei 1879, heeft op Willem Hubertus Dolmans betrekking ${ }^{27}$ (zie figuur 13.7).

4. I Op 13 en 14 juli 1989 werd door de auteur een functionele veedrift bestudeerd in het Franse dorp St: Privat (département Haute Loire), Zowel de route van de drift als de vegetatie erlangs werden aan een nader onderzoek onderworpen en aan de koedrijver werd om informatie gevraagd.

St. Privat, gelegen op een hoogte van $850 \mathrm{~m}$, teit ongeveer 150 bewoners en 60 bewoonde huizen. Hoewel het dorp en zijn bewoners vroeger vrijwel geheel was aangewezen op landbouw en veeteelt, waren er in 1989 nog slechts vier bedrijven met rundvee. Zij zijn op een korte afstand van elkaar aan een straat gelegen (zie. figuur 13,4). Het totaal stuks rundvee van de hoeven in dit straatje bedraagt 20. Elke dag vertrekt deze gemeenschappelijke kudde rond tien uur 's morgens naar de weidegronden en keert rond zes uur terug onder begeleiding van een hond en een drijver. De persoon van de drijver wisselt bij 


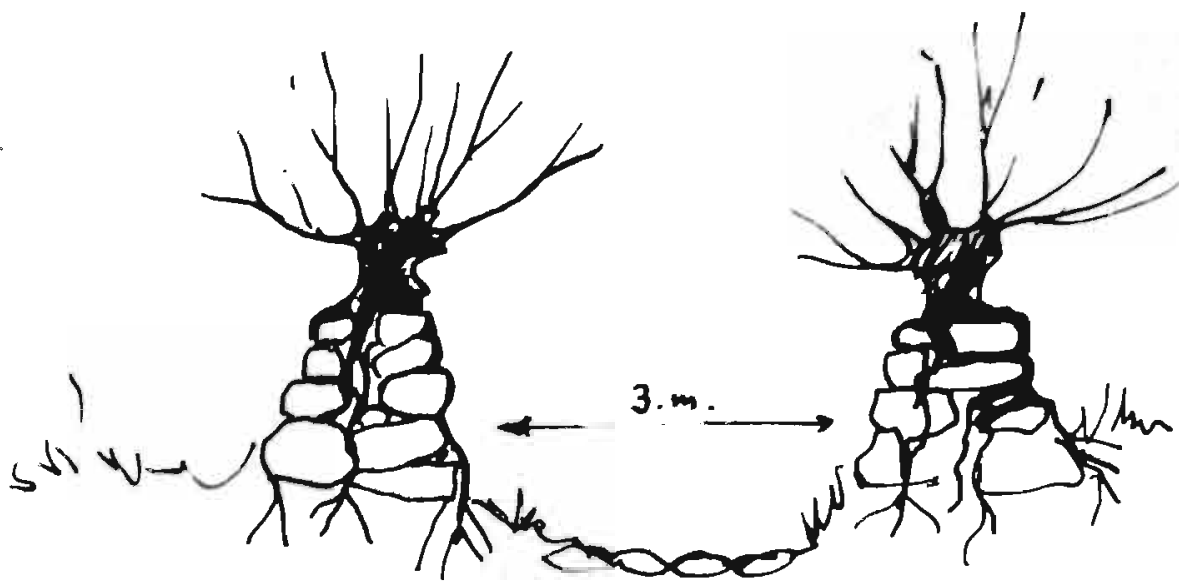

FIGUUR. 13.5i Schematisch proflel van een veedrift in St. Privat (weg I op figuur 13.2). Do met geknotte exsen beplante stapelmuren voorkomen dat de kudde van de heerdgangroute ofwilkt on leveren tevens boerengeriefhout. toerbeurt. Meestal zijn het de echtgenotes van de eigenaren die deze taak op zich nemen. Als de kudde in éèn van de omheinde weidegronden is aangekomen, gaat de drijver terug naar huis.

Als veedriften fungeren twee wegen die op een pleintje beginnen (zie figuur 13.2 en 13.4). Dit zijn de routes I en 2 . De brede weg 3 en het plein 4 fungeren respectievelijk als verzamelplaats (hier liggen ook de ingangen van de stallingen) en als drenk. De drinkplaats bestaat uit een serie gecementeerde bakken, continu gevuld met water dat afkomstig is uit een loden pijp boven één van de bakken. Overigens ligt daarnaast een openbare wasplaats, die niet meer wordt gebruikt. De driftwegen I en 2 zijn, ook zonder de aanwezigheid van de kudde, als veedrift herkenbaar aan de vele mestplakken, die zowel in opgedroogde als in verse toestand op het wegdek zijn gelegen. Daarnaast is hun vorm karakteristiek: weg I bestaat aan de zuidzijde uit een steilrand, aan de noordzijde uit een rotswand: weg 2 is omzoomd met stapelmuren van ongeveer I m hoog, plaatselijk bekroond door braamstruiken en knotessen, waarvan de wortels de stapelmuren in een stevige: greep houden. Uit dergelijke gocitvormige wegen is ontsnapping van vee onmogelijk. Het pleincje bij de drenk is deels ommuurd eñ de verzamelplaats 3 wordt ingesloten door rotswanden en muren. Daar staat ook. eerı noodstal opgesteild, die wordt gebruikt wanneer hoeven moeten worden bekapt. Vroeger werden hier ook de trekossen voorzien van speciale hoefijzers. De andere drenk (8) wordt door het vee niet meeir gebruikt, evenmin als het oostelijk verlengstuk van de verzamelplaats 4, dat een drukke verkeersweg kruist.

\section{2}

Tabel 9.6.1 vermeldt diverse gegevens van de vegetatie van het wegdek aan de noordzijde van de verzarnelplaats. De overwegend grijsgroene en stoffige vegetatie wordt opgevrofijkt door enkele heldergeel bloeiende tooresen (Verbascum phiomoides) op de achtergond. Meer naar het wegdek toe bestaat de vegetatie voornamelijk uit grazige stroken, afgewisseld met lage, onopvallend bloeiende kruiden en tredplanten. De floristische samenstelling geeft een compleet beeld vari onderling samenhangende associaties uit het Wegdistel-verbond (Onopordion) en daarmee verwante plantengemeenschappen, zoals die vroeger mogelijk in $\mathrm{Ne}$ derland, voorkwamen. Op de achtergrond verheft zich tegen de rotswand of de uit na- 
tuurstenen bestaande stapelmuren de $\mathrm{Ge}$ meenschap van de wegdistel (Onopordetum acanthii Br.-81. 1936), waarin de kensoorten wegdistel en absint-alsem domineren. Meer naar het wegdek toe bestaat de minder hoge kruidlaag uit de Gemeenschap van Witte dovenetel en Stinkende ballote (Lamio-Ballotetum foetidae Lohm, 1970). Dit gezelschap wisselt zich plaatselipk af met de Gemeenschap van Brave hendrik (Chenopodietum bonus-henrici Tj. Mull. 1972). Tenslotte bestaat de randstrook van het wegdek uit een dichte strook vegecatie, die grotendeels uit de grassoort kruipertie (Hordeum murinum) is opgebouwd en naar die kensoort Hordeetum murini (Libb. 1932) is genoemd. Deze lintvormige gemeenschap wisselt zich plaatselijk af met stukjes open vegetatie, waarin lage en plat op de bodem liggende soorten voorkomen: het Urico-Malvacetum neglectae Lohm. 1950 (zie figuur 13.5 en 13.6).

Met uitzondering van Verbascum floccosum. die in Nedertand alleen in gecultiveerde toestand voorkomt, zijn de in de opname voorkomende soorten ook in Nederland en in het overige deel van Noordwest-Europa inheems. Echter, in Nederland zijn enkele soorten sinds enkele decennia zeldzaam of zeẹr zeldzaam geworden. Die algemene afname van het voorkomen van kensoorten uit het Onopordion in Nederland, gaat tevens gepaard met een afname van de onderlinge samenhang van de plantengezelschappen, die daartoe kunnen worden gerekend; de hierboven genoemde plantengezelschappen komen weliswaar hier en daar sporadisch in Zuid-Limburg nog wel voor, maar zijn dan incompleet en als rompgemeenschap te beschouwen. Bovendien komen die verschillende gemeenschappen nergens in Zuid-Limburg op één lokaliteit voor. Zowel de geleidelijke afname van het aantal vindplaatsen van soorten die karakteristiek zijn voor het Wegdistel-verbond als het verdwijnen van de onderlinge samenhang van plantengemeenschappen die tot het Onopordion worden gerekend, is ongetwijfeld het gevolg van het verdwijnen van de heerdgang.

De betekenis van de vegetatie van de "koestraat" van St. Privat is, dat zij een concreet beeld geeft van een vegetatietype dat in Nederland, sinds het verdwijnen van de heerdgang, al vele decennia niet meer aanwezig is.

Voor zover nu bekend, komt dit beeld overeen met de historische wegstoffering van een willekeurige agrarische nederzetting in oostelijken zuidelijk Nederland tijdens de perio- de voór 1900. Dit vegetatietype vormde. evenals de heerdgang en andere agro-pastorale praktijken en de daarmee samenhangende vegetatietypen, een wezenlijk onderdeel van de leefwereld in en rond Nederlandse agrarische nederzettingen uit het verleden. Wanneer in openluchumusea historisch verantwoorde reconstructies van gebouwen en nederzetringen worden beoogd, dan passen binnen deze context evenzeer de agro-pastorale bedrijfsvormen van destijds als de verschillende vegetatietypen die daaraan waren gekoppeld, In dit verband is de reconstructie van de vegetatie van een veedrift in het openluchtmuseum te Kommern in de Eifel histo. risch verantwoord.

\section{1} Openluchtmusea die agrarische cultuurrelicten tentoonspreiden, hebben zich niet alleen als doel gesteld om woon-en bedrijfsgebouwen en de zich daarin bevindende materiele goederen en huisdieren te bewaren voor het nageslacht, maar ook de omgeving daarvan zodanig te conserveren dat het gehele cultuurcomplex van cen agrarische nederzetting tot uitdrukking komt. Tot het cultuurcomplex van die nederzetting behoren onder andere moestuinen met bepaalde groenten, boomgaarden met fruitrassen uit die periode, akkers met de daarbijbehorende oude landbouwgewassen en on:kruidgemeenschappen. In dit streven naar een reconstructie die historisch za betrouwbaar mogeliịk is, zịn de in Duitsland gelegen openiuchtmusea toonaạngevend voor Europa. in het openluchumuseum te: Kommern in de Eifiel, dat geografisch aansluit bij Zuid-Limburg, heeft men cen poging gedaan ook de spontaan totstandgekomen vegetatie van nederzettingen te introduceren. ${ }^{2 n}$ Hiertoe behoort de vegetatie langs de dorpswegen, die destijds sterk door de heerdgang werden beïnvioed en als veedriftvegetaties konden worden getypeerd.

De herintroductie van niet-gecultiveerde soorten planten, die kenmerkend waren voor agrarische nederzettingen uit de Eifel tijdens de vorige eeuw (of daarvoor), heeft een tweeledig doel: enerzijds de "stoffering" van de nederzetting zo authentiek mogelijk te maken, maar daarnaast ook het genetisch materiaal van de betreffende soorten voor het nageslacht te bewaren. Dit laatste hangt samen met het gegeven, dat diverse soorten van ruderale milieus in agrarische nederzettingen dreigen uit te sterven. ${ }^{20}$ Dit geldt met name voor soorten uit het Wegdistel-verbond, dat onder andere karakteristiek is voor veedriften in of aan de rand van nederzectingen. In het openluchtmuseum heeft men pleksgewijs binnen de nederzetting zaden of vegetatieve delen van soorten, die tot een bepaald vegetatietype behoren, bijeengebracht. Tevoren waș het substraat dusdanig bewerkt, dat de mogelijkheden voor vestiging en uitbreiding voor dat gewenste vegetatietype optimaal waren. Het project werd gestart in 1980 op 30 proefvlakken. In totaal werden zeven ruderale vegetatietypen aangeplant, waarbij ongeveer 90 soorten waren betrokken. Zaad of plantmateriaal was afkomstig van exemplaren uit de Eifel. ${ }^{30}$

5.2 Tabel 9.7 geeft enige informatie ten aanzien van het onderhoud van vijf van de zeven hierboven genoemde ruderale vegeta. tietypen. Het zal duidelijk zijn, dat daar waar een functionele veedrift ontbreekt, bij de res. tauratie van veedrift begeleidende vegetaties een aantal maatregelen moet worden geno. men, die bij een functionele veedrift spontaan verlopen. De belangrijkste maatregel vormt het regelmatig toedienen van mest. De do. sering daarvan blijkt per vegetatietype in Kommern te verschillen. In tabel 9.7 zijin de vịf vegetatietypen gerangschikt naar hun stal. mestbehoefte. Behalve toevoeging van een (geringe) hoeveetheid staimest behoeven de twee latste yegetatietypen in tabel 9.7 nog andere maatregelen om hun voortbestaan in het openluchtmuseum te garandereri, namelijk wiederi en hec los- en openmaken van de bodem.

Het is zeker geen toeval dat de vijf vegetatietypen die ap bovengenoemde wijze dienen te worden verzorgd langs een functionele veedrift te St. Privat spontaan dezelfde rangschikking hebben aangenomen als die in tabel 9.7. Minstens vier verschillende milieugradiènten zijn hierbij betrokken. De door het over de weg lopende vee veroorzalate mestgradiënt neemt af volgens een lijn die haaks staat op de wegas. De factor "tred", gepaard gaande met een zekere bodemverdichting, heeft hetzelfde verloop; de kruimelstructuur van het substraat onder en vlak naast de veekering garandeert een optimale aératie, die naar de weg toe afneemt. De vochtgradiènt heeft een ingewikkeld verloop: vlak na een regenbui is de toplaag van de bodem langs de min of meer gootvormige weg. rand snel verzadigd. Het substraat onder de veekering is zeker droger. ten historische fenomenen in het landschap. 
110

PUBLICATIES NATUURHISTORISCH GENOOTSCHAP LIMBURG

$X L-I 1993$

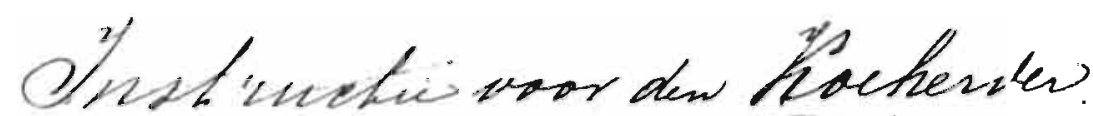
FIGUUR 13.7. Instructies voor den Koeherder te Meerssen", orchiefstuk van de gemeente
Meerssen, daterend 16
mei 1879. ctewexs?

$:$
1
1
5
5
3

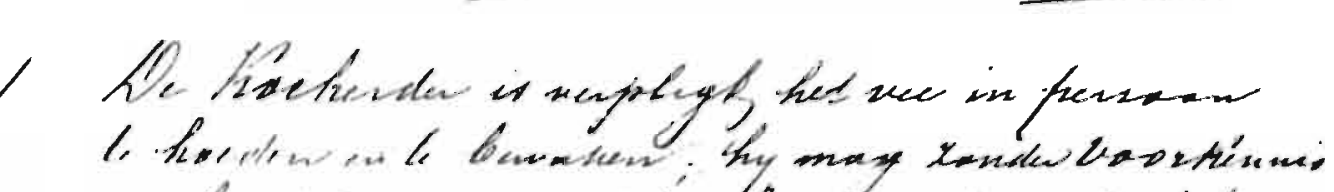

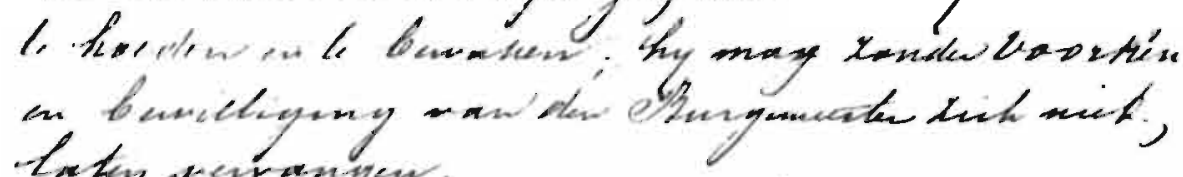
houngerinanyen.

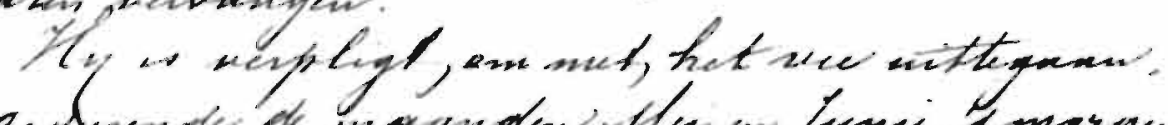

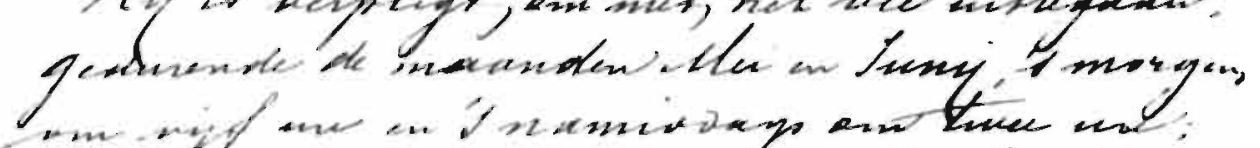

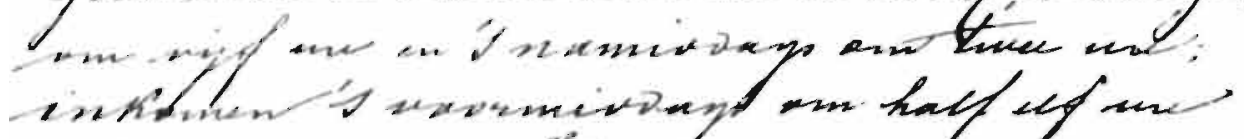

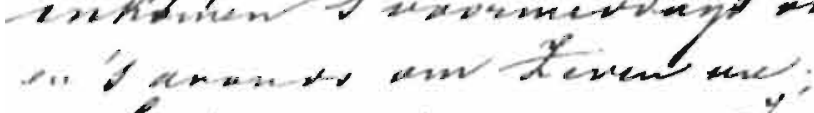

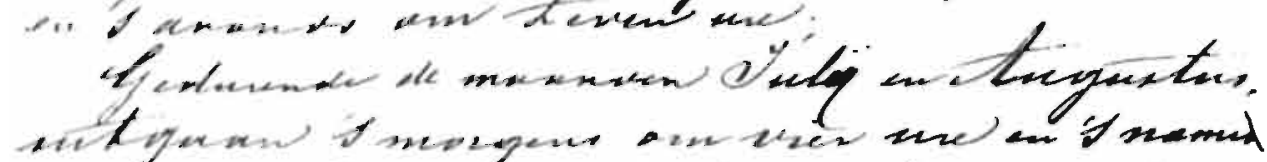

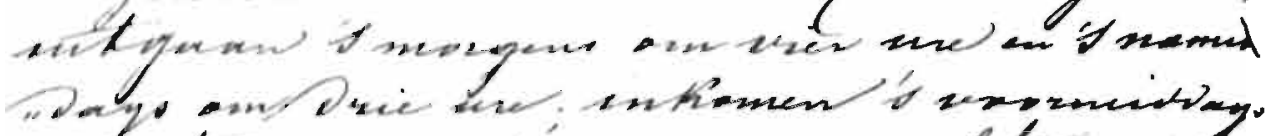

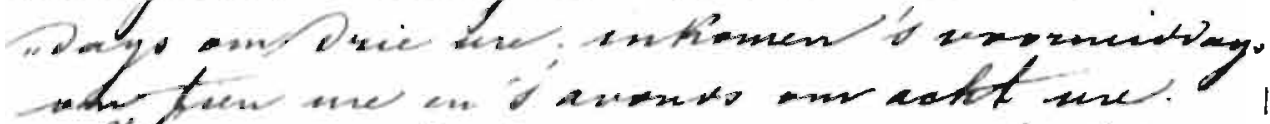

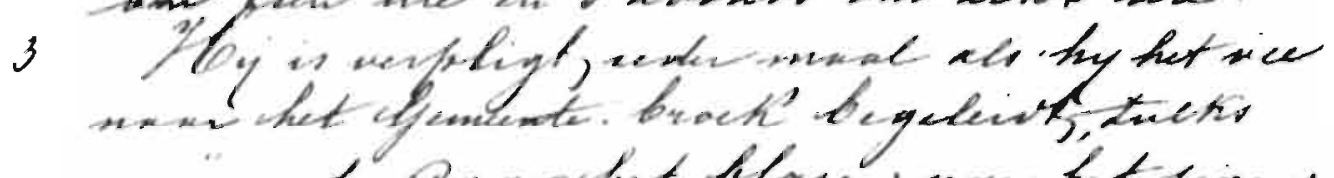

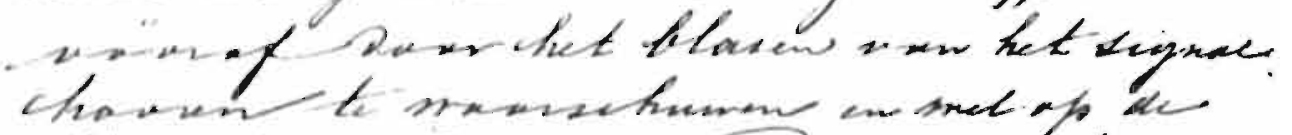

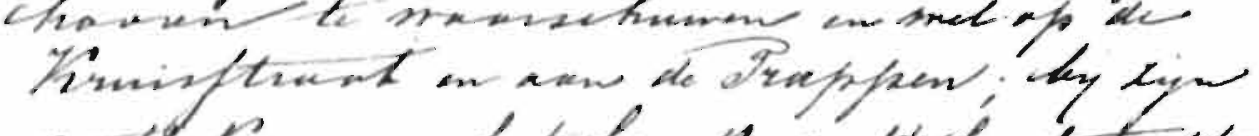

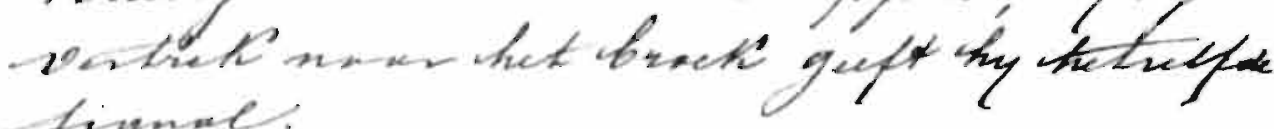

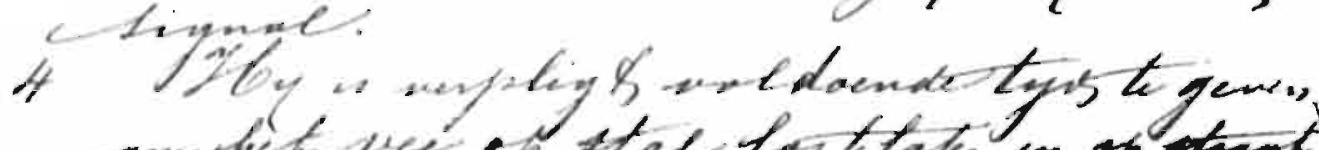

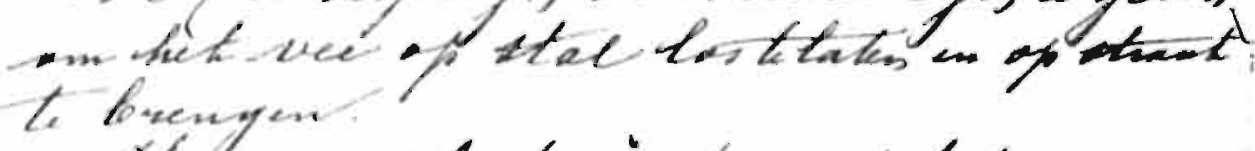

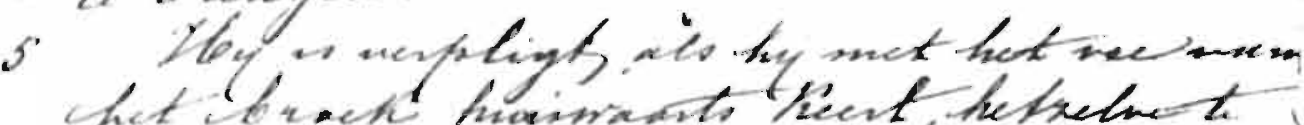

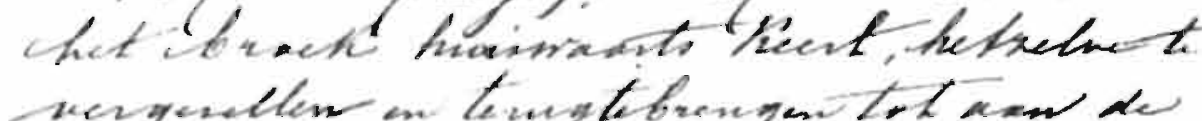
serquelem

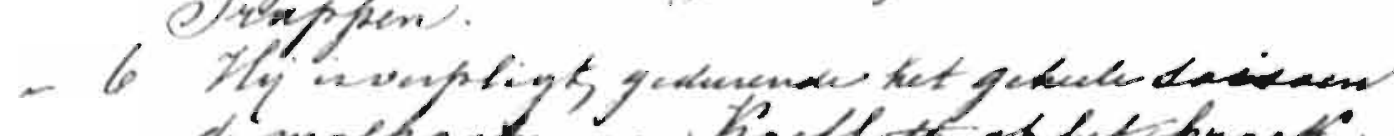
de matho pon en hioflater of hetribuede behanly's te spreinen.

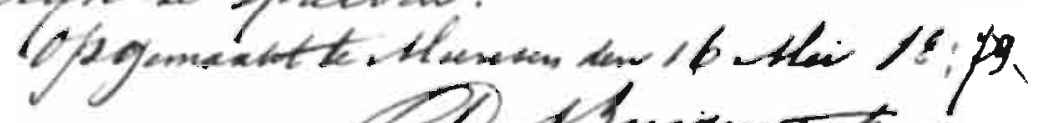


waarvan op dit moment alleen nog sporen in de vorm van holle wegen, in toponiemen of archieven bewaard zijn gebleven. Hier en daar kan men ook nog een aantal plantesoor. ten aantreffen, die destijds uitsluitend aan veedriften gebonden waren, maar deze soorten zullen onherroepelijk verdwijnen, zoals het geval is bij de veedrift in Meerssen.

In Central- en Zuid-Europa bestaan nog steeds intacte en functionele heerdgangen, maar ook hier zal de veedrift binnenkort geheel verdwijnen. Daarmee zal ook een interessante serie vegetatietypen verdwijnen, waarvan de soortensamenstelling niet alleen was aangepast aan het abiotische milieu van de randzone van de veedrift inzake minerale behoeften, bodemverdichting door tred en vochthuishouding, maar ook aangepast moet zijn geweest aan vraat door vee.

Voor een aantal soorten uit het Wegdistelverbond (Onopordion) en het verbond van de Grote klis (Arction) lijken deze mechanismen werkzaam. In elk geval moeten deze laatste functionele veedriften, zoals die van St. Privat, op korte termijn worden bestudeerd.

Het is nu te laat om syntaxonomisch onder. zoek te doen naar veedriftvegetaties in Noordwest-Europa. Alleen daar waar herintroductie van extensieve beweiding weer wordt ingevoerd, bestaat de kans dat zich soorten planten uit ruderale milieus gaan hergroeperen tot min of meer stabicle vegetaties.

Het experiment, uitgevoerd in het openluchtmuseum van Kommern, leert dat zonder een functionele heerdgang veedriftvegetaties slechts dank zij kunstrnatige ingrepen door de mens in stand kunnen worden gehouden.
NOTEN

I Dexe bondige tekat van Steegh (zie Het Landschap van Zuid-Limburg 1987, p. 27) geeft aan dat de heerdgang rowel invloed had op het ontstaan van holle wegen alsook op hetpatroon van nederzettingen in Zuid-Limburg.

- Begrasing in de natuur 1987

Begrazing in de natuor 1987.

CUASON 1977. pp. 83 en 107.

DE GeOOTH EN Venwers 1984, pp 40-42

CIAson 1977, p. 111

Onder andere JANsin 1960, p. 104

Bustaulue 1978, onder andere pp. 97.109

Betumun 1987

10 Sacvetn 1985

11 Denix En VImLinden 1982

12 Hichoes 1991 a

13. Pincacans 1983

14 Zie hooldstuk 4

15 Zie hoofdistuk ?

16. Hixkek et at 1961,p.23

17' Hilifctes, manuscript.

I8. Zie hootidstuk ?

19. Srecs in Het Landschap van Zuid-Limburg 1987, p. 30.

20. Hurase 1990

21 De ooggetuige, f Hallegers, is de vader van de auteur: het verhaal van de "schweitzer" vormde een van ziln "success stories"

22: De term "schweicxer" wend in Zuid-Limburg op meer plastien gebruilut om een koeherder of de koeknecht op eun grote hoeve te benoemen. Yergelipk Duilzinos 1964

23. De signaalhoorn is een karakteristiek attribuut vant de koeherder in Noordwest-Europa.

21 De. Tranchotcaar beeldt op deze plaats een brink-. achige verbreding van de Veeweg, af. Zie figuur : 3.3.

25. Deze coponiemen komen ook voor op de toponie: menkaart van Meerssen. Zie DAs et al. 1977.

2h. De schoudertas is eveneens een karakteristiek onderdeel van de herdersuitmonstering.

27. Het origineel bevindt zich in het archief van J Geifsen te Meerssen.

28 Dörfliche Vegetation im Freilichtrnuseum 19:1. pp. 11.20.

29. Dörliche Vegetation im Freifichumuseum 1981, pp. 61.66.

31) Dorfliche Vegetation im Freilichtmuseum 19\&।, PP 11.20. 


\title{
HARTGESPAN, EEN KARAKTERISTIEKE PLANTESOORT VOOR VEGETATIES LANGS VEEDRIFTEN?
}

\author{
"dit cruyt is voor de gebreken des hicten."
}

1.1 Hartgespan, Leonurus cardiaca L, is een bloemplant die tot de familie van de lip. bloemen behoort en wordt gekenmerkt door een aantal morfologische eigenschappen, die doen vermoeden dat de soort zich door midde! van dieren van het formaat van een schaap laat verspreiden; de droge vruchten bezitten haakvormig omgebogen tanden, die ais enterhaken kunnen fungeren. De bloeistengel blijit na de bloei tot diep in de winter stijí rechtop staan. De bloeiwijze verheft zich minimaal tot op schaaphoogte van de grond, zodat passerende dieren vanaf de nazomer tot en met het volgend voorjaar in staat zijn zowel de vruchten als delen van de uitgedroogde bloeiwijzen aan hun vachten mee te nemen (zie figuur 14.1, 14.2 en 14.3).

Sestegefpay, oft Carbiaca.

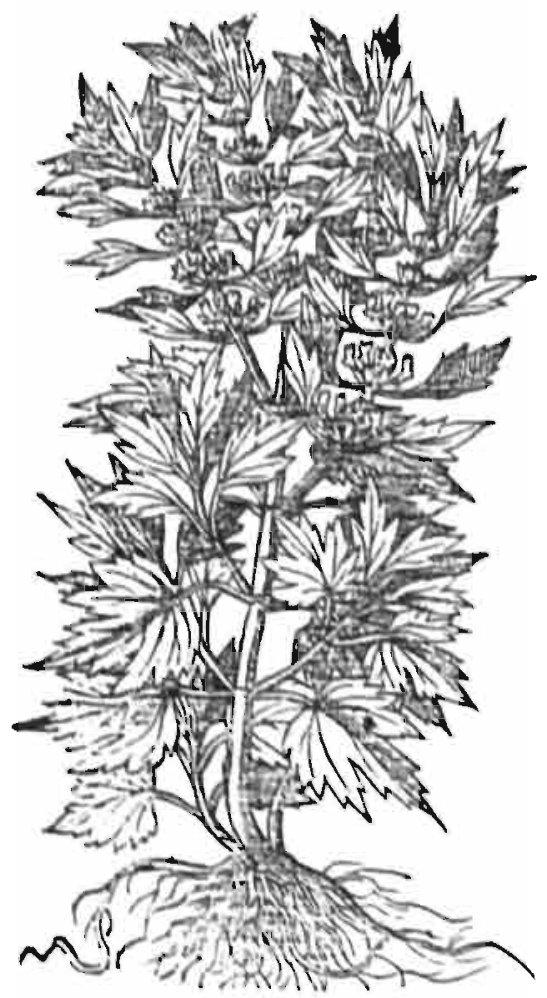

FGUUR 14.1. Hartgespan, hobitus rekening volgens DODOENS I 1603 . Bloeiende exsmplaren bereiken een hoogte ven 100 tot $150 \mathrm{~cm}$. De bloel. bestoande wit kleine rose-witte lipbloemen, is weinig opvallend.
Ook de typische standplaats van hartgespan in geheel Noordwest- en Centraal-Europa langs wegen in de omgeving van nederzettingen op het platteland, doet vermoeden dat een verspreiding via de vacht van loslopend vee of de kleding van hun drijvers mogelijk is. Of hargespan ook momenteel in Zuid-Limburg een karakteristieke veedrift begeleidende plantesoort is, wordt, in dit hoofdstuk nader onderzocht.

Hartgespan, de naam doet zulks al vermoeden, is een oude medicinale plant, waarvan een "aftreksel" van de bladeren als huismiddel tegen onder andlere hartaandoeningen werd gebruikt. Destijds werd zij om die reden in tuinen gecultiveerd. In elk geval kwam tijdens de: vorige eeuw in geheel Noordwesten Centraal-Europa (en zeker in Zuid-Limburg) deze weinig opvallende plantesoort regelmatig voor langs wegen en hagen. meestal in de omgeving van menselijke nederzettingen op plekken waar we nu de grote brandnetel tegenkomen.

$\checkmark$ anaf het midden van deze eeuw werd hartgespan overal in West-Europa zeldzamer. Thans is het in Nederland uiterst zeldzaam. In dit hoofdstuk wordt die achteruitgang beschreven en onderzocht, in hoeverre de achreruitgang kan worden gekoppeld aan het verdwijnen van de heerdgang danwel aan het verdwijnen van de cultuur in boerentuinen om medicinale redenen.

"Toen ik aan de zeekant van Valkeveen in een zoom langs her hakhout drie geheimzinnige Labiaten vond, volgens de flora z.z. Hartgespan... Het heeft dertig jaar geduurd voor ik het weervond in Voornes Duin bij het Breede Water, precies in zo'n zoom langs een struweel..." Aldus Westhoff" in 1966 over twee persoonlijke ontmoetingen met hartgespan.

Het is frappant dat dergelịke ontmoetingen zich in de tijd en de ruimte herhalen: destijds - dat was in 1956 - zag schrijver dezes hartgespan voor het eerst in de zoom van een iepenstruweel in gezelschap van absint-alsem
(Artemisia absinthium), grote brandnetel (Urtica dioica), bijivoet (Arternisia vulgaris) en enkele klissen (Arctium spec.). Die groeiplaats bij het laatste huisje alan de dorpsrand van Meerssen, inmiddels veranderd in een keurige woonwijk, kon worden omschreven als een "overhoek": een brede wegberm, overgaande in een ruigte en struweel, waar puin, rommel, tuin- en slachtafval werd gestort of begraven, waar zo af́ en toe een vuurtje brandde en landbouwgereedschap tijdelijk werd achtergelaten (zie tabel 9.6.2, nr I0). Bijna dertig jaar later zag de auteur hartgespan weer terug in Bemelen in precies zo'n zelfde "overhoek": een brede wegberm. overgaand in ruigte en iepenstruweel in de directe, omgeving van een oud tuindersbedrijfje (vergelijk tabel 9.6.2, nr I). Op die plek bleek hartgespan al in 1940 te zịn vermeld. Het heeft daar waarschijnlijk jaarlijks, in elk geval toten met I 986 gebloeid. Vanaf 1987 is

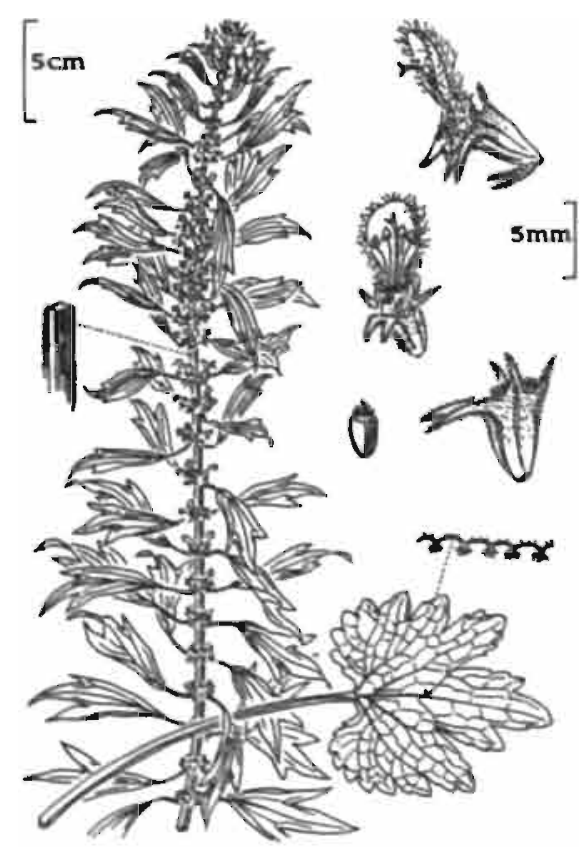

FIGUUR 14.2. Broeiwijze, bloem, rood en rrucht von hartgespan volgens Cuamun et al. 1963. De rucht is roorzien van puntige, rtijve en hookwor. mig gebogen tanden, die als "enterhoken" fungeren in de pels van passerende dieren. 
Leonurus er niet meer teruggevonden en het ligkt erop dat desoortter plaatse isverdwenen.

2 De medicinale waarde van hartgespan heeft vooral betrekking op hartklachten, hetgeen al zou kunnen worden afgeleid uit zowel een deel van de wetenschappelijke nam als uit de Nederlandse, Italiaanse en Zweedse volksnamen.

Diverse kruidenboeken, ${ }^{3}$ uitgegeven vanaf de zeventiende tot en met de twintigste eeuw, en flora's uit deze eeurw' vermelden de medicinale eigenschappen: een aftreksel van de bladeren zou een krachtige medicijn bevatten voor het hart. Ook wordt beweerd dat dit middel goed is voor "de zenuwen", het zou "stimulerend" werken en bovendien geschikt zijn om "wormen af te drijven". De huidige homeopathie" vermeldt als werkame bestanddelen: bitterstoffen, etherische olièn, looistoffen, harsen, choline, flavonoiden, glycosiden en kleine hoeveelheden alkaloiden, zoals stachidrine, betonicine en turicine.

Om bovenvermelde redenen moet hartgespan in het verleden in particuliere tuinen als medicinaal gewas zijn gekweekt. De uitgebreide floristische literatuur van Centraal-en West-Europa laat hierover weinig twijfel bestaan, maar over het moment van introductie in deze delen van Europa worden geen gedetailleerde gegevens verstrekt. Slechrs één kruidboek geeft op, overigens zonder bronvermelding, "omstreeks de Vlle eeuw is hartgespan uit Aziě geïmporzeerd, tijdens de $X V$ e eeuw in kloostertuinen gekweekt, nog in de XVIIle eeuw gewaardeerd en geprezen en vanaf het begin van de X!Xe eeuw in onbruik geraakt". 6

Toch is het merkwaardig dat geen van de negentiende-eeuwse krụidenkennerș, die in Zuid-Limburg als florist actief zijn geweest en die - deels althans - het beroep van arts of apotheker uitoefenden, het kweken van hartgespan in particuliere tuinen hebben vermeld. "Wel vermelden deze floristen de betreffende soort als "spontaan" in ZuidLimburg voorkomend en aan te treffen langs wegen en hagen in de buurt van nederzettingen. Daarom moet worden aangenomen, dat het kweken van hartgespan voor medicinaal gebruik in Zuidlimburgse tuinen op het platteland al tijdens het begin van de vorige eeuw was gestaakt. Hartgespan kwam vanaf die periode in Zuid-Limburg alleen voor als een spontaan gewas, groeiend langs hagen en niet-bebouwde plaatsen in of aan de rand van nederzettingen.
De teelt in tuinen is overigens zeer eenvoudig. Dit was minstens drie eeuwen geleden al' bekend. Dodoens vermeldt "Dit cruydt wast geerne op puynachtige plaetsen / oft steenachtigen gront: het wort oock somwijlen gevonden omtrent de oude vervallen muren. In de hoven pleegtetal te lichtelipiken ende te gewillichlijken te batten ende te aerden. Hertgespan en begeert gansch geen oeffeninghe / ende wast liever op onbebouwde plaetsen / dan op vetten ende bebouwden gront"."

De soort is meerjarig en kan met wortelstokfragmenten gemakkelijk vegetatief worden vermenigvuldigd. De afgestorven bloeistengels ontwikkelen aan hun bases knoppen, die al heel vroeg in het voorjaar uitlopen; een afgescheurde stengelbasisstek loopt makkelijk uic. Het opvallend lang groen blijvende wortelrozet van cen eenjarig exemplaar is winterhard en staat garant voor een groot aantal bloeistengels in het daaropvolgende jaar. Verwildering door middel van zaden treedt eveneens gemakkelijk. op; diverse mensen die hartgespan momenteel om curiositeitsredenen in hun tuinen kweken, kunnen bevestigen dat deze soort in het milieul van de tuin als "onkruid" uit zaad opslaat.

\section{3}

Diverse morfologische eigenschappen, zoals de haakvormig omgebogen kelktanden (zie figuur 14.2), de breekbare vruchtsteel, zaden die na rijpheid gedurende een langere periode in de vrucht blipven, de langgerekte bloeiwiize met de dicht tegen de stengel aangedrukte vruchten, die als, evenzoveel "enterhaken" fungeren en de zich verstijvende bloeistengel na de bloei die daardoor gemakkelijk transporteerbaar is, wijzen op een exo-roöchoor transport; ruigharige dieren van het formaat van een schaap en de broekspijpen van de bezige tuinier of wandelaar, moeten ideale transporteurs zijn van vruchten of delen van de uitgerijpte bloeiwiize.

Een dergelijke verspreidingsstrategie komt meer voor, met name bij plantesoorten die langs wegen en op ruige, kruidenrijke graslanden voorkomen, die onder andere door schaapskudden worden beweid. ${ }^{0}$

Naast onopzettelijk transport van zaad via de vacht van huisvee, heeft, zeker in het verleden en in verband met de medicinale waarde. opzettelijk verspreiding van zaad of van vegetatieve delen door de mens plaatsgevonden. Niet-opzettelijke verspreiding zou vervolgens kunnen geschieden vanuit tuinen. $\mathrm{Op}$ gunstige plaatsen, zoals open wegbermen, puinstortjes, overhoeken en andere ruderale plekken binnen de nederzetting maar buiten het milieu van de tuin, kan de soort zich handhaven, eventueet uitbreiden en zich na verioop van tiịd gaan gedragen als een volledig "wilde" soort. Hartgespan stamt oor. spronkelijk uit Zuidoost-Europa (en Azié) en zou zich met behulp van de mens of diens vee hebben verspreid over geheel Europa, behalve het uiterste westen (Portugal en lerland) en noorden (Ils sland en de noordelijke delen
FIGUUR [4.3. Hartgespan als xoomplant. Onder notuurlyke omstandigheden gedraage hartgespon zich als een roomplant, dat wil zeggen standplaatsen beirinden xich steeds tussen een wot logere en een wot hogere vegetatic. De karokterlstiekn standploats is oun een wegrand, die overgoot in een struweel of een haog, zoals op de tekening. Een vaste begeleider is de grote brondnetel, op de tekening tussen de meidoornhaag en hartgespan.

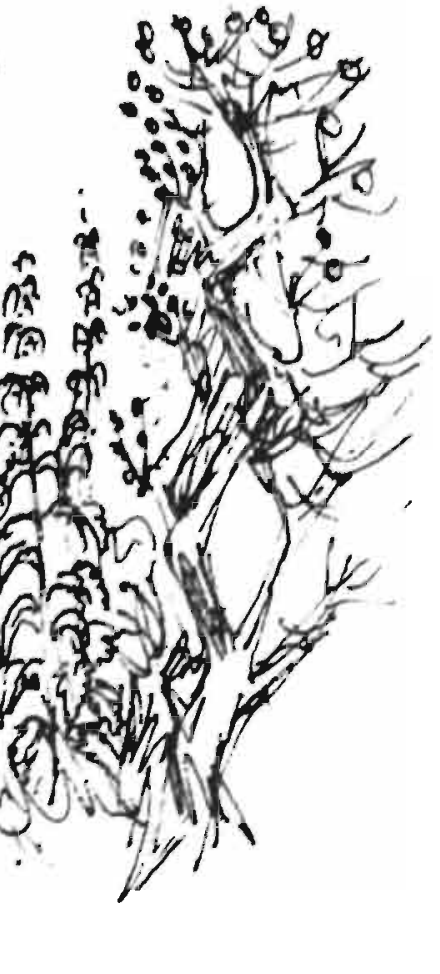




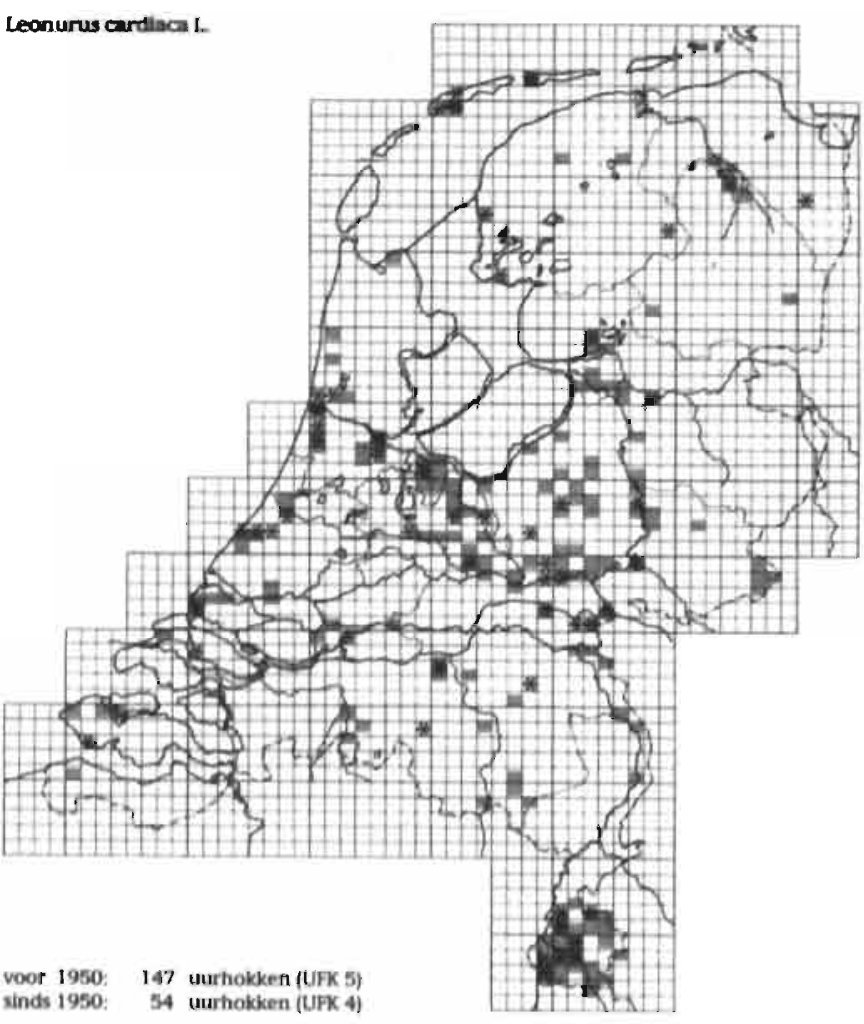

FIGUUR 14.4 Verspreidingskoart van hartgespan in Nederland noar de Atlas van de Nederlandse floro 1985-1989. Het verspreidingspatroon is nogal diffuus met concentraties in het duindistrich, die mogelljk samenhangen met de aanwexigheid van zaden van hartgespan in fazantevoer. De concentratie rond havensteden zou verband kunnen houden met graanoverslog. Opvallend is de sterke ochteruitgang sinds 1950 in Nederland loangegeven met vierkante blokjes vóor 1950 en cen asterisk na 1950). Momenteel, dat wil zeggen in 1991, is hartgespan in Zuid. Limburg nog maar in drie uurhokken oan te

van Scandinavië). Inmiddels is hartgespan de Arlantische Oceaan overgestoken en is het in de Verenigde Staten gesignaleerd. "Alleen afgaande op de verșpreidingskaarties, en de opgaven in regionale flora's, zou men tunnen veronderstellen dater aan de "expansiedrift" van deze "ruderale" en "nitrofiele" trawant

van de grote brandnetel voorlopig geen einde komc. Maar niets is minder waar dan dat. Overal in West-Europa verdwijnt hartgespan in een snel tempo.

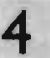

De achteruitgang in Zuid-Limburg tussen 1800 en 1989 is, evident; de al eerder

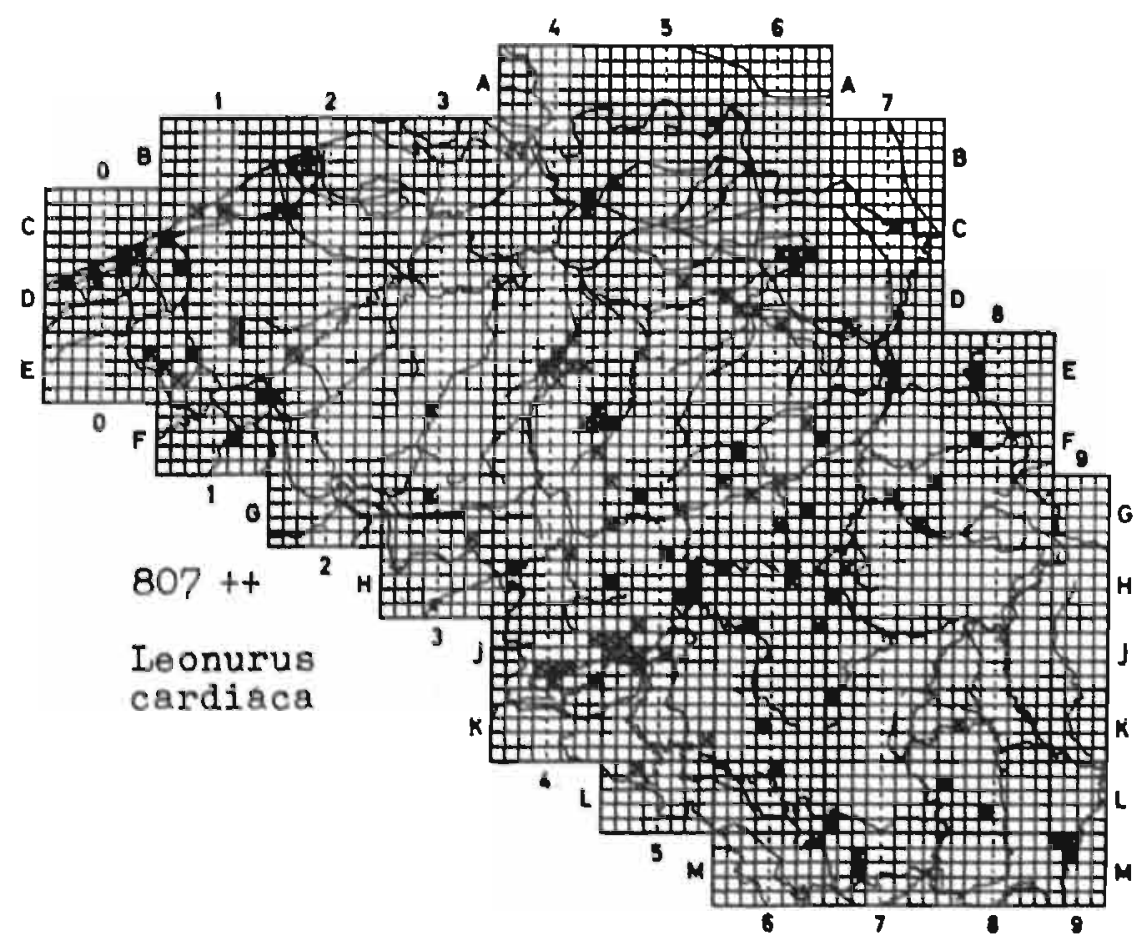

FGGUUR 14.5. Verspreidingskaart van hartgespan in Belgie en Luxemburg naar VAN ROMPAEY EN DELVOSALLE 1979. Net als in Nederland is her verspreidingspatroon diffuus. Ook in Belgiè is hartgespan seldxoam geworden. geciteerde Zuidlimburgse floristen uit de vorige eeuw" " geven weinig informatie omtrent de mate van verspreiding, maar indirect kunnen we uit hun notities opmaken, dat de soort redelijk algemeen moet zijn geweest. In elk geval was Leonurus cardiaca in milieus buiten dat van boerentuinen toentertijd noch zeldzaam, noch zeer algemeen. Tijdens het begin van de twintigste eeuw was dat nog zo; de bekende Zuidlimburgse florist De Wever geeft daarover uitvoerig informatie. ${ }^{12} \mathrm{Hij}$ noemt de standplaatsen van 25 populaties, verspreid over geheel Zuid-Limburg en voegt aan die lijst de in dit verband betekenisvolle afkorting "enz." toe.

Vanaf 1950 verandert dit beeld: volgens het Nederlandse verspreidingskaartje (zie figuur 14.4) is het aantal uurhokken in Zuid-Limburg dan teruggelopen van 20 naar 8 . Voor zover bekend, is dat aantal momenteel drie, dat wil zeggen dat er in 1991, afgezien van de in tuinen gecultiveerde planten, in Zuid-Limburg nog maar in drie verschillende $5 \times 5$ kilometerhokken levensvatbare hartgespanpopulaties aanwezig zijn (vergelijk tabel 9.6.2, nr 5,6 en 7).

De achteruitgang van de populaties rond $\mathrm{Be}$ melen is nog gedetailleerder bekend (vergelijk tabel 9.6.2). Tijdens de periode 1940$1970 \mathrm{kwamen}$ rond dit dorp minstens vijfpopulaties voor, metname onder de Metteberg, aan de Zwarte Weg, aan de voet van de Serocibeirg, aan de weg bij de hotels en an de voet van de Keerderberg. In 1980 waren er nog drie, te weten: Metteberg. Zwarte Weg en - waarschijnlijk - de Strooberg (de populatic werd pas in 1982 herontdekt). In 1991 resteert er van de vijf populaties rond Bemelen nog maar één populatie, bestaande uit vijf exemplaren.

De achteruitgang, van hartgespan in Nederland als geheel vertoont eenzelfde beeld: het betreffende kaartje (zie figuur 14.4) geeft een beetd van de verspreiding in twee perioden: één voor 1950, aangegeven door blokjes en één van de periode 1950 tot: 1982, aangegeven door sterreties. Allereerst valt de sterke afname op van het aantal vindplaatsen tus sen periode 1 en 2, uitgedrukc in uurhokken ( $5 \times 5 \mathrm{~km})$, van ! 47 naar 54. Daardoor is de frequentieklasse, een maat voor de zeldzaamheid, afgenomen van 4 naar 3. Na 1982 heeft zich deze tendens verder voortgezet en volgens de laatste gegevens behoort hartgespan tot categorie 2 , die van de zeer zeldzame soorten. Statistisch gezien, moet hartgespan vóór het jaar 2000 in Nederland zijn uitgestorven. ${ }^{13}$ 
Naast de algemene achteruitgang geeft het laartie nog meer informatie; de spreiding van het aantal uurhokken is niet gebonden aan een bepaald planten-geografisch district. evenmin aan een bepaalde grondsoort. Dit zou kunnen wijzen op een correlatie met het verspreidingspatroon van nederzettingen. De concentraties aan de binnenduinrand bij Haarlem en Wassenaar en de vindplaatsen na 1950 bij havens zouden als adventief kunnen worden betiteld. In het eerste geval als "verontreiniging" in fazantevoer, dat door jagers in de duinen wordt uitgestrooid, " in het andere geval met een scheepslading (bijvoorbeeld wol) meegekomen en als "pothoofdplant" in de havenbuurt opgeslagen. ${ }^{13}$

De afname in Belgie, Luxemburg en elders in West-Europa is mogelijk minder dramatisch; het Belgisch-Luxemburgse verspreidingskaartje (zie figuur 14.5) geeft, in tegenstelling tot het Nederlandse, geen verschil tussen het verspreidingspatroon en de frequentie van het voorkomen vóór en na 1950. Globaal gesproken is het verspreidingspatroon in Belgiè en Luxemburg net zo "los" en "ijl" als in Nederland. Het tekstdeel van de atlas, waarwit het kaartje afkomstig is, vermeldt slechts de opmerking "zeiden standhoudend". Ofschoon geen recente gegevens van de afname van hartgespan in Belgiè zijn bekend, geldt de opmerking "zelden scandhoudend" in elk geval voor de twee standplaatsen op het Belgische deel van de Sint-Pietersberg (vergeliik tabel 9.6, nr 8 en 9). Als de soort hier op dit "floristisch bolwerk" inderdaad is verdwenen, voorspelt dat weinig goeds voor het voortbestaan van hartgespan elders in Belgiè. In Engeland is Leonurus "introduced, rare on waste places and hedge-banks" en "scattered over the British Isles". ${ }^{16}$

In bepaalde delen van Frankrịk schịnt Leonurus nog algemeen te zịn, maar het ontbreekt in het: mediterrane en alpiene ge-

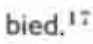

In Oostenrijk komt hartgespan alleen in het Pannonische gebied regelmatig voor. ${ }^{18}$ Persoonlijke observaties in de dorpen rond het meer van Neusiedl bevestigen het door Oberdorfer geschetste beeld van Leonurus als een trouwe kensoort van het Klissen-verbond, een dorpsrand bewonende plantengemeenschap. ${ }^{19}$ In Duitsland ontbreekt hartgespan lokaal, is zeldzaam of verdwijnt in een snel tempo (zie figuur 14.6).

In Zweden vormde "Hjarstillans" het onderwerp van een uitvoerige studie: oorspronkelijk tijdens de middeleeuwen geìntroduceerd als medicinale soort, komt het nog steeds

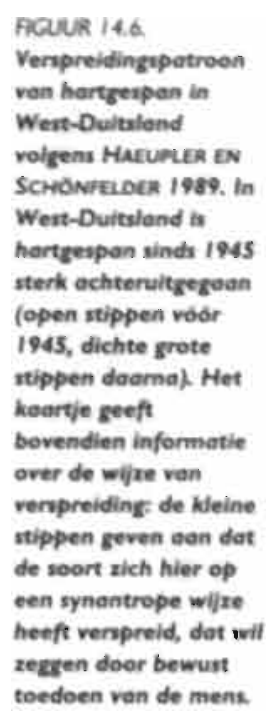

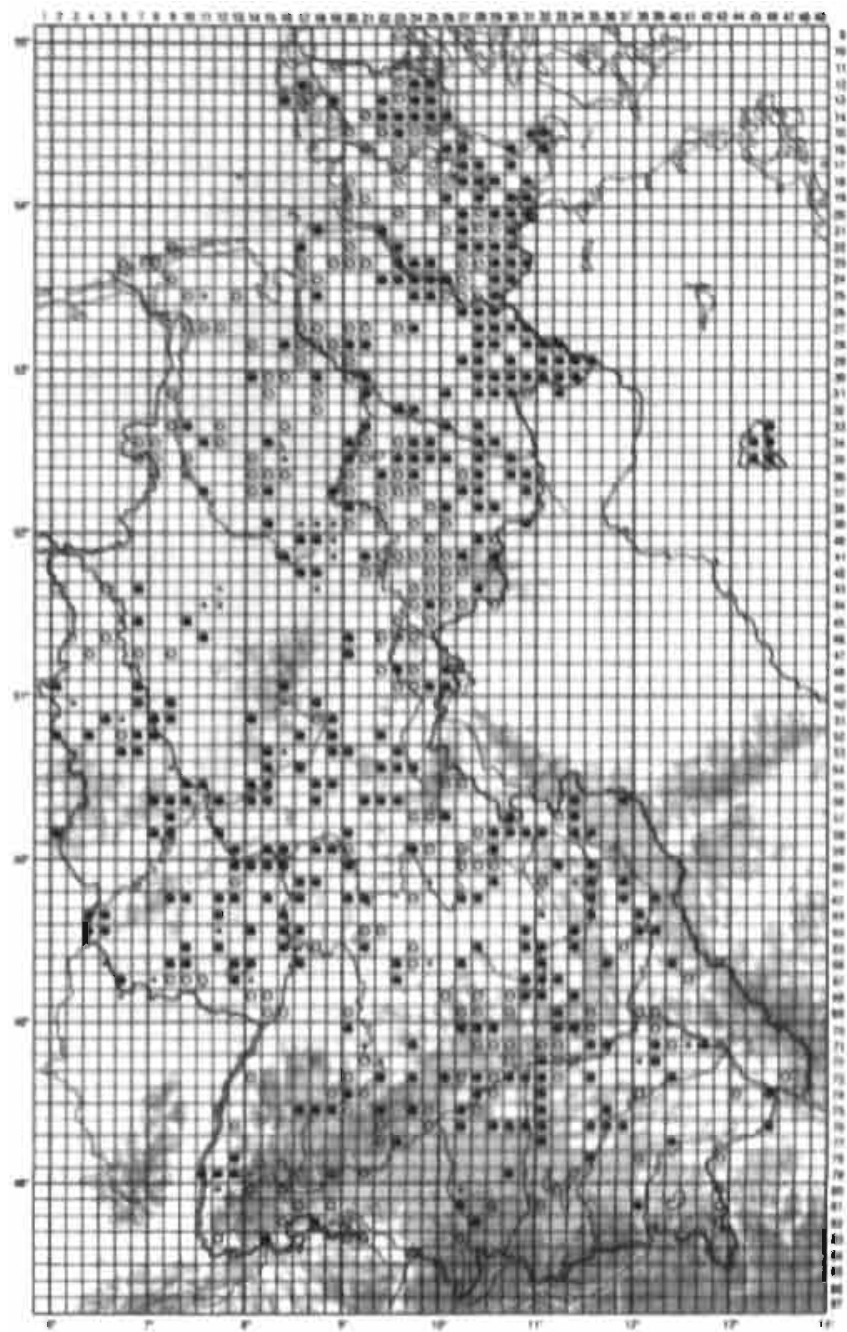

voor in de directe omgeving van menselijke nederzetringen, maar is daar de laatste jaren uiterst zeldzaam geworden. Buiten dat milieu komt hartgespan ook hier en daar langs de zeekust voor. Maar zonder menselijke hulp zal het; in Zweden binnenkort uitsterven. ${ }^{20}$

\section{I Uit algemene groeiplaatsgegevens} van hartgespan, vermeld in diverse flora's van de Zuid-Limburg omringende gebieden of waarvan Zuid-Limburg deel uitmaakt, ${ }^{21}$ floralijsten en manuscripten, op herbariumetiketten, ${ }^{22}$ via mondelijke mededelingen van floristen en persoonlijke observaties in Nederland en in het buitenland valt af te leiden dat ongeveer $80 \%$ van de groeiplaatsen voldoet aan de volgende karakteristieken.

1. Een ligging aan de periferie van een nederzetting, meestal op een afstand van minder dan 100 meter van het dichtstbijzijnde gebouw.

2. Een ligging in een wegberm die als een overhoek kan worden gekarakteriseerd, dat wil zeggen een plek waar diverse menselijke activiteiten plaatsvinden die, algemeen gesproken, een eutrofiërend effect hebben op de vegetatie, waarbij ter plaatse tevens open plekken ontstaan.

3. De groeiplaats vertoont een zonering in de aanwezige vegetatie vanaf een open en onbe. groeide situatie (meestal een onverharde weg) naar een dichte, hoge en houtige vegetatie (een haag of een spontaan ontstaan struweel).

4. Een groeiplaats waar de grote brandnetel (Urtica dioica) domineert. Dit geldt voor de meeste groeiplaatsen in Zuid-Limburg (vergelijk tabel 9,6.2).

In tegenstelling tot de floristische samenstelling die weinig homogeen blijkt te zi.jn, is de structuur van de vegetaties waarin hartgespan voorkomt wel karakteristiek en homogeen van opbouw. Hartgespan maakt deel uit van een zoomvormige vegetatie waarin Ur. tica dioica domineert. Die zoom omvat een lage $(20-40 \mathrm{~cm})$ kruidenriike en een hogere $(160-200 \mathrm{~cm})$ vegetatie en is gelegen tussen een weg en een haag of een struikrand.

In de lage vegetatie is het percentage annuellen gering, overblijvende grove grassen (onder andere Dactylis glomerata) en kruiden (onder andere Lamium album) domineren. In 


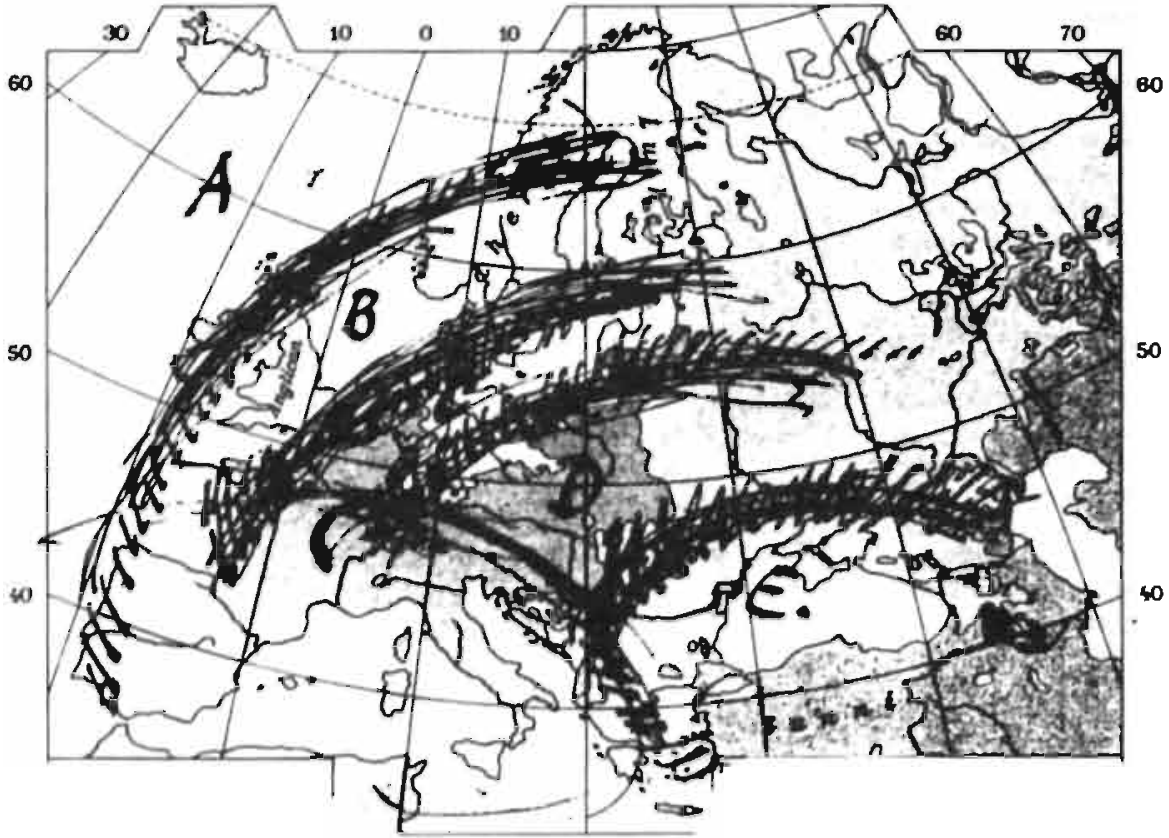

de hogere kruidlaag domineert de grote brandnetel. Leonurus valt daartussen nauwelijks. op buiten de bloeitijd; haar bladeren lijken wel wat op die van de grote brandnetel. Hier en daar staan andere ruigtekruiden: hoge opvallende distels, toortsen of schermbloemen. De struikrand op de achtergrond bestaat uit jong struweel of een meidoornhaag. meestal doorgroeid met klimmende. windende of șliertige soorțen (zie figuur 14.3).

5.2 Oberdorfer heeft in zijn recente standaardwerk "Siddeutsche Pflanzengesell. schaften" ${ }^{23}$ de syntaxonomische positie van hartgespan gekarakteriseerd als een "vermoedelijke" verbondskensoort van het Arction lappae (het Verbond van de Grote klit en andere Klitsoorten), dat wil zeggen een plantengemeenschap, voorkomend op wegbermen en andere plaatsen bij nederzettingen, waar onder andere de grote klit vrijwel steeds een dominerende rol speelt in de vegetatie. Determ "vermoedelijk" behoeft wat nadere uitleg: Oberdorfer constateert aan de hand van de in zijn boek opgenomen tabellen, dat in het oosteliịk deel van zijn onderzoeksgebied hartgespan een trouwe begeleider is van de grote klit; in het westelijk deel ontbreekt hartgespan en wordt hier vervangen door de witte dovenetel (Lamium album), die in het oosten zo goed als afwezig is. Op grond van deze feiten overweegt Oberdorfer het Verbond van de Grote klit op te splitsen in twee onderverbonden, namelijk het Lamio-Arctenion minoris (het On- derverbond van Witte dovenetel en Kleine klit) en het Leonuro-Arctietum tomentosi (het Onderverbond van Hartgespan en Wollige klit).

Het eerstgenoemde onderverbond heeft een meer westelijke, het tweede een meer oostelijke verspreiding in Centraal-Europa. De voorgestelde opsplitsing behoeft, volgens Oberútorfer, nader onderzoek. Maar Oberdorfer zegt tevens dat: dit eigenlijk niet meer mogelijk is, omdat yegetaties met klitten (en hartgespan) in een snel tempo dreigen te verdwijnen in en rond de dorpen binnen zijn onderzoeksgebied.

Naast de status van "vermoedelijke" verbondskensoort geeft dezelfde auteur aan hartgespan nog de status van een associatiekensoort. namelijk van het Leonuro-Ballotetum nigrae. Dit Gezelschap van Hartgespan en Stinkende ballote, dat door Slavner in 1951 in Tsjecho-Slowakije werd beschreven, komt dus ook in Zuid. Duitsland voor, maar, analoog aan het verbondsniveau, is er volgens Oberdorfer weer sprake van een tweetal mogelijke opsplitsingen van deze plantengemeenschap in een westelijk "ras"., waarin Lamium album voorkomt, en een oostelijk "ras" met Leonurus. In elk geval heeft her Gezelschap van Hartgespan en Stinkende ballote een verspreidingsgebied, dat in het oostelijk deel van Centraal-Europa ligt.

Runge en Ellenberg, twee andere vegetatiekundigen uit Duitsland, vermelden in hun recent verschenen publicaties ${ }^{21}$ het Leonuro-Arctietum tomentosi en het LeonuroBallotetum nigrae als gezelschappen, waar-
FGUUR [4.7. Verspreidingskaart van hartgespan in Europo, die rekening houds met de indigeniteit en de wijze van verspreiding samengesteld met behulp van floro's van diverse Europese landen. In zone A komt hartgespon niet voor, in zone $B$ komt hortgespan alleen voor als een gecultiveerde soort en zeer zeldzaom als wilde (?), waarschijnlijk verwilderde soort In zone $C$ kome hartgespon voor als gecultiveerde soort, maor ook verwilderd en mogelijk oorspronkelijk wild. In zone $D$ kome hartgespon vrij algemeen voor als wilde soorh, terwijl het gebied rond $E$ ais het oorsprongsgebied wordt beschouwd. van Leonurus cardiaca één van de kensoorten is. Beide gerneenschappen komen in oostelijk en zuidoostelijk Midden-Europa voor.

5.3 Devegetatiekundige karakteristiek van hartgespan in Frankcrijk wordt door Guinochet en Vilmorin ${ }^{2.5}$ summier aangeduid als typerend voor het Eu-Arction, zoals in Zuidoost-Duitsland, het daarmee venwante Onopordion acanthii (Wegdistel-verbond) en het Chenopodion muralis (het Verbond van Muurganzevoet). Debovengenoemde schrijvers verrnelden nog, twee andere plantengezelschappen, waarin hartgespan in Frankrijk zou voorkomen: het. Berberidion, een plantengemeenschap van struwelen, en het $\mathrm{Cau}$ calion lappulae, een onkruidgemeenschap van graanakkers op kalkrijke bodems. Ofschoon de beide gemeenschappen ook in Nederland voorkomen en voor Zuid-Limburg zelfs typerend zijn, is het voorkomen van hartgespan in deze gemeenschappen in ons land nooit geconstateerd.

Voor Nederland geven Westhoff en Den Held ${ }^{26}$ Leonurus cardiaca op als kensoort van het Balloto-Chenopodietum, het Gezelschap van Stinkende ballote en Brave hendrik. Ten aanzien van dit standpunt past een aantal opmerkingen. Op de eerste plaats dateren de gegevens, waarop deze opinie is gebaseerd, van minstens dertig jaar geleden. Sindsdien is Leonurus cardiaca uiterst zeldzaam geworden in Nederland en brave hendrik bijna uitgestorven. Ook stinkende ballote, de derde kensoort van Balloto-Chenopodietum, gaat sterk achteruit, met name in 
Zuid-Limburg. Hierdoor is een nieuwe situatie ontstaan, die het bestaansrecht van het Balloto-Chenopodietum in Nederland ondergraft. Overigens ondersteunen de gegevens die in tabel 9.6 .2 en 9.6 .3 zijn gepresenteerd, het eventuele bestaan van deze plantengemeenschap in Zuid-Limburg op dit moment nauweliịks; Ballota nigra heeft daarvoor een te lage presentie (slechts in twee van de zeven lokaliteiten; zie opname 10 en 11 van tabel 9.6.3).

Op grond van de summiere gegevens uit tabel 9.6.2 en 9.6.3, die bovendien slechts betrekking hebben op standplaatsen in ZuidLimburg, kunnen ten aanzien van de syntaxonomische positie van Leonurus cardiaca in Nederland geen duidelijke uitspraken worden gedaan. Wel kan worden opgemerkt, dat de hoge presentie- en abundantiecijfers van Urtica dioica (grote brandnetel), waarvan het concurrentievermogen bekend mag worden verondersteld, een ernstige bedreiging vormen voor het voortbestaan van de laatste populaties van hartgespan in het onderzoeksgebied.

Voor Zuid-Limburg en het daaromheen gelegen deel van Noordwest-Europa geldt hartgespan als een archeofyt, die zich uiteindelijk niet heeft kunnen aanpassen aan de turbulente veranderingen, die plaatsvonden in de agro-pastorale bedrijfsvoering van de twintigste eeưw: mogeliịk werd deze soort tijdens de middeleeuwen als medicinale plant hier geĭntroduceerd vanuit CentraalEuropa en mogelijk was hartgespan al tijdens die periode inheems. In elk geval werd hartgespan om medicinale redenen in kloostertuinen en later in particuliere tuinen op het platteland gecultiveerd en heeft deze soort kans gezien zich vanuit die situatie te verwilderen en in te burgeren langs dorpswegen. onder andere dank zị een verspreidingsmechanisme via de vache van de dorpskudden. Het is zeker dat hartgespan zich tijdens de negentiende en de eerste decennia van de twintigste eeuw in Zuid-Limburg op ruime schaal heeft kunnen verspreiden op overhoeken. langs wegen en onder hagen in de directe omgeving van menselijke nederzettingen. In het begin van de negentiende eeuw raakte hier echter het medicinale gebruik in vergetelheid; de soort werd sindsdien niet of nau- welijks meer gecultiveerd. Een zaadaanvoer vanuit tuinen naar overhoeken vond niet meer plaats. In halfnatuurilike situaties (op overhoeken en wegbermen) kon de soort zich echter vele decennia handhaven. Vanaf het tweede kwart van deze eeuw verander. de de agrarisch-economische bedrijfsvoering in Zuid-Limburg. De dorpskudden verdwenen, overhoeken werden opgeruimd of op een andere wijze gebruikt dan voorheen. Periodiek open plekken in de vegetatie, die hartgespan nodig heeft om opnieuw uit een aanwezige zaadbank op te slaan, ontstonden niet meer. De soort werd verdrongen door de concurrentiekrachtiger grote brandnetel, die, zoals bekend, zich in de loop van de laatste decennia enorm heeft uitgebreid en momenteel de nog resterende overhoeken en. wegbermen bij nederzettingen volledig en. permanent domineert.

In Zuid-Limburg zal hartgespan op korte termijn uitsterven, tenzij door de mens bewust wordt ingegrepen. Op Europese schaal is het. lot van hartgespan regionaal bepaald (zie figuur (4.7). In het uiterste noorden en westen werd Leonurus nooit gecultiveerd en kwam het evenmin in halfnatuurlijke milieus voor. In het uiterste zuidoosten van Europa komt het van nature voor of heeft zich dusdanig weten aan te passen aan het, milieu van de veedrift, dac zij zich in niets onderscheidt van andere "wilde" soorten die dit miliẹ kenmerken. Tussen de beide uiterste gebieden van Europa ligt een tweetal zones met elk een aparte status voor de indigeniteit en het toekomstig verspreidingspatroon: in Noordwest-Europa zal hartgespan verdwiịnen als gevolg van het in onbruik raken van een teelt om medicinale redenen, als gevolg van het verdvvijnen van de dorpskudden en veranderingen in het milieu van dorpswegbermen. Deze stelling geldt in ieder geval voor Zweden, Nederland en Engeland. Voor delen van Europa die wat meer central liggen (delen van Frankrijk, Belgiē en West-Duitsland), geldt dat (nog?) niet. In Centraal-Europa, met uitzondering van de Alpen, met name in het Pannonische gebied, heeft hartgespan zich een vaste plaats weten te veroveren in antropogene milieus en komt daar zo algemeen voor, dat van een ernstige achteruitgang op dit moment nog geen sprake is.

\section{NOTEN}

1 DoOOEN 1608

2 Westhon 1966, p. 25.

3 Onder andere Dodotns 1608, PAMtow 1980. Theunzova er al. 1984 en Van Os 1988

4 Onder andere Heci 1975, POUniN 1970, Foumate 1961. Heukes en Van dex MeqOen 1994, De LanGHet al 1983.

5 ParLOW 1980

6 VAN OS 1988

7 LeEUNE 1811-1813, BONY DE 5T. VINCENT 1821 . Funguiner 1838 en Dumourn 1868

8 Doooens 1608

9 Hutcias $1985 \mathrm{C}$

10 Tumet al 1972

11 Zie noot 7

12 De Wrven 1918 en De Wever santekeningen, on. gepubliceerd. Aanwexig in het archief van het $\mathrm{Na}$. tuurhistorisch Genootschap te Masstriche.

13 Wuba et al 1985-1991, deel 3. pp. 162-163

14 Westhor et al 1970-1973, deel I. p. 68.

15 Wistrote etal 1970.1973 , deel 1, p. 65 en volgen. de.

16. TumN et al. 1972

17 FOUnNiER 1961 en GUINOCHET IN DE VIMOMIN 1975.

18 GAnckt 1972 en HtGi 1975

19 Soddeutsche Planzengesellachaften 1987

20 SVENSON EN Wichen 198 ?

21 De Lancat et al 1983, DumOuUN 1868, Htor 1975.

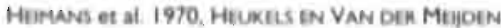
1984, Adas van de Nederiandse flora 1985-1989. ROMPAEY IN DLIVOSALIS 1979, HARUPLIA IN SCHOnfliden 1989, Wuon et al 1985-1991 en Wistrom et al $\{970.197\}$

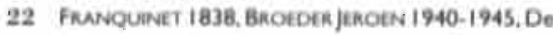
Wever, aantekeningen en manuscripten Pelt, manu. script, beide ongepubliceerd. Aanwezig in het archief van het Natuurhistorisch Genootschap te Mas. tricht. De herbaria van Rieter, De Wever en Gregoire bevinden zich in het Natuurhistorisch Museum te Mastricht

23 Oscoovra in Suddeutsche Planzenguselischaften 1987.

24 RUNGE 1986 en Euenesng 1982

25 GunNOCHET EN DE VIIMONON 1975

26 WESTMOFF EN DEN HELD 1975 



\title{
DE ROL VAN HET MERGELLANDSCHAAP IN HET NATUURBEHEER
}

\author{
"De sjöp wjèrt bie 't köt."
}

(De herdersschop behoor bij de kudde);

uitspraak van de laatste traditionele Zuidlimburgse herder Sjang Brouwers. gedaan te Honthem in 1974 bij het overhandigen van zijn herdersschopje aan de schrijver.

1 De titel van dit boek "Heerdgang in Zuidelijk Limburg" draagt als ondertitel "Een vorm van extensieve beweiding in verleden, heden en toekomst". In het eerste deel, bestaande uit de hoofdstukken I tot en met 8. is het verleden van de extensieve beweiding toegelicht aan de hand van toponiemen die. wat hun oorspronkelijke en functionele betckenis betreft, aantonen dat in het verleden de beweiding door vee in kuddeverband een grote rol heeft gespeeld in de historische ontwikkeling van het Zuidlimburgse cultuurlandschap.

Het tweede deel van dit boek, de hoofdstukken 9 toten met 14 , heeft als thema "de wording van het heden" van het Zuidlimburgse landschap. Het zijn oecologische visies op delen van het huidige landschap of levende onderdelen daarvan. De factor "extensieve beweiding" vormt de rode draad binnen deze hoofdstukken.

Het derde deel van dit boek, dat volgens de ondertitel de "toekomst" tot onderwerp heeft, bestaat slechts uit één hoofdstuk. Daarin wordt vanuit de oecologie een toekomstperspectief geschetst van de rol, die de extensieve veehouderij in hẹt steeds dichter bevolkc rakende Noordwest-Europa, en dus ook in Zuid-Limburg, zal gaan spelen. In de aanstaande verschuiving van intensief naar extensief beheer van graslanden past de recente ontwikkeling van een lokaal voorkomend heideschapenras, dat vanaf 1978 in toenemende mate door natuurterrein beherende instanties werd en wordt ingezet om hun terreinen op een extensieve wijze te beheren. Dit heideras, waarover in dit hoofdstuk nadere informatie wordt verstrekt, staat momenteel bekend onder de naam mergellandschaap. Vervolgens wordt summier aangeduid, waaraan het succes van de extensieve wijze van beheer door middel van mergellandschapen te danken is. Tenslotte wordt de hoop en de stellige verwachting uitgesproken, dat extensieve beweiding door mergellandschapen in kuddeverband een positieve bijdrage levert aan het herstel van natuurwaarden in Zuid-Limburg.

2 In de meeste delen van het geindustrialiseerde en dichtbevolkte NoordwestEuropa heeft de economische groei van de bio-industrie en de daarvan deel uitmakende intensieve veehouderij haar grenzen bereikt.' Met name in Nederland wordt door de overheid in toenemende mate getrache de groei van de "boterberg" en de "melkplas" af te remmen. Tegelijkertijd worden door deze maatregelen de indirecte gevolgen van de overproduktie verminderd, die voornamelijk betrekking hebben op de achteruitgang van de kwaliteit van het milieu. Tot die serie maatregelen behoren het vaststellen van de zogenaamde melk- en mestquota, het verbod tot mestimport, braakligpremies, bergboerregelingen, ooipremies, subsidies voor het handhaven van onder andere hagen en poelen en vele andere.

De: omvorming van marginale landbouw. gronden tot natuurgebieden, het uitbreiden van bescaande natuurreservaten in het kader van herinrichtingen van het landschap of het niet meer in agrarisch gebruik nemen van gronden met een voormalig industrieel karakter; zoals bijvoorbeeld uitgebate mergelgroeven, of grindgaten bestemmen tot natuurgebied, behoort eveneens tot hetzelfde pakket van bovengenoemde maatregelen. Om de versnelde toename van het aanwezige of te ontwikkelen natuurgebied toch goed te kunnen beheren, hebben de diverse natuurterrein beherende instanties, deels op grond van wetenschappelijk onderzoek. deels ook gedwongen door personeelsgebrek of ontoereikende financièle middelen, een methode "van stal gehaald" om hun ter- reinen adequaat te beheren. Deze "nieuwe" vorm van beheer staat bekend als extensieve begrazing door grote herbivoren."

Ook binnen het gebied van onderzoek heef zich de hierboven geschetste ontwikkeling voorgedaan; in nauwelijks 30 jaar veranderde hier een agrarische bedrijfsvoering, bestaande uit veel, vaak kleine of middelgrote bedrijven met een gemengd karakter en de nadruk op de verbouw van granen, in een grootschalige bio-industrie met de nadruk op intensieve veehouderij dcior een beperkt aantal kapitaalintensieve bedrijven. ${ }^{3}$ De negatieve gevolgen van deze veranderingen ten aanzien van het milieu bleven niet uit. Bodemerosie, "schaalvergroting, stankoverlast, verontreiniging van her oppervlaktewater, daling van de grondwaterspiegel ${ }^{5}$ en grandwaterverontreiniging rnet zorgwekkende gevolgen, voor het drinkwater, ${ }^{\prime}$ alarmerende afname van het aantal soorten van de wilde flora ${ }^{i}$ en fauna zijn verschijnselen gewrorden, waar ook de doorsnee burger mee te maken heeft. Zelifs in bestaande natuurreservaten doet zich de invloed van de omringende bio-industrie gelden in de vorm van mestinspoeling., zure regen" en onttrekking van grondwater, waardoor de divẹrșiteit vạn de flora en fauna zelfs in bestaande reservaten in ernstige mate achteruit is gegaan.

Sinds het einde van de jaren zeventig deden zich echter ook enige positieve effecten ten aanzien van het milieu in het onderzoeksgebied voor. Bestaande natuurreservaten werden uitgebreid, met bufferzones, uitloopgebieden of andere delen van het cultuurlandschap, die op deze wijze werden onttrokken aan bio-industrieel gebruik. Tevens werden diverșe nieuwe natuurgebieden aangewezen. Geplande ruilverkavelingen werden, met name in het relatief kleinschalige Zuidlimburgse cultuurlandschap, uitgesteld of zodanig van opzet veranderd dat de term "ruilver- 


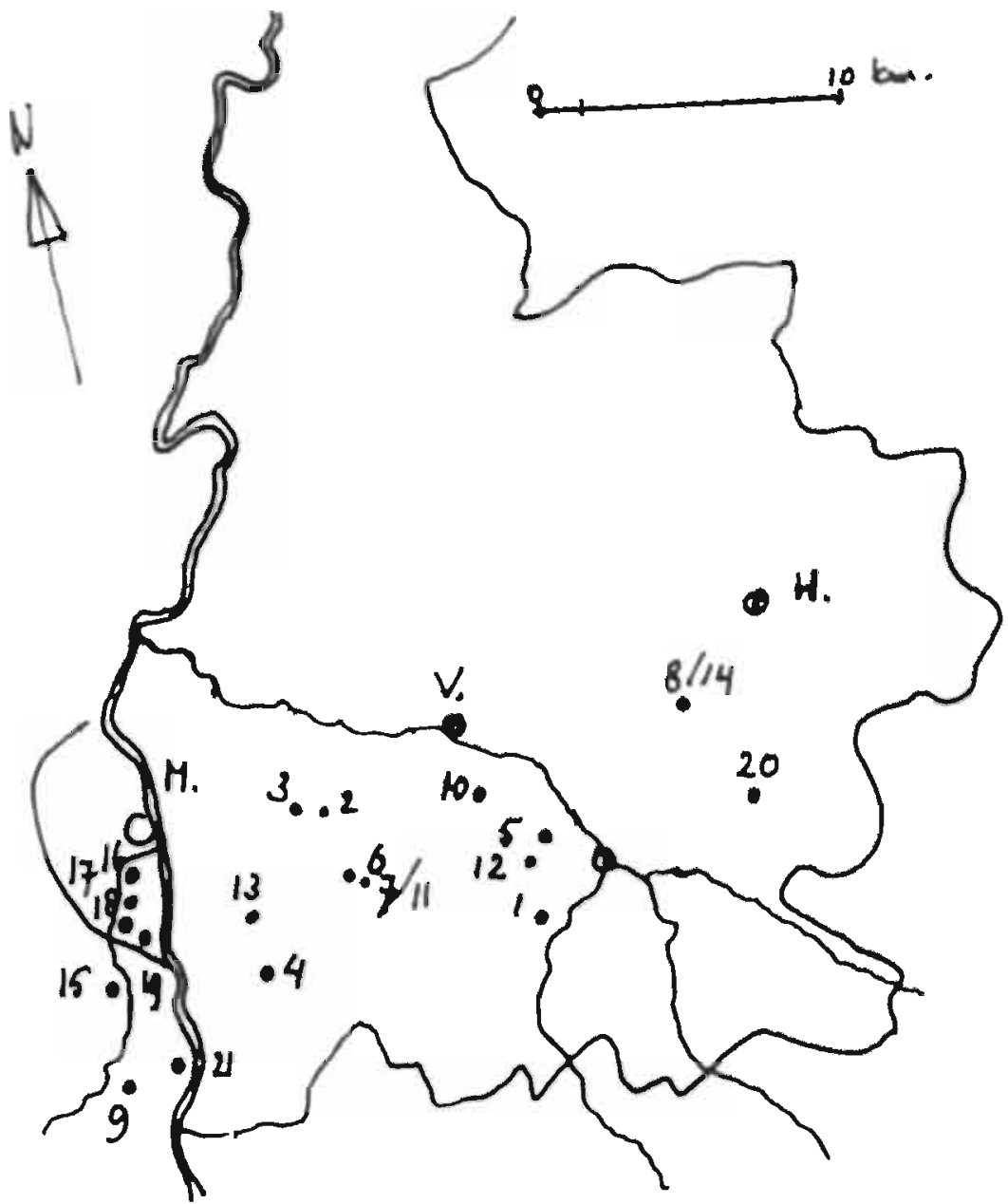

FGUUR 15.1. Kaort van het onderzoelksgebied met daorop aongegeven de ligging van notururgebieden, die door middel von een extensieve bewriding met mergeliandschapen worden beheerd.

De betekenis vain de cijfers is ols volgr: 1. Vosgrubbe, 2 . Hoefijxer, 3. Bemelerberg 4. Zure Dries, 5. Dikkensweide, 6. Juilanagroeve, 1. Kooberz, deel $a, 8$. Kunderberg, deel van de Stichting Het Limburss Landschop, 9. Lova, I0. Gerendal, 11. Kooberg, deel b, 12. Berghofweide, 13. Rieseber: 14. Kunderberg, deel van het Stoatsbosbeheer, 15. Tiendeberg, 16. Westhelling van de Sint-Pietersberg, 17. Kannerheide, 18. Poppelmondedal, 19. Akkers blj Poppelmondedal, 20. Klingeleberg 21. Thier de Lanaye.

kaveling" werd gewijzigd in "herinrichting"' 10 Eén van de belangrijkste positieve factoren in het natuurbeheer tijdens, die periode bestond uit de herintroductie van extensieve beweiding, voornamelijk met behulp van mergellandschapen, in 1978.

3. Extensieve beweiding in natuurreservaten heeft zich vooral in de zones rond urbane gebieden sterk ontwikkeld sinds 1980 (zie figuur I5.1). Rond Maastricht bestaat er al vanaf 1979 een kudde bij Bemelen, die de natuurreservaten "De Bemelerberg" en het "Hoefijzer" beweidt. Een kleinere groep schapen begraast delen van de "Schiepersberg", gelegen tussen Bemelen en Cadier en Keer. Ten zuidwesten van de stad Maastricht zal in de nabije toekomst een grote kudde de hellingen en het plateau van de Sint-Pietersberg gaan beheren. Ook op het Belgisch dee! van de Sint-Pietersberg worden sinds 1987 mergellandschapen ingezet bị het beheer van natuurreservaten. In het dal van de Maas ten zuiden van de stad Maastricht wordt extensieve beweiding sinds 1990 toegepast, maar in dit geval wordt rundvee ingeschakeld. Rond de stad Heerien liggen de natuurgebieden de "Brunssummerheide" en de "Kunder. berg": beide droge schraallanden worden extensief door schapen beweid. Ten oosten van Roermond ligt het grote natuurgebied de "Meinweg", een grensoverschrijdend landschapspark "in oprichting", waarvan het beheer voornamelijk uit een extensieve begra. zing zal gaan bestaan. Ten zuiden van Roermond, aan de Maas, begrazen paarden en runderen op extensieve wijze het in 1990 opgerichte natuurreservaat. "Koningssteen"". Verspreid binnen het zuidelijk gedeelte van de Nederlandse provincie Limburg ligt voorts nog een aantal reservaten, waar extensieve beweiding wordt toegepast het natuurgebied "Gerendal" te Strucht; de "Klingeleberg" bii Simpelveld, de "Rieseberg" en de "Zure Dries" bij Gronsveld, de "Berghofweide" en de "Wijlre-akkers" te Stokkem en de "Vosgrubbe" bij Reijmerstok. Dit zijn droge schraallandreservaten die door mergellandschapen worden begraasd, terwijl de natte graslandreservaten in het beekdal langs de Geull bij Epen en Mechelen en langs de Noor bij Noorbeek extensief door rundvee worden beweid.

3.2 Tenslotte moet ten aanzien van de groei van de extensieve beweiding als methode van beheer in natuurreservaten binnen het gebied van onderzoek nog worden opgemerkt, dat een groot gebied, gelegen tussen Geul en Gulp, op de nominatie staat om op deze wijze te worden beheerd. Een grote kudde mergellandschapen, waarvan de huisvesting ergens op het plateau van Landsrade is gesitueerd; zal voor het beheer van dit gebiedzorgdragen. "In alle hierboven genoemde gebieden wordt extensieve beweiding toegepast op grazig kruidige vegetaties binnen rasters. Maar ook niet-ingerasterde graslanden en andere grazig kruidige vegetatietypen zouden in de toekomst extenșief kunnen worden beweid. Dat gelde voor bossen. struwelen, ruige wegbermen en de begroeiingen van brakliggende akkers en voormali. ge vestingwerken die ook in het verleden door schaapskudden werden bezocht. Ten aanzien van deze vegetaties wordt om diverse redenen een extensieve begrazing overwogen en is reeds op kleine schaa! geëxperimenteerd, onder andere in het Oombos bij Strucht, ${ }^{12}$ de vestingwerken "Hoge Fronten" bị Maastricht ${ }^{13}$ en op voormalige graanakkers en veldwegen van de Sint-Pietersberg. Het zal duidelijk zijn dat in deze gevalien waar een raster ontbreekt, een herder onontbeerlijk zal zijn.

De snelheid en omvang waarmee extensieve beweiding als methode van beheer in natuurreservaten is toegenomen sinds 1980, komt in figuur 15.2 duidelijk naar voren.

Figuur 15.3 laat de groeicurve zien van het aantal geregistreerde mergellandschapen sinds de oprichting van het stamboek in 1979. Hoewel niet alle dieren van dit ras zijn of worden ingezet om schrale graslanden te 


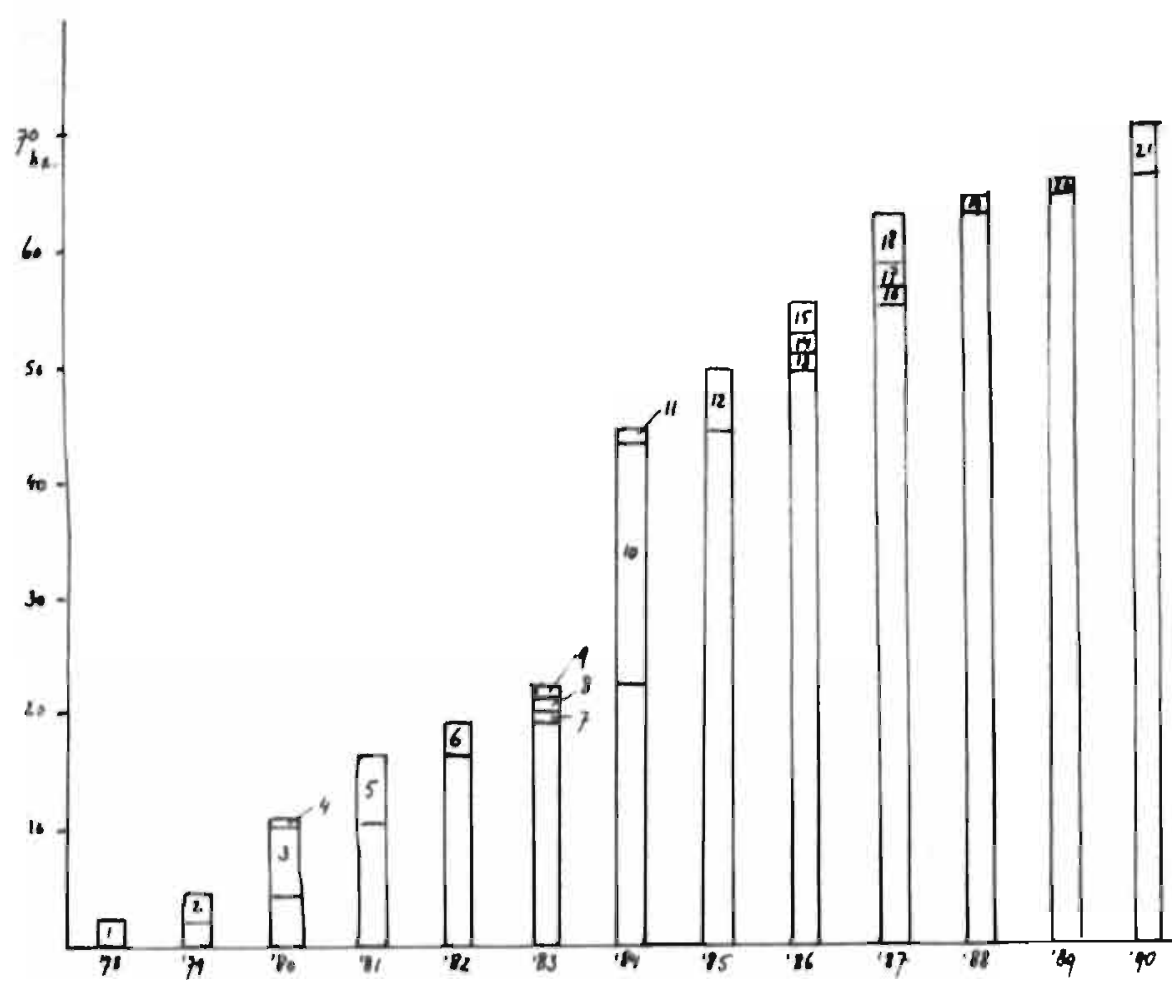

FIGUUR 15.2. De toenome van extensieve beweiding doar mergellandschopen in het natuurbeheer in Zuid-Limburg, sinds 1978. Begonnen in de winter van 1978-1979 met een gebled van 3 ha is het oppervlak door mergellandschapen beweld gebled in 1990 uitgegroeid tot ruim 70 ho. De betekenis van de cijfer I $\mathrm{t} / \mathrm{m}$ X komt overeen meî de in figuur 15.1 genoemde natuurreservoten.

beheren, wordt toch op grote schaal door natuurterrein beherende instanties gebruikgemaakt van dit sobere heideschaperas.

Van zeer recente datum stammen experimenten met andere grote grazers dan schapen. Zowel het aantal reservaten dat door rundvee of paarden op een extensieve wijze wordt begraasd als, hun omvang is nog beperkt. maar dit zal in de toekomst zeker worden uitgebreid.

4.1 In deze paragraaf zal de lezer op cen beknopte wijze kennismaken met het ras, dat gedurende vele eeuwen in Zuid-Limburg ingeschakeld is geweest in het landschapsbeheer en waarvan de diensten als zodanig sinds kort, na een onderbreking van enige decennia, opnieuw erkenning hebben gevonden. Achtereenvolgens worden gegevens verstrekt omtrent de naam van het ras en de plaats ervan binnen de huidige Nederlandse schaperassen, de chronologie van de fokkerij, de functies van de kudde in de agro-pastorale bedrijfswoering rond het begin van deze eeuw en de huidige functies in het landschapsbeheer.

Twee dialectsynoniemen voor het huidige mergellandschaap, vanaf 1975 onder die naam bekend, te weten "heisjäöp." (letterlijk: heideschapen) of "kötsjäöp" (letterlijk: kud- deschapen), geven meer informatie over de taxonomische en functionele betekenis van het ras dan de term mergellandschaap, die uitsluitend betrekking heeft op de geografische verspreiding. Overigens is de laatste aanduiding in zoverre onjuist, dat het ras vroeger een ruimere verspreiding kende, dan het gebied waar "mergel". dat wil zeggen kalksteen, aan de oppervlakte komt. ${ }^{\text {" }}$

De term "heisjaop" sluit aan bij de in Nederland gebruikelijke indeling in "heiderassen" en "weiderassen". Er bestaan binnen ons land vijf heideschaperassen: Drentse, Veluwse. Kempische heideschapen en voorts schonebekers en mergellanders. ${ }^{13}$ In hun exterieur vertonen ze veel morfologische, fysiologische, ethologische en andere overeenkomsten. ${ }^{16}$ Mergellandschapen zijn middelgrote. taaie dieren met een goed ontwikkeld loopwerk, in staat vele kilometers, per dag af te leggen en zich op moeilijk begaanbaar terrein goed te bewegen. Ze werden in kudden gehouden. Vandaar de naam "kötsjäop" in Zuid-Limburg.

4.2 De typebeschrijving van het ras werd gebaseerd op de informatie van Sjang Brouwers (zie figuur 15.4), de laatste traditionele schaapherder in Zuid-Limburg, wiens ervaringen met en herinneringen aan zijn

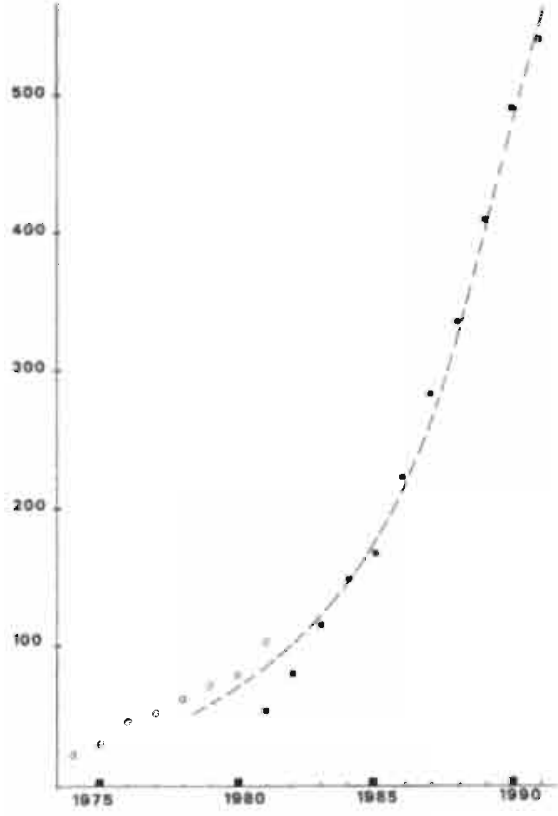

FIGUUR 15.3. De toename van het aantal mergellandschopen sinds 1974 naar gegevens van de Vereniging "Oos Mergellandsjaop". De snelle toename is vooral te danken aon hun kwaliteiten als "restcurateurs" van droge schraallanden. In de toekomst zou dit ros eveneens kunnen worden gebruike in het beheer van wegbermen, groenstroken, golfbanen en braakliggende bouwgranden.

kudde op schrift zijn gesteld. ${ }^{17}$ Daarnaast werd de typebeschrijving getoetst aan de hand van enige tientallen oude foto's van schaapskudden die tijdens het onderzoek werden verzameld ${ }^{12}$ (vergelijk tabel 10). Hoewel mergellandschapen in veel opzichten duidelijk zijn verwant aan de overige in Nederland voorkomende heiderassen en daarmee veel exterieur eigenschappen delen, zij̣n er toch duideliike verschillen aan te wijzen, waardoor ook leken in staat zijn dit ras te onderscheiden van andere schaperassen in Nederland. ${ }^{19}$ Ook wat betreft hun "interieur" zijn er verschillen; een onderzoek naar bloedgroepen die binnen de Nederlandse schaperassen voorkomen, toonde zowel verschillen als overeenkomsten aan. Op grond van dit onderzoek werd een verwantschapsdendrogram opgesteld, dat een indruk geeft van de mate van verwantschap tussen de in Nederland voorkomende schaperas$\operatorname{sen}^{20}$ (zie figuur 15.5).

Gezien het beperkt aantal mergellandschapen binnen Nederland, geldt het ras als een "Zeldzaam Huisdier" (zie figuur 15.6) en wordt het door de geliịnamige stichting als zodanig erkend. ${ }^{21}$

Rond 1970 was het aantal mergellandschapen zeer beperkt; een kleine groep van ongeveer 20 dieren verbleef in het natuurreser- 
vat Gerendal; enkele tientallen exemplaren, veelal met Texels bloed ingekruist, kwamen als "huisschapen" bij boeren in westelijlk Zuid-Limburg voor, en verder werden door de fokkers van het Kempische heideschaap in Heeze-Leende dieren afgestoten, die als niet typisch Kempisch werden beschouwd. Uit deze heterogene groepen zocht de oudscheper Sjang Brouwers exemplaren uit, die het meest beantwoordden aan de door hem opgestelde typebeschrijving. Deze fokgroep, aangevuld in 1976 met het restant van de kudde in het Gerendal, vormde het basismateriaal van het ras. In 1979 werd de vereniging "Oos Mergellandsjaop" opgericht, die zich blijkens haar statuten onder andere tot doel stelde het ras voor de toekomst te behouden en te streven naar eén of meer kudden in het Mergelland. In dat jaar telde de vereniging 30 leden: tien jaar later was dit aantal meer dan verdubbeld. Het bestuur van de vereniging draagt de zorg van de fok over aan een fok-technische commissie, die het stamboek bijhoudt en de gegevens digitaal verwerkt. Jaarlijks wordt onder andere een rammendag georganiseerd, waarop de aangeboden rammen worden gekeurd en beoordeeld. De keurcommissie van de vereniging beslist welke rammen in aanmerking komen als fokdieren.

In de agro-pastorale bedrijfsvoering van de Zuidlimburgse nederzettingen tijdens de vorige eeuw werden de schaapskudden primair gehouden omwille van de mest, die vermengd met stro in de potstal werd opgespaard en twee keer per jaar werd geleegd. ${ }^{22}$ De opbrengst aan vlees, huiden of wol was minder belangrijk dan de mestproduktie. De door de kudde benutte weidegronden lagen verspreid in vrijwel alle delen van het iandschap binnen een gemeente. De scheper betaalde voor de "heuj" (letterlijk: hoede) een geringe pacht aan de gemeente voor die delen, die het eigendom waren van de gemeente, zoals wegbermen, bossen en heiden. Voor particuliere gronden, onder andere stoppelbeweiding op graanakkers, overhoeken en boomgaarden gedurende de winter, was alleen de toestemming nodig van de eigenaar. Formeel kon de eigenaar weigeren om de kudde op zijn perceel toe te laten, hetgeen gebeurde door het plaatsen van de "vriewösị"., maar ưit eigenbelang werd de toegang van de kudde tot het betreffende perceel zelden geweigerd ${ }^{23}$ (zie figuur 15,4).

De jaarcyclus van beweiding werd voornamelijk bepaald door de seizoengebonden kwaliteit en kwantiteit van het voedsel in de

AGUUR is.4.

Sjang Brouwers (190)-

1979 , de lastste

troditionele scheper in

het Mergelland. Foto

van P. van Nieuwen-

hoven. De ervaringen

en herinneringen van

dere oude scheper

hebben een belangrily

ke rol gespeeld bij de

terugfok van

mergellanduchopen.

Hier plant hil een

"vriewdil", een oeroud teken dat de herder de toegang tot het betreffende perceel verbood.

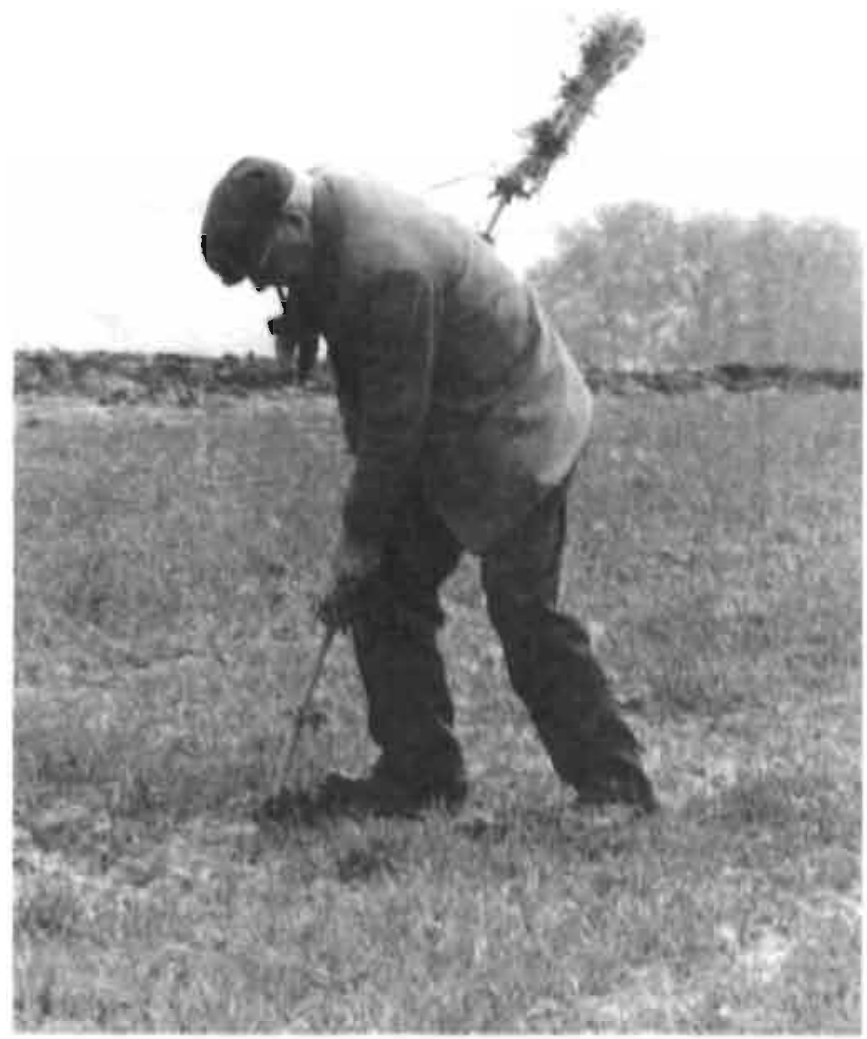

verschillende delen van het nederzettingsterritorium. $\mathrm{Bij}$ strenge vorst of veel sneeuw bleef de kudde opgestald. Ze werd bijgevoerd met roggestro of ander voedsel van inferieure kwaliteit. Tijdens het vroege voorjaar werden vooral holle wegen en wegbermen begraasd, omdat hier de vegetatie al vroeg in het. jaar uitloopt. Pas in mei werden kalkgraslanden en andere dioge schraallandtypen, die in eigendom waren van de gemeente, bezocht. Vlak na de oogst van het wintergraan in de maand juli verscheen de kudde op de uitgestrekte stoppelvelden en kon de vegetatie op de gemeenteheide voor de tweede keer in bloei komen. Laat in de herfst en gedurende de hele winter, wanneer het akkerareaal weer in gebruik was genomen, verscheen de kudde weer op de gemeenteheide. in de bossen en op andere plaatsen waar nogvoedsel voor de kudde te vinden was (zie figuur 15.7).

Hoewel er binnen het agro-pastorale bedriff van toen geen sprake was van doelbewust natuurbeheer, heeft deze wijze van beheer
FGUUR 15.5. De mate ven yerwantschop tusien do in Nederlond inheemse schoperassen naar Burs 1982 . De gegevens hebben slechts betrekking op de relotieve verwantschap tussen xeven zeldxame Nederlandse schaperas. sen. Beide in Drenthe vooritomende rassen, het Drents heideschoap $(\mathrm{DH})$ en de Schoonebe-

ker (SB), vertonen onderling weinig genetische verschillen (dot wil xezgen hun verwantschapi is hoog). Datzelfde gegeven geldt voor de in Midden-Nederland voorkomende Veluwse (VH) en Kempische (KIH) heideschapen. Ondanka het feit dat mergellandschapen (ML) een duidelijke bloedverwantschop vertonen met de overige heiderassen, nemen zij een oparte plaots in tussen de in Nederland voorkomende heiderossen die in kuddeverbond worden gehouden. Het Zwortblesschoop (ZBB) en het Friese melkschaop (FM) xijn nouw verwant en werden niet in kudden gehouden.

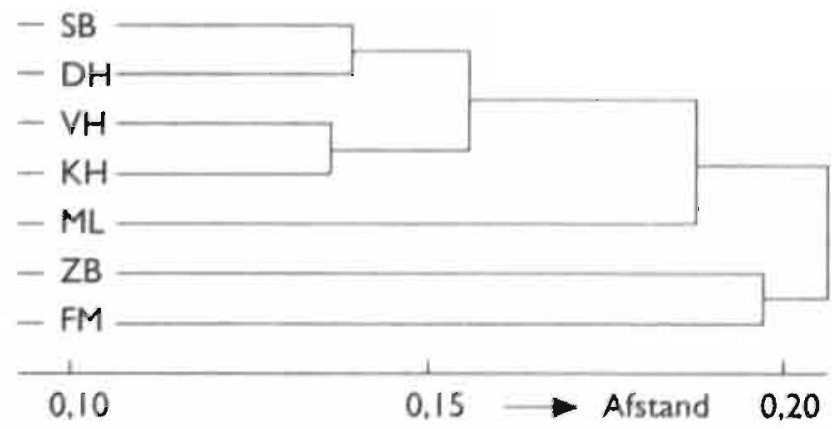




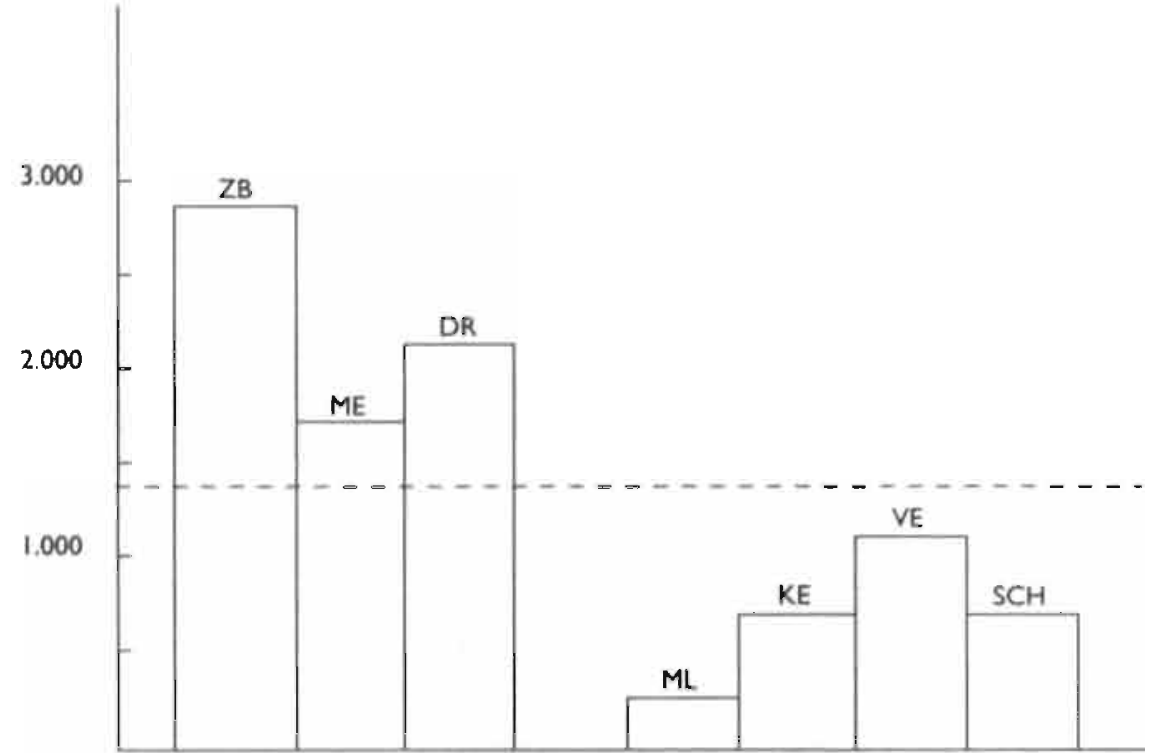

FIGUUR 15.6. De xeldxaamheidsgraad van enige Nederlandse hulsdieren noor ANONYMUS 1990. Het mergellanduchaap (ML.) is het meert bedreigde Nederlandse schoperas. De overige lettercombinaties betekenen: ZB: Zwartbles, AE: melkschaop, DH: Drents heideschaop, KH: Kempisch heideschoop, VH: Veluws heideschoap en SCH: Schoonebeker. De gestippelde IIIn geeft de bovengrens aan van de gevorenxone, dot will zeggen blj cen aantal dieren boven de lijn is hat gavoar von inteelt te verwoartoxen.

een zeer posicieve invloed gehad op het ontstaan en continueren van soortenrijke en stabiele biotopen.

4.3 Denieuwe beweidingsvormen, die zich variaf de jaren tachtig binnen Zuid-Lim. burg voordoen, hebben echter wel tot doel het beheer van droge schraallanden dusdanig te optimaliseren, dat dezelfde soortenrijke en stabiele biotopen van toen worden hersteld. Het is dan ook duidelijk dat dit op dezelfde wijze als destijds moet plaatsvinden: het huidige natuurbeheer in deze biotopen moet zo veel mogelijk op het traditionele beheer aansluiten. ${ }^{24}$

In principe kan een tweetal wijzen van extensief beweidingsbeheer worden uitgevoerd: een wijze die geheel gelijk is aan de traditioneie, dat wil zeggen met vaste scheper en een vaste kudde, die op dezelfde tijden en plaatsen binnen een gemeente zijn kudde laat weiden. De tweede wijze bestaat uit een beweiding binnen een raster, dus zonder herder, die echter plaats vindt onder dezelfde omstandigheden als destijds, dat wil zeggen met een begrazing van het schraalland tijdens de voorzomer en de late hertst. Gedurende de rest van het jaar moet de kudde naar an= dere weidegronden worden verplaacst. Dit gebeurt in zogenaamde parkeergraslanden. Dit systeem wordt op dit moment in vrijwel alle Zuidlimburgse droge schraallanden, voor zover zij de status van natuurreservaat hebben, toegepast.

De meest ideale vorm van extensieve beweiding, zeker yanuit de visie van de natuurbeheerder, is echter die met een kudde onder leiding van een herder, die elke dag vanuit een schaapskooi vertrekt. Een trekkende kudde met een potstal effectueert niet alleen een optimale yerschraling van het te beweiden gebied, maar ook een verschralingsgradiēnt. die ontstaat tussen de weidegebieden en de potstal in de nederzetting. Tevens zijn de kansen die een zich frequent verplaatsende schaapskudde oplevert voor de verspreiding van talrijke plantesoorten vele malen groter dan bij een ingerasterde kudde. ${ }^{25}$ Daarbij komt dat de bermen van wegen, braakliggen. de akkers, bossen en overhoeken en andere grazig kruidige begroeiingen kunnen worden meegenomen in een beweidingsschema. Dergelijke biotopen zouden anders niet beheerd danwel slecht worden beheerd. Het is duidelijk dat bị deze wijze van beheer de isolatie van de schraallandreservaten wordt doorbroken.

Er zijn nog meer voordelen verbonden aan een scheper met kudde; de toeristische attractie van een schaapskudde met scheper en honden is bekend, maar ook is de veterinaire zorg en de algemene veiligheid van de kudde beter gegarandeerd met een herder dan bij een groepschapen binnen een omheining.
Anno 1990 zijn er drie kudden met herders in het gebied van onderzoek en wel op de Brunssummerheide, langs het Julianakanaal en op de Sint-Pietersberg. De grote kudde zonder een vaste herder en in eigendom van net Staatsbosbeheer in het Gerendai, die yoor de beweiding van schrale graslanden in het Gerendal en op de daarvan op ongeveer 20 kilometer gelegen Kunderberg zorg draagt, z.ou beter in twee afzonderlijke kudden kunnen worden opgesplitst. In het droogdal Bemelen-Margraten, waar momenteel twee kleine groepen schapen binnen rasters, voorkomen, zou een samenvoeging daarvan tot een trekkende kudde het beheer optimaliseren.

Op de nominatie voor een scheper met kudde staat het plateau van Landsrade; hier liggen uitgestrekte schrale graslanden, die in het kader van de herinrichting "Mergelland Oost" toi natuurreservat zịn verklaard en het eigendom zijn van natuurterrein beherende instanties.

5. I In deze paragraaf wordt een overzicht gegeven van effecten, die door extensieve beweiding met mergellandschapen worden veroorzaakt op verschillende kwan. tificeerbare aspecten van de vegetatie van een aantal biotopen. Het overzicht geefr de belangrijkste resultaten weer van eerder on. derzoek naar de veranderingen in de structuur, soortensamenstelling en andere eigenschappen van de vegetaties in graslanden; bossen en graanakkers onder de invloed van externsieve beweiding. Tevens worden enige diergroepen besproken, die door deze vorm van beheer voordelen ondervinden.

Zelfs in de ogen van een leek vallen de veranderingen in de structuur van een graslandvegetatie het meest op; een homogene, de bodern geheel bedekkende grasmat verandert na de beweiding in een mozaiekpatroon van kort begraasde delen, die elkaar afwisselen met ruigere plekken en via paadjes met elkaar worden verbonden. De structuurvariatie neemt toe zowel op het horizontale viak als in verticale richting. ${ }^{26}$

Structuuronderzoek op beweide en niet-beweide graslanden heeft verder vitgewezen. dat in de natuurlijke, ongestoorde successie een aantal stadia te onderscheiden is, waarvan de richting van verandering door beweiding wordt omgekeerd. ${ }^{27}$ Op deze wijze kan door middel van beweiding een bepaald stadium van de successie worden gefixeerd (zie figuur 15.8).

Een belangrijke maatstaf voor de kwaliteit 
van een natuurgebied is de floristische diversitert; biị herhaling zijn zowel op diverse plaatsen in Nederland als daarbuiten experimenten gedaan om na te gaan, welke methode van beheer de soortdiversiteit het meest gunstig beinvloedt. Wanneer het droge, grazig kruidige vegetaties betreft, geeft extensieve beweiding de garantie voor de hoogste soortdiversiteit boven andere beheertechnieken. zoals maaien, branden en nietsdoen. ${ }^{2 \mathrm{H}}$

Voor de binnen het onderzoeksgebied voorkomende droge schraallanden geldt het historisch argument, dat hier uitsluitend extensieve beweiding plaats vond des te meer; branden of maaien zijn als traditionele wijzen van beheer binnen Zuid-Limburg in het verleden niet of nauwelijks toegepast. Dit in tegenstelling tot de heidevelden op de zandgronden buiten het gebied van onderzoek.

5.2. Van wezenliik belang is tevens het onderzoek naar de hoedanigheid van de zich veranderende vegetatie onder invioed van een extensieve beweiding. Pas wanneer soorten die kenmerkend zijn voor droge schraallanden in aantal en areaal toenemen of zelfs opnieuw verschijnen en evențeel soorten die niet karakteristiek zijn afnemen en verdwijnen, kan men spreken van een geslaagde restauratie van het biotoop. ${ }^{29}$ Een voorwaarde om zulks vast te stellen, is wel dat de oorspronkeliịke samenstelling van de vegetatie bekend moet zijn.

Dank zij her vele en gedecailleerde onderzoek met een yoornamelijk beschrijvend karakter, dat zich over een periode van bijna twee eeuwen uitstrekt ${ }^{30}$ en dat in de laatste jaren werd aangevuld met experimenteel onderzoek, "zijn ook de mechanismen ontdekt van het herstel van droge schraallanden. Sleutelbegrippen in dit verband zijn: begrazingsresistentie, selectieve vraat, zoöchoor transport en milieudifferentiatie op kleine schaal, veroorzaakt door het grazende dier. Ten aanzien van de geslaagde faunisțische restauratie van de droge schraallanden heerst minder zekerheid, ${ }^{32}$ De achtergrond van dit gebrek aan kennis is onder andere hierin gelegen, dat de betreffende gebieden in het verleden niet of nauwelijks zijn onderzocht; een faunistisch overzicht per gebied ontbreekt of is zeer onvolledig. Daarnaast geldt dat veel diersoorten, met name vogels, zoogdieren en tot op zekere hoogte ook vlinders, een groter biotoop benutten dan het schraallandreservat hen biedt.

Het, overigens in omvang beperkte, onderzoek naar het voorkomen van soorten die-

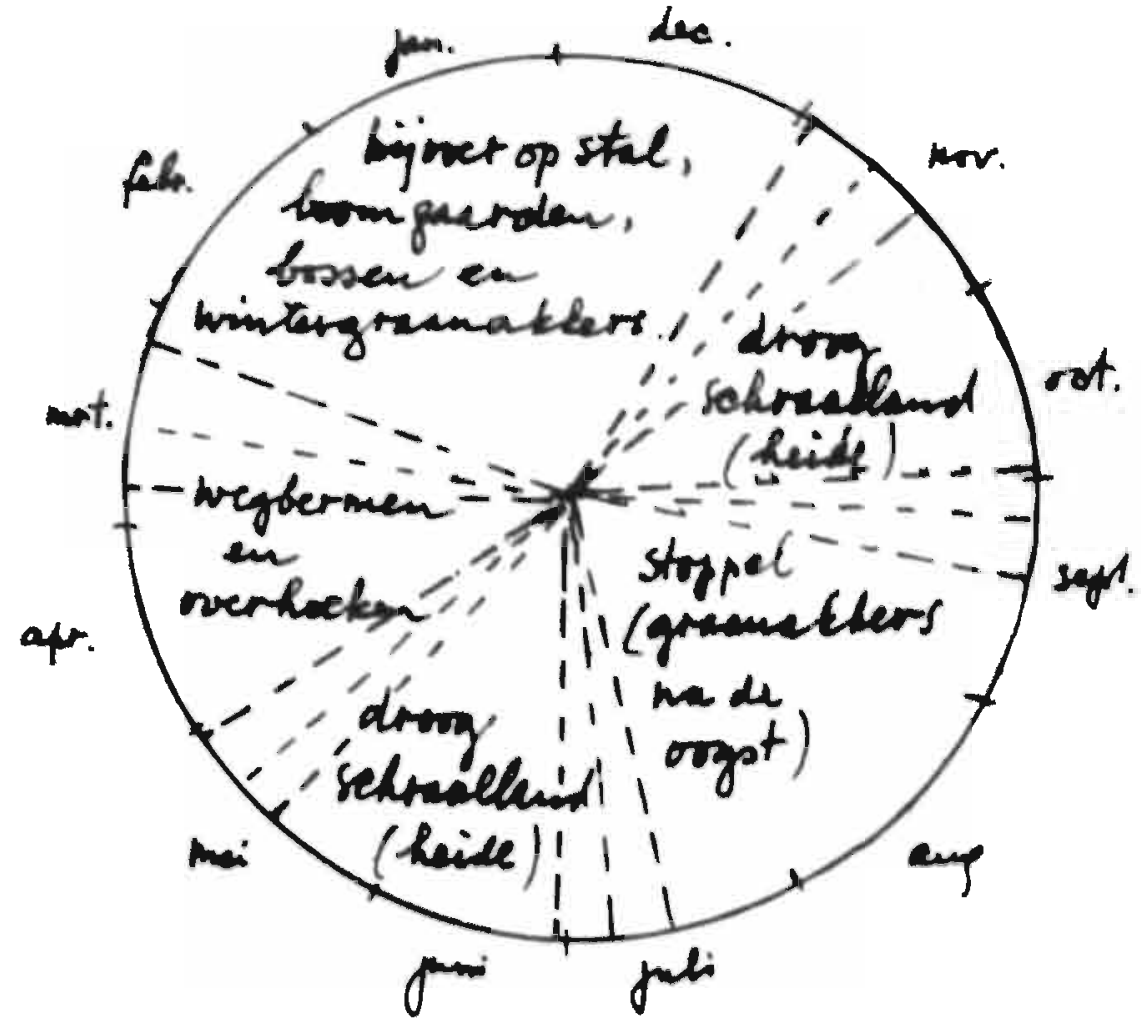

FICUUR 15.7. Jaorcyclua van de "heuj", det wil recren gronden die doer de traditionele scheper mochten worden beweid. Het is binnen het kader van het neturibeheer belangrijk te weten dot de vegetotie van droge schraallanden niet permanent werd beweid. In de voorzomer in naxomer bexocht de kudde respectievelijk de wagbermen en de rtoppelakkerz. In de winterperiode werd de kudde bij slecht weer op stal gevoerd on werden bossen en wintergraanakkers bezocht. Op het droge schradiland is el dus sprake van een voorzomer- th een naxomerrust voor de segetatie, die In dexe periode tot bloel en xaodzetting kon komen.

ren uit diverse systematische groepen op de Bemelerberg, ${ }^{33}$ heeft echter geleerd dat het schraalland ook in faunistisch opzicht zeer soortenriị $k$ is en dat de extensieve beweiding met mergellandschapen voor veel soortengroepen, onder andere voor mieren, sprinkhanen en hun verwanten, mestkevers, thermofiele loopkevers, bepaalde soorten vlinders en slakken waarschijnlijk gunstige levensmogelijkheden biedt of althans niet schadelijk is.

Tevens staat vast, dat de voor de schapen aangelegde drinkpoelen de diversiteit aan dierenleven binnen het reservaat aanzienlijk hebben vergroot. Dit geldt met name voor amfibieèn en libellen.

De veranderingen in andere vegetatietypen dan droge schraallanden, zoals bossen, wegbermen en braakliggende akkers ten gevolge yan extensieve beweiding, zijn minder uitvoerig bestudeerd. Een experiment van bosbegrazing in het Gerendal was dusdanig positief, dat bosbegrazing gedurende de winterperiode wordt voorgesteld als een aanvullende methode om de zogenaamde hakhoutflo- ra uit te breiden, ${ }^{34}$ in elk geval behoorde bosbegrazing door schapen in de winterperiode tot het traditionele beheer van bossen.

Een grote toekomst voor wegbeimbegrazing ligtnog open. Het huidige beheer daarvan laat te wẹnsen over, maar begrazing van wegbermen zoals vroeger, kan ook nu uitsluitend via een kudde onder leiding van een herder plaatsvinden. Bovendien is zulks slechts mogelijk in gebieden met een lage verkeersintersiteit. Vooriopig kan aan wegbermbegrazing geen onderzoek worden besteed, maar dit staat wel op het programma yoor de Sint-Pietersberg en het plateau van Landsrade.

Vegetatieveranderingen op braakliggende akkers, die op een zeer extensieve wijze door mergellandschapen worden beweid, leveren spectaculaire resultaten op. De Wijilre-akkers, voormalige graanakkers op een kalkrijke bodem, nu het eigendom van Staatsbosbeheer, ontwikkelden zich in korte tijd tot zeer soortenrijke graslanden, met name rijk aan orchideeèn. ${ }^{35}$. Op een voormalige akker op de Kruisberg bij Wahlwiller verscheen na een jaar al een complete vegetatie, die karak- 


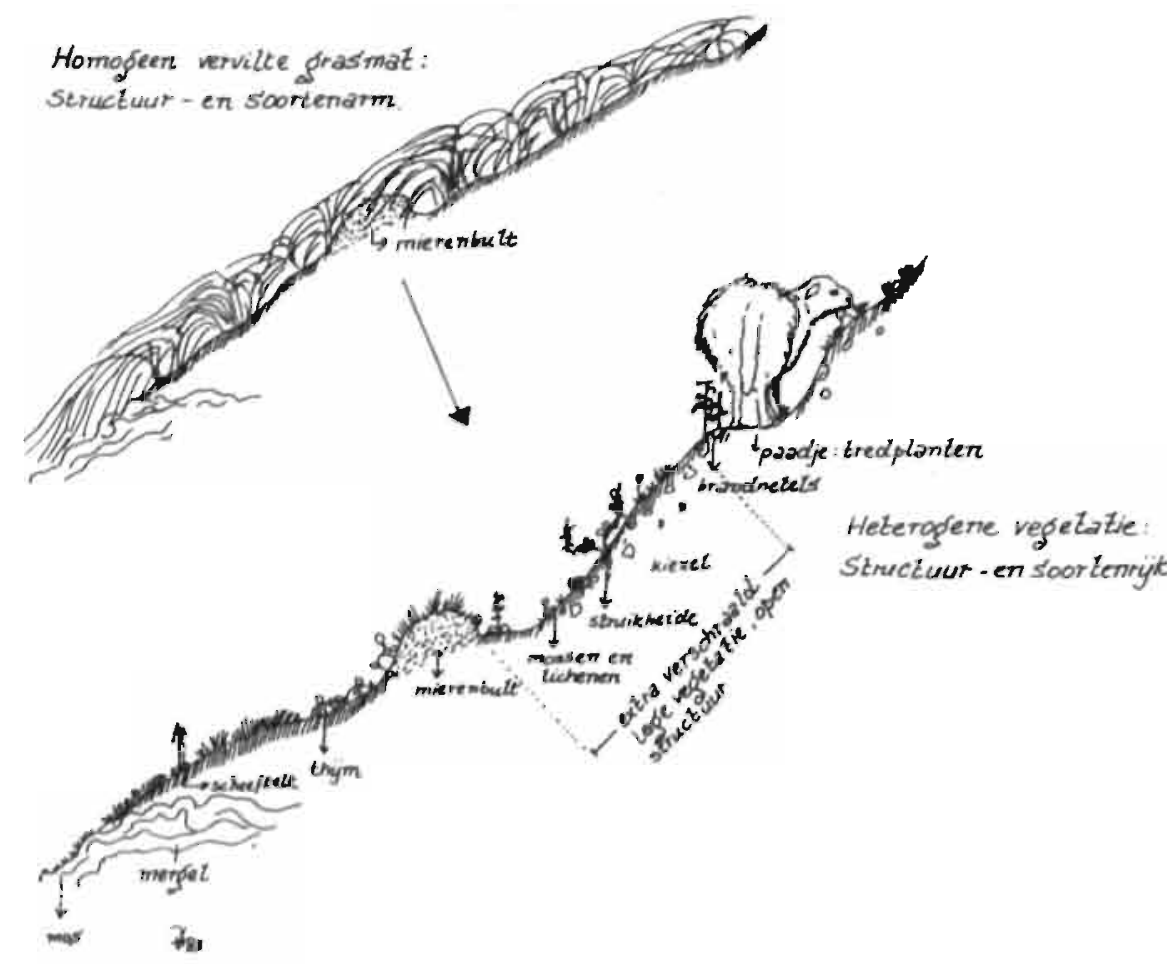

FIGUUR, 15.8. Milleudifferentiotie, ontstaan door de activiteiten van schapen op cen kolkgrosiand. Tekening van $\}$. Hermans. Voor de herintroductie van begraxing was de vegetatie van de meeste kalkgraslanden "vervilt", dat wil zegaen bepnalde grassoorten domineerden dusdanig. dat het vegetatledek volledig was gesloten en veel soorten kruiden werden verdrongen. Na enige jaren von beweiding ontstaot een soortenrijk vegetatiedek door plaatselijke tred, vraat en verschraling.

teristiek was voor wintergraanakkers op kalk, een vegetatietype dat momenteel vrijwel is uitgestorven. Ook op de Sint-Pietersberg verscheen tijdens de braakperiode van een akker op kalkrijke grond een spectaculair ogende graan-onkruidflara. Ook hiep werd een aantal soorten planten waargenomen, die in het gebied als uitgestorven werden gewaand.

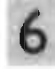
Gesteund en anangemoedigd door wetenschappelijk onderzoek heeft de methode van de extensieve beweiding overal in Noordwesteuropese natuurgebieden sinds kort furore gemaakt. In het dichtbevolkte. door de bio-industrie ernstig bedreigde. maar desondanks nog met "natuur" rijk bedeelde Zuid-Limburg. wordt de noodzaak om delen van dit gebied opnieuw in te richten als natuurgebied steeds groter. Om de bestaande natuurgebieden op een verantwoorde en overigens goedkope wijze te beheren, hebben de natuurterrein beherende instanties sinds 1980 op cen succesvolle wiize gebruikgemaakt van het mergellandschaap. Hiermee is tevens een deel van het taaie en mooie dieren onder leiding van een herder zijn diensten zal uitbreiden. culturele erfgoed van het Merge!land in ere tingen, dat bij een verdere uitbreiding van het areaal natuurgebied en bị het totstandkomen van verbindingen tussen geïsoleerd gelegen natuurreservaten, dic ras van sobere.

\section{NO.TEN}

VINA 1980, pp. 73-74

2 HILLGERS 1990

3 JANSEN EN RUTTEN 1992.

1 Bemeumans in Bodemerosie 1988.

5 Van Gool en De Mars 1989

6 RANG 1986.

7 CoRtenRaAd en MULDer 1989.

8 HiLegers 1984 a.

9 Boesink 1989.

10 Ruil.vericaveling Mergeiland 1991.

11 HILLEGERS $1991 \mathrm{~b}$.

12 HILLEGES 19896 .

13 BONNEMAYER EN DIETVORST 1979.

1) HILLGERS 1985 b.

15 BOTTEMA EN OUSON 1979.

16 CLASON 1980.

17 HILLEERS 1984 a.

18 Zielijst:van foto's betreffende mergellandschapen in tabet 10.

19 HILLGERS EN REUTEN 1978, pp. 130-131.

20 BUYS 1982.

21 CLASON 1980

22 HILLEERS EN REUTEN 1978. p. 135.

23. HILLEGERS EN REUTEN 1978, p. 134.

21 WILLEMS 1987.

25 HILFGERS $1985 \mathrm{C}$.

26 HiLLEGERS 1983b, p. 26 en volgende.

27 HiLleGERS $1982 \mathrm{~b}$.

28 Een overziche van de belangrijkste literatuur betreffende beweiding van droge schraalianden wordt ge. geven door WILLEMS 1987. pp. 39-42

29 HiLegers 1983a.

30 De literatuurlipst betreffende de natuurwetenschappeligke aspecten van de Sint-Pietersberg, brigehouden tot i983. omvat 980 titels. Zie VaN SCMAIK 1983, pp. 553-563 en Gruatsma 1985.

31 Hetexperimenteel onderzoek wordt verricht door de vakgroep plantenoecologie van de Rijksuniversiteit: Utrecht. waarvan de resultaten onder andere werden gepubliceerd in jarverslagen (zie jaarversłag onderzoek kalkgraslandproject (984) en in een vijfal dissertaties (zie BOBBINK 1989, SCMENKEVVELO EN VERKAAR 1984. VAN TOOREN 1989. DE KROON 1990 en WILLEMS 1980).

32 AUKEMA 1983

33 HILLEGERS 1984a. Diverse hoofdstukken van deze publicatie zijn gewijd aan de relatie tussen de fiora en de fauna van begrasase kalkgrasianden.

34 HILLEGERS $1989 \mathrm{~b}$.

35 HENNEKENS et al. 1983 


\section{SAMENVATTING}

Het substantief "heerd", het centrale begrip van dit boek, is een in de Centraal-en Noordwesteuropese talen haast vergeten of nog voorkomend synoniem voor "kudde" of voor de leider daarvan. De term "heerdgang" betekent dan letterlijk de gang van de heerd, dat wil zeggen de dagelijkse gang van de kudde onder leiding van de herder vanuit de nachtstalling in de nederzetting naar de weidegronden in de gemeente en terug.

Het gebied waarin heerdgang en zijn effecten werden bestudeerd, omvat als kern het Mergelland, dat deel van Duitsland. Belgiè en Nederland waar mergel aan de oppervlakte komt. Tevens werden, vergelijkenderwijs. delen van het daaromheen gelegen gebied betrokken in deze studie en wel zodanig, dat het geheel min of meer overeen komt met het gebied, gelegen binnen de stedenvierhoek Luik, Aken, Roermond en Hasselt. Deze streek wordt sinds kort aangeduid met de term Euregio.

De studic houdt zich bezig met twee aspecren van de heerdgang; het eerste aspect betreft het patroon dat heerdgang heeft achter . gelaten per nederzetting en het daaromheen gelegen landschap. Dit onderzoek, vastgelegd in deell, is historisch-geografisch gericht. Bij die speurtocht naar veedriften, verzamelplaatsen, veedrenken en weideplaatsen per nederzetting in het verleden, hebben vooral toponiemen, dit zija veld- en straatnamen. een belangrijke rol gespeeld. Dergelijke namen hebben gefungeerd als taalkundige "gidsfossielen", die de onderzoeker in staat stellen het patroon van heerdgang per nederzetting te reconstrueren. In een beperkt aantal nederzettingen, met name daar waar onmiskenbare heerdgangnamen, zoals "Veestraat" of "Veedrift" en "Koesweide" of "Schaapsberg" bewaard zijn gebleven, is een reconstructie van die heerdgang geen probleem. In diverse andere nederzettingen bestaan echter namen voor wegen en percelen. waarvan de heerdgang-indicatieve betekenis minder voor de hand ligt, "bies(c)"-toponiemen hebben zeer waarschijnlijk betrekking op "beest" in de zin van "koebeest", het element "groen" in veel veld-en wegnamen binnen het onderzoeksgebied betekent vermoedelijk "groenland" in de zin van een weideplaats en het taalkundig element "mes" of "mis" in toponiemen heeft vermoedelijk meer uit, te staan met de uitwerpselen van het vee dan met een kerkdienst.

Ook voor weideplaatsen bestaan of bestonden diverse begrippen in toponiemen of in dialectvormen, die in het huidig taalgebruik zo goed als verdwenen zijn, maar in toponiemen zijn "gefossiliseerd", bijvoorbeeld het oude woord "dries", waarvan de oorspronkelijke betekenis "(semipermanente) braak" in het huidig taalgebruik verloren is gegaan. Juist in verband met deze uitgestorven boerenterm wordt uitvoerig ingegaan op de begripsverwarring rond de term "drieslagstelsel". Her laatste hoofdstuk van dee! I sluit af met een overzicht van het ontstaan van het nederzettingspatroon, waarin de heerdgang een zeer belangriịke rol speelde.

Deel il van deze studie, samenvaliend met het woord "heden" uit; de ondertitel, behandelt aspecten van de processen die met heerdgang samenhangen. Deze processen zijn bestudeerd vanuit de oecologie, een studieterrein van de bioloog, dat echter veel aanknopingspunten heeft met de factoren ruimte en tijd. Een oecologische benadering van de ontginningsgeschiedenis kan het inzicht in het ontstaan en functioneren vas nederzettingen binnen de hun toegemeten ruimte wezenlijk verrijken.

Hec belangrijkste proces dar, door heerdgang in ruimte en tijd werd uitgeoefend, kome voort uit "het grazen". Uit onderzoek naar de effecten van begrazing door een kudde mergellandschapen, verricht in de afgelopen 12 jaar in diverse weideplaatsen met de status, natuurreservaat, is gebleken dat de soortensamenstelling van de vegetatie in hoge mate afhankelijk is van de soort grazer. de begrazingsdruk en de periode, waarin begrazing plaats vindt. Daarnaast zijn abiotische eigenschappen van de weidegronden determinerend voor de floristische samenstelling van de vegetatie. Het onderzoek heeft ondubbelzinnig kunnen aantonen, dat bepaalde graslanden door middel van het herstel van de heerdgang kunnen worden gerestaureerd, dat: wil zeggen hun floristische en de daarvan afhankelijke faunistische rijkdom binnen een tijdsbestek van een decennium kunnen terugkrijgen. Dit is een uitermate positief gegeven in deze tijd van overwegend oecologisch verval.

Behalve over permanente weidegronden kon de dorpskudde periodiek over andere graasplaatsen beschikken: gedurende vele eeuwen vvaren de na de oogst braakliggende akkers welkome en aanvullende weidegronden. Niet alleen door het verdwijnen van de kudde op de "stoppel", maar ook door een reeks van andere landbouwkundige maatregelen is de botanische rijkdom en de daarvan afhankelijke wilde fauna van het akkerareaal sindsdien sterk veranderd. Met name is de biologische diversiteit sindsdien dusdanig sterk afgenomen, dat op diverse plaatsen in Noordwest-Europa akkers worden beheerd door natuur beherende instanties.

Naast permanente en periodieke weidegronden begraasde de kudde tevens de bermen van haar eigen veedriften, die door een eigen specifieke vegetatie werden gekenmerkt. In West-Europa is het te laat om dit vegetatietype te bestuderen, in Zuid-Europa bestaan nog wel functionele veedriften en is de specificke vegetatie langs dorpswegen nog volledig intact. Nu op diverse plaatsen in Europa "openluchtmusea", dat wil zeggen reconstructies van nederzectingen met de daarbijbehorende agro-pastorale bedrijfsvoeringen, worden gesticht, is het zinvol eveneens aandacht te schenken aan de voor dergelijke nederzettingen karakteristieke wegbermflora. Het laatste hoofdstuk van deell II is gewijd aan een plantesoort, die in een dergelijk milieu placht voor te komen en zonJer herstel van heerdgang zeker in Nederland zal uitsterven.

In hec laatste deel van deze studie, dat op de toekomst van de heerdgang binnen het gebied van onderzoek betrekking heeft, komt duidelijk naar voren dat met behulp van een historisch verantwoorde, toerist-vriendelijke en economisch haalbare beheertechniek minstens drie biotopert kunnen worden gereconstrueerd, die voorheen binnen het gebied van onderzoek niet of slecht werden beheerd.

De mogelijkheden tot restauratie van de buitengewoon soortenriike en oogstrelende vegetaties van droge: schraallanden, graanakkers en wegbermen, tezamen met hun kenmerkende fauna, waartoe ook het mergellandschaap zou kunnen worden gerekend, zijn daarmee tot politieke keuzen geworden. 


\section{ZUSAMMENFASSUNG}

Das Substantiv "heerd" (deutsch: "Herde") ist ein in den nordwesteuropaischen Sprachen fast vergessenes oder kaum noch vorkommendes Synonym fur das niederländische "kudde", also die Herde, oder auch für den Hirten. Der Begriff "heerdgang" bedeutet dann wôrtlich den Gang der Herde unter Fürung des Hirten von der Nachtstallung im Ort zu den Weidegründen der Gemeinde und zurück.

Das Gebiet, in dem dieser Weidegang und seine Auswirkungen untersucht wurden. umfaßt als Kern des Mergelland, das sich uber Teile Deutschlands, Belgiens und der Niederlande erstreckt. Außerdem wurden zum Vergleich angrenzende Gebiete in die Studie einbezogen, und zwar so, daß das Ganze sich mit. dem Bereich innerhalb des Städtevierecks Lüttich, Aachen, Roermond, und Hasselt deckt - der seit kurzem so bezeichneten "Euregio" also. Die Studie befaßt sich mit zwei Aspekten des Weidegangs; der erste Aspekt betrifft die Spuren, die der Weidegang in der betreffenden Ansiedlung und der umliegenden Landschaft hinterlassen hat. Diese Untersuchung, durchgeführt in Teil I, ist historisch-geographisch ausgerichtec: Beim Aufspüren von Viehtriften, Sammelstellen, Viehtränken und Weideplätzen der Vergangenheit je Ansiedlung haben vor allem Toponyme, da $B$ heißt: Feld- und Wegenamen eine wichtige Rolle gespielt. Solche Namen haben als sprachliche "Leitfossilien" fungiert, die es dem Autor dieser Unterșuchung ermöglichen, das Schema des Weidegangs je Ansiedlung zu rekonstruieren. In einer beschränkten Zahl von Ansiedlungen, namentlich dort, wo unverkennbare Weidegangnamen wie "Veestraat" (Viehweg) oder "Veedrift" (Viehtrift) und "Koeweide" (Kuhweide) oder "Schaapșberg" (Schafberg) erhalten geblieben sind, ist, eine Rekonstruktion dieses Weidegangs kein Problem. In verschiedenen anderen Ortslagen kommen jedoch Namen von Wegen und Parzellen vor, deren auf einen Weidegang verweisende Bedeutung weniger auf der Hand liegt; "bies(t)"-Toponyme beziehen sich wahrscheinlich auf "beest" im Sinn von "koebeest" (Kuh), das Wortelement "groen" (Grün) in zahlreichen Feld- und Wegenamen innerhalb des Untersuchungsgebiets bedeutet vermutlich "groenland" (Grünland) im Sinn von Weideplatz und das Sprachelement "mes" oder "mis" in Toponymen hat vermutlich mehr zu tun mit den Ausscheidungen des Viehs als mit einem Gottesdienst (deutsch also "Mist" und nicht "Messe"). Auch für Weideplätze gibt es oder gab es verschiedene Begriffe in Toponymen oder in Dialektformen, die im heutigen Sprachgebrauch so gut wie verschwunden, in einigen Fallen jedoch als "Fossilien" erhalten sind, zum Beispiel das alte Wort "dries", dessen ursprüngliche Bedeutung "Langzeit- oder Dauer-Brache" im heutigen Sprachgebrauch verloren gegangen ist. Gerade im Zusammenhang mit diesem ausgestorbenen Bauernwort wird ausfuhrlich auf die Begriffsverwirrung rund um den Terminus "drieslagstelsel" (deutsçch meișt mit "Dreifelderwirtschaft" wiedergegeben) eingegangen. Das letzte Kapitel von Teil I schließt ab mit einer Übersicht Ober die Entstehung des Siedlungsmusters, in dem der Weidegang eine sehr wichtige Rolle spielte. Teil II dieser Studie, zusammenfallend mit dem Wort "heden" aus dem Untertitel, behandelt Aspekte der Prozesse, die mit dem Weidegang zusammenhăngen. Diese Prozesse werden untersucht vom Standpunkt der Okologie aus, einem Studiengebiet des Biologen also, das aber viele Anknüpfungspunkte mit den Faktoren Raum und Zeit aufweist. Ein ökologischer Ansatz bei der Behandlung der Rodungsgeschichte kann die Einsicht in die Entstehung und das Funktionieren von Ansiedlungen innerhalb des ihnen zugeordnețen Raumes weșentlich bereichern:

Der wichtigste ProzeB, der in Raum und Zeit durch den Weidegang ausgelöst wurde, ergibt sich "aus dem Grasen". Aus einer Untersuchung nach dem Auswirkungen der Beweidung durch eine Herde Mergellandschafe, die wăhrend der vergangenen 12 jahre auf verschiedenen Weideplätzen mit Naturreservat-Status durchgefuhrt wurde, ist deutlich geworden, daß die Artenzusammenstellung der Vegetation in hohem $\mathrm{Maß}$ abhängig ist vom grasenden Viehtyp, vom Weidedruck und vom Zeitraum der Beweidung. Daneben sind abiotische Eigenschaften der Weidegründe mitbestimmend fur die floristische Zusammenstellung der Vegetation. Die Untersuchung hat zweifelsfrei aufzeigen können, daß bestimmte Grasländereien durch die erneute Aufnahme des Weidegangs wiederhergestellt werden, daB heißt ihren floristischen und den davon abhängigen faunisti- schen Reichtum innerhalb eines Jahrzehnts zurückgewinnen können. Dies ist eine außerordentlich positive Tatsache in einer Zeit uberwiegenden ökologischen Verfalls.

AuBer uber ständige Weidegründe konnte die Dorfherde periodisch auch uber andere Graslandereien verfuggen; walhrend vieler Jahrhunderte waren die nach der Ernte brachliegenden Äcker willkommene Ergànzungsflachen. Nicht nur wegen des Verschwindens der Herde vom "Stoppelfeld", sondern auch infolge einer Reihe anderer landwirtschaftlicher MaBregein hat sich der botanische Reichtum und die davon abhangige Wildfauna stark verandert. Seit Aufgabe der alten Nutzungsform hat die biologische Vielfalt derart stark abgenommen, daB an verschiedenen Orten in Nordwesteuropa Ácker mittierweile unter der Obhut von Naturschutz-Instanzen stehen.

Neben permanenten und periodischen Weidegründen begraste die Herde gleichzeitig die Randstreifen ihrer eigenen Viehtriften, die durch eine eigene spezifische Vegetation gekennzeichnet sind. In Westeuropa ist es zu spăt, um diesen Vegetationstyp zu studieren, in Sudeuropa aber gibt es noch benutzte Viehtriften und ist dementsprechenci die spezifische Vegetation entlang der Dorfwege voll intakt. Da gegenwärtig an verschiedenen Orten in Europa "Freilichtmuseen", daß heißt Rekonstruktionen von Ansiedlungen mit den zugehörigen agro-pastoralen Betriebsformen gegründet werden, ist es sinnvoll, auch der für solche Siedlungen charakteristischen "Wegrandflora" Beachtung zu schenken. Das letzte Kapitel von Teil II ist einer Pflanzenart gewidmet, die fruher in einem derartigen Ökotop regelmäBig vorkam und die ohne Wiẹderaufnahme des Weidegangs in den Niederlanden sicher zum Aussterben verurteilt wäre.

Im letzten Teil der vorliegenden Studie, der sich auf die Zukunft des Weidegangs im Untersuchungsgebiet bezieht, wird deutlich hervorgehoben, daß̣' mit Hilfe einer historisch begründeten, tourismusfreundlichen und wirtschaftlich vertretbaren Vorgehensweise mindestens drei Biotope wiederhergestellt werden können, die bis dato innerhalb des Untersuchungsgebiets nicht oder kaum gepflegt wurden.

Die Möglichkeiten zur Wiederherstellung der auBerordentlich artenreichen und das 
Auge verwöhnenden Vegetation von mageren Trockenrasen, Getreideäckern und Wegrändern auch in der Mergellandschaft sind damit zu einer politischen Option geworden.

\section{SUMMARY}

The noun "heerd", the equivalent for the Old English "heord", which in turn is derived from the original Teutonic "herdâ", is the central concept of this book. In the languages of central and northwestern Europe it is an almost forgotten or rare synonym for the Dutch noun "kudde" (cf. the pre-Teutonic "kerdhâ"). meaning, "herd" or flock, or for the keeper of the herd. Consequently, the term "heerdgang" literally means the "herd's walk", i.e. the daily routine of a herd or flock being walked by the herdsman or shepherd from its night shelter in the settlement to the common pasturelands and back. The term may thus lend itself to a translation into the Old English "herdwick", meaning the tract of land under the charge of a herdsman.

The area in which the phenomenon of the herdwick and its effects. have been studied comprises at its centre the "Mergelland", or marllands, which covers that part of Germany. Belgium, and the Netherlands in which marlstone comes to the surface. By way of comparison, sections of the surrounding area have also been included in this study in such a way that the total area under survey corresponds more or less to the region confined within a quadrangle of the four towns of Hasselt and Liège in Belgium. Aachen in Germa$n y$, and Roermond in the Netherlands. This area, the main body of which is comprised by Dutch territory, has recently been distinguished by the term "Euregio".

The study is concerned with two aspects of the herdwick; the first aspect bears upon the pattern left behind in each settiement and its surrounding environment by the herd's routinely being walked to and from a settlement's common pasturelands. This inquiry. recorded in part $\mathbf{i}$, takes its direction from historical geography. In this search for cattledroves, cattledrifts, watering places, and pasture grounds for each early settlement, an important part has been played by (Dutch) toponyms, i.e. by local names for fields, roads, and places. Such names have acted as linguistic "guiding fossils", relics from the past ena- bling the researcher to reconstruct the herdwick's pattern for each settlement. In a limited number of setclements, notably those in which names have been preserved that undisputably indicate a herdwick, such as "Veestraat" (meaning "cattlestreet") or "Veedrift" ("cattledrift"), and "Koeweide" ("cow's meadow") or "Schaapsberg" ("sheep's hill"), a reconstruction of the herdwick in question presents no problem. In various other settlements however, there are names for roads and plots of land, whose meanings are less obviously an indication of a herdwick; local toponyms ending in the suffix "bies $(t)$ " may very well be related to the Dutch noun " (koe)beest". or "beast" in the Middle English sense of the word, in which it refers to farm stock or cattle: the element "groen" (meaning "green") in many field and road names, within the area under survey probably means "green land" or "green", in the sense in which Tennyson speaks of "a simple village green" (In Memoriam, Ixiv), in which it deñotes a piece of grassy land situated in or near a village; and the linguistic element "mes" or "mis" in toponyms is probably more closely related to the Dutch noun "mest" (meaning "manure") than with the religicous service called "mis" ("mass" in Eng. lish). Similarly, pasture grounds were or still are being referred to by various concepts in toponyms or local dialects which have virtually disappeared in contemporary usage but have "fossilized", as it were, in toponyms, e.g. the archaic word "dries", whose original meaning of "(semipermanent) wasteland" has been lost in contemporary usage. Precisely in connection with this relict peasant term, the conceptual confusion concerning the notion of the "three-field system" ("drieslagstelsel" in Dutch) has been pursued in detail. The last chapter of part / concludes with an outline of the development of the settlement pattern in which the herdwick played a major part

In part ll of this study, certain aspects of processes are discussed which are presently re- lated to the effects of a herdwick. These processes have been studied from the perspective of ecology, a biologist's field of study touching in many ways however, on the factors of space and time. An ecological approach of the history of cultivation may substantially improve our understanding of the origin and function of settlements within the limits of their allotted space.

The most important process generated by a herdwick in space and time, is a result of "pasturage". Investigation of the effects of pasturing a flock of marlland sheep, carried out in the past 12 years on various pasture grounds having received resource conservation status, has shown that the structure of plant species variecy on these grounds is highly dependent on the type of ruminant being pastured, the size of the flock, and the period in which pasturing takes place. In addition there are abiotic features of pasture grounds that determine the variecy of their herbaceous vegetation. The investigation has made it possible to establish unequivocally that by reinstituting the herdwick, certain grasslands may be restored, i.e. that the wealth of their plant and its dependent animal life may be recovered within the space of a decennium. This is an extremely positive outcome in a time predominated by ecological degradation.

In addition to the (permanent) common pasture, other feeding grounds were periodically available to sustain the village livestock; for centuries, fields lying fallow after harvest provided a welcome: supplement in pasture grounds. The disappearance of the flock on the "stubble.", together with a succession of other agricultural measures, has since then effected a profound change in the botanical wealth and its dependent wildlife on arable acreage. Biological diversity in particular has since then decreased to such an extent that. arable fields in various locations in northwestern Europe are now being administered by natural resource conservation agencies. 
As well as on the common pasture and on periodically available feeding grounds, a flock or herd would also graze on the banks of its own cattledrifts, which as a consequence displayed its own distinctive vegetation charac. teristics. In western Europe it is too late to be able to study this specific variety of vegecation, but in southern Europe some cattledrifts are still being used and distinctive village roadside vegetation may still be entirely intact. Now that on various locations in Europe "folk museums" are being established. i.e. settlement reconstructions including their pastoral forms of farm management, it may be worthwhile also to pay attention to roadside plant varieties distinctive of such settlements. The last chapter of part II is devoted to one variety that once used to flourish in this particular kind of environment and that without a reinstitution of the herdwick will certainly become extinct in the Necherlands.

The last part of this study, which concerns itself with the future of the herdwick within the area under survey, clearly shows that by means of a historically sound, tourist-friend- ly, and economically practical management technique, at least three types of habitat may be reconstructed which within the area under survey have formertly been managed badly or not at all.

The possibilities to restore the striking diversity of delightful plant varieties peculiar to arid soils, cornfields, and roadsides, together with their distinctive wildlife which may also include the marlland sheep, have now become a political choice.

\section{RÉSUMÉ}

Le terme "heerd", mot clé dans cette êtude. est une expression typique des langues germaniques. II s'applique non seulement au troupeau de moutons, au bétail en général. mais aussi au chef du troupeau. $C_{e}$ mot "heerd" ètait aussi utilisé dans le dialecte wallon parlé le long de la frontière linguistique. L"hierdal volie" designait le parcours du bètail tandis que le "heert" "hierdi" en wallon liégeois actuel) signifiait "vacher" et "berger". Le vocable "heerdgang" (pacage itinérant) était plus oụ moins utilisé dạs la région concernée par cette étude, région transfrontalière belge, allemande et néerlandaise, limitée par les villes de Liège, Aix-la-Chapelle et Ruremonde.

Le pacage itinérant (heerdgang) était une activité habituelle de la vie agro-pastorale d'antan. !l a été utilisé pendant des siècles. Aujourd'hui, il a presque disparu d'Europe. Cette coutume traditionnelle a laissè des traces non seulement dans l'environnement. mais aussi dans la toponymie des lieux. Ainsi le terme "Hé", par exemple "Sur hé" à Wonck, désigne une propriété communale oú les troupeaux locaux pouvaient paître.

Les deux premiers chapitres de l'ouvrage sont consacrés au thème toponymique déculant du terme "heerdgang".

Le troisiéme chapitre développe l"utilisation

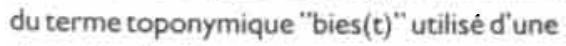
place dans le village ou dans une composition, d'une route, d'un terrain herbacé ou d'un petit plan d'eau. Le troupeau communal est toujours associé à ces cas géographiques; il paraît probant que l'élément "bies $(\mathrm{t})$ " signifie "tête de bétail".

De même, le quatrième chapitre s'intêresse au terme "mare" et de ses synonymes ger. maniques désignant des points d'eau stagnants destinés à désaltérer le bétail avant le retour à l'étable.

Le cinquième chapitre s'attache au mot "dries" ("triche" ou "trithe" en wallon liegeois actuel), qui dèsigne une terre de culture restée en jachère régulière où le bétail de la localité avait le droit đe pâturer:

Les éléments toponymiques "groen" (vert) et "mes $(t)$ " (bouse), associés à des noms de routes. pâturages et mares, sont en corrélation avec les troupeaux. La couleur verte de la végétation permanente aussi que la présence de bouse caractérisent les páturages utilisés.

Le chapitre huit développe le rôle joué par les troupeaux de cochons. de bovins et d'ovins dans la composition du paysage et même du village dans la région délimitée.

La deuxième partie de l'ouvrage est axée sur la végétation actuelle des anciens pâturages. Nombre de ces terrains ont disparu depuis le siècle dernier. Ils ont été boisés, engraissés, privatisès ou bétonnès, entraịnant ainsi la disparition de la végétation originelle adaptée au pacage périodique. Notre société industrielle ria laissé que des lambeaux de ces anciens påturages.

Cependant, la richesse exceptionnelle de la flore et de la faune de ces reliquats, a suscité. depuis 1950 un centre d'intérêt développé. dans le chapitre neuf, qui met en exergue les nombreuses espèces d'orchidées indigènes des pelouses calcaires.

Le chapitre dix met l'accent sur le Thero-Airion, végètation caractéristique des dessus de pente decalcifiés.

Jadis, les troupeaux étaient aussi menés sur des pâturages temporaires constitués de champs mis en jachere. Ces "trixhes" ou "driesen" recelaient une richesse naturelle ètonnante.

L'abondon des jachères et l'industrialisation de l'agriculture ont provoqué la régression. voire la disparition de cette flore particulière. Les chapitres onze ec douze conseillent de gèrer les cuftures céréales comme jadis pour sauver les espèces messicoles. Ils insistent aussi sur la réintroduction du pacage ovin. La "draille", terme toponymique des Cévennes, ou "dreef" en néerlandaiș, désigne les chemins de passage des troupeaux. Les bords. étaient broutes et la végétation était adaptée au pâturage, au piétinement et à l'engrais. sement qui ont favorisé de grands plantes commes les chardons. Cette végétation est dénommée "Onopordion" apres un chardon caractéristique. Cet Onopordion est en voie. de disparition sauf là oủ le heer dgang est en. core pratiqué, comme ça et la dans l'Au.. vergne. Dans un musée de plein air a Kommern près d'Aix-la-Chapelle on a essayé d'introduire cette végétation caractéristique des vieux villages.

La troisième partie comporte un chapitre qui est un plaidoyer passionné pour la réintro. duction partielle du heerdgang dans la région d'étude. Une race de moutons a survécu, le: "mergellandschaap". La race s'est adaptee admirablement aux conditions moins favorables. Elle peut se nourrir d'une végétation. maigre adaptée à son tour au broutement régulier. Un biosystème de păturages, de "trixhes" et de drailles comportant une richesse biologique étonnante et témoin de la vie agro-pastorale d'antan, en harmonie depuis des, siécles, ne peut pas exister sans heerdgang. 


\section{LITERATUUR}

Advies landschopsbouw herinrichting Mergelland-Dost I onder red. van N. van Keulen, Roermond 1987 Agrarische geschiedenis van Nederland / onder red. $\operatorname{van}$ L. Noordegraaf, 's-Gravenhage I 986.

Algernene geschiedenis der Nederlanden / onder red. van D.P. Blok (et al.). (deel I- I 5), Haarlem 19811982

ALLemEersCH, L. (et al.), Heide in Limburg. Tielt 1988.

AMKREUTZ, L (et al.), Kirchraödsjer dieksiejoneer, Kerkrade 1987

ANONYMUS, Overlevingsplan voor oude Nederlandse veerassen, in: Zeldzoam Huisdier, 15 (1990) nr 2, pp. 2-16

Atlas van de Nederlandse flora I onder red. van J. Mennema (et al.), (deel 1-3), Utrecht-Voerendaal 1985-1989.

Augustus, L., Wijnstraat of Wijngrache, in: De Maasgouw. 92(1973) nr 6. pp. 175-194.

AUKEMA, B., De invertebratenfauna van de Zuidlimburgse kalkgraslanden, de wantsen (Hemiptera. Heteroptera), in: Natuurhistorisch Moandblad. 72(1983) nr 8. pp. 129-135

Aus Geschichte und Landeskunde : Forschungen und Darstellungen : Franz Steinbach gewidmet von seinen Freunden und Schülem / onder red. van J. Braubach (et al,), Bonn 1960.

BAKELS, C.C., Four Linearbandkeramik settlements and their environment : a paleoecological study of Sittard, Stein, Elstoo and Hinheim, L eiden 1987.

BAKEL.S, C.C., Graan, het oude goud, in. Notuur en Techniek, 58(1990) nr 3. pp. 240-249

BAKKER, J.P., Nature management by grazing and cutting, Dordrecht-Boston-London 1989

BARKMAN. J. Beschouwingen over het begrip zeidzaamheid bijplanten, in: Gorteria, 4(1968) nr 6 8. pp. $79-86$.

BEAUJEAN, H.A., Geschiedenis van Hoensbroek en omgeving. Heerlen 1949

BECMMANN, R.. Des arbres et des hormmes : lo forêtt ou moyen-dge, Paris 1984.

Begrozing in de notuur / onder red. van S. de Bie. W. Joenje en S.E. van Wieren. Wageningen 1987 Beschermd natuurmonument St. Pietersberg, inrich tings- en beheersplon / Rapport Provincie Limburg. juli 1992.

BEHETS. J.. Het gebruik wan de gemene weide en de andere gemene gronden in de wijsdommen van het graofschop Loon (Handelingen van de Koninklijke Commissie voor de uitgaven der Qude Wẹtten en Verordeningen van Belgié; boekdeel XXVI), Brussel 1975. pp. 147-192.

BERTRAND, C. Meerssen in oude onsichten. Zaltbommel 1981.

Beijers, H. G. - van Bussel en G. VAN Berkel. Veldnamen als historische bron, een handleiding voor me thodisch onderzoek, "s-Hertogenbosch 1991

BIELEMAN, J., Boeren op het Drentse zand, 1600 . 1910: een nieuwe visie op de "oude" landbouw. Wageningen 1987.

BLINK. H., Geschiedenis van de boerenstand en de landbouw in Nederland. Groningen 1902

BLOK. D.P., De Franken in Nederland, 3e druk, Haarlem 1979.

BLONDEN, J.L., De straatnamen van Maastricht, Maastricht. 1933.
BoBsinK, R., Brachypodium pinnatum and the species diversity in chalkgrasslands. Utrecht 1989.

Bodemerosie / onder red. van H. Bemelmans, in: Limburgs Milieu, 2(1988) nr 4-5, pp. 3-46.

BOILEAU, A. Enquêtte dialectale sur la toponymie germanique du nord-est de la province de Liège، Liège 1945.

BOILEA, A., Toponymie dialectale germano-romane du nord-est de la province de Liège. Paris 1971.

BOMMEL, H.M.V.V. VAN, Enige oude plaarselijke benamingen bij Maastricht, in: De Moasgouw. 95(!976) nr 6, pp. 150-161.

BONGERS. M.J.W.M. EN V.T. VAN VILSTEREN, Waldviehbauerntum: een wildwestverhaal?, in: Historisch Geografisch Tijdschrift. 4(1986) nr 3. pp. 76-81

BONNEMAYER, J.J.A.M. EN P.J.M. DIETVORST, DE Hoge Fronten, een landschapsoecologisch onderzoek in de Hoge Fronten ten behoeve van het behoud van de muurhagedis (Zoölogisch Laboratorium, afdeling Dieroecologie van de Katholieke Universiteit Nijmegen; rapport nr (67). Niimegen 1979.

BONT, A.P. DE. Dialekt van Kempenland. (deel 3). Assen 1969. (DI. 3: Geografische namen). BORYDEST. VINCENT.J.B.M.A.G.. Voyage souterrain, ou description du Plateou de St. Pierre de Moestricht et de ses vostes cryptes, Paris $\mid 821$.

BosCH, J.H.W. Bijdragen tot de geschiedenis van Schinveld, Sittard 1974.

BoșEBROEK, PH., Twintig jaar orchideceèntuin in Limburg, stand van zaken, in: Notuurhistorisch Moandblad, 69(1980) ar 7.8, pp, !31-136.

BOTTEMA, 5. EN A. T. CLASON, Het schoop in Neder land, Zutphen 1979

BOVENS. TH., Op grampeer ziene sjoet, in: De Maaspost, 30 maart 1988, p. 16

BRINK. F.H VANDEN, Zoogdierengids van Europa ten westen van $30^{\circ}$ oosterlengte. Amsterdam-Brussel 1955

Brinkenboek, een verkenning van de brinken in Drenthe / onder red. van E. Houting, K. de Poel en J. van der Vaart, Assen 1981.

BrisebarRE, A. Les Bergers des Cevennes, Paris 1978 BROEDERJEROEN, De Keerderberg. Manuscript uit de periode 1940-1945, aanwezig in het Natuurhistorisch Museum Maastricht.

BROEK. J.M. VAN DE. Toponymie en bodemgesteldheid, in: De Bronk, 9(|96।), pp. 66-7|

Brouwers, E., Duizend joor Klimmen, Heerlen 1986

Buiks, C.J.M., Veldnamen en natuurhistorie, in: De Levende Notuur, 89(1988a) nr 2, pp. 55-62.

Buiks, C.J.M., Oude veldnamen en historische geografie, in: Historisch Geografisch Tijdschrift, 2(1988b) pp. 50-61

BUIS. J. Historia forestis: Nederiandse bosgeschiedenis, ( 2 delen). Wageningen 1985.

BUND, C.F. VAN DER, Poelen in het Mergeliand, inventorisatieropport, vierde herpetogeografisch verslog. Utrecht 1964

BuntinX, J. EN M. Gissseung, Het oudste goederen. register van Oudenbiesen (1280-1344), Tongeren 1965.

Burs, R.C. Genetische afistand tussen zeldzame schaperassen, in: Zeldzaam Huisdier, 7(1982) ne 2. pp. 60-64
Burs, J. (etal.), Toekomst yoor de otter in Limburg. in: Natuurhistorisch Moandblad, 80(1991) nr II. pp. 198-208.

Bijdroge tot de historie van Margraten / onder red. van Hi.M.R. Heidendal, Margraten 1983.

CAFRITZ, R.. L GOWING AND D. ROSAND, Places of delight: the pastoral londscape, London 1988.

CARTER, D. EN R. PHILIPS, Vlinders in Europa. Utrecht-Antwerpen 1983

CASTIER, W. VAN, Namen der straten van Mechelen, Mechelen 1901.

CATE, C.L TEN, Wan god mast gift : Bilder aus; der Geschichte der Schweinezucht im Walde. Wageningen 1972

ClaEssens, V.TH. (et al.), Berg en Terblijt: van twee, heerlijkheden naar ééngemeente. Valkenburgaan de Geul 1981.

CLAPMAN, A.R. (et al.), Floro of the British Isles: Illustrations, part III, (deel 3), Cambridge 1963. (DI. 3: Boraginaceae-Compositae)!

CLASON. A. Jacht en veeteelt, Haarlem 1977.

CLASON, A., Zeldzame huisdierrassen, Zutphen 1980

Cassification of plant communities / onder red. van R.H. Whittaker, Den Haag 1978.

CORTENRAAD, J. ENT. MULDER, Bedreigde planten in Limburg, in: Notuurhistorisch Maandblad, $78(1989)$ nr 11, pp. 181-184

CrujNS, A.H. EN F.W. I. KRIELLAARS, Het gemengde. landbouwbedrif op de zandgronden in Noord-Brabant 1800-1885 (Bijdragen tot de geschiedenis van het zuiden van Nederland; deel (XXII), Tilburg 1987. CUYPERS, J.: Bewoningspatronen in Eys, in: De Moasgouw i, 95(1976) nr 5, pp, 87-106.

DALE, J.H. VAN, Groot Woordenboek der Nederiondse Taal : tiende, geheel opnieuw bewerkte en zeer vermeerderde druk, (2 delen), 's- Gravenhage 1976.

DAM, D. VAN, Atmospheric deposition and nutrient cycling in chalk grassiand. Meppel 1990.

DAS, R., TH. KLOET EN R. DE PRUYSSENAERE DE LA WOESTINE, Inventarisatierapport gemeente Meerssen 1977. Meerssen 1977. (Gestencilde uitgave).

Delfstoffen in Limburg I onder red. van P.C.M. Rademakers (et al.), Valkenswaard 1989.

DERIX: J. EN SJ. VERLINDEN, Die al wil koopen wat hij ziet. : de geschiedenis van de Venraysche Schaapscompognieèn, (2 delen). Venlo 1982.

DERVILL, A... L.assolement triennal dans la. France du Nord au Moyen Age, in: Revue Historique, CCLXXX(1988) tome 2, pp. 337-376.

DIEMONT, W.H. ENA.J.H.M. VAN DE VEN, De kalkgraslanden van Zuid-Limburg, in: Publicaties van het Natuurhistorisch Genootschap in Limburg; De phanerogamen, reeks VI( 1953), pp. 3-20.

DITTMAer, $H$. Esch und Driesch, ein Beitrag zur agrargeschichtlichen Wortkunde, in: Aus Geschichte und Londeskunde. Festschrift F. Steinboch, Bonn 1960, pp. 704-726.

DitTmaier. H., Rheinische Flumamen. Bonn 1963.

DODOENS, R. Herbarius oft Cruydt-boeck, Leiden 1608

DOPF_ER. P. Schepenbrieven van het kapittel van Sc. Servas, deel IIl: (1470-1508), in: Publications de ta Société Histonque et Archéologique dans le Limbourg. 43(1907). pp. 416-516 
Därfiche Vegetotion im Freilichtmuseum/ onder red. van A. Zippelius (Stiftung zum Schutre gefahrdeter Pflanzen: Heft 3). Bonn 1981.

Donake, TH. Woordenlijst van het Valkenburgs plat. Valkenburg 1928.

DUIVENVOORDE. N. VAN, Reoctiemechanismen en overlevingsstrategietin van planten in begroosde ecosystemen Verslag Natuurbeheer, LU. Wageningen: nr 721). Wageningen 1984.

Dumoulun, LJ.G. Guide du botaniste dans les envrons de Moestricht, Maestricht 1868.

DulyzinGs, H. Veldnamen in het Ransdalerveld, in: Geulrond. I (1983) nr 2, pp. 78-80.

Dulzzincas. H.. De schweizer, in: Geulrand, 2(1984) nr 5. pp. 84-85.

DUizziNGs, H., Over twee soorten berg in Valkenburgse veldnamen, in: Geulrand, 5(1987) nr 20. pp. 34-35.

Dijk, H.F. VAN, B.G. GRAATSMA EN J.N.M. VAN Roor, Droge stroomdalgraslanden langs de Moas (Wetenschappelijke mededelingen van de KNNV: nr 165), Utreche 1984.

ELIENaERG. H., Vegetotion Mitteleuropas mit den ALpen in okologischer Sicht, 3e Auflage. Stuttgart 1982 ENDEPOLS, H.J.E., Woordenboek of diksjender van't Mestreechs. Maastricht 1955.

ENINEN, E UND W. JANSSEN, Deutsche Agrargeschichte (Wissenschaftliche Paperbacks; nr 12). Wiesbaden 1979.

ErMEN, E vaN (et al.). Limburg in koort en prent. Thelt 1985

FenNer, M. Seed ecology, London-New York 1985. FEsTY, O. L'agriculture pendant la révolution française, l'utilisation des jochères, Paris 1950.

FISCHER, G. UND W. HERBORN, Rheinische Landwin schaft um 1820: die Schwerze Agrorenquete im Regierungsbezirk Aachen, Köln 1987

Flora en founa van het gebied van Caestert tussen Kanne en Ternoaien / onder red. van JW. Siuiter en P.j. van Heerdt (Publicaties der Wetenschappelijke Belgisch...Nederlandse Commissie ter Bescherming van de St. Pietersberg; nr 8), Brussel-'s. Gravenhage 1964.

FORSTE, W. Die Herkunft des Wortes Driesch, in: Niederdeutsches Wort, 6(1966). pp. 57-68.

FOURNIER, P., Les quatre flores de France, Paris 1961. FrANQUINET, J.L. Flore len ll, Maastricht 1838. Manuscript, aanwezig in het Natuurhistorisch Museum Maastricht:

FRANSSEN. G.H. Van Simplevei tot Simpelveld, Simpelveld 1970 .

GARCKE, A., Illustrierte Flora von Deutschiand und angrenzende Gebiete, Berlin-Hamburg 1972.

GERAEDS, G. ENF.G.K. CUSTERS, Van Abdissenstroot tot Zondkuil, Swalmen!983.

GeUSSENS. J.. Alden Biesen, Lanaken 1986.

GOOL. C. VAN EN H. DE MARS. Verdrogingsverschijnselen in natuurgebieden in Limburg, resultoten van een onderzoek uitgevoerd in het kader van de voorbereiding van het Waterhuishoudingsplan van de provincie Limburg. Maastricht 1989. (Rapport Provinciaal Bestuur van Limburg).

GoOSSENS, H.M.H., Ubach over Worms, van Overworms kwartier tot gemeente Landgroof, Ubach over Worms 1981 .

GOOSSENS, H.M.H, EN A.J.M. GIELEN, Uboch over Worms in oude ansichten. Zaltbommel 1972

GRAATSMA, B.G., De flora van de St. Pietersberg een grensgeval, in: Natuurhistorisch Maandbiod, 74(1985) ni- 4. pp. 57-76.
GRANDGAGNE, Ch. Dictionnaire etymologique de to langue wollone, herdr., Bruxelles 1890 . (Oorspr. uitg. Liege (845)

GRuME, J.P. Plant strotegies and vegetotion processes, Chichester-New York 1979

GroOTH, M.E.TH, DE EN G.J. Verwers, Op goede gronden : de eerste boeren in Noondwest-Europa, Leiden 1984.

GUINOCHET, M. ET R. DE VUMORIN, Flore de France, (deel 2), Paris 1975.

Grsseu.inG, M. Etymologie van dries, in: Mededelingen van de Vereniging voor Noomkunde te Leuven en de Commissie voor Noamikunde te Amstendam, 28(1952). pp. 48-51.

Grsset.ING, M. Toponymisch woordenboek voor Betgie, Nederiand, Luxemburg. Noord Frankrijk en West Duitsland (voor 1226), Leuven 1960

GrsseunG, M. Etymologie van dries, in: Noomkun. de. 7(1975), pp. 258-265.

HABETS, J., Limburgse wipdommen, 's-Gravenhage 1891 .

HACKENG, R. Grondbezit en -exploitatie in de heerbijkheid Vijtingen tijdens de Middelecuwen, Nijmegen 1982 (Doctoraal scriptie K.U. Nijmegen).

HAEUPLER, H. UND P. SCHONFE DER, Adlas der Fornund Blutenpflanzen der Bundesrepublik Deutschland, Ze Auflage, Stuttgart 1989

HAGERS, J.-K., Middeleeuwse rotskunst te Valkenburg, in: S.O.K.Mededelingen, (1991) nr 17. pp. 28. 40.

HAMtRS, H., Ubochsberg en zijn omgeving. Ubachsberg 1973. (Gestencilde uitgave)

HARANT, H. ET D. JARRY, Guide du noturaliste dans le Midi de la France, Neufchítel-Paris 1987.

HARTMANN. J.L.H. De reconstructie van een middeleeuws landschop (Maaslandșe Monografièèn; nr 44), Assen-Mastricht: 1986.

HASSELT. I.L VAN, EN W. SANGERS, Wessem: een stodje met allure, Beek 1957.

HEES, F. VAN, Maostrichtse monumententool, HeerIen 1979 .

HEGI. G., Illustrierte Flora von Mittel-Europa. (Band V. Teil 4), München 1975.

Heimans, E. H.W. Heinsius en JaC.P. THusse, Geilfustreerde flora van Nederiand. 2 le druk, Amster. dam-Antwerpen 1970.

HEKKER, R., De ontwikkeling van het boerenhuis in Limburg, in: Publications de la Societé Historique ei Archéologique dans le Limbourg, 78-82 (1942-1946). P. 25-83.

HEKKER, R. (et al.), Dorp en stod in Limburg: ontstoon, ontwikkeling, bescherming en herstel van historische nederzettingen, Zutphen 1981.

HENDRIX. W.P.A.M., Geomorfogenetische processen in zuidwest-Limburg, in: Natuurhistorisch Maandblod. 73(1984) nr 2, pp. 35-43.

HENNEKENS, S.. J. SCHAMINEE EN V. WESTHOFF, De ontwikkeling van krijthellinggrasianden op verlaten akkers, in: Natuurhistorisch Maondblod. 72 (1983) nr 8, pp. 136-143

HERESWITHA, M., Huize Hoosten in St. Odilienberg. in: Roerstreek, 3(1971). P. 23-26

HERMANNS, W., Aachener Sprachschatz : Worterbuch der Aachener Mundart. Aachen 1970

HeRMans. f. (et al.). De Peschbeemden, een nog onbekend hellingveentje, in: Notuurhistorisch Moandblad. 72(1983) no 10/11. p. 237-241.

HEUKELOM. J, VAN, Toponymie van Kanne, Maastriche 1939

Heukels, H., Plantenotios bevattende apbeeldingen van de in Nederland in het wild groeiende planten. Groningen 19!!

Heukes. H. en R. van der Mejden, flora won Nederiand, 20e druk, Groningen 1984.

HiL.egers. H.P.M. Heidevelden in het Mergelland, in: Notuurhistorisch Moandblad, $67(1980)$ nr 9, pp. $121-140$.

HiLfegers, H.P.M. Het Mergellandschaap en ziin milieu, verleden, heden, toekomst, in: Zeldroam Huisdier, (1981 a) nr 6, pp, 12-24.

HIL.EGESS. H.P.M. Het vegetatiepatroon van de drie Nederlandse Rhinonthussoorten (Roteloar) in ZuidLimburg en het Belgische Jekerdal, Utrecht 198 !b. (Rapport Staatsbosbeheer).

HuLfGens, H.P.M. Vegetoties met Colluna vulgaris (L) Hull in het Mergelland, Uereche 1982a. (Rapport Staatsbosbeheer).

HillfGens. H.P.M. De vegetatiesuccessie op de Be. melerhei won 1800-1979, Venlo 1982b. (Rapport Stichting Limburgs Landschap).

HiL.LGes, H.P.M. Het lasate schepersschopje, in: Natuurhestorisch Maandblod, 71 ( $1982 \mathrm{c}$ ) nr 2. p. 26. HiL.fGers, H.P.M. De vegetatiesuccessie op de Bemelerhei von 1979-1982, Venlo 1983a. (Rapport Stichting Limburgs Landschap)

HiL.fGers, H.P.M. Beweidingseffecten van Mergelfandschapen in enkele natuurteservaten in het Mergelland, in: Publicoties van het Notuurhistorisch Genootschap in Limburg, reeks XXXi1(1983b) afl. 1 . 2. pp. 24-30

HiLifgens, H.P.M (red.), De Bemelerberg. een bundel artikelen over de natuur- en cultuurhistorische betekenis van een droog schraallandreservaat, in: Publicoties van het Natuuhistorisch Genootschap in Limburg, reeks Xxxiv(! 984a) aff 1-5.

HillLEgerS, H.F.M. De Kunderberg : een overzicht, Venlor 1984b. (Rapport, uitgegeven door de Stich. ting Limburgs Landschap).

HLLEgers. H.P.M. De jeneverbes, uitgestorven in het Mergelland?, in: Notuurhistorisch Macindbled, 74(!985a) nr 3, pp. 42-44.

HILLGERS, H.P.M. Het schaap in het mergellandschap, in: TH-Aken: witgove Stichting studiekontokt Technische Hogeschool Aken. 27 (1985 b) nr 2, pp. 3-. 10.

HiLLEgers, H.P.M. Exozoochoor transport van diasporen door mergellandschapen, in: Natuurhistorisch Moandblad. 74(1985c) ne 4, pp 54-56. HiLEGERS, H.P.M. Opgaven van Therc-Airion en Sedo-Cerastion-elementen in Zuid-Limburg in: Natuurhistorisch. Maandblod, 75(1986) ar 3, pp. 58 . 59

HILLEGERS, H.P.M. Houtskeletbouw : vakwerk in vakwerk, in: Notus en Technick, 55(1987) nr 3. pp. 2.18-233

HIL.FGERS, H.P.M., Orchideeên, bizarre superspecialisten, in: Notuur en Techniek, 55(1989a) n 7.pp. 534.545

HIUEGERS, H.P.M., Begrazing van bossen en struwelen, in: Notuuristorisch Moandblod. 78(1989b) nr 6. P. 95-101

HHEGERS, H.P.M., Een merkwaardige zweep uit Honthem, in: Grueles, 2(1989c), pp. 74-76.

HiL.LEFRS. H.P.M. Begrazing; van stal gehaald voor natuurbeheer, in: Natuur en Techniek. $58(1990) \mathrm{nr}$ 7'. pp. 572.585.

HILLEGER5, H.P.M. Bilzekruid in Limburg, in: Notuurhistorisch Maandblad, 88(199/a) nr 1.pp. 1.9 HILLEGER, H.P.M. Grensoverschrijdende milieuprojecten in de Euregio, in: Limburg: Milieu, (1991b) 


\section{nr 2, pp. 16-17.}

HiLLEGERS, H.P.M., De knotwilg in Zuidlimburgse toponiemen (manuscript).

HILLGERS, H.P.M. EN B. REUTEN, Het mergellandschaap, in: Natuurhistorisch Moandfblad, $72(1978)$ ni 9. pp. |2|-|4|

HOMMERICH, L, VAN EN F. WeLters, Gedenkbọẹ Voerendaal, Heerlen 1949.

HOueEN, C., Buchten: von toen en nu, Buchten !978, HUITENGA, T., Nederiands-Engels woordenboek voor landboumwetenschappen, Leiden 1976.

Inleiding tot de oecologie I onder red. van K. Bakker (et al.), Utrecht-Antwerpen 1985.

joarverslag onderzoek kalkgraslondproject / onder red. van P.J.M. van der Aart, Utreche 1984. (Rapport: Riiksuniversiteit Utrecht).

JACOBEIT. W. Schafhatung und Schäfer in Zentraleuropa bis zum Beginn des 20 jahrhunderts, Berlin 1987 . JANSEN, C.R., On the late-glacial and postglacial vegetation of South Limburg, in: Wentia, (1960), pp. 1.112 .

JANSEN, J.C.G.M., Landbouw rond Mastricht (1610-1865): en analyse van de exploitatie-uitkomsten van enige iosstbedrịven in halfwinning, in: Studies over de sociool-econsmische geschiedenis van Limburg, Xill(1968), pp. 1.98.

JANSEN, J.C.G.M., Jenever in opmars, 1650-1815. in: Compus Liber; bundel opstellen over de geschiedenis van Maastricht (Werken / uitgegeven door het Limburgs Geschied-en Oudheidkundig Genootschap; nr 8), Maastricht 1982a, pp. 273-298.

JANSEN, J.C.G.M., Heren en boeren in Limburg 1150-1800, in: Studies over de sociooteconomische geschiedenis van Limburg. Xxvi!(1982b), pp. 1-22.

JANSEN. J.C.G.M. EN W. J. M.J. RUTTEN, Geschiedenis van de landbouw in Limburg in de twintigste ceuw (Maslandse Monografieèn; of 52). LeeuwardenMechelen 1992

JANSEN. J.C.G.M. EN W. VAN DE 'WESTERINGH "Dat ging cyer zijn hout: overmatig gebruik van bossen in het zuiden van Limburg van de hoge middeleeuwen tot, in de 20 e eeuw, in: Studies over de sociaat economische geschiedenis van Limburg, XXVIH(1983), PP. 19.63.

JANSSEN DE LIMPENS, K.J.TH., De Noaberschap der Viflener Rotten, 1319-1940 ; rechtsgeschiedenis van een bosmark, in: Publications de la Société Historique et Archéologique dans le Limbourg. 109(1973). pp. 197-224

JANSSEN DE LIMPENS. K.J.TH., Rechtsbronnen van het Hertogdam Limburg en de Landen van Overmaze. Bussum 1976

JASPAR, E. Kint geer eur eige stod?, Maastricht 1968. JASPAR, E. (et al.), 750 joar parochie St. Geertruid. Maastricht 1972.

JASPARS, G., Groeselder diksjenèr, Gronsveld 1979. JONKERGOUW, A.E.L., Sittards oudste verieden. Sitard 1976.

De Kotholieke encyclopaedie / onder red. van J. Sassen, (deel 1-25), Amsterdam 1933-1939.

KATS.J.C.P. Remunjs woordebook, Roermond 1985. KEMPKENS, J. Oude veld. en plaatsnamen, in: Roerstreek, 7(1975), pp. 125-130.

KENGEN, A., Uit Geul's verleden, Sittard 1926.

KILIAEN, C., Dictionorium Teutonico-latinum, heruitgave, New York 1975. (Oorspr. uitg. Hildesheim 1588).

KNAEPEN, R., Lommel, de Vrijheid en het Teutendorp. Brussel 1972

KOENEN, M. EN]. ENDEPOLS, Verkdarend handwoor- denboek der Nederlandse taal, Groningen 1966. KORNECK, D., Beitrag zur Kenntnis mitteleuropaischer Felsgrusgesellschaften (Sedo-Scleranthetalia), in: Mitteilungen der floristisch-soziologischen Arbeitsgemeinschaft. N.F. (1975) nr 18. pp. 45-102. KRAUSCH, H.-D., Die Sandtrockenrasen. (SedoScleranthethea) in Brandenburg, in: Mitteilungen der fioristisch-soziologischen Arbeitsgemeinschaft. N.F. (1986) nr 13, pp. 71-100.

KREUTZ, C.A.J., De verspreiding van de inheernse orchideeèn in Nederiand, Zutphen 1987.

KREUTZ, C A.J.. Orchideeễn in Zuid-Limburg, Zutphen 1992.

KRINGS, W., Wertung und Umwertung von Allmenden im Rhein-Maas-Gebiet vom Spätmittelaiter bis zur Mitte des 19. Jahrhunderts (Maaslandse Monografieen; nr 20). Assen-Amsterdam 1976.

KROON, J.C.J.M. DE, In search of a foraging plant, the donal growth of Brachypodium pinnotum and Carex flacco, Utreche 1990.

KUYPER, I. Gemeenteatlas van Limburg, heruitgave, Maasbree 1981. (Oorspr. uitg. Leeuwarden 1869). LAENEN, M. Openluchtmuseum Bokrijk, Brusse! 1986.

Het Landschap van Zuid-Limburg / onder red. van S. Barends (et al.), Utrecht 1987.

LANGHE. J.E. DE (et al.), Flora van Belgiê, het Groothertogdam Luxemburg, Noord Frankrijk en aangrenzende gebieden, Meise 1983.

Longs de weg / onder red, van P. Stuart en M.E.Th de Grooth, Nuth 1978

LEBENS. J. (et ai.), Born, een koninklijk domein met een boeiend verleden, Beek 1978.

LEBRUN, J. (et al.). Les, associations végetales de Beigique, in: Bulletin de la Socièté Rayale de Bergique. 82(1949). Pp. 105-157.

LEEUWEN, C.HR.G. VAN, Het verband tussen naruurilike en anthropogene landschapsvormen, bezien vanuit de betrekkingen in grensmilieu's, in: Gorterio, 2(1965). pp. 93-105.

LejeUNE, A.L.S. Flore des environs de Spa, (2 delen). Liège 1811.1813

LEMMIERLING, L. Veldnamen in Schin op Geul, in: Geulrand, 5(1984), pp. 73-77.

LEMMERLING, L, Det vreuger jaore, volksleven en vollks cultuur in het mergelland, (deel [-10). Oirsbeek 1978-1985.

LENDERS, T., De Meinweg : een potentieel nationaal park, in: Roerstreek, 15 ( i983), pp. 18-43.

Limburg : Lannoo's provinciegidsen. Tielt 1986.

LINDEMANS, J., Toponymische verschijnselen, geografisch bewerkt (Nomina geographica Flandrica : studièn en monografieèn over Vlaamsche plaatsnaam. kunde. Studiên: V. 2). 's-Gravenhage 1946.

LINDEMANS, J., Het probleem dries, in: Mededelingen van de Vereniging voor Noamkunde te Leuven en de Commissie voor Noamkunde te Amsterdam, 27(1951), pp. 15-24.

LINDEMANS. J. Nogmaals het: probleem dries, in: Mededelingen van de Vereniging voor Noamkunde te Leuven en de Commissie voor Noamikunde te Amsterdam. 28(1952), pp. 89-90.

LINDEMANS, P.. De betekenis van de Vlaamse land. bouw in de XVle tot de XVIlle eeuw voor de landbouw in West-Europa, in: Landbouwgeschiedenis I uitgegeven door het Ministerie van Landbouw en Visserij, hoofdafdeling documentatie en publicatie. is-Gravenhage 1960, pp. 97-106.

LONDO, G., De decimale schaal voor vegecatie opnamen van permanente kwadraten, in: Gorterio.
7(1975) nr 7, pp. 10 i-106.

LuX, G.V., Rosmeer door de eeuwen heen, Rosmeer 1982.

Mabelis, A., Mieren van de St. Pietersberg, in: Euglena : kontaktblad van de jeugdbond voor natuurstudie en milieubescherming, $\mathbf{6}(1987)$ nr 2, pp. 32-35. MAELEN, PH. VANOER, Dictionnoire géograp̣hique du Limbourg (Maaslandse Monografieèn; nr 25). Assen-Amsterdam 1978. (Oorspr. uitg. Brussel 1835).

Man's impact on vegetotion / onder red, van W. Holzner, M.j.A. Werger and I. Ikusima, Den HaagBoston-London 1983.

MANSION, J. De voornaamste bestanddelen der Vlaamse plaatsnamen, Brussel 1935.

MAST, G. VAIN DER, Tien jaar aktief natuurbeheer in de Brunssummerheide en Schinveldse Bossen, Maastricht 1983. (Uitg. Natuurhistorisch Genootschap in Limburg).

MELTZER, J. EN V. WESTHOFf, Inleiding tot de plantensociologie. '5-Graveland 1944.

Meltzer, J., F. Stafleu en V. Westhoff, Onze droge grasionden, Utrecht 1940.

MERKEN, M., Veldnamen in Bemelen, in: Parochieblad "De Tump", Bemelen ( 986 ). (Gestencilde uitgave).

MEulemans, M., Straat- en veldnamen uit het oude Oirsbeek, in: Het Land van Herle, 4(1954) nr 3. pp. 67.68.

MOLEMANS, ]. EN ]. MERTENS, Zonhoven : historischnoamkundige studie, Zonhoven-Leuven 1982.

MOLEMANS. J. EN J. MERTENS, Opglobbeek : een rijk verleden, Tessenderlo 1984.

Molemans, I. EN E. Paulissen, As, in het yerleden. Tongeren 1976.

MOLEN, $H$. VAN DER: (et al.), Omstreden landbouw, Utrecht-Antwerpen 1987 .

Morreau, L.J.: Die. Yseren stodi Moestricht : uit de geschiedenis, van Nederlands meest befcumde vesting. Maastricht 1974.

MULDER, T. EN J. CORTENRAAD. Beekdalplanten in Zuid-Limburg; stand van zaker, en perspectieven, in: Notuurhistorisch Moandblad, $79(1990)$ nr 3/4, pp. 27-14.

MUNSTERS, A., De souvereiniteit van de Graetheide, in: Historisch jaarboek: voor het Land von Zwent:bold. 7(1986). pp. 58-88.

Notuurbeleidsplan: Regeringsbeslissing, Handelingen Twẹe Kamer der Staten-Generaal, vergaderjaar 1989-1990, 21 149, nr 2-3.

Het Nederiandse landschap : een historisch-geografișche benadering / onder red. van S. Barends (et al.). Utrecht 1986.

NIEUWENHUIZEN, K.., Zuid-Limburg in 19 e eeuwse foto's, Amsterdam 1977.

NISSEN, P.., De straten van Linne en hun namen, in: Roerstreek, 9(1977). pp. 53-66.

Notren, J.G.M., De Chinezen van Nederland, Valkenburg 1974 .

NOTTEN, J.G.M., Namen noemen in Broekhem, in: Geulrand, 1 I (1985), pp. 78-81.

Ons eigen land : uitgegeven door den ANWB toeristenbond voor Nederland ter gelegenheid van zijn viffentwintig joar bestoon, Dordrecht 1908.

Ontdek het Mergelland / onder red. van P.J. van Nieuwenhoven, Amsterdam-Hilverșum 1978.

OREMUS.J.M.S. Processen rond het weiderecht op het Stadbroek te Sittard, in: Historisch joarboek voor het Land von Zwentiboild, 7(1986), pp. 113-123.

OS. F.H.L. vAN, Gids voor geneeskrochtige planten, 
Amsterdam-Brussel 1988

PALEOW, M. Handboek van geneeskrochtoge kruiden, Helmond-Antwerpen 1980

Peuzens, E, fH. DE RIX EN J.M.B. Thissen, De verspreiding van haarwild in Limburg in de tweede helft van de negentiende eeuw, in: Notuarhistorisch Moandblad, 75(1986) nr 10, pp. 192-196.

PETESON, RT, G. MOUNTFORT EN P.AD. HOLLOM, Vogelgids, Amsterdam-Brussel 1964.

PHILPPENS. H.J. Houthems verieden, Eygelshoven 1983.

PAll.ex.J.F.R.J.C.G.M.JANSEN EN TH.JA.H. ClaEsSENS. Geschiedenis van de landbouw in Limburg 1750 1914 (Masalandse Monografiețn; nr 4), Assen 1964.

PINCKAERS. J., Brave Hendrik (Chenopodium bonus-henricus L), cen verdwipnende soort?. in: Notuurhistorisch Moandblod. 72(1983) nr 10/11. pp. 233-235

POLuNin. O.. Bloemen en planter van Europa, Wageningen 1970

Pruns, H.H.THL, De ontwikkeling van grasiandvegetobes in Noordwest-Europo, Groningen 1988. (Doctoral verslag van het $L a b$, voor Plantenoecologie van de R.U, Groningen)

Purs, C., Montogne St. Pierre, refuge noturel, Vise 1984. (Edition de l'échevinat de l'environnement de Vise).

QUDX, CHR, Beitroege zu einer historisch-topografscher Beschreibung des Kreises Eupen, herdr.. Aachen 1978. (Oorspr, uitg. Aachen 1837).

RAEVEN, L, Veldnamen in de voormalige gemeente Hulsberg, in: Geulrond, 2(1984a) nr 7, pp, 61 -63. RAEVEN, $L$, Veldnamen in Aalbeek en de Heek, in: Geulrand, 2(1984b) nr 8, pp. 95-97.

RAEVEN, L. Veldnamen in. Berg en Geulhem, in: Geulrand, 3(1985) nr 12. pp. 51-52

RANG, M.C., De ongewilde effekten van de meststoffen AMvB op de nitraatuitspoeling in het Mergelland, in: H2O, 19(1986) nr 23, pp. 552-556.

RENES, J.. Typologieèn van bewonings- en perceelsvor. men. Wageningen 1982

RENES, ].. West-Brabant : een cultuurhistorisch landschapsonderzoek, in: Bijdragen tot de Studie von het Brabants Heem, 26(1985).

RENES, J. De geschiedenis van het Zuidlimburgse cultuuriandschop (Maaslandse Monografieën, groot formaat: $n$ r 6). Assen-Maastricht 1988

RENES, J. Cultururlandschap en historisch-landschoppeligke woarden in het herinrichtingsgebied Mergetland-Oost (Staring Centrum Wageningen: rapport $\mathrm{nr}$ 3), Wageningen 1989.

RENES; J.. Het cultuurlandschap in MergellandOost, in: Natuurhistorisch Maandblad, 83(1993) nr 1. pp, 3-27

ROEBROECK, E. Een Midden-Limburgs pachtcontract uit 1695, in: Studies over de sociool-economische geschiedenis van Limburg, Xvul(1973). pp. 33-53.

ROEBROEKS, W.. Oermensen in Nederiand : de archeologie van de oude steentjj. Amsterdam 1990. ROMPAEY, E VANEN L Deivosalif, Atlas van de Betgische en Luxemburgse floro. Meise 1979

ROSENER, W. Bovern im Mittelalter, München 1985. ROTHMALER, W_ Excursionsflora für die Gebiete der DDR und BRD, Berlin 1976

Ruilverkaveling Mergelland : voorontwerp / uitgave Landinrichtingscommissie, Roermond 1991.

RuiteN, J. Het "Scurte Campken" te Asenray, in: Roerstreek, 17(1985), pp. 166-177.

RUNGE, F. Die Pflanzengesellschoften Mitteleuropos.
Aschendorf 1986

Sudeen, T. Schin op Geul in oude ansichten, Zaltbommel 1985 .

SAumaNr. J.H. Hoensbroek in oude ansichten, Zaltbommel 1972 .

SALVETI. F. De Beenhouwersstroot, het viees en het ombocht doorheen tijden en kulturen, Tiek 1985

SAnDers, $\mathrm{H}$., Oude toponiemen in de gemeente Venray, in: De Bronk, 9(1961/1962). pp. 89.90.

SANGERS. W. (et al), Roosteren, wie het reilde en zeil. de. Beek. 1980

SCHAIK, D.C. vaN, De Sint Pietersberg: met een oan. vullend gedeelte 1938-1983. Thom 1983.

SCHAMineE, J.H.j. EN M.G.H. BONGERS Vochtige hooilanden langs de Mechelderbeek (Zuid-Limburg) : een plantensociologische en landschapsoecologische beschouwing. in: Notuurhistorisch Moondblad, 80(1991) nr 7/8. pp. 125.135.

SCHAMINEE, J.H.J. A. STOHTELER EN V, WesthoH, De identificatie en classificatie van plantensociolo. gisch onverzadigde gemeenschappen, in: Strotiotes. 2(1991), pp. 42-52.

SCHEL aEgG, PJ.G. Woordenboek van het Sittarch dialect. Amsterdam 1979

SCHENKEVED, A.J.M EN H.JPA. VERUAar, On the ecology of short tived forbs in chalk grasslands. Utrecht 1984.

SCHOBBen, FX. Groenstrod en de Groenstroters in vroeger dagen, Nieuwenhagen 1958.

SCHOPHAU5, R. Niederdeutsche Bezeignungen der Binse, in: Niederdeutsches Wort, 6(1966), pp. 77.100 .

SCHAJNEMAKERS, A. Munstergeleen, een monogrofie over een Limburgse gemeente, Maastricht 1965 SCHRIJNEMAKERS. A., Nederlands-Limburgse nederzettingsmamen (deel $\mathrm{XX}$ ), in: Veldeke, 57(1982), no 6. pp. 20-26

SCHRJNAMMAKERS, A., De Groenseykerstraat en de Tomeikerweg, in: Tijdschrift Heemkunde Geleen, (1983) nr 1.pp. 7.11.

SCHRUNEMAKERS, A., Uit de nederzettingsgeschiedenis van Krawinckel, in: Tijdschrift Heemkunde Geleen, (1 984a) nr. I. pp. 36-48.

SCHRJJNEMAKERS, A., Rode, de oudste nederzettingsgeschiedenis van her land vari Rode. Maastriche $1984 \mathrm{~b}$

SCHRJJNEMAKERS, A., De verklaring van Wolf-toponiemen, in: Naamkunde : mededelingen van het Instituut voor Noamkunde te Leuven en van het P.J. Meertensinstituut te Amsterdam, 18(1986) aff. 1-4, pp. 77 . 102

SCHUMACHER, W. Flora und Vegetation der Sötenicher Kalkunulde (Eifel), in: Decheniana, Beihefte 19(1977).

SimONIS, A.H. Historisch boeket. Sittard 1975

SissingH, G., Oniknuid-associaties in Nederland', 'sGravenhage 1950.

SLENTER, J., Enige gegevens over het staller. van vee. in de Heerder-en Keerderberg in: 5.O.K.Medede. lingen, (1984) nr 4, pp. 17-20

SLICHER VAN BATH, B., De ograrische geschiedenis van West-Europo, 500-1750. Utrecht-Amsterdam 1960.

SMEETS. F. TH. Limbricht in oude onsichten. Zaltbommel 1971 .

SMIDT, J. DE, De Nederlandse heidevegetoties (Wetenschappelijke Mededelingen van de Koniniclipke. Nederlandse Natuurhistorische Vereniging: $n r$ 144). Amsterdam 1981

SPIERTS, H.). Nieuwenhagen, in: Het Lond von Her. le:jublicumboek 1950-1960, Heerlen 1961, pp. 157. 174

STALLAERT, K.. Glossarium wan verouderde rechtstermen, kunstwoorden en andere uitdrukkingen, (deel 1. 3), Leiden 1890-1977.

STARiNG, W.H.C. De bodem wọn Nederiond, (deel 1.2). Haarlem 1856-1860.

STARING, W.H.C., Voormoals en thans : opstellen over Neerlands grondgesteldheid. Zwolle 1858.

STAkING, W.H.C., Schoolkoart woor de notuurkunde en de volksvijt van Nederland (15 kaarten en legenda), Rotterdam s.a. (Facsimile-uitgave, gereproduceerd naar origineel van 1860 ).

STAUING, W.H.C, Voormools en thans: opstellen over Neerlands grondgesteldheid (2e druk, bewerkt door F. van Pesch), Zwolle 1878

STrEGH, A. TH.. Monumenten atlos van Nederland, 2 e druk, Zutphen 1985

STEVENS. J. (et al.), Holle wegen in Limburg. Rekem 1987.

Suddeutsche Pflanzengesellschaften, (Teil II) / onder red van E. Oberdorfer (et al.), 2e druk, StuttgartNew York 1987

SVENSON, R. EN M. WiGheN, Hiartstillans histora och biologi i Sverige, in: Svensk Botanisk Tidskrift. 78(1987), pp 263-276.

STKORA, K.V. EN V. WESTHOF, Droge stroomdal. grasianden langs Maas en Niers, in: Gorterio, $9(1987) \mathrm{nr}$ 10. pp. 334-341.

Symposium kalkgrastanden : beheren voor de toe. komst, in: Publicaties van het Notuurhistorisch Genootschap in Limburg, reeks XXXIII (1983) aff. 1-2. THitL. A. Lo flore et la vegetotion au Porc National de Lesse et Lomme (Ardenne ẹt Gaume: monographie nr 5), Bruxelles 1964

THUNEN, J.H. VON, Der isolierte Staat in Beziehung ouf Landwirtschaft und Nationalokonomie (Sammlung sozialwissenschaftlicher Meister; 13), 2e druk, Jena 1921. (Oorspr, uitg. Rostock 1842).

THURzOVA, L. (et al.), Elzeviers gids van geneeskrochtige kruiden; Amsterdam 1984

Tis ol vont Vercken, cotologus von de kunst- en docu. mentaire ientoonstelling over vee en vlees : jubileum. uitgove yan de Antwerpse verenigingen voor vee en viees / onder red. van A. Linters, Antwerpen 1988. TOOREN, B.F. VAN, The ecological role of the bryophyte layer in Dutch chalk grasslands, Utrecht 1989. TUMMERS, P.L.M., Romoans in Limburgse oardrijkskundige namen. Assen 1962.

TUPAN, H.R., De Drentse scheper, Assen 1985.

Tumin, T. (et al.), Floro Europaea, (deel 3), Cambridge 1972

VEEN, P.A.F. VAN, Etymologisch woordenboek, Utrecht-Antwerpen 1989

VENIE, J.M. VAN DE. Gedenkboek van Eygelshoven, Maaseriche 1931.

VENNE, J.M. VAN DE, Geschiedenis van Heer, Maastricht 1957 .

VERA, $F_{4}$ De Oostvoardersplassen : van spontone notuuruitborsting: tot gerichte notuurontwikkeling. Weert 1988.

VERDAM, J.. Middelnederionds hondwoordenboek. Den Haag 1976.

VERVLOET. A. A. Inleiding tot de historische geogrofie van de Nederlandse cuituurlandschoppen, Wageningen 1984.

VERVLOET, J.A.J., Het "Waldviehbauerntum": commentaar bij een opmerkelijke uitspraak, in: Historisch Geogrofisch Tijdschrift. 3(1987), pp. I! 7-119. VERWIJ, E, J. VERDAM EN F.A. SLOETT, Middeineder- 
lands woordenboek, (deel 1-16), Den Haag 18551941.

VINK, A.P.A., Landschopsecologie en landgebruik, Utrecht 1980.

VOS, A. DE, Het toponiem Dries te Evergem, in: Mededelingen van de Vereniging voor Naamkunde te Leuven en de Commissie voor Noamkunde te Amsterdam, 28(1952), pp. 53-56.

VRIES, J. DE, Etymologisch woordenboek, Utrecht.Antwerpen 1958.

VRIES, J. DE, Nederlands etymologisch woordenboek, Leiden 1971.

VROMEN, W. ., Uit Schinveld's verleden, in: Het Land von Herle, 17(1967) nr 2. pp. 33-36.

VROMEN, W. J. Hillensberg, in: Het Land van Herle, 22(1972) nr 2, pp. 57.59.

WATTEZ, J.-R. Groupements sabulicoles pionniers des carrières de la partie occidentale du nord de la France, in: Colloques phytosociologiques, vi(1977), pp. 283-318. (VI: La vigétation des pelouses sèches a therophytes).

WEBB, D.A. An Irish floro, Dundalk 1977.

WEEDA. E.J. (et al.), Nederiandse oecologische floro. (4 delen). Deventer 1985-1991.

WEt.TERS. A., Bijdrogen tot de geschiedenis van de parochie Echt. Maastricht 1923.

WELTERS, A., Bijdragen tot de geschiedenis von Echt. Maastriche 1926.

WELTERS, A., Uit Volkenburgs verieden, Valkenburg 1968.

WESTERINGH, W, VAN DE, Radebrikgronden in löss onder oud bos in Zuid-Limburg, in: Notuurhistorisch Moondblod, 78(1981) ar 10, pp. 165-170.

WESTHOFF, $V_{\text {, }}$ Uitweiding over een inweiding, botanische herinneringeri aan het Gool, in: De Levende Notuur, 69(1966), pp, 25-36.

WESTHOFF, $V$, EN A.J. DEN HELD. Plantengemeenschappen in Nederland, Zutphen 1975.

WESTHOFF, V. (et al.), Wilde planten, (3 delen), Deventer 1970-1973.

WEStREENEN, F.S. VAN. De geschiedenis van de onderaardse kalksteengroeven, in: S.O.K.Mededelingen. (1988) nr 12. pp. 4.32.

WEVER, A. DE, Lijst van eenige wildgroeiende en gekweekte planten in Z-Limburg, in: Jaarboek van het Notuurhistorisch Genootschap Limburg, $10(1918)$. pp. 49-91.

WILLEMS. J.H. Limestone grassiands in North.West Europe, Utrecht 1980.

W!LLEMS, J.H. Het Brachypodio-Sieglingietum Will. et Blanck. 1975 in Zuid-Limburg, in: Gorteria. 1 (1982) ni I.pp. 14-21.

WiLEMS.J.H., Het belang van het voortbestaan van de Zuidlimburgse kalkgraslanden, in: Publicaties van het Natuurhistorisch Genootschap in Limburg, reeks XXXm(1983) afl. 1-2, pp. 2-9.

WILLEMS. J.H. Ons knijtand Zuid-Limburg. (deel vi) (Wetenschappelijke Mededelingen van de Koninklijke Nederlandse Natuurhistorische Vereniging: ni 184). Utreche 1987\%. (DI. vr: Kalkgrasland in ZuidLimburg).

WILLEMS, J.H. EN F.G. BLANCKENBORG, Kallkgraslandvegetaties van de Sc. Pietersberg ten zuiden van Maastricht, in: Publicaties von het Natuurhistorisch Genootschop in Limburg, reeks xxv(1 1975) aff. I. pp. 1-24.

WILLERDING, U., Zur Geschichte der Unkrauter Europos, Neumünster 1986.

WOLKINGER, F. AND S. PLANK, Dry grassiands of Europe (Nature and Environmental series; nr 21).
Strasbourg |98|.

WIIST, M.A. VAN DER, Een kijkje in enkele boerenbedrịven in Hoensbroek omstreeks 1835, in: Het Land van Herle, 35(1985) nr 2. pp. !23-135.

IJSSELING, M.A. EN A. SCHEYGROND, De zoogdieren van Nederland, Zutphen 1950.

ZONNEVELD. J.I.S., Levend land: de geografie van het Nederlandse landschap, Utrecht-Antwerpen 1985. 


\section{LIJST VAN KAARTEN}

De onderstaande lijst van karten, die toponiemen vermelden, is chronologisch gerangschikt. Elke kaart of serie van kaarten is voorzien van een tussen haakjes geplaatste afkorting, die in de meeste gevallen uit drie letters bestaat. Deze letterafkortingen komen tevens voor achter de toponiemen die in de bijlagen worden vermeld.

\section{(Fer) FERRARISKAART}

Carte de cabinet des Pays-Bas autrichiens, levée a l'initiative du comte de Ferraris (1771-1778), deel 1-12, schaal 1:11.520, uitgegeven op schaal 1:25.000 door de Koninklijke Bibliotheek van Belgie en het Gemeentekrediet van Belgie,, Brussel 1965

\section{(Tra) TRANCHOTKAART}

Kartenaufnahme der Rheinlande durch Tranchot (1803-1813) und Von Múffling (1816-1820) mit Ergănzungsblättern 1826-1828, schaal 1:20.000, uitgegeven op schaal $1: 2.500$ door het Landesvermessung. samt Nordirhein-Westfalen, Bonn 1968.

\section{(Hal) GROTE HiSTORISCHE. ATLAS VAN NEDERLAND}

Deel 4, Zuid-Nederland 1838-1858, schaal I:50.000. Groningen 1990.

\section{(KuY) KUTPERKAARTEN}

Gemeente-atlas van Nederland, deel II. Limburg, opgenomen door J. Kuyper in de periode 1860-1865, zonder schaalvermelding. Leeuwarden, herdruk Maasbree [1981].

\section{(TOP) TOPOGRAFISCHE ATLASSEN}

Chromotopografische Kaart des Rijks, opgenomen in de periode 1890-1924, deel II, Limburg, schaa! 1:25.000, heruitgave, Den Ilp 1989.

Grote topografische Atlas vari Nederland, deel 4, Zuid Nederland, schaal 1:25.000, met register, Groningen 1987.

(Str) STROOMKAARTEN

Verzarneling kadastrale kaarten van Zuid-Limburg en omgeving uit de periode 1910-1920, aangevuld met aantekeningen door de landmeter Stroom, aanwezig in het archief van het Sociaal Historisch Centrum te Maastricht.

\section{(Top.2) TOPOGRAFISCHE KAART}

Blad 60 D. Hoensbroek, schaal 1:25.000, uitgegeven door de Topografische Dienst. Delft 1968.

\section{(Top) TOPOGRAFSCHE KAART}

Topografische kaart van Zuid-Limburg, uitgegeven door de Topografische Dienst, schaal 1:50.000, Delft 1980.

\section{(A.A) AUTO ATLAS}

Auto atlas van Limburg. Roermond 1983. (Omvat alle plattegronden van Zuidlimburgse nederzettingen met straatnamen).

\section{(SAB) STRATENATLAS VAN BELGIE}

Deel I, Limburg, Antwerpen-Utrecht 1984.

\section{(SAN) STRATENATLAS VAN NEDERLAND}

Deel 5, Limburg. Antwerpen-Utrecht 1986.

\section{(Geo) GEOLOGISCHE KAART}

Zuid-Limburg en omgeving, uitgegeven door de Rijiksgeologische Dienst, afd. Kartering, schaal I:50.000, Haariem s.a.

(Kad) KADASTRALE KAARTEN

(KaN) KADASTRALE KAART VAN DE GEMEENTE NUTH Archief Gemeente Nuth.

(KaW) KADASTRALE KAART VAN DE GEMEENTE WITTEM Archief Staatsbosbeheer Maastricht. 


\section{TOELICHTING}

Dit deel omvat het basismateriaal van deze studie. Voor deel I, de hoofdstukken I tot en met: 7, bestaat dit uit toponiemen, die eerst in tabellen zijn gerangschikt. Het eerste ciffer van elke tabel komt overeen met het betreffende hoofdstuknummer. De overige cijfers in de tabellen zijn volgnummers. Achter elk toponiem staat de naam van de gemeente of de nederzetting waar het toponiem voorkomt en een letterafkorting van drie letters. Dit zijn de eerste drie letters van de auteur van het werk, waarin het betreffende toponiem wordt vermeld.

"Den Dreef/ Borgharen / Str" betekent dus, dat het toponiem "Den Dreef" voorkomt in de (voormalige) gemeente Borgharen en dat het werd vermeld door Stroom. Een alfabetisch gerangschikte lijst van auteur-afkortingen wordt hieronder vermeld. Wanneer een auteur ontbreekt, wordt de titel van het boek, waarin het betreffende toponiem wordt aangetroffen, afgekort met de dric eerste letters van de titel. In deze gevallen zijn de letters in kapitaal weergegeven.

\section{LIJST VAN AFKORTINGEN}

Liist van afkortingen van de bronvermeldingen in de tabellen van de hoofdstukken I tot en met 7 .

De trefwoorden achter het $=$ teken hebben ofwel betrekking op de auteur van het werk. waarin het betreffende toponiem wordt vermeld en het jaar waarin deze publicatie is verschenen ofwel wordt een andere bron (meestal een kaart) genoemd, waarin het toponiem voor komt. De literatuurlijst of de lljst van kaarten vermelden de bron in detail. Achter de komma wordt de naam vermeld yan een gemeente of een topografisch groter gebied, waarin het toponiem werd aangețroffen,

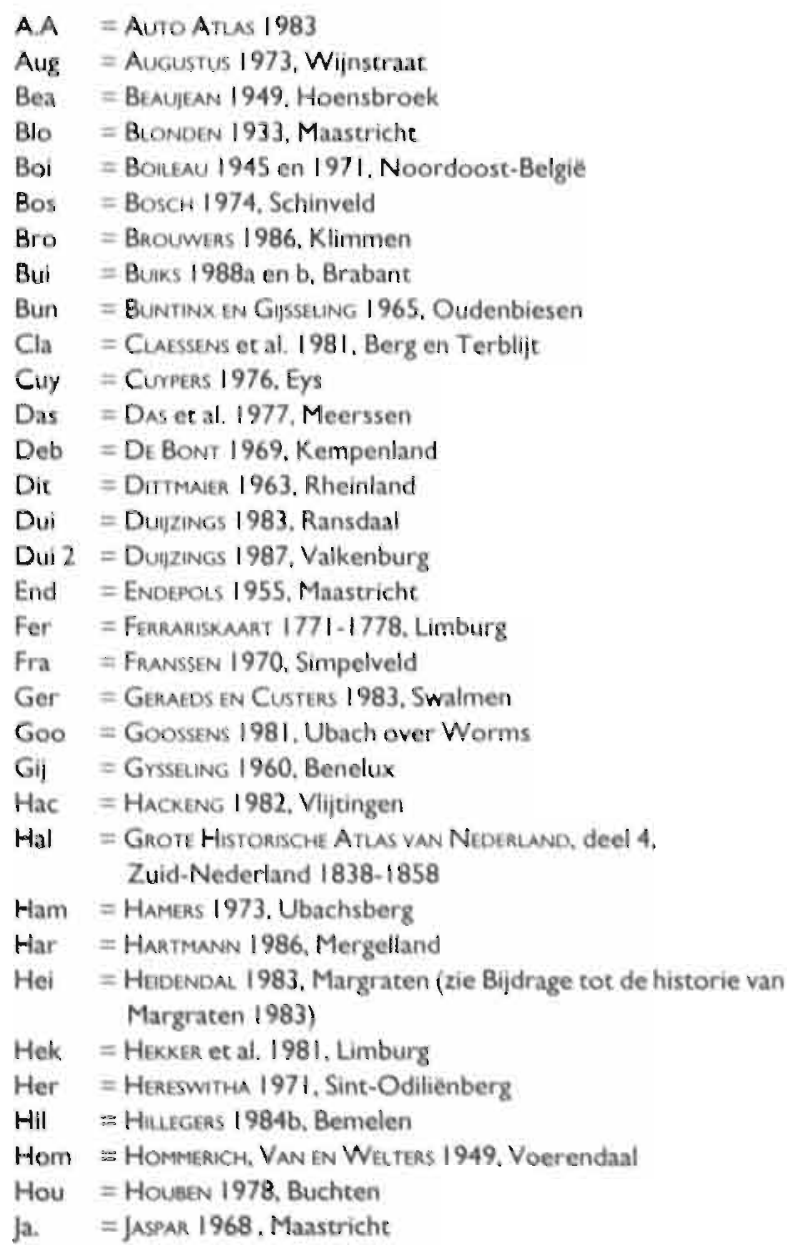

Jas = Jaspars 1979, Gronsveld

Jon = JONRERGOUW 1976, Sittard

$\mathrm{Kad}=$ KADASTRALF KAARTEN LUMBURG $1930-1950$

Kem $=$ KeMPRENS 1975. Posterholt

Ken = KENGEN 1926, Geulle

KuY = KuYPER 198I, Limburg

Leb = LeBens et al. 1978, Born

Lem = LeMMERLing 1984, Schin op Geul

Lin = LiNDEMANS 1946. Vlaanderen

Lux $=$ Lux 1982, Rosmeer

Mer = MeRKEN 1986, Bemelen

Meu = Meulemans 1954, Oirsbeek

Nis = NisSEN 1977, Linne

Phi = PHiluppens 1983. Houthem

Qui = Qux 1978, Eupen

Rae = RAEVEN 1984a, Hulsberg

Ren = RENes 1993, Mergelland-Oost

Ren 2 = ReNes 1985, West - Brabant

SAB = StratenatLas VAN Bel.Gie | 984, Limburg

Sal = SAUMANS 1972, Hoensbroek

SAN = Stratenatlas VAN NEDERLAND 1986, Limburg

San = SAnGers et al. 1980. Roosteren

Sand = SANDERS 1961/1962, Venray

Sche = SCHELBERG 1979, Sittard

Schr = SCHRINEMAKERS 1965, Munstergeleen

Schr 2 = SCHRINEMAKERS 1984b, Rode

$\operatorname{Sim}=$ SimoNis 1975, Sittard

Sme = SMEETS 1971 , Limbricht

Spi = SPERTS 1961, Nieuwerhagen

Sta = Stallaert 1890-1977, Nederland

Str. = STROOMKAARTEN 1910-1920, Zuid-Limburg

TOP = TOPOGRAFISCHE ATLAS VAN LIMBURG EN ZUID-NEDERLANC

TOP = TOPOGRAFISCHE KAART YAN ZUIO-LIMBURG 1980

Tra = TRANCHOTKAART $1803-1813$

V.B $=$ VAN BOMMEL 1976, Maastricht

V.E = VAN ERMEN et al. 1985, Limburg

V.H = VAN HASSET EN SANGERS 1957, Wessem

v.H = VAN Heukelom 1939, Kanne

Vro = VROMEN 1972, Hillensberg

$V . V$ = VAN DE VENNE 1957, Heer

V.V2 = VAN DE VENNE 1931, Eygelshoven

Wel = WETERS 1923. parochie Eche

Wel $2=$ WELTERS 1926, Echt

Wel $3=$ WELTERS 1968. Valkenburg

$W_{\text {II }}=$ VAN DER $_{\text {WIST }}$ 1985. Hoensbroek 


\section{TABELLEN}

\section{Heide-toponiennen}

\section{TABEL}

\section{HEIDE-TOPONIEMEN}

Deze abel geeft een lipst van 67 heide-toponiemen, gelegen in Zuid-Limburg en buiten het gebied van de Graetheide en de Brunssummerheide, waarvan de begrenzing op de Tranchotkaart wordt weergegeven. De betreffende heide-toponiemen worden in detail gelokaliseerd op de figuren 9.2 .1 tot en met 9.2 .9

Plateaurandheiden van het plateau van Sint-Pleter

1. Sint-Pieters- / Fer / Sint-Pieter

2. Kanner-/Str/Kanne

Plateaurandheiden van het plateau van Margraten

3. Reurkens - / Str / Eijsden

4. Mescher-/Ser/Mesch

5. Maerlanter-/Tra/Maarland

6. Breuster-/Tra/Breust

7. Tak-/Tra/Mheer

8. Banholter-/Top/Banholt

9. Grote-/5tr/Sint-Geertruid

10. De- $(=$ Bemeler- $) /$ Hil $/$ Bemelen

11. Plat-/Hill / Bemelen

12 't Hetie/ Hil / Bemelen

13. Roother-/Str/'t Rooth

14. Pape-/Hill/Margraten

15. Kleine-/TOP/Terblijt

16. Grote- $/ \mathrm{Cla} / \mathrm{Berg}$

17. Ambyer-/Tra/Amby

18. Rothernmer-/Str / Rothem

19. Meerssener-/Tra/Meerssen

20. Geulhemmer-/Str/Geulhem

21. Berger-/ Cla/Berg.

22. Grote- $/ \mathrm{Cla} /$ Berg

23. Vilter-/Tra/Vilt.

24. De grote-/Str/Sibbe

25. Koervers-/Str/Sibbe

26. Laam-/Str / Gerendal

27. De lieg-/Lem/Strucht:

28. De hoeg-/ Lem / Strucht

29. Ingber-/Str/lingber

30. Reijmerstokker-/Str / Reijmerstok

31. Koe- / Str / Hoogeruts

32. Banholter-/Str / Banholt
Heiden van het plateau van Landsrade

33. Hoebender-/Tra / bij (het verdwenen gehucht) Houbender(straat)

34. Crapoels-/Str/Crapoel

35. Heijenrath / TOP/bij Slenaken

36. Eper-/TOP/Epen

37. Looker-/Kad/Landsrade

Heiden van het plateau van Vijlen

38. Cottesser / Str / Cottessen

39. Achter de- / Ren / Wolthaag

40. Folbers-/Ren/Mamelis

Heiden van het plateau van Bahneheide

41. Bocholtzer - / TOP / Bochholta

42. Bane-/TOP/Bahneheide

43. Linkens - Fra / Simpelveld

Heiden van het plateau van Ubachsberg

44. Eyser-/TOP/Eys

45. Ribbel-/Str, SAN/Ubachsberg

46. Rijvel-/Su/Ubachsberg

47. Vrouw-/ Ham/Ubachsberg

48. Moor-/Str/Elkenrade

49. Kleine-/Ren/Benzenrade

50. Hooghees-/Tra/Benzenrade

51. Poschkens-/Ren/Huk

52. Spelcholzer-/TOP/Spekholz

53. Kahl-/TOP/Spekholz

Hẹidẹn van het plateau van Rode

54. Bleijer-/TOP

55. Chèvremonter-/St:

56. Pannes-/TOP/Horbach

57. Heyde/Hal/Horbach

58. Forster-/TOP/Ursfeld

Heiden van het plateau van Schimmert.

59. Heiveld / SAN / Bunde

60. 't Hetie/Das / Raar

61. Heiland/Str/Ulestraten

62. Pere-/SAN/Schimmert

63. Schutte-/Str/Klimmen

64. Heijhof/ Hal / Hulsberg

65. Hetteken/ Hal/Spaubeek

Heiden van het plateau van Doenrade

66. Thuller-/Str/Thul

67. Heiberg/Str/Amstenrade 


\section{Heerdgang-indicatieve toponiemen}

Overzicht 2.I Veeverzamelplaatsen, 2.2 Veedriften (primaire en secundaire), 2.3 Beweide territoria, 2.4 Valders en andere veekeringen, 2.5 Oriëntatie- en rustpunten, 2.6 Drenken.

\section{TABEL 2.I VEEVERZAMELPLAATSEN IN NEDERZETTINGEN}

Toponymisch aanwijsbaar als "dries" in de nederzettingen Catsop. Colmont, Holtum (zie hoofdstuk 2) en als "bies(t)" in Berg, Gemmenich, Heythuysen, Moelingen, Schimmert, Schinveld en Sint-Martens-Voeren (zie hoofdstuk 3). Kartograîsch aanwijsbare driehoekige, spoelvormige of smal rechthoekige dorpspleinties in de nederzettingen (volgens de Tranchotkaarten): Arendsgenhout, Banholt. Bahneheide. Cadier en Keer, Heijenrath, (volgens de Kuyperkaarten): Guttekoven, Bergenhuizen, Bochholtzerheide, Eygelshoven, Groor Haasdal, Vroelen en (volgens kadastrale kaarten) Trintelen (Cuy). Ikonografisch aanwijsbare dorpspleintjes met toebehoren in Heer (Hek) en Frimersum (Hek).

Het toponiem "maar" of "meer", in de betekenis van een grote poel op een dorpsplein, is eveneens indicatief voor een dorpsplein. Maar-toponiemen worden vermeld in tabel 4.1.

\section{TABEL 2.2.1 \\ PRIMAIRE VEEDRIFTEN}

Uit het toponiem is de (voormalige) heerdgang direct afleidbaar

Collectief-aanduidingen. Den Dreef / Borgharen / Stri Herderstraat / Echt / SAN, Schepersweg / Herten / SAN, Schepersweg / Ubachsberg/ Ham, Schepersgats/Stein/SAN. Heggerdrift/Schinnen (Hegge)/SAN.

Veeroutes. Veewegen of -straten komen momenteel (zie SAN) voor in de gemeenten Sittard, Meerssen, Geleen, Beek, Landgraal (Ubach over Worms). Valkenburg (Berg)، Schinnen. Schin op Geul, Stein (Nattenhoven), Herten. Ubachsberg. Elsloo, Onderbanken, Linne, Sint-Odiliënberg en Montfort Heerdstraat / Echt / SAN; onder de talrijke "Heerstraten" of "Heerwegen" schuilt mogelijk nog een aantal afgesleten "Heerdwegen" (heerd = kudde). Dit vereist nader onderzoek

Voor Biesroutes $($ Bies $=$ biest $=$ koe $)$ vergelijke men hoofdstuk $\mathbf{3}$.

Koewegen en hun synoniemen. Koewegen of -straten komen momenteel (zie SAN) voor in de gemeenten Valkenburg (Terblijt). Landgraaf (Schaesberg). Schinveld, Obbicht, Maastricht, Stein (Meers en Nattenhoven). Hoensbroek, Kerkrade. Born, Eijsden (Rijckhole), vroeger onder andere ook in de gemeenten Bochholtz / Fra, Schinnen (Puth) / Str. Eygelshoven / Str. Gronsveld / jas. Maarland / jas. en Heugem / Str. Synoniemen zijn: Koedreef/ Amby / Str. Rindergats/Vaals (Wahlwiller) / SAN, Kalverstraat/Wahlwiller/Str. Kaversjtraot / Gronsveld / Jas. Pinckenstege / Berg en Terblijt / Cla, en Koevaart/ Elsloo / SAN.

Overige "vee + weg"-toponiemen: Schaapsweg / Schinnen (Puth) / Str. Schaapsweg / Sint-Odiliënberg / SAN. Schaapsweg / Vlodrop / SAN. Geitenweg / Nuth/SAN. Mettestraat/Hoensbroek/SAN. Paardsweg/Brunssum / SAN, en Gansbaan / Meerssen / SAN.

\section{TABEL 2.2 .2 SECUNDAIRE VEEDRIFTEN}

Uit de naam is indirect de heerdgang afleidbaar. Onder deze categorie vallen de Mestwegen (zie hoofdstuk 6). "Holle" en "brede" wegen zijn door hun kenmerkend profiel en breedte ideale veedriften. Beide wegtypen zijn in toponiemen vastgelegd, maar in het kader van deze studie niet nader onderzocht

Haag-toponiemen; niet alle toponiemen waarin het element "haag" is opgesloten, duiden op een veekering. Mogelijk heeft een aantal betrekking op een landweer, een wal beplant met struikgewas en voorzien van greppels. Deze wallen bezaten een verdedigingsfunctie. Mogelijk is er een aantal haag-toponiemen in de onderstaande lijsten dat betrekking heeft op geïsoleerde struwelen of op een door beweiding sterk gedegradeerd bos dat uit schraalland bestaat waarin struweel voor komt. In de onderstaande lijst is getracht een aantal categorieèn aan te brengen.

Haag-toponiemen; betrekking hebbend op wegen met een radiair verloop, dat wil zeggen het dorpscentrum verlatend in de richting van een schraalland en rond 1800 voorzien van hagen (volgens Tra)

I. Haagstraat / SAN / Sittard, gaat over in de Veeweg richting Graetheide

2. Haagstraat/SAN/Schimmert, vanaf Clensel richting plateaurand

3. Haagstraat/SAN/Reijmerscok, vanaf dorpskern met Puchof in de richting van schraalland op plateaurand

4. Heggenstraat / SAN / Schaesberg, vanuit kern richting (Brunssumme:r)heide

5. Hagensweg/SA.N/Schimmert, vanuit Klein Haasdal richting plateaurand

6. Hageweg/Str/Amby, vanafHagehof(= Tiendschuur) via Koedreef naar de Ambyerheide

7. Heggerweg/ Ham/Ubachsberg, aansluitend op Bredenwegrichting plateaurand met schraalland

8. Heggerweg / Str / Eygeishoven, richting graslanden langs de Anstel bij Strijthagen

9. Langhaagweg/SAN/Stein, richting, Graetheide

10. Kromhaag̨weg / SAN, Cury / Eys, vanuit Overeys naar de Eyserheide

11. Haagweg/S,AN/ Limbricht, parallel met. Veestraat richting Graetheide

12. Meyshagerweg/SAN / = Meisag/Tra/Munstergeleen, richting Hondskerk (zie hoofdstuk 6)

13. Haagstraat / SAN / Merkelbeek, gaat over in Groenhaagweg richting gehucht Haag

14. Heggerweg/SAN/Spaubeek, richting gehucht Hegge

Haag-toponiemen; wegen met een niet-radiair verfoop, gelegen aan de periferie vañ de nederzecting

1. Hageweg/Sir/Libeek

2. Hagerweg/SAN/Klimmen

3. Hegstraat/SAN/Munstergeleen

4. Hagenstraac/SAN/Sweikhuizen

5. Breede Haag/Schr, Jor / Munstergeleen

6. Lange Heggen/Str/ Nuth

7. Langheck! Tra/Terwinselen

8. Langhaagweg / SAN / Stein

9. Onder dic; Cleene Hegge / $V$. $/$ / Heer

10. Hekske / Spi / Nieuwenhagen

11. Haageinde/SA,N/ Nieuwstadt

12. Bij Trienke ig'in Hek / Goo / Ubach over Worms

13. De eerste haag / Str / Beek

14. Achter de eerste haag/SAN/Eijsden, Breust

15. Aan Hagengraaf/Str/Banholt

16. Lintjeshaag/SAN/Limbricht

17. Op Thelen haag / Str / tussen Banholt en Bruisterbosch

18. Smeets hage / y.H/Kanne

19. Aan Reinties haag / Str / Terlinden

20. Vroomen Haag / Str / Viịlen

21. Aan Piet haag / Str / tussen Lemiers en Mamelis, nu huize "Piet Haan"

Haag-toponiemen; nederzettingen, gesticht op het einde van de reekering van de drift, daar waar deze over gaat in het beweide schraalland ( $=$ einde nederzetting?), of gesticht op schraalland, waarin struweel voor kome

1. Wolfhaag / TOP/gehucht bij Vaals, richting Malensbos

2. Wolfhagen / TOP/gehucht bij Schinnen

3. Printhagen / TOP / Beek, Einzelhof bij Beek

4. Winthagen / TOP / gehucht bij Voerendaal

5. Hilleshagen / SAN/gehucht bij Viplen

6. Nieuwenhagen / TOP/dorp bij Heerlen

7. Haagsittard / TOP/gehuche bij Sittard

8. Haag/Schr/gehucht bij Munstergeleen

9. Hagenrode / TOP / oude naam voor Haanrade bij Kerkrade

10. Hainrade / TOP/ oude naam voor Einrade, een boerderij bij Vaals

11. Hegge / TOP / gehucht bij Nuth 
12. Haag / Kuy / gehucht bil Douve en Merkelbeek

13. De Heek en Overheek/ TOP / gehuchten bij Klimmen

14. Terhagen/TOP/gehucht bij Geulle

15. Wehrhagen/TOP/Groot en Klein Wehrhagen, gehuchten bij Wehr

16. Op de Haaghoff / Str / Einzelhof bij Mesch in voormalig heidegebied

17. Hagenhof / Str / Amby, oude naam voor hoeve de Tiendschur

18. Strijthagen / TOP / kasteelhoeve bị Terwinselen

Hags-toponiemen; veldnamen in weidegebieden

1. De Heeg/Tra/Heer

2. Hagwilder / Cla/ Berg

3. Die Hegge / Cla / Berg

4. Boven de heggen / Str / Reilmerstok

5. Vaalserhaag/Str/Vaals

6. Bolderhaag/Str / Riemst

7. Duyvelshaag/Str/Meerssen

8. Kathagen / TOP/Nuth

9. Achter de hegge / Str / Benzenrade

10. Dorenshaag/Str/Slenaken

11. Heckenbeemd/Str/ Hoensbroek

Haag-toponiemen; veldnamen; akkercomplex, omgeven door een haag, of weidegebieden, waarin struweel voor komt

I. Dalder Haag / Tra / bij Millen

2. Hagveld / Tra / bij Millen

3. Hagen Veld / Str = Hagefeld / Tra / Ijzeren, tussen Ifzeren en Scheulder

4. Haagveld / Goo / Ubach over Worms

Haag-toponiemen; grensstruik aan de periferie van de gemeente?

1. Het Hagen doorstien / jas / Gronsveld (= haagdoorntie?)

2. Het Haagen Doornsteen / Str / Heer, grens met Gronsveld ( = 1)

3. Hagedoorn / Ken, SAN / Geulle

4. Hagendoorn/SAN/Amstenrade

Haag-toponiemen; overige haag-toponiemen

1. Molenhaagweg/Str / Reijmerstok, tussen Reijmerstok en de molen langs de Gulp

2. Zomerse Haag / Str / Sittard, langs de Veestraat

3. Huskens hegge / Sṭr / Heerlen, tusșen Hẹerlẹn en hẹt gehucht Husken

4. Pisheggen/Str/Ijzeren

5. Mensheck ! Tra / tussen kasteel Strijthagen en de Anstel

6. Konijnshagen/Str/Gronsveld, tussen de Trichter-en Berteberg

7. Wijngaardshage/SAN/Oirsbeek

8. Jonge Hagen / SAN / Mheer

9. Eyckhagen/SAN/Schaesberg

10. In de Vinck hage / V.V/ Heer

11. Aan de Viest Heggen / Str / Klimmen, ten noordwesten van Overheek

12. In de Volegs Hegge / Str / Wiịire, ten westen van de Wrakelberg

Eind-toponiemen; de aanduiding van de lokatie van de onderstaande eind-toponiemen is gebaseerd op topografische kaarten, daterend wit het begin van de negentiende ceuw (Tra en Kuy)

1. Hoebendereind(straat) / Schr / Munstergelẹen

2. Kuileneinde / SAN / Meerssen, einde van de bebouwde kom, richting plateau

3. Op 't indsje / Reijmerstok, cafe, gelegen op het einde van de bebouwde kom, richting plateau

4. Op ' Indsje / Cadier en Keer / als nr 3 en Einderweg / SAN / richting plateau

5. Einde / Bea, Kuy / Heerlerheide / gehucht aan het noord-einde van de bebouwde kom

6. Aan de Einden / Str / Eygelshoven, noordoost-einde van de bebouwde kom

7. Het Einde en Einderkoolhof/Str, SAN/Puth, zuid-einde van de bebouw. de kom

8. Aan Schuileneinde/Str/Schinnen

9. Aan't Eind/Str/Nieuwenhagen

10. Wolfeynde / Str / Beek, noordwest-einde van de bebouwde kom, richting heide

11. Het Einde / Str / Elsloo, Catsop, zuid-einde van de bebouwde kom. richting plateau

12. Eind(straat) / SAN / Geleen, noordwest-einde van de bebouwde kom. richting heide

13. Schettereind / SAN / Roosteren, zuidwest-deel van de bebouwing

14. Oevereind/SAN/Roosteren, noordoost-einde van de bebouwde kom

15. Keereind/SAN/Scein, zuid-einde van de bebouwde kom

16. Houtereind/SAN/Stein, west-einde van de bebouwde kom

17. Meerser Eind(straat) /SAN/Stein, Meers, noordoost-einde van de bebouwde kom

18. Gen einde / SAN / Itteren, voormalig einde van de bebouwde kom

19. Eind(straar) / SAN / Șinc-Geertruid, ruidwest-einde van de bebouwde kom, richting heide

20. Buiteneind/SAN/Sint-Geertruid, noord-einde van de bebouwde kom

21. Geneinde(straat) / SAN, Kuy / Valkenburg, noordwest-einde van de bebouwde kom met "tol"

22. Einder(straat)/SAN/Wittem, Wahlwiller, oost-einde van de bebouw. de kom

23. Klimmerseind / SAN / Eijsden, oost-einde van de bebouwde kom, richting heide

24. Eind(straat) / SAN / Bingelrade, noord-einde van de bebouwde kom richting schraalland

25. Einde(rstraat) / SAN/ Hoensbroek, noordwest-einde van het gehucht Kouvenrade, richting heide

26. Eind(erstraat) en Eind(straat) / SAN / Schinveld, noord-einde, richting schraalland

27. Eind(straat) / SAN / Jabeek, zuid-einde, richting plateau

28. Eind(weg) en Eind/SAN/Asselt, noord-einde

29. Bovenste Eind / SAN / Echt, zuidwest-einde

30. Nieuw Eind, verbasterd tot Nulland/Schr $2 /$ Kerkrade

31. West Eind / Das / Meerssen, noordwest-einde van de voormalige be bourwde kon

Wegen nar beweide territoria. Deze zijn samengesteld uit de naam van een beweid gebied en die van een route. Deze categorie toponiemen bestaat naar alle warschijnlijkheid uit heerdgangwegen. Er zijn binnen het onderzoeksgebied vele tientallen voorbeelden bekend; de onderstaande lijst is exemplarisch bedoeld; van elk type "beweid gebied" wordt een voorbeeld gegeven.

I. Broekweg/Meerssen/SAN

2. Beemderweg/Schinveld / SAN

3. Engwegen / Valkenburg (Schin op Geul) / SAN

4. Weerdweg / Linne / SAN

5. Breulenstrat / Wijle (Etenaken) / SAN

6. Weidenweg/Schinnen/SAN

7. Pasweg/Bunde/SAN

8. Heiweg/Meerssen/SAN

9. Hetjesweg (hitje = kleine heide) / Meerssen / SAN

\section{TABEL 2.3 BEWEIDE TERRITORIA}

Tot deze categorie behoren samenstellingen, opgebouwd uit een naam var een "grazer" en die van een gebied, bijvoorbeeld "Koeweide".

Uit de toponiemenvoorraad van het gebied van onderzoek zijn in deze tabel die samenstellingen ondergebracht, die zijn opgebouwd uit een deel dat de naam van een gedomesticeerde herbivoor in houdt. gevolgd door een deel dat een gebied voorstelt, dat wordt gekenmerkt docr een bepaalde geomorfologische hoedanigheid en een vorm van agrarisch gebruik door onder andere beweiding, Van deze categorie zijn tientallen voorbeelden uit de toponiemenvoorraad bekend. De onderstaande lijst geeft voorbeelden, gerangschikt volgens de soort herbivoor:

Mer "koe" (of een synoniem daarvan) zijn samengesteld: -weide, -broek, -beemd, -bos, -kamp, -del, -berg, heide en -dries.

Met "schaap" (of een synoniem daarvan):-broek, -del, -weide, -dries, -berg en -aard.

Met "paard" (of een synoniem daarvan); - broek, -weide, -kamp, -dries en -priend. Met "varken" (of een synoniem daarvan): -brock, weide, -del, -dries, -weerd. -groes en -heide

Met "gans": -broek, -weide, -dries, -akker en -berg. 
Koebergen; in geschreven bronnen valt de grote variatie op van de spelling van het substantief "koe". In toponiemen is er sprake van diezelfde variatie. Met het geomorfologisch element "berg" wordt binnen het onderzoeksgebied eerder een plateaurand bedoeld. Mogelijk zijn de onderstaande "koebergeri" van oorsprong plateaurandgraslanden voor rundvee.

1. Kooberg / Cadier en Keer, plateaurandheide en schraalland / Tra

2. Kooberg/Kanne, plateaurandheide en schraalland/Tra

3. Couberg/Sint-Geertruid, plateaurandgrasland / Tra

4. Cauberg/Valkenburg, plateaurand/TOP

5. Caberg / nederzetting op de plateaurand bij Maastricht/TOP

6. Cauberg / Vijitingen/Hac

Namen van graslanden langs beken en rivieren.

De in deze en volgende cabel opgesomde lijst van weidegronden is voorname. lijk onclcend aan bestaande toponiemen uit het gebied van onderzoek; elk type wordt summier omschreven wat betreft taalkundige variatie (fonetische va. rianten van het grondwoord, pluralis- en diminutiefvormen), landschaps. oecologische hoedanigheid (geomorfologische positie en historisch-agrarisch gebruik). frequentie en verspreiding in het onderzoeksgebied.

Beemd (bant, band, beent, beempt, pluralisvorm: onder andere beenje, benete): 's winters overstroomde graslanden in rivier- of beekdalen. Het achtergebleven slib fungeerde als een natuurlijke bemesting, waardoor deze graslanden relatief voedselrịk en produktief waren. Ze werden als hooilan* den gebruikt en tot het moment van de hooioogst, traditioneel rond Sint-jan (24 juni), van beweiding uitgesloten. Daarna kon beweiding plaatsvinden. De talkundige genese van "beemd" uit "bi-hamede" (= omheind grasland bij rivier) sluit hierbij aan. Beemd-toponiemen komen algemeen voor in het onderzoeksgebied, maar beperken zich vrijwel tot de beek-of rivierdalen (zie figuur 9.1 )

Broek (brook, broeck, bruk, diminutiefvorm: broeksken, breuksken): drassige graslanden met hier en daar bosrescanten, de zogenaamde broekbossen. voornamelijk bestaande uit vee-resistente boomsoorten (onder andere els = Alnus spec.). De min of meer permanente moerassige toestand van broeken vindt zịn oorzaak meer in kwel- of bronsituaties ter plaatse dan in stagnatie van het winterse overstromingswater; broek-toponiemen komer ook op hogere delen in het dal voor en bezitten een ruime verspreiding. In samenste! lingen vait de hoge frequentie op van de caponiemen "varkensbroek" en "gemeentebroek". De karakteristieke ligging is aan de gemeentegrens. In de meeste gevallen heeft het toponiem betrekking op uitgestrekte, weinig produktieve, extensief benutte weidegronden voor koeien en varkens, in eigendom vas de gemeente.

Ooi (oye, oo en of): rịvierdalgraslanden; op basis van slechts vier attestaties in Maastricht (V.B), Meerssen (Das), Amby (SAN) en Berg (Cla), meer met beemden dan met broeken verwant. Taalkundig samenhangend met "ooi" is mogelijk "ooiseling" (= kleine ooi?), in de betekenis van "met struikgewas omgeven weide". Het toponiem Oeslingerstraat te Gronsveld (Jas, SAN) zou met dit woord verband kunnen houden.

Ham; grasland bij rivier. Mogelịk "melkboche", een verzamelplaats voor rundvee. Binnen het gebied van onderzoek slechts enkele attestaties: Ham bi Roermond (SA.N). 't Hemke bij Sint-Odilienberg (Top) en Ham aan het riviercje de Worm bij Kerkrade (Top)

Brul (breul): rivierdalgrasland. In het Rijndal is het toponiem algemeen. In het gebied van onderzoek alleen langs de Geul bij Meerssen: Bovenste en Onderste Breulen (Das) en bij Wijlre: Breulenstraat (SAN).

Eng (ing): laaggelegen en vochtig grasiand, onder andere te Sittard (Str), Brunssum (SAN) en te Schin op Geul (Lem).

Pas (paes, pesch, diminutiefvorm: peschelke): meestal in rivierdalen gelegen. communaal beweide graslanden aan de periferie van de gemeente; "pascere" = beweiden. Het toponiem komt voor te Itteren, Bleijerheide, Born, Bunde, Geleen, Susteren, Valkenburg (Sibbe), Margraten (SAN). Houthem (Phi) en Simpelveld (Fra)

Weerd (weert): door dijken omgeven (?) rivierdalgraslanden, frequent langs. de Maas voorkomend. Ze vormden uitgestrekte weidegronden die 's winters overstroomden.

Griend (greend); niet door dijken (?) omgeven, laaggelegen knotwilgenaanplantingen. Na het becindigen van deze vorm van hakhoutcultuur werd de term griend ook gebruike voor graslanden langs de Maas, die alleen gedurende de zomermaanden konden worden beweid.

Groes (groos); op grond van slechts een tweetal attestaties in Gronsveld (Jas) en Urmond (Sim) is alleen een karakteristiek. "wild grasland" mogelijk.
Namen van graslanden op droge gronden

De in delen van toponiemen yoorkomende landschapseenheden "berg" er "hei" zijn droog gelegen, dat wil zeggen ze liggen buiten het overstromingsbereik van de rivier en vaak op de plateaurand.

"Bergen" komen in het afgevlakte plateaulandschap van Zuid-Limburg eigenliik niet voor, het zijn - geomorfologisch gesproken - plateauranden. Voor zover deze steile hellingen voor alkkerbouw ongeschikt en met bos of grasland begroeid waren. kwamen zil voor beweiding in aanmerking. Beweidings-indicatief zịn berg-toponiemen, wanneer zį̣zịn samengesteld uit een deel dat een begrazer of een begrazings-resistente plantesoort in houdt, zoals bijvoorbeeld Metreberg, Geitsberg (met = geit). Hamelsberg (hamel = gecas treerde ram), Boxberg, Kooberg en Kalverberg, respectievelijk te Bemelen (Top). Heerien (Str), Wijire (Tra), Mesch (Str), Cadier en Keer (Top) en Meerș̦en (Top), of Wagelerberg. Wirakelberg (wageler = wrakei = jenever bes), Ginsterberg (ginster $=$ brem), respectievelijk te Ubachsberg ( $\mathrm{Ham})$ en Mechelen (Tra).

Heide-toponiemen (hei, diminutiefvorm: hețe, hitje, hetteke) komen frequent voor (zie tabel I); het zijn "wilde" graslanden, eventueel met dwergstruiken en struweel begroeid. Geomorfologisch kan een driecal typen worden onderscheiden: plateauheiden, plateaurandheiden en plateaukopheiden, die karakteristiek waren voor bepaalde delen van het onderzoeksgebied. Net als in de overige delen van Noordwest-Europa is het heide-areaal dramatisch afgenomen binnen Zuid-Limburg: de laatste restanten vormen, door hun overweldigende soortenrijkdom, momenteel natuurreservaten. De heide vormde tevens het laatste biotoop, dat door herders met kudden werd beweid.

Diverse Kreke-, Krekele- of Krikelbergen en -velden zijn eveneens als droge schraallanden te karakteriseren. Hun betekenis is ofwel ontleend aan de veld' krekel (Creticus campestris), een typische bewoner van droge schraallanden met een opvallend geluid, ofwel aan de sleedoorn (Prunus spinosa), dialectisch "kreke" of "krieke" voor de eetbare vruchten. die eveneens karakteristiek is voor hetzelfde milieu.

Het toponiem Kreke(l)berg of -yeld komt yoor in Amstenrade (Top), Terhorst (Tra), Wịlre (Str). Cadier en Keer (Str). Eygelshoven (Str). Nieuwenhagen (Str), Stein (SAN), Rothem (Str) en Ubachsberg (Ham).

Kamp (kemp, diminutiefvorm: kemke); met hagen of andere veekeringen omgeven percelen, meestal onttrokken aan gemene gronden. Vermoedelijk private ontginningen, van laat-middeleeuwse (?) oorsprong, Van de vele (meer dan 300!) in het onderzoeksgebied gelegen kamp-toponiemen zịn er șlechts drie samengesteld met een grazer: een permanente beweiding door grazers lijkt uitzonderlijk. Het toponiem kamp is in zoverre heerdgang-indicatief, dat beweiding wordt uitgestoten.

Het element "wei" in toponiemen is betrekkelijk zeldzaam en waarschiinnlijk laat in gebruik gekomen; de huidige betekenis als omheind grasland, waarin grazers worden opgesioten, sluit hierbij aan.

Het toponiem "veld", zeer frequent voorkomend, betekent oorspronkelijk het buiten de akkers gelegen beweide deel van het dorpsterritoir, de latere betekenis is "akkercomplex".

Aard; slechts eenmaal voorkomend in "Weeraard" te Kanne (v.H), dat mogelijksynoniem is voor "rammenweide", schijnt elders een type grasland geweest te zijn (zie LINDEMANS 1946).

\section{TABEL 2.4}

\section{VALDERS EN ANDERE VEEKERINGEN}

Valder-toponiemen

I. Valderen / Hulsberg/ Hom

2. Vouwerweg/Houthem/SAN

3. Vouwerweg/Sitcard/SAN

4. Valderensveld/Geleen/Tra

5. Beuls Vauwere / Nieuwenhagen / Sp

6. Belvalderen / Nieuwenhagen / SAN.

7. Volderstraat (dialectisch "vauwer"-straat) / Meerssen / SAN

8. Valderensweg/Doenrade / SAN

9. Vauwerstrat/Born / SAN

10. Valderstraat/Stein / SAN

11. Vaiderenstraat / Geleen / SAN

12. Vauwere / Mechelen / naam van hotel

13. Vauwerhofstraat/Schimmert/SAN 
14. Aan het Valderen / Heer / V.V

15. Vogelvalderen/Brunssum/SAN

16. Valderen / Kanne / v.H

17. Bisfalder/Swalmen/Ger

18. Aan het Valderen/Mastricht (Heugem) / SAN

19. Hontsvalderen / Swalmen / Ger

Valder-synoniemen: klap, varen, grindel, stegel en gar

1. Klapstraat / Etenaken / SAN

2. Kleine Flap / Heijenrath / naam voor een huis aan de Nederlands-Belgische grens

3. Gaarstraat/Roosteren/Str

4. Smeetsgeerkensweg / Nuch / SAN (geerke = diminutiefvorm van gaar)

5. Achter de garen en Garensveld / Rosmeer / SAB

6. Struckvaren / Limbricht / SAN

7. Valgair/Vlodrop/Str

8. Collegaarweg/Sibbe / SAN

9. Aan het varen / Wessem / San

10. Varenbeukerweg/Heerlen/SAN

11. Gevaren/Swalmen/SAN

12. Keulenergryndel/Simpelveld/Fra

13. Kroepgryndel/Simpelveld/Fra

14. Heigrindelweg/Heerlen/SAN

15. Veltpoort/Swalmen / Ger

16. Barrier en Barrierweg / Klimmen / SAN

17. Slagboomsweg/Nuth/SAN

18. Slagboom/Urmond/Ser

19. Stiegel/Ejisden/SAN

20. Stegel/Kanne/ $/ \mathrm{H}$

21. Koyestegelgats/Hoensbroek/Bea

22. Stegelstraat/Nuth/SAN

23. Stegelenhof en -straad/Schinnen / SAN

24. Stegelbroekweide/Eygelshoven/Str

\section{TABEL 2.5}

\section{ORIENTTATIE. EN RUSTPUNTEN IN HET LANDSCHAP}

Niet-levende (grens)markeringen: grensstenen, -heuvels, -palen, -kruisen en-galgen
1. Op de blauwe steen / grens Nuth-Wijnandsrade / Kuy
2. Schonen steyn (weg) / grens Meerssen-Geulle / SAN
3i. Langensteen / grens Mheer-Reijmerstok/Tra
4. Aan de Greune Paol / U Urmond / Ștr.
5. Aan de Paol/Eijsden/Str
6. Op de galling / Margraten, op de gemeentegrens/ Hei
7. Marie Vliegen galling / Kanne / Str
8. Aan't Gericht (op de Cajersberg) / Heer / V.V
9. Boven het Gericht / Berg en Terblijt, op de gemeentegrens / Cla
10. De Gerechten / Aalbeek / Rae
I!. Gericht(straat)/Stein / SAN
12. Galgenveld/ Hoensbroek / Bea
13. Galgenboomke/Schaesberg, op de gemeentegrens/Ion

Solicaire bomen op wegkruisingen en op gemeentegrenzen, per soort gerangschikt

Eik (Quercus spec.)

1. Aan het Eikske/grens Eys-Wahlwiller/Sur

2 Tomeik(erweg)/grensboom bij een tomme (= aarden heuvel) / Geleen ISAN / Schr

3. Eyksiken(sweg) / grens Geulle-Elsloo / SAN

4. A gen Eikske / grens Sint-Geertruid-Herkenrade / Str

5. Gen Eikske / grens Margraten-Wijire / Hei

6. Eikske/Vilt / Dui

7. Herzoghis Eyk / Tra

8. Eikske/Schaesberg / TOP

9. Aan de knabben Eik / Sittard / Str

10. Weg onder de Eiken / Vaals / SAN
Linde (Tlia spec.)

1. Aan de Linde / grens Born-Nieuwstadt / SAN

2. Aan de Linde / Schinnen (Puth) / SAN

1. Mheerelindje / grens Mheer-Noorbeek / Str

4. Meuleberg linde / Heerien / Tra

5. Sourether Linde / Simpelveld / Tra

6. Eyser linde / Eys/Cuy

7. A jen Ling en Lindestraat/Vaals / SAN

8. A gen Ling / grens Rimburg-Ubach over Worms / Goo

9. Kleine Linde / Valkenburg, grens Berg-Terblijt/SAN. Cla

10. Lindje / Kanne/v.H

11. Terlinden / gehucht bil Banholt / SAN

12. Aan de Rumpen Linde / Brunssum / Su

Notenboom (juglans regia)

1. Aan Noteboomken / Benzenrade / Str

2. Aan de Noot/Vaals / SAN

3. Vildnus / Kerkrade / Tra

4. Notelaar/Kanne/v.H

Kers (Prunus avium)

1. Kersboompjesweg/Simpelveld / SAN

2. Aan de Keersboom / Heer / V.V

3. Denkersboom / Margraten / Tra

4. Kerstboom (4)/Ubachsberg / Ham

5. Aan de Keerseboom/Berg/Cla

Peer (Pyrus communis) en mispel (Mespilus germanica)

1. Aan het Peerboomken / Eys-Wahlwiller / Str

2. Peerboom/Voerendal / Str

3. Aan den Mispelenboom en Mispelboom/grens Buchten-Holtum/SAN. Hou

Vlier (Sambucus nigra), dialectisch: heulenter (vergelijk het Duitse Holunder)

1. Gruen Huelenter/Berg/Cla

2. Op de Heulender / Brunssum / Str

3. Aan het Heulenteerken / Riemst/Str

Beuk (Fagus sylvatica), jeneverbes (Juniperus communis), berk (Betula spec.) en es (Fraxinus exelsior)

1. Aan de Beuk / Nieuwenhagen / SAN

2. Beukenboom(sweg)/Sittard/SAN

3. Aan de Boeck / Berg/ Cla

4. Op den Wachtboom / Rimburg / Ster

5. Aan de Bircken / Geulle/Ken

6. Berkelaar / Echt/TOP

7. Isschendael en Eysendalse weg/Meerssen/Str, SAN

8. Esschendiek/Geulle / Ken

9. Eschberg / Vaals / SAN

Niet specifiek genoemde solitaire boomsoorten

1. Op den Hoogeboom / Beek (Groot Genhout) / SAN

2. Aan het Boomken en Boomkenswog / Eijsden / SAN, Str

3. Aan de 19 Buim / Vilt / Dui

4. Aan de korte boom / Margraten / Hei

\section{TABEL 2.6}

\section{DRENKEN}

De namen voor drenken worden uitvoerig besproken in hoofdstuk 4 (zie tabel 4) 


\section{Bies(t)-toponiemen}

TABEL 3.1

\section{BIES(T)-TOPONIEMEN BINNEN HET ONDERZOEKSGEBIED}

Territoria binnen de nederzetting

I. Op de Bies / Berg/SAN, Cla / tot een pleintie verbrede straat, waaraan (vroeger) kerk, poel en waterput

2. Op de Bies (Byes) / Schimmert / SAN, Tra, Kuy / verbrede straat met een voormalige waterloop, een poel en een valder

3. Op de Bies / Heythuysen / SAN, TOP / plein met kerk, van waaruit de Biesstraat verțrekt

4. A gen Bies / Schinveld / Bos / pleintje met poel in de kern van Schinveld

5. Op de Bies / Moelingen / Boi / pleintie, van waaruit de Bijsstraat/SAB / vertrekt naar graslanden langs de Voer

6. Op de Bies / Sint-Martens-Voeren / Boi / pleintie aan de rand van het dorp

7. A gen Bies / Gemmenich / Boi / met Biesweg / Boi / de ligging wordt niet vermeld

8. De Bies / Valkenburg / Wel 3/ de ligging wordt niet vermeld

Territoria buiten de nederzetting

9. Biesland/Maastricht/SAN. Tra / graslanden langs de jeker

10. Biesweyde / Hoensbroek / Meu / de ligging worde niet vermeld

1I. Biesweien / Roosteren / Ser / graslanden langs de Maas

12. In de Biesseweide / Valkenburg / Wel / de ligging wordt niet genoemd

13. In ' $t$ Biesveld / Nijswiller / Str / de Biesweg vormt de verbinding met Nijswiller (zie figuur 3.2)

14. Biesveld/Someren/A.A

15. Biesberg / Eys / Cuy / droog schraalland op de plateaurand

16. Biesenberg / Ulestraten / Str / deel van de plateaurand in gezelschap van Kalverberg

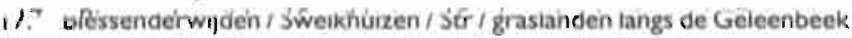

18. Biessenderbos/Sweikhuizen / Str ! plateaurand bil nr !?

19. Bieszender Feld / Höngen/Tra / einde van de Viehstrasse, amgeving van Kooland

20. Biesebruk / Kanne / v.H / broekland langs de jeker

Routes

21. Biesstraat / Brunssum/ SAN / deel van het traject țussen het dorpsplein en de Brunssummerheide

22. Biesstraat / Heythuysen / SA.N / yerbinding van het dorpsplein "Op de Bies" met graslanden langs de Tungelroyșe beek (vergelijk hierboven in 3)

23. Bisseweg/Nuth / SAN / verbinding tussen de kern van Nuth en de Hellebroekerbeemden

24. Biesweg / Bochholtz / SAN, Tra, Kuy / verbinding van de kern van Bochholtz met de periferie van de gemeente, deels een holle weg

25. Biessenweg / Geleen / SAN/verbinding van Geleen met de Biessenhof in het dal van de Geleenbeek

26. Bisweg ! Homburg / Bol. Hal / gehucht in weidelandschap

27. Biesenweg/Maastricht/SAN. Tra / langs de Maas

28. Biesenwal / Maastriche/ SAN. Tra / langs de Maas bij nr 27

29. Biezengats / Hoensbroek / Bea / de ligging wordt niet genoemd; gats = steeg, waarschiịnlijk identiek met Biesegats / Wiị/in broekland en in gezelschap van Koeiweg

30. Biesweg / Nijswiller / SAN, Tra / verbinde Nijswiller met Biesveld (zie figuur 3.2)

31. Biesweg / Born / San, Kuy, Tra / verbindt Oud Roosteren met graslanden langs de Maas en met Biesweien (vergelijk hierboven nr II)

32. Biezenstraat / Beegden / SAN/veriengde van de Schepersstraat

33. Biesserstraat / Geulle / SAN, Kuy, Tra / deel van de verbinding Geulle en graslanden langs de Maas

Met de naam voor een "water" samengesteld

34. Byesseborn/Berg/ $\mathrm{Cla} /$ aan de gemeentegrens op plateau (identiek met or 35?)

35. Biesemaar $/$ Berg $/ \mathrm{Cla} /$ maar $=$ poel
36. Beesepool / Ejisden / SAN / in het Maasdal

37. Bissebeek / Nuth/TOP / beekje in weidelandschap

Overige Bies( $(t)$-toponiemen

38. Aen Bisfalder / Swalmen / Ger / valder = klaphek

39. Bystmael / Berg / Cla / aan de gemeentegrens op plateau, maal = grens (vergelijk hierboven $\mathrm{nr} 34$ )

40. Op ene Biestert / Raren / Boi / aard = graasplaats

41. Bissen / Mechelen / TOP / gehucht bij Mechelen in een komvormig dal, omringd door bos

42. Biesen / Höngen / TOP. Tra / gehucht bij Höngen

43. Biessenhof / Geleen / A.A / geìsoleerd gelègen hoeve in het dal van de Geleenbeek:

44. Biessenhof / Nagelbeek, Schinnen / Schr / geisoleerd gelegen hoeve in het dal van de Geleenbeek.

45. Biessen / Limmel / Schr / laaggelegen kasteeltịe, nu "Bethlehem"

46. Viestheggen / Klimmen / Str / veldnaam, een veekering?

47. Pisheggen / Sibbe / Str / veidnaam (= Bisheggen?), een veekering?

48. Besebrucken / Heer / V.V/ veldnaam, veebrug of broekland

\section{TABEL 3.2}

\section{BIES(T)-TOPONIEMEN BUITEN HET ONDERZOEKSGEBIED}

Territoria binnen de nederzetting

1. Biest / Weert / SAN/ stadsdeel van Weert aan de buitenzijde van de stadswal

2. Bies / Venray / Sand / stadsdeel van Venray aan de buitenzijde van de stadswal

3. Biest / Tilburg / TOP / gehucht ten zuidwesten van Tilburg

4. Biestheuvel/Hoogeloon / Deb

5. Biesheuvel / Almkerk / TOP / gehucht in weidelandschap bij Almkerk

6. Biesheuvel/ Deurne/TOP/gehucht in weidelandschap bili Deurne

7. Biezenheuvel / Eindhover/ TOP / gehucht in weidelandschap bij Eindhoven

8. Biesheuvel / Kaatsheuvel / Ren 2/gehucht in weidelandschap biị Kaatsheuvel

9. Biesdonk / Breda / TOP / stadsdeel vạn Breda

10. Biesdonk / Teteringen / Bui / de ligging wordt niet genoend

11. Biesdonk / Heusdenhout / Bui / de ligging wordt nier genoemd

12. Beswerd / Feerwerd/TOP/gehucht op terp bil Feerwerd

Territoria buiten de nederzetting

13. Beestenveld / De Rips / TOP / veldnaam in voormalig heidegebied

14. Biestvelden/Eindhoven/TOP/veldnaam in rivierdal, daarin het gehuche Biezenheuvel

15. Biesvelden / Asten / TOP / veldnaam in voormalig heidegebied

16. Beesbosch(weg) / Neeroeteren/SAB / veldweg in heidebosgebied

17. Biesbosch/TOP/ voormalig getijdengebied aan de monding van de Maas

18. Biesbosch / Hilvarenbeek / TOP / veldnaam in heidelandschap

19. (de) Bieskampen / Tiel / TOP / veldnaam in weidegebied

20. Biesekamp(weg) / Bochholt (B) / SAB / ștraatnaam

21. Biesthoek / Uden / TOP / veldnaam in voormalig heidegebied aan de gemeentegrens

22. Biesberg / Aken / voormalig heidegebied, nu natuurreservaat

23. Bieshorst / Zutphen / TOP/Einzelhof in weidegebied

24. Biesweerd/Swaimen / TOP/veldnaam in rivierdal

25. Beestemars / Olst / TOP / veldnaam in moerasgebied

26. Biesselt of Bijsseit / Mook / TOP / gehucht in de heide van Mook

27. ('tlage) Bijssel/ Nunspeet / TOP/veldnaam in weidelandschap

28. Biesakker/Deb

29. Biesdries / Deb

30. Biestveld / Deb

31. Biestreld/Deb

32. Biestvelden/Deb

33. Biestveldie / Deb

34. Biesemaet $/ \mathrm{Gij} /$ Oostkerke $/$ mat $=$ made $=$ moerassig weideland

35. Biesemedeken / Gij / Hondschoten / (vergelijk nr 34)

36. Bieseussele / Giị / Londerzeel / eeuwsel = euzel = door bossen of schaar- 
hout ingesloten weide

37. d Bies eurel/ Gij/ Noorderwijk

38. Bieseusel / $\mathrm{G}$ ii / Leest

39. Biesheusels / Gij / Merchtem

40. Bies eussele / Gi / Grimbergen

41. Bies eussels / Gị / Nederokicerzeel

42. Bies eussel/Gị/Ukicel

43. Bieseusel/Gil / Sint-jorisweert

44. Biesenpasch / Gij / Sambeek

45. Bisweide / Grubbenvorst / SAN / laaggelegen weidegebied

46. Biesdeel / Deurne / SAN/strastnaam in de voormalige heide

Routes

47. Biestraat / Gilze /TOP/ eindigend in De Besterd (vergelijk hierboven nr 43)

48. Biesestraat / Dilsen / SAB / tussen het gehucht Rothem en de heide, zipstrat van de Veewes

49. Bieststraat / Hasselt-Rapertingen / SAB / hoofdstrat in het dorpscentrum

50. Bieststraat / Heusden-Zolder / SAB / als nr 47, voerend naar beekdalgraslanden

51. Biesweg / Lanaken-Gellik / SAB / als nr 47, voerend naar voormalig heldegebied

52. Biezenstrat / Beringen, $\mathrm{Paal} / \mathrm{SAB}$ / aan gemeentegrens, parallel met Dreefstraat.

53. Bljsstraat / Riemst, Vlijtingen / SAB, Hac/ veldweg

54. Biezenstraat / Hasselt, Runkst / SAB / veldweg

55. Beisstraat/Hoesselt/SAB/vanuit kern van Oud-Hoesselt naar gemeentegrens

Mer wateraanduiding

56. Bieskuil(straat) / Kortessem / SAB / poel langs een weg, de straat is het verlengde van de Bissemerweg.

57. An der Beismar / Dit / (mar = maar = poel) de ligging wordt niet ge noemd,

58. Biesput ! Aardenburg / TOP / poel in grasland bij het gehucht Eede

59. Biesputten / Someren / SAN / straatnaam in (voormalig) laaggelegen heidegebied

Overige

60. de Biesterij / Rijssen / TOP / Einzelhof in weidelandschap

61. Biessum / Delfzijl / TOP/ terpdorp (= biesheem?)

62. Biesem(straat) / Heers. Mechelen-Bovelingen/SAB

63. Bissem / Kortessem / SAB / gehucht

64. Biezele / dorpje in West-Vlaanderen

65. Ter Biest/Sint-Truiden / SAB / gehucht ten noorden van Sint-Truiden

66. Alde Biesen / Bizen / SAB / in I 220 gesticht op Bieseveld, een komvormig dal met bron

67. Beeste Egge / Ossesluis / TOP / veldnaam in weidegebied

68. Bieshaar / Amersfoort! TOP / stadswijk van Amersfoort

69. Biesplanken / Overioon / TOP / veldnaam in weidegebied

70. Biesthof / Hoogeloon / Deb

71. ter Biest/Sta / hoevenaam

72. de Biest (= de Bist) / Sta / hoevenaam

\section{TABEL 3.3 \\ BIESTER-TOPONIEMEN}

1. De Besterd / Gilze / TOP / gehucht in weidegebied bij Gilze

2 Besterd(strat) / Bilsen / SABB / vanuit kern van Grote Spauwen naar gemeentegrens

3. Besterd/Tilburg/TOP/ stadsdeel

4. de Biesters / Aalst / Deb / weiland

5. 't Beester / Aalten / TOP/gehucht in rivierlandschap

\section{TABEL 3.4}

\section{BIEZE-TOPONIEMEN (IN DE BETEKENIS VAN DE PLAINTI)}

1. De Biezen / Oploo / TOP/ ontginningsgebied in de Peel

2. De Biezen / Bameveld / TOP / veldnaam in weidelandschap bij rivier

3. Biezenbrug / Vianen / TOP / brug bil Vianen, richeing gehucht Hooge Biezent

4. Biezendijk / Vianen / TOP / dijk bij het gehucht Hooge Biezen

5. Riet-en Biezenveld / Klundert / TOP / niet-bedijkt land

6. Hoge Biezenplaat/TOP / veldnaam in de Biesbosch

7. Biezenmortel/TOP / veldnaam

8. Biezenpolder/Oostbung/TOP/oude polder langs de Biezenkreek (vergelijk hieronder ar (3)

9. Biezenstraat / Genk/SAB/ in nieuwbouwwijk in gerelschap van Rietiaan en dergelijke

10. Biezenstraat / Maaseik, Neeroeteren / SAB / in nieuwbouwwijk

11. Biezenweg/Neerpelt/SAB / in nieuwbouwwijk in gezelschap van Hulststraat en dergelijke

12. Biezenstraat / Overpelt / SAB / in nieuwbouwwilk in gezelschap van Buncerasstraat en dergelijke

13. Biezen / Oostburg / TOP / gehucht in de Biezenpolder

14. Biezen / Arendonk / TOP/gehucht in moerassig laagland bij de Biezen. loop

15. De Biezen / Gemert / TOP / gehucht in laagelegen graslanden

16. De Biezen / Dongen / TOP / veldnaam in laaggelegen graslanden

17. Biezengoren / Bladel / TOP / veldraam in laaggelegen graslanden

18. Biezenkuilen / Kaimthout / TOP / ven in de Kalmthoutse heide

19. Biezenloop / Veghel/ TOP / sloot langs kanaal

20. Biezenloop / Sint-Oedenrode / TOP/sloot in haggelegen graslanden

21. Biezenloop / Baarle-Nassau / TOP / beekie in laaggelegen graslanden

22. Biezenloop / Arendonk / TOP / beekje in lagggelegen graslanden:

23. Biezenkreek/Sint-Kruis / TOP / kreek in oud polderlandschap (vergelijk hierboven nr B en (3)

24. Biezenmortel / Helvoirt / TOP / gehucht ten westen van Helvoirt

25. Biezerven(weg) / Someren / SAN/ straat in (voo:malig) Peellandschap 


\section{Drenk-toponiemen}

\section{TABEL 4.I MAAR-TOPONIEMEN}

1. Termaar / TOP, Hei / plateaunederzetting bij Margraten met poel, de "Marekoul" of "Bauerkoul", put en linde op een driehoekig dorpspleintie

2. Termaar / TOP/ plateaunederzetting bij Klimmen

3. Mheer / TOP / plateaunederzetting bij Noorbeek

4. Meer / SAB / plateaunederzetting, met het gehucht Val tot " $V$ almeer" samengevoegd

5. Mheer / SAB, Hac / Vlijtingen, dorpsplein met zouw

6. Rosmeer/SAB, Lux/ plateaunederzetting

7. Peerdsmeer / $S A B$ / Genk, straatnaam

8. Wiemismeer/SAB / plateaunederzetting

9. Meer(land)/SAB/Opkanne, aan voormalig dorpspleintie "Op de Dries"

10. Meer(straat) $/ 5 A B /$ in de oude kern van Paal in gezeischap van Dries. scraat en Baandriesstraat

11. Meer(straat)/SAB / Lindel (Overpelt), in het centrum van Lindel

12. Op de Meer/SAB / Grote Spauwen, verlengde van Biesterdstraat

13. In gheen Mcer / Cla / Terblijt, buiten de kern

14. Op de Meer / SAN / Itteren, in de oude kern

15. De Meerkoel/ Cla / Berg, mogelijk identiek met $\mathrm{nr} / 3$

16. Merewegske / Wel / Echt, de ligging wordt niet genoemd

17. Meerewegske/San/Roosteren

18. Meerstraat/SAN/Bunde, buiten de kern

19. Meerveldweg/SAIN/Grevenbicht

20. De Les Meer / St / Borgharen, buiten de kern

21. De Maar, Oude Maar, Korte Maar, Maarzijde / SAN / in de oude kern van Onderspekholz

22. Maar(veld) / SAN/Kerkrade, in de kern van Kerkrade

23. Maar / Har / Bruisterbosch, pleintie in de oude kern

24. In de Maar / SAN, Vro / Schinveld, binnen de kern

25. De Maar / SAN/Schaesberg, hoevenaam en straatnaam

26. Mareweg/SAN/Schimmert, zijstrat van "Op de Bies", een pleintje

27. Maar / SAN, Ren / Jabeek, dorpsplein met voormalige poel

28. Maerendaal / v.H. Str / Sint-Pieter, begraasd dal, waarin poel?'

29. Maar/SAN/Bingelrade, in centrum met poel

30. Maarstraac/SAN/Brunssum, in de oude kern van Treebeek.

31. Ingmaer / Qui / oude naam voor Ingber

32. Mereveld/Hou/Buchten

33. Borchtmeer/ Kem/Montfoort

34. Smaelmaer/Kem/Sint-Joost

35. Maarland/TOP/nederzetting in het. Maasdal

36. Vogelsmeer / Hac / Vijtingen, veldnaam buiten de nederzetting

37. Mhereweg/ Hac / Veldwezelt, buiten de nederzetting

38. Romaar / Boi / Lontzen, boerderij met twee poelen

39. A jen Maar / Boi / Welkenrath, dorpspiein met: poel

40. Maarveld/Boi/Moresnet, boerderij

\section{TABEL 4.2}

\section{POEL-TOPONIEMEN}

1. De Poul / Hom / Heerlen, in het centrum

2. Bij de Poel/V.V/ Heer

3. Aan Poelken / Jon / Sittard

4. Poel/y.H/Kanne

5. In hec Poelken / Str / Elkenrade

6. Hoeve "De Peul" / Str / Noorbeek

7. Hofpoe! en Hofpoelstraat/Str. SAN / Brunssum

8. Schone Poel/ SAN. Cla / Berg, dorpspoel aan pleintic

9. Grote Poel / Bro / Klimmen, dorpspoel aan pleincie

10. Meesepool/ Goo/Ubach over Worms, dorpspoel op pleintje

11. Beesepool/SAN. 5tr / Eijsden

12. Crapoe! / SAN/gehucht bil Gulpen (= kraaienpoel?)

13. Rabenpfubl/TOP/Moresnes

14. Kranepool/SAN, Tra/voormalig ven in Brunssummerheide (= kraanvogel?)
15. Eendenpoel / Hou / Buchten

16. Endepoel / Keri / Geulle

17. In de Endepoel / Str, Hei / Margraten, buiten het centrum

18. Den Endenpoei / Jon / Sittard

19. De Endepoel/S.AN/Stevensweer

20. Endepoeisdijk/SAN/Echt:

21. Aan de Eggelspoel / Jon / Sittard (eggel = bloedzuiger)

22. Paddepoel/Str/Ulestraten

23. Paddepoel/Str/ Maastricht

24. Aan Heckske Poelke//Jon / Sittard

25. Kruispoel/ $/ \mathrm{Ham} / \mathrm{Ubachsberg}$

Boileau (Boi) vermeldt voorts 19 poel-toponiemen in de. Voerstreek.

\section{TABEL 4.3 \\ KOEL-TOPONIEMEN}

1. Koulen / Bro / Klirnmen / gehucht bij Walem

2. Op de coul/S,AN/Grevenbicht

3. Op koulke / Jon / Sittard

4. In de Koel/Wel $2 /$ Echt

5. Kuil/v.H/Kanne

6. Koellweg / Str / Nieuwenhagen, aan de Heeruveg

7. Kuilenweg/SAN/Elsloo

8. Keulsteeg/S,AN/Beek

9. Kuilenstraat: / SAN / Meerssen

10. Veldkuilstraat/SAN/Kerkrade

11. Aan de Eggelskoel / Str / Ophoven bij Sittard (eggel = bloedzuiger)

12. De Kwakskuilen / Str / Ulestraten ( $k w a k=k w a k k e r=k i k k e r)$

13. Swaluwekoel/Str/Sweikhuizen

14. Eindgekoul / Tra / Echc (eindge =: pluralisvorm van "eend")

15. Dassenkuil/Str/Winthagen

16. Koniinsikuil/Str / Eijsden

17. Hinnekuil/Str/Gronsveld

18. Hennekuil(straat) / SAN/Born

19. De Vossekuil/SAN/Heerlen

20. Vossekuil/Cuy/Eus

21. Vossekoul/ jon / Sittard

22. Leeuwekuils(weg)/SAN/Nuth

23. Haaskoul/ Hou/Buchten

24. Molskulikens(weg)/SAN/Geleen

25. Pieringkuil/Str/Schinveld

26. Veekoe! / Hei / Giroot Welsden, an pleintie

27. Heerekuil/ Str / Eygelshoven (heer = heerd?)

28. Heerkuil/SAN/Herkenrade

29. Herenskuil/Cuy/Eys

30. Roskuil / S/AN/ Sint-Geertruid (ros = paard?)

31. Verkenskuylen/V.V/Heer

32. Deurekuilke / Ham / Ubachsberg (deur = stier)

33. Dorkuil/ $\mathrm{Ham} /$ Ubachsberg (dor = deur?')

34. Aan de Dorekuil / SAN / Hulsberg (dore $=$ deur?)

35. Bockscoul / jon/ Sittard

36. Brummelekoel / Str. Phi / Houthem (brummele = bram?)

37. Bremskoel (Broemskuil) / Str / Houthem (brem of braam?)

38. De Groenkuil / Str / Wolder (groen van Kroos, Lemna spec.?)

39. Roosecuyl/V.V/Cadier en Keer

40. Kerskoelen / Sur / Benzenrade

41. Mergelskoel / mondelinge mededeling !. Brouwers / Honthem / in de Goudswel, kleine groeve

42. Mergelkuy!/Tra/Craubeek

43. Aan de Mergelkuyl/Str / Eckelrade

44. Mirregelskoul/Tra/Gangelt:

45. Lenculen / Schr, Ja., SAN / Maastricht (= leemkuilen)

46. Leymkoel / Schr/Geleen

47. Leemkoelen/Str/Wahlwiller

48. De Leemkuil/SAN/Munstergeleen

49. Leemkoel/SAN/Schaesberg

50. Leimkoel/ Dui 2/ Vilt.

51. Leimkoel/Scr/Meerssen

52. Leymkoul/Tra/Maaseik 
53. Leemikuilen/ $\mathrm{v}$.H/Kanne

54. Kleikoele / SAN/Nieuwenhagen

55. Kleylcuile / Bea / Heerlerheide

56. Teegelkuylen / San / Roosteren

57. Zandkoel/ $/ \mathrm{Ham} /$ Ubachsberg

58. Aan de Zandkuil / Wel / Echt

59. Sandkuy / Hou / Buchten

60. Kieskoel / SAN/ Schaesberg (kies = grind)

61. Steinkoul/Tra/Susteren

62. Op de Stein koul / Jon / Sittard

63. Aan de Steynkuyl/ Hou / Buchten

64. Steenkoul/Cuy/Eys

65. Steenkuilen/Das / Meerssen

66. Yzerkuilen(straat)/SAN/Rothem

67. Koolkoel(erweg)/SAN/ Heerlen

68. Wasserkoul / Tra / bij, Sitcard op de Graetheide

69. Waterkoul/Bea/Heerlerheide

70. Drinkkoel/Str / Reijmerstok

71. Koelmar/SAN/Schaesberg

72. Meerkoel/Cla/Terblijt

73. Zeeicoulen/Str/Brunssum

74. Langkoel/Str/Mheer

75. Preyekoil / jas / Gronsveld (preie = kreng)

76. De Prije kuil/Str / Mesch

77. Vilderskuil / Ken / Rothem

78. Schinskoel / Str / Waubach (schinne $=$ onder andere villen)

79. Mentjeskuil / Ser / Wahlwiller (mente = diminutiefvorm van mand)

80. Manskoel (Mannscoul)/ Str, Jon / Sittard (= mandskuil?)

81. Maandelkoel / Str / Bemelen (maandel = mand)

82. Reiserkuilen(straat) en Reyserkuylen / SAN / Kerkrade (reiser = pluralisvorm van rips = rijshout).

83. Rischikuil(erweg) / SAN / Bochhoitz

84. Wolfskuilen(weg) / SAN/Vaals

85. Wolfskwy!/Ken/Geulle

86. Wolfskoul! TOF/Gemmenich

87. Holzkuil/Str/Eygelshoven

88. In gen Bauerkoe! / SAN / Termaar (bawwer = vawwer = valder?)

89. Veldkuil(straat) / SAN/Kerkrade

90. Virth Koule / Tra / Millen, aari de weg naar Virch?

91. Trichterkoul/Vro/Schinveld, aan de Trichterweg?

92. Buchterkoul/ Hou/Buchten

93. Maascoul/SAN/Grevenbicht, bij de Maas

94. Boomgaardskui!/Str / Eygelshoven

95. Aar: Lintieskoel / Jon / Sittard (bij een lindeboom?)

96. Peerboomskuil/Ham / Ubachsberg

97. Sjlakkoel $/ \mathrm{Cla}$ ! Vilt. (slak = silk = slijk?

98. Sint-Servaaskoel/Str, Phi/ Houchem

99. Pokers Koule / Str / bij Millen

100. Op de Winkoelen / Str / bij Sibbe

101. Beckskoel/Str/bij Sittard

102. In de Boterkoel/Str / bij Benzenrade

103. Taterkoel/Str/bij Eijsden

104. Geulkoelen/Str/bij Wahlwiller

105. Geulkuil! Tra/Sint-Geertruid

106. Hoogkuil/SAN/Beek

107. Driekuilen(straat) / SAN / Elsiloo

108. Portonnekuil(straar) / SAN/Geleen

109. Giesekoel (Gisekuilen) / SAN, Tra / bij Lutterade op de Graetheide:

1 10. Klinkekoels(weg) / SAN/Limbricht

111. Kneykuiler(weg)/SAN/Bingelrade

112. Rouwkuiler(weg)/SAN/Bochholtr.

113. Vroenkuiler(weg)/SAN/Simpelveld

114. Pastoorskuylen/Str / bij Hoensbroek

115. Hunnerkoel/Str/Urmond

116. Hunnecuyl/Wel/Echt

117. Snijiderskoel/Ken/Geulle

118. Op de Moelekoel / Jon / Sittard

119. Aan de Kutsche (Katse) kocl / Jon / Siturd

120. Aan de Maene coul / Jon / Sitrard

121. Eysekcuil(sweg)/SAN/Limbriche
122. Bruchkoul/Tra/ Waubach

123. Borstekuil(weg)/ Hei/Margraten

124. Lookoelen / Ham / Ubachsberg

125. Borkuil / Ham / Ubachsberg

126. Weeverskuil/ $/ \mathrm{H} / \mathrm{H} / \mathrm{Kanne}$

127. Hessecoul / Bea / Heerlerheide

128. Aan de Schinkelekoel/Wel/Echt

\section{TABEL 4.4 \\ OVEEIGE DAENK-TOPONIEMEN}

I. Drenk(straat) / Schr / Munstergeieen, aan de Geleenbeek

2. Drenk/Schr/Lutterade, aan de beek

3. Den Drink / Str / Beek, in het centrum aan de beek

4. Paerdsdrenk / Str / Echt aan de Kingebeek

5. In de Drenk / V V / Heer, poel aan de rand van de nederzetting

6. De. Drenk / Mer / Bemelen, poel bij het Bemelerbeumke

7. De Drink/Spi / Nieuwenhagen, poel bij de Vaecheshof

8. In de Sautraenke / Tra / Millen

9. Brandpoel/Fra / Simpelveld, poel in de kern, nu Dr. Poelsstraat.

10. Koezoep/Tra / Melick, poel in de heide

II. Kooywater / Str / Borgharen, poel buiten het dorp

12. Dumpel / Cuy / Bosschenfuizen, drinkpoel

13. Ter Weyer / TOP/Heerien, kasteelhoeve met gracht

14. De Weyert/Jas / Gronsveld, voormalige visvijvers

15. De Wiejert / Das, Scr / stuwmeertie bij een watermolen

16. Aan De Weyerkens / Str / Geleen-Lutterade, poelen op de Graetheide

17. Aan de (oude) Weyeren/Str / Ulestraten, buiten het dorp

18. Wiejert/SAN/Montort

19. Weier/Cuy / Bosschenhuizen, poel

20. Weyers / Leb/Born, vijvers rond kasteel Born

21. Weyers/Schr 2/Rolduc. visvijvers bij de abdi

22. Weyersweg/SAN/Vijlen

23. Korenweyer ! SAN ! Stein

24. Wiejertstrat/SAN / Echr

25. Het Weyerken / Hac / Vlijtingen, ve!dnaam buiten de nederzetting

26. Craehen Ven / Sor / ven in de heide bij Maaseik

27. Berger 'Ven, Wit Veñ, Eerste en Twede Wenne, als nr 26

28. Groesvlaas/SAN/Bakel

29. Katcevlaas / SAN/Bakel

\section{TABEL 4.5}

\section{LIJST VAN DORPSPLEINTJES MET POELEN}

Afgetoceld op de Tranchotkaarten en in de Historische: Atlas Limburg ( $H a l$ )

Kaartblad 65, Ganget:

Douve, twee poeien op een rechthoekig plein

Rad ( $=$ Raath), poel op langwerpig plein

jabeek, poel op rechthoekig plein

Schinveld, poel op driehoekig plein

Doenrade, poel in de hoofitstraat

Hastenrath, twee poelen op plein

Kaartbiad 75, Heerlen:

Vaesrade, groot, driehoekig plein met poel

Vrossebrock (= Vrussemig), groot, driehoekig plein

Winthagen, stervormig plein met poel

Craubeek, klein, driehoekig plein met twee poelen

Kaarțblad 73-74, Rekem-West-Valkentourg:

Itteren, groot, driehoekig plein met twee poelen

Borgfiaren, grote poel in de hoofdstrat

Kleine meers (= Catsop), driehoekig plein met een centraal gelegen poel

Kaartblad 85, Vaais:

Bannenheit (= Bahneheide), langwerpige poel op langwerpig plein

Bochholtzheit, poel op driehoekig pleir 
Colmond, langwerpige poel op verbrede dorpsstrat

Eisheit (Eyserheide), langwerpige poel op verbrede dorpsstrat

Horsbach, poel op driehoekig plein

Kaartblad 83-84, Maastricht-Margraten:

Reijmerstok, vierkante poel bij de Puthof en kleine poel bij de kapel

Terhorst, poel op brede dorpsstraat

Eckelrade, poel op driehoekig plein

Cadier en Keer, poel op brede dorpsstraat

De Historische Adlas Limburg beeldt in kleur dorps- en hofpoelen af op de kaartbladen 759 te Jabeek, Merkelbeek. Houtendoeve, Grootdoenrade en Hornmert, 763 te Helle, Hoensbroek, Welten en Klimmen, 766 te Berg, Sibbe, Wolfshuis, Root en Bemelen, 767 te Kunrade, Benzenrade, Simpelveld, Kolmont, Elkenrade, Eiserheide en Trintelen, 770 te Honthem, Reimerstok. Teriinden, Terhorst, Libeek, Herkenrade en Ekkeirade, 771 te Epen, Hilleshagen, Banenheide, Eperheide. Heienrade, Krapoel en Bergheim en 775 te Terziet.

\section{Groen-toponiemen}

\section{TABEL 5.1 GROEN(E) STRATEN}

I. Berg / Cla : Grunștraet of Groenstraet (1752) / deel van het middeleeuwse (?) interlokale traject Maastricht-Valkenburg-Heerlen; gaat in oostwaartse richting over in de Veestraat, Koeweg en Grote Heide (zie figuur 6.2)

2. Born / Tra : Grün Strass, SAN : Groenstraat / deel van het voormalige interlokale traject Maastricht-Born-Roermond: verlengde van de Kerkstraat, tevens een verbinding met het noordelijk deel van de Graethei

3. Breust/Tra, Kuy, Str, SAN : Groenstraat/verbindt de kern van Breust met het Meezebroek en de Breusterhei, plaatselijk afgezet met hagen

4. Cadier en Keer/Tra, Kuy, SAN: Groenstraat/verbindt het langgerekte dorpsplein, waaraan de kerk en de (voormalige) dorpspoel, put en linde met de plateaurandheiden van de Oreberg en de Wolfskop

5. Eckeirade / Tra : Groeynstraat, Str : Groenstraat / verlengde van de Dorpsstraat; verbindt driehoekig dorpsplein, waaraan kerk, linde. put en (voormalige) poel met onder andere plateaurandgraslanden langs de Hondsbergergrubbe

6. Geleen / Tra, Kuy, Schr : Groenstraat / verlengde van de Dorpsstraat; verbindt de kern van Geleen met graslanden langs de beek (zie figuur 5.3 en hoofdstuk 5)

7. Heer/V.V: Gruynstraat (I588)/identiek met Meysegrebbe en mogelijk met : SAN. Str : Heerder Groenweg; verbindt de kerri van Heer met periodiek overstroomde graslanden buiten de stadsmuur van Wijck (zie figuur 5.5)

8. Honthem / Str : Groenstraat / veldweg vanaf hoeve Baanen naar het zuidwesten, richting Gewanden van Blankenberg en de Hondsbergergrubbe; verloopt in het verlengde van de Groenstrat van Eckelrade

9. Kanne/v.H: Grunstraet (1561) / verbindt het dorpsplein, waaraan een valder, met graslanden langs de beek

10. Kanne/ V.H : Groenstraat (1731) ! de ligging is onbekend

11. Lanaken / V.B : Groenstraat/verbindt de kern van Lanaken met de Grote en Kleine Oo, uiterwaarden langs de Maas ten noorden van Maas. tricht (zie figuur 5.5)

12. Libeek/Tra, Kuy, Str: Groenstraat/veldweg, verbindt de kasteelhoeve Libeek met de Mescherhei

13. Limmel / Tra, Kuy, Das : Groenstraat, Blo: Groene weg / verlengde vạn de Dorpsstraat, verbindt de kern van Limmel met graslanden langs de Maas ten noorden van Wijck (zie figuur 5.5)

14. Linne/Tra, Kuy, Nis, SAN : Groenstraat/verlengde van de Dorpsstraat. gaat over in de Veestraat en verbindt de kern van Linne met de Linnerhei (zie figuur 5.6)

15. Lontzen / Boi : Grünstrasse of Grüner Weg/mogeliik identiek met de Herzogsweg; een oude verbinding tussen Rolduc en Limburg; tevens een "grand chemin à travers des prés"

16. Lutterade/Tra, Kuy, Schr. SAN : Groenstrat/verlengde van de Dorps. straat; verbindt Lutterade met beekdalgraslanden (zie figuur 5.4)

17. Maastricht (Sint-Pieter) / Tra. Str: Groenstrat/momenteel Burg. Ceulenstraat: verbond Sint-Pieter met graslanden langs de jeker buiten de stadsmuur van Maastricht (zie figuur 5.5)

18. Meerssen (Amby) ! Blo : Korte en Lange Groenstraat / wegen tussen Rothem of Amby en vochtige graslanden langs de Kanjel en graslanden buiten de stadsmuren van Wijck (zie figuur 5.5)

19. Melick / Tra, Kuy, SAN : Groenstraat / verlengde van de Dorpsstraat: verbindt de kern van Melick met de Melickerhei

20. Munstergeleen / Tra. Kuy, SAN, Schr: Groenstraat / vroeger Kladderscraat, verbindt de kern van Munstergeleen met de beek (zie figurur 5.4)

21. Munstergeleen / Tra, Kuy, SAN. Schr : Groenstraat / verbindt hoeve Abshoven met de Groene weg (zie figuur 5.4)

22. Reijmerstok/Tra. Kuy, Str : Groene straat / deel van het traject tussen Banholt en Rejimerstok; het verlengde (in Banholt) is de Breede Weg

23. Rosmeer/Str: Groenstraat

24. Rukkelingen / V.E : Groenstraet (1662-1680)/verbindt de kern van Rukkelingen met graslanden langs de beek

25. Ubach over Worms/Tra, Kuy: Grünstraat, Str, A.A : Groenstraat/al in 1800 een gehucht, deel van de interlokale route Maastricht-Keulen, te- 
vens een verbinding tussen Ubach over Worms en beekdalgraslanden

26. Wessern/SAN : Groenstraat, V.H: Groenen wegh / verbindt de kern van Wessem met graslanden langs de Mass ten noorden van Wessem

27. Ijzeren/Tra. Str, SAN : Groenstrat/ veriengde van de Kapelstraat (de nederzetting |jzeren bezit geen kerk), gat over in Ijzeren koeweg en Heidebergweg, verbindt de kern met plateaurandheiden

28. Zichen / Bun : Groenstraet (1476) / ten oosten van Zichen

29. Eygelshoven/V.V 2: Groenstraat/de ligging wordt niet vermeld

\section{TABEL 5.2 \\ GROEN(E) WEGEN}

1. Aubel / Boi : Groenen weg / "vieux chemin en cul de sac", doodlopende weg

2. Bingelrade/Tra. Kuy. SAN : Groene weg/veldweg tussen Bingelrade en jabeek: loopt parallel met de Veestrat en Bredestrat van jabeek, die alle de verbinding vormen tussen de nederzettingen op het middenterras en de beemden langs de Rode Beek (zie figuur 6.1)

3. Brunssum en Merkelbeek / Tra, Kuy, SAN : Groene weg / in I800 veldweg loopt parallel met de Groenstraat van Bingelrade (vergelijk nr 2) in de richting van de beemden langs de Rode Beek. De route was plaatselijkgeblokkceerd door een valder (vergelijk A.A: Vogelvalderensweg) (zie figuur 6.1)

4. Bochholaz/Tra, Kuy, Fra, SAN : Groene weg (1580)/veldweg, verbindt de kasteelhoeve Bongart met de Bochholtzerheide

5. Buchten / Hou, Tra : Eerste Groene weg / doodlopende veldweg in het Holtummerveld. alleen vanuit Holtum ber eikbaar (vergelijk $\mathrm{nr}$ 6)

6. Buchten / Hou, Tra : Tweede Groene weg / doodlopende veldweg. parallel met nr 5

7. Echt / Wel : Groene wegh (1750) / de ligging wordt niet vermeld

8. Eyserheide/Cuy : Groene weg/veldweg, verbindt de nederzetting Eys met de heide

9. Gemmenich / Boi : Groenen weg / omgeving, van Grune Benneten (= Groene beemden), momenteel een gehucht

10. Geverik/Tra, Kuy, Str. SAN : Groene(n) weg/ verbindt de kern van Geverik met het Heydeveld (vergelijk. Tra)

11. Gulpen / Tra, Kuy, SAN : Groene weg/ verbindt de kern van (oud). Gulpen met de plateaurandgraslanden van de Dolsbergen de Beversberg

12. Heer/V:V: Groene weg/identiek met Groengraeff, verbindt het Brook (moerassig grasland) met de Molenweg

13. Herten / Tra, Kuy. SAN : Groene weg/verbindt het gehucht Ool met beemden langs de Maas

14. Hilleshagen / Str: Groene weg/verbindt Hilleshagen met het Elzetteren Vijlenerbos, waar tot 1920 beweiding met rundvee plaats vond.

15. Hobbeirade / Tra, Kuy, SAN : Groenen weg/veldweg vanuit Họbelrade in het dal van de Geleenbeek plateauwarts richting Groot Genhout: deels een holle weg

16. Hoogcruts / Tra, Kuy. Str: Groene weg/ doodlopende veldweg, ver bindt de kasteelhoeve Hoogcruts met de plateaurandheiden Kooyheide (Str) en Hamelsberg (Str)

17. Hulsberg/ Kad: Groenen weg/verbindt Hulsberg met het Heydeveld

18. Kasen / Tra, Kuy. SAN : Groenen weg/veldweg, verbindt hoeve Kruisberg (en her gehucht Kasen) met Moorveld

19. Kerikrade / Str. Kuy : Groene weg/veldweg, verbindt de hoeve Ham met Spekholzerheide

20. Kloosterrade/ Schr 2: Grüne Weg of Kloosterveeweg / verbindt de abdijhoeve met diverse, oorsponkelịk beweide territoria (zie figuur 5.1)

21. Libeek/Tra, Kuy, Str: Groene weg/veidweg, verbindt de kasteelhoeve Libeek met de Banholterhei en de Kooberg

22. Lontzen / Boi : Grüner Weg of Grünstrasse (vergelijk tabel 5.1, nr 15)

23. Maarland / Tra, jas: Greune weeg / veldweg, passeert Overbroek en eindigt in de Oosderdriessen: het begin van de route is met hagen afgezet

24. Margraten (Ter Maar)/Tra. Kuy, Str, Hei: Groenen weg/ veldweg, gaat over in Breede weg

25. Mechelen / Tra : Grüne weg/ verbindt Mechelen met het Elzetterbos. Tot 1920 werd hier nog, beweiding met runderen toegepast

26. Meerssen (Raar) / Das: Groene weg/ verbindt het gehucht Raar met de plateaurandheide 't Hetje ( = Kleine heide)
27. Moelingen / Boi : Groene weg / mogelijk identiek met nr 9

28. Munstergeleen / Schr: Groene weg/verbindt de hoeve Abshoven met beekdaigraslanden (zie figuur 5.3)

29. Munstergeleen / Str : Groene weg / korte veldweg op de grens van Geleen en Sittard; mogelijk identiek met de oude heerdgangroute van Munstergeleen naar de Graetheide (zie figuur 5.3)

30. Munstergeleen/Schr: Groene weg/veldweg; verbindt de hoeve Abshoven met de plateaurand. Het is de voortzetting van een Groenstraat (zie figuur 5.3)

31. Retersbeek/Tra, Bro: Groene weg / doodlopende veldweg, verbindt de nederzetting Retersbeck met een uitgestrekt weidegebied aan de bovenloop van de Leuperbeek.

32. Roermond/A.A: Groenen weg/verbindt Roermond met uiterwaar: den langs de Maas

33. Sint-Martens-Voeren / Boi, Fer: Groenen weg/veldweg, verbindt SintMartens-Voerert - via Groene Haag-met de Weersterheide bij Warsage

34. Sint-Pietersvoeren / Boi : Groene weg / "chemin, reliant Rullen A la Grande Route", verbindt het gehucht Rullen met het plateau en de daar* op gelegen interlokale weg

35. Terblijt / Cla : Groene weg/verbindt Terblijt met de plateurandheide

36. Teuven / Boi : Groene weg/ "le chemin n'existe plus""

37. Trintelen/Tra. Kuy, Str, Cuy, : Groene weg/ verbindt Trintelen met de Waukelder (= jeneverbes), een plateaurandheide

38. Ulestraten/Tra, Kuy, Str, SAN : Groenweg/veldweg, verbindt het gehucht Klein Berghem via de Holstraat met. het Heiland, een plateaurandheide

39. Vaesrade/Tra, Kuy: Groene weg/verbindt Vaesrade met beekdalgraslanden

40. Vilt / Cla : Groene wegh / veldweg, gelegen aan de periferie van de gemeente

41. Villen/Tra. Kur, Str, SAN : Groenenweg/zeer lange veldweg; verbindt Viplen via het Vijtenerbos met de beemden langs de Geul bij Camerig

42. Walem / Kad: Groenen weg / veldweg over de Goudsberg; mondt uit op de plateaurand

43. Wessem / SAN : Groene weg / gesitueerd in de uiterwaarden van de Maas

\section{TABEL 5.3 \\ GROENE WEGSKENS}

1. Buchten / Hou : Greun waegske of Meulewaegske / veldweg tussen Holtum en Buchten

2. Haasdal/Kad: Groen wegsken / doodlopende veldweg

3. Heer (of Cadier en Keer) / V.V: Groen wegsken / de ligging is onbekend

4. Rimburg / Str : Groen wegsken / veldweg, verbindt. Rimburg met het Heideveld en de Kruggelheide

5. Roosteren/Str; Groen wegsken / veldweg, tussen Roosteren en Astenberg. Volgens San verdwenen

6. Sittard/Tra, Kuy, Sche: Groen wege / veldweg in het Hinscherveld en gelegen binnen de driehoek kasteel Limbricht-Overhovenheide-Verkensheide

\section{TABEL 5.4 \\ OVERIGE GROEN/GROES-TOPONIEMEN}
Groesbeek/TOP : dorp bij Nijmegen
Groesweg/Str : Schinveld
Groesdel/Str: Ulestraten
Gronsveld / TOP : dorp bij Maastricht.
Gronsdel / Boi: Weerst (= Warsage)
Groenseykerweg/SAN : Geleen
Greunsje / Jas : Gronsveld-Rujckholt
Verkensgroos / Sim : Urmond
Kapellegroos / Wel 2 : grasveld bii kapel te Echt
0. Groes / Wel : Echt In 1772 verbod tot begrazing van de groes
Greuselt / Boi : Homburg
Grunet/Boi : Baelen
13. Groendai(strat)/SAN : Limbricht 
14. Groendal(se bergweg)/SAN : Rejimerstok

15. Groene dal / Boi : Hergenrath

16. Groene dali Boi : Raren

17. Groene dal / Boi : Bilstain

18. Groenendaal/SAN : Ubach over Worms

19. Groenen rein/SAN : Cadier en Keer

20. Groenen rein/Str : Bruisterbosch

21. Groenen boord/SAN : Banholt

22. Groenen boord/SAN: Heerlen

23. Groenkuil/Ser:Wolder

14. Groenenborg/SAN: Schinnen

25. Groene beemden / Boi : Gemmenich

26. Groene graaf/Boi : 's-Gravenvoeren

27. Groengraefi/ V.V: Heer

28. Groenhaag/SAN: Oirsbeek

29. Groenhaag / Boi: Sint-Martens-Voeren

30. Groen hei / Boi : Weerst ( = Warsage)

31. Groenstergrache/Str: Ubach over Worms

32. Gruenen Grache (1528) / Bun : Bolder
6 Mes/mis-toponiemen

\section{TABEL 6.I MESTWEGEN EN -STRATEN}

I. Kleine mestStrasse / Tra / Millen, gaat over in de "Viehstrasse" en verbindt de nederzetting Millen met graslanden langs, de beek

2. Aan de Mestweg / Str, Goo / Ubach over Worms, omgeving van de "Groenstraat". De mestweg wordt niet door Str genoemd, wel door Goo, die de "Meszweg" vermeldt met daaraan de "Meesepool", een veedrenk midden in de nederzetting Ubach over Worms

\section{TABEL 6.2}

\section{SYNONIEMEN VOOR MESTWEGEN}

1. Drekstraat/Sme / Limbricht, momenteel de "Steenstraat"

2. Drekstraat / Hei / Margraten, verbindt het gehucht Termaar met een veedrenk met her. "Pasveld"

3. Dreckweg/Kad/Nuth

4. Drekweg! V V 2 I Eygelshoven

5. Flatterstraat/Sal / Hoensbroek, momenteel "Nieuwstraat", de verbinding tussen het gehucht, "Overbroek" en graslanden langs de Molenbeek

6. Kladderstraat / Schr / Munstergeleen, synoniem met "Groenstraat". vormt de verbinding tussen het dorp Munstergeleen en graslanden langs de beck

7. Klaterstraat / Pliv / Houthem, verbindt de nederzetting "Strabeek" met graslanden langs de Geul

8. Vuilstraat / A.A / Eijsden, verbindt Eijsden met. Maarland via graslanden

9. Vuilstraat/A.A/Melick

10. Vuylstraat / Phi / Houthem, momenteel "Onderste straat"; verbindt Houthem met graslanden langs de Geul

I1. Vuijte wey en Heynkens vulijlweg/ Her / Sint-Odiliènberg

12. Vuilbeemden / TOP / Roermond, vochtige graslanden langs de Maas

\section{TABEL 6.3}

\section{MES/MISWEGEN}

I. Mesweg of Blijer Mesweg / Cla / Terblijt, yerbindt Berg met Terblijt via de "Kleine Heide" en de "Mesberg"

2. Mesweg, Mestweg, Messewegh of Meesweg / Cla / Berg, verbindt Berg met Vilt via de "Grote Heide"

3. Mesweg of Holtermesweg / Rae / Hulsberg, verbindt het dorp Hulsberg met zowel Arendsgenhout als Aalbeek. De Tranchorkaart beeldt hagen af langs deze weg,

4. Misweg, Oude en Nieuwe / SAN/ of Mestweg/ Hal / Merkelbeek, verbinde de nederzetting. "Rad" via de "Groenstraat" met graslanden langs de: Rode Beek

5. Mesweg / SAN / Eys, verbindt het dorp Eys via graslanderi langs de beek met het gehucht Overeys

6. Op den Misweg / Str / Zussen (Belgie), vanuit Zussen naar het noordwesten, richting Maastricht. Waarschịnnliịk identiek met "op ten mestweech die reyckt van Sussen te Triecht wairt" (vergelijk Doppler 1907). De huidige Misweg te Zussen / SAB / is een deel van dit traject

7. Meysstraat / SAN / Wiinandsrade, in de kom van Wijnandsrade

8. Mesgats (gats $=$ smalle weg) $/$ Vro $/$ Hillensberg

TABEL 6.4

MESHAGEN EN -GRUBBEN

1. Meyshagen / Schr / Meisag / Tra / Munstergeleen, verbindt het dorp Munstergeleen met de rand van het plateau

2. Meysegrebbe / V.V/Heer, synoniem met. "Gruynstraat", De Heerder Groenstraat / Tra. SAN/ verbindt de laaggelegen graslanden buiten de stadswallen van Wijck met het dorp Heer. 


\section{TABEL 6.5}

\section{MESTPOEL EN-KOEL}

1. Meesepool / Goo / Ubach over Worms, een veedrenk, gelegen aan de Messweg" in de kom van Ubach over Worms

2 In de Meestkoul / Sor / Benzenrade, perceel tussen Benzenrade en de "Putberg"

\section{TABEL 6.6}

\section{MESBROEK, -BEEK, -WINKEL, -BERG EN.DAL}

1. Meisenbroek / SAN / Maastricht, in de beemden van "Biesland" langs de jeker

2 Meesenbroek / SAN / Heerlen, hoeve langs de Caumerbeek

3. Meysenbroich / Schr / Sittard, hoeve langs de Keutelbeek

4. Meesebroek / SAN / Eijsden, perceel langs de "Vuilstraat" in het Maasdal

5. Messwinckel / TOP / Kempen (Duitsland), beemden langs de Roer

6. Mesberg/Cla/Terblijt, deel van de plateaurand, grenzend aan de Kleine Heide

7. Meysberg / Bea / Hoensbroek, de juiste ligging wordt niet vermeld

8. Meysendaelwegh / Wel / Echt, de juiste ligging wordt niet vermeld

9. Meisberg / TOP / Hunsel, hoeve, gelegen in het dal van de Uffelse beek.

\section{Dries-toponiemen, overzicht van de tabellen}

7.1 De dries als pleintie binnen een nederzetting

7.2 De dries ats braaklizzend perceel aan de stadsmuur

7.3 De dries als aanduiding voor een nederzetting (hoeve of gehucht)

7.4 De dries als aanduiding voor een perceel buiten de nederzetting (simplex-vormen)

7.5 Composita-vormen

7.5.1 Het toponiem dries + de naam van een dier

7.5.2 Hec toponiem dries + de naam van een plantesoort of een vegetatietype

7.5.3 Het toponiem dries + de naam van de eigenaar of gebruiker 7.5.4 Het toponiem dries + de aanduiding van een inferieur substraat 7.5 .5 Het toponiem dries + overige aanduidingen

\section{TABEL 7.1}

\section{HET TOPONIEM "DRIES" ALS AANDUIDING VOOR EEN} DORPSPLEIN(TJE)

1. De Grote Dries / Holtum / SAN / groot plein, momenteel voetbalveld. aan de rand van Holtum

2. Kleine Dries / Holtum / SAN. Kuy / driehoekig pleintie in de oude kern van Holtum

3. Lindendries(straat) / Meers / SAN. Kuy / in 1800 een langwerpig, rechthoekig pleintie in de kern van Meers

4. Op den Dries / Pey/SAN, Kuy / driehoekig pleintie aan de Dorpsstraat te Pey

5. Op den Dries / Mesch/SAN/pleintie in de kern van Mesch, waaraan de "Drieshof" is gelegen

6. Op de Driessen / Koningabos / SAN, Kuy / vierkant dorpsplein

7. Op den Dries / Groot Welsden / Hel, Kuy / driehoekig pleintie

8. Op den Dries/Eygelshoven/Str, Kuy. SAN/plein in de kern van Eygelshoven

9. Op den driesch / Raren / Boi / pleintie in de kern van Raren

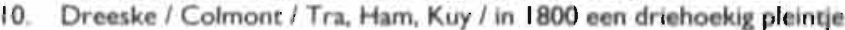
met kapel en poel

11. Dries / Heerierheide / Bea. Kuy / plein in de kern van Heerlerheide

12. Driessen (weg) / Grijzegrubben / SAN, Kuy / driehoekig plein mec daaraan de hoeve "Drieschen"

13. Driessen(straat) / Neeritter / SAN, Kuy / vierkant plẹințe in de kern van Neeritter

14. Op de Dries/Catsop/SAN, Kuy / plein met kapel en poel in de kern van Catsop

15. Op den driesch ( $=$ Verkensdries $) /$ Kanne $/$ v.H $/$ pleintje met poel

\section{TABEL 7.2}

HET TOPONIEM "DRIES" ALS AANDUIDING VOOR EEN PERCEEL, GELEGEN AAN DE BUITENZIJDE VAN DE STADS. MUUR

I. Maagdendries / Maastricht/ Jas, SAN, End/ perceel aan de Boschpoort. voormalig eigendom van een nonnenklooster

2. Pontriesch / Aken / Wel 3/ perceel aan de Ponttor

3. Bergdriesch / Aken / Wel 3 / perceel in de omgeving van nr 2

4. Hoorderdries / Nieuwstadt / SAN / buiten de. Millerpoort

5. Maagdendries / Hasselt / SAB / stratnaam in de oude kern van Hasselc

\section{TABEL 7.3}

\section{HET TOPONIEM "DRIES" ALS AANDUIDING VOOR EEN NEDERZETTING IN DE BETEKENIS VAN EEN HOEVE, EEN GROEPJE HUIZEN OF EEN GEHUCHT}

1. Drieshof/Mesch/Str/hoeve, gelegen aan de Dries (vergelijk tabel 7.1. nr 5)

2. Ten Driesch / Voerendaal / Hom / hoeve, genoemd in 1550 
3. Ten Driesch / Hombourg / TOP / wwee bij elkaar gelegen hoeven

4. Driessen / Remersdaal / TOP / enkele hoeven

5. Drieschen / Moresnet / TOP / twee bij elkaar gelegen hoeven

6. Driesch / Haaren / TOP / gehucht bij Haaren

7. Haaserdriesch / omgeving van Haren / TOP / groep huizen bij het gehucht Haas

8. Eckholterdriesch / Kempen / TOP / gehucht bij Kempen

9. Driesen(straat) / Kinroy / TOP / gehucht bij Kinroy

10. Boekweytsdries / Swalmen / Ger / hoeve, genoemd in 1672

11. Opden Drisch/Moelingen / Boi / gehucht, voordien een perceelaanduiding

12. Op ene Drisch / Walhorn / Boi / hoeve op de Maarelheide

13. Eykdriessen / Baelen / Boi / twee boerderijen te Nereth

14. Op ene Drisch / Teuven / Boi / eenzaam gelegen hoeve op her plateau

15. A gene Drisch / Aubel / Boi / kasteelhoeve

16. Drieschen / Grijzegrubben / hoeve, gelegen aan de Dries (vergelijk tabel 7.1, nr 12)

17. Op e Drischke / Welkenrath / Boi / afgelegen hoeve

18. Giveiderdriessen / Teuven / Bol / afgelegen hoeve op het plateau

19. Op ene drisch / Montzen / Boi / hoeve

20. Zelderdriessen / Hendrik-kapelle / Boi / hoeve

21. Op gen driesschen/Vijlen/Ren / boswachterswoning in het Villenerbos

\section{TABEL 7.4}

\section{HET" TOPONIEM "DRIES" IN SIMPLEX-VORM EN ALS EEN} PERCEELAANDUIDING, GELEGEN BUITEN DE NEDERZETTING

1. In het Driessen / Benzenrade / Str / plateaukop

2. In de Driessen / Benzenrade / Str / omgeving Benzenraderhof

3. Op de Dries/Schinnen/Str

4. Den Dries / Valkenburg / Wel 3 / plateaurand van de Heunsberg.

5. Den Dries / Brunssum / Str / perceel, grenzend aan de Brunssummerhei

6. Dẹ Driessen / Rothem/Str/onvruchtbaar perceel ten westen van Kruisdonk

7. Op den dries/Schin op Geul/Lem/perceel, gelegen aan de plateaurand

8. Driesschen/Buchten/Hou/veldnaam

9. Aan den Driesch / Sittard/ Jon/veldnaam

10. Drees/Posterholt / Kem/veldnaam

11. Op den Drees/Swalmen/Fer / veldnaam

12. De Dries/Echt/Tra/ veldnaam

13. Op de Driesgen/ Hulsberg/Rae/de ligging is onbekend; wordt genoemd in 1600

14. Op den driesch / Thull / Str / veldnaam

15. Op ene Drisch / "s-Gravenvoeren / Boi / "steengewanden"

16. Op ene Drisch / Sint-Martens-Voeren/Boi/veldnaam

17. Op ene Drisch / Nieuw Moresnet / Boi / veldnaam

18. Op ene Drisch / Hergenrath / Boi / veldnaam

19. Op ene Drisch / Moresnet / Boi / veldnaam; destijds braakliggend terrein

20. Op ene Drisch / Eynatten / Boi / veldnaam

21. Op ene Drisch/Eupen/Boi/veldnaam

22. Op ene Drisch / Baelen / Boi / veldnaam

23. Op den Dries / Heijenrath / naam van een hotel, gelegen op de plateaurand

24. De Dreesj/Ubach over Worms / Goo / weiland in de Rukkener

25. Op den Dries / Wessem / SAN / straatnaam buiten Wessem

26. Op den driessen / Kerkrade, Schaesberg / SAN / straatnaam buiten Schaesberg

27. Op de dries / Nijswiller / Ren / veldnaam tussen Plattebos en Colmonderbos
TABEL 7.5 COMPOSITA-VORMEN

\section{TABEL 7.5.}

\section{HET TOPONIEM "DRIES", VOORAFGEGAAN DOOR EEN DIERENNAAM EN GELEGEN BUITEN DE NEDERZETTING}

1. Rinderdriessen/Ubach over Worms/Str, Goo/grenzend aan de Brunssummerheide

2. Coindriesch / Montzen / Boi / = Koeiendries?

3. Horedriesch / Eynatten / Boi / = hoorn(vee)dries?

4. Hoorderdries / Nieuwstadt/SAN

5. Kattedries / Raren / Bol

6. Katzedries / Eupen/Boi

7. Schaepsdries / Baelen / Boi

8. Schapendries / Kettenis / Boi

9. Schaapsdries / Hulsberg-Walem / Rae

I0. Schaepsdries/Roermond/SAN

11. Schaepsdries/Wijlre/Str

12. Moutondriesch / Baelen / Boi

13. Bockendries/Walhorn / Boi

14. Varkensdries/Kanne / v.H/pleintie met poel binnen de nederzetting

15. Paardendries / Brunssum/SAN

16. Ganzendries/Maastricht/Tra

17. Duivendries/Beek/Str, Lem

18. Mussendries/Montzen / Boi

19. Ravendries/Berg/Rae

20. Hazedries / Heijenrath / Str

21. Wolfsdries / Berg/Cla

22. Wolfsdries / Baelen / Boi

\section{TABEL 7.5.2}

HET TOPONIEM "DRIES", VOORAFGEGAAN DOOR EEN

PLANTENNAAM OF EEN VEGETATIETYPE EN MEESTAL GELEGEN BUITEN DE NEDERZETTING

I. Doornendries / Schin op Geul / Lem / begroeid met doornstruiken?

2. Huydries / Beek / Lem / huy of huylig heeft als mogeliike betekenis: "droog" of "hakhout" (vergelijk tabel 7.5.3. nr II)

3. Boekweytsdries / Swalmen / Ger / boekweit is het cultuurgewas van onvruchtbare grond

4. Hennefdries / Eynatten / Boi / Hanf = hennep, een cultuurgewas

5. Berkendries / Moreșnet / Boi / karakteristieke boomșoort voor onvruchtbare gronden

6. Ginsterdries / Baelen / Boi / ginster = brem, karakteristiek gewas van onvruchtbare gronden. Brem werd ook gecultiveerd. onder andere als veevoer, brandhout en materiaal voor de fabricage van bezems.

7. Ginsterdries / Eynatten / Boi / (vergelijk nr 6)

8. Ginsterdries / Wahiwiller / Str, Ren / (vergelịk nr 6)

9. Benede dries / Kettenis / Boi / benete = beemden, laaggelegen perceel

10. Heidries / Boi / grenzend aan heide of begroeid met schraal grasland?

11. Heidries / Baelen / Boi / (vergelifk nr 10)

12. Eikendries / Lontzen / Boi / met eikenhakhout begroeid?

13. Eckholterdriesch / Kempen / Top / naam van een gehucht bij Kempen (vergelijk nr 12)

14. Lindendries(straat) / Meers / SAN. Kuy / pleintie te Meers; de linde is ẹn karakteristieke boomsoort voor dorpspleinen

15. Driesweid / Raren / Boi / = driesweide

16. Boenendries / Baelen / Boi / bonen: cultuurgewas

17. Boschdreesje / Ubach over Worms / Goo / ligging nabij bos

18. Heyligendries of Huilegen dries / Valkenburg / Wel / begroeid met hakhout?

Van buiten het onderzoeksgebied zijn bekend: klaver-, haver-en spurriedriesen. Dit zijn typische braakgewassen (zie hoofdstuk 7). 
TABEL 7.5.3

\section{HET TOPONIEN "ORIES", YOORAFGEGAAN DOOR EEN AANDUIDING VAN EEN EIGENAAR OF GEBRUIKER EN GELEGEN BUITEN DE NEDERZETTING}

1. Den gemeynen dries / Terblijt / Cla / de ligging wordt niet genoemd

2. Den gemeynen dries / Berg/ Cla / gelegen aan de rand van de Meerssener Heide

3. Imstenrader drisje / Imstenrade / Str. Fra / behorend bij Imstenrade

4. Lovenmicher drees / Simpelveld / Fra / behorend bij de hoeve Lovenmich

5. Haaserdriesch / Haas / TOP / gehucht bil de nederzetting Has

6. Oosderdriessen / Oost/Str. Tra / behorend bil Oost

7. Kerkdries / Ubachsberg / Ham / kerkelijk bezit

8. Altaardries / Heerlen / SAN/kerkelijk bezit?

9. Maagdendries / Maastricht/ Jas, SAN/ bezit van een nonnenklooster of daarbil gelegen

10. Maagdendries / Hasselt/ SAB / (vergelijk nr 9)

11. Heyligen dries / Valkenburg/Wel / kerkelijk bezit (vergelijk tabel 7.5.2. $n r$ (8)

12. Heeredrieschen / 's-Gravenvoeren / Boi / bezit van de heer?

13. Herendries / Valkenburg, Sibbe / SAN / (vergelijk nr 12)

14. Kaplaansdries / Ransdaal / Dui / opbrengst, bestemd voor de kapelaan

15. Boajendreesch / Gronsveld / Jas / opbrengst, bestemd voor de (gemeente)bode

16. Kustersdriessen / Ubach over worms / Str. Goo / opbrengst, bestemd voor de koster

17. Schuttendries / Margraten / Hei / bezit van de schutterii\}?

18. Armendries / Buchten / Hou / bezit van het gemeentelijk armenbestuur of arm in de zin van onvruchtbaar?

19. In de Wohbicher dreesje / Ubach over Worms / Goo / Wohbich is het dorp Waubach

20. Rutscher dreesje / Ubach pver Worms / Goo / behorend tot het gehucht Rutsch

21. Stuckesdriesch / Harles / Ren / naam van de eigenaar

22. Mehicopsdries / Ubach over Worms / Goo / naam van de eigenaar

\section{TABEL 7.5.4}

HET TOPONIEM "DRIES", YOORAFGEGAAN DOOR EEN AANDUIDING DIE BETREKKING HEEFT OP DE INFERIEURE KWALITEIT VAN HET SUBSTRAAT VAN DE DRIES EN DIE IS GELEGEN BUITEN DE NEDERZETTING

I. Zure Dries / Gronsveld / Jas / perceel schraal grasland aan de plateaurand

2. Zuren Dries / Welkenrath / Boi

3. Stenen dries/Walhorn/Boi

4. Steendries / Hendrik-kapelle / Boi

5. Leemdries / Lontzen / Boi

6. Leemdiries/Kettenis/Boi

7. Armendries / Buchten / Hou / arm = onvruchtbaar of in het bezit van hes armenbestuur

8. Herkendries / Lontzen / Boi / herk = droog

9. Gatsendries / Montzen / Boi / gats = bedorven, slecht

10. "drieschen, genaemt de maegere man" / Sibbe / Dui 2/ perceel aan de plateaurand

\section{TABEL 7.5.5}

HET TOPONIEM "DRIES": VOORAFGEGAAN DANWEL GEVOLGD DOOR OVERIGE AANDUIDINGEN DAN DE HIERBOVEN GENOEMDE EN MEESTAL GELEGEN BUITEN DE NEDERZETTING

1. Platten dries/ Honthem/ $\mathrm{Str} /$ perceel aan de plateaurand ten zuiden van Honthem

2. Grote dries / Holtum / SAN / groot perceel, momenteel voetbalveld aan de rand van de nederzetting
3. Oude dries / Born / SAN/ straatnaam bil llikhoven

4. Namiddagse Driessen/Ubach over Worms/Str, SAN/percelen, grenzend aan de Brunssummerheide (vergelijk $\mathrm{nr}$ 26)

5. Zwartdriesstraat / Stein / SAN/grenzend aan de Graetheide

6. Langendries / Herten/SAN/buiten de kern van Herten

7. Duikerdries(weg) / Vililen / SAN

8. Aldendries(weg) / Buchten / Sal / (vergelijk nr 3)

9. Schollentriesch/Walhorn / Boi

10. Becissentriesch/Walhom/Boi

11. Lengen triesch / Baelen / Boi / leng = lang?

12. Meye driesch / Baelen / Bo

13. Plage Drisch / Baelen / Boi

14. Puts Driesken / Baelen / Boi

15. Flegels Drisch / Baelen / Boi

16. Molen dries / Eynatten / Bo

17. Boven Dries / Walhorn-Kettenis / Bor

18. Oebesdreesch / Margraten / Hei / perceel aan de plateaurand. Hei vermeldt ook "Obesveld"

19. Bergdriesch/Heerien/SAN

20. Dreesberg / Honthem / Str / perceel aan de plateaurand ten zuiden van Honthem

21. Drieschstraat / Heerlen, Schandelen / SAN / buiten de oude kern

22. Driesweg/Gemmenich / Boi

23. Driesweg/Raren/Boi

24. Dreesi(waegske) / Buchten / Hou

25. Driessenweg/Buchten / Hou

26. Morgendriessen / Ubach over Worms / Goo / grenzend aan de Brunssummerheide. Morgen is een opperylaktemat. Een relatie met de Namiddagse Driessen is evenwel niet uitgesloten (vergelijk hierboven nr 4)

27. Achter de Drischeren / Ubach over Worms / Goo

28. Zengedreesie/ / Ubach over Worms / Goo

29. Sipaardresje / Ubach over Worms / Goo

30. Catharina Drieske/ Gulpen / Str

31. Daldries / Nijswiller / Ren

32. Langen dries / Nijswiller / Ren

\section{TABEL 7.6}

\section{"HEEM". EN "ROT"-NEDERZETTINGEN}

A. Heem (hemem of heirn)-toponiement

Rond Maastrichit en langs de Maas: Heugem, Nekum, Pietershem, Rekem, Boorsem, Kotem en Stokkem (SAN).

Rond Meerssen: Rothem: Geulhem. Houthem, Broekhem en Berghem (SAN) Rond Oud-Valkenburg Walern, Euverem en Neerhem (SAN).

Rond Gulpen: Berghem, Stokkem, Euverem en Wittem (SAN).

Rond Simpelveld: Neerhem, Oppem en Bulkem (Fra).

Overige heem-toponiemen: Honthem (SAN), Broensem (Hei), Brunssum (SAN) en Hunnekum (SAN). De eerste twee liggen vtak bij elkaar op het plateau van Margraten. Ter plaatse stroomt een kleine beek met permanent water, die ter hoogte van Blankeberg verdwijnt. Brunssum ligr aan een beek: Hunnekum lige op ẹen afstand van $500 \mathrm{~m}$ ten opzichte van de beek bij Terstraten.

\section{B. Rot-toponiemen}

V'arianten van rode zịn onder andere: rode, root, rade. raat, rath en reutie. Op het plateau van Margraten liggen: Eckelrade, Herkenrade، Sint-Geertruid (= Sint-Gertrudis-rade), 't Rooth, Reutje(sstraat), Margraten (= Maria-rade, Maar-rade of Sint-Margareten-rade), Raar(hooggrachtweg) bil Bernelen, Rot(weg) in Noorbeek, Hackeroth bij Mheer (SAN) en In ghen Roeth bij Berg (Cla) en Eykenroed bij Cadier en Keer ( $\mathrm{V}, \mathrm{V}$ ).

Op het plateau van Schimmert liggen: ' $t$ Rooth, ' $t$ Reutie, Amstenrood, Goudenrood, Breyenrade ( $\mathrm{S}$ r $)$, Schinroeth (oude naam van Schimmert?, yergelijk Das), Raar, Hobbelrade, Wijnandșrade, Weustenrade (SAN), Wolfrath, Langeraats(kamp).

Op het plateau van, Eperheide liggen: Landsrade, Hejenrath en Rood(weg) (SSAN).

Op het plateau van Vịlen liggen de "Zeven Rotter van Vyle", met name Rott, Raren, Einrade, Elzet. Melleschet, Holset en. Harles. 
Op het plateau van Bahneheide ligt het Rot van Cartiels (Tra) en het kasteel Goedenraad.

Op het plateau van Ubachsberg liggen: Rade(weg) bij Fromberg, Elkenrade. Rood(veldstraat) bij Klimmen, Kunrade, Doevenrade, Benzenrade en Imstenrade.

Op het plateau van Rode liggen: Kerkrade, Herzogenrath, Haanrade. Frohnrath (SAN) en Nieuwenrode (Schr).

Op het plateau van Doenrade liggen: Amstenrade, Bingelrade, Doenrade, Et. zenrade, Kouvenrade (Kuy), Vaesrade, Vogelsroed (Kuy) en Rath (Kuy).

Op het plateau van de Graetheide liggen: Wolfrach, Langeraths(kamp), 'v Rooth, Lutterade, Roetgens(weg), Onderste en Middelste Roed(weg). Roth(weg) en Root(straatie).
De hieronder vermelde tabellen hebben geen betrekking op toponiemen, maar vermelden andere gegevens. Tabel 9 heeft betrekking op floristische en vegetatiekundige basisgegevens voor de hoofdstukken 10, 13 en 14. Tabel 10 betreft een lijst van oude foto's, die in hoofdstuk 15 ter sprake komen.

\section{Vegetatie-opnamen}

\section{TABEL 9.1}

THERO-AIRION-OPNAMEN. MAAS- EN JEKERDAL

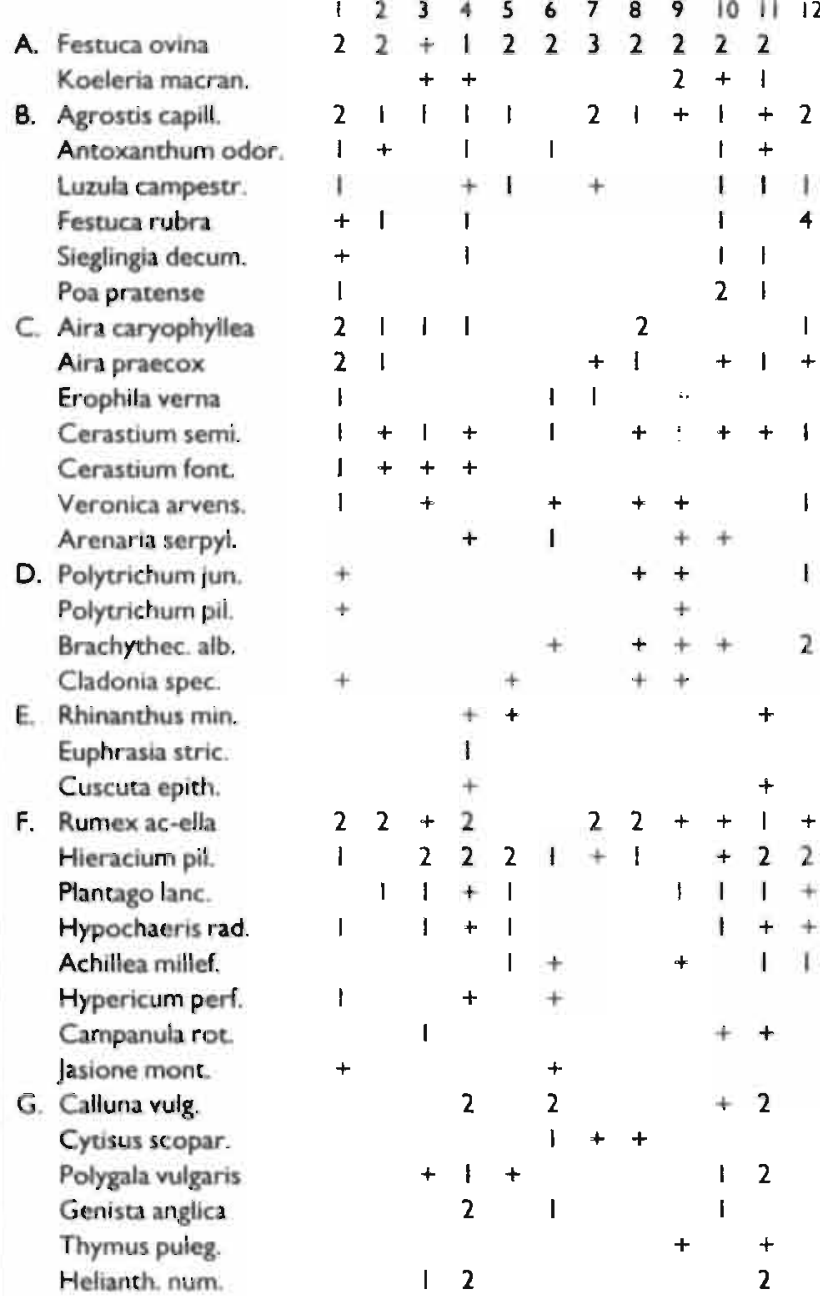

Opnamegegevens

Opname: 1. Bemelen, plateaurand van de Strooberg langs schapepad. Open en korte vegetatie met polleties Festuca ovina. Daartussen open plekken metonder andere de beide soorten Aira en Rumex acetosella. Datum: 09-06-1983. Oppervlakte: $2 \times 2 \mathrm{~m}$. Bedekking: 80\%. Hoogte: 10-15 cm. Expositie: zuidwest Inclinatie: 30. Beheer: extensieve beweiding met mergellandschapen. Deze opname werd eerder gepubliceerd en van commentaar voorzien (vergelijk HILLEGERS 1984a, p. 22).

Opname 2. Als I, maar enkele meters lager op de helling. Bedekking: $80 \%$. Hoogte: maximaal $15 \mathrm{~cm}$.

Opname 3. Kanne, plateaurand van de Kooberg aan de Zusșerdel. Plaatselịk open, plastselijk gesloten, korte en soortenrijke vegetatie met Festuca ovina en Hieracium pilosella. Datum: 04-06-1980. Oppervlakte; $2 \times 2 \mathrm{~m}$. Bedekking: $60 \%$. Hoogte: $15 \mathrm{~cm}$. Expositie: zuid, Inclinatie: 20.

Opname 4. Als 3, maar enkele meters lager op de helling. Gesloten vegetatie met dwergstruikjes van onder andere Genista anglica en Calluna vulgaris. Bedekking: $95 \%$. Hoogte: $15 \mathrm{~cm}$, dwergstruiken: $25 \mathrm{~cm}$ 
Opname 5. Als 3, nog lager op de helling, Gesloten, kort vegetatiedek met Festuca ovina en Rumex acetosella en rozetten van onder andere Hieracium pilosella en Hypochaeris radicata. De opnamen 3. 4 en 5 werden eerder gepubliceerd en van commentaar voorzien (vergelijk HiLLEERS 198 ।b). Beheer extensieve beweiding met rundree.

Opname 6. Bitsingen, Soo Hé, plateaurand van de Sint-Pietersberg aan de Jekerzijde op kiezelrį̣k substraac. Open vegetatie met lage dwergstruiken, mossen en kleine bloemplanten. Beheer, tred en begrazing door konijnen. Datum: 04-05-1984. Oppervlakte: $2 x$ $2 \mathrm{~m}$. Bedekking $50 \%$. Hoogte: $2 \mathrm{~cm}$ (eenjarige kruiden), $10 \mathrm{~cm}$ (Calluna struikjes). Expositie: rwak zuid. Inclinatie: 10.

Opname 7. Cadier en Keer, Hiereberg, plateaurand van het Maasdal. Steilrand van de weg naar de kiezelgroeve. Open vegetatie met Festuca ovina pollen en Rumex acetosella, daartussen bloeiende therofyten. Beheer: begrazing door konijnen. Datum: 27-05-1984. Oppervlakte: $2 \times 2 \mathrm{~m}$. Bedekking 80\%. Hoogte: 5 $\mathrm{cm}$ (annuellen) - $15 \mathrm{~cm}$ (pollen). Expositie: zuid, Inclinatie: 60 .

Opname 8. Als 7, "kopie" in weiland ten noorden van de kiezelgroeve. Open vegetatie met polletjes Festuca ovina en annuelle grassen. Datum: 27-05-1984. Oppervlakte: $3 \times 1 \mathrm{~m}$. Bedekking: $80 \%$. Hoogte: maximaal $15 \mathrm{~cm}$. Expositie: zuid. Inclinatie: 20. Beheer: intensieve beweiding met rundvee.

Opname 9. Masstricht, Sint-Pietersberg, vlak gelegen, kiezelrijk deel van het plateau, ongeveer $100 \mathrm{~m}$ ten zuiden van het fort. Zeer open en lage vegetatie met polvormende grassen (Festuca ovina), annuel. len en kleine rozetten. Datum 03-06-1984. Oppervlakte: $4 \times 4$ $\mathrm{m}$. Bedekcing: $60 \%$. Beheer: parkeerterrein en hondenuitaatplaats. De grazige delen worden jaarlijks gemaaid.

Opname 10. Masstricht, Sint-Pietersberg ten zuiden van het fort. Datum: 02 03-1950. Oppervlakte: $50 \mathrm{~m}$. Auteurs: DIEMONT EN VAN DE VEN 1953, tabel 3, nr 3, pp. 17-18.

Opname 11. Maastricht, grashelling ten westen van het Kannerbos. Datum: 31-05-1950. Oppervlakte: $50 \mathrm{~m}$. Expositie: zuid. Auteurs: DiEMONT EN VAN DE VEN 1953, tabel 3. nr 2, pP. 17-18.

Opname 12. Maastricht Sint-Pietersberg, steilrand tussen Molenvoetpad en Encibos. Lage, gesloten. grazige vegetatie met annuellen, mostapijtjes en rozetplanten. Auteur. V. Westhoff. Datum: 24-051950. Oppervlakte: $0.25 \times 10 \mathrm{~m}$. Expositie: noordwest.

Addenda:

Opname. I. Galium aparine +, Moehringia trinervia +, Echium vulgare I. Senecio vulgaris +. Myosotis stricta !. Desmazeria rigida +. Poa annua 1, Holosteum umbellatum + . Holçus lanatus $\mathrm{I}$.

Opname 2. Stellaria media + , Poa trivialis,+ Crataegus monogyna + (kiemplant), Brachypodium pinnatum I, Viola arvensis + , Holosteum umbellatum + . Scleranthus annuus +, Holcus lanatus +, Myosotis arvensis + . Desmazeria rigida I. Poa annua + .

Opname 3. Trifolium striatum $t$, Vicia lathyroides + , Linaria yulgaris + . Trifolium dubium 2. Bromus mollis + , Ranunculus bulbosus + , Lotus corniculatus + , Saxifraga granulata + , Bellis perennis + .

Opname 4. Trifolium dubium + . Ranunculus bulbosus + , Lotus corniculatus I. Linum catarcticum I, Briza media +

Opname. 5, Brachypodium pinnatum + , Medicago lupilina + , Allium vineale +. Viola canina +. Daucus carota I, Potentilla verna I. Trifolium repens 1. Sanguisorba minor 1. Cracaegus monogyna + (kiemplant). Prunus spinosa + (kiemplant). Rubus spec. + . Centaurea scabiosa +

Opname 6. Medicago lupilina +, Trifolium arvense +, Aphanes arvensis +. Teucrium scorodonia !, Origanum vulgare I, Myosotis ramosissima, Scleranthus annuus +

Opname 7. Arabidopsis thaliana +. Galium verum +. Viola arvensis +, Lotus corniculatus + . Cerastium arvense + , Pottia lanceolata + , Bryum argenteum + .

Opname 8. Cerastium arvense +, Achillea millefolium 1. Trifolium dubium, Poa annua + , Bryum argenteum +.

Opname 9. Dactylis glomerata 1. Trifolium repens +. Plantago major + . Plantago media !, Taraxacum spec. +. Sagina spec. +. Potentilla argentea + . Capsella bursapastoris + . Poa annua + .

Opname 10. Genista pilosa +, Genista tinctoria I. Genista anglica 1. Trifo- lium repens + , Brachypodium pinnatum 2. Pimpinella saxifraga 1. Thymus pulegioides + , Sanguisorba minor + , Ranunculus bulbosus + , Lotus comiculatus + , Potentilla erecta 1 , Briza media I. Succisa pratense I. Hieracium umbellatum I, Viola canina +. Carex caryophyllea +. Rumex acetosa +. Leontodon autumnalis + , Nardus stricta 2.

Opname 11. Trisetum flavescens +, Carex caryophyllea I. Hieracium umbellatum +. Brachypodium pinnatum 1. Pimpinella saxifraga 2. Ranunculus bulbosus + , Lotus comiculatus + , Potentilla erecta 2. Centaurea pratense I. Galium verum +, Briza media I, Sta. chys officinalis 1 .

Opname 12. Vicia angustifolia 1, Trifolium dubium +, Myosotis ramosissima 1. Ornichopus perpusillus I, Ranunculus bulbosus + , Cerastium arvense +, Peltigera polydactyla +, Mnium affine +, Hypnum cupressiforme 2. Atrichum undulatum +. Ceratodon purpurascens 1. Cephaloziella divaricata 3.

De betekenis van de letters $A \mathrm{t} / \mathrm{m} \mathrm{G}$ in de eerste kolom van elke opname is als volgc $\mathrm{A}=$ polvormende gramineeèn, $\mathrm{B}=$ zodevormende gramineeèn. $\mathrm{C}=$ annuellen, $\mathrm{D}=$ mossen, $\mathrm{E}=$ (half)parasieten, $\mathrm{F}=$ bisannuellen of perenne soor ten met bladrozet en $\mathrm{G}=$ dwergstruiken

\section{TABEL 9.2}

\section{THERO-AIRION.OPNAMEN SPOORWEGEN EN SPOORWEG.} EMPLACEMENTEN

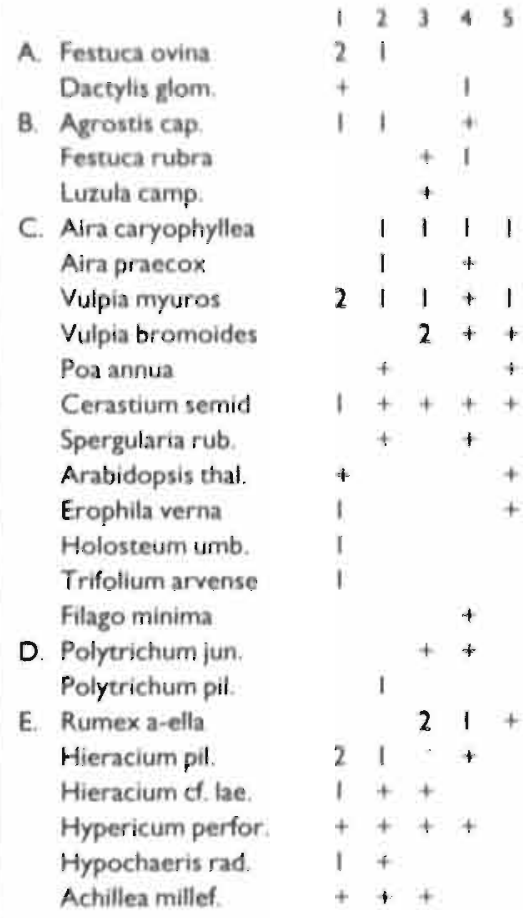

Opnamegegevens:

Opname 1. Linne, spoorweg ter hoogte van de Linnesthel, langs het grofzandige schouwpad. Open, mozaiekrilike structuur. Datum: 20-04-1984: Opperviakte: I $\times 20 \mathrm{~m}$. Bedekking: 65\%. Hoogte: maximaa! $20 \mathrm{~cm}$

Opname 2. Nuth, spoorwegemplacement (zuidelijk deel) langs schouwpad. Korte, open vegetatie met beide Aira soorten in bloei, overgaand in Cytisus struweel. Datum: 05-05-1985. Oppervlakte: $2 \times 10$ m. Bedekking $50 \%$. Hoogte: maximaal $15 \mathrm{~cm}$.

Opname 3. Nuth, spoorwegemplacement langs de Geieenbeek. Polletjes van Rumes acetosella en open vegetatie met annuelien en mos. sen. Datum: 05-05-1985. Oppervlakte: $2 \times 5$ m. Bedekking: $80 \%$ Hoogte: maximaal $20 \mathrm{~cm}$.

Opname 4 Nuth, spoorwegemplacement tussen beide spoorlijnen. Schaar vegetatiedek met bloeiende Rumex acetosella en Filago rozet. jes. Datum: 05-05-1985. Oppervlakte: $3 \times 50$ m. Bedekking: $20 \%$. 
Hoogte: maximaal $20 \mathrm{~cm}$.

Opname 5. Simpelveld, spoorwegemplacement. Ijle vegetatie op kiezelsubstrat met onder andere veel annuellen. Datum: 06-05-1985. Oppervlakte: $5 \times 10 \mathrm{~m}$. Bedekking: $10 \%$. Hoogte: maximaal 25 $\mathrm{crn}$.

\section{Addenda:}

Opname 1. Arenaria serpyllifolia 1, Veronica arvensis 1, Senecio vulgaris I. Ceratodon purpureus I, Brachychecium rutabulum +, Agrostis stolonifera I, Senecio jacobaca +, Plantago lanceolata +, Taracacum spec. +. Lotus corniculatus +, Cerastium fontanum +. Daucus carota + .

Opname 2. Arrhenatherum elatior + , Artemisia vulgaris + , Betula spec. (kiemplant) +, Rubus spec. (kiemplant) +, Solanum dulcamara (kiemplant) + .

Opname 3. Cladonia spec. + , Poa nemoralis + , Poa compressa + , Centaurea jacea + , Lamium album + , Equisetum arvense + , Ranunculus repens + , Rubus spec. + , Cracaegus monogyna (kiemplant) + .

Opname 4. Myosotis arvensis + , Senecio viscosus + , Senecio inaequidens + , Erigeron canadense + , Holcus lanatus + , Salix spec. (kiemplant) + .

Opname 5. Mibora minima + , Alyssum alyssoides + , Cardaminopsis arenosa + , Senecio inaequidens + , Reseda luteola + , Ranunculus sarduus +.

\section{TABEL 9.3}

\section{THERO-AIRION.OPNAMEN. OVERGANGEN NAAR HET} SPERGULO.CORYNEPHORION

\begin{tabular}{|c|c|c|c|c|c|}
\hline & 1 & 2 & 3 & 4 & $s$ \\
\hline A. Festuca ovina & 1 & & 2 & I & \\
\hline Corynephor, can. & ! & ! & 2 & 3 & ! \\
\hline Agrostis capill. & 1 & 2 & 1 & 1 & + \\
\hline Carex arenaria & 1 & & + & & \\
\hline Luzula camp. & 1 & & & & \\
\hline Spergula moris. & & & & 2 & \\
\hline Cerastium semi. & 2 & I & 1 & 1 & \\
\hline Teesdaia nudic: & & + & & I & \\
\hline Ornithopus per. & & 1 & & + & \\
\hline Veronica aryen. & 1 & + & & + & \\
\hline Trifolium arven. & 1 & 1 & I & & \\
\hline Brachythec alb. & 3 & + & 2. & + & + \\
\hline Racomitr. canes. & 1 & & & + & \\
\hline Polytrichum p. & & 1 & + & 2 & \\
\hline Cladonia spec. & & & & + & \\
\hline Rumex ac-ella & 1 & I & 1 & 1 & \\
\hline Hyochaeris rad. & 1 & 1 & 1 & 1 & \\
\hline Hieracium pil. & 1 & & & + & \\
\hline Jasione mont & & & & 1 & \\
\hline Calluna vulgaris & & & + & & \\
\hline Thymus serp. & 1 & & 1 & & \\
\hline Cytisis scop. & & & & & \\
\hline
\end{tabular}

Opnamegegevens:

Opname 1. Melick, Melickerheide, recreatiegebied "Driestruik", voormalig stuifduingebied. Vrijwel gesloten, mozaiekrijke vegetatie met een relatief hoge bedekking door mossen. Datum: 20-04-1984. Oppervlakte: $2 \times 2 \mathrm{~m}$. Bedekking: mossen $50 \%$, bloemplanten 45\%. Hoogte: maximaal $30 \mathrm{~cm}$ (Calluna). Beheer: konijnevraat, betreding.

Opname 2. Herkenbosch, omgeving Herkenboschervennen, voormalig stuifzandgebied, momenteel weideland, $200 \mathrm{~m}$ ten noorden van de spoorwegovergang. Schraal grasland met open plekken en een opvallende structuur van pollen Corynephorus en Festuca ovina. Datum; 20-04-1984. Oppervakte: $2 \times 2 \mathrm{~m}$. Bedekking: $65 \%$. Hoogte: maximaal $25 \mathrm{~cm}$. Beheer: extensieve beweiding door rundvee.

Opname 3. Als 1. Bedekking door mossen $30 \%$, bloemplanten $60 \%$.
Opname 4, Als $2.150 \mathrm{~m}$ ten noorden van de spoorwegovergang. Oppervlakte: $2 \times 2 \mathrm{~m}$. Bedekking, $65 \%$.

Opname 5. Als $2.50 \mathrm{~m}$ ten westen van de spoorwegovergang. Oppervlakte: $2 \times 6 \mathrm{~m}$. Bedekcking: $90 \%$, waarvan $70 \%$ door mossen.

Addenda:

Opname 1. Holosteum umbellatum 1, Arenaria serpyllifolia 1. Taraxacum spec. + .

Opname 2. Erophila verna I. Scleranchus annuus +, Erodium cicutarium I, Viola arvense + . Myosotis stricta + , Leoncodon autumnalis + .

Opname 3. Dactylis glomerata 1.

Opname 4. Holcus lanatus I, Ceratodon purpureus !.

Opname 5. Hieracium spec. + , Hypericum perforatum t.

\section{TABEL 9.4}

\section{THERO-AIRION.OPNAMEN OVERGANGEN NAAR HET SEDO.CERASTION}

A. Festuca ovina

12345

$12 ! 2 !$

B. Agrostis capil Luzula campestr

C. Aira caryophyllea Aira praecox Erophila verna Myosotis stricta Teesdalia nudic. Saxifraga trid. Sedum acre Sedum bolon. Sedum album Erodium cicut

D. Polytrichum pilif. Cladonia spec

E. Euphrasia stricta

F. Rumex acetosella Hieracium pilos. Potentilla verna Hypochaeris rad. Plançago lançẹof:

G. Cytisis scoparius Thymus pulegioid. Helianthernum $\mathrm{n}$. Polygala vulgaris

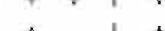

2

2

$++1+$

$+1$

$++$

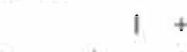

$+1+$

I

$+1+$

$+22$

$++21$

222

$+1$

1 1

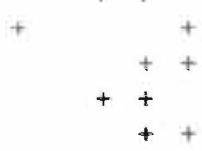

Opnamegegevens:

Opname I, Beesel, Donderberg, rivierduin langs de Maas, kalkhoudende zanden. Kortgrazige, open yegetatie met een mozaiekstructuur. Datum: 11-05-1985. Oppervlakte: $2 \times 2$ m. Bedekcking: $70 \%$. Hoogte: $15 \mathrm{~cm}$. Expositie: zuidwest. Inclinatie: 10. Beheer: extensieve beweiding met rundvee.

Opname 2. Als 1. Bedekking: $80 \%$.

Opname 3. Visé, Thier de Lanaye, bovenrand, van een krijthellinggrasiand, Korte, bijna gesloten vegetatie met veei annuellen. Datum: 22 04-1985. Oppervlakte: $2 \times 2 \mathrm{~m}$. Bedekking: $90 \%$. Hoogte: $15 \mathrm{~cm}$. Expositie: zuidoost. Inclinatie: 20. Beheer: plaatselijk maaien en branden.

Opname 4. Kanne. Zusserdel, steile wegrand met dagzomende kalksteen. Open vegetatie met dichte zoden van Potentilla in bloei. Datum: 04-05-1984, Bedekking: 60\%. Hoogte: $20 \mathrm{~cm}$. Expositie: zuidoost. Inclinatie: 40. Beheer: 0-beheer.

Opname 5. Bemelen, Bemelerberg, boven de ingang van de Winckelberg op dagzomend krijt en zand. Open vegetatie met een mozaiekpatroon. Datum: 04-06-1984. Hoogte: maximaal $15 \mathrm{~cm}$. Expositie: zuidoost. Inclinatie: 10. Beheer: extensieve beweiding met mergellandschapen. 
Addendx:

Opname 1. Sperzularia morisonii 1, Ornithopus perpusillus,+ Corynephorus canescens 2. Vicia hirsuta + , Valerianella spec. +. Viola arvensis.

Opname 3. Daucus caroca + , Pimpinella saudraga + , Koeleria macrantha + Opname 4. Brachypodium pinnatum +. Medicago lupilina + , Allium vineale +, Viola spec +, Achillea millefolium I. Trifolium repens I. Campanula rotundifolia I, Sanguisorba minor I. Galium verum I.

Opname 5. Poa annua I. Echium vulgare I. Arenaria serpyllifolia +

\section{TABEL 9.5}

\section{THERO-AIRION-OPNAMEN. RESTGROEP}

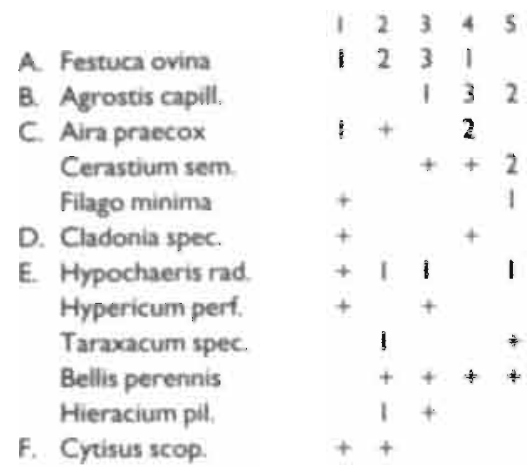

Opnamegegevens:

Opname I. Heel, parkeerterrein van het zwembad Heelderpeel. Mineraalarme zandgrond. Mozaiekrijke, korte vegetatie in voormalig heidegebied. Datum: 05-06-1985. Oppervlakte: $4 \times 4 \mathrm{~m}$. Bedekking: $50 \%$. Hoogte: $20 \mathrm{~cm}$. Beheer: betreding door voetgangers, bodemverdichting door personenauto's, konijnevraat.

Opname 2. Cottessen, weiland boven de Cottessergroeve. Korte, schrale, maar gesloten vegetatie met een zeer dunne humuslaag, Datum: 01-06-1985. Oppervlakte: $2 \times 2 \mathrm{~m}$. Bedekking: $95 \%$. Hoogte: maximaall $10 \mathrm{~cm}$. Beheer: intensieve beweiding met rundvee.

Opname 3. Meerssen, groeve Curfs, zandvlakte op de plateaurand. Schrale, vrijwel gesloten vegecatie van grassen en mossen met hier en daar wat annuellen en rozetplanten. Datum: 25-04-1984. Oppervalkte: $4 \times 4 \mathrm{~m}$. Bedekking $90 \%$. Hoogte: maximaal $20 \mathrm{~cm}$. Beheer: beweiding door reeën en konijnen.

Opname. 4. Beegden, open, grazige plaats in naaldhoutplantage op de voormalige Beegderheide langs een zandpad. Gesloten, soortenarme grasmat met een hoge presentie van Aira praecox. Datum: 0506-1985. Oppervlakte: $4 \times 4 \mathrm{~m}$. Bedekking: $95 \%$. Hoogte: $20 \mathrm{~cm}$. Beheer: betreding door recreanten

Opname 5. Valkenburg. Vilt, voormalige kiezelgroeve op de Vilterheide, momenteel Limburgerbos. Spaarzame vegetatie op vlakke kiezelbodem, plaatselijk kortgrazig. plaatselijk zeer open met annuellen, onder andere Filago. Datum: 24-04-1984. Oppervlak= te: $4 \times 4 \mathrm{~m}$. Bedekking: $50 \%$. Hoogte: maximaal $10 \mathrm{~cm}$. Beheer: betreding door recreanten, koniinevraat.

Addenda:

Opname 1. Corynephorus canescens 2. Betula pubescens (kiemplant) + Calluna vulgaris + , Ornithopus perpusillus + , Achillea millefolium + . Holcus lanatus + , Polytrichum juniperinum + , Plantago lanceolata +, Scleranthus annuus + , Erigeron canadense +, Spergularia rubra + .

Opname 2. Aphanes cf. microcarpa + . Thymus pulegioides + , Ranunculus bulbosus + .

Opname 3. Brachythecium albicans 2, Vulpia bromoides + , Trifolium arvense + , Centaurium pulchellum I. Hieracium spec. + , Luzula campestris +. Betula pubescens (I exemplaar van $30 \mathrm{~cm}$ ).

Opname 4. Trifolium repens 1.

Opname 5. Poa annua, Aphanes arvensis +, Veronica arvensis + , Trifolium repens + , Potentilla anserina + , Cirsium arvense + .
Algemene opmerkingen:

De in totaal 32 opnamen zijn opgesplitst in vijfafzondertijke tabellen. De soortenlijsten van elke tabel zijn vergezeld door een lettercode A $\mathrm{d} / \mathrm{m}$ G, gebaseerd op de levensvorm van de betreffende soort. De betekenis van de onderscheiden levensvormen wordt vermeld onder de eerste tabel. De ciffers achter de soorten zijn een mat voor zowel de bedekking als de presentie van de betreffende soort in de opname. De indeling van de opnamen in de viff groepen is zowel gebaseerd op abiotische kenmerken (onder andere substraat, geografische ligging, expositie) als op biotische kenmerken (onder andere patroon. structuur en soortensamenstelling van de vegetatie) van de afzonderlijke op. namen. De nomenclatuur van de soorten volgt HEUKELS EN VAN DER MEjOEN 1984

\section{TABEL 9.6.1 \\ OPNAME YEEDIRIFT ST, PRIVAT D.D 13-07-1989}

Aspectbepalend in de berm: Onopordium acanthium, Verbascum floccosum en Artemisia absinthium in bloei. Hoogte van de vegetatie maximaal $160 \mathrm{~cm}$, gemiddelde hoogte $40 \mathrm{~cm}$, direct langs de weg $10.20 \mathrm{~cm}$. Bedekking: $80 \%$. De vegetatie langs de weg, bestaande uit een strook van $2 \times 60 \mathrm{~m}$, begrensd door enerzijds de weg en anderzijds een rotswand of muur, is opgebouwd uit diverse structuren: grenzend aan de weg een lage vegetatie, voornamelijk samengesteld uit perenne grassoorten, vooral Hordeum murinum, een hogere, maximaal $40 \mathrm{~cm}$ structuur van kruiden, waarin Chenopodium bonus-henricus domineert en daarachter een plaatselijk hoge vegetatiestructuur. waarin de hierboven genoemde in bloel staande soorten opvallen.

Onopordium acanthium 1, Artemisia absinthium 2, Ballota nigra 2, Chenopodium bonus-henricus 2. Verbascum floccosum 2. Arctium minus 1, Hordeum murinum 1. Marrubium vufgare +, Urtica dioica 2. Bromus sterilis 1, Bromus mollis 1. Anchriscus sylvestris 1. Rubus spec. 1. Lolium perenne +. Capsella bursa-pastoris + , Salvia pratensis + , Artemisia vulgaris 1 , Trifolium repens + . Lamium album +, Carduus nutans I. Vulpia myuros I, Carex cf muricata + Hypericum perforatum I, Chaerophyllum temulum +, Conium maculatum + Convulvulus arvensis 1, Polygonum aviculare I, Malva neglecta + , Senecio $\mathrm{d}$. viscosus +. Ribes uva-crispi +, Galim aparine I, Cirsium arvense 1, Verbena officinalis 1, Cirsium vulgare + en Silene vulgaris +

\section{TABEL 9.6 .2}

\section{OVERZICHT VAN DE STANDPLAATSEN IN ZUID-LIMBURG EN OMGEVING VAN HARTGESPAN (LEONURUS CARDIACA)}

met jaartallen van de eerste en laatste vermelding in de literatust of anderszins ( $m . m$. = mondelinge mededeling), aanduiding van het type standplaats en vervijzing naar eventuele opnamen

1. Zwarte Weg (Bemelen-Heer). 1940: broeder Jeroen in manuscript, rond 1960: L Haesen, Cadier en Keer (m.m.), rond 1970: L Hunties, Cadier en Keer (m.m.), 1984-1987: H. Hillegers. Overhoek en voormalige spoordijk. In de periode 1984-1987 per jaar maximaal 2 exemplaren (fl) tussen brandnetels en enige ieperu (zie opname I en 2 van tabel 9.6.3).

2. Keerderberg (Heer). 1940: broeder Jeroen in manuscript, rond 1960: L. Haesen (Cadier en Keer), kort daarma verdwenen (m.m.). VVegrand tegen haag bij tuin.

3. Zure Dries (Gronsveld), 1984: G. Londo (m.m.), 1985-1987; H. Hillegers. Voormalige grindgroeve met brandplekken, rusţlaats van schapen. per jaar maximaal 5 excmpiaren (fi) tussen brandneteis en ander ruigte (zie opname 3 en 4 van tabel 9:6.3).

4. Gerendal (Oud-Valkenburg), rond 1975:J. Hermans (mm), 1985-1987 H. Hillegers. Wegrand langs bos. per jaar éen exemplaar (ii) tussen brandnetels (zie opname 5 van tabel 9.6.3).

5. Strooberg (Bemelen) rond 1940: L. Meys (Meys en. Hillegers), 1982: S. Hennekens ẹn I, Schaminè, 1982, 1985-1988: H. Hillegers. Overhoek langs wegberm en in het reservat "De Bemelerberg". per jaar $3-5$ exem. plaren $(f)$ wssen brandnetels. Zie foto van deze standplaats in: WuEA et al. 1985-1991, deel III, p. 163 (zie ook opname 6 en 7 van tabel 9.6.3).

6. Bieslanderweg, (Wolder), 1983: P. $\operatorname{van}$ Nieuwenhoven (m.m.), 1984. 1987. $\mathrm{H}$ Hillegers. Ruige wegberm onder meidoornhasg, per jaar 
maximaal 7 exemplaren (fi) tussen brandnetels (zie opname 8 en 9 van tabel 9.6.3).

7. Terstraten (Nuth), rond 19!0; A de Wever (19!6), rond 1965: J. Koelink (m.m.). 1984-1986: H. Hillegers. Overhoek langs wegberm bij boerderij, tussen onder andere brandnetels (zie opname I0 en II van cabel 9.6.3). Tot $1980 \mathrm{kwam}$ Leonurus ook voor op een andere plaats in Terstraten: een wegrand nabiị een andere boerderiị (0. Koelink, m.m.).

8. Thier à la Tombe (Eben, België), 1984-1986: H. Hillegers. Niet in 1987 en 1988, opnieuw in 1991. Wegrand, beschaduwd, één exemplaar (fi) tussen brandnetels (zie opname 12 van tabel 9.6.3).

9. Lanaye (Belgie), 1979: E. Blink (m.m.). Wegrand vlak buiten het dorp.

10. Aan de Biskai (Meerssen); 1956: H. Hillegers. Overhoek op brede wegberm, enkele exemplaren met klissen, bijvoet en absint-alsem. Verdwenen.

11. Metteberg (Bemelen), 1982: W. van der Coulen (m.m.), 1983: H. Hillegers, na 1983 verdwenen. Ruigte in halfschaduw onder voormalige rotswoning met tuin, én exemplaar (f). Tot ongeveer 1920 woonde hier de vroedvrouw van Bemelen.

12. Onder de Hotels (Bemelen), 1940: broeder Jeroen in manuscript (1940). Ruige, deels beschaduwde wegberm met een overhoek.

\section{TABEL 9.6.3}

\section{SYNOPTISCHE TABEL VAN 12 OPNAMEN MET} HARTGESPAN IN ZUID-LIMBURG

$\begin{array}{lll}\text { Standplaats } & \text { Zwarte Weg } \\ \text { Opramenumer } & 1 & 2 \\ \text { Datum } & 20 & 07 \\ & 08 & 08 \\ & 1984 & 1985 \\ \text { Bedekking in } \times & 100 & 100 \\ \text { Expositie } & + & + \\ \text { Hoogte in cm } & 150 & 150 \\ \text { Oppervlakte in m } & 6 \times 2 & 6 \times 2 \\ \text { Leonurus cardiaca } & + & + \\ \text { Urrica dioica } & 4 & 4 \\ \text { Galium aparine } & & \\ \text { Rubus spec. } & 1 & \\ \text { Heracleum sphon. } & 1 & + \\ \text { Cirsium arvense } & \\ \text { Lamium album } & \\ \text { Dactylis glomer. } & \\ \text { Poa annua } \\ \text { Hedera helix }\end{array}$

$\begin{array}{llll}\text { Zure Dries } & \text { Gerendal Bemelen } \\ 3 & 4 & 5 & 6 \\ \text { id. id. } & \text { id. } & \text { id. }\end{array}$

$\begin{array}{llll}100 & 100 & 100 & 100 \\ 2.0 & 20 . & - & - \\ 100 & 100 & 45 & 180 \\ 6 \times 2 & 6 \times 2 & 4 \times 1 & 1 \times 1 \\ + & 1 & + & 2 \\ 4 & 3 & 5 & 5 \\ 2 & 3 & 1 & + \\ + & + & & + \\ & & +\end{array}$

Opmerkingen:

1. De struweelsoorten aan de rand van de opnamen bestaan uit Ulmus campestris (opname: 1, 2, 5, 8, 9, 10,11). Sambucus nigra $(6,8,9,10,11$ ). Crataegus monogyna $(6,7,8,9,10,11)$ en Acer pseudoplatanus (12).

2. = vegetatie, grof gemaaid met klepelmaaier.
Addenda: soorten die minder dan $3 x$ in de opnametabel voorkomen, zijn in opname 1 en 2. Agropyron repens 1, Artemisia vulgaris 1. Humulus lupulus 1. Calystegia sepium 1: Equisetum arvense I en + . Torilis japonica I en + en Epilobium hirsutum I en 2.

opname 3 en 4 . Origanum vulgare + , Cirsium aryense + . Carex sylvatica + . Lithospernum officinale + . In opname 3: Verbascum phlomoides + , Taraxacum spec. +. Trisetum flavescens + en Brachypodium pinnatum + .

opname 7. Glechoma hederacea 1، Holcus ianatus 1. Festuca gigantea 1. Plantago major + en Geum urbanum +.

opname 8 en 9. Geranium robertianum +, Galeopsis tetrahit 2 en 1, Stellaria media 2 en 1. Solanum nigrum + , Poa nemoralis + . In opname 8: Geum urbanum 1. Chaerophyllum temulum I. Scrophularia spec. 1, Cheilidonium majus 1, Bryonia dioica 1. Alliaria petiolata $i$ en Holcus lanatus + .

opname: 10 en II.Bromus sterilis 1. Sisymbrium officinale +. In opname 10: Calystegia sepium +, Loilum perenne 2. Mava neglecta 2. Chenopodium album +, Ballota nigra 1. Euphorbia peplus + , Arrhenaterum elatior 2, Agropyron repens 2 en Convulvulus arvensis I.

\begin{tabular}{lllll} 
Terstraten & \multicolumn{3}{c}{ Woider } & Thier a la Tombe \\
8 & 9 & 10 & 11 & 12 \\
08 & id. & id. & id. & id. \\
& & & & \\
95 & 95 & 80 & 100 & 100 \\
2. & 2. & 20. & 20. & 5 \\
150 & 120 & $30^{*}$ & 60 & 40 \\
$6 \times 2$ & $6 \times 2$ & $10 \times 1$ & $8 \times 2$ & $2 \times 2$ \\
2 & 1 & 3 & 1 & 1 \\
1 & 4 & 1 & 3 & 1 \\
1 & + & & & 1 \\
& & + & & + \\
+ & & & & \\
3 & 2 & 1 & &
\end{tabular}




\section{CURRICULUM VITAE}

Henricus Paschalis Maria Hillegers werd op 24 maart, Paaszondag, 1940 geboren te. Meerssen als tweede zoon van een uit zes jongens bestaand gezin. Van zị̣n vader, aanvankelị̂k onderwịizer en later hoofd van de muloschool in Meerssen, kreeg hij al vanaf zijn prille jeugd lessen in de levende natuur. Na vanaf 1952 enige jaren het gymnasium te Maastricht te hebben bezocht, waar het Grieks en Latijn hem minder boeiden dan het buitenleven, werd hij verbannen naar een kostschool in Roermond. Hij bleef echter lid van het Natuurhistorisch Genootschap te Maastricht, een vereniging die zijin verdere leven bleef bepalen. Hij slaagde voor de "hoofdakte voor onderwijzer" in 1962. Na militaire dienst schreef hij zich in 1964 in als student Biologic aan de Rijksuniversiteit van Groningen. waar hij in 1969 het diploma M.O.-Biologie behalde. Vanaf 1969 tot 1983 was hij leraar Biologie aan een school voor voortgezet onderwijs in Maastricht. In zijn vrije tijd bleef hij zich actief bezighouden met cultuurhistorische en natuurhistorische aspecten van Zuid-Limburg; naast boerenmeubels en een monumentale vakwerkboerderij "restaureerde" hij ook een in Zuid-Limburg inheems schaperas, dat later het mergellandschaap zou gaan heten en vanaf 1979 een belangriike rol zou gaan spelen in het Zuidlimburgse natuurbeheer. Zịn tweede en derde leermeester waren de oude schaapherder Sjang Brouwers en vooral Prof. Dr. Victor Westhofi. Aangemoedigd door het succes van extensieve beweiding met mergellandschapen op schrale graslanden publiceerde hij diverse artikelen. meestal in het Natuurhistorisch Maandblad, vitgegeven door het al eerder genoernde Natuurhistorisch Genootschap, en was hị actief betrokken bị de organisatie en uitwerking van enkele symposia en tentoonstellingen in het kader van restaumetes van het Zuidlimburgse milieu.

In 1978 begonnen aan de studie, behaalde hij in 1984 het doctoraal examen Biologie aan de Rijksuniversiteit te Groningen met als, thema's mergellandschapen en natuurbeheer. Beide thema's spelen eveneens een hoofdrol in deze dissertatie, die mogelijk werd gemaakt door het aan de Rijksuniversiteit van Limburg, verbonden Sociaal Historisch Centrum te Maastricht. 
HOOFDREDACTIE: Drs. J. van der Coelen, Drs. B.G. Graatsma REDACTIE: Merr. Drs. F.N. Dingemans-Bakels, Drs. D.Th. de Grat, J.T. Hermans, Drs. H.P.M. Hillegers, Mevr. Lic. M. Lejeune, Drs, T.J.D. Mulder REDACTIE-ASSISTENT: R.B.G.M. Steverink REDACTIE-ADRES: Postbus 882, 6200 AW Maastricht ONTWERP BASIS-TYPOCRAFIE EN OMSLAG: Stefan Gratsma, Maastricht GRAFISCHE VERZORGING: bvdm, Bureau van de Manakker bv, Maastricht DRUK: Swalmer Handelsdrukkerij, Swalmen 
a vele jaren heeft de reeks "Publicaties van het

Natuurhistorisch Genootschap in Limburg" met deze uitgave weer een dissertatie op het programma.

Deze publicatie is geen "standaard" dissertatie, dat wil zeggen geen uitgave voor een zeer kleine en gespecialiseerde kring van lezers. Integendeel, "Heerdgang in Zuidelijk Limburg" heeft voor een breed lezerspubliek, dat in diverse aspecten van de cultuur- en natuurhistorie van dit zo ongelooflijk rijke gebied is geinteresseerd, heel wat nieuws en interessants te bieden.

De heerdgang van vroeger, de "dagelijkse rondgang van de dorpskudde door de gemeente onder leiding van de dorpsherder", heeft duidelijk sporen nagelaten in de huidige nederzettingen. Namen van wegen en weideplaatsen, maar ook dorpsplattegronden en het patroon van wegen buiten de nederzetting laten zien hoe de heerdgang het landschap vorm en kleur gaf.

De om hun rijke fauna en flora zo bekende kalkgraslanden en daaraan verwante graslandtypen die in de vorm van natuurreservaten zijn blijven voortbestaan, blijken "wilde weidegronden" van vroeger te zijn die door middel van extensieve beweiding weer kunnen worden hersteld.

Zelfs graslanden, wegbermen en akkers, die door onder andere de bio-industrie veel van hun soortenrijkdom hebben verloren, kunnen door middel van extensieve beweiding met mergellandschapen worden hersteld.

Een leesbaar boek met een optimistische visie op de toekomst van een gewest dat als model dient voor het toekomstige Europa. 